GABRIELA LIMA RAMENZONI

A CONSTRUÇÃO DE UMA CULTURA JURÍDICA: ANÁLISE SOBRE O COTIDIANO DO BACHAREL NA ACADEMIA DO LARGO DE SÃO FRANCISCO ENTRE 1857-1870

\author{
DISSERTAÇÃO DE MESTRADO
}

ORIENTADOR: PROFESSOR DOUTOR SAMUEL RODRIGUES BARBOSA

FACULDADE DE DIREITO DA UNIVERSIDADE DE SÃO PAULO

SÃO PAULO

2014 
GABRIELA LiMA RAMENZONI

MATRICULA No 5697640

\title{
A CONSTRUÇÃO DE UMA CULTURA JURÍDICA: ANÁLISE SOBRE O COTIDIANO DO BACHAREL NA ACADEMIA DO LARGO DE SÃO FRANCISCO ENTRE 1857-1870
}

\author{
Dissertação de Mestrado apresentada como \\ requisito parcial à obtenção do título de \\ Mestre em Direito, na área de concentração \\ Filosofia e Teoria Geral do Direito, sob \\ orientação do Professor Doutor Samuel \\ Rodrigues Barbosa
}

Faculdade de Direito da Universidade de SÃo Paulo Departamento de Filosofia e TeOria Geral do Direito (DFD) SÃo PaUlo 
Nome da Candidata: Gabriela Lima Ramenzoni

Orientador: Professor Doutor Samuel Rodrigues Barbosa

Título: A construção de uma cultura jurídica: análise sobre o cotidiano do bacharel na academia do Largo de São Francisco entre 1857-1870

Dissertação apresentada à Faculdade de Direito da Universidade de São Paulo para obtenção do título de mestre em Direito

Aprovado em:

Prof Dr. Instituição

Julgamento: Assinatura:

Prof Dr. Instituição

Julgamento: Assinatura:

Prof Dr. Instituição

Julgamento: Assinatura: 
"O Brasil é o caboclo sem dinheiro Procurando o doutor n'algum lugar Ou será o professor Darcy Ribeiro Que fugiu do hospital pra se tratar?" Celso Viáfora e Vicente Barreto 
Em memória ao meu avô,

Cândido Jorge de Lima. 
À minha mãe Rita, por ter me apresentado Villa-lobos, ao meu pai Celso, por me fazer acreditar na ética, à minha irmã Liza por ser minha inspiração acadêmica, ao meu irmão Alexandre pelos desafios e incitamentos, aos meus avós Anna e Cândido e minha tiaavó Tote pelo lampejo histórico, aos meus tios Ana e Roberto e à minha prima Thaís por confiarem em mim.

Ao meu orientador Samuel Rodrigues Barbosa, por me mostrar o caminho da ciência da História do Direito.

Aos professores Fernando Menezes e José Rodrigo Rodriguez pelas sugestões e críticas feitas na Banca de qualificação.

Aos professores Antonio Manuel Hespanha, Bernardo Sordi, Celso Campilongo, Jean Paul Rocha, e Ricardo Fonseca por ajudarem a traçar o caminho.

À bibliotecária Augusta, pelo carinho e dedicação.

Aos amigos Addas Oliveira, Ana Navarrete, Austreia Magalhães, Brenda Castor, Edson Nacata, Flávia Annenberg, Larissa Ferrari, Leonardo Vaccaro, Mariana Lial, Paula Navarrete, Paula Dias, Raul Teixeira, Rebeca Dias, Renata Gomes, Stacy Natalie, Thaís Pinhata que passaram pelos momentos difíceis comigo, sempre me ajudando e incentivando.

À Fundação de Amparo à Pesquisa do Estado de São Paulo - FAPESP pelo financiamento. 
$\begin{array}{ll}\text { RESUMO } & 9\end{array}$

$\begin{array}{ll}\text { ABSTRACT } & 10\end{array}$

$\begin{array}{ll}\text { INTRODUÇÃO } & 11\end{array}$

1. A ACADEMIa COMO ALICERCE DA CULTURA JURÍDICA OITOCENTISTA 21

1.1 A CUltura E O ENSINO JURÍDico de SÃo PAUlo 22

1.2 O BACHAREL E O MITO 28

1.3 UM CONTROLE SOBRE O ENSINO JURÍDICO

2. A Formação da Cultura Jurídica Administrativa e da Metodologia ACADÊMICA

2.1 A Literatura Brasileira sobre a Cultura Jurídico-Administrativa NO SEGUNDO IMPÉRIO $\quad 70$

2.1.1 O Ensino Jurídico e a História Tradicional do Direito Administrativo $\begin{array}{ll}\text { Brasileiro } & 72\end{array}$

2.1.2 O Ensino Jurídico e a Cultura Administrativista do Conselho de Estado 75

2.1.3 O Ensino Jurídico e a Gênese do Direito Administrativo Brasileiro 86

2.2 ASPECTOS SOBRE O COTIDIANO METOdOLÓGICO DE ENSINO 95

2.2.1 A Relação entre a Faculdade de São Paulo e o Governo Central 97

2.2.2 A Importância da Utilização dos Compêndios no Ensino Jurídico 102

2.2.3 O Perfil Acadêmico de Professores na Faculdade de Direito 112

2.2.4 Análise Histórica da Formação da Cadeira de Direito Administrativo 120

2.2.5 A Dinâmica entre a Faculdade e a Sociedade pelos Estudantes 126

2.2.6 A Ratificação Acadêmica 132

2.3. A Metodologia de Ensino 139

2.3.1 O Romantismo 140

2.3.2 A Técnica 148

2.3.3 A Semântica jurídica do Ensino 156 
3. A ConstruÇão da Cultura Jurídica Administrativa Oitocentista a Partir da Análise de DissertaÇões de Direito da ACAdemia de São Paulo 162

$\begin{array}{ll}\text { 3.1 ANÁLISE GERAL DAS DiSSERTAÇÕES } & 164\end{array}$

$\begin{array}{ll}\text { 3.2 EXAME ESPECÍFICO DAS DiSSERTAÇÕES } & 187\end{array}$

3.2.1 Sobre a Centralização Administrativa 195

3.2.2 Sobre as Distinções dos Poderes 204

3.2.3 Sobre o Contencioso Administrativo 208

$\begin{array}{lr}\text { CONSIDERAÇÕES FINAIS } & 214\end{array}$

$\begin{array}{ll}\text { BIBLIOGRAFIA } & 217\end{array}$

$\begin{array}{ll}\text { ANEXOS } & 224\end{array}$ 
O tema desta dissertação trata do envolvimento da academia de Direito de São Paulo do século XIX na formação da cultura jurídica brasileira, em especial, na área do Direito Administrativo. Esta discussão parte da análise do perfil histórico do bacharel desenvolvido pela literatura tradicional e de como haveria meios, nesse ambiente de ensino, para apreender um raciocínio jurídico definido. Assim, estudam-se documentos históricos atinentes ao cotidiano de ensino que permitem auxiliar na compreensão do complexo processo de desenvolvimento da metodologia da faculdade de São Paulo e, também, da estruturação da cadeira de Direito Administrativo, de forma a configurar esta hipótese de formação de pensamento jurídico. Por fim, para tratar de um caso concreto que ilustre esta dinâmica do ensino e a cultura jurídica administrativa, realizase a análise geral e também específica de algumas dissertações de Direito Administrativo elaboradas pelos estudantes da faculdade de São Paulo, particularmente, entre os anos de 1857 e 1870. Dessa forma, será possível determinar a hipótese de construção de um pensamento jurídico definido, dogmático, ativo, coerente com o contexto da formação das ideias do Brasil imperial.

Palavras-chave: ensino jurídico; cultura jurídica; Direito Administrativo; bacharel; dissertação de Direito. 
The subject of the present dissertation embraces the role of the law academy of São Paulo at the nineteenth century on the composing of the Brazilian legal culture, especially at the administrative law. This discussion starts from the analysis of the student's profile already developed by the traditional literature and of how there would be means at his educational environment to learn a define juridical argument. Therefore, there is the study of historian documents of the law school routine which allows understanding the complex process of the methodology development at the academia of São Paulo and also the organization of the chair of administrative law so the hypothesis of the generation of a judicial thinking could be configure. At long last, to conceive the exam of a case that illustrate this dynamic of the education and the administrative judicial culture, it's performed the general and specific analysis of exams of administrative law by the students of the academy of São Paulo, particularly at the years of 1857 and 1870 . Thereby, it will be possible to define the hypothesis of the construction of a judicial reasoning which is definite, dogmatic, active and consistent with the Brazilian contest of the develop of the ideas at that century.

Keywords: legal education; judicial culture; administrative law; student; law exams. 


\section{INTRODUÇÃO}

Esta pesquisa tem como problemática geral o fomento da discussão acerca da contribuição do ensino na academia de Direito na produção de cultura jurídica no século XIX, de forma a aproximar o diálogo entre a sociedade e o Direito no Brasil pelo redescobrimento de suas fontes jurídico-históricas. Nesse sentido, a ideia é valorizar o estudo atento às necessidades brasileiras em detrimento do manequim europeu, nos seguintes termos:

\footnotetext{
“(...)na América Latina, a abertura do saber jurídico aos problemas da sociedade e aos direitos vividos é hoje muito maior do que na Europa, na qual permanece - ou, até, se acentua - um formalismo doutrinal que separa o direito da vida e a dogmática jurídica dos outros saberes." 1
}

Especificamente, o escopo é problematizar a particularidade da construção de nossa cultura jurídica pelo exame atento do cotidiano da academia de São Paulo em meados da segunda metade do século XIX, palco histórico onde suas fontes demonstram a hipótese de se haver constituído um pensamento jurídico definido, posto que dogmático, ativo, coerente com relação ao contexto social e com aspectos de universalidade cultural que existira na formação das ideias do Brasil daquele período.

E, para delimitar a pesquisa e trabalhar com maior profundidade analítica das fontes históricas, restringimos o olhar para algumas décadas da segunda metade do século XIX entre os anos de 1857 e 1870. Em verdade, há uma demanda acadêmica pelo redescobrimento da História do ensino jurídico brasileiro e, também, de revisão da leitura sobre sua produção de pensamento e de cultura jurídica. Nesse sentido, a segunda metade do século XIX é interessante para um aprofundamento do tema da produção da cultura jurídica, inclusive, da administrativista, pois há um extenso universo de fontes primárias para serem analisadas que estão restritas a um espaço bem limitado nos dois cursos jurídicos do Brasil, em Pernambuco e em São Paulo.

\footnotetext{
${ }^{1}$ HESPANHA, Antonio Manuel. Cultura jurídica europeia: sintese de um milénio Coimbra: Almedina, $2012.7 \mathrm{p}$.
} 
Em tal período histórico, havia um contexto e um ambiente propício para o desenvolvimento das ideias no mundo acadêmico por diversos motivos: vivia-se uma relativa estabilidade social que permitia, e até incentivava, a atuação política e jurídica do estudante de Direito junto à sociedade, mesmo porque perseverava a possibilidade de circulação de novos pensamentos que se afastavam da influência da antiga metrópole portuguesa e que começavam a ser traduzidos de outros países da Europa.

Aliado a isto, os anos entre 1857 e 1870, são justamente posteriores ao momento de criação da cadeira de Direito Administrativo, por decreto em 1854, e são os anos que marcam a temporalidade das fontes primárias investigadas nesta pesquisa e que são grande importância para compreender o pensamento jurídico dos estudantes de São Paulo, quais sejam, as dissertações de Direito Administrativo.

Em outra medida, a faculdade de São Paulo foi a opção investigativa em razão das características urbanas da província, por ser o local em que havia um crescimento do mercado e da dinâmica social, principalmente em razão da produção cafeeira. Formava-se, em verdade, uma dinâmica relevante entre a cidade e a faculdade, bem como um intercâmbio de estudantes de diversas regiões do país, o que enriquecia o a produção cultural da academia jurídica.

Além disso, a escolha da faculdade paulistana é interessante para possibilitar o diálogo crítico com a investigação de Sérgio Adorno ${ }^{2}$ cuja tese defende que a formação cultural e a vida acadêmica do bacharel só se perpetuaram pelas atividades extracurriculares, com os jornais políticos e literários, o que excluiu justamente a hipótese de que havia um cotidiano das relações didáticas entre alunos e professores e do próprio ensino jurídico em sentido estrito, bem como perpetua uma visão pouco unitária da produção do pensamento jurídico dentro da escola.

Agora a opção pelo estudo da produção de cultura jurídica na área administrativista se justifica por dois motivos principais. Primeiramente, porque é pertinente aprofundar o estudo sobre uma matéria jurídica que trata justamente sobre a realidade prática e administrativa de um Estado, já que o estudante de Direito

\footnotetext{
2 ADORNO, Sérgio. Os aprendizes do poder: o bacharelismo liberal na política brasileira. Rio de Janeiro: Paz e Terra, 1988. 157 p.
} 
Administrativo seria o mesmo que teria um papel fundamental naquele período nos cargos burocráticos e na política. Assim, será possível compreender qual o pensamento jurídico da faculdade a respeito da atuação do Estado, ou seja, como se percebia o mesmo aparato jurídico e administrativo de que fariam os bacharéis parte.

É a oportunidade de constatar qual entendimento curricular era formado pelos estudantes sobre a política e a burocracia estatal.

Somando-se a isso, compreender o modelo administrativo do segundo Império partindo do aprendizado e saber do próprio bacharel é de grande auxílio para entender como a cultura jurídica brasileira traduziu na academia as estruturas jurídicas administrativas estrangeiras pelo país, notadamente, o sistema administrativista francês ${ }^{3}$.

Em segundo lugar, há a questão que divide o Direito em privado e público. A escolha pelo Direito Administrativo - ao invés da cadeira de Direito Romano, também recém-criada, então, em 1854 - é justamente para compreender a visão publicista do bacharel quanto a vida pública e o Estado, se seria uma noção não interventora do Estado ou já com conceito mais disciplinar-regulamentar ou, ainda, num nível intermediário.

Desse modo, a limitação do tema da investigação da produção da cultura jurídica somente ao Direito Administrativo permite aprofundar o conhecimento da produção de um saber jurídico de vital importância tanto para a compreensão da vida acadêmica como também da própria vida política brasileira daquele período, tendo o bacharel como principal elo nesta compreensão.

E, tratando sobre a divisão dos capítulos, primeiramente será discutida a participação do bacharel na formação da cultura jurídica brasileira, ao que segue uma análise de documentos históricos que explicitam a dinâmica da rotina metodológica de ensino específico da academia do largo de São Francisco com atenção para criação da cadeira de Direito Administrativo e, por fim, apresenta-se a análise de dissertações de

\footnotetext{
${ }^{3}$ A HISTORY of the Philosophy of Law in the Civil Law World, 1600-1900. In: HOFMANN, Hasso; GROSSI, Paolo; CANALE, Damiano (org). A treatise of legal philosophy and general jurisprudence, NewYork: Springer. v. 9, cap. 6. p. 240-241.
} 
Direito Administrativo escritas pelos estudantes, bem como o seu diálogo com a produção de cultura jurídica na área administrativa.

O primeiro capítulo se inicia com a delimitação de uma hipótese do conceito de "cultura jurídica" que fosse pertinente a nesta dissertação. Por uma questão metodológica, a ideia é partir de um conceito base parcial e a contento para a conjuntura desta pesquisa histórica ${ }^{4}$. Nesse sentido, utilizaremos o conceito de cultura jurídica apresentado por Ricardo Fonseca ${ }^{5}$, mas de uma maneira mais extensiva, guiada pelas discussões traçadas por Antonio Hespanha ${ }^{6}$, por um lado, e instigada pela discussão sociológica do pluralismo jurídico inspirado numa nova lida da hermenêutica jurídica de autores como Boaventura de Souza Santos ${ }^{7}$, por outro, de forma a estimular novos parâmetros semânticos.

Assim, cultura jurídica para esta pesquisa, conforme se aprofundará no capítulo primeiro, é toda a produção jurídica que inclui elementos sociais, econômicos, doutrinais e discursivos que circulavam não só nas instituições jurídicas, mas em quaisquer níveis sociais e conjunturais que pudessem dar tipicidade ao Direito brasileiro. Nesse sentido, produziu-se, em algum nível, cultura num centro institucional de efeitos gerais, como o Conselho de Estado e, também no contexto local de uma província com pouca expressão política, mas que solucionava seus problemas sociais com uma solução jurídica própria e não oficial. A diferença de nível para a compreensão destes vários âmbitos de produção de cultura jurídica, que esbarra na dominação das fontes escritas, no estudo do modelo institucional, no conceito de sociedades complexas e simples, é o maior problema para desenvolver uma definição como esta.

Em acréscimo, podemos considerar que o Estado burocrático que se formava no Brasil oitocentista, muito embora almejasse o legalismo e proporções ambiciosas do controle jurídico institucional, havia diversas fontes do Direito que se alastravam nos

\footnotetext{
${ }^{4}$ KOSSELECK, Reinhart. Futuro passado: contribuição semântica dos tempos históricos. Rio de Janeiro: Contraponto: Ed. Puc-Rio, 2006. p. 104-118.

${ }^{5}$ OS JURISTAS e a cultura jurídica brasileira na segunda metade do século XIX. in: Quaderni Fiorentini per la storia del pensiero giuridico moderno, Milano, Giuffrè, n. 35, 2006. p.339-343.

${ }^{6}$ CATEGORIAS: uma reflexão sobre a prática de classificar. Análise Social, v. XXXVIII (168), 2003. p. 823-840; Op. cit, p. 55-60.

${ }^{7}$ NOTAS sobre a história jurídico-social de Pasárgada, in: SOUTO, Claudio \& FALCÃO, Joaquim (org.), Sociologia e Direito. São Paulo: Livraria Pioneira Editora, 1980.
} 
confins espaciais de um imenso país ainda em construção. E, portanto, a lei real é apenas uma entre muitas normas jurídicas existentes, e é por este motivo que nos deparamos com um conceito de cultura jurídica aberto, que possibilita o diálogo dinâmico da construção de pensamento jurídico administrativista em um microcosmo por excelência institucional, tal como a faculdade de Direito de São Paulo com quaisquer fontes históricas do Direito que influenciassem na organização jurídicoadministrativa.

Após, tratamos da bibliografia brasileira existente sobre o tema do bacharel no período imperial brasileiro, particularmente a literatura que estudou o desenvolvimento do ensino jurídico na cidade de São Paulo, nesse período inicial da segunda metade do século XIX. Isto porque, é necessário verificarmos se é possível partir da proposição de que havia cultura jurídica produzida nas faculdades do império. Este, em verdade, é um tema controverso sobre o qual se deve avançar para poder estudar as fontes $\mathrm{e}$ compreender a dinâmica de produção de conhecimento jurídico administrativista dentro da faculdade daquele período. Assim, passamos justamente à segunda parte do capítulo inicial: o que autores asseveram sobre o perfil bacharel, ou melhor, acerca da participação político-jurídica do bacharel na construção da cultura jurídica brasileira.

Isto porque não é possível discutir a edificação de pensamento na escola de Direito paulista sem conhecer melhor seu principal protagonista neste estudo. Para tanto, dá se destaque ao material desenvolvido por Venâncio Filho ${ }^{8}$, Sérgio Adorno ${ }^{9}$ sobre o papel do bacharel na produção de cultura jurídica no período imperial.

Este estudo da literatura permite apontar informações relevantes não só sobre o estudo acerca deste personagem relevante para a construção das ideias brasileiras, mas também sobre o cotidiano metodológico jurídico da faculdade. Além disso, também aponta para o interesse advindos do governo central em manter, em certa medida, o controle científico e político dentro da faculdade de Direito a fim de que se mantivesse o poder simbólico ${ }^{10}$ do Direito dentro dos ditames da camada dominante, ou seja, uma estudo piano, não tão avançado doutrinariamente, preso ao ranço de obras antigas e que

\footnotetext{
${ }^{8}$ FILHO, Alberto Venâncio. Das arcadas ao bacharelismo. 2 Ed., São Paulo: Perspectiva, 2005.

${ }^{9}$ ADORNO, Sérgio. Op. cit.

${ }^{10}$ BOURDIEU, Pierre. O poder simbólico. 16 Ed., Rio de Janeiro: Bertrand Brasil, 2012. p 209-254.
} 
perpetuava uma análise interpretativa dos estudantes coerente ao modelo jurídicoadministrativo instalado.

Quanto ao segundo capítulo, este responde pela análise de dois âmbitos que se entrelaçam. Primeiro, o estudo do que se produziu na cultura jurídica administrativa no século XIX no âmbito da doutrina e do Conselho de estado. Para tanto, utilizar-se-á o material analisado por Maria Sylvia Zanella di Pietro ${ }^{11}$, de José Reinaldo Lima Lopes ${ }^{12}$ e de Walter Guandalini $J r^{13}$, que apresentam aspectos relevantes tanto sobre a interpretação jurídica, como de teorias administrativistas que predominavam naquele período.

Segundo, realizamos o estudo do cotidiano de ensino da faculdade, com especial atenção para aspectos relação entre estudante e professor e para o processo de habilitação acadêmica do estudante para que passasse de ano, ou seja, os exames, as sabatinas $^{14}$, as dissertações, as lições ${ }^{15}$, as faltas e tudo que fosse necessário para tanto. Esta segunda parte do capítulo se divide em seis partes: a relação entre o governo e a faculdade, os compêndios, os professores, a formação histórica da cadeira de direito administrativo, dinâmica entre a faculdade e a sociedade pelo estudante e a ratificação acadêmica.

Os documentos históricos em análise são, principalmente, a legislação, para tratar acerca do aspecto formal e o material de memória aprimorado pelas tradições e reminiscências de Almeida Nogueira e de Spencer Vampré. Outros materiais históricos serão utilizados residualmente, mesmo porque o quantum informativo destas duas fontes primárias é de um grande arsenal de possibilidades para pesquisa. Em meio às "estudantadas"16 dos alunos e "broteradas"17 de professores, ambos estes materiais

\footnotetext{
${ }^{11} 500$ ANOS de Direito Administrativo brasileiro. in: Revista da Procuradoria Geral do Estado da Bahia. Brasília: ENAP, v. 26, n. 2, 2000. p. 29- 54.

${ }^{12}$ LIMA LOPES, José Reinaldo. O oráculo de delfos: o Conselho de Estado no Brasil. São Paulo: Saraiva, 2010.

${ }^{13}$ GUANDALINI JR., Walter. Gênese do direito administrativo brasileiro: formação, conteúdo e função a ciência do direito administrativo durante a construção do Estado no Brasil imperial. Tese (Doutorado em Direito), Paraná: UFPR. 2011.

${ }^{14}$ Sabatinas são as tomadas de pontos pelos professores dos alunos.

${ }^{15}$ Lições eram em sala de aula.

${ }^{16}$ Conforme se verá, "Estudantadas" é a forma de Almeida Nogueira caracterizar as sapequices e as aventuras que estudantes da faculdade de São Paulo viviam.
} 
discorrem sobre informações cientificamente que apontam para diversos aspectos não só sobre a rotina da metodologia de ensino jurídico como também permite despontar aspectos da própria história social e da cultura.

Ambos os estudos sobre o cotidiano de ensino e das discussões jurídicoadministrativas serão relevantes para proporcionar a noção do tipo de ambiente a que estaria envolta a análise tanto da metodologia de ensino da faculdade, realizada na última parte do capítulo segundo, como também da produção das dissertações de Direito Administrativo.

Conforme demonstraremos no segundo capítulo, a análise entrelaçada entre o que determinava a legislação emitida pelo governo imperial e os estatutos aprovados pela congregação dos lentes da faculdade de São Paulo e o que indica essas memórias acadêmicas de Nogueira e Spencer permite juntar uma série de indícios que demonstram aspectos dinâmicos da construção da metodologia dentro da faculdade, que proporcionaria justamente a apreensão de um pensamento jurídico definido pelo estudante de Direito.

Quanto a isto, a parte final do capítulo segundo busca justamente traçar elementos que fariam parte dessa metodologia de ensino jurídico. Assim, primeiramente haveria o âmbito romântico da formação, ou seja, a produção de um pensamento sociocultural pelo estudante dentro do ambiente acadêmico. Este é seguido pela análise do âmbito técnico da didática de ensino da faculdade, que se trata justamente de dois aspectos essenciais para os estudantes desenvolverem seu pensamento jurídico: o uso da Retórica e, ainda, o modelo interpretativo ensinado majoritariamente pelos professores e compêndios utilizados. Por fim, há o âmbito semântico que proporcionava todo um sentido àquela instituição para houvesse esse processo de habilitação acadêmica dos estudantes para concluírem o ano e, ainda, um sentido aos estudantes para produzir a dissertação de Direito.

Dentre os aspectos conclusos dessa dinâmica análise do perfil metodológico apreendido na faculdade de Direito de São Paulo em meados do século XIX estão desde

\footnotetext{
${ }^{17}$ Conforme também se verá, o professor Brotero ficou conhecido também por Almeida Nogueira pelas suas "Broteradas", ou seja, estórias anedóticas de seu perfil irreverente e curioso.
} 
a noção da dissertação como gênero literário direcionado ao professor até a origem escolástica da Retórica utilizada na faculdade, a qual teria uma origem portuguesa. Ora, tal perfil metodológico possibilita, assim, que se atente para um horizonte mínimo no momento de navegar pela análise das dissertações de Direito Administrativo, no terceiro capítulo.

Assim, o último capítulo procura tratar sobre a hipótese de construção histórica da cultura jurídica do Direito Administrativo brasileiro a partir de uma análise de dissertações de alunos entre 1857 e 1870 na academia de São Paulo.

Ao se partir desta lógica, o capitulo 3 procura examinar o processo de produção de pensamento jurídico na academia de São Paulo a partir das dissertações de Direito Administrativo. Primeiro, passamos a fazer a delimitação geral e panorâmica das dissertações de administrativo existentes em todo o período entre os anos de 1857 e 1870, contabilizando-se 1209 dissertações de alunos que desenvolvem temas distribuídos em 23 theses ${ }^{18}$ diferentes conforme cada ano letivo, sendo duas theses distintas por ano.

E, assim, esta ampla moldura das dissertações possibilitará inferir algumas análises sobre temas de importância dogmática ou política presentes e, ainda, levantar aqueles que deixaram de serem lembrados pelo professor. Para isto, evidentemente, será necessário examinar pinturas diversas sobre o mesmo tema histórico - tanto no aspecto de construção do pensamento dogmático da ciência do Direito Administrativo, como no quesito mais político ou de funcionamento burocrático do Brasil - ou seja, apontar o conteúdo técnico desta pintura histórica, como também o contexto político-social de sua criação.

A título de exemplo, um tema relevante, e que foi tratado em 1857 e 1867 por duas theses distintas feitas pelo lente, foi a questão da descentralização no cenário político nacional era justamente, tópica esta que percorrera praticamente todo o século

\footnotetext{
${ }^{18}$ Theses são os temas apresentados pelos professores para serem desenvolvidos pelos estudantes em suas dissertações.
} 
XIX, de acordo com a análise de Miriam Dolhnikoff ${ }^{19}$. Esta considera que houve um pacto entre as elites locais com o governo central de forma a cederem ambos os interesses certos privilégios e organizações jurídico-administrativas a fim de manter tal organização descentralizada. Ao mesmo tempo, também foi um assunto retratado pela doutrina da época, pelo Conselheiro Ribas e o Visconde de Uruguai, de forma que consideraram haver no brasil se consagrado uma noção de centralização política, ou seja de concentração específica dos poderes de interesses públicos gerais para o governo central e de descentralização administrativa, com o controle reservado ao poder local de interesses que fossem particulares a tal âmbito.

Por fim, passamos para o segundo item deste último capítulo, qual seja, o exame específico de dissertações de Direito Administrativo. Para tanto, foi feita a escolha qualitativa e quantitativa das theses de forma a se analisar três temas distintos por três vezes com estudantes distintos, totalizando o número de nove alunos e, consequentemente, de nove dissertações. A escolha dos alunos seguiu com um processo aleatório, valorizando justamente o elemento espontâneo e do aluno-médio para o exame, em detrimento da análise de nomes famosos e tão-somente de "estudantões".

Assim, das 23 theses a que se teve acesso com a pesquisa panorâmica das dissertações de Direito Administrativo que encontramos na biblioteca central da faculdade de Direito da USP, escolhemos três temas tratados, mas com o exame de cinco theses, ou seja, em dois momentos há dois temas que se repetem, permitindo analisar duas theses diferentes sobre o mesmo tema. Nesse sentido, as temáticas escolhidas foram: "centralização governamental e administrativa", "contencioso administrativo" e, por fim, "relação da administração com os Poderes do Estado".

Este estudo necessitará da ajuda particular do compêndio do Conselheiro Ribas, já que fora o material oficial de estudo de Direito Administrativo pelos estudantes de ambas as faculdades de Direito.

Enfim, a dissertação procura concluir apontado positivamente pela hipótese de que houve não só um cotidiano acadêmico com uma complexa metodologia na

\footnotetext{
${ }^{19}$ DOLHNIKOFF, Miriam. O pacto imperial: origens do federalismo no Brasil. São Paulo: Editora Globo, 2007. p. 285-286.
} 
faculdade de São Paulo, que abarcava desde aspectos da formação sociocultural da época, como as atuações literárias e as "estudantadas" até um modelo técnico de apreender a interpretar e lidar com a lógica jurídica, de forma a consagrar nesse dinamismo de elaboração do cotidiano do ensino uma forma de pensamento definido àquele tempo e que era, ao mesmo tempo, dominada por um controle simbólico de quem detinha o poder. 


\section{Capítulo 1}

\section{A ACAdemia COMO ALICERCE da CULTURA JURídicA OITOCENTISTA}

Este capítulo objetiva aprofundar a compreensão sobre o tema histórico da cultura jurídica brasileira pela particular análise do cotidiano acadêmico da faculdade de Direito de São Paulo em meados do século XIX. Para tanto, parte-se da delimitação do conceito de cultura jurídica para chegar à literatura de base existente sobre o tema do bacharelismo no período imperial brasileiro, particularmente, o material que examinou mais a fundo o ensino jurídico no antigo convento de São Francisco, em São Paulo, nesse período inicial da segunda metade do século XIX, qual seja, "das arcadas ao bacharelismo", de Alberto Venâncio Filho ${ }^{20}$ e "aprendizes do poder", de Sérgio Adorno ${ }^{21}$.

Após retratar o que esta literatura contribuiu para a discussão sobre a cultura jurídica oitocentista no Brasil, apresentam-se alguns indicativos críticos feitos por Ricardo Marcelo Fonseca acerca das novas possibilidades de estudo de fontes históricas produzidas nas faculdades do império, particularmente a paulista, ao que se demonstra a necessidade de se construir novas pontes para interligar os documentos históricos e colaborar para a compreensão da dinâmica continental do pensamento jurídico brasileiro em dois âmbitos: tanto no que se refere a elementos que perpetuam um discurso e um funcionamento da academia resultante das relações de poder como da própria relação cotidiana da formação do pensamento jurídico na academia.

Particularmente em referência ao segundo ângulo, a análise da rotina do ensino jurídico da segunda metade do século XIX, esta pesquisa de mestrado pinçou elementos desenvolvidos por estes e outros autores e, logo em seguida, atentou-se para a necessidade de se avaliar os seguintes aspectos: (a) a metodologia do aprendizado jurídico; (b) a relação acadêmica entre o estudante e a faculdade de Direito; (c) a dinâmica do cotidiano de habilitação dos alunos no final do ano, a que se chamará nesta pesquisa de ratificação acadêmica.

\footnotetext{
${ }^{20}$ FILHO, Alberto Venâncio. Op. Cit.

${ }^{21}$ ADORNO, Sérgio, Op. Cit.
} 
No que se refere ao primeiro âmbito de análise, para também incitar o estudo num nível que trate sobre as relações de poder e a formação dos bacharéis, tema este relevante também para compreender a dinâmica da constituição do ensino jurídico e, portanto, para apontar aspectos da cultura jurídica brasileira do século XI, utilizar-se-á o material desenvolvido por Edmundo Campos, as "profissões imperiais",22. Este será o chamariz para se relacionar o tema do ensino jurídico com os interesses acadêmicojurídicos do poder simbólico de Bourdieu ${ }^{23}$, referencial teórico da pesquisa. Caminharse-á, então, para o segundo capítulo.

\subsection{A Cultura Jurídica e o Ensino Jurídico de São Paulo}

A dúvida central que se lança logo neste início de capítulo advém de duas querelas presentes em ambas as pesquisas sobre a História da cultura e do ensino jurídico brasileiro: como se compreende a cultura jurídica de um país historicamente tão multifacetário tal como o Brasil? E é possível afirmar que se desenvolveu, no segundo reinado, a produção de cultura jurídica no ambiente acadêmico?

Estes dois questionamentos formam a base metodológica de compreensão desta pesquisa, portanto se propõe aqui primeiramente um conceito base ${ }^{24}$ de significação histórica de "cultura jurídica", ao que se segue o exame mais a fundo sobre se se desenvolveu a produção de cultura jurídica na faculdade de São Paulo, ou seja, raciocínios e concepções de ideias genuinamente jurídicos, isto por meio da apresentação da discussão controversa da literatura acerca do bacharelismo oitocentista.

Esta pesquisa não procura solucionar tais controvérsias, mas sim formar uma base metodológica sólida para a estrutura do mestrado de modo a fomentar a

\footnotetext{
22 CAMPOS, Edmundo Coelho. Profissões imperiais: medicina, engenharia e advocacia no Rio de Janeiro 1822-1930. Rio de Janeiro: Editora Record, 1999.

${ }^{23}$ BOURDIEU, Pierre. Op. Cit.

${ }^{24}$ Não se trata de um conceito definitivo ou único.
} 
importância de se desenvolver novas pesquisas de fontes históricas e de aprofundar a problemática sobre a cultura e o ensino jurídico ${ }^{25}$.

Nesses termos, parte-se para a conceituação basilar de cultura jurídica. O seu significado histórico aqui desenvolvido abrange tanto um aspecto semântico técnico como sociológico, que se entrelaçam a fim de formar o conceito base utilizado na pesquisa. A primeira parte da definição de Ricardo Fonseca, que considera a cultura jurídica como "o conjunto de padrões que circulavam e prevaleciam nas instituições jurídicas brasileiras do Império (faculdades, institutos profissionais de advogados e magistrados, o foro e, em alguns casos, no parlamento), e que atribuíam alguma tipicidade ao Direito brasileiro" 26.

O autor não traz a cultura jurídica brasileira para o seu âmbito factual histórico, que abrange os mais diversos aspectos dos aparatos institucionais existentes na sociedade brasileira da época. Seu tom é de categorização dinâmica da cultura jurídica em seus diversos ângulos conflitivos e paradoxais de formação no século XIX, inclusive no que diz respeito à análise do discurso. Permite, assim, relacioná-la com os mais diversos aspectos antropológicos daquele Estado ainda em construção.

Ressalta-se, não obstante, que este aspecto técnico guarda em sua significação a relação da cultura jurídica com o social, o econômico, o dogmático e o humano. Sua semântica social está salvaguardada. Contudo, isto não significa que seja um conceito de cultura jurídica que tenha traçado definitivamente a sua noção sociológica, já que restringe o meio de emanação das fontes tão-somente ao que era institucionalizado pelo império. Ora, a própria análise interna da sociedade brasileira daquele período não permite que se limite o conceito de cultura jurídica aos prédios e à sociedade sob o domínio da corte e é por isso que esta pesquisa se apropria de um aspecto sociológico para, então defini-la.

Assim, muito embora pareça natural considerar suficiente tão-somente o aspecto técnico acima delimitado, já que a própria produção histórico-jurídica da

\footnotetext{
${ }^{25}$ KOSSELECK, Reinhart. Futuro Passado: Contribuição Semântica dos Tempos Históricos. Rio de Janeiro: Contraponto e Puc-Rio, 2006. p.104-118.

${ }^{26}$ FONSECA, Ricardo Marcelo. Op. Cit. p. 340.
} 
faculdade de São Paulo pode se incluída na categoria institucional, esta pesquisa considera que o conceito de cultura jurídica deve se permitir alcançar um diálogo para além das instituições padrão de produção do conhecimento jurídico. Por isso, expandese o conceito de cultura jurídica para um parâmetro de aceitação de produção histórica do Direito além do institucional ${ }^{27}$, admitindo a emanação periférica das fontes ${ }^{28}$.

Trocando em miúdos, o conceito de cultura jurídica a que se filia esta pesquisa abrange a produção jurídica imanente tanto dos ambientes institucionais do império como também de todo e qualquer meio que, para se sustentar socialmente, exalasse noções e instrumentos que se utilizavam de lógica jurídica. Esta construção semântica de cultura jurídica só tem sentido histórico quando concatenada com os diversos elementos sociais, econômicos, doutrinais e discursivos que dialogavam e circulavam nos variados níveis sociais e conjunturais que, em seu dinamismo, deram a tipicidade à cultura do Direito no Brasil oitocentista.

E isto permite compreender uma análise do discurso para além do controle centralizado do poder, posto que admite o pluralismo de vozes discursivas, inclusive da periferia social e política, muito embora esta não detivesse o controle da máquina do poder naquele período. Em verdade, o efeito desta concepção de cultura jurídica não é imediato para a pesquisa, que trata justamente sobre fontes históricas institucionais, mas permite abrir estas mesmas fontes para o diálogo com as eventuais emanações do Direito que não viessem da corte do Rio de Janeiro.

Nesse sentido, se se analisar, num primeiro momento, a these de Direito Administrativo apresentada para estudantes da faculdade de São Paulo dissertarem sobre "em que se distinguem o poder administrativo e o judiciário?", ela traz a discussão de uma problemática científica e jurídica predominantemente institucional, já que demanda o conhecimento técnico acerca de uma diferenciação dentro da estrutura governamental do Estado brasileiro, entre o poder administrativo e o poder judiciário.

Contudo, esta análise não deve desconsiderar um segundo plano mais complexo de compreensão da construção da cultura jurídica brasileira, posto que a via

\footnotetext{
${ }^{27}$ HESPANHA, Antonio Manuel. Op. Cit. p. 823-840; Op. cit, p. 55-60.

${ }^{28}$ SANTOS, Boaventura de Souza. Op. Cit.
} 
do exame tão-somente institucional não abrange, por exemplo, a discussão acerca da forma pela qual o juiz de paz e o governador litigavam entre si, envolvendo toda a comunidade local e inclusive da província de forma a resolver a questão muitas vezes não pelo meio formal ou institucional (encaminhamento para parecer do Conselho de Estado), mas sim pelo meio local de resolução de conflitos (acordo informal ou extra institucional). Assim, compreender esta dinâmica que existe entre todas as fontes relevantes para o meio do Direito, inclusive aquelas "não oficiais", possibilita uma noção conceitual mais completa e aberta da formação da cultura jurídica brasileira.

De outra sorte, podemos considerar que o Estado burocrático em formação no Brasil oitocentista, muito embora almejasse o legalismo e proporções ambiciosas do controle jurídico institucional, produziu diversas fontes do Direito que se alastravam nos confins de um extenso país ainda em construção. A lei real é apenas uma entre muitas normas jurídicas existentes, e é por este motivo que esta pesquisa absorve um conceito de cultura jurídica aberto.

Assim, muito embora não seja categórico afirmar, ainda neste primeiro passo da pesquisa sobre as dissertações de Direito da faculdade de São Paulo, que havia a produção de conhecimento jurídico dentro da faculdade de Direito voltada tanto para a discussão institucional como para querelas de âmbito local, esta pesquisa considerou relevante abranger esta posição semântica para, então, analisar com uma textura aberta de significação das fontes históricas principais para esta pesquisa, quais sejam, as dissertações de Direito Administrativo dos alunos da faculdade de São Paulo.

Todavia, embora esta conceituação acerca da cultura jurídica apresente uma hipótese possível para a compreensão histórica da construção do pensamento jurídico brasileiro, ainda não foi decidida sobre a segunda questão levantada no início deste subitem: sobre se se desenvolvera, no segundo reinado, a produção de cultura jurídica no ambiente acadêmico. Mesmo porque, a demarcação da relação entre cultura e ensino jurídico no império é uma temática controversa. A literatura diverge amplamente, desde aqueles que assemelham a semântica do conceito de cultura jurídica com o conceito de bacharelismo até quem desconsidere a relevância do ambiente acadêmico para esta produção de pensamento, desvinculando qualquer relação entre eles. 
No primeiro caso, por exemplo, o autor Nelson Nogueira Saldanha, que desenvolve um trabalho sobre a História das ideias políticas no Brasil, aborda esse fenômeno específico do "bacharelismo" numa conceituação mais mitológica presente na mentalidade nacional e, ao mesmo tempo, como um fator social essencial na formação das ideias no Brasil ${ }^{29}$. Ou seja, trata-se de um aspecto mais alegórico e imaginativo que fazia parte da sociedade.

Agora o teórico Roque Spencer Maciel de Barros considera o bacharelismo "uma das principais molas da ilustração brasileira, não era uma forma de alienação, mas um princípio civilizador" ${ }^{30}$. Ambos estes autores colocam a importância histórica do bacharelismo na formação não só da cultura jurídica, mas da própria civilização brasileira, o primeiro de uma forma mais imaginativa e o segundo de uma forma mais concreta.

De outro modo, há autores que veem negativamente a influência do fenômeno do bacharelismo na formação das ideias em geral do pensamento brasileiro. Nomes como de Gustavo Barroso e Oliveira Vianna trazem o papel do estudante de Direito para uma discussão crítica da sua alienação social, do idealismo utópico, do pretenciosismo do saber, do mal cultural, das doutrinas deletérias, dos formalismos acadianos $^{31}$. Estes autores sequer consideram a possibilidade de tal personagem histórico ter, em algum momento, produzido cultura jurídica e, ainda, haver se formado em meio a um cotidiano de pensamento jurídico. Portanto, afasta qualquer semelhança semântica entre estes conceitos.

Já Afonso Arinos de Melo Franco ${ }^{32}$, diversamente, define o bacharelismo pela sua diferenciação com o "juridicismo", pois este fenômeno é representado pelo personagem histórico do Direito, o jurista, enquanto que aquele é reproduzido pelo

\footnotetext{
${ }^{29}$ SALDANHA, Nelson Nogueira. História das ideias políticas no Brasil. Recife: Imprensa Universitária da UFPE, 1968. 53p.

${ }^{30}$ BARROS, Roque Spencer Maciel de. A ilustração brasileira e a ideia de universidade. São Paulo: USP, 1959. 25p.

${ }^{31}$ Apud ALENCASTRO, Luiz Felipe. O fardo dos bacharéis. São Paulo: Novos Estudos Cebrap, n. 19, dez. 1987. p. 68-72; BARROSO, Gustavo. História secreta do Brasil: primeira parte: do descobrimento à abdicação de D. Pedro I. 2 Ed. São Paulo: Nacional, 1937.; MOTA FILHO, Candido, A vida de Eduardo Prado, Rio de Janeiro: livraria J. Olympio, 1967.; VIANNA, Francisco José de Oliveira, $O$ idealismo da constituição. 2. Ed. São Paulo: Nacional, 1939.

${ }^{32}$ FRANCO, Afonso Arinos de Melo. A alma do tempo: memórias, formação e mocidade, 1 Ed., Rio de Janeiro: J. Olympio, 1961.
} 
conhecedor das leis, o bacharel. Para este autor, portanto, o jurista produziu cultura jurídica enquanto que o bacharel participou dos campos de atuação política. Portanto, para este autor, há um tipo específico de profissional jurídico que produziu cultura jurídica: o jurista.

Não obstante, esta pesquisa não procura solucionar este embate acadêmico, mas, de qualquer forma, necessita definir o alcance de seu objeto de estudo, posto que se considerar afirmativa ou negativamente a importância das faculdades de Direito na produção de cultura jurídica altera profundamente o modo de analisar a dinâmica de aprendizado e de aprovação dos estudantes para serem bacharéis.

Os problemas metodológicos de se acatar a posição negativa da literatura sobre a produção de conhecimento jurídico relevante nas faculdades do império são de duas ordens: primeiro, no plano interno de análise das fontes, este posicionamento que desconsidera o pensar jurídico na academia prejudica a compreensão dinâmica e aberta não só das dissertações como do material que trata acerca do que se chamou, anteriormente, de ratificação acadêmica, pois vê no ensino jurídico do século XIX tãosomente sua face caótica e desqualificada, abafando qualquer nova faísca documental que aqueça esta área de pesquisa.

E, em segundo lugar, preterir a possibilidade de elaboração de raciocínios jurídicos dentro da academia em prol da análise exclusiva de outras fontes históricojurídicas, tais como os julgados dos tribunais ou pareceres do Conselho de Estado, prejudica a compreensão dinâmica destas mesmas fontes, pois acaba por deixar uma lacuna na análise da construção da cultura jurídica do século XIX. Isto não só porque os bacharéis faziam parte majoritária do corpo burocrático do Estado, mas também porque é relevante comparar quais os principais temas da área de Direito Administrativo perseveravam em um órgão tal como o Conselho de Estado e que também estavam presentes nos estudos dos alunos de Direito. Deste exame é possível depreender diversas novas hipóteses de análises acerca da construção da cultura jurídica e ela só é possível se se admitir a hipótese de que havia produção de cultura jurídica numa faculdade de Direito do império como a de São Paulo. 
Mas como se trata esta de uma temática cara à pesquisa, pois envolve um dos fundamentos hipotéticos para a investigação das fontes, reservou-se nos próximos subitens espaço para esmiuçar as principais teorias da literatura acerca do ensino e a produção de pensamento jurídico no século XIX, bem como para tratar sobre os interesses daqueles que detinham o poder institucional e econômico em manter um tipo específico de metodologia de ensino jurídico.

\subsection{O Bacharel e o Mito}

Conforme se demonstrou acima, o conceito de "bacharelismo" é utilizado com diversos sentidos e diferentes ângulos de análise pelos estudiosos sobre o tema do ensino do Direito. Em verdade sua significação carrega toda uma mistura semântica que foi se enovelando com o passar da História brasileira, podendo-se nos dias atuais suscitar ainda elementos que perduraram e, ao mesmo tempo, constatar-se que já não são preservados alguns efeitos de sentido que existiam no passado. Em verdade, a palavra e a coisa nunca se encaixaram completamente quando se compara a literatura existente acerca do tema. Inclusive, porque há certa confusão, no século XIX, da noção de "bacharelismo" com o próprio conceito de "bacharel", com a delimitação de "cultura jurídica" e mesmo com a organização do Estado.

Assim, este subitem apresenta uma alternativa para compreender o fenômeno do "bacharelismo" por meio da caracterização do próprio bacharel por parte da literatura existente sobre ensino jurídico. O estudo crítico da tipologia existente sobre o bacharel, com destaque para o perfil traçado por dois autores centrais, Venâncio Filho e Adorno, possibilitará vislumbrar o entendimento tradicional que existe acerca do ensino jurídico oitocentista, bem como a compreender sua contribuição para a construção da cultura jurídica oitocentista brasileira.

Isto porque a produção de conhecimento dentro da academia de Direito era um parte de emanação das diversas fontes que edificavam a cultura jurídica oitocentista brasileira, de modo que envolvia o personagem histórico do bacharel, a estrutura organizativa do Estado e, ainda, se formava politicamente pelo fenômeno do bacharelismo. Portanto não há que se confundirem tais conceitos, muito embora eles dialoguem entre si e complementem o sentido de cultura jurídica. Em verdade, para 
compreender esta dinâmica, somente pelo esforço de análise das fontes históricas poderse-á aprimorar o limite entre o conceito e a mitologia envolta ao fenômeno do bacharelismo.

Logo, esta pesquisa não foi instigada a realizar mais uma classificação do bacharelismo, mas sim a observar hipóteses de perfis dos bacharéis, particularmente um específico. Dentre elas, nomes como Gilberto Freyre ${ }^{33}$, Sérgio Buarque de Hollanda ${ }^{34}$, Raimundo Faoro ${ }^{35}$, Sérgio Adorno ${ }^{36}$ e Alberto Venâncio Filho ${ }^{37}$ aparecem com trabalhos acadêmicos respeitosos sobre o tema, mas de âmbito qualitativo mais geral sobre o bacharelismo.

Destes, somente Adorno realizou um grande levantamento bibliográfico sobre a rotina dos estudantes da faculdade de São Paulo entre meados de 1830 e 1870, ainda que mais atento ao quesito extracurricular, na produção jornalística estudantil. Este autor, que realizou uma análise mais especializada de parte da obra de Venâncio Filho, representa uma leitura particular acerca da caracterização do bacharel, a que se dará destaque aqui. Em outra medida, pelos outros autores supracitados são realizados estudos mais gerais sobre o ensino jurídico e a rotina do bacharel, sem aprofundar a análise das fontes históricas existentes nas faculdades do império.

Contudo, nenhum deles realizou um estudo que demonstrasse o que ocorria nas salas de aula, como era a rotina de aprovação dos estudantes, sobre o que tratavam os compêndios feitos pelos lentes e as postillas, materiais feitos pelos alunos para estudo. De acordo com Ricardo Fonseca ${ }^{38}$, deve haver uma releitura sobre o tema do bacharelismo no Brasil por meio da análise das fontes, pois muito desta literatura já produzida acaba por apresentar tão-somente um ângulo de análise acerca do bacharel que não guarda um sentido completo com a realidade histórica.

\footnotetext{
${ }^{33}$ FREYRE, Gilberto. Sobrados e mucambos: decadência do patriarcado rural e desenvolvimento do urbano. 2 Ed., II Tomo, 3 v, Rio de Janeiro: Livraria J. Olympio Editora, 1951.

${ }^{34}$ HOLLANDA, Sérgio Buarque de. Raízes do Brasil. 13 ed., Rio de Janeiro: J. Olympo, 1979.

${ }^{35}$ O ENSINO jurídico no Brasil e as suas personalidades históricas: uma recuperação de seu passado para reconhecer seu futuro. in: Ensino Jurídico OAB: 170 anos de cursos jurídicos no Brasil. 1 Ed., Brasília: Conselho Federal da Ordem dos Advogados do Brasil, 1997. p. 35-55.

${ }^{36}$ ADORNO, Sérgio, Op Cit.

${ }^{37}$ FILHO, Alberto Venâncio, Op. Cit.

${ }^{38}$ Op. Cit. p. 365.
} 
De qualquer modo, pela análise atenta a todos estes grandes nomes da pesquisa histórico-sociológica brasileira, foi possível depreender que o modelo de bacharel existente no século XIX apresentado por estes autores se subdivide em três paradigmas principais. Discorrer-se-á primeiramente acerca de dois deles e, por fim, tratar-se-á com um exame mais a fundo acerca do terceiro tipo de bacharel, apresentado justamente por Sérgio Adorno e Alberto Venâncio Filho.

Isto porque, primeiramente, estes apresentam uma análise de fontes históricas mais específica e detalhada com relação à metodologia de ensino aplicada nos cursos jurídicos quando comparada com aquela realizada pelos demais e, ainda, porque esta terceira forma de caracterizar o bacharel abrange o estudo do cotidiano da construção do pensamento dentro das faculdades do império. Notadamente Sérgio Adorno faz sua extensa pesquisa sobre a própria faculdade de São Paulo, o que será relevante para esta investigação, conforme se depreenderá.

Assim, o primeiro tipo é o bacharel ornamental. Aqui, a tese principal é que o ensino dado ao estudante de Direito representa uma cultura de fachada na sociedade brasileira, pois faz parte de um longo processo histórico de erudições e de formalismos culturais que pretendem ocultar segregações e desarranjos sociais. Nesse sentido, poucos realmente utilizavam os conhecimentos recebidos durante o curso em sua vida prática, mas sim se limitavam a aprender citações eruditas e afrancesadas sem ter real conhecimento das demandas do contexto a que estava inserido.

Isto significa que o bacharel se limitava a compreender muitas exacerbações intelectuais e formalismos, mas com poucos conhecimentos práticos para a atuação na vida cotidiana da sociedade. Ou seja, era como se estivessem os alunos desvinculados do dinamismo dos acontecimentos sociais e resistentes a mudanças, pois escondiam uma institucionalidade de privilégios econômicos e complexas desigualdades sociais embaixo de um manto de ponderação política e neutralidade.

Esta tese sobre o bacharel critica a representação ilusória de uma premissa defendida por intelectuais participantes do poder político que imaginavam ser responsabilidade do ensino moldar a sociedade e não o contrário. Portanto, não compreenderiam estes que a própria sociedade, em suas relações e conflitos, define seus 
valores $^{39}$ e, só então, consegue determinar os instrumentos possíveis de mediá-los. E são os cursos jurídicos desse período uma absoluta representação desse pensamento social de parte da camada dominante.

É baseado nesta ideia que se perpetuou no imaginário do povo brasileiro a relação enraizada do bacharel com a ideia de poder, como se fosse uma "habilitação" para o exercício do poder. E este bacharel ornamental seria um intelectual jurídico de fachada, pois não dialogava com o cotidiano social e não tinha conhecimento crítico para dar uma utilização prática ao sistema jurídico a invés de só perpetuar artificialismos, imitações (in)conscientes e impensadas de estruturas estrangeiras.

Este primeiro grupo de ideias críticas sobre o ensino jurídico do segundo império brasileiro denota duas questões essenciais: que o título de bacharel é mais um instrumento de poder do que a produção de uma cultura jurídica; e que o bacharel perpetua uma curiosa herança colonial de ascensão ao poder de nobres por moldes liberais, em outras palavras, o bacharelismo era a legitimação liberal de conservadores no poder.

Esta crítica tão ferrenha ao bacharel advém de relevantes autores como Sérgio Buarque e Gilberto Freyre, defensores da tese de que havia uma produção de cultura jurídica no período oitocentista frágil e dependente de interesses políticos pela manutenção de relações personalistas e paternalistas do poder.

Primeiramente, Sérgio Buarque ${ }^{40}$, em "raízes do Brasil", utiliza o termo bacharelismo para relacioná-lo com as questões históricas nacionais ligadas ao personalismo e ao patrimonialismo brasileiro. Ou seja, demostra que o bacharel faz parte de todo um sistema social cheio de paradoxos e com sérias reminiscências do período colonial e, como que num reflexo disto, representa uma forte necessidade dos intelectuais brasileiros se utilizarem ao mesmo tempo na formulação de suas ideias doutrinas distintas e contraditórias, desde que fossem sedutoras.

\footnotetext{
${ }^{39}$ EDUCAÇÃO e modernidade no Brasil, in: Cultura Vozes, São Paulo. v. 93, n 1, 1999. p. 122-145.

${ }^{40}$ HOLLANDA, Sérgio Buarque de. Op. Cit. p. 113-117.
} 
Mas assevera que não é situação exclusiva do Brasil a presença do bacharel na vida política e cultural de um Estado, exemplificando o caso da independência dos Estados Unidos que também foi repleta pela presença dos bacharéis e, ainda, relaciona esta tradição a uma origem portuguesa.

Quanto à questão da profissionalização dos estudantes de Direito, por exemplo, afirma que o trabalho, neste país, representa um mero acidente na vida dos indivíduos, pois a satisfação destes não se encontra no resultado ou no esforço laboral, mas sim na própria pessoa. Nesse sentido, são raros os advogados que se contentavam com sua profissão, pois sempre estavam tentando alcançar outros postos com mais elevado status social e material. E isto seria uma das causas de inúmeros bacharéis ocuparem vários cargos, mas sem exercê-los adequadamente.

Portanto, haveria a ambição pessoal de muitos indivíduos de obter diplomas de bacharéis tão-somente para almejar os cargos superiores, constituindo-se esta como uma herança que permanece no pensamento da sociedade brasileira: formar-se advogado era um bom sinal social, pois isto garantiria segurança e estabilidade. Ao mesmo tempo, também é remanescente nesta sociedade um tipo de pensamento personalista, ou seja, uma valoração do "eu" em detrimento do coletivo, por exemplo, no modo de atuação com pouco esforço pessoal de muitos indivíduos em cargos públicos.

Por fim, Sérgio Buarque discorre sobre uma característica que considera muito marcante na realidade erudita brasileira - também um modelo a ser seguido pelos bacharéis - qual seja, a valorização excessiva de ideias com formas fixas, genéricas e, em contrapartida, o desprezo por pensamentos vagos, indagativos ou que meramente obriguem qualquer necessidade de esforço mental e de limitação aos valores pessoais.

Ora, esta obra do autor traz três elementos do próprio pensamento brasileiro e, junto a isto, da produção de cultura jurídica pelo bacharel, quais sejam, a produção de saberes contraditórios; o personalismo e o patrimonialismo; e o desprezo pelo esforço mental. Assim, o pensamento do bacharel brasileiro valoriza a produção de cultura jurídica de fachada, elitizada, personalista, ornamentada, desligada de qualquer atuação coletiva ou de interesse verdadeiramente público que não fosse para benefício próprio. E isto não quer dizer que inexistia uma cultura jurídica, mas tão-somente que esta era 
um frágil e contraditório resultado de todo o processo histórico colonialista e de manipulação superficial dos saberes do Direito.

Agora, em relação à tese desenvolvida por Gilberto Freyre em seu trabalho "sobrados e mucambos" ${ }^{41}$, que retrata a formação de um elemento intermediador da nova sociedade que estava se desenvolvendo no século XIX, qual seja, o mulato. Há, em alguma medida, um paralelo sobre esta função mediadora do mulato nas relações entre o escravo e os senhores, que agora se davam nos mucambos e grandes sobrados da cidade, e o bacharel, pois este seria intermediário dos interesses e das disputas políticas pelo poder.

Com o passar do tempo no século XIX, foi crescendo o prestígio do bacharel nos meios urbanos e rústicos. O autor denota que era possível observar, em jornais e revistas, avisos sobre bacharéis ou doutores formados, como se anunciassem de forma inconsciente um novo poder que se formava no Brasil: a aristocracia de toga, distinta daquela antiga ruralista. Nesse sentido, constituir-se-iam como importantes mediadores entre as novas segregações e os antigos autoritarismos que ainda perpetuavam, particularmente, em cidades como São Paulo.

Assim, Gilberto Freyre defende a hipótese de que não havia uma produção de pensamento jurídico nas faculdades de Direito que formasse bacharéis preparados para a realidade brasileira, mas tão-somente eram perpetuados os estudos com a transposição de doutrinas e teorias estrangeiras que pouco poderiam auxiliar na prática jurídica nacional.

Desse modo, o bacharel era um tipo histórico utilizado como instrumento político para manter a suposta acomodação entre os antagonismos sociais, e não um resultado desse antagonismo, conforme se verifica em Sérgio Buarque. O primeiro caracteriza o estudante de Direito como um tipo distante da realidade social e representante de um domínio intelectual baseado nos ditames europeus, particularmente franceses e, assim, pouco atentos para questões de importância brasileira.

\footnotetext{
${ }^{41}$ FREYRE, Gilberto. Op. Cit. p. 951-960.
} 
O segundo tipo caracteriza o bacharel burocrático. Aqui, o único motivo que justifica a criação das faculdades de Direitos no Brasil é, tão-somente, formar o corpo de burocratas do Estado nacional. Então o bacharel faria parte do primeiro capítulo da burocracia brasileira. O século XIX, no Brasil, representou a vitória de um projeto conservador que estava disposto a acalmar os ânimos da luta pelo poder através de procedimentos burocráticos inerentes a uma dominação patrimonial. Assim, esta teoria, desenvolvida por autores como Raymundo Faoro, Wander Bastos e o próprio Sérgio Adorno retrata justamente o processo de evolução de um liberalismo conservador nas estruturas políticas e sociais do Brasil, sendo o bacharel representante da manutenção desse status quo, através de aspectos individualista, antipopulares e conservadores em geral $^{42}$.

Primeiramente, uma obra de âmbito mais tratadista sobre toda a História do poder no Brasil, que é o trabalho de Raymundo Faoro "os donos do poder" ${ }^{43}$, retrata de forma constante, desde o período colonial até os tempos ditatoriais do século XX, descrevendo todo o processo pelo qual a burocracia estamental se sobrepôs à atuação do Estado e, ainda, perpetuou as ideias coloniais sob a representação da elite através do bacharel.

Esta tese relaciona, de uma maneira geral, a formação do bacharel ao aparelho de Estado brasileiro e destaca que esta participação burocrática foi definida de forma premeditada pelas camadas da elite cultural dominantes, posto que teriam sido os cursos jurídicos tão-somente criados a fim de possibilitar o reinado dos bacharéis na burocracia do Império. Nesse sentido, o bacharel, o promotor, o juiz, junto com os parlamentares e demais estadistas, não foram criadores da ordem social e política, mas sim seus filhos legítimos. Ou seja, o sistema preparou escolas de Direito com o escopo de gerarem os letrados e os bacharéis para ocuparem os cargos da burocracia brasileira, regulando a educação de acordo com as suas exigências.

\footnotetext{
${ }^{42}$ WOLKMER, Antônio Carlos. História do Direito no Brasil. 3. Ed, Rio de Janeiro: Forense, 2002. 79p. ${ }^{43}$ FAORO, Raymundo. Os donos do poder: formação do patronato político brasileiro. 3. Ed, Rio de Janeiro: Globo, 2001.
} 
De fato, é de se admitir que inúmeros dos bacharéis formados na faculdade de Direito, ao menos de acordo com os dados trazidos por José Murilo de Carvalho ${ }^{44}$ e pelo memorialista Almeida Nogueira ${ }^{45}$, fizeram realmente parte do corpo burocrático do Estado. Contudo, discorda-se que tenha sido este o único papel do bacharel na sociedade e, tampouco, que a importância da produção de cultura jurídica do bacharelismo se tenha reduzido a só formar burocratas.

O autor Aurélio Wander Bastos, em seu trabalho "O Estado e a formação dos currículos jurídicos do Brasil" "46, esmiúça este tema tratado por Faoro de uma forma mais específica sobre a instituição das faculdades de Direito no Brasil a fim de formarem tão-somente burocratas. Nessa linha de pensamento, ele considera que a organização dos cursos jurídicos no Brasil foi absolutamente voltada a fim de atender os interesses e demandas do Estado em detrimento das expectativas judiciais da sociedade. Formariam burocratas estatais e não advogados ${ }^{47}$. Nesse sentido, o sistema preparava escolas para gerar letrados e bacharéis, necessários à burocracia, regulando a educação de acordo com suas exigências sociais ${ }^{48}$.

Assevera, também, que a formação dos cursos jurídicos no Brasil estava estritamente ligada à consolidação do Estado imperial e era resultado das expectativas das elites, bem como das contradições sociais. Mas em contrapartida, não desconsidera a possibilidade de produção de cultura jurídica para outros fins. Por exemplo, este autor dá uma orientação mais específica sobre como se dava o cotidiano de construção de pensamento jurídico por parte do bacharel, pois delimita que o chamado "advogado" deveria ser um bacharel mais voltado para as questões da origem do conhecimento jurídico, portanto era incentivado para o aprendizado do Direito Romano. Não obstante,

\footnotetext{
${ }^{44}$ CARVALHO, José Murilo de. A construção da ordem: a elite política imperial. Rio de Janeiro: Civilização Brasileira, 3. Ed, 2007.

${ }^{45}$ NOGUEIRA, J. L. Almeida. A academia de São Paulo tradições e reminiscências: estudantes, estudantes, estudantadas, 1827-1977. 1 Ed. v. 1-9. São Paulo: Vanorden, 1907.

${ }^{46}$ BASTOS, Aurélio Wander. Op. Cit.

${ }^{47}$ O ESTADO e a formação dos currículos jurídicos do Brasil. in: Os cursos jurídicos e as elites políticas brasileiras. Brasília: Câmara dos Deputados, 1978.

${ }^{48}$ FAORO, Raymundo. Os donos do poder: formação do patronato político brasileiro, 3. Ed. Rio de Janeiro: Globo, 2001. p. 464-465.
} 
quando se pretendia abrir a formação do bacharel para as questões gerais do Estado e da sociedade, era incentivado o aprendizado do direito público ${ }^{49}$.

Ou seja, ambas estas as análises, do bacharel ornamental e do bacharel burocrático traçam aspectos relevantes acerca de tal personagem histórico nacional, que participara vivamente, em meio ao contexto do primeiro e segundo reinado, da formação das ideias políticas brasileiras. Contudo, são estes perfis gerais, que não foram desenvolvidos pelo uso dos documentos históricos das academias imperiais, mas baseados em análises sociológicas e políticas de autores que procuraram em seus respectivos períodos compreender melhor a complexa construção da própria etimologia brasileira.

Portanto, sua influência é indireta, conforme se perceberá nas constatações do terceiro subitem deste capítulo. Sérgio Adorno, diferentemente, é um sociólogo que chegou até a origem das fontes para realizar o seu traçado acerca do bacharel. Este autor será mais relevante para a análise das fontes históricas feitas nos capítulos segundo e terceiro. Assim sendo, ele, junto com indicativos já anteriormente traçados por Venâncio Filho, caracteriza o terceiro tipo, do bacharel extracurricular.

Ambos os autores consideravam que existiria uma produção de cultura jurídica no ambiente acadêmico, contudo o aprendizado do estudante de Direito se restringiria ao ambiente da boemia cultural e da discussão política. Este é o retrato do bacharel totalmente desligado do ensino dentro da sala de aula e do estudo de livros, pois somente se envolvia na produção de um pensamento jurídico em favor de envolvimentos de declamação de poesias, de encontros na calada da noite, bem como na produção jornalística de forte atuação política.

Esta tese, desenvolvida de uma forma mais ampla pelo escritor Alberto Venâncio Filho e mais detalhada por Sérgio Adorno, defende que a formação e profissionalização estudantil ocorriam nos intervalos dos institutos acadêmicos, nos

\footnotetext{
${ }^{49}$ O ENSINO Jurídico no Brasil e as suas personalidades históricas: uma recuperação de seu passado para reconhecer seu futuro. In: Ensino Jurídico OAB, 170 anos de Cursos Jurídicos do Brasil. Brasília: Conselho Federal da Ordem dos Advogados do Brasil, 1997.
} 
debates sobre assuntos gerais e locais da política brasileira, compartilhando a noção de que o bacharel participava da vida política e cultural do país.

"Das arcadas ao bacharelismo" é uma obra muito significativa por ter criterioso resumo não só da História do ensino jurídico brasileiro como ainda aspectos da metodologia e do funcionamento da relação docente e discente consideráveis. Nesse sentido, traz várias informações que descrevem de uma forma geral como era o cotidiano do bacharel que se formou em meados do século XIX e, particularmente, também trata sobre a rotina da academia do largo de São Francisco. Para tanto, utilizase de diversas fontes primárias relevantes, como a legislação, discussões legislativas, os memorialistas Almeida Nogueira, Spencer Vamprée ${ }^{50}$, além de diversos estudantes daquela academia.

Não se pode afirmar que tenha sido um autor que tratou tão-somente sobre o aspecto extracurricular do bacharel, posto que dialoga também com as características presentes no perfil do bacharel ornamental e burocrático. Contudo, ele traz diversos indicativos relevantes, com a análise das fontes supramencionadas, os quais refletem o perfil do bacharel que teve grande parte de sua formação fora do currículo tradicional e da sala de aula.

Inicialmente, Venâncio Filho considera que havia grandes dificuldades de colocar em prática os cursos jurídicos no primeiro período monárquico, pois o país era muito carente de quadros humanos para preenchimento de vagas de professores e de equipamentos e lugares apropriados para a criação dos cursos, tanto que trouxeram alguns professores de Coimbra e utilizaram espaços religiosos para estabelecer as escolas de Direito. Junto a isto, existiria um problema burocrático de luta pela concentração do poder nas mãos do diretor em contrapartida com o governo central. Conforme se verá posteriormente, este problema foi mitigado em parte na segunda metade do século XIX.

Além disso, também se percebiam diversos problemas de âmbito metodológico na aplicação do ensino e da aprendizagem: ocorriam sérios desentendimentos entre os

\footnotetext{
${ }^{50}$ VAMPRÉ, Spencer. Memórias para a história da academia de São Paulo. São Paulo: Conselho de Cultura. v.1-2. 1977.
} 
docentes, denotavam-se fortes entraves na relação saudável entre os alunos e os professores, o que acompanhava um quadro perene de desleixo, péssima qualidade do ensino e de faltas de ambos os lados do corpo discente e docente ${ }^{51}$.

Assim, para este autor o aprendizado dos bacharéis era basicamente guiado por um grande espírito de praticidade ${ }^{52}$ - noção esta que contradiz a tese de Freyre - e uma considerável falta de capacidade abstrata e de teorização jurídica - confirmando a tese de Sérgio Buarque. Assim, o quadro era, de um lado, uma incapacidade dos professores de apreenderem novos métodos e de ensinarem recentes teorias evolutivas do Direito e, de outro, uma impossibilidade por parte dos alunos de compreenderem raciocínios lógicos.

Ora, apesar de Venâncio Filho considerar que o segundo reinado representou algumas transformações desse contexto, já que houve uma maior ramificação de áreas e de professores e um aumento relativo do controle da qualidade do ensino, ainda sim, descreve que se perseverou a precariedade da estrutura, a deficiência do interesse acadêmico tanto por parte dos estudantes como dos professores, estes que recebiam baixa remuneração e normalmente o magistério era visto como uma profissão subsidiária. $^{53}$

Há um apontamento interessante feito por ele, que denota alguma produção de pensamento jurídico, pois discorre que houve o desenvolvimento das ideias de autores como Savigny por estudantes como Teixeira de Freitas, ou seja, uma influência francesa no nosso corpo civil, bem como das ideias sociológicas do positivismo. Este é o primeiro dado relevante do autor sobre a produção de cultura jurídica nas faculdades de Direito $^{54}$.

Não obstante, considera que a produção cultural dos bacharéis estava localizada fora das salas de aula, nas discussões de pátio sobre literatura, política, na realização de um jornalismo acadêmico e de peças teatrais. $\mathrm{O}$ autor cita que havia uma considerável produção de discussões políticas em favor do abolicionismo e do

\footnotetext{
${ }^{51}$ VENÂNCIO FILHO, Alberto. Op. Cit. 28-50.

${ }^{52}$ VENÂNCIO FILHO, Alberto. Op. Cit. 51-69.

${ }^{53}$ VENÂNCIO FILHO, Alberto. Op. Cit. 112-160.

${ }^{54}$ VENÂNCIO FILHO, Alberto. Op. Cit. 280-296.
} 
republicanismo, por exemplo. Pode-se considerar esta como sendo a primeira grande tese apresentada pelo autor: a produção de cultura jurídica nas faculdades de Direito se localizava fora das salas de aulas e das lições acadêmicas.

A segunda tese apresentada por ele se refere justamente ao bacharel burocrático, pois discorre que, profissionalmente, os bacharéis formados iriam, na maior parte das vezes, trabalhar na burocracia do Estado, bem como participar da conjuntura política do país, tanto no partido liberal como no conservador. Formavam eles, assim a discussão elitizada e intelectual da política do país ${ }^{55}$.

Nesse sentido, retrata o autor de uma forma mais negativa os hábitos do bacharel no Brasil, confirmando o que Sérgio Buarque chamou de a "praga dos bacharéis", pois eram estes, em sua maioria, omissos em suas profissões, aumentavam a artificialidade formal das relações públicas, permaneciam exercendo uma função pública parasitária e, ainda, havia aqueles que propagavam uma deficiente política social, o que dificultava o desenvolvimento da sociedade brasileira.

Outro tema importante tratado pelo autor é sobre aquela diferenciação entre "bacharelismo" e "juridicismo". Primeiro, define bacharelismo como uma técnica jurídica aplicada ao meio político, portanto não possui qualquer ambição intelectual de teorizar ou filosofar o Direito, pois somente se preocupa com a agudeza prática para aplicação. Um exemplo deste tipo seria Rui Barbosa. Já o termo "bacharelice", acrescenta, seria a incapacidade de compreensão das sutilezas do raciocínio jurídico, ou seja, há bacharéis que não merecem a advocacia e há advogados que não merecem ser bacharéis $^{56}$.

Enquanto isto, o jurista tem maior capacidade indutiva, é mais observador da complexidade social e consegue realizar abstrações teóricas e formular novas ideias jurídicas. Portanto, seria o jurista parte do campo mais progressista do Direito, enquanto que o bacharel permaneceria num âmbito mais de conservadorismo, só respondendo aos ditames das leis. Ora, esta tese também é muito relevante nesta pesquisa para pensar se

\footnotetext{
${ }^{55}$ VENÂNCIO FILHO, Alberto. Op. Cit. p. 130-157.

${ }^{56}$ VENÂNCIO FILHO, Alberto. Op. Cit. p. 271-293.
} 
o estudante de Direito da faculdade de São Paulo retratava de alguma forma esses perfis sociais, portanto será mais densamente abarcada no terceiro subitem deste capítulo.

Conclui Venâncio Filho a sua obra considerando, num resumo da História do ensino jurídico brasileiro, que o bacharel tinha uma formação absolutamente inadequada nas faculdades de Direito e, junto a isto, tornou-se um profissional incapaz de corresponder social e economicamente às demandas do país. Este é um dos motivos históricos de este profissional, tão presente na política e cultura brasileira, ter sido substituído, conforme o tempo, em seu papel por engenheiros, economistas, administradores e tecnocratas em geral $^{57}$.

Tratada esta primeira obra, que possui uma grande aglomeração de ideias sobre o ensino jurídico brasileiro como um todo, é agora a vez de delimitar o trabalho "aprendizes do poder", do sociólogo Sérgio Adorno, que traz duas teses principais. Primeiro descreve o bacharel como um pivô de representação e manutenção política dos interesses das camadas dominantes em manter um liberalismo conservador no Brasil; e, em segundo lugar, assevera que a produção cultural jurídica do bacharel se dava também fora das salas de aula, no ambiente extracurricular, por meio da produção jornalística literária e política e era nesse meio que perpetuava os interesses políticos da camada dominante liberal-conservadora no poder.

Quanto à primeira tese, retrata Adorno que ocorria no processo de formação no Brasil a consagração de um modelo liberal peculiar, definindo-o como:

"processo de formação cultural e profissional dos bacharéis (...) no contexto da emergência da ordem social competitiva na sociedade brasileira e da solidificação do liberalismo econômico e político enquanto ideologia dos extratos sociais dominantes saídos vitoriosamente da revolução descolonizadora ${ }^{58, "}$.

Esta ideia procura demonstrar como a criação de cursos jurídicos ocorreu principalmente para atender às razões e aos interesses da alta camada imperial que, ao menos em termos ideológicos, possuía uma homogeneidade em defesa da manutenção

\footnotetext{
${ }^{57}$ VENÂNCIO FILHO. Alberto. Op. Cit. p. 302-336.
}

${ }^{58}$ ADORNO, Sérgio. Op. Cit. p. 19. 
das estruturas de poder. Nesse sentido, também é uma tese que dialoga muito com o perfil do bacharel burocrático.

Em outra medida, a segunda tese de Adorno defende que não haveria um pensamento jurídico desenvolvido na sala de aula, mas tão-somente nos intervalos e envolvimentos extracurriculares. Em outras palavras, a formação dos bacharéis não residiria no ensino-aprendizagem, mas sim nas condições sociais, intelectuais e culturais que transformaram o ambiente extracurricular da sala de aula ${ }^{59}$.

A vida acadêmica, desse período, nunca se restringira a atividades curriculares ou se sustentou com as relações didáticas entre alunos e professores. Ela ocorrera fora da sala de aula, pois os estudantes não só participavam de debates sobre assuntos nacionais, locais e mesmo cotidianos, como também articulavam alianças entre grupos partidários e promoviam campanhas. Constituíam comissões para tratar de assuntos variados ligados à academia e a fatos políticos e, assim, as suas associações desempenhavam o papel que deveria ser das salas de aula.

Dessa forma, teriam surgido os primeiros advogados democratas e defensores das liberdades civis e políticas, do abolicionismo e do republicanismo. Da mesma forma, perpetuavam um clima ideológico e artístico das arcadas, com uma busca pela erudição e identificação com a cultura europeia, principalmente a inglesa, a francesa e a alemã, pois utilizavam seus modelos de pensamento desenfreadamente. Assim, importavam-se eles com formas de pensamento de um modo abrupto e, sem pensar em sua aplicação prática na sociedade brasileira, em que se perpetuavam profundas e radicais diferenças com as nações europeias.

Assim, foram os bacharéis educados para formalismo, creditando à juridicidade como limitação de poder e fonte de legitimidade. Também nesses traços se sobressaíram a prudência e a moderação política, pois foi resultado do legado da academia aos bacharéis o aprendizado de que o segredo da harmonia na vida civil e política residia na descoberta de pontos de equilíbrio entre radicalismos contrapostos, entre os avanços da História e a precaução própria aos espíritos "práticos e reflexivos".

\footnotetext{
${ }^{59}$ ADORNO, Sérgio. Op. Cit. p. 91-156.
} 
A faculdade foi, assim, responsável por uma prática pedagógica comprometida com os processos de exploração econômica e de dominação política, distanciado o bacharel do exercício da função crítica ${ }^{60}$. Nesse sentido, desde o princípio os cursos jurídicos estavam preocupados em constituir uma elite política coesa, disciplinada, devota às razões do Estado e à frente dos negócios públicos a fim substituir a tradicional burocracia herdada da administração joanina.

Portanto, esta estrutura do ensino jurídico levou os estudantes a desconsiderarem o espaço das salas de aula como espaço responsável por sua profissionalização. Nesse sentido, era uma metodologia de ensino composta pelo autodidatismo, sem padrões mínimos e uniformes de pedagogia, bem como recheado de contradições ideológicas em relação ao corpo docente, de fundamentos filosóficos de origens distintas e contrastantes entre a academia formal e a real.

Considera, ainda, que pouco se referiam os bacharéis às normas legais ou à ordem jurídica em seu conjunto, citando como exemplo que as questões de "Direito Público" mencionadas pelos alunos eram as discussões políticas, partidárias e sobre as formas de governo.

Em vista a esse quadro demonstrado pelo autor, considera que não se constituiu a academia de Direito de São Paulo como um lugar privilegiado da produção da cultura jurídica liberal brasileira, ao menos durante o regime monárquico. Aliás, a única formação jurídica que destaca Adorno ter ocorrido nessa academia era a questão da visão contratualista e individualista por parte dos bacharéis em relação a quaisquer fenômenos jurídicos da sociedade ${ }^{61}$.

Conclui, assim que o segredo do ensino jurídico no império é que este nunca fora feito pelas ciências jurídicas. Menos que juristas, a academia de São Paulo formou bacharéis com uma militância política orientada por princípios intelectuais, que fez dessa vida intelectual uma convivência política.

\footnotetext{
${ }^{60}$ A FUNÇÃO social da dogmática e a crise do ensino e da cultura jurídica brasileira. in: Revista de Ciências Sociais, Rio de Janeiro: IUPERJ. 21, 1979. p. 87-113.

${ }^{61}$ ADORNO, Sérgio. Op. Cit. 27p.
} 
Diversas destas análises são muito relevantes para esta pesquisa, contudo se devem apresentar algumas ressalvas. Primeiramente, o fato de Adorno desconsiderar que a produção de uma cultura jurídica brasileira do século XIX na faculdade de São Paulo tinha sido um processo conjuntural, posto que afirma ter ocorrido desenvolvimento de pensamento jurídico só no contexto extracurricular, pois defende haver vários documentos históricos que o comprovam e, em contrapartida, pouca documentação que demonstre o aprendizado na sala de aula.

A investigação de fontes feita por este mestrado procura demonstrar que existem fontes parcamente trabalhadas que tratam justamente sobre o trato da aprendizagem entre o professor e o aluno e, ainda, que indicam um universo de possibilidades investigativas no que tange à formação do pensamento e da lógica jurídica dentro da faculdade de Direito de São Paulo, incluindo não só o ambiente externo como também interno. E, para tanto, a separação imaginária do que produzia juridicamente o bacharel, ou seja, a divisão entre o que ele produziria nas arcadas ou dentro das aulas seria prejudicial à compreensão do ensino jurídico e, consequentemente, de parte relevante da construção da cultura jurídica oitocentista brasileira.

Junto a isto se faz a segunda crítica à Adorno, particularmente, sobre a divisão das circunstâncias de aprendizado entre a academia real e formal, posto que considera a primeira justamente a produção de ensino fora da sala de aula e a outra era algo inexistente, já que a produção jurídica baseada nos ditames formais de metodologia propostos pela legislação de ensino jurídico era ínfima e não se comparava quantitativamente com a produção jornalística e literária dos bacharéis.

Discorda-se aqui que esta divisão entre o formal e o real seja tão óbvia. Muito embora seja ingênuo afirmar que os estatutos do Visconde de Cachoeira tenham sido seguidos em sua mais positiva intenção pelas faculdades de Direito, também não é categórico afirmar que foram completamente ignorados pelo cotidiano do ensino oitocentista. Por exemplo, Adorno desconsidera que houvesse um aprendizado por meio do método oral dentro da própria sala de aula e só delimita como cultura jurídica o pensamento escrito, mas fontes como de Almeida Nogueira e Spencer Vampré indicam 
a forte presença de sabatinas feitas pelos professores, inclusive delimitando a existência de provas orais em todos os semestres, não se distanciando tanto dos regulamentos da época.

E, afinal, é possível considerar que não havia qualquer produção de pensamento jurídico dentro da sala de aula em uma faculdade de Direito do Brasil oitocentista? Pois se fizeram provas, produziram sebentas ${ }^{62}$, criticavam as aulas dos professores, criaram memórias dos anos na faculdade, defenderam teses de doutorado e alguns até viraram professores, porque a afirmação de que perseverava um vazio na produção jurídica curricular do bacharel seria tão óbvia?

Ao mesmo tempo, são grandes os indícios nas fontes das dificuldades de ensino, de problemas graves de metodologia e de relacionamento entre os professores e alunos. Estes obstáculos do ensino jurídico oitocentista fazem parte das incoerências e adversidades por que o Brasil passou no século XIX, já que era um país politicamente em formação, socialmente elitista e academicamente despreparado para dar formação. E não que o quadro internacional fosse muito mais desenvolvido nesse aspecto metodológico.

Mas isto não significa que devam ser ignoradas as fontes que refletem justamente essa relação basilar da escola tradicional ocidental, quais sejam, os materiais utilizados para aprovação dos alunos no ano: as dissertações, as tomadas de lições, as sabatinas e a presença. Estes estudos de fontes potencialmente podem contribuir para a compreensão da formação da cultura jurídica brasileira.

Talvez o problema de fundo da tese de Adorno, afinal, seja justamente seu entendimento sobre o que é produção de cultura jurídica na sociedade brasileira ${ }^{63}$. Conforme se definira assim, quaisquer aspectos que fossem importantes para trazer a tipicidade ao Direito brasileiro devem ser considerados para compreender o que era a cultura jurídica oitocentista. Portanto, tanto a retórica aprendida nas arcadas no momento de discutir sobre um poeta como aquela utilizada para convencer o professor

\footnotetext{
${ }^{62}$ Sebentas, ou postillas, são os materiais produzidos e difundidos pelos estudantes sobre as aulas dadas pelo professor. Normalmente, havia os responsáveis em fazê-las em cada turma.

${ }^{63}$ FONSECA, Ricardo Marcelo. Op. Cit. 369p.
} 
no exame oral final sobre o que diz a legislação mais recente são relevantes. Nesse sentido, considera Ricardo Fonseca:

“(...) não parece adequado o procedimento de Adorno em separar o saber do jurista deste período do saber literário e retórico (sobretudo da cultura clássica), (...) separar a prática do jurista da sua atividade política e jornalística. Tudo isso formava uma unidade, que constituía a própria identidade do homem das letras jurídicas do século XIX.” ${ }^{64}$.

Nesse sentido, considera-se que este perfil traçado sobre o bacharel por Adorno tem sua importância em aprofundar a questão da produção jornalística e literária, inclusive por ser uma pesquisa de bibliografia consideravelmente extensa sobre o assunto. Entretanto, não consegue tal perfil apresentar uma visão multidimensional que a produção de cultura jurídica na academia merece.

Esta tese sobre o bacharel dialoga de uma forma positiva, mas truncada, com o primeiro perfil do bacharel ornamental, isto porque ambos defendem a produção literária e política do estudante de Direito, mas o primeiro o descreve como um formalista que escrevia de forma rebuscada e dava preferência às culturas francesas e inglesas enquanto que o segundo o retrata como o literato e poeta brasileiro, nacionalista e romântico.

Ao mesmo tempo, o estudante é descrito por Adorno é traçado com um perfil quase profissional de produtor de jornais políticos e que criticava em suas publicações toda a imoralidade e problemas da sociedade brasileira. De outra forma, o perfil do bacharel ornamental era descrito como afrancesado, supostamente neutro e desconhecedor das necessidades sociais do país.

Não obstante, existem estudos mais recentes sobre o ensino jurídico brasileiro que apresentam novos indicativos para compreender o perfil do bacharel. Ricardo Marcelo Fonseca ${ }^{65}$, por exemplo, que apresentou críticas à literatura tradicional sobre a sua forma de entendimento da História do Direito brasileiro e da produção de

\footnotetext{
${ }^{64}$ FONSECA, Ricardo Marcelo. Op. Cit. p. 366-369.

${ }^{65}$ FONSECA, Ricardo Marcelo. Op. Cit. 336-370.
} 
pensamento jurídico, abarca razoavelmente acerca do ensino jurídico e o aprendizado do bacharel no século XIX.

Primeiramente, ele parte da ideia de que os traços de cultura jurídica brasileira irão se formar num processo de tensão social, em que a leitura e a experiência do Direito ocorrerão interdependentes com as vicissitudes históricas nacionais ainda em formação, o que resultará nas características de uma cultura bastante próprias e que definirão, em parte, a identidade nacional.

Considera que tais paradoxos e dilemas são constituidores da condição de compreensão do pensamento jurídico brasileiro e, ao mesmo tempo, concorda que a criação dos cursos superiores foi o resultado da vontade das camadas dominantes de formar os quadros burocráticos e pensantes do novo Brasil, afastando-se também do modelo português, que nunca promovera qualquer forma de cultura em sua colônia ao contrário da colonização espanhola.

Não obstante, assevera que é somente a partir da segunda metade do século XIX em que se pode definitivamente destacar características de uma original produção de cultura jurídica brasileira, pois foi então que a formação dos professores já havia sido constituída aqui, mais distante e autônoma dos caminhos jurídicos que foram trilhados pela antiga metrópole, bem como porque já era possível se constatar o crescimento da produção de materiais acadêmicos a partir de 1850 .

É denotado por neste autor, ainda, alguns traços intelectuais marcantes do jurista brasileiro desse período. Por exemplo, no que tange à cadeira de Direito Natural, retrata Fonseca em seu artigo ${ }^{66}$ quais as concepções jurídicas que perfaziam esta área do conhecimento jurídico, um breve detalhamento biográfico e acadêmico do principal lente desse período, qual seja, Avelar Brotero $^{67}$ e sua falta de método e critério de ensino, que material este lente se utilizava para explicar as matérias e, apontando, ao final, um modelo característico de formação jurídica naturalista que perdurara mais de 40 anos na faculdade de São Paulo.

\footnotetext{
${ }^{66}$ FONSECA, Ricardo Marcelo. Op. Cit. 366-70

${ }^{67}$ BLAKE, Sacramento, Op. Cit. v. 5, 1899. 37p.
} 
Isto induz a considerar a hipótese de influência deste professor sobre a formação do pensamento de grande parte dos bacharéis formados nessa época histórica. Por exemplo, Fonseca considera perceptível que ocorrera a penetração problemática do racionalismo iluminista europeu no meio cultural do Direito brasileiro por meio de um ecletismo de concepções teóricas que dificilmente poderiam ser conciliáveis. Ou seja, era uma concepção escolástica de Direito Natural, algo que comprova a modernidade brasileira feita pela metade em razão de um filtro de ensino bastante conservador e préliberal.

Além dessa análise, o autor busca identificar o perfil do jurista quanto à sua postura diante dos saberes e da academia. Sua relação com a vida pública e com os saberes das ciências humanas: seu modo de agir como intelectual e seu papel na sociedade. Para tanto, desenvolve uma remota aplicação da ideia de que ocorreu, no Brasil, a passagem do estilo do jurista eloquente para o jurista cientista, desenvolvida por Carlos Petit.

Isto porque, inicialmente, para entrar nas faculdades, era necessário ao estudante passar por um processo preparatório de erudição de línguas e demais habilitações das "humanidades", ao mesmo tempo, que também a sua formação literária, jornalística e política seria relevante para caracterizar o perfil do bacharel. Este seria o jurista eloquente. Por outro lado, a partir dos anos de 1860, assevera Fonseca que surgia no Brasil um novo perfil de jurista, o jurista científico e aplicado às correntes acadêmicas de aprendizado.

Com esta panorâmica análise sobre hipóteses e indicativos relevantes aproveitados das fontes históricas acerca do ensino jurídico no século XIX no Brasil, conclui este autor que se faz necessário revisar algumas interpretações a fimm de atualizar esta discussão da produção de sua cultura jurídica.

Nesse sentido, realiza uma crítica à tese de Adorno, pois considera que este sociólogo perde de vista que o perfil do bacharel brasileiro do século XIX não era estranho a uma cultura assentada na oralidade e alheia à produção de conhecimento “impressa" e assentada numa linguagem 'científica' livre de arroubos eloquentes. Considera que um jurista de características românticas não deixa de ser jurista e de haver produzido sim pensamento jurídico. Assevera, ainda, não se poder defender que 
existia naquela época o posterior modelo de cientista acadêmico do século XX. Assim, estaria equivocado Adorno ao desconsiderar a produção literária e retórica do bacharel como parte da construção densamente complexa, mas ao mesmo tempo unitária do raciocínio jurídico da academia.

Portanto, encerra o autor considerando que escapa a Sérgio Adorno justamente se atentar para a definição de cultura jurídica utilizada, bem como que é baldado tentar separar a academia real da academia formal, pois tal dualidade não existia, ao menos no Brasil daquele contexto.

Parece, a esta pesquisa, que há alguns aspectos relevantes a se considerar para a análise das fontes nos próximos capítulos. Primeiramente, que cada área do conhecimento ensinada nas faculdades de Direito do império produziu documentos que revelam a forma de pensar e de raciocinar dos bacharéis, em parte pela sua formação político-literária, em parte pelos seus pré-requisitos retóricos, mas também em parte pela influência minimamente exercida pelas lições, sabatinas, sebentas, compêndios, aulas, provas orais e dissertações sobre o cotidiano acadêmico do aluno através de seu lente e da congregação de lentes.

Em segundo lugar, há uma questão importante para se refletir previamente antes de continuar com esta investigação: existiu ou não uma separação clara entre a cultura jurídica produzida pelo "bacharel" e pelo "jurista" em meados do século XIX? Ou seja, dividia-se o pensamento jurídico brasileiro oitocentista entre duas espécies distintas e nunca interligáveis, o bacharelismo, postura do advogado, e o juridicismo, atitude do jurista?

Se se observar o que considera Afonso Arinos, em seu livro de memórias "a alma do tempo", sobre o primeiro tipo de produção de pensamento no Direito, ele considera que: 
“o bacharelismo é a técnica jurídica aplicada especialmente à realidade pública. Não é teórico, sobretudo não é abstrato nem filosófico. Os bacharéis políticos nada têm de filósofos." 68 .

Ao mesmo tempo, também descreveu este autor a outra especificidade de pensamento jurídico existente:

"O juridicismo evolui para uma espécie de abstração científica, certo gênero de clericalismo (no sentido de Julien Benda) que nos deu Teixeira de Freitas, Lafayette, Clóvis Beviláqua e mesmo Tobias Barreto ou Pedro Lessa, cujos temperamentos ferventes não eliminaram aquela irresistível tendência à formação teórica que os incompatibilizava com a vida pública. Os juristas-teóricos apolíticos amavam a filosofia todos eles, Freitas, Tobias, Lafayete, Clóvis e Lessa." ${ }^{69}$.

Em vista a tais delimitações, questiona-se se todo jurista possui maior capacidade indutiva e criativa que o bacharel, preso sempre à lei e ao conservadorismo. Será esta separação clara? A importância de se compatibilizar ou não destes perfis sobre o estudo de caso em tela está em compreender como aquele cotidiano acadêmico retrata o enfoque da produção jurídica de pensamento: se remanescia esta no mundo do bacharel extracurricular e na vida prática (predominando a teoria do bacharelismo), se permanecia na sala de aula e na erudição curricular (predominando a teoria do juridicismo) ou, ainda, se estava em ambas (predominando uma teoria mista).

Em suma, apresentada a principal literatura existente sobre o tema do ensino jurídico e o bacharel, foi possível depreender algumas pistas acerca da forma com a qual se deu o cotidiano da produção de pensamento jurídico na faculdade de Direito de São Paulo entre os anos de 1857 e 1870, notadamente, que há alguns aspectos importantes no que se refere aos três elementos supramencionados no início deste item, que eram: a questão da metodologia de ensino, a relação do bacharel dentro da faculdade e a forma de ratificação acadêmica, sendo esta última a menos tratada por ambos. E será a tese do bacharel extracurricular que possibilitou a maior apreensão sobre tais quesitos do ensino jurídico.

\footnotetext{
${ }^{68}$ Apud VENANCIO FILHO, 1977. p. 295-296.

${ }^{69}$ Apud VENANCIO FILHO, 1977. 291p.
} 
No que se refere aos dois primeiros elementos da metodologia de ensino. Depreende-se que os problemas começaram deste a criação dos cursos inapropriada quer seja por questões físicas quer seja pelos objetivos de formação do corpo burocrático do Estado. Assim, como não houve um preparo para a organização de método para o aprendizado jurídico, havia desentendimentos e falta de relação cooperativa entre o corpo discente e docente, perseverava o desinteresse, desleixo, desatualização das teorias ensinadas, bem como a falta de qualidade de ensino e da própria presença e participação de ambos os lados.

Além disso, o aprendizado era autodidata, pragmático, sem incentivo à capacidade de compreensão de raciocínios lógicos, abstração e teorização, mas sim com valorização de aspectos prático-processuais. Portanto, os bacharéis se formavam com a compreensão formalista do Direito, posto que a juridicidade dava ao mesmo tempo legitimidade e limitação ao poder, bem como a noção moderada da política a fim de encontrar harmonicamente o equilíbrio entre pontos opostos. Além disso, era por meio da visão contratualista e individualista que observavam estes bacharéis os fenômenos jurídicos da sociedade em detrimento da formação publicista ou conjuntural do Direito.

Particularmente no que tange ao terceiro aspecto, da ratificação acadêmica, é possível depreender que a preocupação do governo que instituiu tais escolas de Direito era mais ligada aos interesses econômicos e político do que ao aprendizado ou à produção propriamente da cultura jurídica, por isso tais autores consideram que não havia incentivo de uma formação metodológica qualificada e, assim, a base de ratificação acadêmica era afrouxada e despreocupada para com a apreensão de conhecimento jurídico.

Não obstante, deve-se atentar que as duas primeiras teses sobre o bacharel ornamental e burocrático trouxeram alguns posicionamentos relevantes também para compreender o desenvolvimento da cultura jurídica brasileira neste período histórico. Assim, ainda se faz necessário tecer alguns aspectos acerca da relação dos interesses do poder para com a forma do funcionamento do ensino jurídico neste período. Tratar-se-á sobre isto no próximo subitem deste capítulo. 


\subsection{Um Controle sobre o Ensino Jurídico}

Após tratar acerca do conceito de cultura jurídica e sua relação com o ensino jurídico, bem como delimitar as hipóteses dos três perfis do bacharel, com destaque para o bacharel extracurricular e, ainda, explicitar alguns pontos relevantes para a compreensão das fontes que serão estudadas nos próximos capítulos, este capítulo primário da pesquisa finaliza com o objetivo de compreender como pode ter os interesses das camadas altas da sociedade e do governo central brasileiro no século XIX influenciado, em alguma medida, na formação das profissões jurídicas, mais especificadamente, na metodologia de ensino da faculdade de Direito de São Paulo. E, sequencialmente, já haverá elementos suficientes para abarcar aquela questão acerca da divisão entre o bacharel e o jurista, supramencionada.

A importância desta abordagem relacional da metodologia de ensino com este âmbito externo das relações de poder deve existir porque a faculdade de São Paulo não era um microcosmo de produção jurídica que sobrevivia isolado, mas sim em comunicação e diálogo em diversos níveis externos: com a própria sociedade, com a conjuntura sócio-política da época, com os outros meios de emanação de cultura jurídica e, ainda, com os próprios interesses do governo.

Não obstante, entre tantas relações possíveis, a influência determinante da corte e, conjuntamente, da camada dominante sobre certas decisões de rumo dos cursos jurídicos não poderia ser ignorada. Isto porque parte do que determinava metodologicamente o funcionamento do cotidiano de ensino advinha do governo central que, invariavelmente, era formado pelo grupo escol da sociedade brasileira. Em termos imediatos, por exemplo, pode-se citar que influenciava na escolha final do concurso público para professores, na escolha dos diretores da escola, na decisão última de recursos feitos por alunos a fim de obter absolvição ou abrandamento de penas definidas pela congregação dos professores e, ainda, na aprovação dos compêndios feitos pelos professores. Estes são algumas amostras de como o Rio de Janeiro poderia interferir se tivesse interesse, como o fez diversas vezes.

De outro modo, num aspecto mais discreto e indireto, foram as grandes decisões da elite no parlamento que se determinou as principais regras básicas da 
estrutura de ensino que perdurou invariavelmente por todo o império, no mínimo. Por exemplo, a escolha de se não criar universidades no país, do local dos cursos, das matérias a serem ensinadas e dentre outras importantes decisões tomadas por esta penumbrosa camada dominante, alvo de tantas teses relevantes sobre o século XIX no Brasil.

Em verdade, não é possível afirmar que tenha sido definitiva a influência do governo sobre as faculdades de Direito, mas sim que, em alguma medida, esta existiu. Assim, optou-se nesta dissertação por destacar uma hipótese de projeto de ensino que foi promovido pelos interesses discutidos no parlamento brasileiro, qual seja, o viés apresentado pelas "profissões imperiais" 70 , material desenvolvido por Edmundo Coelho Campos. Em alguma medida, esta dialoga com os dois perfis traçados do bacharel ornamental e o bacharel burocrático.

Não obstante, a ideia não será de fazer mais um raciocínio teórico geral distante das fontes, mas sim de apresentar uma teoria acerca da metodologia de ensino que fora influenciada por estas forças de influência advindas de quem tinha o controle da máquina, ou ainda, do poder simbólico.

A obra de Edmundo Campos faz uma leitura acerca do processo de constituição das três profissões tradicionais no século XIX, que são a medicina, a advocacia e a engenharia, sendo a relação destas com o Estado o elo essencial da pesquisa. Para tanto, ele se utiliza de diversos modelos de países ocidentais para auxiliar na compreensão deste fenômeno que relaciona o Estado à formação dos profissionais do Direito, particularmente, os advogados para, então, analisar o específico caso brasileiro.

Primeiramente é realizado um aprofundado exame para definir o conceito de "profissão liberal" 71 , revelando-se certa dificuldade de se encontrar um consenso nas discussões em diversos países, inclusive no Brasil, com os debates na câmara ${ }^{72}$ e o lobby feito pelos próprios profissionais em seu favor. $\mathrm{O}$ autor, por fim, faz o uso do termo "profissões" para definir ocupações de nível superior, contudo, a significação de

\footnotetext{
${ }^{70}$ CAMPOS, Edmundo Coelho. Op. Cit. 1999.

${ }^{71}$ CAMPOS, Edmundo Coelho. Op. Cit. 20p.

${ }^{72}$ ANAIS da Câmara dos deputados. sessões de 4 de set. e 4 de out. de 1877, apêndice, p. 135-146, 32-39.
} 
"liberais" seria ainda mais complicada de se manusear, posto que lidaria com um aspecto muito relevante na História das profissões, qual seja, do credencialismo educacional.

No Brasil, desde a independência já havia a base para se realizar um credenciamento de profissões a fim de regulamentá-las e, em certa medida, institucionalizá-las, passando desde já pela ainda corrente controvérsia da liberdade profissional. O autor trabalha com o peso do Estado ao lado da influência das camadas dominantes para resolver esta questão. Em regra, o que ocorreria é que por todo o mundo há uma confecção de privilégios pelo Estado associados a esta regulação ${ }^{73}$.

Assim, em termos gerais, Campos explicita a literatura existente sobre o tema de regulação profissional, que considera haver tradicionalmente dois modelos gerais: o outrora considerado "bem sucedido" anglo-americano, que valorizava a autorregulação e o europeu-continental, que promovia a intervenção estatal como algo essencial para formar tais profissionais liberais. Contudo, ele rechaça essa separação estrita e sobrevalorização da autorregulação das profissões à medida que considera sempre haver a interferência, mesmo que mínima, do Estado na História das profissões.

Primeiramente, dentre diversos países retratados, para esta dissertação, faz-se mais relevante destacar que havia dois tipos distintos de formação metodológica do ensino jurídico, baseados nos modelos francês e o inglês.

Ao se observar o contexto de formação histórica deste último, a princípio, é notável que, muito embora houvesse alguma intervenção do parlamento inglês em certos aspectos da formação jurídica, sempre foi predominante a responsabilidade dada aos magistrados em harmonizar e adaptar os costumes locais ${ }^{74}$ em detrimento do uso das leis reais. Assim, a cultura jurídica do Common Law nasceria predominantemente fora das universidades e de um relacionamento com a burocracia real, sendo os juízes os responsáveis por definir as qualificações para o exercício das atividades forenses perante os tribunais sob sua jurisdição, o que, posteriormente, seria delegado aos Barristers, que se organizaram nas quatro Inns of Court, em meados do século XIX.

\footnotetext{
${ }^{73}$ CAMPOS, Edmundo Coelho. Op. Cit. 36p.

${ }^{74}$ The law of the land.
} 
Estas, especificamente, detinham a autonomia e o monopólio de preparo profissional de seus membros para apresentação dos casos perante a High Court, bem como para terem acesso à magistratura. Diversamente, os Solicitors eram os processualistas que guardavam o acesso aos Barristers e aos procedimentos legais, organizados na Law Society, portanto, possuíam um prestígio menor que os primeiros, muito embora dispusessem de certo poder para barganha e aliança de interesses como, por exemplo, no caso dos proprietários de terra que buscavam a manutenção do instituto da herança.

Tanto este modelo formação jurídica como o americano instituem que as "profissões" só seriam aquelas ocupações em que o mercado fora o fator determinante e não o Estado, ou seja, somente nestes dois casos, seriam tais profissionais "livres", com autonomia profissional e corporativa. Assim, seria feito um monopólio profissional da prestação de serviços que foi concedido pelo Estado às associações profissionais.

No caso francês, ao se atentar para o complexo desenvolvimento da autonomia profissional da Ordre des Avocats na Revolução Francesa, formou-se um modelo institucionalizado das profissões, com o controle estatal sendo exercido por meio do ensino jurídico e, sequencialmente, sobre o credenciamento e licenciamento para o exercício profissional. Assim, na França houve uma formação jurídica diversa do caso inglês, em que as universidades de elite mantinham a educação clássica em divergência com a formação técnica dada pelas associações, assim como era distinta com o caso estadunidense, em que era das escolas particulares a competência para licenciar o exercício profissional.

Não obstante, o autor considera que o problema dos sociólogos ao fazerem esta análise é que eles fundiram a História com os dois personagens sem liquidar com um deles: ou o mercado ou o Estado. Isto porque quando se analisa o processo de constituição das profissões modernas na Europa continental, este seria incompreensível sem a consideração do papel do Estado. Contudo, a análise deste processo de profissionalização só pelo ângulo da predominância da influência do mercado ou do Estado é considerada empobrecedora e precária por ele. 
Por exemplo, na Alemanha, os advogados não concebiam a regulação estatal como fator adverso aos seus projetos profissionais, sendo que o burocrata jurista alemão tinha muito prestígio e poder e, enquanto isto, os advogados franceses estavam participando ativamente nas quedas dos sucessivos regimes até a terceira república.

E como se situaria o Brasil nesse contexto? A partir de meados da segunda metade do século XIX, o código dos Advogados de 1879 refletiu sobre a tendência liberalizante, mas Estado jamais se retirara inteiramente de influenciar sobre esfera da advocacia, posto que desde o início foi importante na trama da profissionalização.

Não obstante, considera o autor que ser trata de uma discussão interminável sobre se era Estado brasileiro forte ou fraco. Em verdade, não se constituía aqui no século XIX um país de forte cultura estatal, posto que não se falava muito o termo "Estado" nos debates nas câmaras legislativas, mas sim de "Governo", "Poderes Executivo" e "Poder Moderador". Contudo, não se pode considerar o Brasil imperial uma sociedade sem Estado e nem sequer de uma tradição de continua preocupação intelectual com a ideia de Estado.

A engenharia administrativa brasileira tinha uma base legislativa organizacional e hierárquica feita aos pedaços, sem verdadeiro nexo, com ideias desencontradas, remendos de tecidos estranhos advindos de lutas, tempos, dores e experiências alheias ao contexto brasileiro, conforme considera o próprio Visconde de Uruguai $^{75}$. Na mesma medida, tampouco a arquitetura social, a ideia de nação foi bem construída pelos estadistas brasileiros. Portanto, mais interessante que buscar a essência ou o conceito do Estado brasileiro, melhor seria observar o que acontecia nele, o que esse Estado fazia ou deixava de fazer.

Em verdade, os políticos e estadistas do século XIX eram pragmáticos e sem construções abstratas, portanto preferiam as estruturas organizacionais e formas concretas do governo a conceituar juridicamente o Estado ou se preocupar com funcionalidades ou simetrias mesmo na construção de artefatos institucionais copiados de projetos feitos para outros terrenos, climas e usos.

\footnotetext{
${ }^{75}$ SOUSA, P. J. Soares de. Ensaios sobre o direito administrativo. Rio de Janeiro: ministério da justica, 1960. p 122, 359-360, 383.
} 
E como isto se relaciona com a formação profissional dos bacharéis no século XIX? Campos realiza um aprofundado estudo acerca da construção da cultura jurídica brasileira no século XIX, denotando a participação de tais personagens nessa produção, bem como de outros aspectos diversos. Por exemplo, nos casos específicos das áreas de Direito Civil e Administrativo, ele retrata que persistiram tais áreas jurídicas em lastimável estado de confusão jurisprudencial, sendo que os juristas carregavam suas obras de materiais estranhos à conjuntura jurídica brasileira, em razão da possibilidade arbitrária da "Lei da Boa razão".

Teixeira de Freitas, a seu ver, é um dos autores que ressalta a importância da obra dos praxistas portugueses nesse caos jurídico, sendo que ele mesmo usara de sua experiência pratica para adaptar as necessidades do foro brasileiro:

\footnotetext{
"sabia ele também que apenas uma ínfima fração deles podia dispensar as lições dos praxistas, e que mesmo dentro da elite dos 'jurisconsultos' poucos seriam capazes de prosseguir por si sós na elucidação de complicadas questões de exegese jurisprudencial" ${ }^{76}$.
}

Particularmente quanto ao contencioso administrativo, sua análise indica que preponderava o caos nos litígios entre particulares e a Administração estatal, posto que muito poucos foram os pontos definidos e fixados em regulamentos ou leis. Da mesma forma, nos casos que nasciam da aplicação das atribuições administrativas dos Ministros de Estado e Presidentes de Província, haveria extrema confusão, pois muitas das soluções oferecidas nem sequer estavam impressas e não haveria propriamente prática e jurisprudência administrativa ${ }^{77}$.

A partir deste exemplo específico da falta de cunho na área administrativista e de diversos outros, como a prolongação processual promovida pelos inúmeros recursos de advogados hábeis que podiam buscar um costume esquecido no tempo, uma filigrana processual, a fim de ganhar da causa, sem preocupação com ética profissional ${ }^{78}$

\footnotetext{
${ }^{76}$ CAMPOS, Edmundo Coelho. Op. Cit. 158p.

${ }_{77}^{77}$ SOUSA, P. J. Soares de. Op. Cit. 104p; DE ANDRADE, Nuno Pinhero, Op. Cit. p. 663-691.

${ }^{78} \mathrm{O}$ autor demonstra que isso não era uma peculiaridade brasileira, pois nos EUA, os advogados tinham péssimo conceito.
} 
- Campos procura demonstrar que se propagava uma falta de autonomia do Judiciário, pois dependia financeiramente do Executivo e era subordinado ao Legislativo.

Além do que, na falta de interpretação ${ }^{79}$ da lei pelo Poder Legislativo ${ }^{80}$, o Executivo exercia esta função de autoridade, somente cabendo ao Judiciário aplicá-las, sem sequer questionar sua constitucionalidade ${ }^{81}$. Quanto a isto, cita o Marquês de São Vicente:

"se os atos do governo forem subordinados aos juízes ordinários, este constituirão o verdadeiro governo e a administração, sacrificando porventura o bem público ao particular, e guiando-se por apreciações estranhas e morosas" ${ }^{82}$.

Nesse sentido, considera o autor que não seria concebível naquela época que um juiz cuidasse dos litígios dos particulares com o Estado, no âmbito do contencioso administrativo. Assim, não havia uniformidade na jurisprudência, já que eram as interpretações do Poder Executivo tão instáveis como a sucessão de gabinetes, e, além disso, os juízes, os delegados de política e os presidentes de Relação sempre consultavam excessivamente os Ministérios e o Conselho de Estado que proferiam com avisos, resoluções, regulamentos e circulantes de modo muito inconsistente e até contraditórios $^{83}$.

Não obstante, havia interesses políticos em manter o judiciário dócil à "hermenêutica" do partido no poder. Então até a proclamação da República, a competência do Supremo Tribunal era limitada à concessão de vistas, permanecendo assim as Relações como a última instância.

Contudo, a despeito de historicamente os advogados sempre lutarem pelo mundo em favor da independência do judiciário, "no Império do Brasil, entretanto, um

\footnotetext{
${ }^{79}$ Reclamada por Feijó esta falta de interpretação, quando Ministro da Justiça.

${ }^{80}$ RELATÓRIO da Repartição dos Negócios da Justiça apresentado à Assembleia Geral Legislativa, sessão ordinária, 1832. p. 13-14.

${ }^{81}$ NABUCO, Joaquim. Um estadista do império: Nabuco de Araújo. Rio de Janeiro: B. L. Garnier. v. 1, 1873. 281p.

${ }^{82}$ Apud CAMPOS, Edmundo Coelho. Op. Cit. p. 163.

${ }^{83}$ Apud CAMPOS, Edmundo Coelho. Op. Cit. p. 164.
} 
Judiciário inerme, dependente e subordinado fez par com uma advocacia forense destituída de brilho e de honra" ${ }^{84}$.

Eis que toda esta problemática da formação da cultura jurídica brasileira tratada pelo autor começa a voltar sua atenção para o problema específico da formação dos operadores do Direito. Particularmente, em relação à advocacia, ele considera que mesmo após a independência houve uma cópia considerável dos três tipos de operadores existentes no modelo português ${ }^{85}$ : em primeiro lugar, havia o advogado formado em Coimbra e, de 1827 em diante, de São Paulo e Olinda, sendo o diploma suficiente para exercício da advocacia, dispensando exames e licenças e podendo o bacharel procurar em qualquer dos tribunais. Estes são os profissionais em destaque de análise nesta pesquisa.

Contudo, ainda há outros dois tipos de advogados, que não detinham graus acadêmicos nas faculdades de Direito, mas que também influenciaram na produção de cultura jurídica no século XIX brasileiro, em alguma medida. Assim, primeiro havia os advogados provisionados, que se submetiam a exames teóricos e práticos de jurisprudência pelos presidentes dos tribunais da Relação e só podiam exercer a profissão nos tribunais de primeira instância e lugares onde faltasse advogado formado. E, por fim, existiam os solicitadores, também sem diploma como os provisionados, que se submetiam pelos juízes de Direito a exames apenas sobre prática do processo. Ambos deveriam requerer renovação de suas licenças ou provisões no prazo de dois a quatro anos.

Não obstante, considera que esta classificação era passível de uma série de controvérsias a esse respeito. Na prática, então, o critério de diferenciação entre as categorias de procuradores é de natureza social e cultural muito mais que formal-legal, ou seja, a interpretação mais estreita dizia que procuradores eram os advogados formados e provisionados e os solicitadores, sem estabelecer diferença entre eles.

Contudo, os praxistas buscavam nas Ordenações para fixar que procuradores judiciais poderiam ser todos os que não fossem excluídos pela lei: o menor de 21 anos;

\footnotetext{
${ }^{84}$ Apud CAMPOS, Edmundo Coelho. Op. Cit. 166p.

${ }^{85}$ Apud CAMPOS, Edmundo Coelho. Op. Cit. 167p.
} 
o furioso ou demente e pródigo; a mulher, com algumas exceções; quem fosse condenado por falsidade ou perdido o ofício por erro; pessoas poderosas em razão de cargo, como magistrados e oficiais, clérigos e religiosos, empregados da fazenda. Especificadamente no código do processo criminal, poderiam ser procuradores quem a pessoa escolhesse, de acordo com o artigo 322. E, assim, os rábulas sobreviveriam até meados de 1930 .

Portanto se pode concluir que o grau de incerteza e insegurança quanto a este tema era alto, sendo a advocacia como uma categoria profissional residual, para qualquer um. Em contrapartida havia a elite dos bacharéis, que exaltava o culto à ciência do Direito, mas cuja produção doutrinal e jurisprudencial foi de uma pobreza franciscana.

Nesses termos, considera o autor que o advogado da elite brasileira com sua retórica e formação diferenciada, formou uma cultura avessa ao foro e a formulações mais abstratas, pragmática, que desprezava os praxistas e advogados de pequenas causas, bem como que detinham ideais pela pureza da ciência do Direito, mas que era apática com os problemas que afligiam a sociedade, posto que eram movidos pelos seus próprios interesses e de seus clientes muito mais do que por uma ética advocatícia, posto que se aproveitavam das vantagens da confusa legislação portuguesa que influenciou e foi vigente no Brasil em grande parte deste período histórico.

Seria um dos motivos a falta de faculdades de Direito para constituir sistemas jurídico-formais abstratos? Respondendo negativamente, o autor considera que mesmo em São Paulo e Pernambuco não havia uma produção de cultura jurídica considerável.

Por fim, também se destaca um aspecto acerca da análise que o autor faz sobre o Instituto dos Advogados Brasileiros, que quando fora fundado, em 1842, não recebia subvenção governamental e se colocava com frequência na defesa dos interesses dos advogados - interesse na "honra" profissional, estratégia de afirmação de status. Tal instituto, cuja função ainda não havia sido bem definida, evitava escrupulosamente as questões políticas e quase nunca criticava o governo. 
Foi somente a partir do final do século XIX que se definiu pelo regulamento de 1888 que sua função seria para "o estudo do Direito, na sua História; assistência judiciária", muito embora os estatutos de 1842 considerassem que a finalidade era "organizar a ordem dos advogados em proveito geral da ciência da jurisprudência" ${ }^{86}$.

Eis que, então, sob a influência francesa, o IAB almejou ter toda a autoridade absoluta que possuía a Ordre des Avocats para poder subordinar, disciplinar e moralizar os usos e costumes do foro. Desejavam, para tanto, a proteção do Estado, mas não sua submissão a ele. Contudo, como o apoio dos sócios era precário, ele nunca se fortaleceu ou sequer influenciou em alguma medida a formação jurídica de seus profissionais ${ }^{87}$.

Ora, este material trabalhado por Edmundo Campos traz diversos elementos que cercam a formação histórica dos profissionais jurídicos entre os quais, particularmente os estudantes da faculdade de Direito de São Paulo em meados do século XIX. Bourdieu, em seu trabalho contínuo que constituiu a obra "o poder simbólico", retrata em um capítulo específico acerca da força do Direito sobre o controle violento de seus símbolos sobre a sociedade. Entre os aspectos que este autor aborda como fomentador deste controle está justamente a formação e o aprendizado do Direito.

Ocorre que há uma razão basilar para que o formato do Direito, de seu formalismo, sua aparência de neutralidade, seu distanciamento da sociedade, seu linguajar próprio, toda esta construção simbólica que forma uma lógica de funcionamento a qual chamará Bourdieu de apriorização ${ }^{88}$. A razão será justamente manter um aspecto de distanciamento e desligamento dos movimentos conjunturais e políticos da sociedade.

Se observarmos o contexto de formação da cultura jurídica brasileira no século XIX, parece que a partir desta noção fica mais claro que, em verdade, havia sim um interesse muito intrínseco nesta suposta submissão do Poder Judiciário, neste desligamento do IAB com as questões políticas, neste formalismo dos bacharéis

\footnotetext{
${ }^{86}$ Apud CAMPOS, Edmundo Coelho. Op. Cit. 188p.

${ }^{87}$ Apud CAMPOS, Edmundo Coelho. Op. Cit. p. 189-191.

${ }^{88}$ BOURDIEU. Pierre. Op. Cit. p. 215-216.
} 
formados pelas academias de Direito e ao mesmo tempo aversão às problemáticas da sociedade e do advogado de porta de cadeia. Em verdade, há uma coadunação de interesses e forças daqueles que controlam o poder simbólico que, de uma forma simplificada, Bourdieu concederá à camada dominante este privilégio, com apoio e condescendência estatal.

Assim, o que este subitem procura demonstrar é que havia também uma força de interesses que determinou violentamente certos simbolismos dentro das faculdades de Direito do império e, portanto, que influenciaria, em alguma medida, na sua metodologia. Assim, parece ingênuo afirmar que a estrutura de funcionamento da academia de São Paulo era simplesmente destituída de método e de qualidade de ensino. Em verdade, não só as fontes demonstram que algum tipo de ensino e lógica jurídica foi apreendida pelos seus estudantes como ainda havia interesses estruturais muito veementes que determinariam a formação deste pensamento acadêmico.

Nesse sentido, os rituais de funcionamento da faculdade como a indumentária, a obrigatoriedade de formalismos dentro de aula, o formato e mesmo a estrutura física das salas, aspectos psicológicos de gagueira e dificuldade da fala de diversos alunos por um lado e os elementos que proporcionavam o aprendizado como as sabatinas, o compêndios aprovados pelo governo central, a escolha do diretor, o próprio desleixo e desvalorização da profissão do magistério e o inevitável desleixo dos professores, as matérias exigidas para que se fosse matriculado no primeiro ano, o próprio formado de habilitação para ser aprovado de ano e outros tantos aspectos que serão em alguma medida abordados nos próximos dois capítulos possuem alguma relação com esta estrutura de poder vigente naquele período e o perfil do bacharel e a compreensão do próprio ensino jurídico brasileiro inevitavelmente serão influenciados por isto.

E é neste sentido que se retoma a discussão acerca daquela diferenciação entre o juridicismo e o bacharelismo anteriormente apontada. Edmundo Campos apontou que existiam três tipos de advogados que operavam o Direito naquela sociedade imperial: o bacharel formado na academia de Direito, erudito e formal, avesso às problemáticas da sociedade e aos dois outros tipos de advogados: o que devia passar por testes teóricos e práticos e que podia atuar quando não havia o primeiro e aquele que tão-somente entendia de processo e que ficaria com as demandas remanescentes. 
Contudo, não parece ser possível assemelhar o bacharel ou o jurista ao último tipo que, majoritariamente seria conhecido como o rábula, que só possui conhecimento jurídico restrito ao funcionamento processual do Direito, mas não detém qualquer cabedal material ou força política de atuação na sociedade. O segundo tipo já é mais difícil fazer este raciocínio, pois muito embora ele não possua formação acadêmica, o que é compreensível num país com tão poucas faculdades de Direito, ele necessita realizar testes teóricos e práticos promovidos por um órgão institucional para poder exercer a advocacia. Isto também pode sugerir que possua já um grau maior de influência política em seu meio, mesmo que seja local. Portanto como se pode diferenciar este do bacharel formado na academia, além deste motivo formal já sobressalente?

Parece que o meio sócio-político e de formação cultural jurídica em que se proporcionou a existência de tais profissionais do Direito proporcionou uma variedade considerável de perfis de operadores do Direito em geral no que tange à produção de conhecimento jurídico e de atuação prática na sociedade. A tarefa desta pesquisa, contudo, não será classifica-los, mas tão-somente explicitar quais seriam aqueles suscetíveis de análise histórico-jurídica por esta investigação.

Primeiramente, quanto à querela em relação à separação entre o bacharel e o jurista, não parece a esta pesquisa que ela seja muito clara e útil. O exemplo mais significativo disto é o próprio Teixeira de Freitas que se por foi um grande acadêmico pesquisador e conhecedor teórico de grandes autores contemporâneos como Savigny, ele também foi um grande prático e utilizador de seu conhecimento concreto da atuação processual do Direito para desenvolver sua consolidação civil. Portanto, para esta pesquisa, havia uma simbiose ou, no mínimo, uma falta de separação de tais tipos de estudantes no ensino jurídico brasileiro, ou seja, o bacharel e o jurista poderiam ser duas facetas do mesmo personagem histórico, igualmente presentes na academia.

E, em segundo, lugar, a especificidade deste profissional do Direito em relação aos outros dois mencionados por Edmundo Campos não ocorreu por ter sido protegido por associações credenciadas ou ter sua formação prática promovida por alguma organização autônoma, mas sim pela institucionalização de sua formação jurídica. $\mathrm{Ou}$ 
seja, o título de bacharel, em alguma medida, dava um status social específico que, em alguma medida, proporcionava a possibilidade de se utilizar uma metodologia de aprendizado jurídico formalista, mas ao mesmo tempo em que demandava um senso pragmático processual. E isto se aplica não só ao advogado, mas também a outros operadores do Direito naquele contexto.

Além disso, baseava-se numa relação ritualística senão distante na maior parte das vezes, mas principalmente hierarquizada e simbólica do estudante com os lentes e a própria faculdade de Direito. Necessário reforçar que esta hipótese se confirma mesmo nos casos em que a relação era de desleixo e com falta de dedicação por parte do corpo docente no ensino, pois ainda sim, esta noção simbólico-formal era inserida no raciocínio lógico-jurídico do estudante de Direito.

Por fim, isto se refletia na chamada dinâmica de ratificação acadêmica do aluno, posto que exigia dele uma habilidade de grande cabedal linguístico e material erudito, muito conivente com os interesses daqueles que detinham o poder simbólico e que determinavam a força que o Direito deveria ter naquela sociedade: respeitar o modelo legalista que fundamentava não só o distanciamento para com a sociedade como também proporcionava justificar uma ausência de vinculação do operador do Direito às querelas daquela sociedade.

Ambos os elementos observados neste subitem e no item anterior possibilitam inferir melhor certos aspectos do ensino jurídico a fim de possibilitar uma melhor compreensão das fontes e, ainda, depreender aspectos sobre a construção da cultura jurídica brasileira no século XIX. Assim, segue-se para o segundo capítulo. 


\section{Capítulo 2}

\section{A Formação da Cultura Jurídica Administrativa e da Metodologia ACADÊMICA}

O segundo capítulo é um ensaio para o terceiro, que analisa as dissertações de Direito Administrativo dos anos de 1857 e 1870 da faculdade de São Paulo. Isto porque ele procura, num primeiro momento, trazer argumentos e estudos para compreender o caráter da produção de cultura jurídica da área jurídico-administrativa daquele período e, em seguida, reflete sobre aspectos do cotidiano da faculdade a fim de compreender, minimamente, o rito para a habilitação dos alunos no final do ano, a chamada ratificação acadêmica e, por fim, a metodologia do aprendizado jurídico.

Acredita-se que esta é a atmosfera ideal para que se possa realizar o estudo das fontes históricas no último capítulo com mais propriedade. E, assim, será possível depreender sobre a particular formação de pensamento jurídico na faculdade de São Paulo e, então, contribuir para o entendimento acerca do desenvolvimento da cultura jurídica oitocentista brasileira. Ou seja, será partindo deste microcosmo acadêmico que se pretende alcançar, entre novos meandros da cultura jurídica, uma discussão mais crítica no rio da História do Direito brasileiro.

E, em meio ao vasto universo jurídico possível de áreas estudadas dentro de uma academia de Direito para avaliar a produção deste pensamento, fez-se a escolha pela matéria do Direito Administrativo. Assim, primeiramente se apresentará a fundamentação da temporalidade, a espacialidade e escolha dessa área para possibilitar acrescentar na pesquisa sobre a História do ensino e da cultura jurídica brasileira.

Com relação à escolha do período limitado, esta foi feita por dois motivos principais. Primeiro, porque a segunda metade do século XIX é considerada o período de uma produção de cultura jurídica predominantemente nacional e isto também no âmbito particular do ensino jurídico, posto que os professores eram, em sua maioria, brasileiros formados aqui e, também, porque já havia uma produção de material doutrinário, estudos e obras sobre as áreas do Direito, basicamente produzidos pelos 
próprio lentes e por doutrinadores. Em segundo lugar, por um motivo de limitação material, já que as fontes que embasam a pesquisa de Direito Administrativo são de 1857 a 1870, especificadamente.

Na mesma medida, a espacialidade é essencial para o estudo de caso e também para demonstrar unicidade no objeto de investigação. Assim, foi preferível optar pelo estudo de tão-somente um dos cursos jurídicos daquele período para possibilitar maior profundidade na investigação. E, nesse sentido, a faculdade de São Paulo foi escolhida porque se formava em meio a uma relação produtiva com a cidade, bem como pelo intercâmbio de estudantes de diversas regiões do país, o que enriquecia o dinamismo cultural da academia. De outro modo, a escolha da faculdade paulistana foi importante para possibilitar um diálogo e análise comparativa deste estudo com a investigação de Sérgio Adorno, que trata justamente sobre a formação cultural e acadêmica do bacharel de São Paulo ${ }^{89}$.

Por fim, restou a limitação do objeto de estudo em razão da linha do conhecimento jurídico, já que esta pesquisa procura identificar qual o pensamento jurídico produzido no cotidiano de ensino da São Paulo de meados do século XIX com enfoque no saber produzido na área administrativa. A escolha da pesquisa por esta área, que era, então, recém-criada pelo decreto $\mathrm{n}^{\mathrm{o}} 1.386$ de 1854 a fim de fazer parte do ciclo de matérias do quinto ano como a terceira cadeira, justifica-se por dois motivos principais.

Primeiramente, por uma questão que envolve o próprio conceito e objeto da ciência do Direito Administrativo, pois a produção da ciência jurídica administrativista, desde aquele período, abarca o estudo jurídico da administração pública e de seus agentes, a relação com os administrativos e dos demais instrumentos relativos ao funcionamento da administração pública ${ }^{90}$ Assim, muito embora o sentido e a conceituação da ciência do Direito Administrativo ainda estivessem em formação naquele período histórico, mesmo na Europa ${ }^{91}$, sua proximidade semântica com a

\footnotetext{
${ }^{89}$ ADORNO, Sérgio. Op. Cit.

${ }^{90}$ RIBAS, Antonio Joaquim. Direito Administrativo Brasileiro. Brasília: Ministério da Justiça, 1968. p. $15-17$.

${ }^{91}$ MANNORI, Luca; SORDI. Bernardo. Storia di diritto amministrativo. Bari: Laterza, 2001.
} 
construção do Estado era intrínseca, mesmo na específica realidade do caso brasileiro, conforme se verificará com a pesquisa de Guandalini $^{92}$.

E, nesse âmbito, fez-se presente o bacharel na construção deste Estado, conforme fora já tratado na análise do perfil do bacharel burocrático. Logo, a escolha de compreender como os estudantes de Direito apreendiam a lógica e o raciocínio administrativista faz-se pertinente, posto que uma parte considerável de tais alunos estaria futuramente em cargos administrativos e políticos.

Assim, com o enfoque nesta área será possível realizar um estudo de dois níveis. Primeiramente, num nível mais interno à própria faculdade, o estudo do pensamento jurídico envolto à área Administrativa permite estudar mais a fundo aquele instinto progressista e questionador do “jurista” e sua compreensão crítica da máquina pública e, ao mesmo tempo, atentar para aquele espírito legalista e político do "bacharel" sobre o funcionamento do governo.

E, em segundo lugar, o estudo das características da produção de cultura jurídica na área jurídico-administrativa permite auxiliar na compreensão do modelo de estruturação do segundo Império e no respaldo simbólico que o Direito proporciona para o controle do poder. Não havia uma organização administrativa e jurídica consagrada para proporcionar o funcionamento da máquina estatal, mas sim uma corrida atrapalhada e minimamente direcionada a fim de que se estruturasse um modelo legalista e coerente para respaldar quem detinha o controle do poder ${ }^{93}$. Nesse sentido, o microcosmo da faculdade reflete, em parte, o desenrolar dos atos na formação tanto do funcionamento burocrático e do corpo legislativo e doutrinário, como também da dificuldade científica e intelectual pela qual vivia o país nos meados do século XIX.

Em outra medida, a escolha pela área do saber administrativo tem mais uma justificativa considerável. Era uma disciplina ainda em formação no contexto mundial e recém-criada no Brasil, de modo que a abrangência doutrinária ainda estava em construção, o que limita o campo de abrangência da pesquisa, diferentemente se fosse a área processual ou civil. Somado a isto, a escolha pelo Direito Administrativo - ao

\footnotetext{
${ }^{92}$ GUANDALINI JR. Walter. Op. Cit.

${ }^{93}$ GUANDALINI JR. Walter. Op. Cit. 178p.
} 
invés da cadeira de Direito Romano, também instituída em 1854 - é justamente para compreender a lógica publicista do ensino, mais relevante num contexto político e de controle do poder.

Desse modo, a limitação do tema da investigação sobre cultura jurídica do Direito Administrativo permite aprofundar o conhecimento da produção de um saber jurídico de vital importância tanto para a compreensão da vida acadêmica como também da própria vida política brasileira daquele período, tendo o bacharel como principal elo nesta compreensão.

Assim, apresentados os principais aspectos que circundam a escolha temporal, espacial e temática que delimitam este estudo acerca do ensino jurídico e da construção da cultura jurídica brasileira no século XIX, há alguns aspectos prévios que merecem destaque. Primeiramente, conforme já fora analisado no capítulo primeiro, a hipótese da pesquisa é de que há indícios de uma produção de pensamento administrativista dentro do ambiente acadêmico onde se formaram parte de personalidades do Direito participantes não só da construção do Estado brasileiro, mas da própria formação do cotidiano jurídico e social da população em geral ${ }^{94}$. Aliada a esta premissa maior, desenvolveu-se a hipótese singular de que o estudante de Direito médio que passou pela faculdade de São Paulo de meados de 1860 apreendeu, em alguma medida, um raciocínio jurídico definido, universal, ativo e coerente com relação ao contexto social, político e dogmático que existia no Brasil daquele tempo.

Trabalha-se, portanto, com a hipótese de que foi uma edificação de pensamento construída na polifonia de elementos históricos, a qual formou o raciocínio jurídico apreendido pelo estudante de Direito. Mas qual seria o diálogo entre este aprendizado dos bacharéis com o contexto geral da produção de cultura jurídica administrativa do século XIX?

Brandão afirmou o seguinte acerca da relação entre as fontes históricas de Direito Administrativo de mil e oitocentos no Brasil:

\footnotetext{
${ }^{94}$ E não é possível sequer afirmar que só se restringia à elite essa atuação, basta analisar causas importantes no judiciário tal como a da questão da liberdade dos escravos negros que, quando conseguiam curador, argumentava-se pela premissa normativa da Lei Feijó de 1831, que proibia o tráfico transatlântico de escravos.
} 


\begin{abstract}
"o Direito Administrativo no Império é toda a construção da Jurisprudência administrativa feita pelo Conselho de Estado em suas diversas fases, é toda a legislação sobre terras, especialmente sobre terrenos de marinha e terras devolutas, é a legislação de águas, de minas, é a legislação sobre concessões ferroviárias e de portos, com traços marcantes e bem definidos, é o regime de garantias de juros, base do nosso desenvolvimento na origem da construção do nosso sistema de estradas de ferro e navegação, etc. É todo o debate em torno do contencioso administrativo, da competência dos tribunais administrativos e judiciais. É, ainda, a construção doutrinária, feita pelos professores e pelos tratadistas, como Uruguay, Ribas, Pereira do Rêgo, etc." (grifos nossos) ${ }^{95}$.
\end{abstract}

Este apontamento, feito pelo autor lá em meados dos anos 60, evidencia a existência de alguns focos de produção administrativista. Não há o destaque específico para o debate amplo entre tais fontes, nem se vislumbra qualquer referência ao âmbito de produção acadêmica nas faculdades de Direito, mas sim menção à "construção doutrinária, feita por professores (...) como (...) Ribas (...)".

Mas seriam estas fontes formadoras de conteúdos administrativos isolados ou provocados por discussões científicas e interesses políticos? Se se fizer uma análise complementar entre autores como Murilo de Carvalho, Miriam Dolhnikoff, Reinaldo Lopes e Walter Guandalini $J r$, ver-se-á que havia não só diversas redes de argumentações políticas no momento de se aprovar uma lei, do Conselho de Estado ${ }^{96}$ apresentar seu parecer ou do contencioso administrativo ser incitado a se manifestar, como, também era latente, em alguma medida, o perduro de análises jurídicas que motivavam tais disputas pela fundamentação das decisões. Estas análises, invariavelmente, acabaram por possibilitar a formação de uma cultura jurídica no século XIX no Brasil, muito embora o próprio Visconde de Uruguai constatasse que naquela conjuntura histórica isto tudo se dera de forma confusa e sem método, tanto no sentido contencioso como acadêmico ${ }^{97}$.

E é nesse mesmo contexto que Conselheiro Ribas desenvolveu sua obra de Direito Administrativo cujo desenvolvimento se deu quando fora professor substituto da

95 CAVAlCANTI, Themistocles Brandão. Apresentação in: Paulino Soares de Souza, Ensaio sobre o Direito Administrativo. Rio de Janeiro: Imprensa Nacional, 1960. p. I-X.

96 Muito embora os pareceres do Conselho de Estado evitaram opinar sobre temas estritamente de disputas políticas, Lima Lopes considerou que as disputas políticas chegavam nas mãos dos Conselheiros.

${ }^{97}$ Apud LIMA LOPES, José Reinaldo de. Op. Cit. 123p. 
cadeira de Administrativo na faculdade de São Paulo, entre os anos de 1855 e 1856, muito embora sua publicação tenha saído em $1861^{98}$. Ele pretendeu, metodologicamente, proporcionar a seus alunos um curso mais completo e prático, já que não considerava existir material na época compatível com a demanda dos estudos acadêmicos brasileiros ${ }^{99}$. Ora, em alguma medida, também seria fator determinante sobre a elaboração intelectual da obra o panorama político, posto que o autor era consciente de que seu compêndio teria de passar pelo crivo não só da congregação, como também do governo imperial ${ }^{100}$.

Assim, introduzido o ambiente preliminar do período, apresenta-se uma proposição (canto geral) que condensa o ciclo da relação entre o ensino jurídico e a cultura administrativista oitocentista: (i) havia diversas melodias que soaram na formação do pensamento da cultura jurídica administrativa, dentre as quais os sons advindos das faculdades de Direito (ii) que se acordavam harmonicamente com o elemento acadêmico-científico produzido das lições, sabatinas e pontos cobrados aos alunos e com o componente da influência governamental sobre a eventual determinação do cotidiano dos cursos ${ }^{101}$. Assim, (iii) as theses comportavam, em geral, intenções do professor em utilizar uma corrente de pensamento jurídico ou indicar um aspecto político brasileiro, como também (iv) as dissertações ilustravam, via de regra, desígnios dos alunos em participar dos diversos atos acadêmicos com o objetivo prático de obterem a aprovação na cadeira, ao mesmo tempo em que formavam um raciocínio jurídico resultante da conciliação entre certo modo de pensamento e suas ideias políticas. E, assim, (v) este microcosmo acadêmico consoa no contexto jurídico maior do período, de completa diversidade de ritmos e de intensidade ${ }^{102}$ das vozes políticas e científicas que influenciariam a construção do pensamento administrativista brasileiro.

Enfim, as fontes apresentadas acima por Brandão foram positivamente provocadas por discussões científicas e também por interesses políticos, numa relação

\footnotetext{
${ }^{98}$ BLAKE, Sacramento. Op. Cit. 1883. 204p.

${ }^{99}$ RIBAS, Antonio Joaquim. Op. Cit. p. 13-17.

${ }^{100}$ Talvez isto tenha influenciado inclusive a importância que o Conselheiro Ribas concede ao Imperador em sua obra, conforme analisa Guandalini.

101 Por exemplo a aprovação de compêndios para serem utilizados em aula, tal como o de Direito Administrativo do Conselheiro Ribas

${ }^{102}$ Intensidade no sentido de volume.
} 
complexa e difusa da qual, em alguma medida, conforme se procurará demonstrar a seguir, fazia parte o ambiente acadêmico das faculdades de Direito do Império.

\title{
2.1 A Literatura Brasileira sobre a Cultura Jurídico-Administrativa no Segundo Império
}

\begin{abstract}
"É lamentável que todas as composições de compositores brasileiros, desde as obras sinfônicas ou de música de câmara dos Srs. [Alberto] Nepomuceno e [Henrique] Oswald até as sonatas impressionistas do Sr. [Oswaldo] Guerra ou as obras orquestrais do Sr. Villa-Lobos (um jovem de temperamento robusto, cheio de ousadias), sejam um reflexo das diferentes fases que se sucederam na Europa de Brahms a Debussy e que o elemento nacional não seja expresso de uma maneira mais viva e original. A influência do folclore brasileiro, tão rico em ritmos e de uma linha melódica tão particular, se faz sentir raramente nas obras dos compositores cariocas. Quando um tema popular ou ritmo de uma dança é utilizado em uma obra musical, este elemento indígena é deformado porque o autor o vê através das lentes de Wagner ou de Saint-Saëns, se ele tem sessenta anos, ou através das de Debussy, se ele tem apenas trinta",103.
\end{abstract}

Este apontamento feito por Milhaud, um compositor francês que morou no Brasil no final da década de 10, talvez traga uma querela histórica brasileira que perpassa, através dos tempos, volúvel conforme a área e o contexto, como uma sombra na formação das ideias e da cultura brasileira - sombra da qual a área jurídica tampouco se esquiva. Ora, mesmo considerando a distância magistral do estágio maduro do Estado brasileiro contemporâneo, da sua relativamente estável democracia, da urbanização e industrialização predominantes, ou seja, ainda que seja notável a separação entre as áreas da música erudita no início do século XX e da pesquisa história-jurídica no preâmbulo do século XXI, é possível constatar uma permanência na orientação de certos autores brasileiros em preferir adquirir a bússola linguísticopragmática importada da Europa a desbravar a construção de pensamento próprio.

Ora, sabe-se que o elemento indígena na obra de Villa-Lobos foi fruto de uma pesquisa empírica e analítica que se constituiu na base de brilhantes artifícios rítmicos, harmônicos e melódicos, valorizadores de técnicas como paralelismo, ostinato,

\footnotetext{
${ }^{103}$ Apud LAGO, Manoel A. C. do. (Org.). O boi no telhado: Darius Milhaud e a música brasileira no modernismo francês. São Paulo: Instituto Moreira Salles. 2012.
} 
estaticidade, síncope, uso de quintas e quartas e inúmeros elementos, os quais um músico ocidental mais conservador àquela época - que valorizava a produção polifônica clássica de um Beethoven - iria considerar primitiva e pouco moderna à época, não obstante divergisse este da posição de um Stravinsky ou de um Stokowsky, observadores da genialidade villalobiana.

Segundo ponto interessante é que muitos consideram o ápice da produção de Villa-Lobos a união do particular rítmico e melódico brasileiro com o modelo geral técnico bachiano ${ }^{104}$. Como o próprio compositor carioca mencionou, a música de Bach é universal ${ }^{105}$. E assim se produziu uma peça como a "Bachiana $n^{\circ} 2,4^{\circ}$ movimento Toccata, O Trenzinho Caipira", sem estuchar de teorias, mas sim valorizado elementos universais e particulares num conjunto harmoniosamente dialógico.

Quanto a isto, quando se pensa em estudar uma História do ensino do Direito Administrativo brasileiro, é interessante apreciar a dinâmica da relação entre as construções gerais de pensamento administrativista europeias (técnica basilar) com as particularidades da estrutura jurídico-funcional do Estado nacional oitocentista (melodia) e os conceitos históricos apreendidos nas fontes brasileiras (ritmo), no seu próprio contexto particular. As ideias estão fora do lugar, mas fora do lugar em relação a quem?

Assim, a valorização de modelos universais de pesquisa sem preterir o particular brasileiro se faz relevante especialmente para o aspecto concreto desta pesquisa, pois se objetiva avançar na discussão sobre as hipóteses de construção de pensamento jurídico na academia de São Paulo. Ora, já se destacou a problemática existência da área cinzenta de discussão sobre o bacharelismo e sobre os perfis do bacharel. Também foram apontadas das ideias clássicas de autores como Sérgio Adorno e Venâncio Filho sobre como aspectos da dinâmica metodológica do ensino à época. Contudo, poucos estudos dirigidos e especializados - no caso, de Direito Administrativo - foram travados na área, principalmente, sobre o que representou o elemento cultural do bacharel na História das ideias jurídica e políticas brasileiras ${ }^{106}$.

\footnotetext{
${ }^{104}$ NOBREGA, A. As bachianas de Villa-Lobos. Rio de Janeiro: MEC: Museu Villa-Lobos, 1971. 12p. ${ }^{105}$ Apud HORTA, L. P. Villa-Lobos: uma introdução. Rio de Janeiro: Jorge zahar, 1987. p. 7

${ }^{106}$ FONSECA, Ricardo Marcelo. Op. Cit. 336-370.
} 
Primeiro, porque a maioria da doutrina administrativista sequer cita a constituição do circulo acadêmico de Direito Administrativo. Segundo, porque a minoria que se arriscou a tratar sobre o tema tampouco demonstrou um grau de investigação histórica aprofundado sobre as fontes, tão-somente se limitando a listar nomes de professores, acontecimentos e compêndios produzidos. Terceiro, porque parte das pesquisas bem servidas de uma metodologia crítica e moderna de Histórica do Direito Administrativo caem no problema de (i) se sobrepor a análise do discurso ou da História social em detrimento do uso crítico-histórico dos conceitos presentes nas fontes e de (ii) permitir o predomínio da melodia europeia na análise particular brasileira.

Não obstante, considerando a importância de se fazer um diálogo entre as fontes que tratam sobre temas que se entrelaçam, seguem algumas pesquisas que se consideraram aqui relevantes à discussão sobre o ensino jurídico de Direito Administrativo e a cultura jurídica. Para que não se caísse numa armadilha de classificações perigosas sobre tipos de pesquisa, destaca-se que a divisão é meramente baseada no quão específica é a pesquisa sobre o tema tratado nesta dissertação. Portanto, partir-se-á da investigação mais geral até alcançar a teses mais aprofundadas sobre a temática.

\subsubsection{O Ensino Jurídico e a História Tradicional do Direito Administrativo Brasileiro}

Inicialmente, a análise primária da literatura no Brasil que trata sobre o aspecto dogmático e positivo do Direito Administrativo permite concluir quão lacunosa é a pesquisa sobre a História desta área, sendo mais grave ainda no caso do ensino jurídico administrativista, conforme aponta Guandalini:

\footnotetext{
"Não obstante, a maioria absoluta dos doutrinadores da matéria se limita a mencionar a criação das primeiras cadeiras de Direito Administrativo nas faculdades de Direito do país, indicando os autores mais importantes da área - isso quando chegam a discutir a história da disciplina em suas obras. É o que fazem, por exemplo, Caio Tácito (1975), que apenas examina a história da disciplina na Europa; Antônio Queiroz Telles (1995),
} 
Hely Lopes Meirelles (2008), Diógenes Gasparin (1995) e José Cretella Jr. (1966, 1989, 1991), que se limitam a discorrer sobre a criação da cadeira nas faculdades de Direito; e Lúcia Valle Figueiredo (2003) e Celso Antônio Bandeira de Mello (2007), que sequer abordam a história da disciplina em suas obras manualísticas." ${ }^{107}$.

Ora, isto aponta a falta na pesquisa de autores renomados do Direito Administrativo da sua História acadêmica, muito embora ainda haja fontes históricas não analisadas que podem contribuir para a discussão histórica e para a compreensão da formação jurídica da ciência administrativa.

Assim, é relevante sopesar criticamente o diálogo entre os documentos que constituem a significação histórica do Direito Administrativo. E o estímulo à produção de pensamento no ensino jurídico administrativo, junto ao cultivo de doutrinas, à manufatura consultiva do Conselho de Estado, à legislação, aos julgados do legislativo e do judiciário, são estas fontes históricas que podem contribuir para a discussão sobre a construção desta área específica da cultura jurídica brasileira.

Assim, quanto à escassa literatura que aponta, em alguma medida, elementos históricos sobre o ensino do Direito Administrativo no século XIX, foram observadas três obras distintas. Primeiramente, destaca-se o artigo de "500 anos do Direito Administrativo brasileiro", produzido pela professora Maria Sylvia Zanella di Pietro ${ }^{108}$, porque este material representa um exemplo do retrato mais tradicional da pesquisa histórica do Direito Administrativo ${ }^{109}$.

Atentando-se para o seu propósito conciso e panorâmico, o artigo desenvolve, dentre outras questões, um pequeno histórico do surgimento da área na Europa e realiza uma breve evolução cronológica desde o período colonial no Brasil até os tempos hodiernos. Particularmente, quanto ao período monárquico, a autora ressalta alguns elementos de organização administrativa importantes, como a existência de uma harmonia entre os Poderes Executivo, Legislativo, Judiciário e Moderador; e, ainda, a criação do Conselho de Estado como órgão consultivo, comparando-o com a

\footnotetext{
${ }^{107}$ GUANDALINI JR, Walter. Op. Cit. $124 \mathrm{p}$.

${ }^{108}$ Op. Cit. p. 29-54.

${ }^{109}$ BURKE, Peter (Org). A escrita da história: novas perspectivas. São Paulo: Editora UNESP, 2011. p.20-25.
} 
importância do Conselho de Estado francês. Também dá atenção para diversos doutrinadores na movimentação científica da ciência, dentre os quais Pereira do Rego, Tavares da Veiga Cabral, Visconde de Uruguai, José Rubino de Oliveira, Duarte Pereira, Joaquim Ribas e Furtado de Mendonça.

Em especial sobre o ensino de Direito Administrativo, o artigo destaca a produção dos professores-doutrinadores em prol do desenvolvimento da ciência e a cita un passant a criação da cadeira em São Paulo em 1855, com a figura em destaque de Ribas como professor de exercício. Em verdade, foram lentes de Direito Administrativo na faculdade de São Paulo Joaquim Ribas e Furtado de Mendonça, não obstante o primeiro e Veiga Cabral tivessem se consagrado notadamente como professores de Direito Civil.

Di Pietro caracteriza a falta de uniformidade dessa doutrina, mesmo porque não havia padronização sequer em relação ao seu objeto. Algo compreensível, tendo em vista o aspecto gelatinoso da ciência do Direito Administrativo, ainda em formação no século XIX, inclusive pela intersecção de áreas que hoje são autônomas, tais como Constitucional e Tributário. Outros pontos relevantes levantados são sobre a forma como se relacionaram a Administração e os Poderes, bem como sobre a caracterização dos atos administrativos que, conforme se verá, são temáticas abarcadas também nas Theses apresentadas para os estudantes da faculdade dissertações. Isto demonstra o enlace entre as fontes históricas, já que parte importante destes doutrinadores foram lentes do largo de São Francisco.

Nota-se nessa pesquisa uma forma de abordagem da História do Direito Administrativo e, consequentemente, do ensino do Direito Administrativo brasileiro que valoriza a análise mormente narrativa dos acontecimentos, com um viés estático muito voltado para a descrição da legislação, dos julgados e da doutrina e, ainda, cativo à delimitação institucional. É uma História "vista de cima", que parte tão-somente de feitos dos que eram considerados grandes homens da área, ou seja, de doutrinadores e professores. Não há uma atenção para o elemento da relação propriamente acadêmica, mas da emanação de informações advindas de um só sentido, o docente. 
Não há discussão histórico-crítica dos conceitos jurídicos ou mesmo atilada aos aspectos do poder e questões de desenvoltura estrutural do regime político. A preocupação é muito mais quantitativa e atenta à análise dos fatos históricos em seus aspectos individuais - e não ao diálogo dos acontecimentos político-administrativos. E, por fim, é perceptível a noção de História do Direito como uma ciência objetiva e exata, sem ponderação sobre as inconstâncias e incertezas do sujeito e do histórico.

Não obstante, existem outras pesquisas sobre a História do ensino administrativo. Se se observar o panorama existente das demais obras e se descartar, por bem, as produções que fazem um resgate até do código de Hamurabi para tratar de atos administrativos, há algumas opções válidas, metodologicamente falando, sobre a produção da cultura jurídica administrativista no Brasil oitocentista. Optou-se, assim, pelas duas a seguir.

\subsubsection{O Ensino Jurídico e a Cultura Administrativista do Conselho de Estado}

Primeiramente, a atenção dada ao "O Oráculo de Delfos - O Conselho de Estado no Brasil-Império", de José Reinaldo de Lima Lopes se deu porque ela desenvolve uma investigação aprofundada no quadro de fontes históricas acerca de uma específica instituição do período monárquico, a qual produzirá debates na área do Direito Administrativo relevantes, segundo o autor. Assim, a discussão trazida sobre a importância do Conselho de Estado na cultura jurídica oitocentista brasileira objetiva rediscutir a elaboração de conhecimento jurídico - para além das discussões políticas daquele período.

Não obstante, quando se trata do tema da "produção jurídico-intelectual" acadêmica, o autor a vê com o olhar negativo, visto que os bacharéis tiveram sua importância na política e na construção do Estado nacional, mas não na produção de conhecimento técnico ou dogmático-jurídico. Para tanto, ele faz uso dos autores Adorno e Venâncio Filho e, paralelamente, defende que a extensa documentação existente na corte parlamentar e no Conselho de Estado demonstraria concretamente a sofisticação deste âmbito de produção de cultura jurídica: 


\begin{abstract}
“Talvez não seja o caso de ultrapassar os limites da constatação sociológica, segundo a qual as faculdades de Direito eram uma espécie de criadouro de agentes do Estado, (...) não é descabido dizer que sua cultura jurídica tem papel subalterno quando comparada com as sociedades polidas da cristandade europeia. (...) Ao mesmo tempo, porém, é certo que as fontes (debates parlamentares, relatórios de ministros e decisões do Conselho de Estado) sugerem um grau sofisticado de argumentação se não em todos pelo menos em numerosos textos da elite imperial". ${ }^{110}$
\end{abstract}

Contudo, Lima Lopes também pesa a mão na análise sobre o ensino jurídico de outros países ${ }^{111}$. Além do caso alemão, que seria o único com uma formação intelectual mais produtiva, e das especificidades particulares dos sistemas estadunidense e inglês de ensino, ele suscita o exemplo francês que, contrariamente, tinha um modelo híbrido, em que se dedicavam os juristas ao mesmo tempo à academia, a funções de governo e de legislação e, ainda, à advocacia. Somado a isto, a formação jurídica era em âmbito familiar ou por meio da própria prática, o que ilustra como as faculdades de Direito tinham funções intelectuais de menor alcance se se comparar com o grau de elaboração acadêmico, científico ou mesmo de erudição, que hoje se dá na maioria das ilustres escolas de Direito ocidentais.

Além disso, assevera o autor que grandes nomes do Direito francês não foram acadêmicos, passando longe da universidade, como, por exemplo, André Dupin, Désiré Dallloz, Tropplong e, particularmente, Louis Marie de Cormenin que, considerado o pai fundador do Direito Administrativo francês, foi advogado e auditor do Conselho de Estado, sendo só na posterioridade designado professor da escola de Administração.

Nestes termos, teria tal modelo napoleônico sido transportado para no Brasil, posto que aqui o magistério também era considerado como um emprego público qualquer do Estado, sem tradição prévia universitária e, assim, transitavam os professores entre a administração e a academia.

Não obstante, esta lacuna na academia não teria impedido a formação de uma cultura jurídica de alto nível no Brasil fora dos muros da escola, pois muitos dos juristas

\footnotetext{
${ }^{110}$ LIMA LOPES, José Reinaldo de. Op. Cit. p. 100-101.

${ }^{111}$ LIMA LOPES, José Reinaldo de. Op. Cit. 102p.
} 
importantes nesta produção intelectual não foram professores. O problema que ocorria era a falta de orientação e organização na construção dessa cultura, por falha institucional na organização do Estado. Mas, então, como poderia haver um Estado de bacharéis, mas sem uma grande cultura jurídica?

O autor considera que a cultura jurídica no Brasil monárquico teria mais um papel propulsor e a qualidade de senso prático, pois estava predominantemente nas mãos de homens de ação e não de acadêmicos à moda alemã. Nesse ínterim, havia duas tarefas importantes para os juristas daquele tempo: constituir o Direito nacional, bem como erguer um Estado Constitucional Liberal. E seria o Conselho de Estado o maior fornecedor dessa cultura que, inclusive, começou a valorizá-lo como órgão produtor de jurisprudência à medida que dava respaldo jurídico nas razões de decidir do Imperador, auxiliando o Poder Moderador.

Ressalva-se aqui, não obstante, conforme o próprio autor proferiu, que ainda há muitas discussões a serem feitas na área, principalmente se se levar em conta o universo de fontes ainda pouco analisados ${ }^{112}$, portanto o estudo da dinâmica sobre quem era $\mathrm{o}$ grande emissor jurídico do Império ainda pode ser revisto com o trabalho árduo do exame de fontes ainda pouco observadas, inclusive na área de produção de conhecimento nas faculdades de Direito.

Aliás, quanto à importância do meio acadêmico na produção de cultura jurídica, por exemplo, descobriu-se uma recente pesquisa francesa que trata justamente sobre o tema do ensino público e administrativo nas faculdades do século XIX, demonstrando que lá a literatura em geral deu atenção, por muito tempo, à projeção do Conselho de Estado francês na cultura jurídica administrativista, mas que novas pesquisas têm mitigado esta certeza em prol da produção doutrinária acadêmica e citando, especificadamente, o professor Foucart como elemento importante nessa discussão na faculdade de Poirtiers, em meados do século XIX ${ }^{113}$. Eis porque sempre se deve repensar a pesquisa de fontes e conceitos históricos, bem como sua interpretação.

\footnotetext{
${ }^{112}$ LIMA LOPES, José Reinaldo de. Op. Cit. p. XIV-XV.

${ }^{113}$ TOUZEIL-DIVINA, Mathieu. Eléments d'histoire de l'enseignement du droit public: la contribuition du Doyen Foucart: 1799-1860. Université de Poitiers, 2007.
} 
O método interpretativo no âmbito jurídico do século XIX é um dos temas tratados na pesquisa de Lima Lopes. Este seria o século que consagrou o sistema constitucional liberal, um complexo processo de construção política que impôs limites ao sistema de interpretação até então vigente ${ }^{114}$, pois desenvolveu um método para além da exegese, que valorizava a obediência aos comandos abstratos ${ }^{115}$ e que sujeitava a lei à ratificação da vontade popular ${ }^{116}$.

Contudo, o processo de redefinição da tarefa do intérprete em vista da supremacia do legislador na ordem constitucional liberal seria uma tarefa difícil de ser posta em prática e é então que o Conselho de Estado se constitui, apropriando-se de duas incumbências interpretativas: tratar da relação entre doutrina e legislação e, ainda, controlar os aplicadores da lei, ou seja, cuidar para que os intérpretes não acumulassem sobre o Direito interesses de classe em detrimento da vontade popular. Seriam, portanto, os conselheiros os intérpretes autorizados a estabelecer ordem jurídica brasileira.

E houvera, no Brasil do século XIX, um período de transição entre a noção geral-abstrata e o caso concreto, pois tanto o legislador como o jurista deveriam estar atentos à conjuntura social, de forma a harmonizá-la com o controle legal. Nesse sentido, o modelo interpretativo dos pareceres do Conselho seguia uma linha restritiva, sem ampliar as eventuais consequências da lei. $\mathrm{O}$ autor enfatiza o exemplo do delicado campo da argumentação jurídica sobre a lei Feijó e o fim da escravidão, considerando que qualquer interpretação mais ampla pelo Conselho da lei poderia trazer um impacto na propriedade e patrimônio dos proprietários, já que gerariam seus pareceres uma doutrina, mesmo que involuntariamente, nas diversas áreas, inclusive no Direito Administrativo.

Ora, isto ilustra o interesse das camadas dominantes, com a aprovação estatal em manter as análises jurídicas daquele período com o aspecto apriorístico outrora suscitado por Bourdieu, ou seja, com a valorização do aspecto distanciado e neutro das fontes em relação aos problemas políticos e sociais, muito embora houvesse sim um

\footnotetext{
${ }^{114}$ Base pela raiz exegética francesa e o pensamento conceitualista clássico alemã. Em Portugal, por exemplo, esta influência era visível nos Estatutos da Universidade de Coimbra de 1772: "que não transcendam os magistrados e professores os justos e impreteríveis limites das suas faculdades".

${ }^{115}$ LIMA LOPES, José Reinaldo de. Op. Cit. 5p.

${ }^{116}$ LIMA LOPES, José Reinaldo de. Op. Cit. p. 10-11.
} 
resultado político muito definido em tal postura: manter o controle do status quo por meio de uma violência simbólica do Direito. E, conforme se verá, não teria sido diferente no formato de estruturação metodológica do ensino jurídico.

Além disso, outra grande alteração importante para a interpretação jurídica era o fato de o soberano não mais acumular as funções de fazer, interpretar e aplicar as leis ${ }^{117}$. Ocorreu que o Estado constitucional, com a separação dos poderes, havia dividido quem fazia as leis e quem as aplicava, sendo que as questões locais e de fato competiam agora ao Poder Judiciário.

E o tema da interpretação das leis, que era historicamente um tema geral do ensino do Direito por meio da disciplina do Direito Natural, passou a ser tratado, ao longo do século XIX, mais na área do Direito Privado, posteriormente aparecendo na introdução dos cursos jurídicos, com a Filosofia do Direito. Não obstante, a particularidade histórica do Direito Civil e suas interpretações ao longo do tempo de grandes escritos tais como o Corpus Iuris Civilis trouxe uma discussão forte e particular para essa área ${ }^{118}$.

Assim, com relação à interpretação na doutrina, dentre as diversas divergências, o autor traz a visão do Conselheiro Ribas ${ }^{119}$, que era favorável à corrente de Savigny quanto à atividade de interpretação do jurista, pois este não deveria explicar ou esclarecer, mas reconstruir o sentido das leis ${ }^{120}$. Ribas realiza uma classificação da interpretação de acordo com os cânones tradicionais do Direito: origem legal privada ou pública $^{121}$, sendo esta última interpretação uma nova elaboração da lei, estando sujeita a princípios e regras da Constituição política e das condições sociais.

Ribas não concordava em realizar uma separação entre a interpretação literal da histórica, posto que seria una, mas dividida harmoniosamente entre os elementos gramatical, lógico, sistemático e histórico, os quais atuam juntos, mas com certa

\footnotetext{
${ }^{117}$ Nesta lógica, os juízes eram meros delegados dos príncipes.

${ }^{118}$ LIMA LOPES, José Reinaldo de. Op. Cit. 84p.

119 De acordo com o autor, Paula Baptista, diferentemente, só considerava que interpretar é sempre descobrir o sentido possível no caso concreto.

${ }^{120}$ LIMA LOPES, José Reinaldo de. Op. Cit. 75p.

${ }^{121}$ A interpretação seria, portanto, autêntica, ou seja, feita pelo poder incumbido de fazer a lei ou usual, feita pelo direito popular ou científico.
} 
predominância de alguns elementos em cada caso, de forma a reconstruir o verdadeiro pensamento da lei. Contudo, ressalta ainda o Conselheiro Ribas que o jurisconsulto não deve interpretar o pensamento da lei, mas sua expressão, como se sugerisse separar a forma do conteúdo da expressão - algo difícil de se proceder, de acordo com Lima Lopes.

Além do Conselheiro Ribas, também são suscitados autores relevantes como o próprio Visconde do Uruguai e Pimenta Bueno, mas aqui se deu destaque para o primeiro em razão de sua proximidade para com a academia de São Paulo.

A seguir, a obra conclui que certas ideias fundamentais de interpretação se repetem nas fontes históricas, pois apesar de ocorrer eventuais discussões entre as correntes existentes, sempre se perfaz um acordo entre elas. E, dentre os principais pontos discutidos, notou-se que a literatura à época admitia majoritariamente que houvesse um conflito constante entre a expressão da lei e seu sentido real, bem como que o legislador é uma peça necessária para dar sentido unitário ao amontoado de leis, mas que, ao mesmo tempo, é sujeito de discurso intencionado no momento em que legisla.

Ao analisar estas controvérsias históricas acerca da interpretação no século XIX no Brasil, Lima Lopes considera que a mudança travada no período não foi da lógica ou mesmo do procedimento interpretativo, mas sim dos valores de base e das presunções que proporcionam a cada cultura a sua identidade. E compreender estas características é, em parte, função do Direito comparado, que analisa os contrastes entre sistemas contemporâneos, assim como é da História do Direito, que analisa a diferença temporal no mesmo sistema. Eis porque afirma ser a pesquisa sobre os pareceres do Conselho relevantes, pois permite compreender melhor a construção da identidade cultural jurídica brasileira em meados do século XIX.

Por fim, ainda sobre a interpretação oitocentista, faz uma comparação de modelos desenvolvidos no Brasil com os da Europa. Nesta, as premissas interpretativas eram a envolta à legalidade, à soberania popular, à liberdade individual, à garantia da liberdade e à limitação dos poderes públicos e privados dentro do sistema. Diversamente, no Brasil, um dos elementos que se destacam no paradigma jurídico- 
intelectual do século XIX é a importância da organização de um Estado moderno, burocrático e impessoal. Não que isso tivesse de fato ocorrido, mas era a ideia de um padrão interpretativo regulador das decisões que importava.

Agora, após esta discussão travada acerca da interpretação, passa a obra a abarcar finalmente o estudo sobre as fontes históricas produzidas no Conselho de Estado cuja atuação, num contexto de fraco desempenho do Supremo Tribunal para unificar a jurisprudência, fora tratada por diversos autores ${ }^{122}$.

Conselheiro Ribas, por um lado, ponderava que não poderia haver caráter autêntico em interpretações das leis que não adviessem do Legislativo, não sendo, portanto, pertinente consagrar no sistema brasileiro o costume francês de interpretar, por meio de avisos, o que decidia a corte. Isto porque não seria respeitada a separação de poderes se se interpretasse a legislação por um órgão ligado ao governo ${ }^{123}$.

Em outra medida, conforme já se suscitara, o Visconde do Uruguai considerava que, com exceção das questões relativas à fazenda, o contencioso administrativo era um caos e que não eram seguidos os pareceres do Conselho. Pereira do Rego, por outro lado, asseverava que tal órgão não era Tribunal de última instância administrativa, mas que supervisionava a administração, apesar insuficientemente. A questão, enfim, foi tratada pelo próprio Conselho, em 1872, com forte atuação de Nabuco em um caso de conflito de jurisdição, decidindo-se que continuaria sendo o órgão tão-somente opinativo.

Lima Lopes também respalda sua análise numa comparação com os exemplos francês e americano sobre a questão, pois em ambos estes países não se definiu o Judiciário propriamente como um Poder, mas como um departamento especializado e de responsabilidade do próprio governo ${ }^{124}$, pelo ministro da justiça. E, assim, se se observar o Direito comparado e o caso concreto do contencioso administrativo - e não somente a interpretação legislativa - será possível perceber que no Brasil também se

\footnotetext{
${ }^{122}$ LIMA LOPES, José Reinaldo de. Op. Cit. p. 96-97.

${ }^{123}$ LIMA LOPES, José Reinaldo de. Op. Cit. 120p.

${ }^{124}$ Há aqui uma divergência de análise, conforme se verá, com a pesquisa de Guandalini.
} 
constituiria esta submissão do judiciário, formando-se como um sistema misto dos dois anteriores, com a devida importância dada ao Conselho.

Enfim, a interpretação legal sobre a possibilidade da existência de um contencioso administrativo foi resultado de um longo processo de discussões que resultou no decreto $\mathrm{n}^{\mathrm{o}} 124$ de $1842^{125}$, em seus artigos 24 a 41 , que tratam sobre a reforma judiciária e os conflitos de jurisdição. Mas muito embora haja a restrição legal ao Conselho, o autor procura demonstrar que a maior parte das consultas feitas pelo Imperador ao órgão foram seguidas, bastando para tanto notar que, dentre as questões por ele tratadas, estavam sempre aquelas em que o Poder Moderador devia ser exercido, como a dissolução da Assembleia; a separação das esferas administrativa e judiciária; os casos em que poder local (Assembleia Provincial) invadia poderes da Assembleia Geral; os dissídios jurídicos que dependiam da aplicação imediata de uma norma jurídica preexistente (tanto em constitucional como legal).

Conclui, portanto que, mesmo sendo um órgão de consulta, foi importante na produção de cultura jurídica no Brasil do século XIX, não se constituindo como mera manobra pessoal autoritária do Imperador.

Além de outras diversas áreas jurídicas, circulavam no "Oráculo de Delfos" diversos temas de Administrativo, constituindo-se como $42 \%$ das consultas feitas a ele. E, dentro desta porcentagem, abrangiam 32,4\% das questões sobre cargos da justiça, $15,2 \%$ sobre jurisdição e competência, $7 \%$ sobre escravidão e $6 \%$ sobre a guarda nacional, dentre outras ${ }^{126}$. Esta quantificação é interessante para esta dissertação de mestrado, pois permite justamente o diálogo do pensamento jurídico construído com as fontes do Conselho e com os temas tratados nos estudos das academias do império, notadamente com as Theses de Administrativo elaborada pelos professores.

Assim, dentre os temas relevantes tratados que envolviam discussões de Direito Administrativo, destaca o autor em sua pesquisa, primeiramente, o controle de constitucionalidade. O Conselho de Estado realizava um exame anual da legislação

\footnotetext{
${ }^{125}$ De acordo com o referido decreto, o Conselho operava em seções distintas, sendo a dos negócios da justiça que ocupava papel especial na medida em que organizava a máquina judiciária e opinava na legislação geral, tanto no âmbito público e no privado.

${ }^{126}$ LIMA LOPES, José Reinaldo de. Op. Cit. p. 169-173.
} 
provincial para verificar se estava conforme a Constituição e os termos do Ato Adicional $^{127}$, principalmente para verificar se a província não havia excedido seus poderes. Em caso positivo, fazia-se uma recomendação ao Ministro de governo para encaminhar a questão à Assembleia Geral. Desse modo, o Conselho guardava certas semelhanças a órgãos de controle de constitucionalidade. Em outra medida, também se tratava acerca de matéria policial criminal, da guarda nacional, realizava-se exame prévio de leis e de temas de reformas importantes, como casamento, hipotecas e reformas judiciais. Nesse sentido, apontavam os conselheiros as falhas na legislação quando eram observadas por eles.

Também se discutia sobre o contencioso Administrativo. O Conselho analisava conflitos de competência e jurisdição, a despeito de o próprio Nabuco de Araújo apontar a inconstitucionalidade do contencioso administrativo e de o tema ter sido tratado normativamente ${ }^{128}$. Nesse sentido, as temáticas abrangiam conflitos de direitos de servidores tais como oficinas de justiça, membros da guarda nacional; como também atritos de jurisdição entre autoridade eclesiástica e a secular; e, ainda, conflitos de competência entre o Judiciário e a Administração, por exemplo, se o Presidente de Província decidisse, numa querela processual, favoravelmente à Administração, o caso subia ao Conselho.

Em terceiro lugar, havia o tema da organização Judiciária. O Conselho recebia, em sua Seção de justiça os pedidos relativos a empregos e ofícios de justiça. Assim, também tratava acerca da organização dos poderes das províncias e do exame das leis provinciais, de modo que fosse possível organizar os serviços e os desmembramentos de comarca e de distritos.

Por fim, havia discussões sobre os recursos de graça ao Poder Moderador, em que o Conselho apresentava a justificativa jurídica para as decisões de recursos promovidos ao Poder Moderador, bem como a resolução de dúvida e interpretação de lei, que era tratada de uma forma semelhante a o conflito de competência, pois o órgão

\footnotetext{
${ }^{127}$ Decreto $\mathrm{n}^{\mathrm{o}} 124$ de1841, art. 21. Lei de interpretação do Ato Adicional.

${ }^{128}$ Por exemplo, a Lei ${ }^{\circ} 581$ de 1850 , Lei Eusébio de Queiros, que tratou sobre o aspecto não contencioso do Conselho.
} 
realizava a análise de questões políticas importantes que rodeavam o debate político e jurídico. Normalmente, as dúvidas viriam dos Poderes Executivo e Judiciário.

Além dos temas extremamente ligados ao âmbito jurídico-administrativo, Lima Lopes dá destaque também a tópicas gerais que envolvem grandes querelas estruturais do Brasil daquele contexto, dentre as quais se destacam: o tema polêmico pelo fim da escravidão; a questão da polícia na justiça e a organização da burocracia, provocada pelo conflito cotidiano entre poder local e central e entre presidente de província e juízes de Direito; a problemática sobre quem seria a autoridade última na interpretação e aplicação da lei; a temática do Estado e a modernização da infraestrutura material, principalmente a partir de 1870, com a industrialização crescente.

É interessante guardar na memória estas análises que o autor descreve terem sido alvo de debates jurídicos dentro do Conselho de Estado. Isto será importante quando se analisar panoramicamente quais os temas tratados pelas theses de Direito Administrativo no último capítulo, bem como aqueles esquecidos.

Por fim, considera o autor que a análise feita pelo Conselho não se baseava em juízo de conveniência, mas no exame prático da legislação de cada caso, pois ocorriam muitas dúvidas com relação à clareza da Constituição sobre temas como a separação de Poderes, sobre a forma como aplicar a lei. Também era necessário revisar anualmente a legislação provincial a fim de mantê-la dentro dos limites de sua esfera de competência, bem como observar os regulamentos publicados pelo governo para aplicar a lei.

Ora, conforme se verá, trata-se de um panorama de análise da cultura jurídica administrativa distinto daquele retratado nas dissertações pois, conforme se verá, havia muita citação de doutrina e de análises histórico-jurídicas, muito embora também houvesse a citação do corpo legislativo.

Nesse contexto, para a análise deste autor, havia uma tomada de partido saliente por parte do Conselho, pois mesmo quando buscava ser neutro, seus pareceres acabavam provocando efeitos políticos. Os exemplos mais expressivos são a demora em se tratar acerca da abolição, a preferência às ideias centralistas, a ponderação pela 
competência exclusiva do Poder Judiciário em interpretar as leis em detrimento do uso doutrinário.

Assim, havia muitos casos que chegavam ao Conselho de Estado como reflexo dessa demanda interpretativa formal, tais como, a incompatibilidade do exercício de diversos cargos pela mesma pessoa, a organização constitucional e a barreira entre legislador e julgador. Além de se vislumbrar pelos conselheiros certa hostilidade à doutrina, posto que não conteria esta o distanciamento lógico da lei. Novamente, retumba o poder simbólico desse tipo de interpretação em favor dos interesses das camadas dominantes, sob concentimento estatal.

Por fim, Lima Lopes conclui que, apesar de não ter um papel decisório, o Conselho supria as lacunas existentes, pois foi através de suas consultas que participara do processo de interpretação, posto que estas detinham certo prestigio. E cita o autor Baptista para concluir seu raciocínio: sua interpretação não era autêntica, não podia usurpar a função legislativa, mas auxiliava a chegar perto da verdade. Auxiliava a criar uma interpretação doutrinal.

Ora, esta pesquisa sobre o Conselho de Estado apresenta três aspectos relevantes para esta investigação de mestrado. Primeiramente, que não só havia uma produção de cultura jurídica naquele período imperial como também ela tinha uma função muito definida, que era aprontar as bases jurídico-formais e legais do Estado ainda em formação.

Em segundo lugar, Lima Lopes delimita diversas temáticas relevantes da conjuntura política que foram tratadas pela sua fonte principal e, assim, demonstra que os juristas reagiam às questões estruturais resultantes das relações de poder, mesmo que de uma forma aparentemente distante e neutra, de forma a influenciar e determinar o resultado destas disputas de força. Por fim, que havia um método interpretativo do Direito, mesmo que ainda incipiente e confuso, pois prevalecia por parte do Conselho de Estado o uso o sentido restrito da lei para resolver os conflitos jurídicos e, consequentemente, criava precedentes e influenciava a doutrina. 
Embora não seja objeto aqui realizar uma análise comparativa de fontes históricas, este material será útil para que se verifique se havia indícios de diálogo entre as theses da cadeira de Direito Administrativo com os temas de produção de cultura jurídica recorrentes à época e se o método de análise jurídica da academia e do Conselho guardava alguma semelhança entre si. Não obstante, será esta uma abordagem residual da análise metodológica das dissertações de Administrativo.

\subsubsection{O Ensino Jurídico e a Gênese do Direito Administrativo Brasileiro}

A investigação de Guandalini sobre a "gênese do Direito Administrativo brasileiro - formação, conteúdo e função da ciência do Direito Administrativo durante a construção do Estado no Brasil imperial” tem a hipótese de que, no Brasil, a ciência do Direito Administrativo não cumpriu a função de fortalecimento do Estado a qual se desenvolveu na Europa do século XIX, mas seu discurso - desde seus conceitos, teorias e vocabulários - foi aqui reterritorializado com uma função diversa: em vez de se regular o exercício de um Estado já vigente, legitimou sua criação e construção. E é por meio da compreensão dessa formação de discurso científico sobre o Direito Administrativo que o autor demonstra as características da realidade jurídicoadministrativa brasileira.

Para tanto, primeiramente ele analisa do processo de formação da cultura jurídica na Europa ${ }^{129}$ daquele tempo para então apresentar o que se desenvolveu no Brasil em termos de construção intelectual administrativista a fim de justificar o modelo aqui instaurado. Na Europa dos séculos XVIII e XIX, verificou-se um processo de criação do Direito Administrativo e, ao mesmo tempo, de autonomização da ciência jurídica administrativista a qual se difundiria no intelectual tanto da área acadêmica - já que se constituía como disciplina das faculdades de Direito - como ainda na cultura tratadística, em que se analisava da jurisprudência do Conselho de Estado ${ }^{130}$.

\footnotetext{
${ }^{129}$ O material base da análise de Guandalini sobre a Europa é a obra de SORDI, Bernardo; MANORI, Luca. Op. Cit.

${ }^{130}$ GUANDALINI JR. Walter. Op. Cit. p. 1-2.
} 
Assim, a formação do Estado burocrático à época - com a separação entre administração pública e poder jurisdicional, com a autonomia do Estado para centralizar poder político, com a regulamentação da cidade e o fortalecimento da ordem capitalista com as revoluções burguesas - permitiu que a coisa "administração", num âmbito jurídico-formal, pudesse já viver sem ponto comum com o judiciário, de forma a significar o poder estatal.

E para os juristas europeus darem conteúdo a esta "coisa", desenvolveu-se um estudo para além da área civil e privada em geral, o qual seria justamente a ciência jurídico-administrativa. Eis que a palavra "Direito Administrativo" se afirmou sobre um discurso de racionalização a posteriori da realidade ${ }^{131}$. Não obstante, considera Guandalini que a construção dessa área também edificava a própria administração: era o processo de maturidade do processo histórico de fortificação de um Estado nacional autônomo que regula suas próprias atividades.

Não obstante, no Brasil oitocentista, vislumbrava-se contexto completamente diverso, com uma específica sociedade e distinta função política dessa disciplinante napoleônica. $\mathrm{O}$ autor considera que havia um atraso de cinquenta anos em relação ao desenvolvimento da ciência do Direito Administrativo francês, pois embora tenha sido criada a disciplina em 1854, não havia ainda a administração pública organizada para ser seu objeto de estudo. Eis que a ciência não se desenvolveu um processo de racionalização concomitante ou a posteriori com o Estado, como foi o caso europeu, mas sim a incorporação de um conjunto de doutrinas alienígenas que detinham pouca relação com a realidade política e institucional do Brasil.

Guandalini usa para esta análise a hipótese foucaultiana sobre o dispositivo de poder na modernidade, sendo que a existência do Direito Administrativo pressuporia a racionalização jurídica de práticas disciplinares típicas da sociedade de normalização, o que não havia no Brasil até o início século $\mathrm{XX}$. Isto porque a soberania brasileira não era tradicional como a de países europeus, dificultando sua fundamentação jurídica de legitimidade em Direitos ancestrais originários. Então o Direito Administrativo precisaria aqui de outro fundamento jurídico de legitimidade adequado, com uma 
função acessória e incipiente da organização do poder político estatal, baseada na figura da unidade nacional, o Imperador.

Portanto, a recente ciência do Direito Administrativo brasileira legitimava o poder político ao mitificar juridicamente a figura imperial, trazendo absolutismo ao seu Poder Moderador a fim de cobrir a carência estatal percebida com a independência política. Nesses termos, diferentemente do contexto europeu, aqui teria ela uma função menos fundamental à estabilidade do regime político, funcionando especificamente como alicerce do discurso jurídico de argumentação e organização do novo Estado nacional.

Passa-se aqui, neste processo de reterritorialização da ciência jurídicoadministrativa, da função administrativo-regulamentar europeia para função constituinte-soberana brasileira. E é com esta análise que o autor decodifica a construção da cultura jurídica pública no Brasil do século XIX por meio da análise das razões históricas da formação da ciência do Direito Administrativo, dos temas por ela debatidos e do pensamento jurídico desenvolvido, fazendo-o pela compreensão da sua gênese como configuração discursiva inserida no tecido histórico, bem como sua função política no processo de construção de um Estado Nacional ${ }^{132}$.

Há interesse na pesquisa de Guandalini em identificar o discurso jurídico especializado que circulava entre as elites políticas e intelectuais, pois mais relevante do que saber o locutor, é ter em mente qual o discurso que circula por seus enunciadores. Não quer ele reiterar a cientificidade da ciência do Direito Administrativo, mas tratar da sua pretensão de poder, pois mesmo entre os "teóricos" e os "práticos" do Direito, formavam-se equilíbrios de poder provisório que dinamicamente funcionavam de forma a alcançar a significação real da norma ${ }^{133}$.

Assim, considera que havia três campos de atuação do discurso da elite burocrática: no âmbito do Conselho de Estado (produção de jurisprudência), nas faculdades de Direito e, ainda, na produção científica dos compêndios e livros escritos sobre Direito Administrativo. Com a análise conjunta desses aspectos, seria possível

\footnotetext{
${ }^{132}$ GUANDALINI JR. Walter. Op. Cit. p. 171-176.
}

${ }^{133}$ BOURDIEU, Pierre. Op Cit. p 217-224. 
perceber a homogeneidade funcional do discurso e de transformações por que passou a ciência no processo histórico. Para esta pesquisa de mestrado, o interesse é destacar alguns aspectos dos dois últimos âmbitos de produção de discurso.

$\mathrm{Na}$ parte final desse doutorado, o autor divide a pesquisa em períodos cronológicos, classificando o segundo de "formação do Direito Administrativo", entre os anos de 1854-1879, pois é o contexto em que se constrói um saber erudito baseado em conceitos próprios da área. $\mathrm{O}$ destaque que se dá é para a análise crítica de inúmeras obras que foram publicadas nesse período, dentre as quais se destacam as de caráter tratadístico: "Elementos de Direito Administrativo Brasileiro", de 1857, de Pereira do Rego; "Direito Público Brasileiro e Análise da Constituição do Império", de 1857, de Pimenta Bueno; "Direito Administrativo Brasileiro", de 1859, de Veiga Cabral; "Ensaio sobre o Direito Administrativo Brasileiro", de 1862, do Visconde do Uruguai; "Excerto de Direito Administrativo Pátrio", de 1864, de Furtado de Mendonça; "Direito Administrativo Brasileiro", de 1866, de Joaquim Ribas.

Guandalini analisa criticamente os elementos que considera relevantes da obra desses autores de forma a defender sua teoria acerca do modelo de pensamento de Direito Administrativo que se desenvolveu no Brasil. Destacar-se-á aqui tão-somente aspectos sobre alguns autores e sua análise considerados relevante para esta pesquisa de mestrado dando destaque para o Conselheiro Ribas e Veiga Cabral.

Assim, ele considera que essa produção bibliográfica teve um caráter de debate tardio de desenvolvimento, já que se afigurou na segunda metade do século XIX. De qualquer forma, ela organizara teoricamente os preceitos da nova ciência e legitimavam a constituição de um governo legítimo para o Estado brasileiro, pois afirmava reiteradamente o Imperador como alicerce fundamental do sistema político e administrativo.

A substituição de Silveira da Motta por Antonio Joaquim Ribas, de acordo com Guandalini ainda em 1855, possibilitou a este utilizar apontamentos preparados para dar as lições e a desenvolver seu compêndio em 1856, que foi utilizado nas duas faculdades. Ele mesmo considerou que a sua obra de Direito Administrativo foi redigida para ser introdutória, na medida em que discute categorias básicas do Direito Administrativo em 
três títulos que serão aqui desenvolvidos: a natureza da ciência e suas divisões; as relações da administração com outros poderes; os administrados, nacionais, estrangeiros e escravos ${ }^{134}$.

Primeiramente, no título da ciência do Direito Administrativo, ele desenvolve acerca de sua autonomia científica, as ciências que lhe são auxiliares e as fontes. Sua premissa era de que a análise de teorias estrangeiras não deveria ser feita acriticamente; que o estudo do Direito Administrativo não poderia ser mero conhecimento de leis administrativas, mas sim focado nas ideias gerais e sínteses fundamentais da área; que é de interesse tanto da administração como dos indivíduos conhecer o Direito Administrativo.

Também acentua a importância das ciências auxiliares do Direito Administrativo, quais sejam, o Direito Público Positivo, o Direito Privado do Direito Administrativo, a Economia Política e a Estatística para a Ciência da Administração. Desse modo, demonstra um caráter científico da disciplina e a sua necessidade de elaboração teórica unificadora e nacional, acentuando que o Direito deve ser compreendido no seu sentido amplo, como ciência que estuda a organização administrativa, mas também em seu sentido restritivo, posto que se trata de ciência dos direitos e deveres da administração e dos administrados - temática esta discutida na Europa desde final século XVIII.

Ora, portanto a interpretação que Ribas ensina é mais no sentido amplo e menos legalista, já que depende da análise conjuntural e semântica da ciência. $\mathrm{O}$ aspecto restritivo do entendimento da matéria é justamente sobre sua especificidade temática em relação a outras áreas do conhecimento jurídico. Portanto, Guandalini considera que a essência desta ciência administrativista observava o governo dos homens de um modo jurídico, como instrumento de controle da ordem específica a regular direitos e deveres, mas não como controle técnico, baseado no binômio "utilidade e necessidade", nem mesmo como um instrumento de controle dos indivíduos - elementos estes relevantes no desenvolvimento desta ciência na sociedade europeia oitocentista.

${ }^{134}$ Apud GUANDALINI JR, Walter. Op. Cit. p. 158-166. 
Assim, o autor considera que esta função disciplinar-normalizadora tradicional da administração jurídico-soberana na Europa não seria completamente desenvolvida no Brasil, pois como demonstra o próprio Conselheiro Ribas, muito embora houvesse aqui a discussão sobre natureza da administração pública e do poder político, interviria o Estado na vida social tão-somente para conservar relação harmônica, mas não para regular a sociedade ${ }^{135}$.

Assim, não existiria no Brasil a regulação estatal a fim de controlar aspectos da vida social, religião, ciência, estética, indústria. O que se verificou aqui foi uma interferência mútua para manter as relações sócio-políticas e auxílio na sua realização, mas com autonomia e independência. E, assim, fica caracterizada a produção de cultura jurídica não intervencionista e liberal do Estado brasileiro. Desse modo, seriam proporcionadas duas condições de organização administrativa asseguradas pelo Direito: a independência e a unidade, que se constituía como fiel do império naquele tempo da estabilidade política e, no espaço, centralização governamental administrativa.

De acordo com Guandalini, aqui havia na consistência jurídico-administrativa a importância sobressalente da independência do Imperador como chefe do Poder Executivo do que a separação do aparelho de Estado face ao Poder Judiciário, esta que seria a questão essencial na elaboração do Direito Administrativo francês, diversamente do que assevera Lima Lopes, que aponta pela penumbra da separação do Judiciário.

Assim, valorizava-se a hierarquia não como a ação normalizadora da burocracia, mas sim em sua condição natural das funções de Estado, pois o Imperador não deveria se constituir como um vigilante hierárquico, mas sim tal como o centro de convergência das aspirações nacionais e ponto de origem da ação de governo e administração. Ribas, assim, ressaltava a figura imperial no estudo jurídico-administrativo.

Guandalini, ainda, levanta pontos de nosso estatuto que guardavam características do período do antigo regime como, por exemplo, o âmbito do poder local exercido por juízes de paz e juízes de direito e, inclusive, por particulares na

\footnotetext{
${ }^{135}$ GUANDALINI JR, Walter. Op. Cit. 178p.
} 
estruturação do poder, muito embora a função administrativa só proporcionasse forças à autoridade central e não transferisse a autoridade nos governos locais.

Em outra medida, critica este autor o Conselheiro Ribas por este não analisar efetivamente o tipo de relações estabelecido entre administração e administrados quanto aos direitos, deveres e prerrogativas, posto que este só realiza uma classificação da população entre as classes nacionais, os estrangeiros e os escravos, identificando quais os direitos originários atribuídos ou aplicados a cada uma dessas classes. Estes direitos não se fundamentam no exercício do poder administrativo imperial nem na ordem jurídica constitucional, mas na própria natureza das coisas. Assim, o poder político estabelecido fundava a soberania da nacionalidade, mas não o controle minucioso da vida social.

Destaca, por fim, com esta análise de $\operatorname{Ribas}^{136}$ que o Direito Administrativo brasileiro detinha o escopo da intervenção mínima para a manutenção da ordem social e do contentamento popular, enquanto que o Direito europeu constituía como objetivo da intervenção sobre a sociedade o fortalecimento do Estado. Além disso, havia a mitificação jurídica da função moderador-executiva do Imperador, constituindo-se como fator de unidade e fundamento de legitimidade para o Estado nacional brasileiro.

A seguir, o autor realiza a análise da obra de Veiga Cabral, intencionado a fornecer plano de código administrativo brasileiro, com princípios, legislação e intento de coordenação dos elementos da ciência, baseado principalmente doutrina francesa ${ }^{137}$. Destaca que o caráter da obra é mais técnico quando comparada com outros estudos do período, pois dedica várias páginas ao estudo do processo administrativo, à questão da repartição de competências, à classificação de bens públicos, ao estudo da polícia muito embora Guandalini considere irreal a análise, posto que seria mais uma cópia da discussão europeia e, ao mesmo tempo, uma demonstração de apoio ao poder do Imperador.

\footnotetext{
${ }^{136}$ GUANDALINI JR, Walter. Op. Cit. 183p.

${ }^{137}$ Dentre os autores, ele cita Cormenin, Macarel, de Gerando, Proudhon, Foucart, Dufour, La Ferriere, Vivien, Magnitot, Blanch, Servigny, Chauveau Adolphe, Florent-Lefebvre, Cabantous e Pradier, muitos dos quais se observará na análise das dissertações de Administrativo.
} 
Este autor clássico se preocupa com a construção teórica científica acerca da matéria, mas não se atém ao caráter nacional da ciência, posto que se utiliza de muita doutrina estrangeira, notadamente a francesa, para realizar a análise. Considera ele que a centralização é princípio essencial e vital da Administração porque permite a unidade administrativa, propicia a conservação e a segurança da sociedade e, ainda, consagra a independência nacional e a integridade do Império. Seria apenas pra execução direta das leis e medidas de detalhe que se reconhece à Administração alguma independência do poder político do Imperador.

Nesta medida, faz referência da discussão teórica na Europa, preocupada com a instrumentalização do Direito Administrativo, mas também tem preocupação com a reterritorialização do vocabulário por estabelecer o Imperador como principal responsável pelo objetivo, reforçando a centralização e legitimação de sua posição como alicerce do sistema político.

Particularmente sobre a análise das funções administrativas, fica perceptível que o vocabulário e as questões de caráter disciplinar são abordados numa perspectiva para compatibilizar o arsenal como funcionamento concreto do dispositivo de poder soberano.

Finalmente, o ultimo capítulo da obra de Veiga Cabral trata da Administração local, subordinada à administração geral ${ }^{138}$; dos Presidentes e Conselheiros de Província, respectivamente os caracterizando como meros executores das ordens emanadas do poder central e da autoridade do Conselho de Estado. Ele também realiza uma crítica à confusão de competências atribuídas às entidades públicas locais, como a Assembleia Provincial, a Câmara Municipal, as fábricas paroquiais, dos estabelecimentos municipais de humanidade, bem como trata acerca do orçamento provincial e municipal. Nesse âmbito, este autor reivindica a criação de um administrador para cada município e sua separação das atribuições das câmaras municipais, de forma a possibilitar a deliberação político-legislativa e execução administrativa.

\footnotetext{
${ }^{138}$ GUANDALINI JR, Walter. Op. Cit. p. 194-195.
} 
Assim, reforça-se a ideia de que o discurso jus-administrativista do período não tinha função administrativa-normalizadora, mas sim constituinte soberana, de organização dos poderes existentes e sua vinculação ao poder central. Em outra medida, também prova a falta de organização da administração pública no Brasil com competências claras e definidas.

Ora, Guandalini apontou diferenças técnicas e interpretativas entre as obras desses dois doutrinadores, ambos os professores da faculdade de Direito de São Paulo, sendo que Ribas foi substituto de várias matérias, inclusive de Direito Administrativo e Veiga Cabral foi um professor anterior ao primeiro, sendo proprietário da cadeira de Direito Civil, título que também obteria Ribas, posteriormente. De outra forma, embora seja suscitada a obra de Furtado de Mendonça, professor e proprietário da cadeira de Direito Administrativo majoritariamente no período da análise das dissertações feita nesta pesquisa, o estudo de "Excerto de Direito Administrativo Pátrio" não foi abarcado por Guandalini.

Assim, a conclusão a que chega este autor sobre a doutrina existente naquele período de Direito Administrativo é que havia um papel constituinte-soberano voltado para a função do Estado Brasileiro, atribuição de fundamento de legitimidade ao poder soberano do Imperador, bem como que sobrevivia o Estado brasileiro com exercício harmônico de competências variadas e concorrentes pelos mais variados agentes do poder imperial, conforme organização por jurisdições típicas do modelo de Estado préadministrativo e pré-normalizador.

Será relevante para a compreensão do estudo da cadeira de Administrativo, bem como para a análise das dissertações o uso desses autores, um representando a técnica de tradução da cultura jurídico-administrativa francesa (Veiga Cabral) e o outro com uma análise prática e mais atenta ao caso brasileiro (Ribas). Será possível depreender ambos os tipos de interpretação pelos estudantes em suas dissertações, havendo certas disparidades entre as respostas comparativas dos estudantes. Em alguns casos, há uma análise mais prática e legalista. Outros, um estudo histórico aprofundado, muito retórico e mais atento a discussões filosóficas do desenvolvimento da disciplina. Há, ainda, desde aquele que não elogiará o poder absoluto do Imperador em prol de uma noção modelo administrativo brasileiro mais descentralizado. 
Nesse sentido, será proveitoso realizar o estudo das dissertações a fim de compreender como a academia refletia não só sobre os temas relevantes doutrinária e politicamente discutidos naquela época pelas outras emanações de fontes jurídicoadministrativas, como também para aflorar como era sua interpretação acerca de tais temas.

\subsection{Aspectos sobre o Cotidiano Metodológico de Ensino}

Após apresentar tais pesquisas recentes acerca da produção de cultura jurídica do Direito Administrativo e discorrer sobre algumas de suas fontes históricas relevantes, esta segunda parte do capítulo segundo objetiva colocar a mão à obra e retratar aspectos relevantes da rotina do ensino da faculdade de São Paulo que se concentram em dois âmbitos: a relação acadêmica entre o estudante e professor dentro da faculdade de Direito e o processo de habilitação dos estudantes a fim de que passassem de ano e/ou se graduassem como bacharéis, que é a chamada ratificação acadêmica.

E, por ser um estudo muito amplo e complexo, deu-se especial destaque para os aspectos que possibilitassem compreender o ambiente envolto à formação da cadeira de Direito Administrativo, bem como ao processo de atos acadêmicos no qual foram elaboradas as dissertações da área de Direito Administrativo. Assim, utilizar-se-á a lupa do ensino jurídico para analisar a imagem específica da construção da cultura jurídica administrativa, dando uma atenção especial para o pódio acadêmico onde se constituiu historicamente sua lógica de pensamento jurídico.

Não obstante, quando se analisa fontes relativas a um tema histórico em particular, muitas vezes, a densidade que é exigida pelo objeto em estudo demanda um olhar ao elemento histórico anterior. Nesse sentido, apesar de a "palavra" "cadeira de Direito Administrativo" ter surgido em 1854, a "coisa" já existia antes ${ }^{139}$, mesmo que ainda capenga e em formação ${ }^{140}$. Ora, para não se prender à discussão sobre a origem material do Direito Administrativo ou da ciência administrativa brasileira, tão-somente

\footnotetext{
${ }^{139}$ MANNORI, Luca; SORDI. Bernardo. Op. Cit. p.5-16.

${ }^{140}$ GUANDALINI JR., Walter. Op. Cit. p. 171-176.
} 
serão apontadas algumas indicações de elementos relevantes para a discussão intelectual que eram anteriores a temporalidade da pesquisa, que abrange entre 1857 e 1870.

Nesse sentido, como a ciência do Direito Administrativo ainda vivera num limbo científico que amadurecia conforme prosseguia o século XIX, foi possível apreender pela análise das fontes que vários elementos formadores desse cotidiano acadêmico de ensino - como o relacionamento entre aluno e professor, a elaboração dos compêndios, a ratificação acadêmica - existiam antes à temporalidade aqui em destaque, entre 1857 e 1870. Tais componentes da estrutura do ensino jurídico são grandes auxiliares na compreensão não só da formação teórico-interpretativa do Direito Administrativo como ainda da sua relação para com o desenvolvimento social, econômico e político daquele período.

Para tanto, o material utilizado nesta parte envolve especialmente o uso das fontes primárias de Almeida Nogueira ${ }^{141}$, Spencer Vampré ${ }^{142}$ e a legislação de ensino jurídico, com o uso residual de biografias e memórias existentes acerca deste contexto de ensino. Da mesma forma, será possível compreender como o meio de utilização de compêndios, o trato entre os alunos e professores, os meios de ratificação acadêmica, em suma, a estrutura de organização base da metodologia do ensino jurídico determinaria o funcionamento e a lógica na qual se estruturou a cadeira de Administrativo, bem como foram elaboradas as suas dissertações aqui em análise. Não obstante, ressalta-se que estes indicativos preliminares só fomentam a discussão principal.

Assim sendo, este estudo é feito em seis elementos divididos em seis subitens. Todos são baseados na importância da relação entre professor e aluno, bem como em como se desenvolveu o processo de ratificação acadêmica e todos influenciariam, em alguma medida, na formação da metodologia de ensino do Direito desse início da segunda metade do século XIX em São Paulo, a qual será mais bem delimitada no último item desse capítulo segundo. Não obstante, alguns desses elementos se

\footnotetext{
${ }^{141}$ NOGUEIRA, J. L. Almeida. A academia de São Paulo tradições e reminiscências: estudantes, estudantes, estudantadas, 1827-1977. 1 Ed. v. 1-9. São Paulo: Vanorden, 1907; VAMPRÉ, Spencer. Op. Cit.

${ }^{142}$ A base bibliográfica utilizada neste capítulo, além da legislação de ensino jurídico, são os materiais memorialistas de Spencer Vampré e Almeida Nogueira, salvo menção em contrário.
} 
apresentam de uma forma mais latente, outros com efeitos mais diretos na estruturação do raciocínio jurídico apreendido pelos estudantes.

O objetivo deste exame não é realizar o estudo exaustivo sobre a análise do cotidiano de ensino jurídico por meio desses temas, mas sim elencar os indicativos essenciais apreendidos da referida rotina para que se compreenda melhor o papel de tais elementos na metodologia de ensino acadêmica e, consequentemente, seus efeitos sobre a formação da cadeira de Direito Administrativo e sobre a estruturação das dissertações dos estudantes. De outra forma, a análise de tais efeitos será mais visível no estudo promovido no item 2.3, que trata justamente sobre a metodologia de ensino e um prólogo para o estudo das dissertações de Direito Administrativo, feita no terceiro capítulo.

\subsubsection{A Relação entre a Faculdade de Direito e o Governo Central}

Relembrando a discussão travada na última parte do capítulo primeiro, este subitem representa uma busca pela compreensão de que medida a metodologia de ensino fora influenciada, em parte, por determinações e restrições advindas do Rio de Janeiro. Isto é relevante para que se tenha sempre em mente que havia um interesse em controlar o elemento simbólico da academia, isto é, os rituais acadêmicos, as indumentárias, o distanciamento do aluno com o professor, o aspecto tribuna da escola e, ainda, a materialidade interpretativa do Direito que seria ensinada pelos professores e estudada pelos alunos.

Deve-se destacar, ainda, que este controle não era direto e visível sobre as faculdades jurídicas do Império, mas é perceptível em alguns detalhes e aspectos interessantes acerca da organização da rotina acadêmica, conforme se verá.

Assim, sobre a interação que se desenvolveu em meados do século XIX entre o governo central e a faculdade, a análise da legislação e dos autores memorialistas aponta que predominava uma tentativa formal e institucional de controle dos cursos jurídicos. Isto vem de certa origem portuguesa que fora estritamente rígida para com a elaboração do ensino em suas colônias, tanto que, no Brasil, tal possibilidade de educação superior 
não existiu ${ }^{143}$. Nesse sentido, também considera Edmundo Campos, conforme foi já exposto anteriormente, que o Brasil também teria interferências do governo sobre o desenvolvimento do ensino das profissões liberais de Engenharia, Direito e Medicina, já que haveria interesses intrínsecos da camada dominante no desenvolvimento de tais áreas.

Assim, muito embora subsistissem alguns conflitos e resistências de São Paulo a fim de se estabelecer a autonomia dos cursos jurídicos, este domínio era exercido de diversas formas, como a nomeação direta do diretor, o controle residual sobre a escolha do corpo docente e mesmo discente e, ainda, as diversas trocas de informações e cartas entre a pasta do Império responsável com a diretoria da faculdade.

Em verdade, a decretação da criação dos cursos jurídicos gerou a pasta do Império que era responsável para estabelecer troca de informes e organizar os funcionamentos dos cursos jurídicos. Amaral Gurgel, por exemplo, que fora diretor interino entre meados da década de 1840 e efetivo entre 1857 e 1864, trocava constantemente cartas e avisos com Ministros do Império acerca dos métodos e textos adotados. Especificamente, Vampré retrata um caso de 1849, em que Gurgel se comunicara ao Ministro Visconde de Monte Alegre sobre que tipo de compêndio era usado pelo professor do primeiro ano de Direito Público, bem como que tipo de metodologia de ensino era adotada.

Nesse sentido, o decreto imperial $\mathrm{n}^{\circ} 1.134$, de 30 de março de 1853 , determinara que o diretor da faculdade de Direito era alguém de nomeação pelo próprio governo e que, portanto, poderia ser demitido quando assim entendesse. Além disso, na eventualidade de impedimentos ou faltas acometidas por esta personalidade, ele seria substituído por quem o Rio de Janeiro designasse e, provisoriamente, pelo lente mais antigo que estivesse em exercício.

Além do controle da diretoria, é relevante considerar que o órgão mais importante e determinante dentro da faculdade era a congregação dos lentes, posto que emitia os regramentos internos e exercia uma inspeção metodológica tanto sobre o

\footnotetext{
${ }^{143}$ História Intelectual no Brasil: a retórica como chave de leitura. in: Topoi. Rio de Janeiro, n. 1, 2006. $126 \mathrm{p}$.
} 
corpo docente como discente. Assim, pelo decreto $\mathrm{n}^{\mathrm{o}}$ 3.454, de 26 de abril de 1865, em seu artigo 16:

"Compete á Congregação: $\S 1^{\circ}$ Exercer a inspecção scientifica da Faculdade no tocante ao systema e methodo do ensino, aos livros e compendios seguidos nas aulas, propondo ao Governo as reformas ou alterações que forem aconselhadas pela experiencia, ou pelo progresso das Sciencias Sociaes e Juridicas. $§ 2^{\circ}$ Empregar a maior vigilancia em evitar a introducção de praticas abusivas na disciplina escolar, ou no regimen da Faculdade, tendo o maior escrupulo na manutenção dos bons costumes, e auxiliando o Director no desempenho de suas funcções."

A fiscalização acadêmica era feita na medida em que os lentes catedráticos deveria apresentar à congregação no início de março o programa de ensino de sua cadeira a fim de que ela o aprovasse. Assim, após que este programa passasse pelo crivo da congregação, não poderia ser submetido a modificações senão pela própria assembleia de lentes. Não obstante, além disso, o diretor deveria encaminhar ao Ministério do Império até início de abril a cópia dos programas adotados para as cadeiras e, também, era obrigado a informar quaisquer alterações que fossem feitas ${ }^{144}$.

Dessa forma, o parlamento tomou precauções a fim de que obtivesse certo controle sobre a congregação docente. Vampré, inclusive, alerta que não existia a sua autonomia, pois o governo tinha o direito de intervir e inspecionar a respeito de qualquer matéria propriamente de ensino jurídico ou transcendente que fosse inadmissível, em consonância com os estatutos de ensino.

Especificamente com relação ao controle sobre os professores, de acordo com o decreto $\mathrm{n}^{\mathrm{o}} 1.134$, de 30 de março de 1853, eles deviam se apresentar na faculdade "urbanizadamente (...) respeitar a religião, imperador, a moral e a constituição, abster-se de propagar doutrinas e perverter o espírito e corromper o coração". Assim, se acaso os lentes agissem de forma a sofrer a faculdade com esta reputação, seriam advertidos, primeiramente, pela congregação e, se desprezassem as admoestações e insistissem nos

\footnotetext{
${ }^{144}$ Artigos 244 a 246 do Decreto $\mathrm{n}^{\mathrm{o}} 1.568$, de 24 de Fevereiro de 1855 , que aprova o Regulamento complementar dos Estatutos das Faculdades de Direito, expedido para a execução do § 3..$^{\circ}$ do art. 21 do Decreto n. ${ }^{\circ} 1.386$ de 28 de Abril de 1854.
} 
desregramentos, deveria a congregação dar parte ao governo, que os podia suspendê-los por até dois anos ou pior.

Além disso, havia alguns requisitos formais que o lente deveria preencher para alcançar o status de proprietário de uma cadeira nas faculdades do Império. Assim, era necessário que tivesse o grau de doutor, prestar concurso para professor substituto, apresentar theses e, quando vagasse alguma cadeira, passaria a titular. A congregação dos lentes se responsabilizava pela escolha, mas a influência do governo imperial não pode ser ignorada no que se refere à seleção dos professores. Diversas vezes, Almeida Nogueira aponta nomes fortes que ficaram na terceira posição do concurso e que foram escolhidos para serem lentes.

Além do processo formal para a absorção de novos professores, haveria alguns artifícios possíveis para o governo manter os olhos sobre quem dava as aulas, principalmente se mantivesse bom relacionamento com o diretor, que trocava anualmente cartas com a administração imperial e encaminhava relatórios. Como já se sabe, os compêndios teriam que ser aprovados também no Rio de Janeiro, o que demonstra outo tipo de controle central. Um exemplo clássico de intervenção central era quando os alunos pediam penas menores ou absolvição das acusações e penas aplicadas pela faculdade em razão de quaisquer "estudantadas".

Contudo, também podia ser mitigada a inspeção governamental, posto que este controle formal não garantia a vinculação do professor no momento em que proferia as lições ou tomava as sabatinas. Em verdade, o controle prático do ensino parecia ser muito mais vinculado à Congregação dos lentes, posto que ela era responsável pela realização dos concursos para professores, ela que decidia quais as theses que seriam alvo de dissertação dos alunos e, principalmente, é relevante ter em mente que era nessa Congregação o ambiente propício para os lentes decidirem coletivamente sobre o caminho acadêmico a ser trilhado.

Em outra medida, também havia a preocupação e o interesse do Rio de Janeiro não só para que houvesse conformidade (que aparentemente não ocorria) entre os compêndios de São Paulo e Pernambuco, bem como procuravam ter certo controle tanto 
do que proferiam os professores na faculdade, como ainda do que exalavam os estudantes de intelectualidade na sociedade.

Por exemplo, Vampré considera que haveria um lente ${ }^{145}$ em São Paulo que afirmava entre amigos que um monarca constitucional é um círculo quadrado. Em Pernambuco, o professor Pedro Autran da Mata e Albuquerque tratava sobre as possibilidades de o povo derrubar o governo por meio da força.

Ora, isto demonstra a cautela no trato do governo central para com o andamento acadêmico e social dentro das faculdades de Direito. Nesse sentido, era uma preocupação constante a influência política dos estudantes, principalmente no período da formação dos cursos jurídicos e de instabilidade política do primeiro Império. De acordo com Nogueira, por exemplo, entre os anos de 1828 e 1832, os alunos da faculdade eram considerados "espíritos eminentemente brazileiros e liberaes numa sociedade de portugueses retrógrados e de francezes indiferentes, os estudantes não podiam deixar de ser considerados um elemento perigoso para a ordem social naqueles agitados dias em que a nação se convulsionava e a própria coroa imperial estava em vésperas de cair da cabeça lamentavelmente oca de Pedro I. A cada notícia vinda do Rio de algum novo cheque à politica imperial e áulica e de alguma nova manifestação do liberalismo exaltado, encontravam os estudantes motivo para enthusiasmos e inconsideradas expansões, que punham em risco a paz das famílias e a tranquilidade publica" ${ }^{, 146}$.

Com o passar do tempo, muito embora o Império tivesse alcançado estabilidade e não houvesse mais este temor, ainda sim "os estudantes tinham adquirido absoluto predomínio: a academia tinha-se tornado o foco da vida politica naquela época agitada; e a vizinhança desse foco cedo iniciava os estudantes de preparatórios no conhecimento das coisas politicas" ${ }^{147}$. Por isso, talvez, existissem avisos do governo que tolhiam socialmente os estudantes da faculdade, literalmente, de pisar no palco.

\footnotetext{
${ }^{145}$ Provavelmente, o professor Brotero.

${ }^{146}$ RECORDAÇÕES históricas. in: Correio paulistano. 2 de set, 1905.

${ }^{147}$ VIEIRA BUENO, F. de Assis. Autobiografia. s/Ed. Campinas, 1899.
} 
Ou seja, remanescia certo receito de uma completa liberdade de pensamento e de expressão cultural pela academia. Tais aspectos acerca tanto de alguns professores e da fama da influência política dos bacharéis preocupavam os parlamentares e de juristas do gabinete do Império, de forma que ao menos buscavam manter um mínimo de presença e controle do poder político dentro dos centros de produção de pensamento. Nesse quesito, foram rejeitadas muitas das emendas do Senado que seguissem outra lógica, por exemplo, aquela a favor da livre nomeação do diretor pela congregação dos lentes.

Estas informações indicam que a relação de autonomia política e acadêmica entre a faculdade de São Paulo e o governo central não foi estável, posto que havia o interesse do governo em manter o dirigente e, na medida do possível, o corpo docente dentro dos ditames do que se acordava no parlamento e no executivo. Assim, muito embora não fosse possível conferir um controle total nessa relação, vislumbram-se empreendimentos formais por parte do governo para manter o manejo do que se discutia nas arcadas como em sala de aula por meio da escolha dos diretores e do controle mínimo dos compêndios.

\subsubsection{A Importância da Utilização dos Compêndios no Ensino Jurídico}

Este subitem realiza uma descrição que avança na compreensão sobre qual era a dinâmica do uso dos compêndios dentro da faculdade de São Paulo, ou seja, o manejo do material que seria não só a base explicativa dos lentes para com os alunos nas aulas, mas também para que estes estudassem para as sabatinas, lições e as próprias dissertações.

O escopo deste subitem não é analisar nos mínimos detalhes os próprios compêndios de Direito Administrativo, mesmo porque parte deste trabalho já fora elaborada por outros autores, inclusive pelo próprio Walter Guandalini. O objetivo aqui é diverso, mais atento a destacar quais os compêndios que envolveram a formação do ensino de Direito Público e, em especial, da cadeira de Direito Administrativo, bem como a compreender a dinâmica de utilização e manejo deste material histórico dentro da faculdade. Ou seja, procura-se aqui clarear a rotina de criação, institucionalização e uso prático do compêndio. 
Para tanto, o primeiro material histórico que trata acerca deste manejo dos compêndios foi o projeto de estatuto de ensino do Visconde da Cachoeira, que destaca a importância do uso dos compêndios nos exercícios práticos das aulas, de acordo com seu Capítulo $\mathrm{X}$, asseverando que o professor deveria gastar a primeira meia hora em ouvir as lições e a última hora em explicar o compêndio. Além disso, é documento que indica qualitativamente diversos autores para o uso compêndico, alguns destes realmente utilizados com a instituição dos cursos jurídicos de São Paulo. E, assim, como ainda não havia a cadeira de Direito Administrativo em 1825, ano em que o Visconde elaborara sua obra, dar-se-á destaque para os compêndios de áreas que influenciariam, em alguma medida, a compreensão do ensino de Direito Público na faculdade de São Paulo.

Assim, a primeira das duas cadeiras do ano inaugural deveria abranger o estudo de "Direito Natural e Direito Público Universal". Ora, esse autor considera que é na área de Direito Natural onde se executa o estudo primordial de jurisprudência na faculdade e que, portanto, o professor titular deveria utilizá-la para tratar da generalidade das leis. Assim, inicialmente, deveria ser feito o resumo da sua História desde os antigos até os modernos, bem como das compilações mais relevantes, tais como de Grocio, Puffendorfio, Wolfio, e Thomassio, os quais apanharam do Direito Romano diversas regras.

Assim, era necessário se limitar o Direito Natural ao regulamento dos direitos e obrigações dos homens entre si e, então, seria o Direito Público a área responsável por cuidar das relações sociais, bem como dos deveres da massa geral da nação para com o soberano e deste para com ela. E seus compêndios deveriam ser baseados nas explicações dos princípios de Heinecio, Felice, Burlamaqui, Wolfio e Cardoso, muito embora não pudesse ser feita uma escravatura das ideias destes autores sobre o ensino na faculdade, mas sim a absorção do que há de interessante e se utilizando do que houvesse de mais moderno naquele contexto sobre o mesmo objeto.

Após tratar desta área basilar, o professor poderia passar para a matéria de "Direito Público Universal, e Particular". Os compêndios utilizados seriam de Brie, Perrault e de quem fosse mais apropriado. E, para além de se estudar o conhecimento 
dos princípios nos compêndios, o Visconde de Cachoeira observa a importância de se adotar a Constituição do Império para explicar o Direito Publico, Particular e Nacional.

Em outra medida, passadas pelas demais áreas até que os estudantes estivessem preparados com as matérias elementares dos primeiros dois anos, poderiam se dedicar os lentes do terceiro ano a explicar todo Direito Pátrio, Publico, Particular, e Criminal. Portanto, fica perceptível neste projeto de ensino jurídico elaborado a relevância da matéria de Direito Público como área do conhecimento basilar no ensino jurídico.

Interessante é a citação de outro doutrinador que o estatuto do Visconde de Cachoeira considera importante para a compreensão doutrinal do Direito Publico Pátrio, qual seja, José de Mello Freire. Este autor seria frequentemente suscitado em diversas dissertações de Direito inclusive de áreas do conhecimento das mais variadas, como Civil e Constitucional e, ainda, na área de Direito Administrativo. Contudo, o próprio autor admite que, em razão da insuficiência deste material, que fora produzido em período que não havia conhecimento dos princípios do Direito Público Filosófico, era relevante que o professor atualizasse as problemáticas tratadas no livro de Mello Freire com a então conjuntura jurídica por meio de um compêndio resumido.

Após, seria o mesmo lente responsável pela área que seria denominada o autor de "Direito Público Eclesiástico, Universal e Nacional", de forma a explicar os seus princípios elementares pelos compêndios de Gmeinero, Fleury e Bohemero particularmente para o Direito Público Eclesiástico Universal. Em outra medida, acerca do Direito Público Eclesiástico Nacional, seria novamente de grande importância o estudo de Mello Freire e seu capítulo "De Jure principis circa sacra” bem como o que se encontrasse esparso pelas ordenações e leis posteriormente promulgadas.

Estes foram os principais materiais preliminarmente investigados nas fontes que apontariam alguma importância para a compreensão de como se formou o estudo do Direito Público na faculdade de São Paulo, ainda em meados da primeira metade do século XIX. São indicativos relevantes de que havia uma preocupação por parte deste autor a fim de que os professores realizassem em seus compêndios uma atualização dos estudos jurídicos para não prender os estudantes ao que foi escrito no passado e não contemplasse o país em formação. Seria este um exemplo dos estímulos para que os 
lentes fossem ao mesmo tempo doutrinadores. Não obstante, não haveria um padrão quanto a isto, pois a História jurídica aponta para vários doutrinadores que não se dedicariam à academia e, ao mesmo tempo, também existiriam diversos professores que não se dariam bem na produção acadêmica.

Após, traz-se um projeto que é o cerne do padrão da forma de se institucionalizar os compêndios dentro da faculdade de Direito. O projeto de lei de 5 de julho de $1826^{148}$ sugere com uma grade curricular bem distinta daquela do Visconde de Cachoeira, posto que organizara uma dedicação ao estudo histórico e público muito maior, conforme se verificará no subitem 2.2.4. Mas sua importância aqui é com relação ao procedimento de elaboração formal de um compêndio acadêmico. Assim, este projeto de Januário da Cunha Barbosa e José Cardoso Pereira de Melo asseverara que deveriam ser os compêndios escolhidos pelos lentes ou, então, feitos por eles de forma a submetendo-os à aprovação pela congregação e com remissão ao governo para fornecimento.

Ora, este modelo seguirá de um modo muito semelhante nas próximas leis criadas sobre ensino jurídico: primeiro a criação ou escolha pelo professor, após o encaminhamento para aprovação da congregação e, por fim, a remessa para o governo central. As diferenças entre as leis são de algumas nuances. Por exemplo, ao se atentar para a lei de 11 de agosto de 1827, discorre, em seu artigo $7^{\circ}$, que os lentes organizariam os compêndios no mesmo sentido que o projeto acima, mas se faz a ressalva de que as doutrinas deveriam estivar de acordo com o sistema fundado pela nação e que fossem aprovadas não só pela congregação docente como pela própria Assembleia imperial. Assim, a primeira lei do ensino jurídico representa, em alguma medida, um quadro de controle do que era produzido jurídico-cientificamente na academia por parte do governo central.

Nesse mesmo ano, no mês de novembro, o então diretor General Arouche Rendon remetera por carta ao Ministro de Império Visconde de São Leopoldo a informação de determinara ao lente do primeiro ano que trouxesse seus compêndios referentes às matérias que iria ensinar, de forma que seria indispensável compor um abreviado da análise da Constituição do Império como resumo. Portanto, seguira os

${ }^{148}$ Elaborados por Januario da Cunha Barbosa e José Cardoso Pereira de Melo. 
passos pontilhados pelo Visconde de Cachoeira. Em termos práticos, os compêndios eram "taxados e vendidos aos Estudantes".

Agora, é chegado o momento para dedicar alguns parágrafos sobre o uso compêndico do professor José Maria de Avela Brotero. Almeida Nogueira narra que teria havido atritos, já neste início dos cursos jurídicos de São Paulo, desse lente com o diretor Rendon em relação à organização do compêndio para a aula de Direito Natural, posto que este professor demorar a cumprir o artigo $7^{\circ}$ da lei de 11 de agosto e encaminhar o seu compêndio de "Princípios de Direito Natural", para a câmara dos deputados aprovarem, o que só aconteceria em 1830.

Aqui é interessante observar não só a dificuldade da elaboração de compêndios pelo corpo docente, que neste começo ainda nem estava completo, mas também na real possibilidade de não serem estes aprovados caso não condissessem com os interesses do governo. Assim, a câmara dos deputados não aprovara o compêndio de Brotero, feito às pressas, que foi alvo de diversas críticas do Rio de Janeiro. Ele foi escrito majoritariamente em francês, um pouco em português e em latim, com extração direta de preceitos da obra de Mably, "Droit et Devoirs des Citoyens" e, ainda, apontava trechos de Haveltius, Perreault Cabanis, Barthez e outros menores. Destaca-se a $4^{\text {a }}$ nota do compêndio, de “Aplicação do Direito Público ao Direito Natural”.

A câmara discutiu, em meio a diversos parlamentares, que não havia ligação e harmonia nas matérias do compêndio de Brotero, nem uniformidade no estilo, sendo uma verdadeira compilação de diferentes autores, que não seguiram os mesmos princípios nem se exprimiram semelhante estilo. Além disso, ponderaram diversas outras críticas, dentre as quais, que os raciocínios não possuíam força de convicção, nem os termos clareza e precisão, que compreendia matérias heterogêneas ao Direito Natural $^{149}$, que as notas eram repetidas e extensas, que apresentava mais matéria positiva do que filosófica e não detinha espírito crítico ou agudez.

Assim, em razão das críticas, foi determinado que seria utilizado como compêndio "Eléments de Législation Naturelle", de Pearrault. Não obstante, a fonte

\footnotetext{
149 Paço da Câmara dos Deputados, ROCHA, J. R. Soares; AMARAL, A. J do.; FRANÇA, A. Ferreira, 30 de jun., 1830.
} 
memorialista de Nogueira descreva que, embora Brotero utilizasse o compêndio determinado, seu então colega de área, o Padre Antonio Maria de Moura, preferia adotar o compêndio de Fortuna. Nesses termos, na prática, cada professor utilizava qual doutrina quisesse, não havendo qualquer sinalização para a coerência do ensino que utilizasse ao mesmo tempo tais doutrinas.

Posteriormente, já no também conturbado período político da Regência, o decreto de 7 de novembro de 1831, que aprovara provisoriamente os novos estatutos para os cursos de ciências jurídicas e sociais do Império, mantinha a mesma conotação do que era previsto na lei 11 de agosto sobre os compêndios, destacando-se que deveria haver também a aprovação formal pela congregação e da Assembleia Geral sobre qualquer alteração que fosse feita nos compêndios.

De acordo com Vampré, já em meados de 1849, a informação que o então diretor Amaral Gurgel passara para o Ministro do Império Visconde de Monte Alegre, acerca dos textos adotados como compêndio no primeiro ano pelo lente proprietário da cadeira de Direito Público e das Gentes o "Tratado de Direito das Gentes" de Vattel, mantendo o professor do segundo ano o mesmo autor, sendo que ambos elaboravam uma síntese analítica das doutrinas dos publicitas antigos e os modernos de forma a buscar acompanhar as alterações de pensamento conforme o tempo.

Assim, também aparece mais um indicativo da tentativa acadêmica, mais por parte do corpo docente em explicitar as doutrinas para os alunos de uma forma atualizada, a despeito das obras utilizadas estarem com vestígios de obsolescência, muito embora em outros casos as fontes indicassem o desprezo por certos professores em se dedicarem à atualização doutrinária. Nesse sentido, é possível compreender porque a maior parte dos autores citados pelos estudantes nas dissertações era de décadas anteriores ao ano em que foram produzidas as dissertações, conforme se verá.

Outrossim, manteve-se mais uma vez a mesma estrutura de aprovação dos compêndios, de acordo com o artigo 112 do decreto $\mathrm{n}^{\mathrm{o}}$ 1.134, de 30 de março de 1853. Sua diferença com o decreto $\mathrm{n}^{\circ} 1.386$, de 28 de abril de 1854, é a de que, neste haveria o direito a prêmios para os lentes ou as pessoas que compusessem compêndios ou obras para uso das aulas, bem como para aqueles que melhor traduzissem os materiais 
estrangeiros, claro que após serem ouvidos pela congregação e serem aprovados pelo governo. Ou seja, novamente um indicativo da necessidade da própria faculdade e, também, do governo central em estimular a elaboração de materiais de pensamento e cultura jurídica a fim de ser utilizados pelo corpo docente e discente.

Por fim, o último decreto que renova minimamente sobre o manejo institucional dos compêndios é o 1.568 , de 24 de fevereiro de 1855, que aprova o regulamento complementar dos estatutos das faculdades de Direito, expedido para a execução do $\S 3^{\circ}$ do artigo 21 do decreto anterior ${ }^{150}$. Assim, quando se trata sobre os exercícios práticos das aulas, em seu artigo 239, determina que as preleções dos professores seriam dadas sobre compêndios certos e determinados, compostos pelos mesmos lentes ou, então, sobre aqueles adotados dentre os que já foram impressos. Para tanto, também seria novamente necessária a aprovação da congregação e do governo.

Particularmente em relação à questão do controle exercido pelo governo central sobre a produção acadêmica, Spencer Vampré possui uma interpretação mais permissiva do Rio de Janeiro, pois considera que se acaso os compêndios fossem aceitos pela Assembleia Geral, o governo os faria imprimir e fornecer às escolas, com o objetivo de recompensar os lentes cujos materiais de ensino fossem aprovados sem, no entanto, submetê-los em absoluto ao voto da Assembleia. Assim, este autor considera que, embora não houvesse grande autonomia pelos estatutos de ensino jurídico, a aprovação legislativa constituía um prêmio e um incentivo, antes do que condição essencial ao ensino, de forma que se mantinha a liberdade da investigação científica. Esta é a sua interpretação ao art. 7 da lei 11 de agosto.

Contudo, parece a esta pesquisa de mestrado que, apesar de na prática não ser possível ao governo controlar academicamente o que se produzia nas faculdades do Império, a leitura comparada destas fontes que tratam sobre a institucionalização dos compêndios delatam ser latente um interesse minimamente formal em controlar o que era ensinado e proferido dentro das salas de aula do largo de São Francisco, ao mesmo tempo em que fica visível que também havia uma tentativa mais formal do que prática

${ }^{150}$ Decreto $\mathrm{n}^{\mathrm{o}} 1.386$ de 1854, art. 21. Compete á Congregação, alêm das outras funcções que por estes Estatutos lhe são conferidas: (...) $3^{\circ}$ Organisar, no prazo de dous mezes da publicação destes Estatutos, e submetter á approvação do Governo, o Regulamento complementar para a boa execução delles, tomando por base as respectivas disposições. 
de estimular a produção compêndica inclusive porque esta não se restringia só como papel do docente, mas também de qualquer pessoa.

Em especial sobre os compêndios de Direito Administrativo utilizados na faculdade de São Paulo, não há qualquer indício de que tenha havido manipulação ou alteração por parte da congregação ou mesmo da Assembleia Central. Aliás, quanto a tais compêndios, é relevante traçar algumas ponderações, começando-se com a obra de Prudêncio Giraldes Tavares da Veiga Cabral, professor titular da cadeira de Direito Civil, mas que publicou a obra "Direito Administrativo Brasileiro", em $1859^{151}$.

Pela análise das fontes, não é possível afirmar quão utilizada ou estudada esta obra foi pelos alunos, não obstante Almeida Nogueira dê uma pista ao descrever sobre o interesse do estudante José Vieira Couto de Magalhães em obter a simpatia de Veiga Cabral, posto que havia comprado dois exemplares do "Direito Administrativo" e, além disso, afirmava que o "Direito Administrativo era, de fato, um estudo difícil, confuso e uma ciência ainda embrionária; mas depois da recente publicação da notável obra do Dr. Veiga Cabral, dissiparam-se todas as obscuridades e este ramo do estudo jurídico deu assinalado passo para o seu progresso". Isto traz um indicativo de que a obra foi, em alguma medida, utilizada pelo corpo discente, mesmo que fosse para obter aprovação por este docente.

Quanto a ela, considerou Nogueira que a grande evolução pela qual passou a organização administrativa tornou a obra antiquada, apesar de assinalar um progresso relativo, atendendo à época de sua publicação e no estudo das instituições pátrias. Em outra medida, Duarte de Azevedo tratou sobre o livro, glosando sobre o contencioso administrativo e contrariando a doutrina do autor. Em complementação, Spencer Vampré asseverou que foi com a lei de criação da cadeira de Direito Administrativo, em 1851, que Veiga Cabral escreveu seu tratado na área, sendo seu estilo claro, simples, mas que falhara pela falta de crítica às instituições e excesso de fillosofia, sem a qual os estudos se reduziriam a meras sínteses de legislação.

${ }^{151}$ VEIGA CABRAL, G. T. Direito Administrativo Brasileiro. v 1 in $8^{\circ}$, Rio de Janeiro: Laemmert, 1859. 
Em outra medida, conforme foi retratado anteriormente, Guandalini elogia em termos técnicos a elaboração deste autor, que tinha intenção de ser um Código de Administrativo, já que detinha diversos elementos principiológicos como de coordenação da ciência e da legislação. Contudo, sua base era muito presa à elaboração francesa e pouco realística ao contexto brasileiro, não obstante mantivesse a estrutura definida por esse autor acerca da doutrina brasileira, em botar o Imperador num pedestal místico a fim de justificar a construção do Estado nacional. Coincidência ou não, algumas das dissertações de Direito Administrativo analisadas refletem justamente este modelo científico estruturado por Veiga Cabral: excesso de citações francesas e tecnicismos desligados da realidade brasileira.

Igualmente, pela análise de Almeida Nogueira, Sacramento Blake e Spencer Vampré, não há muita consistência sobre o desenrolar compêndico da cadeira de Administrativo. Primeiramente, o máximo que se tem notícia sobre os ensinamentos do professor José Ignácio Silveira da Mota, que foi titular com a criação da cadeira, em 1854 e 1855, tendo pedido prontamente licença e jubilação. A informação que Nogueira passa é de que o "velho lente não se esmerou por explicar aprofundadamente a nova disciplina. Usava apontamentos com que consultava na cátedra e, por vezes, embrenhado em demonstrações incidentes e perdia o fio do assunto principal". E, de acordo com a memória de Ferreira Rezende, este professor, em sua aula inaugural, teria dito que não havia encontrado um compêndio para a disciplina que iria ensinar e que, portanto, iria adotar o Jornal do Comércio como livro básico para seu curso ${ }^{152}$, para a indignação dos estudantes.

Em outra medida, os outros compêndios de Direito Administrativo que foram utilizados na faculdade de que se tem notícia pelas fontes são, primeiramente, o "Direito Administrativo Brasileiro" de Antonio Joaquim Ribas ${ }^{153}$, que já fora suscitado aqui anteriormente pelos autores José Reinaldo Lopes e Walter Guandalini e que teve seu compêndio baseado em suas aulas como professor substitutivo entre a licença de Silveira da Motta e a titularidade de Furtado de Mendonça, a qual fora de 1856 até 1871. Sabe-se que a publicação dos compêndios de Furtado, "Excerto de Direito Administrativo" e de Ribas é, respectivamente, de 1866 e 1861. Mas, ao mesmo tempo,

\footnotetext{
${ }^{152}$ REZENDE, Francisco de Paula Ferreira de. Minhas Recordações. Rio de Janeiro: J. Olympio, 1944.

${ }^{153}$ Sacramento Blake, Op Cit., v. 1, p. 203.
} 
também demonstram as fontes que a obra de Ribas fora baseada em suas aulas e lições de Direito Administrativo, em meados de 1855 e 1856.

A hipótese com que se trabalha, e se desenvolverá posteriormente, é a de que os estudantes tiveram um contato considerável e positivo com a doutrina do Conselheiro Ribas na década de 1850, mas passaram sob a influência das ideias do Conselheiro Furtado, posto que este não só era um professor exigente e conhecedor da matéria administrativa, como ainda produziu uma obra na área. Não obstante, as obras memorialistas não permitem chegar a uma conclusão sobre se predominou o ensino da obra do primeiro ou do segundo professor.

De acordo com Américo Lacombe, a importância da obra de Furtado seria de menor importância do que a de $\operatorname{Ribas}^{154}$, mas isto tampouco permite inferir qual o compêndio que predominantemente foi utilizada pelos alunos ou, ainda, se foram usadas variavelmente as diversas obras existentes no período, como a de Veiga Cabral, Pereira do Rego, Pimenta Bueno, Visconde do Uruguai, dentre outros. De fato, esta pesquisa se atentou a realizar uma análise comparativa especificamente do compêndio de Ribas com as theses e dissertações produzidas na área de Direito Administrativo da faculdade de São Paulo e obteve resultados positivos, já que várias das temáticas se repetem.

Contudo, isto não exclui o uso deste vasto universo de fontes sobre os quais o professor Furtado poderia ter abarcado com os alunos. Mesmo porque, o estudo das dissertações no último capítulo também demonstrava inferências nada assemelhadas ao estilo do Conselheiro Ribas na escrita dos estudantes, conforme se verá. Nesse sentido, sublinha-se a necessidade para que sejam realizem novos estudos acerca desta relação acadêmica íntima entre o que ensinavam os professores e o que refletiam os estudantes através das dissertações, sabatinas e lições.

De outra sorte, é interessante relembrar que, de acordo com Guandalini, o Antonio Ribas tinha um estudo sério, crítico, aprofundado, atento ao contexto brasileiro e organizado da área administrativa. Sua interpretação é mais no sentido amplo e menos legalista, já que dependia da análise conjuntural e semântica da ciência. Por fim,

\footnotetext{
${ }^{154}$ RIBAS, Antonio Joaquim. Op. Cit. 10p.
} 
destaca-se que este autor consideraria a essência desta ciência, baseava-se no governo dos homens de um modo jurídico, mas como instrumento de controle da ordem específica a regular direitos e deveres e não como o modelo europeu, em que se desenvolveu na área jurídico-administrativa o controle técnico, baseado no binômio "utilidade e necessidade", nem mesmo como um instrumento de controle dos indivíduos.

Assim, para este autor, o Direito Administrativo, enquanto que no caso europeu constituía como objetivo da intervenção sobre a sociedade o fortalecimento do Estado, no Brasil, detinha o escopo da intervenção mínima para a manutenção da ordem social e do contentamento popular. E isto se refletiria no compêndio utilizado pelos alunos. De fato, será possível depreender alguns aspectos da proteção do particular em detrimento da interferência estatal nas dissertações de Direito Administrativo, mas esta não era a regra geral.

\subsubsection{O Perfil Acadêmico de Professores na Faculdade de Direito}

O estudo das fontes permitiu depreender diversos aspectos relevantes acerca da desenvoltura acadêmica dos professores dentro da faculdade de Direito, desde a forma como se dava a sua entrada na faculdade até a sua jubilação. Para além da legislação, que apresenta extensa informação acerca da rotina docente, as fontes memorialistas também apresentam alguns elementos curiosos e controversos sobre os professores. Não obstante, este subitem objetiva especificamente auxiliar a compreender o perfil histórico de professores que seriam importantes para o estudo da metodologia de ensino do Direito Administrativo.

Primeiramente, acerca da forma como a função de professor era compreendida pelo governo. Havia sim aqueles que se preocupavam com a valorização salarial e da importância do cargo de lente. No limiar da lei 11 de agosto, por exemplo, Cruz Ferreira propôs que os lentes tivessem honorários e honras dos desembargadores das 
Relações das províncias ${ }^{155}$, posto que sua responsabilidade não seria menor aos dos operadores do Direito.

Não obstante, mesmo que fosse valorizada a profissão, desde este período o professor de Direito era visto como um cargo público assemelhado aos demais das áreas jurídicas, sendo o ensino jurídico mais a incipiência da habilitação para esses empregos posteriores. Ora, Lima Lopes não realizou uma ressalva muito distinta acerca do ensino jurídico nessa época em países europeus, conforme se demonstrou anteriormente.

Assim, como também fora tratado em parte no capítulo primeiro, na prática, não havia uma valorização particularmente acadêmica dos professores, mais muito mais que estes formassem operadores do Direito condizentes com o sistema governamental instaurado. Contudo, isto não significa que inexistia uma metodologia e uma formação de pensamento que a faculdade refletia nos estudantes, que fosse por meio do ensino dos professores, quer fosse por aspectos latentes dos rituais formais de passagem acadêmica, desde a vestimenta em sala de aula até as formas para habilitação no ano.

Outrossim, quando se fala em analisar o corpo docente de uma faculdade de Direito do Império, há dois âmbitos que se entrelaçam, em alguma medida: os aspectos formais pelos quais os professores eram submetidos desde sua eventual entrada no corpo docente e, ainda, os aspectos materiais e qualitativos do ensino desses professores que, após a análise das fontes, observou-se que dependia do caso a caso, muito embora houvesse uma estrutura mínima baseada nos ditames tanto da congregação, da diretoria, como do Rio de Janeiro.

Assim, apesar de ser relevante compreender os ritos formais da faculdade para com o corpo docente, isto pode ser alvo de outra pesquisa. O destaque aqui é mais para o âmbito material e qualitativo e, logo, como já houve uma análise acerca das formas de controle sobre os professores no subitem 2.2.1, neste o destaque será para o perfil particular de alguns professores.

${ }^{155}$ SPENCER, Vampré. Op. Cit. v. 1-2, 25p. 
Primeiramente, há que se destacarem alguns elementos acerca do corpo docente ulterior à criação da cadeira de Direito Administrativo, já que não só a formação de base do pensamento jurídico seria em parte formada por ele e, também, porque os próprios lentes de Direito Administrativo teriam sido alunos destes professores mais antigos.

Assim, abre-se com o perfil do professor José Maria de Avellar Brotero, que foi lente em São Paulo desde a criação da faculdade até seu falecimento, em 1873. Este professor deu, fundamentalmente, aulas de Direito Natural, Direito Público em geral, Diplomacia, Direito das Gentes e, também, de Direito Constitucional, sendo professor dos dois primeiros e basilares anos e, ainda, um dos responsáveis pela formação de diversos alunos e professores do largo de São Francisco.

Sua formação jurídica foi em Coimbra, tendo decidido vir para o Brasil por ser contra o contra o regime absoluto então dominante em Portugal, em 1824, muito embora Sacramento Blake afirme que Brotero teria vindo para cá a convite do Ministro do Império Antonio Luiz Pereira da Cunha para ser professor no curso de ciências sociais e jurídicas no Rio de Janeiro, em $1825^{156}$. Não obstante, sua nomeação se deu para a faculdade de São Paulo, em 1828, para lecionar no primeiro ano com a cadeira de "Direito Natural, Publico, Análise da Constituição do Império, Direito das Gentes e Diplomacia”, a qual seguiria também como professor no segundo ano.

As fontes o retratam como professor eloquente que doutrinava "pelos princípios do mais adeantado liberalismo", de acordo com Vampré. Em termos de profissões para além do magistério, Sacramento Blake assevera que, dentre diversos cargos, fora também Conselheiro do Império. Obteve o grau de doutor em 1831, após já ser professor na faculdade, e escrevera as seguintes obras que aqui se destacam: "Princípios de Direito Natural", em 1829; "Princípios de Direito Público Universal”, em 1837; "Philosofia do Direito Constitucional", em 1842; "os três primeiros parágrafos de Wattel", sem data.

Não seria irrelevante relembrar que fora este o professor que teve o compêndio de Direito Natural recusado pelos deputados gerais, principalmente por ser um conjunto

\footnotetext{
${ }^{156}$ BLAKE, Sacramento. Diccionario Bibliografico Brazileiro. Rio de Janeiro: Imprensa Nacional, v. 1, 1883. 37p.
} 
desarmônico de teorias compiladas e inserir matérias heterogêneas ao Direito Natural. Seu perfil político parece controverso, em partes sendo um grande profeta do mais "adeante liberalismo" e, ao mesmo tempo, sendo "socialista" de acordo com a cabeça de Almeida Nogueira. Contudo, suas participações interinas na diretoria da faculdade indicam que era um professor confiável ao governo, não representando um deleitamento de teorias opostas ao sistema jurídico-administrativo vigente, conforme se analisará em um espaço oportuno nesta dissertação, mas sim um professor academicamente irreverente.

Pode-se finalizar considerando que sua metodologia era pouco metódica, mais baseada em matérias positivas, sem grande espírito crítico e, ainda, seu relacionamento acadêmico era presente e condescendente para com os estudantes, diferentemente do professor Prudêncio Giraldes Tavares da Veiga Cabral. Este, aliás, também se bacharelou em Portugal e obteve o grau de doutor já no Brasil, em 1834, mas ficou reconhecido por seu difícil trato na cadeira titular de Direito Civil Pátrio ${ }^{157}$. Almeida Nogueira o caracterizou com "vasta cultura jurídica" e eloquência, mas ao mesmo tempo era um lente ruim, já que oferecia pouca assiduidade ou diligência e tampouco explicava as doutrinas da sua cadeira "por morosidade". Em geral, se limitava a ler o paragrafo do compêndio em português ou em latim, acrescentando o comentário de que "a doutrina é clara", ou seja, não explicitava a matéria.

Era um docente mais preocupado com a vernaculidade da forma, quer nas preleções, nas lições, nas sabatinas e atos dos estudantes. Traduzia compêndio de Mello e citava textos do Direito Romano. Almeida Nogueira traz indícios de que alguns alunos teriam problemas nas aulas com este professor em razão de motivos alheios à temática intelectual e acadêmica, sugerindo que não era a dedicação acadêmica necessariamente a forma com a qual avaliaria os estudantes.

Profissionalmente, além do magistério, Veiga Cabral foi magistrado, propendeu para partido conservador, mas não investiu em cargos de eleição popular ou da pública administração, tendo sido sócio do Instituto Histórico e Geográfico Brasileiro. Exercera, não obstante, duas vezes o cargo de diretoria interina e foi lente até 1861. Sua

\footnotetext{
${ }^{157}$ BLAKE, Sacramento. Opus Cit. v. 7, 1899. 85p.
} 
importância maior, para esta pesquisa talvez seja em razão da sua publicação sobre o Direito Administrativo. Não obstante, fora um professor que determinaria o tipo de pensamento civilista dos estudantes, conjuntamente com o Padre Vicente Pires da Motta $^{158}$, que ensinava no terceiro e no quarto ano Direito Civil. Ambos utilizariam o compêndio de Mello Freire.

Com relação ao professor Manuel Joaquim Amaral Gurgel, este foi aluno da primeira turma de 1828 da faculdade de São Paulo. Em 1834, fora nomeado lente catedrático da primeira cadeira do segundo ano de "Direito Natural, Publico e das Gentes", alternando com Brotero, de quem seria a antítese, de acordo com Almeida Nogueira, pois Amaral Gurgel tinha uma formação mais liberal, com a "elocução correta, fluente, lógico e persuasivo". Ele foi diretor em substituição do Visconde de Goiânia quando se criaram as cadeiras de Direito Administrativo e de Direito Romano, tornando-se, a partir de 1857, diretor efetivo. Além disso, exerceu cargos políticos e administrativos em São Paulo, por exemplo, fora membro do Conselho Geral da Província e do Conselho de Estado do Império.

Particularmente sobre Antonio Joaquim Ribas, este nasceu em $1819^{159}$, no Rio de Janeiro, e falecera em 1890. Ele foi discípulo direto de Julio Franck, estudando Filosofia, História Universal, Literatura, Latim, Grego, Francês, Inglês e Alemão nas aulas do curso anexo. Fez sua matrícula para estudar nos cursos jurídicos de São Paulo em 1835, bacharelando-se em 1839 e, no ano seguinte, requerendo defesa de teses para doutorado.

Em 1841, foi nomeado professor de História Universal, nas aulas menores, cadeira que, desde a morte de Júlio Franck, vinha exercendo interinamente. Cresceu, assim, sua fama na literatura, no jornalismo e principalmente adquirindo um excelente perfil acadêmico, sem tanta presença no corpo político e administrativo brasileiro.

Assim, com a reforma de 1854 , foi naturalmente nomeado substituto inclusive sem ter passado por concurso, podendo ser professor de quaisquer cadeiras carentes, tal como foi o caso de Direito Administrativo, com a licença de Silveira da Motta.

\footnotetext{
${ }^{158}$ BLAKE, Sacramento. Op. Cit. v. 7, 1899. 369p.

${ }^{159}$ Em 1820, Cf. Sacramento Blake.
} 
"Ninguém sobre ele se avantajou no exercício do alto magistério", pondera Almeida Nogueira, pois era "metódico e claro na exposição, profundo nas investigações, criterioso nos conceitos, lógico e agudo na crítica invencível na argumentação. E todas estas vantagens realçadas, quanto à forma, por palavra fluente e elegante, dicção nítida e voz agradável timbre"160. Contudo, não há nas fontes outros detalhes acerca da metodologia e sobre os autores que Ribas utilizara, sendo a maior pista para esta pesquisa análises feitas na primeira parte deste capítulo acerca deste relevante autor para a formação da ciência jurídico-administrativa são relevantes.

Almeida Nogueira afirma que, com a licença de Silveira da Motta, veio Ribas a reger a cadeira de Direito Administrativo entre meados de 1855 e 1856, quando elaborou as anotações que deu origem ao seu manual da então recém-criada ciência jurídica no Brasil. Assim, seu compêndio fora usado desde 1855 e sua publicação saíra em $1861^{161}$.

Consta, ainda, em tais fontes que fora professor substituto das áreas de Economia Política, Direito Eclesiástico, Direito Público e também de Direito Administrativo até sua nomeação como lente proprietário da cadeira de "Direito Civil Pátrio, Análise e comparação do Direito Romano”, em 1860, jubilando-se em 1870.

Dentre os aspectos mais relevantes de sua biografia, Ribas escreveu no jornal acadêmico "Ensaios Literários" ${ }^{162}$, fez parte de diversas comissões importantes no governo provincial e geral, dentre elas, a Comissão constituída pelo Gabinete de Zacarias, em 1864, para tratar do projeto de Consolidação Civil, junto com Visconde do Uruguai, Nabuco e Francisco José Furtado, ou seja, ele possuía relação constante com autores contemporâneos relevantes na área do Direito Administrativo. Em verdade, seu compêndio "o Direito Administrativo brasileiro" foi aprovado em ambas as Faculdades de Direito ${ }^{163}$, demonstrando o bom relacionamento com o governo central.

\footnotetext{
${ }^{160}$ NOGUEIRA, J. L. Almeida. Op. Cit. v. 9, p. 22-23.

${ }^{161}$ BLAKE, Sacramento. Op. Cit. v. 1, 1899. 203p.

162 A IMPRENSA periódica de São Paulo desde seus primórdios em 1823-1914. in: Revista do Instituto Histórico e Geográfico de São Paulo. v. 19, São Paulo: Tipografia do Diário Oficial, 1915. 411p.

${ }^{163}$ Sacramento Blake. Op. Cit. v. 1, 203p.
} 
Tratar-se-á mais acerca deste professor no futuro, dada a sua importância para a formação da cadeira de Administrativo naquele contexto histórico.

Da mesma forma, merece destaque o professor Francisco Maria de Souza Furtado de Mendonça ${ }^{164}$, que seria a cabeça docente do curso e, também, da metodologia de ensino de Direito Administrativo. Este autor, nascido em Angola, em 1812, veio criança para o Brasil e aqui fez sua formação acadêmica. De acordo com Spencer, matriculou-se Furtado em 1834, bacharelando-se em 1838 e defendendo teses em 1839. Assim, foi nomeado lente substituto no mesmo ano, tendo-se consagrado como lente catedrático de Direito Administrativo especificamente pelo decreto 31 de março de 1856.

Conservou desde 1839 apontamentos sobre todos os anos acadêmicos, nomes das comissões examinadores, de todos os estudantes, bacharéis e doutoras e as respectivas notas de julgamento. Explicava a ciência do Direito Administrativo de forma metódica, de acordo com Almeida Nogueira, com vasta noção das leis, decretos, regulamentos, portarias, ordens, avisos e decisões - o que tornava o curso algum tanto indigesto para os estudantes. Utilizava, para tanto, o "Repertório das Leis do Brasil”, em 5 volumes, que abrangia o período desde 1808 até 1862, bem como seu "Excerto de Direito Administrativo Pátrio" para servir de compêndio no quinto ano. Não era um professor presente. Não há menção acerca do uso do compêndio de Ribas nesta fonte, contudo. Em nenhuma das dissertações se vislumbrou citação ao compêndio de Furtado ou mesmo de Ribas, sendo os autores brasileiros mencionados Pimenta Bueno e o Visconde do Uruguai.

Nogueira assevera que Furtado era temido, não só porque era delegado de polícia, mas por ser um lente de casuística argumentação, posto que seria rígido e demandava dos estudantes conhecimento específico da legislação. Por exemplo, na banca do quinto ano do aluno João Pinto Moreira, este professor deixou o bacharelando expor o ponto sorteado e depois lhe objetou na letra expressa de um aviso, pois a disposição expressa do texto contrariava a doutrina exposta pelo estudante. Então respondeu este que o "aviso, citado por V. Exa., foi revogado por outro de... (e citou

\footnotetext{
${ }^{164}$ Sacramento Blake. Op. Cit. v. 3, 41p.
} 
data: ano, mês e dia). Ele não está colecionado, respondeu, foi inserto, apenas, no Jornal do Comércio" 165 .

Assim, esta pequena estória, contada num estilo mais anedótico pelo autor de "tradições e reminiscências", indica a exigência acadêmica de que tivessem os estudantes um conhecimento jurídico-formal do funcionamento administrativo do Estado. Nesse sentido, Furtado é um professor que, em diversos momentos destas fontes memorialistas, aponta para esta ânsia pela ciência jurídica em interpretar com o modelo legalista do século XIX a estrutura administrativa, muito embora Nogueira o tenha descrito como um professor sem método de ensino. Talvez aqui haja uma diversidade clara com Ribas, pois este possui um exame mais de corpo analítico da ciência administrativa e menos legalista. Isto, em certa medida, conforme se verá, na forma como os estudantes elaboravam as suas dissertações: utilizando todos os métodos e, ao mesmo tempo, não perpetuando um tipo específico, já que em certos momentos seriam legalistas e, em outros, historiadores filosóficos.

Conselheiro Furtado desempenhara cargos administrativos e de eleição popular, sendo liberal e tendo exercido por um longo período de tempo atividade de delegado de polícia de São Paulo, bem como fora membro do Instituto da Ordem dos Advogados brasileiros. Não era, nesse sentido, um lente muito presente.

Ora, estes perfis traçados auxiliam a compreender a formação da cadeira de Direito Administrativo, bem como a entender a relação humana que existia entre os professores e os alunos. O estudo das fontes, por exemplo, indicara várias estórias que demonstrariam a influência dessa relação informal entre o corpo docente e discente sobre a ratificação acadêmica, principalmente quando se analisa caso a caso o histórico de cada estudante. Da mesma forma, também se faz relevante compreender em alguma medida esta dinâmica para o estudo das dissertações de Direito Administrativo.

${ }^{165}$ NOGUEIRA, J. L. Almeida. Op. Cit. v. p 44-46 


\subsubsection{Análise Histórica da Formação da Cadeira de Direito Administrativo}

Este subitem trata especificamente do desenvolvimento histórico da academia brasileira em relação ao Direito Público em meados do século XIX e, especialmente, à área jurídico-administrativa. Para tanto, parte-se do outrora citado Estatuto do Visconde de Cachoeira que, em seu preâmbulo, sobre a necessidade de se compreender e traçar um plano de estudos no curso jurídico dos princípios elementares de Direito Natural, Público, das Gentes, Comercial, Político e Diplomático, principalmente no que tange ao seu andamento e ao método. $\mathrm{O}$ autor suscita, inclusive, elementos e instrumentos jurídicos incipientes, mas que seriam esmiuçados posteriormente na área do Direito Administrativo, como o princípio da "moral pública", a questão do "prejuízo público" e também se trata sobre "homens de Estado".

Há, ainda, um destaque dado pelo Visconde de Cachoeira ao estudo da jurisprudência pátria em detrimento do demasiado relevo acadêmico ao Direito Romano, assim como da erudição transbordante dos estatutos coimbrãs ${ }^{166}$. Assim, depreende-se que o autor havia o interesse em realizar um ensino jurídico próximo da atualidade e da praticidade do estudo do Direito Público.

Considera que o período ideal de estruturação das matérias envolveria, primeiramente, um estudo de base sobre uma matéria atinente a questões de organização do Estado com a cadeira de "Ensino Natural e Público Universal” e de Direito Natural, posto que descrevem os princípios gerais e universais para regulação dos direitos, deveres e convenções do homem. Em outra medida, seria da mesma forma relevante que os professores demonstrassem aos alunos o complexo desenvolvimento dos direitos e obrigações das nações para com os soberanos, bem como seus limites a fim de se alcançar a tranquilidade pública e consolidação do governo.

Assim, este autor dá ênfase para a figura do Imperador para que se alcançasse a estabilidade e, também, traz um destaque para a importância do estudo Eclesiástico, tanto na espera particular como na pública e internacional. Particularmente sobre os

\footnotetext{
${ }^{166}$ Estas deficiências e faltas de direito pátrio e da prática do foro foram supridas pelo Alvará de $16 / 01 / 1805$
} 
estudos do terceiro ano, de acordo com o mesmo estatuto, haveria um enfoque para a compreensão do Direito Pátrio e Público, mas também do Direito Particular e Criminal.

Desse modo, partir-se-ia dos princípios da monarquia portuguesa, dos códigos e das compilações existentes até a contemporaneidade para, então, chegar no estudo do Direito Pátrio Público, tanto em seu âmbito particular e universal. Destacava o Visconde da Cachoeira que seria importante aplicar seus princípios ao que existia na legislação pátria e na Constituição, bem como seria inevitável buscar na anterior portuguesa de forma a se expor tanto a legislação antiga e moderna, a administração da Justiça e da Fazenda, a organização dos Tribunais, a natureza dos tributos e imposições públicas, a jurisdição para estabelecer as leis, provimentos de ofício e instrução pública. Ora, na análise sobre a centralização administrativa nas dissertações feitas pelos estudantes, ficou perene este método de análise histórica advinda de tempos remotos até se chegar no período nacional de outorga da Constituição de 1824.

Nesse sentido, fica a indicação da importância do corpo jurídico português, predominantemente no início dos estudos de Direito Público. Embora tenha se diminuído com o passar do tempo, e se considere a segunda metade do século XIX uma fase inteiramente nacional para a produção de cultura jurídica Brasileira, ainda sim, estes são indicativos que permaneceriam, principalmente porque algumas legislações, tal como o Código de Direito Civil não saíram do papel até o século XIX.

Igualmente, também é interessante destacar o projeto de Lei de Cunha Barbosa e Pereira de Melo, de 1826, que propôs uma grade curricular com considerável ênfase na área histórico-política e pública. Assim, destacam-se, das oito cadeiras propostas, a primeira, que ensinaria "Direito Pátrio Civil e Criminal" e a "História da Legislação Nacional"; a terceira cadeira, com o estudo da "Filosofia Jurídica ou Princípios Gerais de Legislação - História das Legislações Antigas e seus Efeitos Políticos"; a quarta cadeira, em que seria o ensino de "Direito Público, Estatística Universal e Geografia Política"; a sexta cadeira com "Direito Político ou Análise das Constituições dos Diversos Governos Antigos e Modernos"; a sétima cadeira seria "Economia Política" e, a oitava cadeira, em que os estudos seriam de "História Filosófica e Política das Nações ou Discussão Histórica dos seus Interesses Recíprocos e suas Negociações”. 
Ora, apesar de não haver nesse projeto especificações sobre qual seria o corpo legislativo, principiológico e doutrinário a ser estudado, traz um indicativo relevante sobre a importância de se formar conhecedores, tanto no âmbito internacional como nacional, das estruturas históricas de funcionamento político e legal da nação. No mesmo tipo de estruturação da grade, havia também o projeto de Lino Coutinho, que por fim não fora aceito ${ }^{167}$.

Não obstante, José Clemente Pereira realizou uma emenda no projeto de Barbosa e Pereira de Melo a fim de que "evitar excesso de Direito Político que se notava no projeto da Comissão" e ressaltar a simplicidade, lógica e maior alcance teórico e prático. Então, seriam dez cadeiras com o acréscimo de Direito Romano e as duas no segundo ano de "Direito Público Universal e das Gentes" e "Direito Público Eclesiástico"; no terceiro ano com a primeira cadeira de "Direito Pátrio, Público e civil"; e no quinto ano com a segunda cadeira de "Estatística, Geografia Política e Diplomacia”.

Em outra medida, também haveria a proposta do deputado paulista Francisco de Paula Sousa e Melo, em 8 de agosto de 1826 que, após votação, viriam a prevalecer ${ }^{168}$ a indicação do estudo das matérias de "História da Legislação Nacional", "Filosofia Jurídica ou Princípios Gerais de Legislação", Direito Público, "Direito Político ou Análise das Constituições dos Diversos Governos Antigos e Modernos e da Constituição do Império", Diplomática e "Ciência da Renda Pública em todas as suas partes", bem como seria retirado o estudo da Estatística Universal, Geografia Política, "História Filosófica e Política das nações” e, por fim, o Direito Romano.

Contudo, a derradeira lei que criou os cursos jurídicos não estaria tão preocupada, em sua grade, com a área pública, tendo ocorrido a supressão de diversos artigos do projeto da comissão e a emenda Paula e Sousa, por fim, caíra no ensaio de 11 de agosto de 1827. Não obstante, teria ocorrido uma ultima discussão em 31 de agosto, apresentando Araújo Basto emenda que se incorporara à lei, determinando-se, no fim, que a primeira cadeira seria do estudo do "Direito Natural, Público, Análise de Constituição do Império, Direito das Gentes e Diplomacia”, ao que continuaria no

\footnotetext{
${ }^{167}$ VAMPRÉ, Spencer. Op. Cit. v. 1-2, 22p.
}

${ }^{168}$ VAMPRÉ, Spencer. Op. Cit. v. 1-2, 24p. 
segundo ano na primeira cadeira, mais o estudo do Direito Público Eclesiástico, na segunda cadeira.

Não houvera qualquer alteração relevante nesse sentido com o decreto de 7 de novembro de 1831, sendo que começaram grandes discussões no parlamento, de acordo com Vampré, em 1851, com a Resolução da Assembleia Geral Legislativa, sancionada pelo decreto n 608 de 1851 e referendada pelo José da Costa Carvalho, o Visconde de Monte Alegre. Assim, determinou-se, nos três artigos que seria autorizado ao governo dar novos estatutos aos cursos jurídicos e a criar as cadeiras de Direito Administrativo e de Direito Romano, que havia sido suprimida, após longas discussões, na lei $11 \mathrm{de}$ agosto e nas subsequentes.

Assim, com base nesse decreto, foi publicado o decreto $\mathrm{n}^{\circ} 1.134$ de 1853 que, além de alterar o nome do curso jurídico para faculdade de Direito de São Paulo, instituía, em seu artigo $3^{\circ}$, que seria a primeira cadeira do primeiro ano de "Direito Natural, e Direito Público Universal”, com continuação na primeira cadeira do segundo ano mais "Direito das Gentes, Diplomacia e Explicação dos tratados então em vigor entre o Brasil e outras Nações". Além disso, no quinto ano seria instituída a segunda cadeira de "Direito Administrativo Pátrio". Cada uma das cadeiras tinha um lente catedrático e titular que acompanhava a turma e, no ano seguinte, caso fosse a matéria comum há dois anos. Havia, então, cinco substitutos para as vacâncias das cadeiras e para servirem no impedimento dos catedráticos.

Mas se questiona porque foi nesse período em que foi criada a cadeira de Administrativo? O Conselheiro Ribas afirma que tardaria a ser criada no Brasil, sendo que ainda estava suprimida a cadeira de De Gerando, na França, quando foram criados os cursos em 1827. Não obstante, em 1833 havia já aparecido, num relatório apresentado às câmaras pelo então Ministro do Império, o Senador Vergueiro, a proposta de criar-se uma cadeira de Administrativo para complementar os estudos das academias. Contudo, a ação só viria quase depois de duas décadas.

Após, viria o decreto $\mathrm{n}^{\mathrm{o}} 1.386$ de 1854, expedido por Couto Ferraz, com algumas poucas alterações. Primeiramente, foi realocada do quinto ano para o primeiro a Análise da Constituição do Império na primeira e, ainda, foi renomeada a cadeira de 
Direito Administrativo excluindo-se o adjetivo "Pátrio" e realocada para se constituir como a terceira cadeira do quinto ano.

Houve ainda um decreto $\mathrm{n}^{\mathrm{o}} 3.454$ de 1865 , que daria novos estatutos às faculdades de Direito, dividindo-as em dois cursos. Primeiramente, o curso de ciências jurídicas, que tinha quatro anos sendo no primeiro ano as cadeiras de "Direito Natural, Privado e Público" e de Direito Romano; no segundo ano era "Análise da Constituição e Direito Criminal, com Análise do Código"; no terceiro ano, seria "Direito Civil Pátrio, com Análise e Comparação do Direito Romano" e "Direito Comercial e Marítimo, com Análise do Código" e, por fim, no quarto ano, as cadeiras seriam de "Direito Civil Pátrio em Continuação" e de "Teórica e Prática do Processo e de Direito Eclesiástico".

Então, o curso de ciências sociais teria três anos, dividindo-se com a primeira cadeira de Direito Natural Privado e Público e a segunda de Análise da Constituição, Direito Internacional e Diplomacia. Por fim, viria no terceiro ano as cadeiras de Direito Administrativo, Economia Política e Direito Eclesiástico. Assim, era possível conferirse o grau de bacharel em ciências jurídicas, de bacharel em ciências sociais e bacharel em ciências jurídicas e sociais.

Contudo, tal decreto não foi posto em execução, pois houve alteração do Ministério e nesse período se estenderam diversas questões históricas de política externa, tais como a guerra do Paraguai, o tratado de aliança e outros ${ }^{169}$, de forma que não houve dedicação ou finanças para se estruturarem tais mudanças nas faculdades de Direito.

Assim sendo, passa-se a tratar sobre o desenvolvimento da terceira cadeira do quinto ano de Direito Administrativo ${ }^{170}$ que, ainda em 1854, seria ocupada pelo catedrático e então titular Silveira da Motta, em detrimento do Barão de Ramalho, que ficara com a titularidade da cadeira de "Direito Criminal e Processo", também do quinto ano. Não obstante, como já se sabe, este lente de administrativo desenvolveu uma relação conflituosa com o corpo discente, posto que fora pouco estudioso, macróbio e sem dedicação para explicar de uma forma mais profunda a nova disciplina, posto que

\footnotetext{
${ }^{169}$ NABUCO, Joaquim. Op. Cit. v. 2, p. 151-200.

${ }^{170}$ Criada em 1854 pelo decreto $n^{\circ} 1.386$ de 28/04/1854.
} 
passava a aula consultava seus apontamentos para auxílio e perdia fio do assunto principal.

Foi um homem que exerceu diversos cargos políticos, tendo participado da tribuna parlamentar como deputado provincial e geral, bem como se perpetuou por trinta e quatro anos como senador. Também foi Conselheiro de Estado e exerceu a advocacia. Mas, de acordo com Vampré, ele nunca teve brilho na academia, tendo sido antes um professor substituto de diversas cadeiras, notadamente, de Direito Criminal e Processo. Após sua promoção em 1854 para catedrático da cadeira de Direito Administrativo, ele entrou no gozo de uma licença, precursora de sua jubilação, a qual foi concedida no ano de 1856, por um decreto de 31 de maio, tendo as críticas dos alunos do quinto ano de 1855 incentivado, de alguma forma, a este professor abandonar a carreira.

Nesse meio tempo, em virtude da reforma dos cursos e com a criação das cadeiras de Direito Administrativo e Romano, foi necessário chamar por decreto, sem mesmo a realização de concurso, os substitutos Gabriel Rodrigues dos Santos, Martim Francisco e Antonio Joaquim Ribas. Não obstante, quando se compara as descrições feitas por Vampré e Nogueira, há algumas inconsistências nas informações acerca de quem teria substituído Silveira da Motta. Nogueira, em um momento de sua obra, informa que foi por Antonio Joaquim Ribas como substituto, mas em outra parte de suas "reminiscências", constava o professor Furtado de Mendonça como professor de Direito Administrativo logo após a licença do antigo professor, enquanto que Antonio Ribas daria aulas substitutivas de Economia Política.

Se se observar uma terceira fonte histórica, a memória histórica de Martim Francisco Ribeiro de Andrada do ano de 1857, obra esta que foi aprovada pela congregação dos lentes, nos termos do artigo 164 dos Estatutos ${ }^{171}$, considera que as cadeiras foram regidas devidamente pelos seus respectivos lentes, com exceção dos casos de Direito Civil e de Economia Política. Logo, como já era catedrático o Furtado de Mendonça de Direito Administrativo nesse ano, é este um indicativo de que a cadeira foi regida por ele a partir de sua nomeação como titular, tendo o Conselheiro Ribas sido

\footnotetext{
${ }^{171}$ Em verdade, é interessante esta memória do referido discente, pois ele considerou que deveria ser ensinado Direito Administrativo já no terceiro, aproximando-o mais da matéria de Direito Constitucional.
} 
professor com mais certidão entre os anos de 1855 e 1856. Após, foi Furtado o lente da cadeira por toda a temporalidade em que se encontraram as dissertações de Direito Administrativo, entre 1857 e 1870.

\subsubsection{A Dinâmica entre a Faculdade e a Sociedade pelos Estudantes}

Este quinto subitem objetiva dar um pouco de voz aos estudantes de Direito. Não para mostrar os "estudantões" que se destacaram na política ou as "estudantadas" que faziam os serelepes pela cidade de São Paulo, mas sim para incitar três aspectos que apontam para a relação entre o aluno e a sociedade por meio da faculdade: primeiramente, a penetração acadêmica. Faz-se um retrato geral de como era o perfil do aluno que entraria na faculdade e, para tanto, iniciar-se-á tratando sobre quais eram os requisitos primordialmente materiais para que um estudante entrasse na faculdade.

Em seguida, o diálogo acadêmico. É trazida uma análise estudantil sobre a relação da faculdade para com a sociedade por meio da apresentação de um documento de tom memorialista produzido por um aluno de Direito sobre o funcionamento acadêmico da escola e como deveria ela dialogar com a sociedade.

E, por fim, os frutos acadêmicos. Esta é a parte para se destacar como o estudante conseguia refletir o que a sociedade emitia para a faculdade e, ao mesmo tempo, ele trazia raios de discussão acadêmica para ambientes fora do largo de São Francisco. Para isso, será apresentado um pouco a vivência acadêmica e cultural dos estudantes para além das arcadas.

Desse modo, começa-se ilustrando que tipo de estudantes eram selecionados para entrar na faculdade de Direito, principalmente nos quesitos de nível intelectual. No início, eram necessários exames preparatórios para entrar no curso. Assim, a lei de 11 de agosto determinava como sendo imprescindível a aprovação dos candidatos em Língua Francesa, Gramática Latina, Retórica, Filosofia Racional e Moral e, por fim, Geometria. 
Destas matérias, destaca-se, além da Retórica, que era um elemento relevante para a elaboração do texto bacharelesco e também das argumentações feitas entre professores e alunos, conforme se verá no próximo subitem, a necessidade da Língua Francesa como um conhecimento basilar para os estudantes posteriormente no estudo de Administrativo, posto que, conforme afirma o Visconde de Cachoeira em seu projeto de Estatuto:

“(...) na segunda [lingua francesa] se acham tambem escriptos os melhores livros de direito natural publico, e das gentes, maritimo, e commercial, que convem consultar, maiormente entrando estas doutrinas no plano de estudos de Curso Jurídico, e sendo escriptos em francez muitos dos livros, que devem por ora servir de compendios."

Em outra medida, o conhecimento da Filosofia Racional e Moral auxiliava os estudantes em uma compreensão para além das leis, possibilitando tirar conclusões de princípios, e para resolver os casos que demandariam ir para além da legislação ou de outros julgados. O mesmo autor considera que parte do Direito subsistiria com a arte crítica, que ensina a avaliar os elementos probatórios e conhecer a evidencia moral, o testemunho por documentos e afirmações verbais. Nesse sentido, a Moral ou a Ética seriam a base metodológica para se compreender o estudo do Direito Natural. Assim, também há aqui um indicativo acerca da interpretação jurídica tida com como base deste ensino.

Com o passar dos anos e dos decretos já muitas vezes supracitados, houve algumas alterações do corpo destas matérias preparatórias para o curso jurídico e que, inclusive, eram ensinadas no curso anexo, por professores muito dos quais seriam lentes substitutos e catedráticos da faculdade. Assim, em 1831, incluíram-se a Língua Inglesa, a Lógica Metafísica e a Ética, a História e a Geografia. Após, em 1853, foram também acrescentadas a Aritmética e a Poética, assim permanecendo por um longo período. Contudo, já seria possível ao estudante, ao invés de realizar estes exames preparatórios, apresentar diploma de bacharel em Letras pelo colégio D. Pedro II ou um título de aprovação obtido nos cursos anuais da capital do Império.

Ora, com estas informações, quando se pensa na quantidade mínima de alfabetizados e estudados no Brasil do século XIX, isto demonstra quão limitado e 
seletivo socialmente era o corpo de jovens que poderiam penetrar na faculdade de Direito. Muitos, em verdade, viriam de famílias abastardas, produtores de café, industriais ou ainda filhos de pais intelectualmente influentes.

Não obstante, havia alguma variedade interessante de estudantes a que é possível fazer um pequeno indicativo para pesquisas posteriores. Por exemplo, além dos conhecidos nomes de Presidentes da República e políticos famosos, o largo São Francisco também acolheu alguns alunos de origem humilde, muitos que produziriam as sebentas para receber alguma quantia dos outros alunos e outros que já seria mais velhos, formados já em outra área ou mesmo advindos da Europa. As fontes históricas são extremamente ricas para se realizar uma análise acerca da origem social, financeira, naturalidade, escolhas profissionais, perfis de estudantes dentro da própria faculdade e, ainda, as opções políticas.

Em alguma medida, estas informações são relevantes em dois níveis quando se estuda as dissertações de Direito Administrativo. Para pesquisas posteriores, é interessante considerar uma análise que infira a relação entre o cabedal social de que partiam os estudantes quando escreviam suas dissertações. Em outra medida, esta compreensão da formação retórica, linguística, filosófica e literária dos estudantes é muito relevante na compreensão da lógica semântica de produção das fontes histórica.

Enfim, incitado um pouco sobre a peneira que a faculdade utilizava para obter seus estudantes, passa-se, agora, para tratar sobre como o estudante compreendia o papel da faculdade na sociedade. João Theodoro Xavier de Matos foi o aluno responsável por escrever a memória acadêmica do ano de 1862. Assim, além de descrever acontecimentos do ano, este estudante propôs diversas propostas de como poderia ser aprimorada a metodologia de ensino da faculdade e também propõe um diálogo interessante da academia com a sociedade.

Ele propunha a publicação das provas escritas para obviar aos defeitos dos exames a toda sociedade. Sua justificativa era de que:

\footnotetext{
“nenhum membro das comissões julgadoras, por mais solicitado pelas inspirações de uma caridade mal entendida, terá coragem de lançar nota boa ou sofrível em um escrito de duas linhas
} 
em uma prova péssima ou sombreada por muitos borrões ou emendas. Os próprios estudantes, suas famílias, disseminadas pelo império, seus protetores ou amigos se apressarão a lerem, confrontarem e avaliarem o mérito, dessas provas, ou a consultarem sobre elas pessoas entendidas. Teremos, então, senhores, esta influencia, tão desejada, pacífica e sempre salutar da sociedade civilizada sobre a instrução publica. Servirá ela de sentinela incansável da nossa dignidade, promovendo constantemente do cumprimento pontual e severo da justiça. Destarte, mais se estreitarão os vínculos de harmonia, que prendem a instrução pública do império às liberdades de sua instituições políticas, que, sempre ao lado do governo, tanto no centro como nas localidades, coloca como grande auxílio, a influencia popular a opinião de todos." ${ }^{172}$

Assim, ele recomendava que tanto o estudante como toda a sociedade devesse pagar uma taxa para custear as despesas da impressão de forma a contribuir esta difusão de pensamento entre todos.

Ora, deste pequeno trecho deste documento histórico é possível inferir duas hipóteses relevantes para o futuro da pesquisa sobre o ensino jurídico brasileiro: não só havia sim alguma preocupação por parte dos estudantes em aprimorarem a metodologia do ensino jurídico dentro da faculdade, como ainda que este trecho do documento produzido pelo aluno representa uma atenção estudantil para a difusão do conhecimento acadêmico produzido. Portanto, havia um interesse de levar o aprendizado dentro das salas de aula para além das arcadas, não por meio de discussões políticas ou pela proclamação de poesias, mas sim por uma argumentação jurídica sobre pontos científicos específicos ao que eram aprendidos, por exemplo, nas dissertações.

Muito embora não seja possível depreender que tenha ocorrido tal dinâmica proposta pelo aluno, principalmente ao se considerar, primeiro, o número de analfabetos na cidade e, segundo, o provável desinteresse por parte da massa docente em realizar tal feito, ainda sim, é relevante compreender que havia essa dinâmica dentro do ambiente acadêmico, mesmo da lógica de produção de pensamento jurídico por parte dos estudantes.

Por fim, um terceiro aspecto relevante para se compreender também o funcionamento da dinâmica relacional da faculdade com a sociedade é a relação da

\footnotetext{
${ }^{172}$ MEMÓRIA histórica dos acontecimentos notáveis da Faculdade de Direito de São Paulo, durante o ano de 1862; aprovado na parte histórica pela congregação da mesma Faculdade, dia 2 de mar. de 1863. São Paulo: Typ. Imparcial. 16p.
} 
academia com o desenvolvimento social e político principalmente da cidade de São Paulo. Foi um lento processo pelo qual passava a sociedade paulistana e com a qual os bacharéis acompanharam, em alguma medida. Assim, quando se observa a população, as discussões políticas, a estrutura e a logística que eram praticamente nulas quando se instalou o curso jurídico, na segunda metade do século XIX já se percebia um processo de efervescências no ambiente social paulistano, a vinda da estrada de ferro, o crescimento do comércio e das trocas, destacando-se também como fase de renascimento literário.

Desse modo, muito embora as fontes retratem certa separação entre os costumes da cidade, naquele tempo ainda pequena e monótona quando comparada com as movimentações acadêmicas, ainda sim foi considerável a presença do corpo acadêmico em São Paulo tanto na vida econômica, como administrativa e artística e mesmo no desenvolvimento intelectual da província ${ }^{173}$.

Nesse sentido, o funcionamento da faculdade não poderia estar desligado dos acontecimentos de seu tempo. Logo, não seria coincidência que a importância do jornalismo acadêmico floresceu em uma época em que também nasciam diversos materiais periódicos. Há inúmeros exemplos da importância desse jornalismo, já muito tratada por Sérgio Adorno em seu "aprendizes do poder".

A título de exemplificação, fundou-se em 1850 o "Ensaio philosophico paulistano", com sua revista mensal que era a mais célebre associação acadêmica em concorrência com o "Atheneu Paulistano", de $1852^{174}$. Já em 1854, surgira o primeiro número do "Correio Paulistano", que não só tratava sobre os acontecimentos da cidade como também registrava a presença dos acadêmicos com as estudantadas, as serenatas, as reclamações dos "futricas" contra os moços, notícias de reuniões intelectuais, vaias nos teatros, versos e improvisos a artistas, folhetins, romances, dramas e poemas estudantis.

\footnotetext{
${ }^{173}$ ZALUAR, Augusto Emílio. Peregrinação pela província de São Paulo. 1. Ed., São Paulo: Garnier, 1862. 92p.

${ }^{174}$ A IMPRENSA periódica de São Paulo desde seus primórdios em 1823-1914. in: Revista do Instituto Histórico e Geográfico de São Paulo. v. 19, São Paulo: Tipografia do Diário Oficial, 1915. p. 433-480.
} 
Em meados da década de 60, havia livreiros dos quais se aproveitavam os estudantes para obter material para estudo, tais como o Bernardino José Dias Torres de Oliveira, que ficava na então rua da imperatriz ${ }^{175}$; a de Gustavo Gravesnor, na rua de São Bento; e de José Fernandes de Sousa, na Pandega. Em outra medida, existiam nessa época três tipografias, sendo a Imperial, na rua do ouvidor, onde se imprimia, dentre diversos periódicos, dentre os quais, várias das revistas acadêmicas. Isto fora essencial para a circulação tanto de obras literárias, jornalísticas como também de discussão acadêmica.

Quanto a isto, é relevante destacar que esse universo jornalístico não se restringia ao ambiente das arcadas. Diversos professores, como Amaral Gurgel, João da Silva Carrão e Barão de Ramalho eram presidentes honorários de muitas destas revistas, demonstrando que também o corpo docente se relacionava com esta dinâmica jornalística e que esta presença era algo confortável com o cotidiano do aprendizado de ensino. Nesse sentido, também considerou Spencer Vampré que, em 1858, se criou um instituto acadêmico que compreendia cinco seções correspondentes aos cinco anos do curso.

Importante, ainda, destacar que, nessa época, em meio às constantes serenatas acadêmicas, normalmente realizadas de quarta e sábado, perpetuaram-se consideráveis movimentações literárias da mesma forma que circulava a publicação de diversos livros e transcendiam em sessões ordinárias das associações científicas ou literárias diversas discussões sobre teses de Direito, de Filosofia, de História e de Literatura.

Em outra medida, neste período, enquanto os alunos escreviam as dissertações de Direito Administrativo, estavam também participando da crescente sociedade abolicionista, de acordo com Spencer Vampré, já que fora criada em 1863 por iniciativa de França Carvalho com o nome de "Fraternização", tendo libertado diversos cativos, bem como conclamado os ideais abolicionistas.

Ora, faz-se necessário atentar que a metodologia de ensino não poderia ficar imune a essa produção de informações políticas e culturais envolta à faculdade de

$\overline{175}$ Atualmente, a rua 15 de novembro. 
Direito e promovidas por muitos dos estudantes. Assim, aqui ficam alguns indicativos relevantes acerca do enlace entre a academia e a sociedade, principalmente pela visão dos próprios estudantes, que foram os produtores das fontes aqui em destaque de estudo histórico-jurídico.

\subsubsection{A Ratificação Acadêmica}

Tratados todos estes subitens, é chegado o contexto de compreender melhor como funcionava a dinâmica de habilitação dos estudantes para passarem de ano ou, eventualmente, obterem o grau de bacharel, a chamada a ratificação acadêmica. Este último subitem fecha esta análise das fontes que retrata o funcionamento do cotidiano jurídico da academia de São Paulo.

Assim, quando se atenta para o primeiro material relevante a tratar sobre ensino jurídico, este redige amplamente como deveria ser o andamento e as demandas dos saberes que a academia exerceria sobre os alunos a fim de que se formassem bacharéis de Direito. De acordo com o Estatuto do Visconde de Cachoeira, no que se refere ao ensino dentro das salas, cada uma delas deveria ter lições de hora e meia, sendo a primeira meia hora dedicada a ouvir os estudantes e o restante do tempo para explicar o compêndio.

Mas isto não seria suficiente para avaliar o aluno, posto que no sábado de cada semana deveria ocorrer um ato com três estudantes defendentes e seis arguentes, todos sorteados, sobre uma matéria dentre as explicadas durante a semana. Ao passo que, no final de cada mês, dariam os professores ponto aos discípulos, dentre as doutrinas explicadas, a fim de que estes produzissem uma dissertação por escrito em português para que se denotasse "o bom gosto de escrever" e o "progresso dos conhecimentos".

Portanto, havia um âmbito diário, semanal e mensal de avaliação do aprendizado dos estudantes. Não obstante, também existia outro aspecto limitativo para se habilitar o aluno no ano, que era a quantidade de faltas nas aulas. Se se completasse o aluno quinze faltas sem causa ou, ainda, quarenta faltas justificadas, ele perdia o ano. Assim sendo, deveria se reunir a congregação geral dos lentes para tratar da habilitação dos estudantes 
no ano, decidindo que estudantes tinha perdido ou sido aproveitados no ano a fim de serem, então, admitidos para exame final. Também era neste contexto determinados que lentes os deveriam examinar.

Assim, com a lista dos estudantes habilitados para exame, os lentes de cada ano arranjavam os pontos de forma a incluir as doutrinas de todas as cadeiras e as teses mais importantes. Tirava-se o ponto na véspera do exame, fazendo-se de modo que o estudante tivesse vinte e quatro horas para estudar. Neste exame final, faziam a arguição dois examinadores nos quatro primeiros anos, devendo cada um arguir por espaço de meia hora sobre as matérias do ponto.

Não obstante, relembrando que o estudo deste mestrado é direcionado para uma cadeira do quinto ano, é relevante destacar que havia um diferencial para o aluno do quinto ano, que teria quarenta e oito horas para estudo, já que seriam seus exames mais complicados e, também, teria eles que dissertar sobre outro ponto tirado, nos termos do capítulo VII, $\S 2^{\circ}$, que assim dispõe:

\footnotetext{
"Nestas analyses [análises de texto e decisão pátria feitas pelos professores] mostrará origem jurudica da materia; a justa combinação de principios elementares de direito natural, que lhe são relativas; a jurisprudencia analoga das nações polidas, e a applicação que tem no fôro nacional, acostumando assim os ouvintes não só a chegarem ao perfeito conhecimento das leis, pelo methodo analytico, como a escreverem pelo mesmo methodo as dissertações, e fazendo-lhes adquirir a pratica para as allegações de ponderação, que houverem de fazer no fõro, e causas celebres."
}

Assim sendo, seriam três examinadores para o quinto ano, de forma que o presidente argumentava sobre a dissertação feita pelo examinando acerca do assunto que lhe coubera por sorte. Neste caso, duravam duas horas o exame, sendo cada argumentação de meia hora. Ou seja, os exames desde o início eram mais rigorosos para os quintanistas, posto que demandavam maior zelo e mérito dos alunos e, logo, duravam mais tempo.

Por fim, os lentes votariam a portas fechadas com a letra "A", de "aprovado" ou "R", de "reprovado". Aquele que tivesse um somente um voto "R" contra si seria 
"simplesmente aprovado", o que não era comum no quinto ano e, se ocorresse, resultava em revolta por parte do corpo discente.

A lei 11 de agosto, nesse quesito, conforme seu artigo $10^{\circ}$, indicava que se seguiria os estatutos do Visconde de Cachoeira. Agora com o decreto de 1831, foram instituídas algumas alterações e maiores especificações daquelas traçadas pelo documento anterior.

Primeiramente, foi reforçado que os estudantes só seriam admitidos a exames se habilitados previamente pela congregação, que tiraria e aprovaria os pontos e o horário para o exame de cada um dos alunos. Tais pontos deveriam incluir doutrinas. Além disso, seria a partir do terceiro ano que os estudantes deveriam tirar mais um ponto dentre as matérias dos seus respectivos anos a fim de dissertarem por escrito, em linguagem vulgar, de forma a argumentar a dissertação no início do exame. Assim, os examinadores deveriam arguir com os examinandos agora por vinte minutos ${ }^{176}$ e o presidente da banca, pelo mesmo tempo, sabatinaria os alunos do terceiro, quarto e quinto ano acerca da dissertação feita.

Em suma, mantinha-se o padrão do modelo do estatuto do Visconde de Cachoeira. Não obstante, conforme passara o tempo, a próxima legislação relevante sobre ensino jurídico apresentara um corpo mais detalhado de informações acerca da dinâmica de habilitação dos estudantes.

Primeiramente, o decreto $n^{\circ} 1.134$ de 1853 segue o mesmo modelo de ensino, pois asseverava que os lentes deveriam lecionar todos os dias úteis da semana, sendo cada lição de uma hora e meia até os quartanistas. Na primeira parte do tempo os lentes designariam os estudantes que quisessem ouvir sobre o tema do dia e, após, explicariam na outra metade. Especificamente para os quintanistas, que tinham três aulas, as lições durariam uma hora. Ou seja, era comum a argumentação dos estudantes com os professores nas aulas, tal como indicara o estatuto de Cachoeira.

\footnotetext{
${ }^{176}$ SPENCER, Vampré. Op. Cit. v.1-2. 134p.
} 
Além disso, no último dia útil de cada semana haveria uma sabatina sobre as matérias explicadas e também poderia ser adicionado algum ponto pelo lente que considerasse relacionado. Assim, seriam três defendentes e seis arguentes nestes exercícios, tirados por sorteio de urna. As preleções deveriam ser sobre os compêndios determinados para a aula. Ora, todos estes procedimentos se assemelham às sabatinas diárias e semanais determinada outrora pelo antigo estatuto, tão-somente estão aqui mais detalhadas.

Assim, o diferencial seria o exame acima do semanal. No artigo 116 deste decreto, determinava-se que, em épocas separadas, os lentes deveriam escolher dois pontos tirados das matérias explicadas e deveriam ordenar que os estudantes realizassem dentro de um mês uma dissertação escrita. Portanto, teria mais tempo o estudante para elaborar esta dissertação do que aquela mensalmente suscitada pelo primeiro documento analisado. Não se sabe se porque assim poderia o estudante se dedicar com mais profundidade à dissertação, mesmo porque após o exame das dissertações, haveria uma sabatina extraordinária pelo lente e, além disso, estariam presentes aos examinadores no ato do exame do respectivo ano. Nesses termos, a dedicação do aluno para com estas dissertações deveria ser considerável a fim de obter a habilitação no ano.

E estas são as dissertações examinadas no capítulo terceiro.

Além disso, no final de cada ano, haveria a reunião da congregação a fim de realizar o processo de habilitação, ou seja, verificar as faltas dos alunos e as notas que os professores deram ao aluno pelo ano para, então, procederem com a habilitação dos estudantes para exame e escolherem os pontos. Com isto, se depreende que havia um exame mais objetivo que era a quantidade de faltas existentes e um mais atento à nota que o professor deste ao aluno. Não há maiores especificações sobre os critérios do professor para dar esta nota e tampouco para os professores decidirem se estava habilitado o aluno para exames a não ser pela quantidade de faltas.

O exame das fontes demonstra que havia subornos dos bedéis e quaisquer funcionários responsáveis por marcarem as faltas dos estudantes a fim de que estes não perdessem o ano por este motivo. Também houve vários indicativos de que não havia 
um critério transparente e fundamentado para as habilitações dos alunos no que tange a esta "nota" do professor. Em alguns casos, havia muita condescendência, mas também houve anos em que ocorriam várias perdas do ano de alunos.

Um professor, por exemplo, muito subjetivo em suas notas do que qualquer coisa era o Veiga Cabral, que às vezes não permitia a habilitação de um aluno em razão de seu nome não the apetecer. Em outra medida, o trio parada dura Ramalho, Furtado e Carrão eram professores que às vezes apertavam a rigidez para com os alunos, agora pela descrição de Almeida Nogueira, não é possível compreender se esta rigidez era realmente excessiva, justa ou meramente acima da média condescendente a que estavam acostumados os alunos. Há um caso reconhecido em 1865 de reprovações "em massa" de alunos em razão desses professores, bem como de uma movimentação discente a fim de se resolver o problema, conforme narra divertidamente Nogueira.

De outra forma, determinou-se por este decreto de 1853 que nos dois primeiros anos, os exames eram feitos em conjunto de alunos sobre pontos relacionados às matérias do ano os quais seriam sorteados vinte e quatro horas antes, enquanto que a partir do terceiro ano seriam feitos singularmente. Diversamente, nos dois últimos anos, haveria mais uma dissertação feita pelo estudante com objeto análise à matéria do ponto, que também aqui deveria ser baseado nos compêndios adotados e as matérias explicadas. Com o decreto $\mathrm{n}^{\circ} 3.414$ de 1854, esta especificidade de produzir uma dissertação seria a partir do terceiro ano.

Particularmente acerca dos pontos escolhidos, deveria ser feito um ponto parcial referente a cada cadeira de forma que houvesse um ponto só em uma cédula. Deveriam abranger os pontos a totalidade das matérias explicadas no ano sem que houvesse mais dificuldade em um do que o outro. Além disso, para os dois últimos anos, também deveria haver os pontos referentes à dissertação. No final deveria ser escrito um ponto só em uma cédula.

Os pontos seriam apresentados para a congregação aprova-los ou modifica-los a fim de que se mantivesse o nível de dificuldade das matérias quanto fosse possível, no número e na amplidão das matérias mais difíceis, principalmente na combinação das que pertencem a diferentes cadeiras. 
No artigo 126, há a indicação de que no último ano seriam quatro examinadores, sendo o presidente arguidor da matéria da dissertação, que competia no quarto ano ao lente curso ensino pertencesse o objeto da dissertação. Os exames começariam pelo professor mais novo. Contudo, as fontes indicavam que eram feitos os exames do quinto ano tão-somente com os três professores acima suscitados: Ramalho, Furtado e Carrão, às vezes com a falta de um, mas totalizavam três professores, tão-somente.

Por fim, havia a possibilidade ao aluno que fosse "aprovado simplesmente" de se matricular novamente no mesmo ano, o que não é indicado como algo muito comum de acordo com as fontes.

Houve duas diferenças relevantes no decreto $\mathrm{n}^{\mathrm{o}} 1.386$ de 1854 , primeiramente, ressaltava-se que os lentes que tivessem regido as cadeiras durante o ano deveriam ser de preferencia designados examinadores dos respectivos estudantes. Além disso, faz uma observação sobre a realização de exames, posto que o governo poderia determinar, quando julgasse conveniente e após fosse ouvida a congregação que fossem vagos os exames de cadeiras que "não forem meramente positivas".

Ora, este artigo 75 indica uma ressalva de interferência governamental sobre a ratificação acadêmica, posto que dispensaria de exames as matérias que não tratasse do que era genuíno e puro à cadeira, contudo não há indicativo nas memórias de Almeida Nogueira e Spencer Vampré acerca dessa possibilidade ter sido utilizada pelo governo.

Pela leitura do decreto $\mathrm{n}^{\circ} 1.568$, de 1855 , há muitas repetições desse ritual de ratificação acadêmica. Há um indicativo relevante, no artigo 48, para que se estude mais a fundo estas aprovações, já que era responsabilidade do secretário numerar e registrar os pontos das matérias explicadas em cada ano em livros especiais, também com o nome do Estudante sorteado para o ponto, pela ordem das datas e separadamente. Além disso, criava o secretário as cédulas com cada ponto para ser colocadas na urna a chave.

Aqui se explicita também que os estudantes a partir do terceiro ano tirariam dois pontos, sendo o segundo a fim de elaboração de uma dissertação, em língua vultar, cuja doutrina seria defendida e arguida pelo presidente do exame. Mantinha-se, ainda, a 
ordem de que seriam quatro examinadores para o quinto ano com arguição de vinte minutos.

Em outra medida, o decreto de 1855 retrata um pouco mais detalhadamente como deveriam ser feitas as lições dos professores. Indica, em seu artigo 240 que as preleções deveriam conter todas as explicações necessárias aos alunos, a fim de que houvesse mais fácil compreensão e desenvolvimento da matéria de que tratassem, para correção de qualquer doutrina equivocada ou duvidosa com relação "aos progressos da sciência" e, ainda, para conhecer os diferentes sistemas que pudessem haver sobre o assunto.

$\mathrm{Na}$ eventualidade dos estudantes não compreenderem algum ponto, poderiam propor dúvidas verbais ou escritas ao lente dentro da aula ou na casa do lente. Este, em reação, deveria explicar o objeto e resolver as dúvidas no mesmo dia ou no seguinte, salvo se fosse ela objeto de sabatina.

Mantém-se neste decreto a determinação de que se realizassem duas dissertações no ano para os alunos de todas as cadeiras, com a única diferença do prazo, que agora seria de um mês e meio para realiza-las. Este regulamento, descrito no artigo 243 referese às dissertações examinadas por esta pesquisa, sendo que deveriam ser arquivadas por ordem dos anos pelo secretário, conforme se verificou que estavam.

Não há nada de muito divergente a ser tratado acerca do decreto de 1865 . Não obstante, ocorreram diversas mudanças a partir dos anos de 1870, ao que começa a reforma de Benjamin Constant e também do ensino livre, mas não abrangem mais a temporalidade ou influenciariam, em qualquer ângulo, esta pesquisa.

Assim, estes são os aspectos mais relevantes que se observou em relação à organização formal da ratificação acadêmica que estaria envolta da elaboração das dissertações e, em especial, das dissertações de Direito Administrativo. Diversos aspectos das fontes legislativas estão demonstradas quando se analisa as histórias, os feitos e descrições dos memorialistas, embora também haja controvérsias nas próprias fontes de Nogueira e de Spencer. 


\subsection{A Metodologia de Ensino}

Após apresentar qual o universo geral de discussões acerca do tema da cultura jurídica do Direito Administrativo no século XIX brasileiro e de retratar a rotina de funcionamento do ensino da faculdade de São Paulo, de forma a destacar elementos que influenciam a formação da cadeira de Direito Administrativo, este item final do capítulo tem o escopo de realizar uma análise sobre a metodologia de ensino jurídico, em especial para a formação da área administrativista.

Assim, aqui será feito um exame crítico dos elementos apresentados no item acima por meio da delimitação de três níveis relevantes que consagrariam, entrelaçados, a metodologia de ensino da faculdade de Direito de São Paulo. Trata-se de um ensaio para o capítulo 3, que realiza a análise em âmbito geral e específica das dissertações de Direito Administrativo.

Em verdade, encontrar-se-á o contexto de produção das dissertações em meio a dois âmbitos de discussões que se entrelaçam. Num ângulo mais microcósmico, é relevante aprofundar como se deu a metodologia de ensino da cadeira de Administrativo na faculdade paulistana e, ainda, já num aspecto que observe toda a pintura da cultura jurídica produzida no século XIX na área de Direito Administrativo e encontre as pinceladas feitas pela academia de São Paulo. E, se possível, procurar compreender qual o significado de tais pinceladas na pintura como um todo.

Tal tarefa é muito árdua, mesmo porque a pesquisa brasileira ainda sequer consegue enxergar o quadro sem estar embaçado. Portanto, mais do que encontrar qual seria a lente exata ou a teoria verdadeira para interpretar o quadro, esta parte final do capítulo 2 procura apontar indícios do que seria positivo ou não se atentar quando se pensa na produção de cultura jurídica administrativa na academia de São Paulo dentro do contexto brasileiro oitocentista como um todo.

Para tanto, dividir-se-á o item 2.3 em três níveis para melhor compreender o estudo da metodologia de ensino do Direito Administrativo nesse período em São Paulo. Primeiramente, destaca-se o aspecto romântico dentro do ambiente acadêmico, 
ou seja, as influências e construção das ideias daquele período histórico, no que tange aos âmbitos sociológicos e culturais. Em segundo lugar, traz-se como destaque o nível técnico desenvolvido no largo de São Francisco, ou seja, qual o método interpretativo e a retórica apreendidos.

Por fim, é feita a análise num nível semântico da metodologia de ensino, ou seja, procura-se compreender se o significado era assemelhando à coisa. Assim, é o momento de compreender como a relação de ensino compreendia a matéria administrativa, se prevalecia um sentido concreto da ciência ou então seu o caráter gelatinoso e, ainda, se havia ou não um sentido para o estudante de produção daquela dissertação que não fosse obtenção de uma aprovação do professor a fim de ser ratificado academicamente e se tornar um bacharel.

\subsubsection{O Romantismo}

A escolha do termo "Romantismo" para tratar sobre as influências culturais e sociológicas dentro da metodologia do ensino jurídico de meados do século XIX não foi aleatória. Em verdade, procura-se instigar a compreensão complexa acerca do contexto histórico em que se formara o pensamento jurídico na academia de São Paulo no âmbito das influências literárias e das artes, pois a cultura auxilia a compreender o caráter angustiado do jovem brasileiro minimamente letrado e que conviveu em um meio intelectual e passionalmente agitado como a academia.

Ora, não é uma questão de vangloriar os artistas da academia e nem tampouco de ver com olhos pejorativos o excesso boêmio e literário dos bacharéis que vibraram em meados do século XIX brasileiro. Em verdade, parece que o excesso, seja de adoração ou de repulsa dos investigadores acadêmicos não auxilia a compreender a conjuntura intelectual em que se desenvolveu o pensamento jurídico do bacharel. Ao invés disso, por que não considerar como sendo parte do ensino jurídico esta característica cultural viva e dinâmica de tal personagem histórico tão discutido pela sua importância política na construção burocrática do Império? 
As influências literárias e românticas de um estudante de Direito não retira a possibilidade dele desenvolver um raciocínio lógico-jurídico. Pelo contrário. Nogueira, por exemplo, aponta, em suas "tradições e reminiscências", diversos casos concretos de estudantes que eram tão presentes na vida literária e artística da cidade de São Paulo como também exímios alunos em aula e nas sabatinas.

Em outra medida, este subitem procura também refletir sobre um dos inúmeros aspectos sociológicos sobre esse período que são importantes para a compreensão do pensamento jurídico na academia. No caso, a questão da então recente independência e construção do Estado brasileiro trazia um paradoxo que envolvia o sentimento antilusófobo e nacionalista, mas ao mesmo tempo aportuguesado e transoceânico da formação das ideias brasileiras e, nesse ínterim, também faria parte o ensino do Direito daquele período da coesa inautenticidade brasileira ${ }^{177}$.

Assim, primeiramente sobre o Romantismo dentro da academia. Necessário destacar, conforme ensina Alfredo Bosi ${ }^{178}$, que não se deve ater aos "ismos" como se estes fossem determinantes na compreensão da formação cultural de um país. Não obstante, há diversas características que se perpetuaram dentro da faculdade que afloravam aspectos românticos, como a exaltação nacionalista, católica, retoricamente liberal que advinham da primeira geração, mas também a boemia e o conflito do "eu" com o meio da segunda geração e as críticas sociais e nacionalismo guerreiro do condoreirismo.

Ora, o Brasil, como outros países que foram colonizados, procurava encontrar sua identidade e, nesse sentido, precisaria de algum estímulo para o discurso de nação independente e forte. O próprio imperador D. Pedro II seria um estimulador à construção dessa cultura, eis que criara diversos órgãos ${ }^{179}$ e, além disso, seu governo foi reconhecido como um período de considerável liberdade de expressão.

\footnotetext{
${ }^{177}$ HOLLANDA, Sérgio Buarque de (Org). História geral da civilização brasileira, Tomo II: O Brasil monárquico, vol. 3: Reações e transações. 1976. São Paulo - Rio de Janeiro: Difel, 3 Ed. 323p.

${ }^{178}$ BOSI, Alfredo. A Construção Nacional: 1830-1889. in: SCHWARCZ, Lilian Mortiz (Org.). História do Brasil Nação: 1808-2010. Rio de Janeiro: Ed. Objetiva, 2012. p. 229-230.

179 SCHWARCZ, Lilian Mortiz. As Barbas do Imperador: D. Pedro II, um monarca dos trópicos. 2. Ed. São Paulo: Companhia das Letras, 126p.
} 
Nesse sentido, considera-se o papel do estudante de Direito, principalmente em um país em que não havia instituições universitárias ou acadêmicas de estudo aprofundado, relevante para aflorar este espírito. E isto se reflete, em alguma medida, também no perfil da metodologia de ensino, basta analisar com um pouco de atenção a dinâmica descrita pelas fontes históricas e, ao mesmo tempo, atentar-se para os vários perfis do bacharel traçados no primeiro capítulo.

Culturalmente pensando, seria inevitável, por exemplo, que houvesse um estímulo à formação de bacharéis burocráticos. Isto porque a lógica daquele período, na academia, conclamava que os estudantes aprendessem três coisas essenciais: que as instituições demandavam o conhecimento ritualístico da forma; que era possível realizar vários empreendimentos ao mesmo tempo; e que tudo podia ser revertido, quer fosse por um plano bem arquitetado, quer fosse pelo escapismo.

Não obstante, estes aprendizados vinham como que subentendidos com o funcionamento cotidiano da faculdade. Primeiro, sobre o aprendizado de que as instituições demandavam um conhecimento ritualístico da forma. Ora, isto se dava porque as regras de funcionamento da escola eram ${ }^{180}$, no mínimo, muito extensivas, delongadas, cheias de pompas e circunstâncias mais do que por alguma materialidade de sentido. Ainda mais porque era uma faculdade de Direito, então a questão da vestimenta, do trato para com os professores, a sequência dos atos acadêmicos e outras tantas descrições já suscitadas no item anterior demonstram a exigência do estudante um aprendizado paciente e, ao mesmo tempo, maduro para poder levar sua vida acadêmica.

Nesse sentido, a cultura do Romantismo descritivo, enfadonho, cheio de cerimonialismo, que encobria parte a literatura de meados do século XIX, como Joaquim Manuel de Macedo, José de Alencar e outros também refletia este tipo de perfil cheio de rituais formais de passagem. Um perfil que um burocrata da corte, do parlamento também deveria personalizar.

Em seguida, sobre a possibilidade de se realizar vários empreendimentos ao mesmo tempo. Ora, basta partir do exemplo dado pela falta de dedicação às aulas e ao

${ }^{180}$ E ainda o são. 
ensino por parte de diversos professores, que eram profissionais em várias áreas ao mesmo tempo e, ainda, observar a possibilidade do bacharel descobrir seu potencial para exercer várias atividades ao mesmo tempo enquanto estava na academia para que se encontre mais um perfil bem característico do Romantismo, presente, mesmo que de uma forma espontânea e despretensiosa, na metodologia de ensino.

Quando se analisa a obra de Sérgio Adorno, que se atentara para o bacharel extracurricular, como um grande literário e jornalista em detrimento da participação nas aulas, parece que ela se olvidou de todos os registros de alunos nas fontes de Nogueira e Spencer que eram dramaturgos, poetas, músicos, boêmios, jornalistas, políticos ao mesmo tempo também tinham um relacionamento elogioso para com o corpo docente e, ainda, eram considerados melhores alunos da sala, estudiosos e que discutiam doutrinas científicas do Direito com os colegas. Certo que não eram todos, mas existia esse dinamismo no perfil da academia daquele tempo.

É interessante compreender que este caminhar dinâmico, múltiplo e expansivo do bacharel, muito embora se assemelhe mais ao Humanismo universal de meados do século XVI, também guarda alguns aspectos do Romantismo, como o interesse pelas discussões políticas afloradas do condoreirismo, a boemia e as artes em geral do byronismo. Ora, isto não o impediria de, muitas vezes, tornar-se um grande político e administrador pelo país, que exerceria justamente várias profissões ao mesmo tempo quer fossem superficialmente exercidas, conforme assevera Sérgio Buarque - quer fossem em alguma medida realizadas em razão da demanda intensa da elite em encontrar homens para exercerem os inúmeros postos de um extenso Império em construção.

Nesse sentido, a relevância de compreender como o bacharel via a relação da faculdade com a sociedade e de se atentar para a efervescência cultural e política em que se encontrava o bacharel. Ora, dificilmente não haveria algum momento em que este âmbito no cotidiano não influenciaria a metodologia de ensino, quer fosse por motins promovidos por estudantes que discordaram do resultado da ratificação acadêmica de um ano, quer fosse pela defesa quimérica de um estudante em prol da mudança da forma como era realizada a dinâmica acadêmica, quer fosse pela participação do corpo docente como presidentes honorários em jornais acadêmicos. 
Nesse sentido, é possível compreender que o homem estadista prático, apontado anteriormente por Lima Lopes, teria uma formação acadêmica que o iniciaria para tal pragmatismo jurídico. Em verdade, conforme se tratara no capítulo primeiro, o ambiente acadêmico proporcionava tanto o bacharel político e prático como o jurista filosófico e crítico.

Por fim, com relação ao último aspecto do Romantismo dentro da academia, de que tudo podia ser revertido, ou por um plano bem arquitetado ou pelo escapismo, objetiva-se demonstrar que também havia um elemento nem sempre presente, mas latente acerca da ratificação acadêmica. Isto porque, é perceptível que, embora existisse uma massa que seguia regularmente os ditames ritualísticos da escola, também havia alguns seres que pulavam certas etapas do ritual de ratificação acadêmica (não iam às aulas, não estudavam ou não participavam das sabatinas) e que eram aprovados, ao mesmo tempo em que alguns morriam ou desistiam do curso no meio.

O escapismo é característica mais óbvia do Romantismo, que se vislumbraria aqui por aqueles que desistiram da faculdade ou morreram por ali. Agora, além disso, também é possível considerar um aspecto quase "sargento de milícias" de alguns estudantes da academia o que, em parte é compreensível, justamente em razão do extenso de ritual a que eram submetidos, mas que também formava seres que fariam o mesmo com o uso da máquina pública e de suas funções estatais. Enfim, homens peraltas que teriam apreendido em parte este ritmo para com as instituições desde a academia.

Nesse sentido, as fontes apresentam inúmeros casos de estudantes que compravam para conseguirem a ratificação acadêmica e passarem de ano, ou seja, que buscavam a feição do professor por meio de presentes e elogios, que subornavam os bedéis a fim de que tivessem só o número de faltas permitido, que pagavam para outros alunos fazerem suas tarefas escolares, dentre outros tantos.

Assim, esta é uma análise acerca da questão cultural que se perpetuava, mesmo que nas entrelinhas, na redação acadêmico-jurídica. Em outra medida, também parece relevante demonstrar um aspecto sociológico da formação metodológica da academia de São Paulo. Evidentemente, há inúmeras possibilidades de análises sociológicas, muitas 
das quais já foram realizadas pela literatura acerca do bacharel, o bacharelismo, a cultura jurídica brasileira do século XIX e o ensino jurídico. Contudo, destacar-se-á uma que ficara visível nesta investigação de fontes, que é o curioso paradoxo inautêntico e brasileiro, envolvido pelo sentimento antilusófobo e nacionalista, mas ao mesmo tempo aportuguesado e transoceânico e como isto estaria presente no cotidiano da metodologia de ensino de Direito na São Paulo daquele período.

Deste antes da criação dos cursos jurídicos, ainda em limiar do processo de independência brasileira, discutiam-se, no parlamento, aspectos relevantes tanto sobre a influência portuguesa como de construir o formato da grade curricular. Em 1823, em um contexto histórico complicado não só de organização administrativa interna, instabilidade política como de reconhecimento externo do processo de independência brasileiro se faziam inúmeras discussões acerca da criação de centros superiores de ensino $^{181}$. Um dos aspectos era justamente sobre quão influente seria a cultura jurídica portuguesa no Brasil, tendo subsistido a certeza de se criar um curso jurídico em São Paulo e, a princípio, sob o governo metodológico provisório dos estatutos da Universidade de Coimbra ${ }^{182}$.

Não obstante, a questão não havia ainda sido resolvida. Bernardo Pereira de Vasconcelos, já no ensaio da lei 11 de agosto, considerou que o estudo de Direito Público em Coimbra o transformara num bárbaro e que deveria ser desaprendido ${ }^{183}$. Ele dera exemplos de doutrinas esdrúxulas que ouvira e atribuía a decadência dos estudos coimbrãs ao isolamento da universidade inquisitiva e atenta ao ranço dos seus compêndios. Portanto, este parlamentar considerava inspirador as legislações da Alemanha, França e Inglaterra para organizar metodologicamente o curso jurídico, notadamente, na área pública.

Da mesma forma, quando se atenta para o projeto do Visconde de Cachoeira, que determinaria diversos aspectos do ensino jurídico durante o século XIX, Vampré observa que são feitas diversas críticas ao pedantismo do corpo docente português e ao

\footnotetext{
${ }^{181}$ Relatores Martim Francisco Ribeiro de Andrada, Antonio Rodrigues Velloso de Oliveira, Antonio Gonçalves Gomide, Manuel Jacintho Nigueira da Gama.

${ }^{182}$ VAMPRÉ, Spencer. Op. Cit. v. 1-2. 15p.

${ }^{183}$ CARVALHO, José Murilo de. Bernardo Pereira de Vasconcelos. Rio de Janeiro: Ed. 34, 1999. p. 3944.
} 
modelo dos estatutos coimbrãs, sendo necessário um regimento mais apropriado para uma escola e que primasse pelo método e pelos trabalhos práticos bem mais do que pela discussão de tratados eruditos antigos.

Contudo, para além da metade do século XIX, ainda seria possível observar aspectos que delatavam o não prosseguimento desse sentimento lusófobo. Não somente porque perseveravam alguns professores portugueses e de formação coimbrã na faculdade, como Brotero e Veiga Cabral, ou mesmo porque eram utilizados compêndios portugueses, mesmo que arcaico para a formação brasileira, tal como Mello Freire, mas principalmente porque o próprio uso legislativo brasileiro era baseado em uma parte considerável da estrutura jurídica lusa, portanto seria improvável um estudo de cultura jurídica portuguesa na formação da academia brasileira.

Nesse sentido, destaca-se na análise das fontes no terceiro capítulo a importância do elemento português e, ainda, do aspecto transoceânico das dissertações. Há dissertações que desenvolvem uma análise deste o feudalismo e a formação do reino de Portugal para alcançar a Constituição de 1824. Na mesma medida, as citações e menções a autores e países estrangeiros é o padrão básico de dissertar, formando-se uma confusa mistura de autores que dão opiniões acerca do tema, mas que pouco se desenvolve a discussão sobre o caso brasileiro acerca do assunto.

Em verdade, era um elemento paradoxal na formação social brasileira, assim como o interesse pelas mais diversas filosofias e teorias estrangeiras sem qualquer harmonia ou maiores entendimentos. Desde a escolástica, passando pelo racionalismo alemão e alcançando as ideias positivistas, é perceptível que no Brasil a corrente prevalecente de pensamento era o "ecletismo", pois foi "mais que o positivismo, a 'filosofia que mais extensas e profundas raízes encontrou na alma brasileira' e ainda no fim do império, ele tinha vigência, se não a tem até hoje... O sucesso do ecletismo fusão sem método e sem crítica, como dele disse Eisler - consistiu no fato de, a partir de 1830, haver representado num momento de crise das velhas correntes filosóficas e políticas, uma direção conciliadora das opiniões. (...)"184

\footnotetext{
${ }^{184}$ HOLLANDA, Sérgio Buarque de (Org). História geral da civilização brasileira, Tomo II: O Brasil monárquico, vol. 3: Reações e transações. 1976. São Paulo - Rio de Janeiro: Difel, 3 Ed. 327p.
} 
Assim, esta solução ambígua das classes detentoras do poder também estava presente na metodologia de ensino da faculdade de São Paulo de meados do século XIX. Isto é perceptível, em diversos momentos, nos ensinamentos e elaborações de professores. Primeiramente, é tranquilo trazer o exemplo do compêndio de Brotero que, muito embora tivesse sido rejeitado pelo parlamento, ilustrava justamente essa junção desarmônica e acrítica de teorias distintas e meramente transpassadas, mesmo em francês, para o compêndio do professor. Também nesse sentido, a obra de Veiga Cabral de Direito Administrativo também fora criticada por ser uma mera transcrição de teorias francesas, sem qualquer análise ao contexto brasileiro. Ora, seria difícil não vislumbrar tal influência sobre a metodologia de ensino da faculdade.

Nesse sentido, muito embora se tenha atentado para o fato de compêndio de Ribas valorizar uma análise crítica e seletiva de estrangeirismo, a cadeira de Direito Administrativo estaria suscetível à influência de diversos outros professores que assim o procediam como, por exemplo, pode-se afirmar do professor Veiga Cabral, que importava diversas teorias e inteligências estrangeiras para sua obra e que utilizava como base Mello Freire em seu estudo de Civil. Não é demais lembrar que este autor fora recomendado, mesmo que com ressalvas, pelo Visconde de Cachoeira para o estudo do Direito Público em meados da década de 20 e, já em meados da década de 50 e 60, observaram-se dissertações de Civil e Constitucional com a citação e o uso doutrinário deste autor português.

Ora, em alguma medida, este aprendizado teórico meio esquizofrênico, em que dois professores da mesma área não se acertavam na escolha dos compêndios e cada um utilizava o que quisesse, não permitia aos estudantes compreenderem certa coerência e reflexão na formação jurídica dos alunos. Não é a toa que Gilberto Freyre descreve o bacharel como um tipo ornamental ${ }^{185}$ que assomava diversas teorias afrancesadas sem ter noção prática da realidade brasileira, isto é resultado de uma formação jurídica personalizada com uma inautêntica lusofobia e transoceânica transação de teorias europeias.

\footnotetext{
${ }^{185}$ FREYRE, Gilberto. Op. Cit. p. 951-960.
} 
Esta é uma pequena análise acerca de elementos sociológicos presentes nas fontes históricas sobre a faculdade de São Paulo no século XIX. Não houve o objetivo de traçar uma caracterização dessa metodologia paradoxal, mas tão-somente trazer o indicativo de que isto também fazia parte do nível romântico que caracterizava, em alguma medida, o cotidiano metodológico do ensino jurídico daquela instituição, bastando, para tanto, observar a ornamentação da escrita, o indianismo como uma importação frágil do cavaleiro medieval europeu e a confusão do "eu" com o meio.

\subsubsection{A Técnica}

Assim, traçado o aspecto romântico que influenciaria na metodologia de ensino praticada na faculdade de São Paulo, passa-se para o segundo nível, o técnico. Ora, muito embora haja vários estudos que afirmam inexistir um método claro de funcionamento das faculdades de Direito no império, já que não havia dedicação acadêmica ou incentivo governamental, esta pesquisa de mestrado observou uma linha de raciocínio técnico que era demandado dos estudantes a fim de que pudessem receber o grau de bacharel.

Em verdade, não se pode afirmar que tenha sido uma tecnologia de aprendizado deliberada e, tampouco, que fosse absoluta, pois se trata aqui de uma hipótese de análise das fontes históricas combinada com a estrutura sócio-política e de poder a que estava a faculdade inserida.

Não obstante, o estudo da forma com a qual se determinara pela legislação a organização do curso jurídico e, principalmente, o tipo de ratificação acadêmica proposto sobre o comportamento educacional dos estudantes, permitiram inferir que há dois aspectos principais na formação técnica do pensamento jurídico dentro da faculdade de Direito: a retórica da comunicação e a interpretação do corpo jurídico. Sabe-se que a primeira era pressuposto para entrar na faculdade e um estudo comum naquele período histórico. Em outra medida, a segunda era um aprendizado que seria contínuo ao se passar pela academia. Ambas se entrelaçam para formar a técnica básica da metodologia de ensino na faculdade, que seria tão essencial para os operadores do Direito e também para o jurista. 
Nesse sentido, relembra-se para o que fora tratado no capítulo primeiro sobre a diferenciação e semelhança entre o rábula que detinha o conhecimento processual, o advogado que tinha uma maior formação jurídica e que era o substituto na falta do bacharel, o próprio bacharel e o jurista. Ora, parece interessante destacar que o diferencial entre estes personagens é justamente o tipo de conhecimento técnico acerca do Direito. E isto se complicara mais, no primeiro capítulo, justamente em relação à diferença entre o jurista dedicado às letras e aos questionamentos e o bacharel mais atento ao espírito legalista e político do funcionamento do governo.

Em verdade, esta pesquisa de mestrado considera que a técnica de ensino jurídico que, em alguma medida, foi apreendida pelos alunos da faculdade de São Paulo possibilitava aos alunos compreenderem estes dois âmbitos de interpretação do Direito. Tão-somente acontecia que, muitas vezes, um aluno se sobressaia melhor em um tipo do que outro.

Isto só foi possível, de acordo com a análise das fontes, porque essa técnica apreendida era resultado de uma transição pensamento que se refletia no formato da interpretação jurídica, pois esta passaria, durante o século XIX, de uma formação escolástica, jusnaturalista, pré-liberal para o pensamento racional, legalista, positivista e evolucionista.

Portanto, diferentemente do que considera Lima Lopes acerca da produção de cultura jurídica administrativa do Conselho de Estado, considera-se aqui que ainda estava a academia num processo transitório já com aspectos do legalismo e o positivismo, mas ainda assombrado por diversos aspectos do antigo modelo de compreensão jurídica.

De fato, considera Ricardo Fonseca ${ }^{186}$ que este período dos anos 60 no século XIX significou justamente a passagem de um pensamento teológico para um modelo mais científico-racional do Direito dentro das faculdades. Nesse sentido, a interpretação

\footnotetext{
${ }^{186}$ FONSECA, Ricardo. Op. Cit. p. 366-370.
} 
estava, simplesmente, acompanhando as mudanças dos valores de base daquela sociedade.

Quanto a este último ponto, concorda-se com a análise de Lima Lopes sobre a interpretação envolta da cultura jurídica administrativista o Brasil do século XIX, na medida em que ele considera ter sido o Conselho de Estado obrigado a aprender a aplicar o legalismo ao caso concreto, assim seria uma necessidade para o legislador e o jurista começarem a estar atentos à conjuntura social, de forma a harmonizá-la com o controle legal.

Portanto, quando se analisa o corpo explicitado pelas fontes no item anterior e, ainda mais, se se atentar para o que discorreram autores que analisam a formação da cultura jurídica administrativa, é possível depreender que a interpretação que os estudantes de Direito apreenderam representava justamente o reflexo dessa transição, marcada por uma fundamentação jurídica que envolve um ecletismo pouco conciliador de autores antigos e recentes. Assim, esta interpretação era marcada por uma dificuldade de penetração do racionalismo europeu.

Ora, isto se coaduna com a tese de Guandalini acerca de certo atraso do pensamento brasileiro com relação ao europeu, mas ao mesmo tempo traz indícios acerca do método jurídico-interpretativo da academia de São Paulo, posto que se por um lado, durante o século XIX, havia a necessidade de se atentar para a formalidade da letra da lei, por outro, era um período transitório entre a noção jusnaturalista e teológica do Direito para o modelo positivista-racional, muito embora não se considere aqui que isto fosse um atraso, mas tão-somente um modelo distinto do contexto europeu.

Assim, quando se observa, por exemplo o estatuto do Visconde do Cachoeira, é perceptível que ele procurava defender o desenvolvimento de um ensino jurídico arrojado, moderno, crítico, prático, para além da leitura seca da lei e que demonstrasse a dinâmica pela qual o Direito passava naquele período de formação estatal. Contudo, ele estava cercado por doutrinas que ele próprio admitia não suprirem as necessidades de uma faculdade de Direito de um país recentemente independente e num contexto completamente distinto daquele onde foram criadas essas doutrinas. Por isso, ele sempre trazia o indicativo de que o lente era o responsável pela atualização das matérias. 
Em verdade, já em meados da década de 40, a informação passada pela diretoria da faculdade ao Ministro de Império era de que a análise jurídica e interpretativa do lente do primeiro ano, que seguia Vicente Ferrer Neto Paiva e seu "elementos de Direito Natural ou Filosofia do Direito" era que "ora se seguia o método sintético, ora analítico, apresentando e criticam as doutrinas dos publicitas antigos e modernos, procurando acompanhar o progresso das ciências" ${ }^{\text {"187 }}$. Ou seja, em resumo disse que o método de ensino não estava nem para um ensino parado no tempo, mas também não indica grandes perspectivas desse acompanhamento do progresso. Em verdade, a metodologia era justamente esse limbo transitório da interpretação de um corpo incoerente de fontes e desligados com a realidade brasileira a caminho do pensamento legalista e positivista.

No mesmo sentido, também é decreto $\mathrm{n}^{\mathrm{o}} 1.134$ de 1853 um mediador tanto de teorias confusas, como das lacunas que as doutrinas obsoletas deixavam:

\footnotetext{
Art. 113. Nas prelecções se deverá dar todas as explicações que forem necessarias, ou para mais facil comprehensão da materia, quando mui laconica, ou confusamente exposta no compendio ou para correção de doutrina erroneamente sustentada, ou menos conforme com os progressos da sciencia; ou ainda para conhecimento dos differentes systemas scientificos, que possa influir na intelligencia do assumpto que se tratar. Art. 114. Quando os estudantes não comprehenderem algum ponto, poderão propôr suas duvidas ao Lente verbalmente ou por escripto. O Lente, no mesmo dia ou no immediato, explicará o objecto na cadeira; procurando resolver as duvidas apresentadas e esclarecer a intelligencia de seus discipulos.
}

No mesmo sentido, seria o decreto de 1855 , repetindo a necessidade de cautela dos professores para com lacunas e equívocos de doutrina. Contudo, não há um estímulo grande para a pesquisa e a produção de novas doutrinas a ponto de que isto se tornasse realidade, a não ser dos referidos "prêmios" a quem produzisse um compêndio ou traduzisse uma doutrina.

\footnotetext{
${ }^{187}$ VAMPRÉ, Spencer. Memórias para a história da Academia de São Paulo. $2^{\mathrm{a}}$ Ed, Brasília: INL Conselho Federal de Cultura, 1977. p. 235-236.
} 
Além disso, o exame das fontes possibilitou compreender que certos aspectos característicos da cadeira de Direito Administrativo foi inspirado, em certa medida, na forma com a qual se desenvolvera a metodologia de ensino de cadeiras ulteriores. Por exemplo, a influência do professor Brotero na formação para a interpretação do Direito, bem como do pensamento publicista não só de estudantes da faculdade como também dos próprios professores que se formariam na faculdade e isto ainda num contexto de estrema vulnerabilidade metodológica e científica da faculdade durante a primeira metade do século XIX.

Contudo, a coisa não é tão simples, pois não só havia a limitação material de uma formação ainda incipiente da cultura jurídica na primeira metade do século XIX, como ainda porque o governo não objetivava que houvesse grandes revoluções do pensamento. Esse ecletismo de fontes e atraso era, em alguma medida, interessante para uma elite que tão-somente objetivava do Direito a manutenção do status quo e o controle mínimo da intervenção do Estado na sociedade ${ }^{188}$.

Agora este quadro ficará mais claro com a análise da interpretação estimulada aos estudantes na cadeira de Direito Administrativo. Para tanto, utilizar-se-á de dois dos lentes que estudaram e fizeram compêndios da área na faculdade. O primeiro não poderia ser outro senão Veiga Cabral, que produziu um protótipo de código administrativo brasileiro, tecnicamente bem realizado, com princípios, legislação e intento de coordenação dos elementos da ciência, mas simplesmente recortado e copiado da doutrina francesa. Nesse sentido, todo o estudo acerca do processo administrativo, da questão da repartição de competências, dos bens públicos, do poder de polícia, seria uma cópia da discussão europeia sem aprofundar a demanda administrativa brasileira, muito embora mantivesse o apoio ao poder do Imperador, conforme Guandalini.

Assim, muito embora o autor trouxesse elementos de interpretação do Direito Administrativo mais atinente ao modelo positivista e racional, ele mantém a sobrevalorização do Imperador e a centralização como princípio essencial e vital da Administração, portanto a reterritorialização que faz da "palavra" no Brasil teria um

\footnotetext{
${ }^{188}$ HOLLANDA, Sérgio Buarque de (Org). História geral da civilização brasileira, Tomo II: O Brasil monárquico, vol. 3: Reações e transações. 1976. São Paulo - Rio de Janeiro: Difel, 3 Ed. p. 330-340.
} 
objetivo de estabelecer no Imperador o principal enfoque, reforçando a centralização e legitimação de sua posição como alicerce do sistema político. No mesmo sentido, sobre a análise das funções administrativas, ele procura compatibilizar o vocabulário numa perspectiva para compatibilizá-lo com o funcionamento concreto do dispositivo de poder soberano.

Isto reflete o caráter transitório da interpretação dada por Veiga Cabral. Em segundo lugar, a perspectiva da interpretação jurídico-administrativa é mais aprimorada com o Conselheiro Ribas, pois este já apresenta uma autonomia e crítica no pensamento científico maior. Sua premissa era de que a análise de teorias estrangeiras não deveria ser feita aleatoriamente e que o estudo do Direito Administrativo não poderia ser mero conhecimento de leis administrativas, mas sim focado nas ideias gerais e sínteses fundamentais da área.

Ora, portanto a interpretação que Ribas ensina é mais no sentido amplo e menos legalista, já que depende da análise conjuntural e semântica da ciência. $\mathrm{O}$ aspecto restritivo do entendimento da matéria é justamente sobre sua especificidade temática em relação a outras áreas do conhecimento jurídico. Assim, Ribas ilustra claramente que a essência desta ciência administrativista observava o governo dos homens de um modo jurídico, como instrumento de controle da ordem específica a regular direitos e deveres, muito embora Guandalini considere que esta análise do autor ${ }^{189}$ ilustrasse que o Direito Administrativo brasileiro detinha o escopo da intervenção mínima para a manutenção da ordem social e do contentamento popular, enquanto que o Direito europeu constituía como objetivo da intervenção sobre a sociedade o fortalecimento do Estado.

Não obstante, a despeito da análise interpretativa de Ribas se afastar do uso eclético de teorias estrangeiras, aprofundar noções contemporâneas do Direito Administrativo brasileiro e, ainda, de avançar muito não só na interpretação legalista, como também na necessidade da compreensão social para realizar a interpretação jurídica, ele esbarraria também, de acordo com Guandalini, na mitificação jurídica da função moderador-executiva do Imperador, posto que este novamente se constituiriam como fator de unidade e fundamento de legitimidade para o Estado nacional brasileiro.

${ }^{189}$ GUANDALINI JR., Walter. Op. Cit. 183p. 
Assim, restaria fazer uma análise aprofundada sobre o Conselheiro Furtado, mas esta não será possível sem o estudo aprofundado de seu compêndio. Não obstante, a hipótese possível de se depreender pelo contexto é de que Furtado exigia um conhecimento excessivo do corpo legislativo brasileiro em suas sabatinas, tomadas de lições, bem como nos exames finais orais. Contudo, o estudo das dissertações de Direito Administrativo não refletiram qualquer aspecto nesse sentido e, tampouco, citam o nome do compêndio do professor abertamente.

Por fim, feita esta análise acerca da interpretação jurídica apreendida pelos estudantes na faculdade de Direito de São Paulo, resta tratar sobre uma das características mais conclamadas dos bacharéis no século XIX, qual seja, sua capacidade de retórica, a "arte do bem dizer", pressuposto quase predominante de qualquer pessoa que fosse alfabetizada e tivesse o mínimo de instrução.

Para tanto, inicia-se relembrando a crítica de Sérgio Buarque ao bacharel ornamental, aquele tem "amor à frase sonora, ao verbo espontâneo e abundante, à erudição ostentosa, à expressão rara"190, valorizando o rebuscamento mais que ao próprio conhecimento e a ação. Por isso, havia o prestígio da palavra escrita, a fascinação com o título de doutor em detrimento do trabalho manual.

Ora, Sérgio Buarque não está criticando algo que não fosse a retórica do bacharel. Esta realmente era elemento corriqueiro do dia-a-dia da faculdade de Direito. Assim, utilizou-se o estudo de Murilo de Carvalho ${ }^{191}$ acerca deste antigo instrumento da argumentação e se buscou observar dentre as fontes se haveria quaisquer dos elementos que caracterizariam a retórica brasileira de meados do século XIX em textos antigos.

Primeiramente, a questão do argumento de autoridade que era essencial para a Retórica escolástica. Seria exaustivo descrever aqui todas as citações de argumento de autoridade brasileiro, mas principalmente estrangeiro nos compêndios, na própria legislação de ensino e nos próprios documentos memorialistas. Não há dificuldade

\footnotetext{
${ }^{190}$ HOLLANDA, Sérgio Buarque de. Op. Cit, p. 113-117.

${ }^{191}$ História Intelectual no Brasil: a retórica como chave de leitura. in: Topoi. Rio de Janeiro, n. 1, p. 123$152,2006$.
} 
identificar este elemento da retórica nos textos referentes ao ensino jurídico, já que este fora proibido anteriormente à independência brasileira e era ínfimo o corpo de produção científica nacional, principalmente na primeira metade do século.

Nesse sentido, todos os compêndios de Direito Administrativo se utilizavam de argumentação estrangeira e, na mesma lógica estariam as dissertações de Direito Administrativo. Somente se observou com o Conselheiro Ribas uma argumentação mais lógica e menos dependente da citação de autores para argumentar seus raciocínios.

Igualmente, o segundo elemento essencial da Retórica é a textura aberta da argumentação. Ou seja, a possibilidade verborrágica para o convencimento do auditório era infinita, por meio de excesso ornamental e estilístico, afetação, abuso dos tropos de linguagem, que levariam ao vazio dos oradores, repetições inúteis, exibição fútil de erudição, tropos, títulos estrambólicos e obscuros. Esta retórica barroca abarrocada, que fora uma vez criticada por Verney em tempos do Marquês de Pombal, perpetuaria ainda sim suas raízes também no Brasil, particularmente no ambiente acadêmico, conforme se observou tanto no trato oral entre os professores e alunos, como também no âmbito escrito.

Por fim, o último aspecto componente deste jogo de argumentação era o conhecimento do público alvo. Assim sendo, o orador deveria conhecer adequadamente o receptor para quem iria discursar, de forma a escolher os argumentos, os estilos empregados e a pronunciação adequada. Ora, neste âmbito o bacharel foi um mestre em conseguir alterar sua forma e desenvolvimento da argumentação conforme variava seu público, desde as autoridades de mais alto cargo que perpassavam pela faculdade, como o Imperador, Ministros, a diretoria e os demais lentes, com quem guardava os devidos ditames e ornamentos de etiqueta e argumentação para agrado e convencimento.

Neste quesito, a Retórica será um elemento extremamente relevante para analisar as dissertações de Direito Administrativo, posto que era o lente da cadeira seu público alvo. Além disso, também havia outro tipo de Retórica desenvolvido pelo bacharel com no trato jornalístico, que era mais efusivo e passional, da mesma forma com as reuniões literárias e políticas para discussões com seus colegas acerca de temas dos mais variados. 
Assim, feito este pequeno estudo da importância da retórica dentro do ensino jurídico, completa-se o ciclo da formação técnica promovida pela metodologia de ensino dentro da faculdade de Direito de São Paulo entre meados do século XIX.

Portanto, pode-se concluir, considerando que, longe de serem os únicos aspectos presentes na formação metodológica do ensino jurídico desta academia de Direito, foram a interpretação de transição e a Retórica predominantemente escolástica observáveis nesta pesquisa por meio da análise das fontes históricas, principalmente os compêndios, legislação de ensino e as obras memorialistas.

\subsubsection{A Semântica jurídica do Ensino}

Por fim, encerra-se esta análise acerca da metodologia desenvolvida na faculdade por meio de um estudo acerca de um terceiro aspecto dela, o semântico. Assim, considera-se relevante compreender qual o significado da ciência administrativa que a cadeira transmitia aos estudantes: se havia alguma definição coerente da ciência ou, então, se prevalecia o caráter ainda difuso e inconsistente de sua significação. Em outra medida, este subitem procura desenvolver o aspecto da dissertação como gênero literário dirigido ao professor.

Walter Guandalini, quanto a isto, traz apontamentos críticos acerca da produção científica no Brasil desta época, pois aponta para parte da doutrina que tão-somente reescreve doutrinas estrangeiras, notadamente, francesas em detrimento de uma análise interna. Por outro lado, destaca autores como Pimenta Bueno e Ribas que, considerando a qualidade científica de seus trabalhos, teriam sim produzido um material relevante, mas que daria propensão à figura mística do imperador e, além disso, presos a uma justificação de um Estado que ainda estaria a se formar.

O ensino jurídico do Direito Público, como ele assevera, foi marcado pela influência do Direito Eclesiástico e Natural, caracteristicamente pouco racionalista e teocêntrico, modelo este típico do Iluminismo português até 1854, ano de novos estatutos e da institucionalização da cadeira de Administrativo. O ensino buscou, então, 
se laicizar do Direito pré-moderno europeu, intentando para a racionalização e aburguesamento da prática jurídica.

Nesses termos, a cadeira de Direito administrativo seria então uma cadeira mais focada na estrutura e ações do Estado do que em ideias de preservação e proteção naturais e divinas, muito embora o objetivo principal deste estudo de Guandalini fosse justificar a importância do poder central da figura mística do Imperador, bem como de amarrar aqui um tipo de sistema administrativo diverso do modelo europeu, concentrado na função jurídico soberana disciplinar-normalizadora. Aqui, a intervenção administrativa seria subsidiária, pois o Estado mediaria na vida social tão-somente para conservar relação harmônica, mas não para regular a sociedade ${ }^{192}$. E este raciocínio estaria presente inclusive no trabalho de Direito Administrativo desenvolvido por Ribas.

Ora, a análise das fontes permite compreender que o sentido da ciência do Direito Administrativo ainda estava em formação dentro da academia, pois o ambiente de estudo do aluno refletia um sentido transitório que variava entre certo misticismo com a figura imperial, influencias de doutrinas europeias desmedidas e desarmônicas com o contexto brasileiro, mas que ao mesmo tempo era preocupada com a noção legalista da estrutura jurídico-administrativa e em formar um Estado burocrático, minimamente seguro e só intervencionista no que não ferisse os direitos individuais, principalmente, da elite.

Nesse sentido, considera-se que a área científica do Direito Administrativo guardava um caráter ainda gelatinoso, transitório, em formação, mesmo porque, esta incipiência metodológica dos cursos jurídicos brasileiros não difere tanto do contexto europeu, já que autores como Vitor Emmanuelle e Otto Von ainda estavam consagrando o processo de formação institucional acadêmica, conforme demonstra $\operatorname{Sordi}{ }^{193}$.

Não obstante, isto não significa que não houvesse o desenvolvimento de uma cultura jurídica administrativista brasileira nesse âmbito, pois muito embora autores que estudavam o Direito Público nesse período detivessem uma formação estritamente privatista e individualista e desligada da noção de intervenção pública na propriedade e

\footnotetext{
192 GUANDALINI JR. Walter. Op. Cit. 178p.

${ }^{193}$ MANNORI, Luca; SORDI. Bernardo. Op. Cit.
} 
direitos individuais, mesmo assim, havia uma conjuntura de formação do Estado e da relação desse Estado com a sociedade demandava esta análise, quer fosse pelo Conselho de Estado, pelo Parlamento, pelos doutrinadores ou mesmo pelas faculdades de Direito.

Assim, este caráter gelatinoso do Direito Administrativo se refere à relação conturbada entre o contexto factual do Estado - um Estado burocrático que começava a interferir mais com políticas e programas de atuação ${ }^{194}$ - e a formação cultural dos juristas - pré-liberal, privatista, individualizada. E isto num contexto de baixo grau de profissionalização da máquina pública e de rigor científico na produção científica das faculdades e da literatura em geral no Brasil.

Em verdade, parece a esta pesquisa de mestrado que a segunda metade do século XIX, no que se refere à cultura jurídica administrativista brasileira, encontraria o ápice do modelo legalista liberal e não interventor e, ao mesmo tempo, lampejos do que se consagraria no século XX no Brasil, de um Estado controlador - sem mencionar autoritário e místico - com aspectos esquizofrênicos de legalismos e autotutela na organização administrativa e na sua relação com os administrados.

Indícios de tais lampejos transcorrem ligados ao próprio início decadência da monarquia ${ }^{195}$ brasileira com a profissionalização da cultura militarista, a política de terras, da imigração, de fim da escravidão. Todos estes processo complexos que foram palco de grandes discussões no Parlamento e de revolta por parte da população que se sentiu prejudicada com eventuais medidas e políticas (ainda desorganizadas e tímidas) do governo imperial refletiam no âmbito jurídico e, no mesmo sentido, não passariam imunes pela academia de São Paulo, mesmo porque, dos estudantes e professores que ali perduraram, muitos se relacionavam com esta cultura administrativa do Estado.

Não obstante, conclui-se esta discussão acerca do sentido da ciência do Direito Administrativo com dois indicativos possíveis: que era uma cultura administrativa legalista respaldada à doutrina europeia e que, com algumas poucas ressalvas como Uruguai e Ribas, utilizavam artifícios retóricos e de exegese sem se atentarem para o

\footnotetext{
194 PAULA, João Antônio de. A Construção Nacional: 1830-1889. in: SCHWARCZ, Lilian Mortiz (Org.). História do Brasil Nação: 1808-2010. Rio de Janeiro: Ed. Objetiva, 2012. p. 179-224.

195 SCHWARCZ, Lilian Mortiz. Op Cit. 2. Ed. São Paulo: Companhia das Letras, p. 409-464.
} 
caso concreto do desenvolvimento administrativo brasileiro, mas em mera compilação das leis e de tradução de doutrinas francesas. Além disso, ocorria a mistificação da figura do imperador, de forma a justificar juridicamente o Direito Administrativo brasileiro a existência dessa figura e de seus instrumentos de Poder, como o Moderador.

Esta é a análise acerca do caráter gelatinoso e ainda em formação do Direito Administrativo ensinado na faculdade de São Paulo onde foram produzidas as dissertações.

Por fim, entrarão em destaque os próprios estudantes e a noção de que eles escreviam as dissertações buscando o convencimento de um público muito específico: a aprovação pelo seu professor de Direito Administrativo. Mais uma vez, nesse aspecto, a análise das fontes permitiu alcançar uma análise inconclusa sobre quão estritamente interessados os estudantes estavam para alcançar pontuação para passar de ano.

Primeiro que não se pode inferir com certeza se era o próprio lente quem as corrigia. Tem-se conhecimento de que a dissertação fazia parte de todo um conjunto de atos e processos que perdurariam pelo decorrer do ano letivo, desde sabatinas nas aulas, tomada de lições, discussões travadas pelos lentes acerca do tema, dentre outras possibilidades particulares a cada professor.

Por exemplo, o José Bonifácio, de Civil, não era um professor afeito a sabatinas, mas os lentes Furtado e Ramalho, de hermenêutica e processo, eram famosos pelas tomadas de lições. Isto sem contar que havia o exame oral final para os estudantes, em que se tirava um ponto vinte e quatro horas antes da realização do exame, ato este final antes da habilitação final dos estudantes ou aprovação do curso.

Também era inconsistente nas fontes o tema da aprovação dos estudantes, pois apesar de predominantemente se se considerar o relaxamento da rigidez dos professores, principalmente no último ano do curso, há indícios demonstrados por Nogueira e Vampré de que existiram anos de peso, em que se constataram diversas aprovações "simplesmente" e inclusive reprovações. 
Além do que, mesmo que se encontrar o livro de notas e análises das habilitações dos estudantes daquele tempo, o grau científico de análise acerca da qualidade acadêmica dos estudos e da metodologia de ensino seria prejudicado, pois indicam os mesmos autores supracitados que havia muita aleatoriedade na aprovação ou não dos estudantes. As estórias mais divertidas (e tristes) são acerca do professor Veiga Cabral, de Direito Civil, que às vezes não aprovaria um estudante por motivos escabrosos, como por ter nome longo, ou por não se vestir adequadamente. Mas mais interessante é pensar que, se era possível esta arbitrariedade a este professor, isto significa que não havia um critério objetivo e seguro quanto à aprovação dos estudantes pela própria faculdade. Ou seja, era possível que um aluno dedicado e interessado repetisse de ano enquanto um aluno faltante que pagasse ao bedel pelas faltas fosse aprovado.

Por um lado, demonstrou-se que não eram passíveis os alunos com o que consideravam arbitrário e injusto por parte do corpo discente - quer sejam por motivos dignos, quer sejam por desencantamento de alterar sua rotina de estudos. Por exemplo, quando discordavam de certas arbitrariedades e mesmo ofereciam grandes protestos quando se realizava um tipo de ato acadêmico que lhes parecia injusto, como na questão da alteração feita pelo decreto $n^{\circ} 4.675$, de 14 de janeiro de 1871 , que instituíra a prova escrita, feita por uma hora, para todos os anos e pelo decreto $n^{\circ} 4.806$, de 22 de outubro de 1871, que aboliu o prazo de vinte e quatro horas que mediava entre o sorteio do ponto e a prova oral.

Contudo, em outra medida, não eram os estudantes levianos a ponto de se desinteressarem em conseguir a aprovação plena, principalmente porque a cadeira de administrativo era do quinto ano, ou seja, ano que os alunos almejavam obter essa aprovação plena.

Assim, deve-se atentar parcialmente para a relevância da dissertação ser dirigida ao professor. Isto porque, no âmbito metodológico, não há indícios da sua relevância para se obter a ratificação acadêmica e, muito embora haja várias manifestações de pompa e circunstâncias pelos alunos nos introitos de suas dissertações a fim de cortejarem o professor, também é perceptível que outros não estavam tão preocupados em se fazerem compreender. Contudo, só o exame aprofundado das fontes poderá 
responder melhor a esta querela. Neste meio tempo, a ideia desta pesquisa é considerar como um elemento formador a Retórica do estudante ao responder para o professor, mas também os outros elementos constituidores da metodologia aqui explicitados, quer sejam os aspectos do Romantismo, quer sejam da interpretação acadêmica que passava por um modelo transitório. 


\section{Capitulo 3}

A Construção da Cultura Jurídica Administrativa Oitocentista a Partir da Análise de Dissertações de Direito da Academia de São Paulo

O último capítulo objetiva compreender que tipo de pensamento jurídico era refletido pelos estudantes nas dissertações de Direito Administrativo cobradas bianualmente pelos professores como parte do processo de ratificação acadêmica. Neste caso em específico, conforme já fora delimitado no capítulo segundo, as dissertações fazem parte do pressuposto para os estudantes estarem habilitados, junto com a análise das lições tomadas e a verificação da quantidade de faltas. Então, estando habilitado o aluno, estaria ele apto para, então, fazerem o exame final que, no caso específico do quinto ano, tratava-se de uma sabatina acerca de um ponto sorteado em quarenta e oito horas para o estudante se preparar e, ainda, de mais um ponto sorteado para o mesmo quintanista fazer outra dissertação que também seria sabatinada nesse mesmo exame oral final, com a participação de três professores arguidores.

Todo este processo acadêmico, no qual estão inseridas as dissertações que aqui são alvo de investigação, representa parte da metodologia de ensino transmitida para o aluno da faculdade de Direito de São Paulo que, em conjunto com as manifestações do romantismo, da técnica e da semântica, formaria um raciocínio jurídico bem definido.

Assim, após retratar entendimentos da literatura acerca do perfil do bacharel e relacionar sua importância com a construção da cultura jurídica oitocentista, depois de realizar um estudo específico sobre a cultura jurídica na área administrativista do século XIX e examinar aspectos do cotidiano do ensino jurídico que formariam sua metodologia de ensino e, ainda, a estrutura para a elaboração de um raciocínio jurídico pelo bacharel médio, é chegado o momento de estudar mais a fundo a expressão dessa lógica de pensamento emitida pelo estudante de Direito após cinco anos passados naquele cotidiano da faculdade de Direito de São Paulo da segunda metade do século XIX. 
Para tanto, este capítulo se divide em duas partes, primeiramente, faz-se a análise geral das dissertações de Direito Administrativo existentes. Basicamente, este item do capítulo serve para se depreender quais as theses apresentadas pelos professores para serem dissertadas pelos estudantes, bem como se se relacionavam com os temas tratados em outros meios de emanação jurídica também produtores de pensamento administrativo, tal como era o Conselho de Estado e a doutrina administrativista.

Da mesma forma, será interessante destacar quais as temáticas que não foram abarcadas pelos professores e nem desenvolvidas pelo corpo discente, mas que constituíram como foco de discussão da produção de cultura jurídica administrativa da época. Assim, esta análise também se faz importante para compreender o alcance da construção lógica da cultura jurídica no corpo acadêmico brasileiro no século XIX.

Após, o exame aprofundado de dissertações seguirá na segunda parte do capítulo, com a escolha de nove dissertações específicas a fim de esmiuçar a forma pela qual o estudante de Direito desenvolveu seu raciocínio jurídico naquele contexto histórico. E, assim como a técnica das artes plásticas de pegar minúcias da pintura para desenvolver melhor características que representam um sentido completo do quadro como um todo, aqui neste mestrado também se optou por fazer um recorte específico de algumas dissertações a fim de melhor desenvolver a estrutura relacional de ensino instituída no largo de São Francisco.

E, para uso deste capítulo, novamente serão necessárias as mesmas fontes utilizadas no capítulo 2, quais sejam, Almeida Nogueira, Spencer Vampré, a legislação dos cursos jurídicos, mas também será necessário o uso da legislação da área administrativa, o compêndio de Direito Administrativo do Conselheiro Ribas, a biografia do Visconde de Uruguai e as pesquisas de Guandalini, Lima Lopes e di Pietro $^{196}$.

\footnotetext{
${ }^{196}$ Muito embora se saiba da existência de outras fontes, o plano geral de análise limitado do mestrado proporcionará o diálogo com parte das fontes (supracitadas).
} 


\subsection{Análise geral das dissertações}

De acordo com o artigo 243 do decreto $n^{\circ} 1.568$ de 1855, as dissertações eram feitas bianualmente pelos estudantes, em resposta a duas theses apresentadas pelo professor em épocas diferentes e que eram baseadas em pontos tirados das "mais importantes doutrinas que lhes houver explicado". O prazo para entrega era de um mês e meio, sendo que, após, o lente as examinaria e entregaria para arquivo. Não se especifica exatamente que tipo de exame seria feito pelo professor, nem pela legislação e nem pelas outras fontes históricas. Não há indicação de nota ou julgamento nas dissertações, sendo parte do processo de ratificação acadêmica do aluno e, no caso do quintanista, a obtenção do grau de bacharel.

Não obstante, as dissertações encontradas no arquivo da biblioteca central não restaram com uma uniformidade quantitativa entre os anos. Ou seja, existem anos em que não se encontrou uma dissertação sequer de Direito Administrativo, como no ano de 1868. Também existem anos em que só há dissertação referente a uma these, nada mais, como no ano de 1861. Há, ainda, anos em que remanescem setenta e duas dissertações sobre uma these e uma só dissertação acerca de outra these, por exemplo, no ano de 1857.

Isto se deve, além do motivo de se alterar o número de alunos conforme o ano da turma, também em razão da possibilidade de perda de parte dessas fontes históricas, bem como de ainda existirem dissertações perdidas pela biblioteca central da FDUSP, já que sequer estão elas catalogadas no sistema.

As cadeiras das quais se encontraram dissertações abrangiam praticamente todas as áreas de ensino naquela época das faculdades de Direito no Brasil, destacando-se que os nomes variavam conforme as alterações de grade pelos decretos de ensino jurídico. Assim, abrangiam basicamente as áreas de Direito Civil, Direito Comercial, Direito Constitucional, Direito Internacional e das Gentes, Direito Criminal, Direito Eclesiástico, Direito Natural, Direito Romano, Economia Política, Hermenêutica Jurídica e Processo ${ }^{197}$, que também tinham, cada uma, o mesmo padrão de elaboração

\footnotetext{
${ }^{197}$ Ocorriam alterações das cadeiras e de seus respectivos nomes conforme era expedida a legislação de ensino jurídico, destacando-se que: no decreto $\mathrm{n}^{\circ} 1.134$ de 1853 , distribuíam-se em cinco anos, com os
} 
de duas dissertações pelos estudantes com base em duas theses distintas propostas separadamente no ano. Particularmente, com relação à cadeira de Administrativo, as fontes encontradas abrangem o limite temporal de 1857 e 1870 , com algumas lacunas como nos anos de 1868 e 1869, em que não há dissertações e theses.

Isto comprova que as dissertações aqui analisadas especificamente se referem àquelas que eram obrigados os estudantes de todos os anos a realizarem, com o prazo de um mês e meio de um ponto sorteado pelo lente da cadeira, e não as dissertações especiais dos três últimos anos, que eram de outra sorte. Senão, não haveria dissertações das matérias de Direito Natural, Constitucional e Romano, por exemplo, que eram de cadeiras dos primeiros anos.

Os documentos históricos deixados pela cadeira de Direito Administrativo abrangem um extenso material de aproximadamente 1209 dissertações em formato escrito e analítico, mormente de dez páginas cada uma - sendo que algumas possuiriam quatro páginas e outras mais de vinte - distribuídas entre os 174 volumes encontrados pelas bibliotecárias na área restrita, levando-se em conta, novamente, que as dissertações não estão catalogadas na biblioteca central da FDUSP.

As theses administrativas, em específico, percorrem diversas temáticas, tanto em nível científico-dogmático como político, as quais advinham de dois pontos escolhidos separadamente no ano pelo lente da doutrina e dos compêndios estudados durante o ano letivo. Não obstante, eram aprovados tais pontos pela congregação de professores para serem os temas dissertados pelos estudantes em um mês e meio. Este crivo da

nomes: No $1^{\mathrm{o}}$ ano: $1^{\mathrm{a}}$ cadeira: Direito natural, e Direito publico universal e $2^{\mathrm{a}}$ cadeira: Institutos de Direito romano. No $2^{\circ}$ ano: $1^{\mathrm{a}}$ cadeira: Continuação das materias da $1^{\mathrm{a}}$ cadeira do $1^{\mathrm{o}}$ anno; Direito das gentes; Diplomacia, e explicação dos tratados em vigor entre o Brazil e outras nações e $2^{\mathrm{a}}$ cadeira: Continuação do ensino da $2^{\mathrm{a}}$ cadeira do $1^{\circ}$ anno; Direito publico ecclesiastico, e Direito ecclesiastico patrio. No $3^{\circ}$ ano: $1^{\mathrm{a}}$ cadeira: Direito civil patrio com a analyse e comparação do Direito romano e $2^{\mathrm{a}}$ cadeira: Direito criminal incluido o militar, e o Processo criminal patrio. No $4^{\mathrm{o}}$ ano: $1^{\mathrm{a}}$ cadeira: Continuação das materias da $1^{\text {a }}$ cadeira do $3^{\circ}$ anno e $2^{\mathrm{a}}$ cadeira: Direito commercial, e maritimo patrio. No $5^{\mathrm{o}}$ ano: $1^{\mathrm{a}}$ cadeira: Hermeneutica juridica com applicação às Leis; analyse da Constituição; processo civel, e pratica forense; $2^{\mathrm{a}}$ cadeira: Direito administrativo pátrio e $3^{\mathrm{a}}$ cadeira: Economia politica.

E, no decreto $n^{\circ} 1.386$ de 1854 , os respectivos nomes das cadeiras eram: $1^{\circ}$ Anno: $1^{\text {a }}$ Cadeira: Direito natural, Direito Publico Universal, e Analyse da Constituição do Imperio e $2^{\text {a }}$ Cadeira: Institutos de Direito Romano. $2^{\circ}$ Anno $1^{\mathrm{a}}$ Cadeira: Continuação das materias da $1^{\mathrm{a}}$ cadeira do $1^{\mathrm{o}}$ anno, Direito das Gentes e Diplomacia. 2 $2^{\mathrm{a}}$ Cadeira: Direito Ecclesiastico. $3^{\circ}$ Anno $1^{\mathrm{a}}$ Cadeira: Direito Civil Patrio, com a analyse e comparação do Direito Romano. $2^{\mathrm{a}}$ Cadeira: Direito Criminal, incluido o militar. $4^{\mathrm{o}}$ Anno $1^{\mathrm{a}}$ Cadeira: Continuação das materias da $1^{\mathrm{a}}$ cadeira do $3^{\mathrm{o}}$ anno. $2^{\mathrm{a}}$ Cadeira: Direito Maritimo, e Direito Commercial. $5^{\circ}$ Anno $1^{\text {a }}$ Cadeira: Hermeneutica Juridica, Processo civil e criminal, incluido o militar, e pratica forense. $2^{\text {a }}$ Cadeira: Economia Politica. $3^{\text {a }}$ Cadeira: Direito Administrativo. 
congregação era justificado a fim de que não houvesse desnível de dificuldade entre as diversas cadeiras existentes. E é este um ponto relevante, pois significa que não só o professor da cadeira de administrativo em exercício delimitava os pontos a serem tratados como estes deveriam passar pela ponderação de todos os outros professores antes de chegar às mãos dos alunos, ou seja, havia certo controle no que era exigido cientificamente dos alunos por todo o corpo docente reunido.

Um ponto interessante a destacar são as datas de entrega das dissertações, que, conforme se verificou na análise dessas fontes constantemente variavam, sendo que, majoritariamente, havia uma dissertação referente a uma these específica que era entregue no primeiro semestre e também existia outra dissertação referente a outra these específica que seguia com a datação de entregue na segunda metade do ano. Por exemplo, no ano de 1857, as dissertações sobre a these da "centralização" foram entregues aproximadamente na terceira semana de agosto e a única dissertação encontrada sobre "naturalização" era datada perto da terceira semana de outubro.

As datas destas entregas variavam conforme o aluno e o ano. Se se atentar, por exemplo, para as theses do ano de 1860, as dissertações referentes à específica these sobre "distinção entre poder administrativo e judiciário" foram apresentadas para os lentes no início de agosto enquanto que as theses sobre "razões do Conselho de Estado" foram entregues mormente em final de setembro. Além do que, variavam as datas específicas de entrega da dissertação de cada aluno, não sendo possível prever tãosomente pelas dissertações qual a data exata de entrega determinada pela faculdade.

O padrão formal das dissertações era: primeira folha com a capa da dissertação, que deveria conter a informação sobre se era a primeira ou a segunda dissertação da disciplina no ano, o nome da cadeira, o número do aluno, um visto de recebimento da dissertação e o ano, normalmente com a data distinta da que fora realizada a dissertação, assinada no final. Este padrão variava desde a falta do nome da cadeira até a simples inexistência da capa. Após, a segunda folha poderia conter somente qual era a these dissertada pelo estudante, mas também já era comum que este começar a responder na mesma folha. Por fim, na última página deveria haver a data em que foi escrita a dissertação e a assinatura do aluno. Não se encontrou um regimento onde estivesse 
delimitado estas regras, tão-somente se observou qual era o maior padrão seguido pelos alunos, conforme se depreende pelo ANEXO 1.

Além disso, faz-se importante discorrer sobre alguns pontos referentes à dinâmica da aplicação destas provas. Conforme já se explicitara no capítulo segundo, estas dissertações faziam parte de todo um processo complexo de atos e formalidades que habilitariam ou não o aluno para fazer o exame final. Elas, portanto, não se tratavam do exame final em si, mas parte dos estudos semestrais da matéria.

Em outra medida, particularmente quando se atenta para a dinâmica do quinto ano em que era ensinada a cadeira de Direito Administrativo, a análise das fontes indicara que, no quesito de julgamento acadêmico pelos professores, verificou-se uma variação constante conforme os anos entre a maior severidade formal, já que haveria um exame maior e rigoroso por parte do corpo docente e, também, de relaxamento do rigor acadêmico, já que Nogueira e Vampré indicam, em alguns contextos, a diminuição do nível de dificuldade dos exames para a aprovação plena dos quintanistas, com a argumentação defendida por estes de que se fosse o bacharel "aprovado simplesmente", isto seria marcado em seu currículo por toda a vida e o poderia prejudicar. Ora, impossível não fazer uma menção à tese de Sérgio Buarque acerca da valorização excessiva do título, mais do que o trabalho por parte da cultura brasileira.

Não obstante, estas mesmas fontes indicam tempos de severidade por parte dos três lentes do quinto ano, que foram, predominantemente, Furtado, Ramalho e Carrão. Quanto a isto, houve alguns anos com diversas reprovações de quintanistas e, consequentemente, a revolta dos já quase bacharéis em protesto contra qualquer rigidez, chegando-se até a apelação para o Ministério, caso quisesse o aluno. Assim, havia picos variáveis do nível de exigência acadêmica sobre os alunos naquela época, devendo ser feita a análise mais no caso a caso do aluno.

O lente responsável pela cadeira era, conforme já se discorrera no capítulo segundo, Francisco Maria de Souza Furtado de Mendonça e os compêndios utilizados na cadeira foram o de Ribas e do próprio Furtado, além da "Repertório das Leis do Brasil”. Este não era reconhecido como professor assíduo, mas apresentava grande 
conhecimento doutrinal e legislativo. Não se tem notícia de seus eventuais substitutos nas aulas.

Quanto a este aspecto, não há indicativo nas provas de quem corrigiria as dissertações. Sabe-se, não obstante, de acordo com as fontes, que existiam pupilos preferidos pelo professor, provavelmente mais velhos, que lhe auxiliariam nos trabalhos acadêmicos. Tampouco se pode com certeza asseverar acerca da autoria das dissertações, já que há alguns indícios apresentados por Nogueira de que algumas seriam feitas por alunos em nome de outros alunos, além da possibilidade dos alunos simplesmente copiarem as dissertações entre si, o que não fica claro pela análise feita no final deste capítulo.

Estas especulações sobre a autoria não serão aqui objeto de qualquer hipótese, mesmo porque não se teve acesso aos livros de notas e correções feitas das dissertações. Tão-somente é possível observar quando e com que qualificativo - se "aprovado plenamente" ou "simplesmente" - o estudante de bacharelou, muito embora isto não refletisse suas qualidades acadêmicas nos estudos. Assim, não houve neste mestrado um filtro das dissertações feito em relação ao julgamento acadêmico aplicado pela faculdade.

Assim, o escopo desta primeira parte do capítulo é apresentar a análise do plano geral das 1209 dissertações, destacando-se os temas discorridos, ou seja, as theses apresentadas pelos lentes e, num segundo momento, tratando acerca das temáticas presentes ou ausentes em outras discussões de fontes históricas da cultura jurídica administrativa.

O conceito de "these" possui uma qualificação específica neste contexto, pois se refere particularmente a uma sentença, afirmação, questionamento ou mesmo a referência ao número de compêndio a que se refere - resultado da seleção feita pela congregação da faculdade de pontos apresentados pelo lente da matéria. A princípio, deveria ter o mesmo nível de dificuldade não só em relação às theses das outras cadeiras, como também deveria ser compatível com o ano e as teorias ensinadas na cadeira. 
Diferentemente, havia outros tipos de "theses" naquele contexto. Primeiramente, aquelas defendidas pelos bacharéis que procuravam o grau de doutor e, ainda, as theses defendidas por quem objetivava ser professor substituto da faculdade. Contudo, estas definições distintas do conceito de these não tinham relação com as theses sobre as quais se baseavam os estudantes para produzir suas respectivas dissertações.

Segue, então, a Tabela 1, com a separação por ano das theses e a quantificação das dissertações em cada ano ${ }^{198}$ :

Tabela 1 - Número de dissertações de Direito Administrativo referentes a uma these em cada ano

\begin{tabular}{ccc}
\hline Ano & $\begin{array}{c}\text { Total de } \\
\text { dissertações } \\
\text { por ano }\end{array}$ & These \\
\hline
\end{tabular}

18575 dissertações

"O que é centralisação governamental e administrativa? Em que differe da concentração? Qual tem sido a vida e applicação deste principio nas nossas instituições antes e depois da constituição do Império. Se este principio soffreo mingua com a instituição das Assembleias Provinciaes."

"O que é naturalisação; quaes suas especies, processo e recurso de sua denegação? A naturalisação do marido comprehende a da mulher?"

1858127 dissertações “Agentes Administrativos.”

"Quais as relações que constituem o domínio e acção de Direito Administrativo? Compreende as relações civis e públicas? Diferença entre Direito Administrativo, Direito Constitucional e Direito Civil."

\footnotetext{
198 Dissertações da Faculdade de Direito de São Paulo, v. 1-174, Biblioteca Central da Faculdade de Direito da Universidade de São Paulo, São Paulo.
} 
1859104 dissertações "O que se deve entender por actos administratvos, quais são suas espécies?”

"O Direito Público positivo serve de fonte ao administrativo (Compendio § 7)."

1860100 dissertações "Em que se distinguem o poder administrativo e o judiciário?"

"Se as razões do Conselho d'Estado devem ou não ser motivadas."

18611 dissertação "Agentes Auxiliares de Consultas. Congregação da Faculdade de Medicina da Corte. Congregação da Faculdade de Medicina da Bahia."

186217 dissertações "Qual a differença que existe entre Governo e Administração?"

"A Administração quando julga contenciosamente administra?"

"Mando que me confere o $\S 8^{\circ}$ da Const do Imperio art 101, fui por bem relevar a companhia geral de seguros. Feliz lembrança da multa que lhe foi imposta pela Recebedoria do Rio de Janeiro em 13 de Janeiro de 1860 por não haver pago no tempo devido o sello correspondente as duas primeiras chamadas do seu capital.' Questiona-se:

$1^{\circ} \mathrm{Se}$ há differença entre multa criminal e administrativa?

$2^{\circ}$ Se a revallidação do sello é multa ou imposto?

$3^{\circ}$ Se estando esgotados os recurso ordinarios caberá este extraordinários?

$4^{\circ} \mathrm{A}$ remissão de revallidação é ou não perdão da dívida?

$5^{\circ} \mathrm{O}$ perdão de dívida da Fazenda a que poder pertence? $6^{\circ}$ Os arestos a tal respeito que força tem? $7^{\circ}$ a resolução será ou não uma Divisão contenciosa administrativa?

$8^{\circ}$ A jurisdição administrativa só prescreve depois da Const?" 
"A administração quando julga o contencioso administrativo é Juiz e parte ao mesmo tempo?"

186471 dissertações "Quais as relações que constituem o domínio e acção de Direito Administrativo? Compreende as relações civis e públicas? Diferença entre Direito Administrativo, Direito Constitucional e Direito Civil."

"O que se deve entender por actos administrativos, quais são suas espécies?"

186573 dissertações

" $1{ }^{\circ}$ A Authoridade quer administrativa, quer judiciariamente procedendo, mas procedendo oficialmente pode reconhecer como Medicos para corpos de delictos, exames e outros misteres aqueles $\mathrm{q}$ não estiverem habilitados conforme a lei de $3^{\circ}$ de outubro de 1832 , art 12 e 13 ? $2^{\circ}$ Se pode tolher-lhes o exercício da Medicina? $3^{\circ}$ Se não podendo tolher-lhes esse exercício, pode oficialmente aceitar seus atestados?"

"O que se deve entender por actos administrativos, quais são suas espécies?”

1866155 dissertações " $\$ 90$ do Compendio - Actos Administrativo excessivos de poder: Se o acto administrativo não for dictado em virtude do legitimo exercício das atribuições da autoridade administrativa, os juízes e tribunais judiciários não estão obrigados nem devem dar lhe cumprimento, protegendo assim o Direito dos particulares contra os abusos do poder. Nem praticando assim usurpa atribuições alheias, mas só resguarda as suas, porque a autoridade judiciária não é delegada da administrativa."

“\$72 - O Direito Administrativo pertence à encyclopedia jurídica? É ciência social? (ou percente à encyclopédia social?)"

1867115 dissertações "O Art. 39 do Reg $\mathrm{n}^{\circ} 2548$ de 1860 está de conformidade com os princípios do Direito Público e Administrativo?" 
“\$294 do Compendio: A Tutella administrativa será necessária às varias corporações de mão morta existentes no Império? Esta tutela poder-se-há entender a outras corporações? Os presidentes de Provincia como delegados do Poder Executivo exercerão a Tutella quer no $1^{\mathrm{o}}$ quer no $2^{\mathrm{o}}$ caso? (Presidentes como tutores das províncias)"

18680 dissertações

18690 dissertações

187058 dissertações

"§72 - O Direito Administrativo pertence à encyclopedia jurídica? É ciência social? (ou percente à encyclopédia social?)"

“O art. $7^{\circ}$ da Lei de 28 de Agosto de 1830 está revogado pelo art 310 do Codigo Criminal? Caso não esteja, qual a auctoridade competente para applicar a penalidade ao infractor?"

18710 dissertações

18720 dissertações

18730 dissertações

18740 dissertações

18750 dissertações

18760 dissertações

18770 dissertações

18780 dissertações

Total: 1209 dissertações

Antes de discutir sobre tantos temas tratados, importante destacar que não se eram estas theses de escolha aleatória. O crivo da escolha perpassava por alguns requisitos que se pode delimitar entre o âmbito interno (escolha pelo professor da cadeira) e o externo (aprovação pela congregação de todos os lentes). Ou seja, o lente teoricamente deveria se basear nos compêndios, nas aulas e nas lições tomadas com os 
alunos para realizar sua escolha de pontos que seguiriam para a aprovação da congregação da faculdade. Este âmbito externo era importante a fim de que os lentes pudessem organizar as theses apresentadas para serem dissertadas de forma a serem de um mesmo nível de dificuldade para todas as cadeiras do ano.

Particularmente, no caso da cadeira de Administrativo, era esta a terceira cadeira do quinto ano, dividindo as honras com a cadeira de Economia Política e de Processo. Ou seja, a princípio, deveria se desenvolver uma nivelação de difículdade e diálogo entre os lentes do quinto ano. Isto não significa que a regra era seguida a risca, mas se faz notória ao menos a preocupação da legislação e da congregação em promover este ritual de celebração da habilitação dos estudantes a fim de alcançar o grau de bacharel.

Em outra medida, também é relevante lembrar que a dissertação dos estudantes era parte pertencente a um todo complexo de atos e procedimentos para habilitação dos alunos. Isto significa que, para além da dissertação, havia outros meios acadêmicos para se analisar o conhecimento adquirido no ano pelos estudantes, ou seja, não se pode excluir a possibilidade de que uma temática relevante e cara à discussão acadêmica em um ano específico não tenha sido passível de dissertação, mas fora debatido na faculdade por outro meio.

Mais um aspecto interessante é o temporal. De acordo com a legislação, o prazo para dissertar sobre as theses sorteadas era de um mês e meio. Isto significa que não só os estudantes tinham um período razoável para elaborar as dissertações, tendo assim acesso às sebentas, aos compêndios, à legislação, à doutrina, aos julgados e, notadamente, ao auxílio de outros estudantes para tanto. Este é um elemento relevante ao se analisar a dinâmica entre as theses e as dissertações, posto que se pressupõe um nível elevado de qualidade informativa nesse material muito maior do que a realização de uma prova sem consulta de duas horas, além da possibilidade de diálogo entre os alunos do que seria dissertado. Não obstante, a maioria faz a ressalva retórica em suas dissertações analisadas no próximo item, de que o professor desculpasse as eventuais lacunas e falhas.

Especificamente acerca do quantum das dissertações, como já fora mencionado, os números por ano varia, materialmente, em razão das fontes encontradas na biblioteca 
central da FDUSP. Além disso, há a lacuna de fontes da cadeira nos anos de 1868, de 1869 e de 1871 a 1878 , conforme se observa na tabela a seguir, em que se permite inferir onde estão localizadas as dissertações de Direito Administrativo em cada um dos livros que guardam todas as dissertações da faculdade de São Paulo, bem como a que these de Direito Administrativo estas dissertações se referem:

Tabela 2 - Número de dissertações de Direito Administrativo referentes a cada uma das these nos livros de dissertação da faculdade de Direito de São Paulo, da Universidade de São Paulo

These

"O que é centralisação governamental e administrativa? Em que differe da concentração? Qual tem sido a vida e applicação deste principio nas nossas instituições antes e depois da constituição do Império. Se este principio soffreo mingua com a instituição das Assembleias Provinciaes."

"O que é naturalisação; quaes suas especies, processo e recurso de sua denegação? A naturalisação do marido comprehende a da mulher?"

“Agentes Administrativos."

"Quais as relações que constituem o domínio e aç̧ão de Direito Administrativo? Compreende as relações civis e públicas? Diferença entre Direito Administrativo, Direito Constitucional e Direito Civil."

\section{Livro}

1 no Livro 1857 - 1 (2)

2 no Livro 1857 - 3 (4)

1 no Livro 1857 - 8 (9)

Total: 3 dissertações

1 no Livro 1857 - 3 (4)

Total: 1 dissertação

2 no Livro 1858 - 2 (15)

23 no Livro 1858 - 4 (17)

2 no Livro 1858 - 5 (18)

13 no Livro 1858 - 8 (21)

2 no Livro 1858 - 10 (23)

8 no Livro 1858 - 12 (25)

14 no Livro 1858 - 15

1 no Livro 1858 - 16 (29)

Total: 65 dissertações

1 no Livro 1858 - 2 (15)

22 no Livro 1858 - 4 (17)

3 no Livro 1858 - 5 (18)

9 no Livro 1858 - 8 (21)

5 no Livro 1858 - 10 (23)

4 no Livro 1858 - 12 (25)

1 no Livro 1858 - 13 (26)

1 no Livro 1858 - 14 (27)

15 no Livro 1858 -15 (28)

1 no Livro 1858 - 16 (29)

1 no Livro 1864 - 7 (108)

Total: 61 dissertações 
"O que se deve entender por actos administrativos, quais são suas espécies?"

"O Direito Público positivo serve de fonte ao administrativo (Compendio § 7)."

"Em que se distinguem o poder administrativo e o judiciário?"

"Se as razões do Conselho d'Estado devem ou não ser motivadas."

"Agentes Auxiliares de Consultas. Congregação da Faculdade de Medicina da Corte. Congregação da Faculdade de Medicina da Bahia."

"Qual a differença que existe entre Governo e Administração?"
9 no Livro 1859 - 2 (31)

10 no Livro 1859 - 3 (32)

35 no Livro 1859 - 12 (41)

1 no Livro Sem Data (169)

1 no Livro Sem Data (174)

Total: 56 dissertações

8 no Livro 1859 - 2 (3)

9 no Livro 1859 - 3 (32)

33 no Livro 1859 - 12

Total: 50 dissertações

18 no Livro 1860 - 1 (42)

2 no Livro 1860 - 5 (46)

27 no Livro 1860 - 7 (48)

3 no Livro 1860 - 9 (50)

Total: 50 dissertações

19 no Livro 1860 - 1 (42)

3 no Livro 1860 - 5 (46)

27 no Livro 1860 - 7 (48)

1 no Livro 1860 - 9 (50)

Total: 50 dissertações

1 no Livro 1861 - 3 (54)

Total: 1 dissertação

6 no Livro 1862 - 1 (62)

21 no Livro 1862 - 2 (63)

21 no Livro 1862 - 5 (66)

3 no Livro 1862 - 6 (67)

4 no Livro 1862 - 7 (68)

17 no Livro 1862 - 8 (69)

5 no Livro 1862 - 10 (71)

9 no Livro 1862 - 12 (73)

2 no Livro 1862 - 18 (79)

1 no Livro Sem Data

(169)

(174)

1 no Livro Sem Data

Total: 90 dissertações 
"A Administração quando julga contenciosamente administra?"

" Mando que me confere o $\S 8^{\circ}$ da Const do Imperio art 101, fui por bem relevar a companhia geral de seguros. Feliz lembrança da multa que lhe foi imposta pela Recebedoria do Rio de Janeiro em 13 de Janeiro de 1860 por não haver pago no tempo devido o sello correspondente as duas primeiras chamadas do seu capital.' Questiona-se:

$1^{\circ}$ Se há differença entre multa criminal e administrativa?

$2^{\circ}$ Se a revallidação do sello é multa ou imposto?

$3^{\circ} \mathrm{Se}$ estando esgotados os recurso ordinarios caberá este extraordinários?

$4^{\circ}$ A remissão de revallidação é ou não perdão da dívida?

$5^{\circ} \mathrm{O}$ perdão de dívida da Fazenda a que poder pertence?

$6^{\circ}$ Os arestos a tal respeito que força tem? $7^{\circ}$ a resolução será ou não uma Divisão contenciosa administrativa?

$8^{\circ} \mathrm{A}$ jurisdição administrativa só prescreve depois da Const?"

"A administração quando julga o contencioso administrativo é Juiz e parte ao mesmo tempo?"

"Quais as relações que constituem o domínio e acção de Direito Administrativo? Compreende as relações civis e públicas? Diferença entre Direito Administrativo, Direito Constitucional e Direito Civil."
8 no Livro 1862 - $1(62)$

17 no Livro 1862 - 2 (63)

22 no Livro 1862 - 5 (66)

2 no Livro 1862 - 6 (67)

4 no Livro 1862 - 7 (68)

16 no Livro 1862 - 8 (69)

6 no Livro 1862 - 10 (71)

10 no Livro 1862 - 12 (73)

1 no Livro 1862 - 18 (79)

Total: 86 dissertações

7 no livro $1863-4(84)$

1 no Livro 1863 - 6 (86)

14 no Livro 1863 - 7 (87)

2 no Livro 1863 - 9 (89)

21 no Livro 1863 - 10 (90)

12 no Livro 1863 - 11 (91)

8 no Livro 1863 - 13 (93)

22 no Livro 1863 - 15 (95)

11 no Livro 1863 - 19 (99)

6 no Livro 1863 - 20 (100)

1 no Livro 1853- 63 (1)

1 no Livro 1863 (171)

Total: 106 dissertações

2 no Livro 1863 - 3 (83)

14 no Livro 1863 - 4 (84)

10 no Livro 1863 - 7 (87)

1 no Livro 1863 - 9 (89)

20 no Livro 1863 - 10 (90)

12 no Livro 1863 - 11 (91)

7 no Livro 1863 - 13 (93)

15 no Livro 1863 - 15 (95)

4 no Livro 1863 - 17 (97)

7 no Livro 1863 - 19 (99)

8 no Livro 1863 - 20 (100)

1 no Livro 1853- 63 (1)

1 no Livro Sem Data (169)

Total: 102 dissertações

1 no Livro 1864 - 7 (108)

Total: 1 dissertação 
"O que se deve entender por actos administrativos, quais são suas espécies?"

"10 A Authoridade quer administrativa, quer judiciariamente procedendo, mas procedendo oficialmente pode reconhecer como Medicos para corpos de delictos, exames e outros misteres aqueles q não estiverem habilitados conforme a lei de $3^{\circ}$ de outubro de 1832 , art 12 e 13 ? $2^{\circ}$ Se pode tolher-lhes o exercício da Medicina? $3^{\circ}$ Se não podendo tolher-lhes esse exercício, pode oficialmente aceitar seus atestados?"

"O que se deve entender por actos administrativos, quais são suas espécies?”

"§ 90 do Compendio - Actos Administrativo excessivos de poder: Se o acto administrativo não for dictado em virtude do legitimo exercício das atribuições da autoridade administrativa, os juízes e tribunais judiciários não estão obrigados nem devem dar lhe cumprimento, protegendo assim o Direito dos particulares contra os abusos do poder. Nem praticando assim usurpa atribuições alheias, mas só resguarda as suas, porque a autoridade judiciária não é delegada da administrativa."

"§72 - O Direito Administrativo pertence à encyclopedia jurídica? É ciência social? (ou pertence à encyclopédia social?)"
2 no Livro 1864-67 (101)

14 no Livro 1864 - 6 (107)

1 no Livro 1864 - 7 (108)

55 no Livro 1864 - 9 (110)

Total: 72 dissertações

15 no Livro 1865 - 2

(113)

1 no Livro 1865 - 3 (114)

56 no Livro 1865 - 4

(115)

1 no Livro Sem Data

(169)

Total: 73 dissertações

1 no Livro $1865-6$

Total: 1 dissertação

9 no Livro 1866 - 1 (119)

1 no Livro 1866 - 2 (120)

6 no Livro 1866 - 4 (122)

24 no Livro 1866 - 6 (124)

14 no Livro 1866 - 7 (125)

11 no Livro 1866 - 9 (127)

10 no Livro 1866-11 (129)

1 no Livro 1866 (171)

Total: 76 dissertações

6 no Livro 1866 - 1 (119)

4 no Livro 1866 - 2 (120)

6 no Livro 1866 - 4 (122)

24 no Livro 1866 - 6 (124)

18 no Livro 1866 - 7 (125)

10 no Livro 1866 - 9 (127)

1 no Livro 1866 - 10 (128)

9 no Livro 1866 - 11 (129)

1 no Livro Sem Data (171)

Total: 79 dissertações

28 no Livro 1867 - 1 (130)

28 no Livro 1867 - 5 (134)

1 no Livro Sem Data (168)

2 no Livro Sem Data (170)

1 no Livro Sem Data (172)

TOTAL: 60 dissertações 
“\$294 do Compendio: A Tutella administrativa será necessária às varias corporações de mão morta existentes no Império? Esta tutela poder-se-há entender a outras corporações? Os presidentes de Provincia como delegados do Poder Executivo exercerão a Tutella quer no $1^{\circ}$ quer no $2^{\circ}$ caso? (Presidentes como tutores das províncias)"

“\$72 - O Direito Administrativo pertence à encyclopedia jurídica? É ciência social? (ou pertente à encyclopédia social?)"
26 no Livro 1867 - 1 (130)

1 no Livro 1867 - 4 (133)

30 no Livro 1867 - 5 (134)

2 no Livro 1867 (173)

1 no Livro Sem Data (168)

1 no Livro Sem Data (170)

Total: 61 dissertações

1 no Livro 1870 - 1 (148)

2 no Livro 1870 - 2 (149)

7 no Livro 1870 - 4 (151)

1 no Livro 1870 (171)

2 no Livro 1870 (173)

1 no Livro 1862 - 15 (76)

Total: 14 dissertações

11 no Livro 1870 - 1 (148)

3 no Livro 1870 - 2 (149)

26 no Livro 1870 - 5 (152)

5 no Livro 1870 (173)

1 no Livro Sem Data (168)

2 no Livro Sem Data (170)

1 no Livro Sem Data (172)

Total: 49 dissertações

TOTAL: 1209 dissertações

Qualitativamente, com relação aos temas jurídicos abordados nas theses, é possível colocá-los em caixas distintas para a análise. Primeiramente, a caixa da repetição, dividindo-se entre as theses que ecoam de modo idêntico ao longo dos anos, como por exemplo sobre "os atos administrativos"; as theses que reproduzem uma temática semelhante com variações, como é o caso das questões acerca da "relação entre a administração e outros poderes"; e há, ainda, as theses pontuais, de temas que não se repetiriam mais dentre as fontes encontradas. Este dado é relevante para constatar quais os assuntos jurídicos que não só os professores consideravam relevantes como ainda o que os alunos repetidamente estudavam.

Não obstante, isto não significava que o tema por ser pontualmente tratado não seria de alta relevância de discussão. Nesse sentido, também há outra caixa, a da amplitude dos temas tratados, posto que se constataram theses que abarcam matérias dogmáticas abrangentes, assuntos discutidos lá na academia europeia, quais sejam, de 
“delimitação de princípios do Direito Administrativo" ou de "caracterização do próprio ato administrativo" "199, assim como existem theses que se reproduzem especificadamente à conjuntura específica brasileira naquele momento em que ela foi escolhida, como a these acerca dos "agentes auxiliares de consultas e a congregação da faculdade de medicina da Corte e da Bahia".

É possível destacar, ainda, a caixa das theses que tratam de assuntos relevantes à contemporaneidade da política nacional, dividindo-se nas mais diversas temáticas administrativas, como sobre "os pareceres do Conselho de Estado" e sobre "a descentralização ou centralização do poder". Ambos estes tópicos são passíveis de discussão em outras fontes históricas, tais como da Assembleia Geral e do contencioso administrativo.

Para desenvolver de uma forma interlaçada tantas caixas possíveis e imagináveis de delimitação das theses, pensou-se em realizar uma pequena análise da complexidade temática das theses oferecidas para os estudantes de Direito dissertarem a fim de continuarem com seu processo de ratificação acadêmica e, então, obterem o grau de bacharel. Assim, pareceu interessante destacar qual o âmbito de alcance destas dissertações no plano de discussões existentes na área jurídica administrativa ${ }^{200}$. E, um indicativo relevante é justamente a pesquisa de Lima Lopes acerca dos temas que circulavam em seu "Oráculo de Delfos", lembrando que essa investigação demonstrou que $42 \%$ de todas as consultas pesquisadas eram da área de Administrativo, sendo $32,4 \%$ destas sobre questões sobre cargos da justiça, 15,2\% sobre jurisdição e competência, $7 \%$ sobre escravidão e, ainda, $6 \%$ sobre a Guarda nacional.

Ora, dntre as questões do Conselho que tratavam de temas em que o Poder Moderador devia ser exercido, estava: a dissolução da Assembleia; a separação das esferas administrativa e judiciária; as divergências entre poder local (Assembleia Provincial) e da Assembleia Geral; os dissídios jurídicos que dependiam da aplicação imediata de uma norma jurídica preexistente (tanto em constitucional como legal).

\footnotetext{
${ }^{199}$ MANNORI, Luca.; SORDI, Bernardo. Op. Cit.

${ }^{200}$ A relação entre as dissertações e os compêndios será feita amenamente no próximo item, não obstante, pela dificuldade desta relação, seu trato será subsidiário.
} 
Não obstante, deve-se ressaltar que a amplitude na área de administrativo que alcançavam os pareceres do Conselho era menor do que das dissertações, embora a especificidade técnica fosse maior nas consultas. Isto porque o tema administrativo tratado pelo lente, muito embora houvesse a aprovação de um compêndio de regulação vinda do próprio governo central, tinha uma liberdade temática a qual a competência do Conselho não permitia, já que era provocado. Em outra medida, a especificidade técnica do Conselho sugere maior do que a tratada pela academia de São Paulo, não só em razão do público diverso a que eram direcionadas as fontes, mas também pela própria qualidade dos emissores.

De qualquer forma, é ainda positiva a comparação das temáticas tratadas, principalmente para se averiguar o diálogo entre fontes de Direito Administrativo em universos distintos de atuação.

Assim, dentre os temas relevantes tratados no Conselho que envolviam uma discussão de Direito Administrativo, havia: controle de constitucionalidade $^{201}$, contencioso administrativo ${ }^{202}$, organização judiciária ${ }^{203}$, recursos de graça ao Poder Moderador, resolução de dúvida e interpretação de lei ${ }^{204}$. Desses, os que guardam mais destaque nas theses de Direito Administrativo da academia de São Paulo são o contencioso administrativo e organização judiciária, embora houvesse outros também, conforme se depreende pela análise da próxima tabela.

\footnotetext{
${ }^{201}$ ocorria um exame anual da legislação provincial para verificar se estava conforme a Constituição e os termos do Ato Adicional ${ }^{201}$, principalmente para verificar se a província não havia excedido seus poderes. Em caso positivo, fazia-se uma recomendação ao Ministro (governo) para encaminhar a questão à Assembleia Geral, guardando o Conselho certas semelhanças a órgãos de controle de constitucionalidade. Também se tratava acerca de matéria policial criminal, da guarda nacional, fazia exame prévio de leis e de temas de reformas importantes ecomo casamento, hipotecas e reformas judiciais. Apontavam, as vezes, falha da legislação.

${ }^{202} \mathrm{o}$ Conselho analisava conflitos de competência e jurisdição, a despeito de o próprio ${ }^{202}$. Assim, temas como conflito de Direito de servidores como oficinas de justiça, membros da guarda nacional; conflitos entre autoridade eclesiástica e a secular; conflitos entre Judiciário e Administração, por exemplo, se o presidente de província decidisse numa querela processual favoralmente à Administração, o caso subia ao Conselho.

${ }^{203}$ havia para a Seção de justiça que se encaminhavam pedidos relativos a empregos e ofícios de justiça. Também tratava acerca da organização dos poderes das províncias para organizarem seus serviços e examinar das leis provinciais, como por exemplo desmembramento de comarca e de distritos.

${ }^{204}$ de uma forma parecida como era tratado o conflito de competência, fazia-se a análise de questões políticas importantes que rodeavam o debate político e jurídico era feita embora fosse prevista no Regulamento essa possibilidade. As dúvidas vinham do Executivo e do Judiciário.
} 
Além de tais temas, Lima Lopes dá atenção também a tópicas gerais que envolvem grandes querelas estruturais do Brasil daquele tempo, que também apresentariam análises ligadas à cultura jurídico-administrativa, quais sejam, o tema polêmico pelo fim da escravidão; a polícia na justiça e a organização da burocracia, provocada pelo conflito cotidiano entre poder local e central e entre presidente de província e juízes de Direito; quem seria a autoridade última na interpretação e aplicação da lei. O estado e a modernização da infraestrutura material não seria um destaque até a partir de 1870, com a industrialização crescente.

Havia alguns fatores que balizavam a interpretação do Conselho, como a falta de clareza da Constituição quanto à separação dos poderes, o fato de não aplicar poder levar ao crime de prevaricação, o que justificaria tantas consultas a dúvidas de aplicação e, além disso, muita atividade dependia de regulamentos do governo, pois após uma lei, vinha um regulamento do ministro da respectiva área.

Desses, observou-se como presentes nas temáticas das theses a organização da burocracia, o conflito cotidiano entre o poder local e central e entre presidentes de província e juízes de Direito. Não obstante, em meio à análise das dissertações no próximo item, aparecem discussões amenas sobre escravidão e sobre o aumento da necessidade de serviços públicos de infraestrutura.

Nesse sentido, quanto às dissertações de Administrativo, se se contabilizá-las, ao todo, são 23 theses a que se teve alcance. Assim, foi possível encontrar áreas distintas do Direito Administrativo em tais theses a fim de melhor identificar as temáticas tratadas. Assim, para apontar tais áreas de estudo dentro da ciência em questão, optou-se por utilizar um documento contemporâneo às theses. Por isso, as divisões em temáticas foram baseadas nas divisões do compêndio do Conselheiro Ribas. Assim, segue a tabela 3 com tais temáticas: 
Tabela 3 - As Tópicas que envolvem as theses, baseada no compêndio de "Direito Administrativo brasileiro" do Conselheiro Ribas

These

"O que é centralisação governamental e administrativa? Em que differe da concentração? Qual tem sido a vida e applicação deste principio nas nossas instituições antes e depois da constituição do Império. Se este principio soffreo mingua com a instituição das Assembleias Provinciaes."

"O que é naturalisação; quaes suas especies, processo e recurso de sua denegação? A naturalisação do marido comprehende a da mulher?'

“Agentes Administrativos."

"Quais as relações que constituem o domínio e acção de Direito Administrativo? Compreende as relações civis e públicas? Diferença entre Direito Administrativo, Direito Constitucional e Direito Civil.”

"O que se deve entender por actos administrativos, quais são suas espécies?"

"O Direito Público positivo serve de fonte ao administrativo (Compendio § 7)."

"Em que se distinguem o poder administrativo e o judiciário?"

\section{Temática administrativa}

- Das condições essenciais da organização administrativa: a unidade - Necessidade de descentralização administrativa de modo a não comprometer a centralização

- Das Relações da Administração com os Poderes do Estado -Relações da administração com o poder legislativo

- Dos Nacionais - da aquisição da nacionalidade pela naturalização

- Da natureza das funções administrativas

- Da Hierarquia Administrativa

- Das ciências auxiliares e fontes do Direito Administrativo

- Das Relações da Administração com os Poderes do Estado - relações da administração com o poder judicial

- Das formulas dos atos administrativos

- Das ciências auxiliares e fontes do Direito Administrativo

Das relações da Administração com os Poderes do Estado - relações da administração com o poder judicial 
"Se as razões do Conselho d'Estado devem ou não ser motivadas."
- Das Funções Espontâneas e Jurisdicionais - Funções Espontâneas

- Dos Direitos do Poder Executivo

"Agentes Auxiliares de Consultas. - Da Hierarquia Administrativa Congregação da Faculdade de Medicina da Corte. Congregação da Faculdade de Medicina da Bahia."

"Qual a differença que existe entre Governo e Administração?"

“A Administração quando julga contenciosamente administra?"

" Mando que me confere o $\S 8^{\circ}$ da Const do Imperio art 101, fui por bem relevar a companhia geral de seguros. Feliz lembrança da multa que lhe foi imposta pela Recebedoria do Rio de Janeiro em 13 de Janeiro de 1860 por não haver pago no tempo devido o sello correspondente as duas primeiras chamadas do seu capital.' Questiona-se:

$1^{\circ}$ Se há differença entre multa criminal e administrativa?

$2^{\circ} \mathrm{Se}$ a revallidação do sello é multa ou imposto?

$3^{\circ} \mathrm{Se}$ estando esgotados os recurso ordinarios caberá este extraordinários?

$4^{\circ}$ A remissão de revallidação é ou não perdão da dívida?

$5^{\circ} \mathrm{O}$ perdão de dívida da Fazenda a que poder pertence?

$6^{\circ}$ Os arestos a tal respeito que força tem? $7^{\circ}$ a resolução será ou não uma Divisão contenciosa administrativa?

$8^{\circ} \mathrm{A}$ jurisdição administrativa só prescreve depois da Const?"
- Das relações da Administração com os Poderes do Estado - relações da Administração com os poderes moderador e executivo governamental

- Das relações da Administração com os Poderes do Estado - relações da administração com o poder judicial

- Do contencioso administrativo

- Do contencioso Administrativo classificação das funções administrativas contenciosas 
“A administração quando julga o contencioso administrativo é Juiz e parte ao mesmo tempo?"

"Quais as relações que constituem o domínio e acção de Direito Administrativo? Compreende as relações civis e públicas? Diferença entre Direito Administrativo, Direito Constitucional e Direito Civil."

"O que se deve entender por actos administrativos, quais são suas espécies?"

" $1^{\circ}$ A Authoridade quer administrativa, quer judiciariamente procedendo, mas procedendo oficialmente pode reconhecer como Medicos para corpos de delictos, exames e outros misteres aqueles q não estiverem habilitados conforme a lei de $3^{\circ}$ de outubro de 1832 , art 12 e 13 ? $2^{\circ}$ Se pode tolher-lhes o exercício da Medicina? $3^{\circ}$ Se não podendo tolher-lhes esse exercício, pode oficialmente aceitar seus atestados?"

"O que se deve entender por actos administrativos, quais são suas espécies?”

$\S 90$ do Compendio - Actos Administrativo excessivos de poder: Se o acto administrativo não for dictado em virtude do legitimo exercício das atribuições da autoridade administrativa, os juízes e tribunais judiciários não estão obrigados nem devem dar lhe cumprimento, protegendo assim o Direito dos particulares contra os abusos do poder. Nem praticando assim usurpa atribuições alheias, mas só resguarda as suas, porque a autoridade judiciária não é delegada da administrativa."
- Da Competência do Contencioso Administrativo

- Das ciências auxiliares e fontes do Direito Administrativo

- Das Relações da Administração com os Poderes do Estado - relações da administração com o poder judicial.

- Das formulas dos atos administrativos

- Do Contencioso Administrativo

- Das Relações da Administração com Poderes do Estado - realções da administração com o poder judicial

- Das formulas dos atos administrativos

- Das formulas dos atos administrativos

- Do contencioso administrativo 
“\$72 - O Direito Administrativo pertence à encyclopedia jurídica? É ciência social? (ou percente à encyclopédia social?)"

“O Art. 39 do Reg no 2548 de 1860 está de conformidade com os princípios do Direito Público e Administrativo?"

“\$294 do Compendio: A Tutella administrativa será necessária às varias corporações de mão morta existentes no Império? Esta tutela poder-se-há entender a outras corporações? Os presidentes de Provincia como delegados do Poder Executivo exercerão a Tutella quer no $1^{\circ}$ quer no $2^{\circ}$ caso? (Presidentes como tutores das províncias)"

“\$72 - O Direito Administrativo pertence à encyclopedia jurídica? É ciência social? (ou percente à encyclopédia social?)"

“O art. $7^{\circ}$ da Lei de 28 de Agosto de 1830 está revogado pelo art 310 do Codigo Criminal? Caso não esteja, qual a auctoridade competente para applicar a penalidade ao infractor?"
- Do Direito Administrativo

- Das Ciências Auxiliares e Fontes do Direito Administrativo

- Do Contencioso Administrativo

- Da Hierarquia Administrativa $-3^{\circ}$ grau de hierarquia - Os presidentes de provincia

- Do Direito Administrativo

- Da Hierarquia Administrativa

Ora, das theses descritas acima, 7 abarcam o tema sobre as "relações da Administração com os Poderes do Estado"; 5 se referem ao "Contencioso Administrativo"; 4 tratam diretamente sobre as "fórmulas dos atos administrativos"; há 4 que abrangem as "Ciências Auxiliares e Fontes do Direito Administrativo", também 4 que tratam "da Hierarquia Administrativa" e, ainda, 4 sobre "as formulas dos atos administrativos"; 2 referem-se a um tema introdutório "do Direito Administrativo"; 1 trata sobre "os Nacionais", 1 da "natureza das funções administrativas", 1 dos "Direitos do Poder Executivo" e, finalmente, 1 das "Funções Espontâneas e Jurisdicionais". 
Não obstante, quando se observa o índice da obra de $\operatorname{Ribas}^{205}$, depreende-se que havia temáticas ali que não foram tratadas nas theses encontradas dentre as dissertações na biblioteca, dentre as quais: origem histórica do Direito Administrativo; teoria constitucional; funções administrativas no que tange às funções diretas e indiretas, funções consultivas e funções jurisdicionais; classificação das funções administrativas contenciosas e desclassificações; dos administrados em geral, dos estrangeiros e dos escravos. Mas isto não significa que houvesse o trato de algumas dessas temáticas nas discussões travadas em outros níveis do processo de ratificação acadêmica, bem como que o estudante mencionasse aspectos de tais áreas nas dissertações.

Assim, é perceptível pela análise das theses que havia uma grande importância do estudo acadêmico dada à compreensão da dinâmica da administração com a ação dos Poderes, assim como com relação à compreensão dos atos administrativos, da relação com outras áreas do Direito e, ainda, com relação à Hierarquia Administrativa, sendo esta parte do tema de Direito Administrativo mais tratado pelo Conselho de Estado em suas consultas sobre questões de cargo da justiça, jurisdição e competência.

Interessante notar o enfoque para temáticas que envolvessem instrumentos de estruturação da ciência do Direito Administrativo como, a questão do "ato administrativo". Este é um tema diretamente ligado à discussão acadêmica, mais do que à consultas ao Conselho de Estado. Também estão presentes temas de importância política como, por exemplo, a questão da naturalização, relacionada à imigração crescente no Brasil, muito embora tenha uma abordagem individual e não de política pública. Por fim, destacam-se os estudos acerca do próprio Conselho de Estado, como também de profissões liberais, tal como o caso da medicina.

Em outra medida, também há entre essas theses temas que tratam sobre questões de organização jurídico-administrativa. Primeiro, sobre a verificação de legalidade e constitucionalidade com os princípios do Direito Público e Administrativo, há 4 theses (1 sobre âmbito constitucional e 3 em âmbito legal); há 1 sobre perdão de dívida; 6 sobre organização judiciária, ou seja, mais especificadamente, que tratam sobre a

${ }^{205}$ RIBAS, Antonio Joaquim.Op. Cit. p. 233-256. 
centralização e a relação entre governo e judiciário ou governo geral e as províncias; 1 these sobre tutela administrativa provincial.

Em outra medida, são tratadas nessas theses questões acerca da organização da burocracia, provocada pelo conflito cotidiano entre poder local e central e, ainda, entre presidente de província e juízes de Direito; também demandam dos estudantes o reconhecimento de quem seria a autoridade última na interpretação e aplicação da lei.

Enfim, fica visível a importância de se estudar tais fontes históricas a fim de compreender melhor o que a academia estudara acerca da ciência do Direito Administrativo, pois assim será possível o diálogo enriquecedor com outros documentos que se atentaram para esta temática, tal como o Conselho de Estado, as doutrinas, o contencioso administrativo, mas também para apresentar novas lentes para analisar a pintura da cultura jurídica administrativa no Brasil oitocentista.

\subsection{Exame específico das dissertações}

Assim, feito este preâmbulo geral, passa-se para a análise mais aprofundada de nove das 1209 dissertações a fim de possibilitar alguns indícios do pensamento jurídico reproduzido pelos estudantes e, por fim, acrescentar na discussão da cultura jurídica administrativa oitocentista brasileira.

Há algumas questões primárias essenciais de se relembrar antes de iniciar o exame específico de dissertações de Direito Administrativo.

De início, ressalta-se que havia todo um contexto de aprendizado metodológico por trás das dissertações, conforme se verificou nos capítulos anteriores. Assim, é importante se atentar para o fato de que as dissertações funcionam como um gênero de fonte produzida pelos emissores-alunos que se pressupõe direcionada ao receptorprofessor em prol de obtenção da habilitação para o exame final do ano. Trata-se do último ano para conseguirem o título de bacharel. Assim, é uma etapa intermediária da ratificação acadêmica dos estudantes. Na mesma medida, a análise das dissertações deve estar atenta ao contexto histórico e conjuntural da faculdade entre as décadas de 
1850 e 1870, assim como à metodologia apreendida na faculdade, posto que esta proporcionaria o desenvolvimento de um raciocínio lógico peculiar dos estudantes que se refletiriam nas dissertações, baseada nos três âmbitos romântico, técnico e semântico.

Destarte, há muitas variantes que determinam a leitura sobre tais dissertações: primeiramente, num aspecto individual, haveria o nível de conhecimento do aluno, seu interesse em ser habilitado para exame final, sua relação acadêmica e pessoal com o professor, seu histórico social de vivência, por exemplo, se havia se bacharelado em letras ou estudado na Europa, se possuia recursos, se se dedicava mais a outros ramos do conhecimento, dentre outros.

No aspecto geral, também haveria diversas questões que influenciariam na elaboração das dissertações, como o interesse particular da turma sobre o tema, a forma como estudaram, o quanto participavam das aulas e viviam a conjuntura social da cidade e do país, se era um ano com muitas faltas do Conselheiro Furtado e a consequente substituição por outro professor, como também a relação daquele momento da faculdade com o governo central, posto que este tinha a autoridade para interfirir diretamente caso houvesse algum interesse em prol da manutenção simbólica do poder, quer fosse com a alteração da grade acadêmica, tal como se tentou fazer em 1865, com o decreto $\mathrm{n}^{\mathrm{o}} 3.454$ e com a criação do corpo dos "voluntários da pátria", em que diversos estudantes seguiriam para a campanha do Paraguai e se formariam militares e com uma visão muito distinta quando voltassem para a faculdade.

Não obstante, todas estas possibilidades conjunturais não excluíam o fato de que se perpetuou, no seio da faculdade, uma metodologia de ensino e da mente juvenil do estudante um raciocínio jurídico, quer fosse um sapeca ou um "estudantão", quer fosse um futuro presidente da república ou aquele que voltou para sua chácara natal e até desaprendera a ler, quer fosse um ano de mais rigor ou relaxamento acadêmico por parte dos professores.

Isto porque a metodologia justamente era formada, em parte, por um caráter técnico de interpretação e retórica do Direito, mas ao mesmo tempo ela era resultado de aspectos comuns do cotidiano de ensino que formavam um ritual típico de passagem do estudante pela faculdade e, ainda, de aspectos do processo de ratificação jurídica que 
tinham um sentido próprio para o estudante. Junto a todos estes aspectos, conforme se viu no item final do capítulo segundo, ainda havia a especificidade da cadeira de Direito administrativo e de sua significação para a faculdade, que era influenciada, em alguma medida, pelos interesses do governo.

Assim, estes elementos permitem compreender que havia uma máquina acadêmica que provocava algumas correntes no mar em que viviam os cursos jurídicos imperiais. Esta máquina será assemelhada, nesta dissertação de mestrado, à semântica de um instrumento de perpetuação da violência simbólica do período, mas também se poderia chamar tal máquina de o método weberiano de ensino praticado nas sociedades de Civil Law ${ }^{206}$, talvez, ainda, alguns a chamem de microfísica do poder $^{207}$. Todas estas diferentes formas de definir a máquina trabalham com a ideia de que se perpetuava um pensamento dentro dos ambientes escolares jurídicos.

Feita esta primeira ressalva, agora é necessário justificar a escolha do número de dissertações analisadas, já que não seria possível a análise de 1209 provas escritas numa dissertação de mestrado. Assim, optou-se por realizar um exame mais minucioso de nove dissertações referentes a três temáticas da área do Direito Administrativo, mas que envolvem diversas theses de distintos anos e estudantes.

Num primeiro momento, foram-se atentadas diversas possibilidades de escolha quantitativa e qualitativa das dissertações. Havia o critério de análise com mera proporcionalidade, por exemplo, analisando $10 \%$ do número total de dissertações existentes. Apesar de dar uma visão mais ampla e completa, os problemas encontrados foram a falta de critério qualitativo e excesso de dissertações para análise, pois seriam 120 provas, proporcionalmente, para serem examinadas.

Em segundo lugar, pensou-se também em utilizar o critério cronológico, mas de uma forma mais qualitativa, ou seja, com a análise mais seletiva de theses por ano que trouxessem discussões políticas e dogmáticas importantes no contexto nacional e internacional, assim, em cada ano corrente, escolher-se-ia um número mínimo de

\footnotetext{
${ }^{206}$ WEBER, Max. Economia e sociedade: fundamentos da sociologia compreensiva. v. 2, Brasília: Editora Unb, 1999. p. 85-93.

${ }^{207}$ FOUCAULT, Michel. A microfisicica do poder. 16 Ed. Rio de Janeiro: Graal, 2001.
} 
dissertações para exame histórico voltado para este viés. Apesar de dar uma visão mais ampla e completa das provas, alguns problemas foram encontrados, como a falta de um critério mais crítico e seletivo e ainda o excesso de dissertações para análise.

Uma terceira possibilidade seria o critério de análise de 2 tipos de theses distintas: uma que trouxesse tema político relevante e outra em que predominassem questões dogmáticas contemporâneas, ambos aspectos estes importantes para a análise. Evidentemente, as duas theses teriam questões políticas e dogmáticas por trás, mas a ideia seria focar em uma das questões para dar mais especificidade. Por exemplo, no ano de 1857 , análise de todas as provas sobre centralização ( 5 provas) e, no ano de 1858, análise de todas as provas sobre domínio da ação do direito administrativo (64 provas). Este critério da especialidade, apesar de valorizar, em termos de profundidade, questões relevantes no período, perde na possibilidade de uma análise comparativa e ampla de outras theses, além de também pecar pelo excesso de fontes.

Nesse sentido, justamente surgiu a possibilidade de um quarto critério de análise predominantemente quantitativa, ou seja, tão-somente realizar o exame panorâmico e superficial de todas as dissertações existentes. Ora, evidente se faz a perda qualitativa desta análise.

Também se atentou para um quinto critério de análise de theses, movido pela citação dos compêndios suscitados no próprio corpo das theses. Ora, vantagens se dariam também por uma questão de escolha qualitativa baseada nos compêndios, contudo se poderia perder o exame de outras dissertações em que não houvesse essa condição não criteriosa, mesmo porque se sabe que existia necessariamente um compêndio para cada cadeira da faculdade e que o professor, a princípio, deveria se basear nele. Assim, cairia por terra esta escolha de análise das dissertações, além de também não limitar o número de fontes a ser analisado.

Haveria, ainda, o Critério de análise da História não oficial, com análise tãosomente de aspectos nunca antes analisados, diversos, que partissem de fontes não tradicionais para a análise das dissertações de Direito Administrativo, considerando a pluralidade jurídica, além das leis sobre ensino jurídico ou mesmo das estórias contadas pelos memorialistas ou nas biografias existentes. Como era a retórica estudantil dentro 
das dissertações? Como os estudantes compreendiam a relação acadêmica entre professor e aluno por meio da linguagem utilizada nas dissertações? Ou como os alunos se atentavam para o aspecto da escravidão dentro das dissertações? Tais questões demandariam outro tipo de pesquisa, muito mais curioso e atento às entrelinhas, à análise comparativa e paralela com outras fontes que, aparentemente, estão fora do ambito de pesquisa acadêmico e mesmo desta pesquisa. Apesar de ser um critério de análise inspirador, ainda se está caminhando incipientemente com os estudos acerca do pensamento jurídico emitido pelo bacharel e da produção de cultura jurídica administrativista dentro da faculdade. Assim, apesar de desafiante, optou-se por aprofundar o estudo primário das fontes escritas e tradicionais.

Como, então, seria a melhor forma de se compreender, em uma dissertação de mestrado, indícios da dimensão social do pensamento jurídico produzido na faculdade de São Paulo sem efetivar uma pesquisa aprofundada de todas as fontes, sem se basear tão-somente num critério cronológico, sem realizar só uma análise superficial de todas as fontes ou sem elaborar a análise restrita de um só tema de importância política e dogmática? Mais que isso, como seria possível valorizar a discussão crítica, na História do Direito brasileira, de um paradigma de construção do conhecimento jurídico que vá além da visão heróica ou maniqueísta sobre o bacharel e da generalização ou da unicidade da faculdade de São Paulo?

Procurou-se conciliar a análise aprofundada de algumas das questões importantes para a discussão da cultura jurídica administrativista de forma a envolver ambas as perspectivas dogmáticas e políticas nas theses. Assim, ponderou-se analisar as questões sobre "a relação da administração e os Poderes", “o contencioso administrativo" e "a problemática da centralização do poder" pelas seguintes justificativas.

O tema da centralização e descentralização do poder foi um tema muito relevante não só politicamente, já que havia uma constante negociação entre os poderes locais e o governo central, conforme indica o estudo de Dolhnikoff ${ }^{208}$, como também por

${ }^{208}$ DOLHNIKOFF, Miriam. Op Cit. 
definir as bases que justificariam a estruturação jurídico-administrativa do Brasil, ou seja, um império centralizado, mas tecnicamente com gerência de controle local.

Nesse sentido, diversos historiadores se preocupam com essa questão política da administralização centralizada, do "regresso conservador", do motivo porque o Brasil foi o único país que conseguiu se manter um império unificado em meio a um mar de pequenas repúblicas que sofreram processo separatista. Dolhnikoff oferece a tese de que, em verdade, esta estrutura só se manteve porque, muito embora fosse uma centralização política, havia uma série de questões que envolveriam a liberdade regional das províncias, as quais demonstrariam que havia uma descentralização administrativa, utilizando para tanto a própria análise do Visconde do Uruguai.

Nesse sentido, a própria doutrina do Visconde de Uruguai e do Compêndio de Ribas, bem como atuação consultiva do Conselho de Estado são fontes históricas que demonstram que havia também uma preocupação daquele período em discutir acadêmica e cientificamente essa temática.

Em outra medida, a these sobre o contencioso administrativo também envolve uma série de elementos interessantes de análise tanto no âmbito político como doutrinário, isto porque permite vislumbrar como os estudantes entendiam a função da administração num contencioso administrativo, que é um dos temas com maior destaque não só no compêndio de Ribas, como também nas opções dos lentes em colocarem diversas vezes esta temática para a discussão. Em soma a isto, permite compreender que peso de neutralidade e distanciamento dos interesses individuais em prol da ordem social e pública haveria na administração brasileira, de acordo com o ensino na academia de São Paulo.

Por fim, quanto à relação da administração e os Poderes, esta é importante para que permita vislumbrar como os estudantes entendiam a questão da separação dos Poderes e a importância do Judiciário, já que Guandalini apontara que seria um elemento assessório, meramente confirmador legal do funcionamento executivo, liderado pela figura do Imperador. Além disso, Lima Lopes também discute sobre a importância do Poder Judiciário e sua mistura de atuação com os outros poderes. Assim, é possível compreender de que forma haveria uma independência entre os Poderes 
Judiciário e Executivo e, portanto, asseverar sobre a influência do primeiro na construção burocrática do modelo de Estado Brasileiro.

Consideradas tais perspectivas de análise, optou-se por analisar, das 23 theses existentes, especificamente essas três temáticas, que apresentam aspectos jurídicos salientes, tanto no âmbito dogmático como político.

Agora sobre as possibilidades de escolha quantitativa das dissertações, fez-se a opção por examinar nove espécimes, de forma a estudar três dissertações diferentes sobre a mesma temática, fosse sobre centralização, sobre contencioso ou separação dos poderes. Ora, esta subdivisão possibilita realizar uma análise aprofundada e comparativa de algumas dissertações e, ao mesmo tempo, tratar sobre mais de um tema relevante no período.

Enfim, deve-se justificar quanto à escolha dos estudantes que haviam dissertado. A análise não poderia ser dedicada a analisar os "estudantões". Mais que estudantões e estudantadas, todos foram estudantes que viveram um contexto acadêmico específico de produção de pensamento. Claro que para descrever a "cachorra da rainha de Zadig" ${ }^{209}$, seguir-se-á seus rastros deixados pelo caminho, mesmo sem nunca poder realmente saber como era realmente o animal. Ainda sim, uma descrição aproximada sempre será possível. Assim, esta pesquisa indica rastros histórico-jurídicos encontrados pelo caminho. Rastros estes que apresentam relevância para caracterizar o ensino jurídico do Direito Administrativo no curso jurídico da São Paulo de D Pedro II e, assim, acrescentar, numa relação de coordenação com as demais pesquisas históricas sobre a produção de cultura jurídica brasileira no século XIX.

Particularmente em relação à escolha dos estudantes que elaborariam as dissertações analisadas, esta pesquisa de mestrado optou por não escolher das dissertações com base no histórico escolar dos alunos. Isto porque, após extensa análise das fontes acerca dos mais cotados estudantes das turmas que compreendiam os anos das theses, não foi possível encontrar para análise das três theses escolhidas, três estudantes com um histórico escolar muito diferenciado. Muitos daqueles destacados

\footnotetext{
${ }^{209}$ Apud CHALOUB, Sidney. Visões da liberdade: uma história das últimas décadas da escravidão na corte. (tese de doutorado). Campinas: UNICAMP, 1989. p. 1-12
} 
por Nogueira ou não existem registros na biblioteca central de tais dissertações, ou o material está em condições muito delicadas de uso. Assim, não foi o critério do histórico escolar aquele utilizado para a escolha dos alunos dos quais se analisou as dissertações, mas sim justamente da escolha espontânea.

A escolha espontânea de materiais é positiva por dois motivos. Primeiramente, porque a realização da descrição da "cachorra de Zadig" deve seguir os padrões medianos que envolvem a essência do que seria uma cachorra naquele contexto espacial (reinado onde existiam os cachorros das raças tal), temporal (um período em que era comum o uso de uma raça tal) e qualitativo (um cachorro real normalmente atenderia os seguintes padrões). Sabe-se que Zadig não conseguira descrever completamente a cachorra, mas sabia traçar traços comum dela a todos os cachorros e, ao mesmo tempo, trazer a especificidade dela, posto que ele juntara os fatos de ela ser uma cachorra da rainha do seu reino, em um período específico e onde havia o predomínio de raças específicas. Portanto, a escolha aleatória de estudantes permite resguardar a amplitude do conhecimento proferido por eles, que seria do estudante médio.

Assim, foi feita a análise de uma amostragem aleatória simples, sem reposição ${ }^{210}$ dos seguintes alunos: Americo de Moura Marcondes de Andrade e João da Rocha Miranda, ambos do $5^{\circ}$ ano de 1857; Joaquim Antonio Fernandes de Silveira, do $5^{\circ}$ ano de 1867; Antonio Quirino, do $5^{\circ}$ ano de 1860; Augusto Freire da Silva, do $5^{\circ}$ ano de 1862 e Marcellino de Assis Tostes, ambos do $5^{\circ}$ ano de 1862; Estevam Ribeiro de Souza Rezende, Feliciano de Souza Ribeiro Camargo e Luis Eugenio Horta Barbosa, os três do $5^{\circ}$ ano de 1863 .

Assim, festas as devidas ressalvas metodológicas, passa-se à análise das dissertações seguir.

\subsubsection{Sobre a Centralização administrativa}

\footnotetext{
${ }^{210}$ BOLFARINE, Heleno; BUSSAB, W. de Oliveira. Elementos de amostragem. São Paulo: Editora EdgarBlücher: USP. 2005. P. 73-74.
} 
A primeira these a se analisar tem como temática central a "centralização governamental e administrativa", de 1857, bem como sobre sua aplicação em nossas instituições, sua relação com a Constituição e com a instituição das Assembleias Provinciais:

"O que é centralisação governamental e administrativa? Em que differe da concentração? Qual tem sido a vida e applicação deste principio nas nossas instituições antes e depois da constituição do Império. Se este principio soffreo mingua com a instituição das Assembleias Provinciaes."

Escolheu-se a dissertação de Americo de Moura Marcondes de Andrade e de João da Rocha Miranda para realizar a análise acerca desta these.

Será feita uma mais esmiuçada desta primeira dissertação pela sua especificidade retórica, interpretativa e, ainda, por ser o maior material analisado. Após, as análises das outras dissertações serão mais comparativas e com destaque para os autores e elementos relevantes do texto para compreender melhor o pensamento jurídico utilizado por estes alunos. Recomenda-se uma análise do Anexo 2, para tanto.

Assim, Marcondes de Andrade, é um aluno com tipo de escrita bem extensa, com grandes aspectos de oratória, com a citação de vários autores, com argumentação direcionada para público está dirigido, teoricamente, o lente Furtado, e se alonga diversas vezes sobre a amplitude do tema e a necessidade de ser feito pelo examinador uma análise acadêmica proporcionalmente ao limite da dissertação. Considera, ainda, que a centralização é um problema sem solução que demanda um estudo sério de "mil circunstâncias peculiares" do país.

É uma noção complexa e com caracteres opostos, pois depende para ser vantajosa ou prejudiciosa considerar quais os costumes e circunstâncias em que se encontra o país analisado. Além disso, o estudante considera que é uma questão de fato, da história e não de Direito, da filosofia.

Novamente, utiliza o recurso da retórica para fazer um jogo de palavras sobre não poder haver uma vontade absoluta a qualquer forma de governo, mas que se faz 
necessário um governo qualquer para a liberdade e a ordem. Notoriamente, esta brincadeira com as palavras feita pelo aluno pode apontar duas hipóteses: primeiro, que não havia qualquer preocupação ou valorização de quem estaria no governo central, pois todos que tiverem uma organização jurídico-administrativa formal afirmará a defesa o valor filosófico da "liberdade" e positivista da "ordem.

Segundo, que não existe qualquer misticismo ou poder supremo por trás do Imperador, pois tão-somente faz parte do que está estruturado. Mesmo porque, ele ainda utiliza a expressão "somos obrigados a reconhecer" para terminar sua proposição, o que reforça não haver simpatia por ele pela teoria de uma vontade absoluta nas formas de organização governamental, ao que se inclui o Brasil. Eis que cita o princípio autorado a Lafaièrre de que nenhum governo poderia ser hostil à natureza livre, individual e social do homem.

Ora, é interessante que ao invés de relacionar o estudante à discussão sobre centralização num âmbito de embate entre esferas administrativas, ele traz para a interação entre a administração e os administrados, que não podem sobre com a sua intervenção em aspectos privados. Isto reforça a tese de Guandalini acerca da não intervenção governamental brasileira no âmbito privado, que tem uma responsabilidade moral para estabelecer suas regras de conduta.

Após, o aluno reitera os mesmos argumentos, mas realiza agora uma crítica mais direta contra o estribo da força e a escravidão, que não poderiam conviver com a dignidade moral do homem. Reafirma, então, a necessidade do princípio da centralização, mas que deve ser postos justos limites para não ocorrer abuso de poder.

Então, suscita o autor Tocqueville, define o que seria centralização administrativa e governamental, que se separam pelo caráter da universalidade e transcendência da primeira. Portanto parte para uma análise internacional da questão, pois confronta os interesses de países diferentes em ordens distintas. Há interesses universais que afetariam diretamente em todo o país, como uma unidade cujas partes estão interligadas pelas consequências que viriam do centro. Contudo, não seria esta noção a correta a ser aplicada no Brasil, afastando tal teoria o aluno. 
Assim, o estudante inicia seu argumento de um autor mesmo que não o tenha utilizado, tal como se verifica nas regras da Retórica. Após, considera Marcondes de Andrade que também há interesses nas nações que se desligam da unidade, que não se relacionam à universalidade dos cidadãos, mas que, ao mesmo tempo, não oferecem desvantagens ou vantagens diretas para a unidade da nação, mas sim para a localidade onde se encontram. Ora, aqui fica visível a noção principiológica do Direito Público para este estudante, que desconsidera haver uma abrangência coletiva de todos os interesses públicos em proteção aos interesses particulares, posto que o público só se remeteria à defesa da nação contra o estrangeiro e para manter a unidade e coerência nacional.

Sua definição explícita à pergunta feita na these vem agora: considera que tais interesses supracitados se referem à centralização governamental, que fica nas mãos do poder central, sendo uma centralização política, portanto. Em outra medida, a gestão dos interesses caracteriza a centralização administrativa, acrescentando que esta se subdivide nas ordens gerais e locais.

Dessa forma, é perceptível que este aluno emite o mesmo raciocínio de Ribas, pois este, de uma forma bem mais direta e explicativa em seu compêndio, considera que uma das condições essenciais da organização administrativa é a unidade, mas diferencia centralização governamental e administrativa no sentido de que a primeira emana da ação do poder governamental, portanto é condição da vida e da força nacional, enquanto que a segunda vem da unidade da ação dos agentes administrativos, que em verdade seria a descentralização administrativa, prevista nos artigos 71 e 167 da Constituição de $1824^{211}$. Além disso, ambos o aluno e o professor explicitam a problemática restritiva da centralização governamental, de forma que os âmbitos central e local sempre a comprimem ou expandem, de forma que cada um é responsável por um tipo específico de interesse.

Após, o aluno faz uma digressão acerca da relação entre administração com os Poderes e reafirma que os poderes locais são concedidos pelo governo central a fim de se realizar as atribuições de gerir a fortuna pública. Eis que, nesse contexto, suscita diversos aspectos contemporâneos de seu tempo que exigiriam a atuação do poder

${ }^{211}$ RIBAS, Antonio Joaquim. Op. Cit. p. 70-71. 
central para gerir os interesses da nação, tais como: a imigração, a instrução pública "até as últimas classes do povo".

Em seguida, elogia o Ato Adicional no contexto da descentralização administrativa, pois este instituíra devidamente qual seria o âmbito de atuação do poder local e do central. Por exemplo, cita a questão da colonização e catequização indígena, que deveria ficar sob controle de ambos os poderes.

Após, traz a definição de concentração, que seria a reunião no poder central da atribuição de gerir todos os negócios públicos em todos os níveis, portanto ocorre quando o único nível de ação e movimentação do país se dá em âmbito do poder central. Assim, ela inclui os dois tipos de centralização de forma a compactar tanto o âmbito político como administrativo tão-somente nas mãos desse poder central. Então, esmiúça as diferenças entre tais institutos, asseverando que a concentração desvirtuaria a natureza dos governos, como um combustível que causaria a explosão do país.

Passa, então, Marcondes de Andrade a tratar do segundo item de sua dissertação, partindo novamente de uma regressão desde o feudalismo para tratar das soberanias locais e das prerrogativas da nobreza em retomar no sentido oposto o controle central. Ora, não seria leviano destacar o protagonismo real aqui na atuação da História, de acordo com o estudante de Direito. Aqui, ele admitiria que havia um poder absoluto, diversamente do que escrevera no início de sua dissertação, mas logo em seguida considera que a razão marcaria os limites dos homens e que, portanto, a queda de Luiz $X V I$ serviria como representação do porque não se pode concentrar o poder tanto. Assim, é interessante como o autor critica diretamente o absolutismo monárquico.

Após, ele alcança a estruturação histórica e monárquica portuguesa e, então, sua digressão chega ao descobrimento do Brasil por Pedro Álvares Cabral. Assim, parece que aquele modelo ensinado pelo Visconde de Caravelas, de principiar pela História dos princípios de Direito para, então entrar na análise jurídico-dogmática ainda era um padrão seguido pelos alunos. Considera que houve uma tentativa de suplantação do feudalismo para a América, que seria o primeiro período da História brasileira e depois uma permanente concentração, que permaneceria até o início do século XIX, o que inspirara a condenação à monarquia portuguesa. Lusofobia aqui fica transparente. 
Chega, após toda a História desde o feudalismo, à Constituição outorgada em 1824. Considera que a descentralização começava com a separação e independência entre os Poderes, que atuam em esferas distintas e em perfeita harmonia. Esta seria a primeira diferença para com o que se procedia antes da Constituição, sendo que agora haveria momentos de contração e expansão da centralização administrativa de forma que a legislação apontaria momentos de oscilação de tal princípio por vezes pelo espírito democrático e por vezes pelo espírito monárquico.

Então ele explicita diversos exemplos da legislação de como haveria momentos de ganho para o poder local, mas também de contração em favorecimento dos interesses centrais. Contrariado com esta situação, a opinião dele é que para que não haja concentração, não só deve haver o poder local, como este deve ter seus interesses independentes do poder central. Cada vez fica mais latente a noção descentralizada administrativa pelo estudante.

Assim, finaliza com o último item de sua dissertação, que trata especificamente sobre a possibilidade de míngua do princípio da centralização com a instituição das assembleias provinciais. O aluno vê com bons olhos a descentralização administrativa e os interesses do poder local sobre controle local, tão-somente advertido que não deve ocorrer o uso de interesses meramente locais no controle central. Então cita o primeiro autor brasileiro, Pimenta Bueno, para consagrar a questão.

Assim, conclui que houve a necessidade social de se substituir os Conselhos Gerais pelas Assembleias Provinciais, justamente para que os interesses locais permanecessem sob um comando regional e não sob desgaste desnecessário do Rio de Janeiro. Nesse sentido, novamente ressalta o valor liberal do Ato Adicional, que proporcionou atribuições às Assembleias Provinciais maiores. Nesse sentido, teria avançado positivamente pelo gozo das liberdades individuais e sociais, mas sem fazer mingua à centralização.

Os autores que Marcondes de Andrade suscita são Pascal, Lafaièrre, Tocqueville e Pimenta Bueno. 
A seguir, de acordo com o Anexo 3, é feita a análise da dissertação do estudante João da Rocha Miranda, que também tratou sobre o tema da centralização, mas de uma forma muito mais veloz do que o primeiro. Ele também realiza uma pequena introdução sobre a importância do tema e também assevera que depende muito das circunstâncias, do território, dos costumes do país para ser analisado, repetindo o mesmo que Marcondes de Andrade.

Após, considera que toda nação deve possuir um poder central que concentre as forças sociais a fim de que a sociedade caminhe num todo harmônico. E, também reiterando o que dissera o primeiro aluno, de que isto é relevante para que se determine a soberania e independência de uma nação. Após, ele realiza uma exemplificação de diferentes tipos de centralização, tal como os EUA e a Suíça, de forma que ambos só teriam glória porque constituíram um governo central e também utiliza o argumento de autoridade de Lafaièrre e Vivien para reiterar a importância de haver um poder central, mas por serem realmente citações essenciais, posto que não são as definições que ele utilizará a seguir. Assim, mesmo que mais tímido, este aluno também repete certos aspectos da retórica.

Então considera que, na opinião dos mestres da matéria, a característica da centralização do poder não é pela intensidade, mas pela extensão sobre o corpo social, de modo que o poder das autoridades locais desapareceria a fim de dar lugar ao exercício da ação central. Contudo, ele vai em uma outra linha de raciocínio quando comparado com Marcondes de Andrade, pois Rocha Miranda destaca a importância da lei em atribuir aos governos a autoridade geral, trazendo o aspecto legalista-formal para destaque, citando novamente Vivien. Além disso, também admite que haja o exercício das faculdades individuais, substituindo-se quando possível aos poderes locais. Cita, ainda Coquelin, Elias Regnault e Tocqueville para reforçar seu argumento.

Então passa a diferenciar os tipos de centralização, sendo a centralização governamental aquela que se refere à ordem dos fatos políticos, de direção geral da sociedade, compreendendo os serviços que interessam à universalidade dos cidadãos. A centralização administrativa, diferentemente, consistiria na concentração, no governo central de atribuições que se referem aos interesses locais, assim, dar-se-ia quando os 
serviços locais são desempenhados debaixo da direção imediata do governo, ou de autoridades que dele dependem.

Não obstante, considera que a concentração seria um dos elementos da centralização, pois convergiria para o centro as forças locais sem o retorno conveniente. Ao contrário, a centralização seria uma reação benéfica do poder central sobre aqueles interesses que deixaram desprovidos da tutela local, retribui os sacrifícios que exige. Assim, a centralização é quando o poder central despoja as autoridades locais de toda a ação, mas ele próprio atua sobre os interesses locais e a concentração quando o governo central acumula todas as atribuições e deixa os interesses que ficarão abandonados.

Rocha Miranda também inicia sua retomada histórica, assim como o primeiro estudante, mas aqui já parte do absolutismo português e cita as ordenações e instituições portuguesas para demonstrá-lo. Assim, considera que antes da independência haveria a completa centralização, que era o modo como se exerciam os direitos. Considera que então havia uma completa dependência de decisão ao monarca, sendo que as autoridades municipais também restavam sob a inspeção das autoridades superiores. No Brasil, considera que havia descentralização com os donatários e faz um pequeno desenvolvimento histórico da evolução da organização administrativa da América portuguesa chegando à centralização já no início do século XIX.

Rocha Miranda cita os autores Lafaièrre, Vivien, Coquelin, Elias Regnault e Tocqueville.

Assim, é possível observar diversas diferenças entre as respostas, principalmente no formato retórico e à interpretação que os alunos fizeram acerca das definições de centralização e concentração, pois se denotou algumas diferenças. Em outra medida, a segunda metade que trata sobre a questão do princípio com a entrada da constituição e sua suposta mingua restou com a mesma interpretação.

Ora, dada a importância deste tema, segue outra these, conforme o Anexo 4, que trata sobre a descentralização, agora no ano de 1867, já num contexto histórico um pouco mais acentuado e amadurecido acerca da questão, mesmo porque a these que abarca praticamente uma estrutura de análise de caso: 
“§294 do Compendio: A Tutella administrativa será necessária a varias corporações de mão morta existentes no Império? Esta tutela poder-se-há entender a outras corporações? Os presidentes de Provincia como delegados do Poder Executivo exercerão a Tutella quer no $1^{\circ}$ quer no $2^{\circ}$ caso? (Presidentes como tutores das províncias)".

Joaquim Antonio Fernandes de Silveira elabora um texto curto e direto, não obstante tenha realizado uma análise sobre a especificidade da ciência administrativa, considerando que ela se trata de um ramo do Direito Público junto com o Direito Público Constitucional, deixando clara sua distinção para com a classificação feita pelos romanos. Além disso, ele considera que esta área do Direito entra, no Brasil, pelo Poder Executivo, de forma a se dividir entre os ramos: político ou moral e dos interesses gerais da nação e administração, ou seja, a ordem dos interesses públicos.

Assim, é perceptível que o aluno mantém a divisão da centralização entre política e administrativa. Também ainda é notável que ocorra uma mistura entre o Direito Administrativo, a ciência do Direito Administrativo e a Administração, pois em seguida considera que é um Direito que se ocupa da fiscalização das finanças, dos impostos, dos serviços públicos, físcaliza as corporações, casas de beneficências, também proporciona as policiam administrativas e preventivas aos cidadãos, proporcionando a ordem e segurança, como também nas questões administrativas contenciosas.

Considera que o fim da administração pública é suprir as necessidades conforme a sociedade se desenvolve, portanto era necessário que fosse cedido pelo Imperador, chefe do executivo, aos seus agentes imediatos, entre os quais estariam os Presidentes de Província, que são, de acordo com ele, alavancas poderosas em matéria administrativa local. Assim, por uma lei de 1828, poderia essa autoridade intervir em assembleias, igrejas, irmandades, casas de socorro públicas de forma que ela fiscalizaria, criaria e localizaria tais corporações. Aqui há um elemento interessante, mesmo que não esteja muito claro, quanto à necessidade de se desenvolver certas políticas básicas para a população, principalmente, no caso, de salubridade. Curiosamente, haveria aqui o papel de organizações não estatais a fim de suprir essa 
inexistência de intervenções positivas por parte do governo central, principalmente, em áreas longínquas.

Inclusive, o estudante considera haver um alcance ainda maior dessa tutela também às assembleias provinciais, câmaras municipais, tesourarias e quaisquer órgãos locais. Assim, sem a presença do presidente como ação da administração, não estaria bem representado o cidadão na físcalização e da causa pública.

O único autor citado pelo estudante fora Vivien.

O estudo destas três dissertações depreende que o nível de rebuscamento do estudante variava, mas a retórica continuava presente. É possível, também, já depreender um espírito mais no perfil do bacharel e, ao mesmo tempo, aspectos do jurista na análise destes estudantes, pois há desde aquele que permanecia teorizando sobre questões filosóficas e históricas, enquanto que também se verifica elementos de praticidade na análise, principalmente do último estudante, mesmo porque a these envolvia um caso muito mais prático e menos preocupado com questões de definição e especificidade da disciplina jurídico-administrativa o que, curiosamente identifica maior maturidade na formulação de pontos pelos professores.

A interpretação dada não abrangia uma noção mística do imperador ou mesmo grandes defesas pelo modelo jusnaturalista. É mais legalista, mas ainda confusa quanto ao significado dos conceitos, misturando muitas das teorias, ao mesmo tempo em que se permitia um espaço maior para a interpretação dada pelo estudante, já que possuía um nicho grande de autores em que se basear. Assim, aqui se vislumbram elementos trazidos sobre a forma de interpretação de transição ensinada pela faculdade.

A noção interferência do poder público sobre o privado deve ser mínima para Andrade, mediana com Rocha Miranda e não é abarcada pelo terceiro de uma forma clara, parecendo este último, de fato, contente com a intervenção do governo a fím de resolver os problemas públicos, ao que principia a demanda mesmo que inconsciente do estudante por políticas públicas, já que sua formação era mais baseada num raciocínio lógico do Direito Privado. 
Além disso, os dois primeiros citam muito mais autores estrangeiros do que o último, que só utiliza como frase de efeito no início da dissertação e faz uma análise bem mais brasileira, mesmo porque a these o exige, distanciando-se de problemáticas anteriores à constituição e de se perder em meio ao ecletismo das teorias. Não obstante, seria impossível desprezar estes aspectos da mistura de fontes e da influência não desejada, mas inegável do elemento jurídico luso.

\subsubsection{Sobre as Distinções dos Poderes}

Aqui é o espaço para tratar sobre o tema da separação e diferenciação dos poderes, com destaque para o protagonismo da administração. Primeiramente, segue uma these de 1860 é deveras interessante. Possui um fundo político e acadêmico muito forte:

"Em que se distinguem o poder administrativo e o judiciário?"

O primeiro estudante a ser tratado, conforme o Anexo 5, é Antonio Quirino, que suscitando o método de Chauveau, meramente por citar, pois não o usa por ser muito difícil. Enfim, resolve utilizar teorias e compará-las com as leis. Aqui já há um elemento que não fora apresentado anteriormente, que é a análise de um caso prático com a legislação.

Assim, parte da divisão e harmonia dos poderes prevista na Constituição de 1824, em seu artigo $9^{\circ}$ e considera, pelos artigos $101, \S 6^{\circ}$ e 153 que havia uma diferença marcante entre os dois, já que os agentes do poder judiciário são vitalícios, o que proporcionava independência e integridade ao poder, enquanto que os do poder administrativo são "demitíveis", posto que seria um poder mais versátil e sem vitaliciedade.

A seguir, começa a delimitar outros diversos itens diferenciadores entre as áreas. Desse modo, havia a diferença quanto à marcha e direção que cada um desses poderes segue, pois o poder judiciário se promoveria sobre pessoas ou coisas privadas, ou seja, sobre um elemento civil ou criminal, notoriamente, enquanto que a administração 
decide sobre coisas públicas ou entre a coisa pública e privada. Por fim, considera que a autoridade judiciária aplicava leis aos casos sempre previstos, enquanto que a administração é carregada pelas leis de entender suas ordens ou proibições aos casos.

Além disso, a autoridade judiciária se funda sobre títulos, convenções, testemunhas, regras escritas e absolutas, pronunciando-se sobre direitos positivos e devendo aplicar a lei literalmente, enquanto que a administração consulta interesses gerais, interfere na ordem pública e pode interferir livremente sob essa perspectiva.

É interessante aqui a forma como o estudante compreende a noção de legalidade para o Judiciário e para a administração. Esta, para ele, não teria que se atentar para a leitura estrita da lei, mas sim a proteger a ordem social e os interesses públicos, enquanto que seria o Judiciário o Poder preso à letra da lei. Nesse sentido também, indica o estudante que o Judiciário tem a marcha lenta e solene no seu modo de ação, porque para a aplicação das leis aos casos correntes é necessário guardar sempre certa uniformidade, enquanto que a administração já marcha com mais rapidez e violência segundo exigem os administrados. Aqui é possível remeter ao aspecto ritualístico que era apreendido já desde a faculdade pelo estudante de Direito, ou seja, ele aprende a lidar desde cedo com esta "marcha lenta" do Poder Judiciário e se acostuma com ela.

Antonio Quirino cita especialmente Chauveau, demonstrando maior capacidade de resposta prática na dissertação, usa a legislação brasileira e apresenta elementos concretos sobre a separação entre o judiciário e a administração. Sua interpretação obedece um parâmetro de análise prática mais do que um exame amplo e crítico acerca do tema.

Após, para tratar ainda sobre a diferenciação entre os poderes, segue uma these do ano de 1862, que será analisada, conforme os anexos 6 e 7 pelos alunos Augusto Freire da Silva e Marcellino de Assis Tostes:

"Qual a differença que existe entre Governo e Administração?

Agora a diferença é entre Governo e Administração e o estudante é Augusto Freire da Silva começa sua dissertação citando Rousseau sobre a constituição da ação, 
pelo seu lado moral, e a vontade, que determina o ato e possui um lado físico que o executa para explicitar a diferença entre governo e a administração. A força seria o Executivo e a vontade seria o Legislativo. Não obstante, considera que o primeiro tem duas partes distintas: o político e governamental que justamente contribuem para o seu funcionamento.

Assim, para esmiuçar tal argumento, cita diversos autores, dentre eles Macarel, Blanch e Vivien e Chaveau, Cabamtous para chegar na conclusão de que estes autores diferem e mesclam coisas pela sua natureza diversa, ao mesmo tempo em que alguns não estabelecem diferenciação alguma, dentre eles, destaca-se a primeira menção a um autor brasileiro Pimenta Bueno. Ora, é interessante perceber como o estudante permanece no modelo de citação de diversos autores estrangeiros, mas ao mesmo tempo percebe que permanecer nesta metodologia atrapalha a compreensão científica da matéria.

Assim, o estudante toma liberdade de também utilizar a legislação para fundamentar seu argumento. Desse modo, considera que a Constituição trata da administração em capítulos 165 e 172, bem como o tema é abarcado pelo Ato Adicional. Nesse sentido, também ilustra a confusão da legislativa brasileira na área administrativa no que se refere à separação entre os conceitos de governo e administração, e o faz por meio da lei $1^{\circ}$ de outubro de 1828 .

Por fim, passa a dar sua definição. Considera que a administração age quando o direito de um cidadão é ferido, atuando de forma contenciosa ou graciosa. Eis que o Poder Executivo funciona aplicando as medidas de interesse geral aos casos particulares. Diferentemente, o poder governamental trata só sobre os interesses coletivos e conclui asseverando que a administração não se relaciona com o poder político, que é representado pelo governo.

Dentre os autores citados estão Rousseau, Macarel, Blanch e Vivien e Chaveau, Cabamtous, Dufour e Pimenta Bueno. Destaca-se, ainda, que o aluno considera que o Direito Administrativo é ramo do Direito Público e uma ciência filosófica. Ora, a discussão travada pelo estudante está basicamente no início do compêndio de Ribas. 
É interessante perceber como há outra forma de abordar a metodologia de ensino por este estudante, pois muito embora ele tenha consciência da necessidade de citar autores estrangeiros para obter um bom desempenho com a dissertação, ele realiza uma análise crítica do contexto de interpretação dos conceitos de administração e governo, de forma a conceber uma noção que parte de sua síntese crítica com a legislação e a análise da doutrina, com os autores dos mais distintos.

Por fim, de acordo com o Anexo 7, trata-se sobre a mesma these, mas com a dissertação de Direito Administrativo de Marcellino de Assis Tostes.

Aqui, é perceptível que a resposta deste estudante é mais direta e menos analítica que o primeiro, obedecendo uma análise mais prática e categórica do significado dos termos.

Assim, considera que governo é o poder que faz as leis e tem a missão especial de dirigir a sociedade nas vias de seu desenvolvimento, promovendo a sua conservação. Em sentido lato, possui a direção dos interesses internos e externos do Estado e impulsa a administração. Em sentido estrito, seria o sinônimo de executivo. Em outra medida, administração seria autoridade essencialmente ativa é a que possui a execução das leis de interesse geral nas diversas circunscrições do território. Da mesma forma que seria o instrumento da vontade, a ação pura e simples do poder executivo.

Além disso, suscita três diferenças que considera capitais: o governo, ou poder executivo puro, estabelece medidas gerais de interesse geral, é formado por Ministros e recebe suas impressões do legislativo, ao passo que a administração estabelece as medidas particulares, locais, possui os agentes dos mais variados tipos e, ainda, recebe do poder executivo.

Em geral, sua conceituação mantém a mesma noção apresentada por Freire da Silva, tão somente sendo a postura para com a citação dos autores estrangeiros, que é menor e não há um ataque ao ecletismo de doutrinas. Nesse quesito, ele cita Aristóteles, Bilhards e Macael. 
A análise que se faz dos três estudantes que trataram sobre o tema da separação dos poderes é de que ambos conseguiram, mesmo que por uma análise diversa entre cada um, realizar uma definição assemelhada entre a diferença dos conceitos de administração e governo, notando-se, dentre os diversos aspectos mencionados, que há o destaque para o âmbito particular ou público de atuação de cada um desses elementos do Direito Administrativo. Assim, esta temática se repete na análise dos seis estudantes já analisados, enquanto que o método interpretativo continua se mostrando uma penumbra entre a análise legalista e concreta da legislação e aspectos mais ligados à noção filosófica e aberta dos termos.

\subsubsection{Sobre o Contencioso Administrativo}

Por fim, chega-se à última these examinada, qual seja do contencioso administrativo. Ora, se as duas primeiras temáticas já demonstraram certa inquietude dos estudantes em encontrarem uma definição que lhes fosse aplausível dos conceitos e, assim, da diferenciação entre eles, observou-se que quando se trata de especificar a função da administração dentro da atuação contenciosa, a dificuldade de se lançar uma teoria ou uma proposição sem grandes percalços. Assim, segue a these:

\footnotetext{
“A administração quando julga o contencioso administrativo é Juiz e parte ao mesmo tempo?"212
}

Primeiramente, ao se atentar para o Anexo 8, se observará a dissertação de Estevam Ribeiro de Souza Rezende. Trata-se de uma dissertação particularmente confusa, com muita citação de autores estrangeiros dos mais variados, desde Ulpiano, passando por Mello Freire até alcançar os inúmeros autores franceses citados.

Considera que a justiça administrativa, em paralelo à justiça civil, comercial, militar, é a aplicação do direito às relações jurídicas entre os administradores e administrados, reguladas e regidas pelos princípios de Direito Administrativo. Aqui se

\footnotetext{
${ }^{212} \mathrm{Ou}$, ainda, em algumas provas apareceria "O que é justiça administrativa? Quem a autoridade que administra-la?"
} 
verifica novamente que não há preocupação por parte da noção do estudante com o legalismo formal como um princípio essencial para a atuação judicial da administração.

Em verdade, seu principal autor será Mello para tratar sobre o contencioso administrativo. Ora, isto é muito interessante se observar, pois para este, deve haver uma separação entre os juízes do judiciário e os que cuidam de temáticas da área administrativa, devendo ser juízes especiais. Interessante, também, que ele cita o Visconde do Uruguai para ponderar que pela morosidade e regramento formal diverso e a natureza da instituição judiciária, contudo critica o estudante o fato de não existir uma ilustração pelo autor brasileiro acerca do contencioso administrativo. Portanto o primeiro autor responderia melhor sobre o tema, já que propõe a necessidade de haver juízes especiais para tratar do tema.

Após, ele passa a citar incessantemente autores franceses, mas mais para apontar suas falhas e inconsistências em definirem se seria o juiz também parte no contencioso administrativo, posto que cada um consideraria uma possibilidade. Não obstante, conclui que: a justiça administrativa não é excepcional, mas ordinária aplicada às relações jurídicas entre administrados e administradores; que deve ser administrada por tribunais administrativos; que os juízes administrativos devem ser autoridades que não são os mesmos administradores, quando possível; no julgo administrativo devem correr todas as condições da boa justiça - processo regular, recurso, publicidade.

Assim conclui que a administração quando julga não pode ser interessada na questão, mas sim movida pelo interesse geral, de forma que a decisão do poder administrativo garante a responsabilidade de seus agentes.

Dentre os autores citados pelo estudante, estão Chauveau, Ulpiano, José Mello, Visconde do Uruguai, Vivien, Comennin, Bathie. Cabantour, Henrion de Pansey, Portalis, Foucart. Fora o que mais extensamente explicitara doutrinas estrangeiras, inclusive apresentando autores mais contemporâneos, como Foucart, por exemplo.

Após, em atenção ao Anexo 9, será feita a análise da dissertação de Feliciano de Souza Ribeiro Camargo. Não obstante, este estudante não apresentou uma análise muito 
coerente e prática a cerca do tema e, tampouco, foi um bom elaborador de doutrinas estrangeiras e, sequer, crítico delas.

Em suma, considera que a administração é a encarnação do interesse geral e comum, dividindo-se em graciosa ou contenciosa. Assim, haveria três condições para se ter o contencioso: que fosse um fato especial ou ato particular da administração; que a reclamação contra esse ato seja ajuizada sobre um direito adquirido; e que a reclamação diga respeito a um interesse de ordem administrativa.

Da mesma forma, como o Estado se trataria de um conservador da ordem social e pública, ele poderia ode julgar decidir as reclamações apresentadas em âmbito administrativo, mas não poderia ser juiz e parte ao mesmo tempo. Os autores citados são Lafeierre, Cabatour, Portalis.

E, por fim, em atenção ao Anexo 10, apresenta-se a análise da dissertação de Luis Eugenio Horta Barbosa sobre o tema do contencioso administrativo. Considera ele que os autores franceses variam tanto de opinião sobre o contencioso administrativo que é difícil fazer uma escolha, nesse sentido, ele possui uma análise direta e bem crítica aos autores franceses.

Por exemplo, Vivien considerava que a administração no contencioso é juiz e parte ao mesmo tempo e, ainda, que o contencioso administrativo deve pertencer aos tribunais judiciários. Mas admite no final que deveria haver um tribunal específico

O autor realiza várias perguntas ao longo do texto, dentre elas questiona se seria faria mesmo sentido considerar que haveria um problema entre a divisão entre os poderes em razão de o Estado cuidar como juiz do contencioso administrativo, isto porque não teria ele um sentido de "parte" nesse processo como no usual da palavra, posto que a administração não seria obrigada a obedecer as leis e respeitar os contratos que fez. Assim, considera que estaria garantido o respeito da Administração no contencioso para com a outra parte, pois esta teria uma responsabilidade em respeitar a legislação, a qual ela deveria seguir. 
Ora, muito valiosa este questionamento, como se o estudante buscasse compreender em que ponto a administração deveria ser legalista e seguir a fundo os ditames jurídicos estabelecidos em detrimento de seu benefício próprio. Assim, ao respeitar a legislação, estaria a administração respeitando também os interesses públicos. Ora, é justamente o que defende Lima Lopes em sua análise acerca da necessidade de a administração se basear na legalidade para poder se respaldar com o novo modelo antiabsolutista e mais preocupado com os interesses coletivos.

Após, o estudante continua apontando os diversos posicionamentos entre os autores franceses. Não obstante, ao final chega à análise feita pelo Visconde de Uruguai sobre o tema, ou seja, que o contencioso administrativo nasce da natureza única das causas, já que a constituição estabelece que a separação dos poderes. Assim, a administração deixa de administrar quando entra no papel do contencioso e, para não se cair na anarquia na organização dos poderes, os atos da administração sobre atos administração não poderiam ficar de modo algum para outro poder.

Assim este estudante, ao final, consegue realizar uma análise mais atenta ao caso brasileiro, posto que Uruguai teria adotado a noção de que a administração é juiz e parte, pois mesmo que com inconvenientes, entregar o contencioso ao judiciário seria perder a independência. E, ao mesmo tempo, quando a administração é juiz e parte, há uma responsabilidade legal e fiscalização sob a qual ela deve ser submetida. Não obstante, ao final considera que no contencioso a administração não é juiz e parte.

Dentre os autores citados por este estudante estão Vivien, Macarel, Cabatour, Portalis, Laffeierre, Chauveau Henrion de Pansey, Visconde de Uruguai.

Ora, a análise destes três últimos estudantes acerca do contencioso administrativo apresenta diversas dificuldades de conseguir encontrar um limiar concreto entre a noção de juiz e parte da administração no contencioso administrativo. Não obstante, é muito positivo se atentar para a noção legalista mais forte deste último estudante, muito embora fosse ela mais intuitiva do que baseada em alguma doutrina ou compêndio, principalmente quando se observa sua conclusão, mais preocupada em não causar prejuízo ao particular com a atuação desregrada da administração. 
Assim, feitas esta análise específica deste material, é possível concluir alguns elementos importantes. Primeiramente, que o uso da Retórica é predominante em todas as dissertações, variando em tamanho e exagero, mas permanecendo como elemento comum do trato argumentativo daquele contexto histórico. Em outra medida, a análise possibilitou observar vários aspectos que se repetem, como o resguardo do interesse privado em detrimento de qualquer atuação abusiva do poder público, que deve se restringir a proteger os interesses públicos e não prejudicar o particular.

Além disso, também é possível depreender que havia um ecletismo de doutrinas e a mistura confusa de autores, sem nexo ou harmonia, muito mais funcionando como argumento retórico do que para conseguir delimitar devidamente o conceito. Da mesma forma, varia a noção da importância da lei na consagração da atuação da administração pública, desde aqueles que a desconsideravam até os que a apontavam como essencial, mesmo que de uma forma difusa e espontânea na análise.

É possível depreender que ainda a noção da ciência do Direito Administrativo estava em um processo de formação dos conceitos e dos seus instrumentos jurídicos, de forma que estava realmente acompanhando o contexto de formação do Estado burocrático brasileiro, ou seja, de uma forma desorganizada, com a atenção pela proteção dos interesses privados, mas ao mesmo tempo se denotou que não havia uma exaltação da figura do Imperador e, ainda, que havia alguns indícios de preocupação acerca de problemáticas públicas, notadamente da dissertação do aluno Joaquim Antonio Fernandes de Silveira, já dez anos após a elaboração da primeira these, de 1857 e, ainda, mais próximo das mudanças que começariam a ocorrer na década de 1870 no Brasil, com o crescimento de valores de infraestrutura e demandas públicas em geral

Por fim, é interessante notar que não há exatamente uma aplicação de silogismo jurídico por parte estes estudantes, ou seja, aplicar um raciocínio jurídico a uma norma. Normalmente ocorriam citações de doutrinas estrangeiras e, eventualmente, após haveria uma análise acerca da legislação, mas sem tentar buscar examinar comparativamente os dois âmbitos.

Assim, conclui-se a análise das dissertações, que apontam, conforme foi delimitado na parte final do segundo capítulo, que havia uma interpretação transitória 
entre o antigo modelo jusnaturalista e pré-liberal para noções de legalidade-formal e positivistas, de forma a se alcançar um pensamento jurídico do bacharel definido justamente por todos estes elementos incoerentes quando examinados caso a caso, mas que, no todo, formavam uma consistência para com o contexto de formação burocrática difuso e incipiente do Estado brasileiro, como também com relação aos interesses das camadas dominantes em manterem uma noção não muito crítica, presente aos problemas existentes na formação jurídica brasileira e, ainda, que mantivesse um ritual de distanciamento, rebuscamento e aparente neutralidade do Poder Judiciário para com quaisquer demandas sociopolíticas que buscassem a alteração do status quo.

Assim, as dissertações demonstram que, muitas vezes, embora aparecessem dúvidas e questionamentos dos estudantes para com o sistema jurídico com que eles deveriam enfrentar na profissão como bacharel, estas eram abafadas e acobertadas justamente por esta metodologia de ensino já devidamente tratada por esta dissertação de mestrado. 


\section{CONSIDERAÇÕES FINAIS}

Há alguns elementos importantes que foram tratados nesta dissertação a quais se fazem necessário fazer menção. Primeiramente, que a análise das fontes que tratam sobre o ensino jurídico da faculdade, bem como das dissertações de Direito Administrativo permitem alcançar uma compreensão mais aprofundada desse universo acadêmico, que deixa claro não haver somente a produção de conhecimento jurídico extracurricular, nos jornais, nas discussões nas arcadas. Ora, esta grande faceta de produção cultural do bacharelismo não exclui, como se pode perceber, o desenvolvimento de um tipo pensamento jurídico naquela Academia.

Em verdade, é um estudo que possibilita abrir novos horizontes de pesquisa sobre o ensino jurídico, o Direito Administrativo e a própria história da cultura jurídica brasileira, pois abrange um universo de fontes tais como compêndios, legislação, memórias acadêmicas, dissertações dos estudantes, anais do congresso, que permitem entrelaçar o desenvolvimento do ensino jurídico no século XIX no Brasil com a construção da cultura jurídica e, ainda, relacionar ao contexto jurídico-administrativo de construção do Estado nacional.

Nesse sentido, se procurou comprovar a hipótese geral é de que há indícios de uma produção de pensamento administrativista dentro do ambiente acadêmico justamente onde se formariam muitos dos bacharéis participantes não só da construção do Estado brasileiro, mas da formação do cotidiano jurídico e social da população em geral. Além disso, muito embora a influência europeia no estudo científico fosse considerável, ela era não impedia o país de traduzir elementos do desenvolvimento da ciência do Direito Administrativo genuinamente brasileiros, principalmente, quando se atenta para a segunda metade do século XIX.

Ou seja, era uma área do conhecimento que, ao mesmo tempo em que consagrava deveres e direitos da Administração e dos Administrados em relação aos diversos âmbitos jurídicos, desde a noção de centralização até a discussão sobre se 
deveria ou não haver a separação entre o contencioso jurídico e o administrativo, ela também abrangia uma lógica interpretativa específica para o caso brasileiro, em que estavam ainda em formação as bases legais e materiais da organização do Estado.

Aliada a esta premissa maior, desenvolveu-se a hipótese singular de que - a partir da leitura dinâmica das fontes e do olhar histórico-crítico atento a alguns conceitos discutidos nas dissertações dos estudantes e, ainda, a partir da noção complexa de que o sistema jurídico se constitui como uma força ideológica reflexo do domínio das estruturas econômicas e políticas de poder - o estudante de Direito médio que passou pela faculdade de São Paulo de 1860 apreendeu, em alguma medida, um raciocínio jurídico definido, universal, ativo e coerente com relação ao contexto social, político e dogmático que existia no Brasil daquele tempo.

Assim, foi um ensino definido porque era particular àquele espaço e período de tempo. Não exatamente por sua original raridade científica, mas porque há indícios pela análise dos documentos históricos - reflexos da relação cotidiana de ensino e dos atos de aprovação tais como as dissertações - de que se desenvolvia uma dinâmica determinada de apreensão e uso de conceitos jurídicos que representavam inúmeros elementos do desenrolar daquela sociedade política e administrativa. Por isso era, também, um raciocínio jurídico ativo, em movimento e relacional com seu contexto de discussão jurídica brasileira.

Universal porque a própria análise crítico-histórica da formação linguística de "bacharel" compreendia inúmeros significado históricos que formaram um todo semântico, qual seja, o conceito de um jovem que exerceu vários níveis de aprendizado que proporcionaram conhecimentos ultrajurídicos ${ }^{213}$, posto que recitava poesias ao mesmo tempo em que formava grupo de estudos para se preparar para as sabatinas, era grande orador que conclamava o seu "justo" e "correto" politicamente ao mesmo tempo em que era gago e não ia bem nos atos orais, era um músico vadio ao mesmo tempo em que já casara e se formara em outra área de ensino. Universal porque foi um raciocínio jurídico que se formou em tempos de Romantismo cultural em meio a um vazio de produção intelectual e de incipiente formação estatal.

\footnotetext{
${ }^{213}$ Ultra jurídico no sentido de que compreendia um conhecimento que ia além do raciocínio jurídico e incluía, também, saberes políticos, literários, dramáticos, de retórica.
} 
Coerente porque era um pensamento jurídico compatível com o contexto de desenvolvimento sociopolítico porque passava o país naquele contexto. Assim, era coerente porque reproduzia, em alguma medida, certos interesses de classe. Não porque era algo premeditado, mas porque o ambiente acadêmico fazia parte de um poder simbólico maior, um jogo de interesses pelo domínio do conhecimento jurídico e da manipulação da linguagem jurídica.

Dessa forma, conclui-se esta dissertação de mestrado incitando pela releitura da literatura quanto à noção histórica do papel do bacharel dentro da formação da cultura jurídica brasileira para que se caminhe para além de maniqueísmos, mas se atente para a história vista de baixo, a partir de uma noção humana, do cotidiano corriqueiro do funcionamento do ensino jurídico. Assim, novas melodias históricas e harmonias de análise poderão ser firmadas a fim de compreender a formação da cultura jurídica Brasileira. 


\section{BIBLIOGRAFIA}

\section{FONTES PRIMÁRIAS}

Anais da Câmara dos deputados. sessões de 4 de set. e 4 de out. de 1877

Decreto de 7, de Novembro de 1831;

Decreto $n^{\circ} 23$, de 30 de Agosto de 1834;

Decreto $n^{\circ} 34$, de 16 de Setembro de 1834;

Decreto $n^{\circ} 42$, de 19 de Agosto de 1837;

Decreto $n^{\circ} 124$ de 1841

Lei $\mathrm{n}^{\circ} 581$ de 1850

Decreto $\mathrm{n}^{\mathrm{o}}$ 714, de 19 de Setembro de 1853;

Decreto $n^{\circ} 1134$, de 30 de Março de 1853;

Decreto $\mathrm{n}^{\circ}$ 1386, de 28 de Abril de 1854;

Decreto $\mathrm{n}^{\mathrm{o}}$ 1568, de 24 de Fevereiro de 1855;

Decreto $\mathrm{n}^{\circ} 2879$, de 23 de Janeiro de 1862;

Decreto $\mathrm{n}^{\circ} 4675$, de 14 de Janeiro de 1871;

Decreto $n^{\circ} 4806$, de 22 de Outubro de 1871;

Lei de 11 de Agosto de 1827;

Regulamento Complementar dos estatutos das faculdades de direito, expedido na conformidade do $\S 3^{\circ}$ do art. 21 do decreto $\mathrm{n}^{\mathrm{o}} 1386$ de 28 de Abril de 1854;

Relatório da Repartição dos Negócios da Justiça apresentado à Assembleia Geral Legislativa, sessão ordinária, 1832. p. 13-14.

Provas de Direito Administrativo da Faculdade de Direito de São Paulo entre os anos de 1857 e 1870, Biblioteca Central da Faculdade de Direito da Universidade de São Paulo, São Paulo.

Projeto de Regulamento ou Estatuto para o Curso Jurídico pelo Decreto de 9 de Janeiro de 1825 .

A IMPRENSA periódica de São Paulo desde seus primórdios em 1823-1914. in: Revista do Instituto Histórico e Geográfico de São Paulo. v. 19, São Paulo: Tipografia do Diário Oficial, 1915.

CARVALHO, Carlos Leôncio de. Memória histórica da faculdade de direito de São Paulo. São Paulo, v. 2, 1971. 
MEMÓRIA histórica dos acontecimentos notáveis da Faculdade de Direito de São Paulo, durante o ano de 1862; aprovado na parte histórica pela congregação da mesma Faculdade, dia 2 de mar. de 1863. São Paulo: Typ. Imparcial.

NABUCO, Joaquim. Um estadista do império: Nabuco de Araújo. Rio de Janeiro: B. L. Garnier. v. 1, 1873.

NOGUEIRA, J. L. Almeida. A academia de São Paulo: tradições e reminiscências: estudantes, estudantões e estudantadas. São Paulo: Vanorden, v 1-9, 1. Ed. 1907.

RECORDAÇÕES históricas. in: Correio paulistano. 2 de set, 1905.

REZENDE, Francisco de Paula Ferreira de. Minhas Recordações. Rio de Janeiro: J. Olympio, 1944.

RIBAS, Antonio Joaquim. Direito Administrativo Brasileiro. Brasília: Ministério da Justiça, 1968.

VAMPRÉ, Spencer. Memórias para a história da academia de São Paulo. 2 Ed. São Paulo: INL, Conselho Federal de Cultura, 1977.

VEIGA CABRAL, G. T. Direito Administrativo Brasileiro. v 1 in $8^{\circ}$, Rio de Janeiro: Laemmert, 1859.

VIEIRA BUENO, F. de Assis. Autobiografia. s/Ed. Campinas, 1899.

ZALUAR, Augusto Emílio. Peregrinação pela província de São Paulo. 1. Ed., São Paulo: Garnier, 1862.

\section{LITERATURA}

ADORNO, Sérgio. Aprendizes do poder. Rio de Janeiro: Paz e Terra, 1988.

ALENCASTRO, Luiz Felipe. O fardo dos bacharéis. São Paulo: Novos Estudos Cebrap, n. 19, dez 1987.

BARROS, Roque Spencer Maciel de. A ilustração brasileira e a ideia de universidade. São Paulo: Universidade de São Paulo, 1959.

BARROSO, Gustavo. História secreta do Brasil: primeira parte: do descobrimento à abdicação de D. Pedro I. 2. Ed, São Paulo: Nacional, 1937.

BLAKE, Sacramento. Diccionario Bibliografico Brazileiro. Rio de Janeiro: Imprensa Nacional, v. 1, 1883.

BOLFARINE, Heleno; BUSSAB, W. de Oliveira. Elementos de amostragem. São Paulo: Editora Edgar Blücher: USP. 2005.

BOSI, Alfredo. A Construção Nacional: 1830-1889. in: SCHWARCZ, Lilian Mortiz (Org.). História do Brasil Nação: 1808-2010. Rio de Janeiro: Ed. Objetiva, 2012. 
BOURDIEU, Pierre. O Poder Simbólico, Rio de Janeiro: Bertrand Brasil, 1992.

BURKE, Peter (Org). A escrita da história: novas perspectivas. São Paulo: Editora UNESP, 2011.

CARONI, Pio. La solitudine dello storico del diritto. in: Per la storia del pensiero giuridico moderno. VIII, 2009.

CARVALHO, José Murilo de. Os bestializados: o Rio de Janeiro e a república que não foi. São Paulo: Companhia das Letras, 1987.

A formação das almas: o imaginário da república no

Brasil, São Paulo: Companhia das Letras, 1990. 13ª reimpressão. 2003.

. A construção da ordem: a elite política imperial; Teatro

de sombras: a política imperial. Rio de Janeiro: Civilização Brasileira, 3 Ed, 2007.

Bernardo Pereira de Vasconcelos. Rio de Janeiro: Ed.

34, 1999.

CASSESSE, Sabino. Il diritto amministrativo: storia e prospettive. in: Per la storia del pensiero giuridico moderno. VIII, 2010.

CAVAlCANTI, Themistocles Brandão. Apresentação in: Paulino Soares de Souza, Ensaio sobre o Direito Administrativo. Rio de Janeiro: Imprensa Nacional, 1960.

CHALOUB, Sidney. Visões da liberdade: uma história das últimas décadas da escravidão na corte. (tese de doutorado). Campinas: UNICAMP, 1989.

COELHO, Edmundo Campos. As profissões imperiais: medicina, engenharia e advocacia no Rio de Janeiro 1822-1930, Rio de Janeiro: Record, 1999.

COSTA, Pietro. Lo stato immaginario: metafore e paradigmi nella cultura giuridica fra ottocento e novecento. in: Per la storia del pensiero giuridico moderno. VIII. 1986.

DOLHNIKOFF, Miriam. O pacto imperial: origens do federalismo no Brasil. São Paulo: Editora Globo, 2007.

FALCÃO NETO, Joaquim de Arruda. A reforma do ensino jurídico, Rio de Janeiro: Cadernos PUC, $n^{0} 3 / 4,1974$.

FAORO, Raymundo. Os donos do poder: formação do patronato político brasileiro, 3 Ed. Revista, 2001.

FAUSTO, Boris. História do Brasil. São Paulo: EDUSP, 12 Ed, 2007.

FILHO, Alberto Venâncio. Organização da Faculdade de Direito da Universidade de Brasília, Educação e Ciências sociais. Ano VI, v 9, n 16, Jan/abril, 1961.

- Das arcadas ao bacharelismo, 2 Ed, São Paulo:

Perspectiva, 2005. 
FIORAVANTI, Maurizio. La scienza del diritto publico: dottrine dello stato e della costituzione tra otto e novecento. Milano: Giuffrè, 2001, 2 v.

FOUCALT, Michel. Arqueologia do saber. Rio de Janeiro: Forense Universitária, 7. Ed. 2007. . A ordem do discurso, São Paulo: Loyola, 1995. . A microfísica do poder. 16 Ed. Rio de Janeiro: Graal. 2001.

FRANCO, Afonso Arinos de Melo. A alma do tempo:memórias, formação e mocidade. 1. Ed, Rio de Janeiro: J. Olympio, 1961.

FREYRE, Gilberto. Sobrados e mucambos : decadência do patriarcado rural e desenvolvimento do urbano. 2 Ed. Rio de Janeiro: José Olympio, 1951.

GUANDALINI JR., Walter. Gênese do direito administrativo brasileiro: formação, conteúdo e função a ciência do direito administrativo durante a construção do Estado no Brasil imperial. Tese (Doutorado em Direito), Paraná: UFPR. 2011.

GRAMSCI, Antônio, Os Intelectuais e a organização da cultura, Rio de Janeiro: Civilização Brasileira, 1968.

HESPANHA, Antonio Manuel. Cultura jurídica europeia: sintese de um milénio Coimbra: Almedina, 2012.

HOLLANDA. Sérgio Buarque de. Raízes do Brasil, 13 Ed, Rio de Janeiro: J. Olympo, 1979. ( (Org). História geral da civilização brasileira. Tomo II: O Brasil monárquico. vol. 3: Reações e transações. 1976. São Paulo - Rio de Janeiro: Difel, 3 Ed.

HORTA, L. P. Villa-Lobos: uma introdução. Rio de Janeiro: Jorge zahar, 1987.

JÚNIOR, Antônio de Almeida. Sob as Arcadas. Rio de Janeiro: Ministério da Educação. 1965.

KOSSELECK, Reinhart. Futuro passado: contribuição semântica dos tempos históricos. Rio de Janeiro: Contraponto: Ed. Puc-Rio, 2006.

LAGO, Manoel A. C. do. (Org.). O boi no telhado: Darius Milhaud e a música brasileira no modernismo francês. São Paulo: Instituto Moreira Salles. 2012.

LIMA LOPES, José Reinaldo de. O direito na história: lições preliminares. São Paulo: Max Limonad, 2000. . O oráculo de delfos: o Conselho de Estado no Brasil.

São Paulo: Saraiva, 2010. 
MANGABEIRA UNGER, Roberto. Uma Nova Faculdade de Direito no Brasil. in: Mímeo. Fundação Getúlio Vargas, 2003.

MANNORI, Lucca; SORDI, Bernardo. Storia del diritto amministrativo, Bari, Laterza, 2001.

MANNORI, Lucca. Per una preistoria della funzione amministrativa, Cultura giuridica ed attività dei pubblici apparati nell'età del tardi diritto comune. in: Quaderni fiorentini per la storia del pensiero giuridico moderno, v. 19,1990.

MOTA, Carlos Guilherme. Ideologia da cultura brasileira: 1933-1974. São Paulo: Editora 34, 2008. v. 1.

MOTA FILHO, Candido. A vida de Eduardo Prado. Rio de Janeiro: livraria J. Olympio, 1967.

NOBREGA, A. As bachianas de Villa-Lobos. Rio de Janeiro: MEC: Museu VillaLobos, 1971.

PAULA, João Antônio de. A Construção Nacional: 1830-1889. in: SCHWARCZ, Lilian Mortiz (Org.). História do Brasil Nação: 1808-2010. Rio de Janeiro: Ed. Objetiva, 2012.

ROMANO, Santi, Principii di diritto amministrativo italiano, Milan: Società Editrice Libraria.

SALDANHA, Nelson Nogueira. História das ideias políticas no Brasil. Recife: Imprensa Universitária da Universidade Federal de Pernambuco, 1968.

SCHWARCZ, Lilian Mortiz. As barbas do Imperador: D. Pedro II, um monarca dos trópicos. 2. Ed. São Paulo: Companhia das Letras

SORDI, Bernardo. Giustizia e Amministrazione nell'Italia Liberale: la formazione della nozione di interesse legittimo. in: Per la storia del pensiero giuridico moderno. VIII. 1985.

, L'amministrazione Illuminata. Riforma delle Comunità e progetti di Costituzione nella Toscana leopoldina, 1991, $8^{\circ}$.

TOUZEIL-DIVINA, Mathieu. Eléments d'Histoire de l'Enseignement du Droit Public: la Contribuition du Doyen FOUCART (1799-1860), Université de Poitiers, 2007.

VIANNA, Francisco José de Oliveira. O idealismo da constituição. 2. Ed, São Paulo: Nacional, 1939.

WEBER, Max. WEBER, Max. Economia e sociedade: fundamentos da sociologia compreensiva. v. 2, Brasília: Editora Unb, 1999. 
WOLKMER, Antônio Carlos. (Org.) Fundamentos de história do direito. Belo Horizonte: Del Rey, 2007.

WOLKMER, Antônio Carlos. Introdução ao pensamento jurídico crítico. São Paulo: Editora Acadêmica, 1995. . História do direito no Brasil. Rio de Janeiro: Forense, 3.

Ed., 2005.

ZALUAR, Augusto Emílio. Peregrinação pela província de São Paulo. 1. Ed., São Paulo: Garnier, 1862.

. A FUNÇÃO social da dogmática e a crise do ensino e da cultura jurídica brasileira. in: Revista de Ciências Sociais, Rio de Janeiro: IUPERJ. 21, 1979.

A HISTORY of the Philosophy of Law in the Civil Law World, 1600-1900. In: HOFMANN, Hasso; GROSSI, Paolo; CANALE, Damiano (org). A treatise of legal philosophy and general jurisprudence, NewYork: Springer. v. 9.

A IMPRENSA periódica de São Paulo desde seus primórdios em 1823-1914. in: Revista do Instituto Histórico e Geográfico de São Paulo. v. 19, São Paulo: Tipografia do Diário Oficial, 1915.

. A TREATISE of legal philosophy and general jurisprudence. in: HOFMANN, Hasso; GROSSI, Paolo; CANALE, Damiano. A history of the philosophy of law in the civil law world: 1600-1900. v. 9, NewYork, Springer.

. ANAIS do I Seminário sobre o ensino jurídico: círculo do ensino jurídico em Brasília. in: Instituto dos Advogados Brasileiros, Rio de Janeiro: Borsoi, 1969.

. ANÁLISE histórica do ensino jurídico no Brasil. in: Cadernos da Unb: Ensino Jurídico. Editora Universidade de Brasília, 1978-1979.

. CATEGORIAS: uma reflexão sobre a prática de classificar. Análise Social, v. XXXVIII (168), 2003.

. EDUCAÇÃO e modernidade no Brasil, in: Cultura Vozes, São Paulo. v. 93, n $1,1999$.

O ENSINO Jurídico no Brasil e as suas personalidades históricas: uma recuperação de seu passado para reconhecer seu futuro. In: Ensino jurídico OAB: 170 anos de cursos jurídicos do Brasil. Brasília: Conselho Federal da Ordem dos Advogados do Brasil, 1997.

HISTÓRIA intelectual no Brasil: a retórica como chave de leitura. in: Topoi. Rio de Janeiro, n. 1. 2006. 
. MEMÓRIA histórica dos acontecimentos notáveis da faculdade de direito de São Paulo, durante o ano de 1862; aprovado na parte histórica pela congregação da mesma Faculdade, dia 2 de mar. de 1863. São Paulo: Typ. Imparcial, 1863.

. NOTAS sobre a história jurídico-social de Pasárgada, in: SOUTO, Claudio; FALCÃO, Joaquim (org.), Sociologia e Direito. São Paulo: Livraria Pioneira Editora, 1980.

. O DIREITO administrativo e o governo activo: 1800-1910. in: Revista de História das Ideias. v. 26, p. 119-123.

. O ENSINO jurídico nos pareceres de Rui Barbosa. Estudos Universitários. in: Revista da Universidade Federal de Pernambuco, v 9, n 1, Jan./mar., 1969.

. O ESTADO e a formação dos currículos jurídicos do Brasil, in: Os cursos jurídicos e as elites brasileiras, Brasília: Câmara dos Deputados, 1978.

. OS JURISTAS como couteiros: a ordem na Europa ocidental dos inícios da idade moderna. In: Instituto de Ciências Sociais da Universidade de Lisboa, Análise Social, v. XXXVI (161), 2001.

. OS JURISTAS e a cultura jurídica brasileira na segunda metade do século XIX. Quaderni Fiorentini per la storia del pensiero giuridico moderno, Milano, Giuffrè, n. 35, 2006.

- QUADERNI Fiorentini di Centro di Studi per la Storia del Pensiero Giuridico Moderno della Universià degli Studi di Firenzi. milano: Giuffrè v. I a 40.

. REFORMA do Ensino Jurídico: Carta do Professor Braz de Souza Arruda. in: Revista da Faculdade de Direito da Universidade de São Paulo. v 53, 1958.

. SAN TIAGO Dantas e o ensino jurídico. In: Revista do Instituto do Açúcar e do Álcool. 120, Jan./mar., 1973.

. SAN TIAGO Dantas - Pensador do Direito. in: Cadernos de Pós-graduação da Faculdade de Direito da UERJ, Ano I, nº 1, set./1995.

. SOBRE O ENSINO do Direito e suas relações com as ciências políticas e econômicas. in: VIII Congresso de Direito Comparado. Upsala, Suécia. ago./1966.

. 500 ANOS de Direito Administrativo brasileiro. in: Revista da Procuradoria Geral do Estado da Bahia. Brasília: ENAP, v. 26, n. 2, 2000. 


\section{AneXos}

Anexo 1 - Modelo de capa padrão utilizado pelos estudantes nas dissertações de Direito.

Anexo 2 - Dissertação de Direito Administrativo de Americo de Moura Marcondes de Andrade .

Anexo 3 - Dissertação de Direito Administrativo de João da Rocha Miranda.

Anexo 4 - Dissertação de Direito Administrativo de Joaquim Antonio Fernandes de Silveira.

Anexo 5 - Dissertação de Direito Administrativo de Antonio Quirino.

Anexo 6 - Dissertação de Direito Administrativo de Augusto Freire da Silva.

Anexo 7 - Dissertação de Direito Administrativo de Marcellino de Assis Tostes.

Anexo 8 - Dissertação de Direito Administrativo de Estevam Ribeiro de Souza Rezende.

Anexo 9 - Dissertação de Direito Administrativo de Feliciano de Souza Ribeiro

Camargo.

Anexo 10 - Dissertação de Direito Administrativo de Luis Eugenio Horta Barbosa. 
Anexo 1 - Modelo de capa padrão utilizado pelos estudantes nas dissertações de Direito

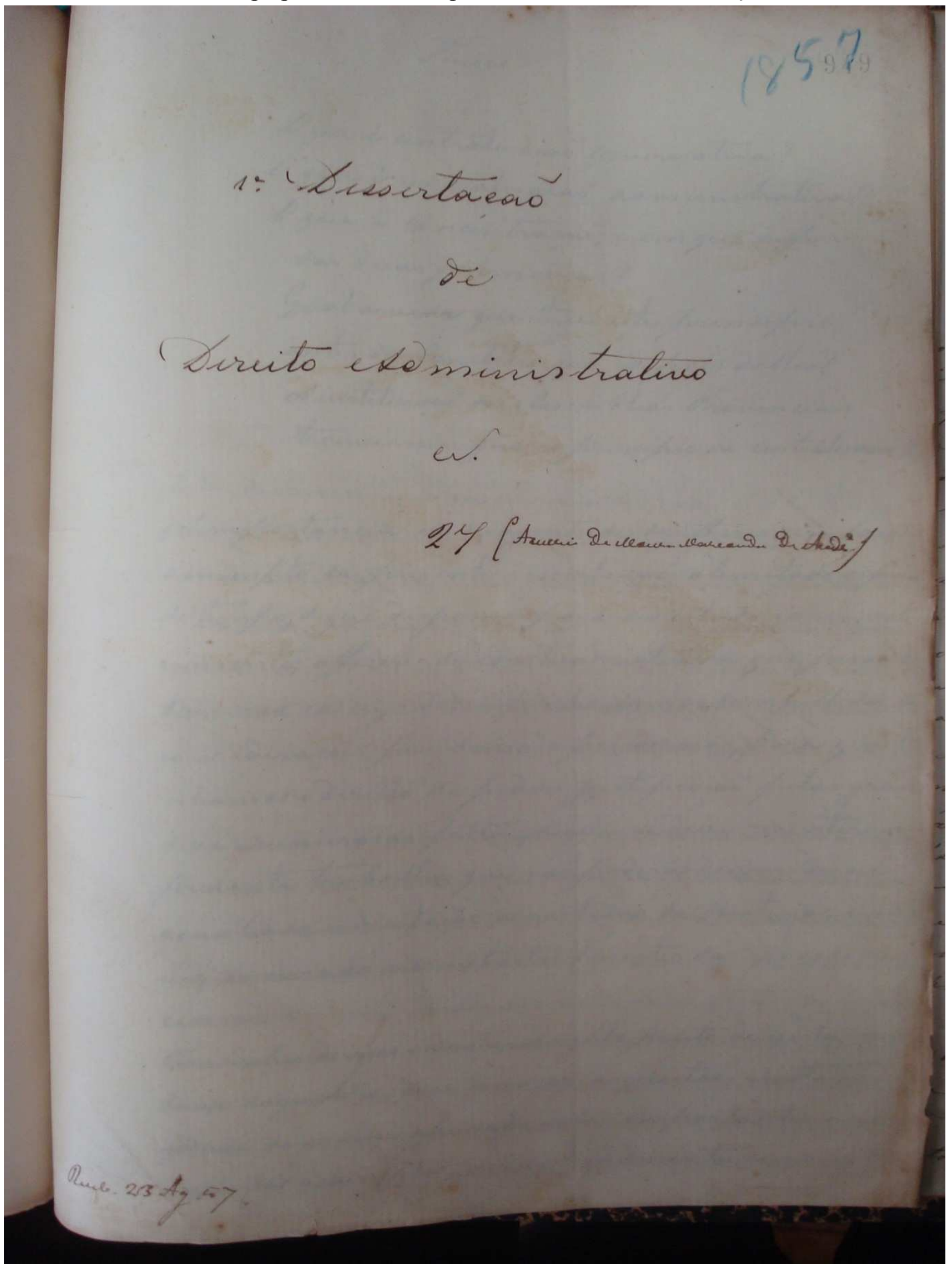


Anexo 2 - Dissertação de Direito Administrativo de Americo de Moura Marcondes de

\section{Andrade}

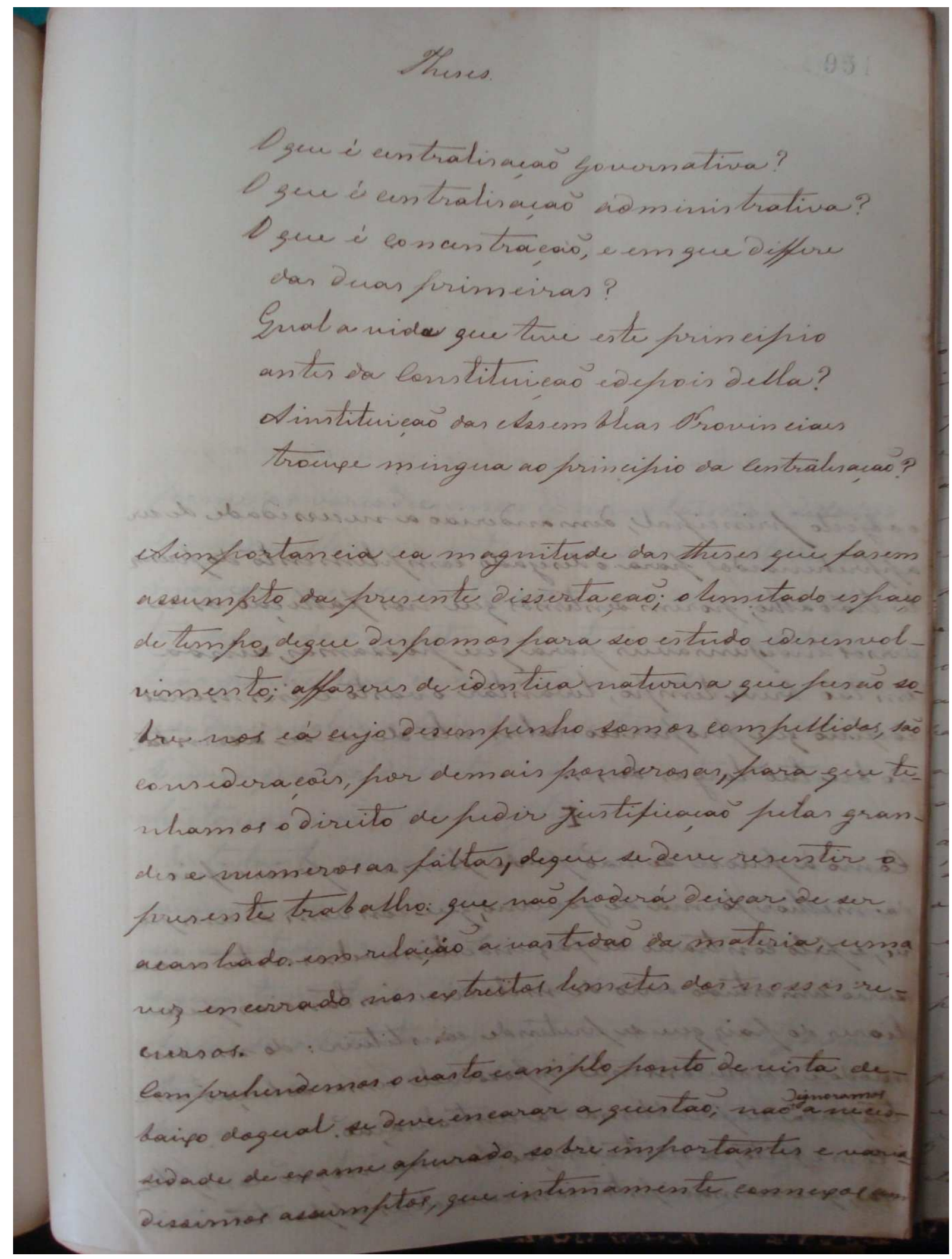


227

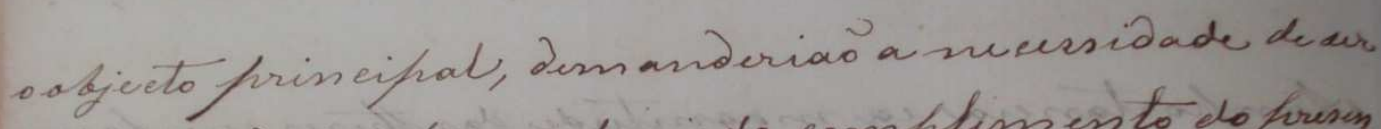
affrichinaidas frara o des jado eam fliss ess to do freson te trabatho; foriss sentisnos gere nos fallecio os re

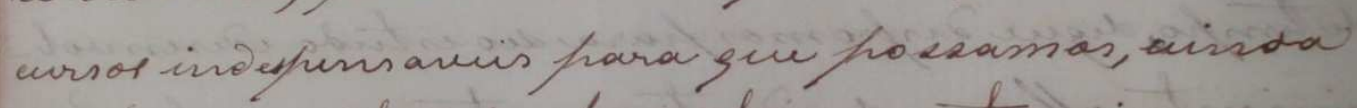
iss tao brive tempro, hivintar ovasto e insisienso'

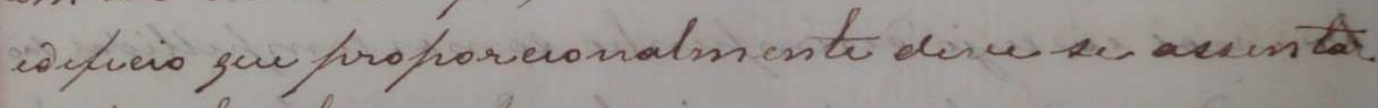
Lo bre tao largas bases.

I

Como à firiori se now pable firmar ofrin cifio

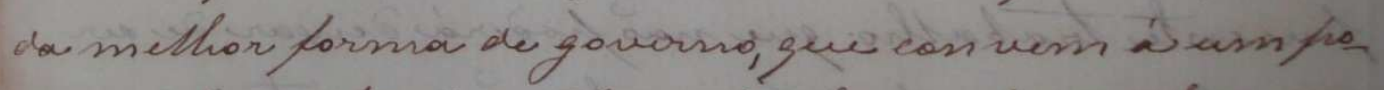

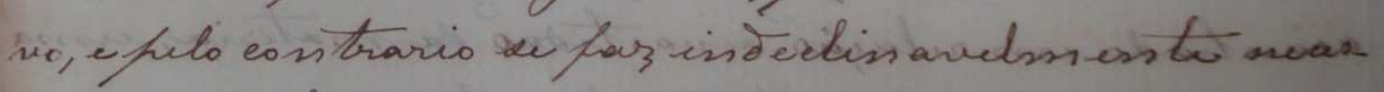
sario um estudo durio de mil circums tasscias fuav

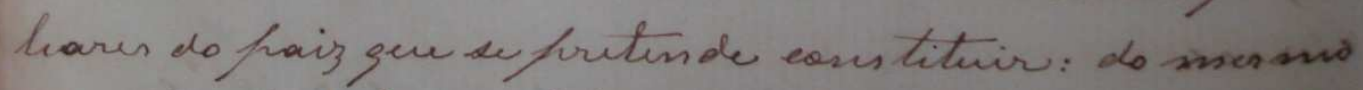

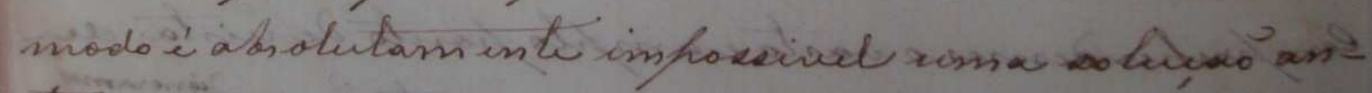

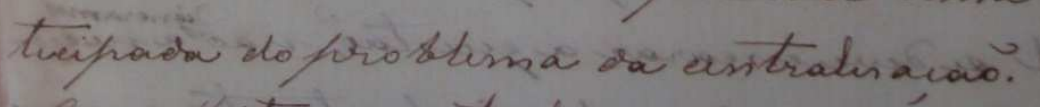

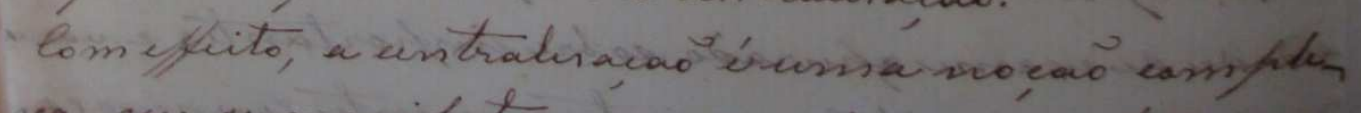
ya, gue wi manifis ta cam caracteres ofías tos cans 
228

forme as variadiesins as èreunis tancias debaifo de erja influens eia activa. Ds seos resultadas sao

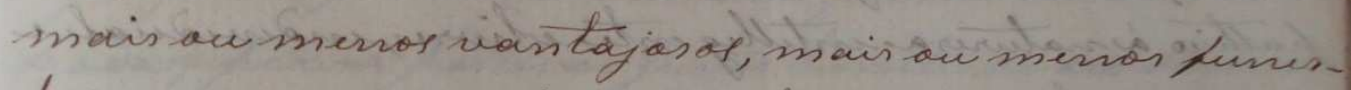
tor segundos caracter as cos turnes, as haditas i ou tras farticulares eircums lanseias, sob as geiaus nive

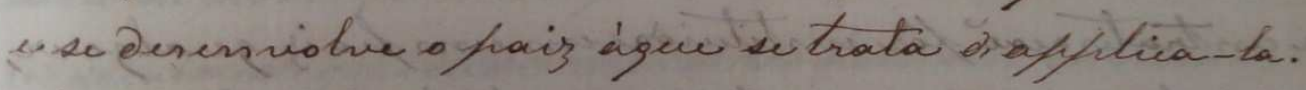
Euma geustao de facto enao dedireito, frertissece a historia enio ás fhitas fhia.

In tutanto, canno 2 is Paseat, tiv as socico ades now vivern des do momiento en que a tess desterrado do

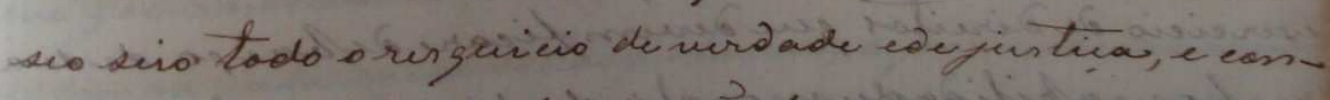
seguintemente in bara nao fiscamas acoiziar Lanidade abioluta a gualgeur forma de geverme

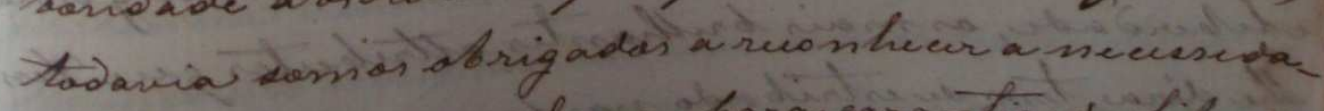

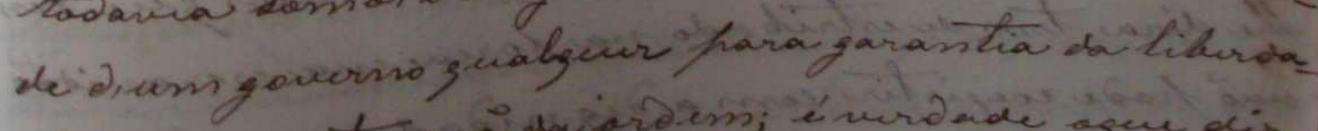

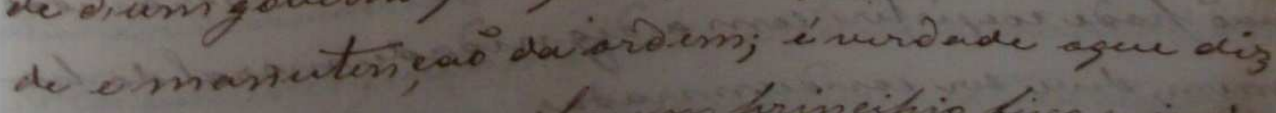

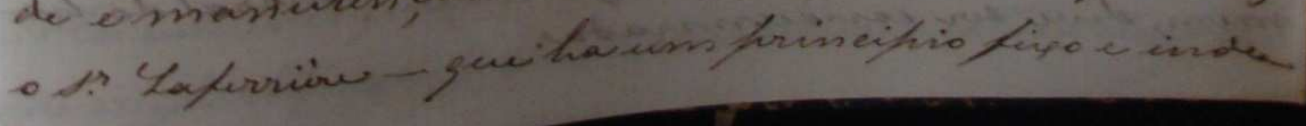


229

dissanel, que derre frescotis à todas as modas diarga-

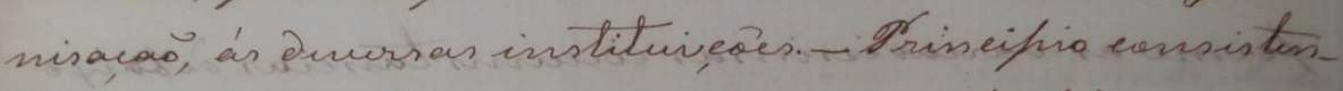

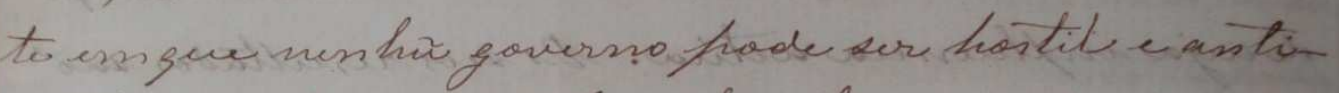
frattico à natures a intilly ente chive, indervidiale sociat do homem.

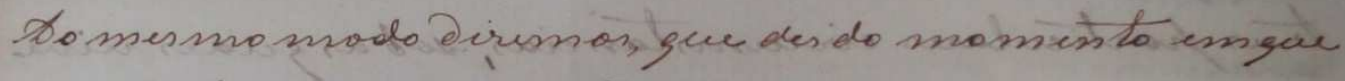

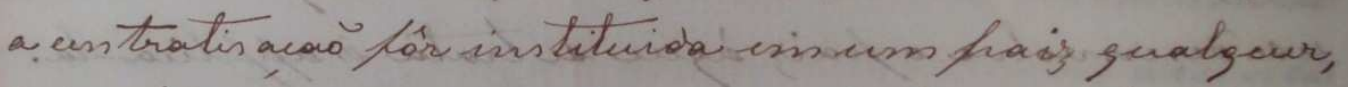

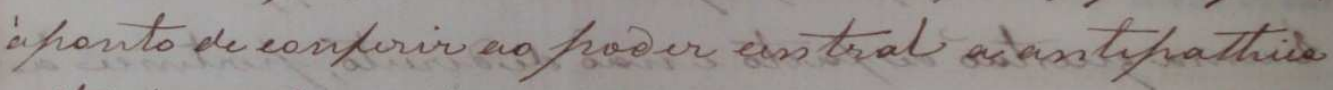

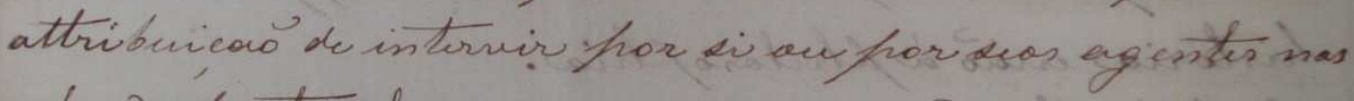
relavis frartieulares, nos negocios indinberpen docic cuavo, fristabeleundo as rigras de sua canowetaino upereicio de direitos gue derem fiear delabipa de civa rufromabilidade moral; ses do mopress to emgore

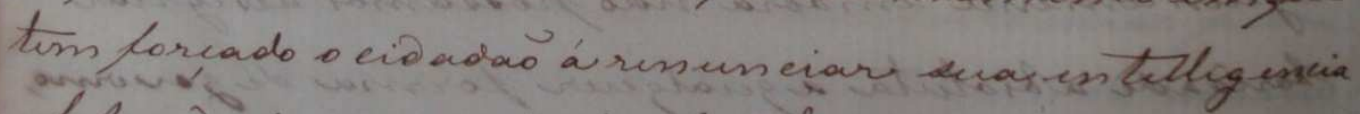

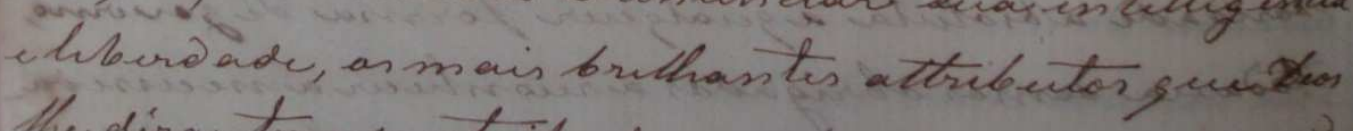
the dira, tem avestrib ado na forca enareperaviduse

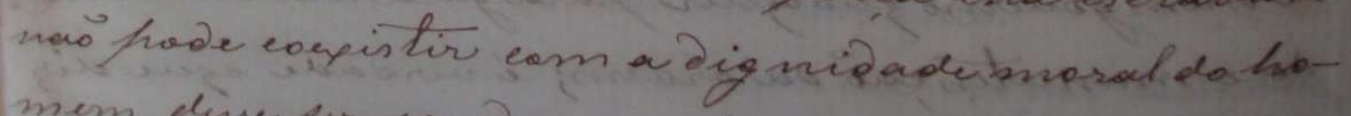
mem, dive ker candemsada. 


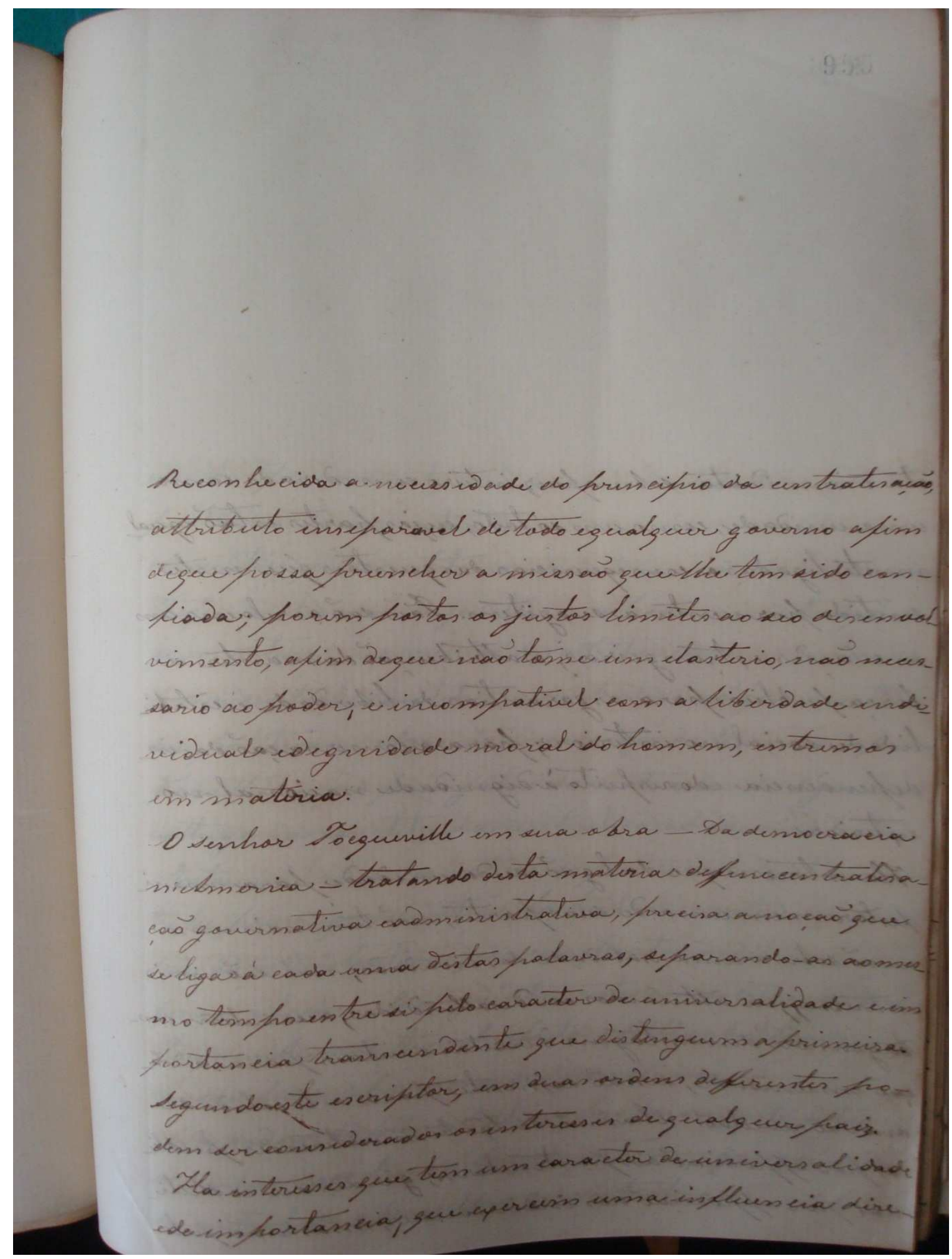




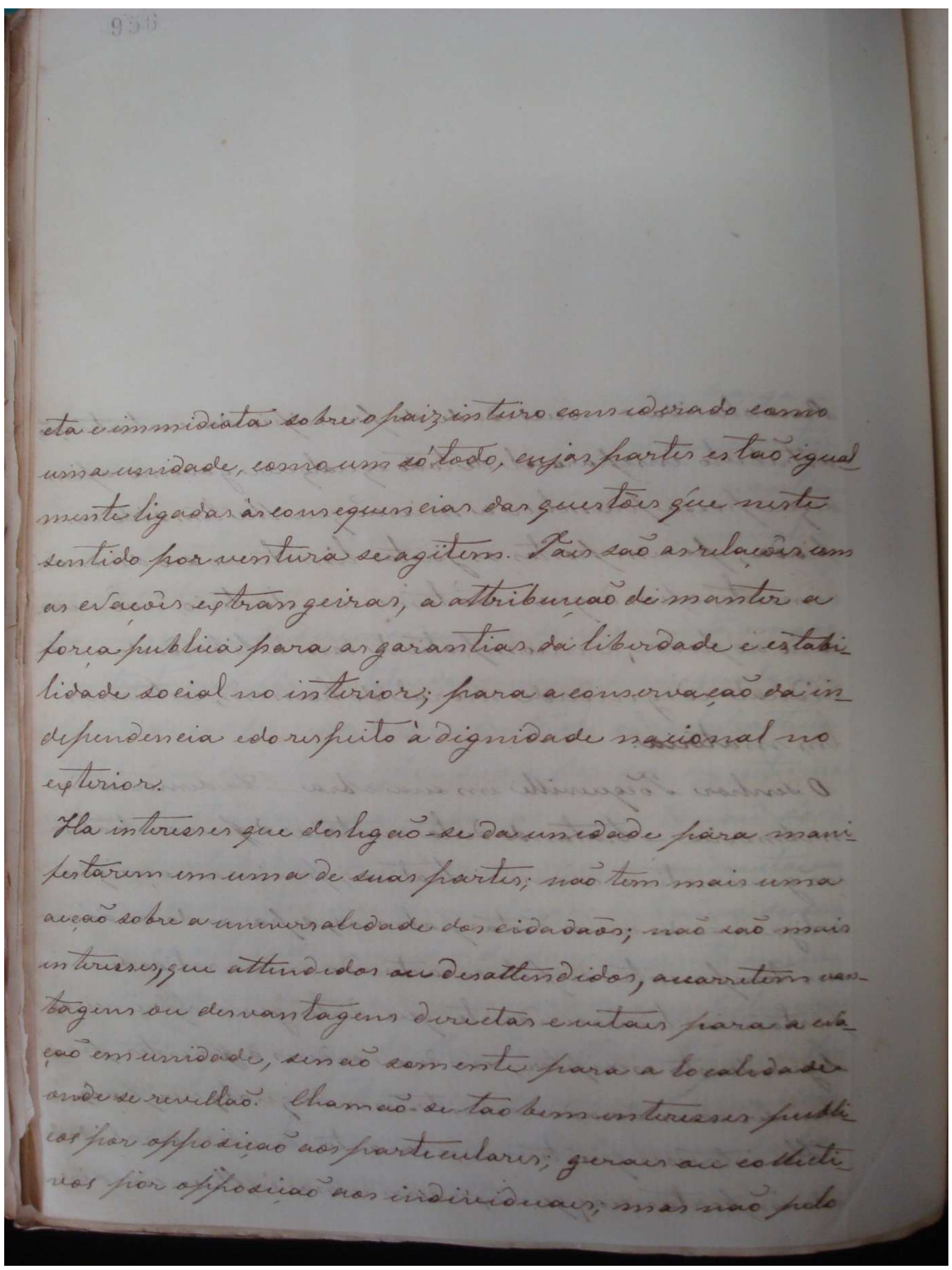




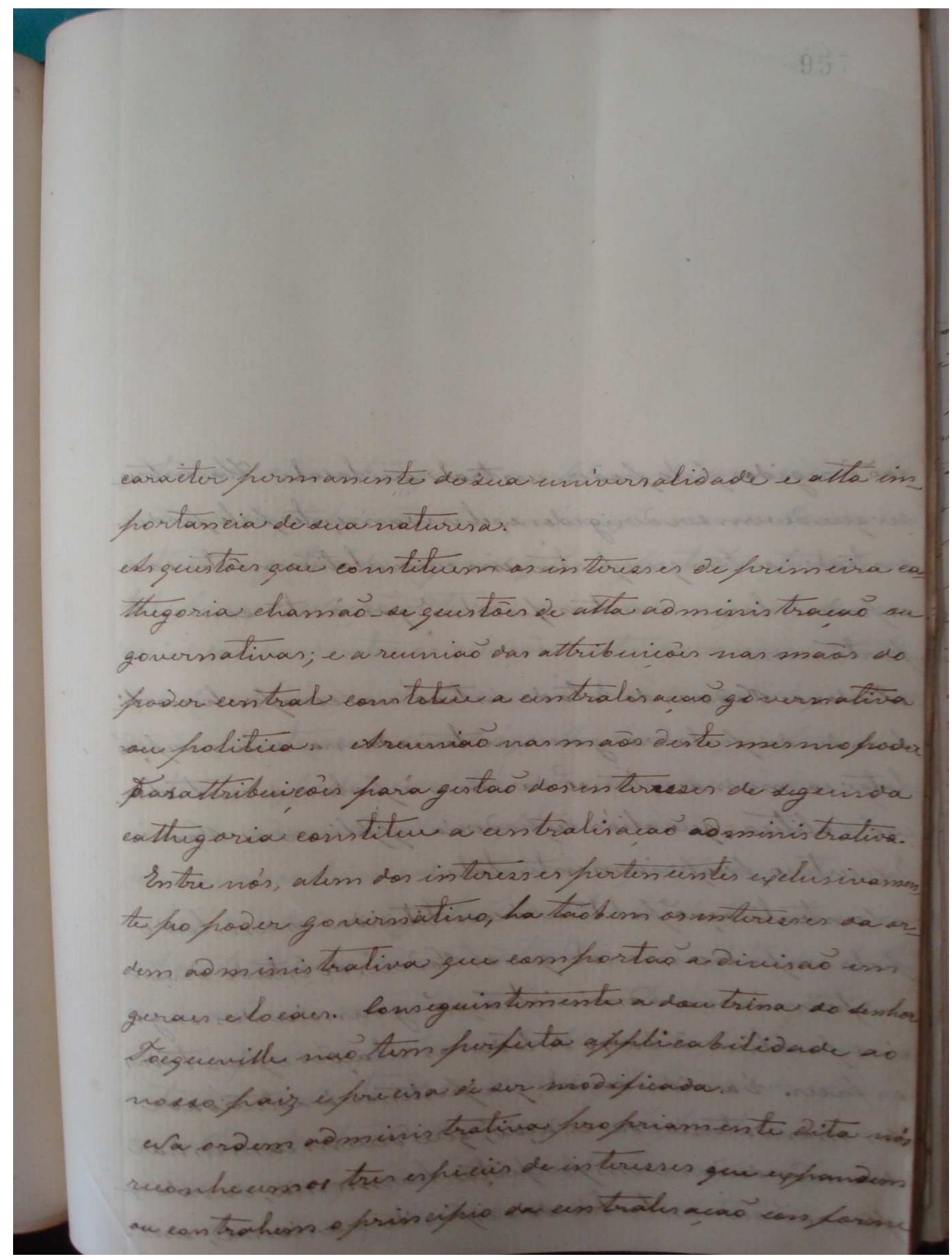




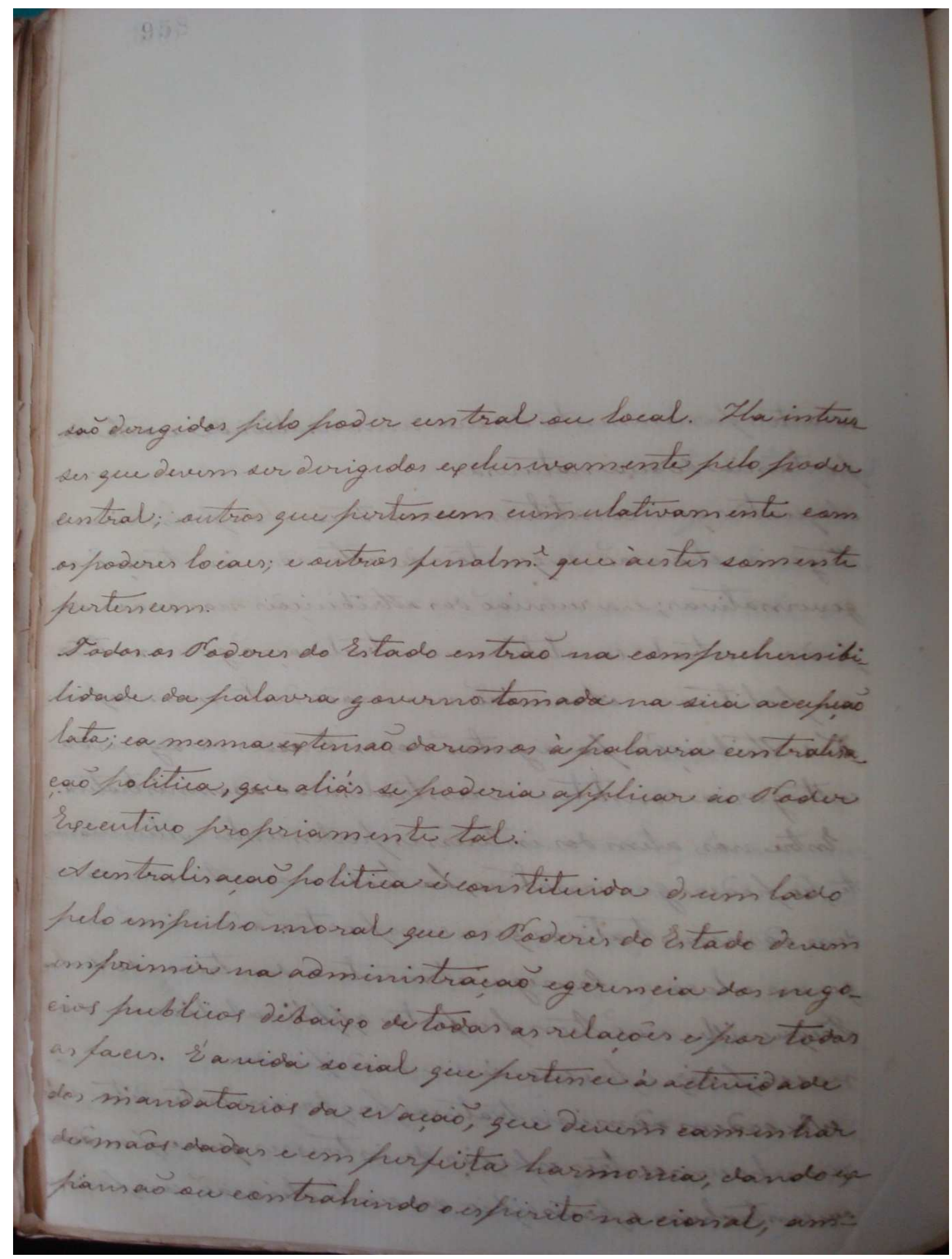




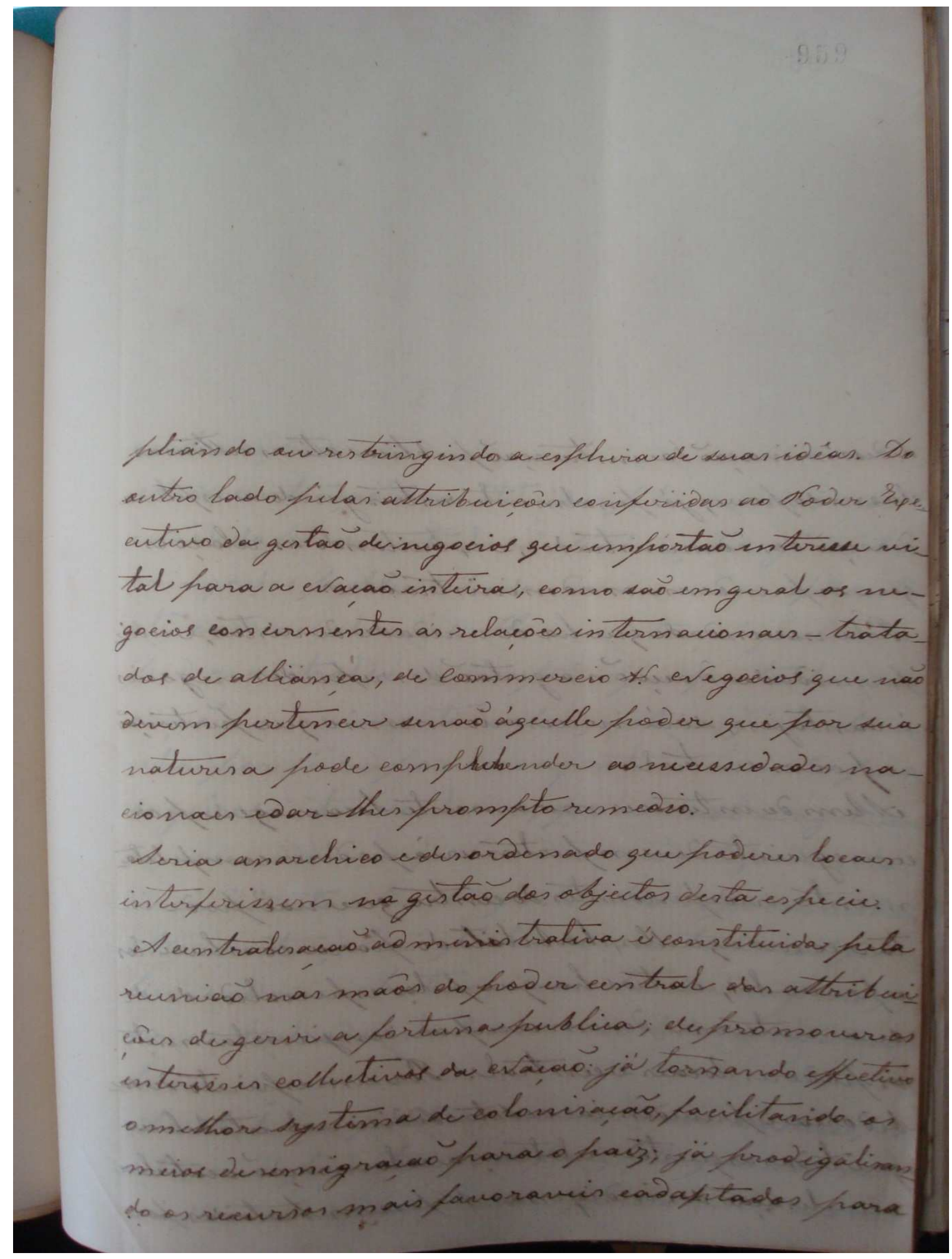




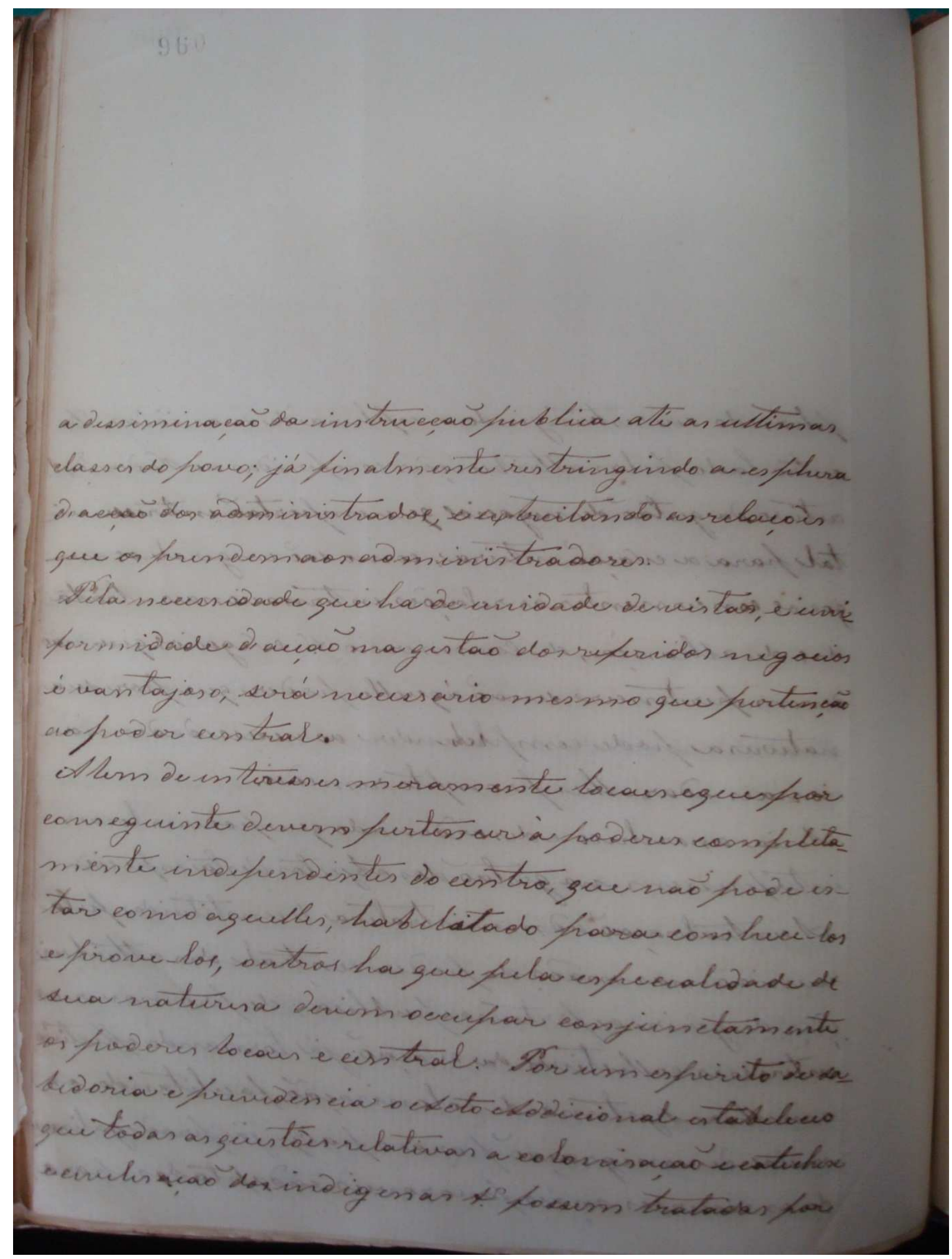


236

ambos exfroderes.

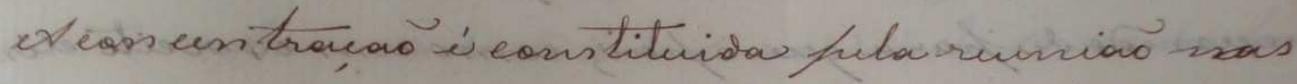
mar do foder entral da attribuievo de gerir todes os negoios furblives des dos mais ins igarificantes

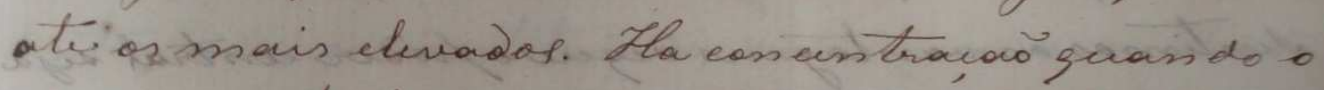
foper entral isunico princifio gue tin ha vida aesao inavimento no hais in tiro; geu en terre. wha fior di aw hor seas agentas ros mais foussageirar interises locan; gie ahi now se ag-term

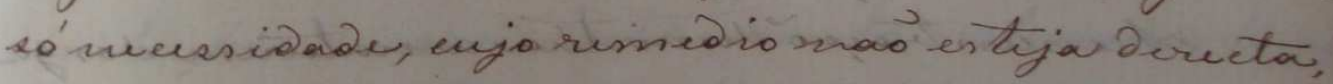

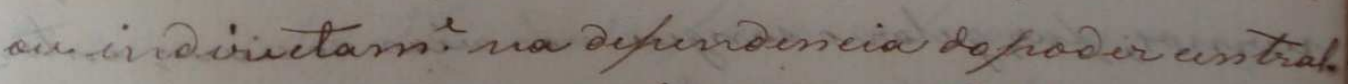

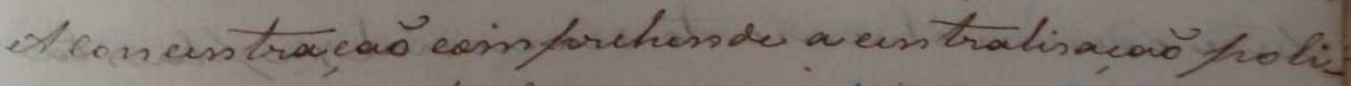
Liva eaminis trativa, ervontwea domais mo ho den en trab edirito de abcarver tados as ess tereeces Locus.

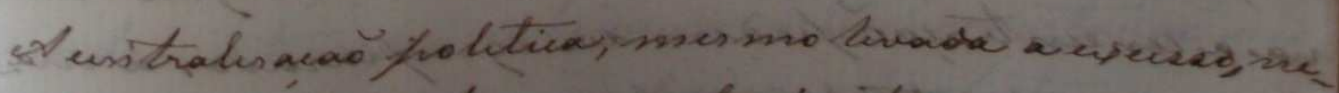

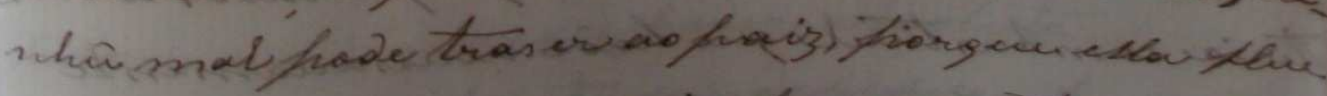

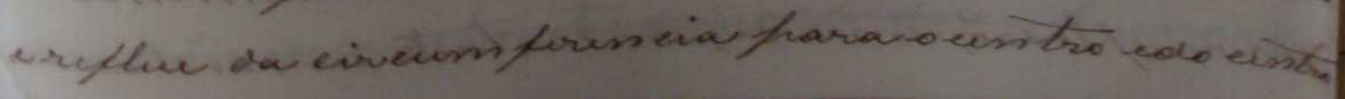




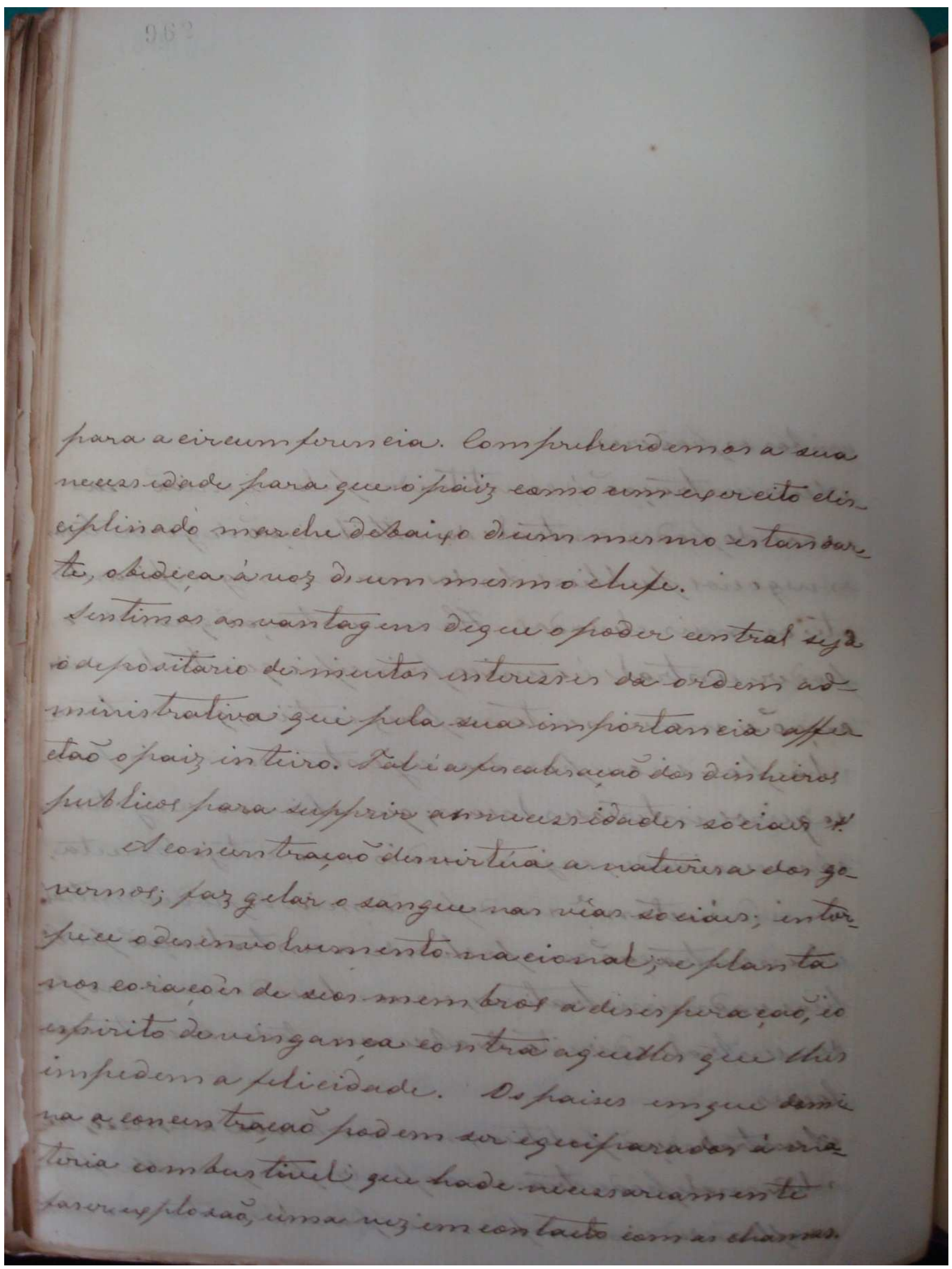




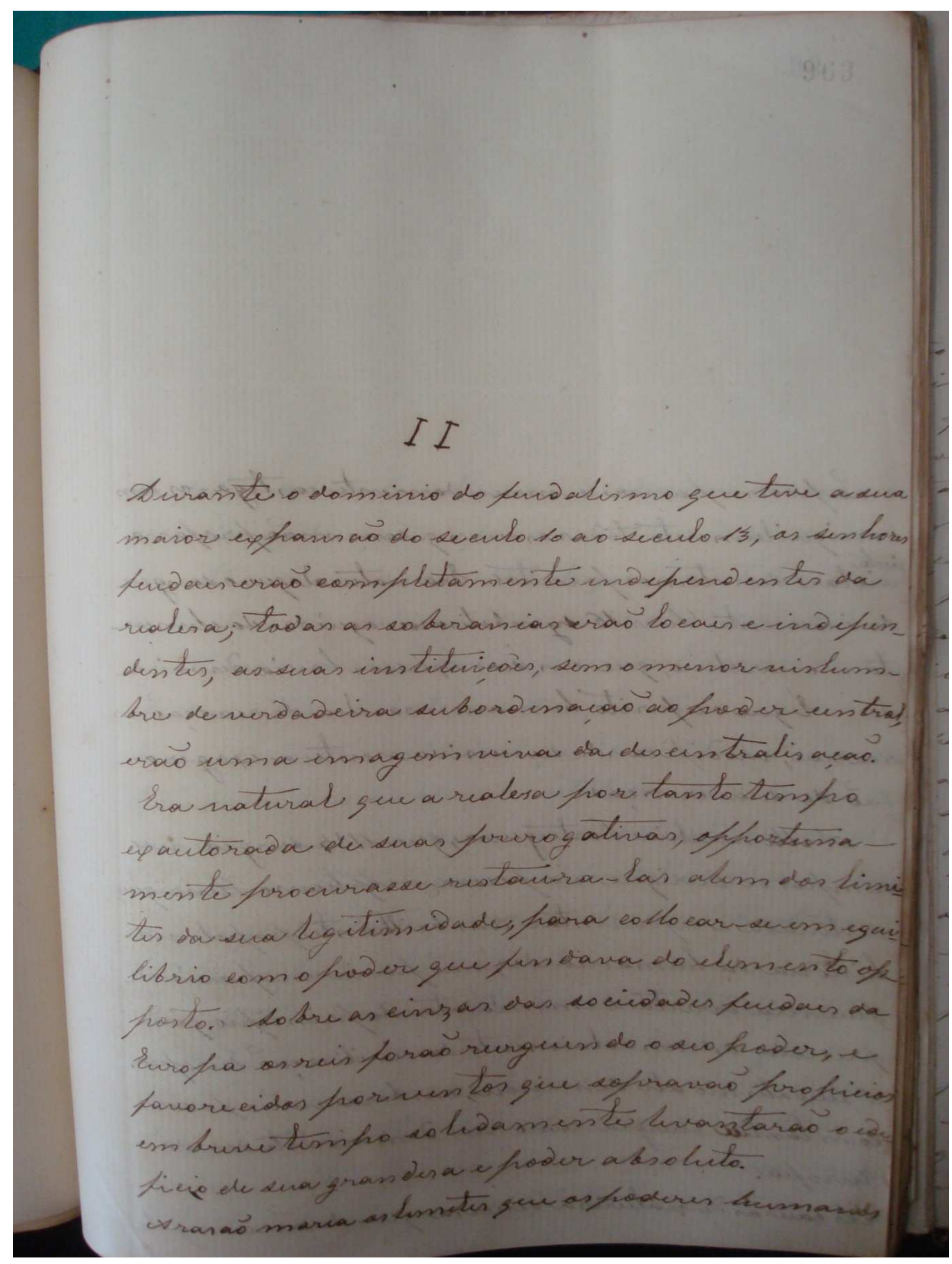




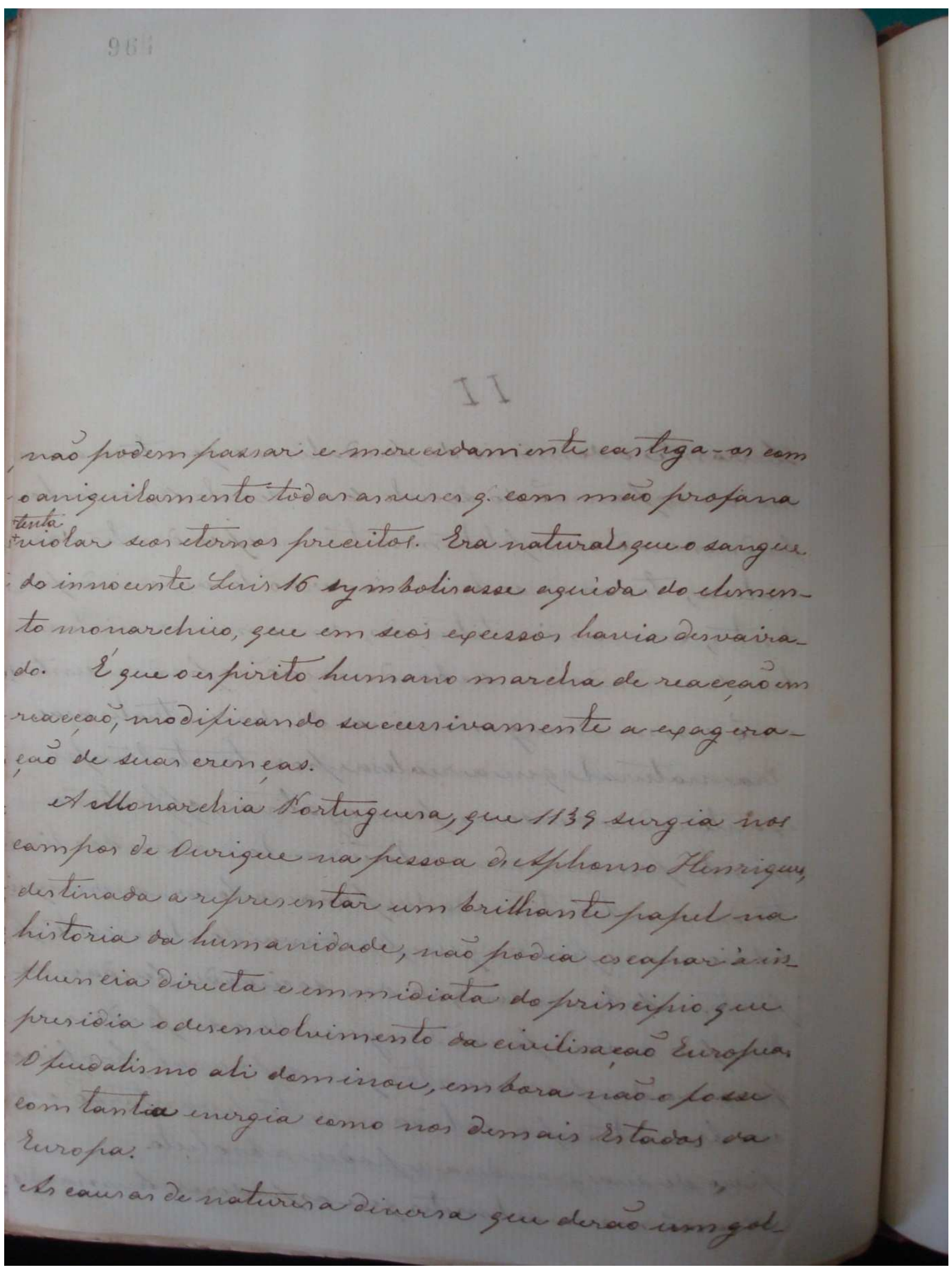




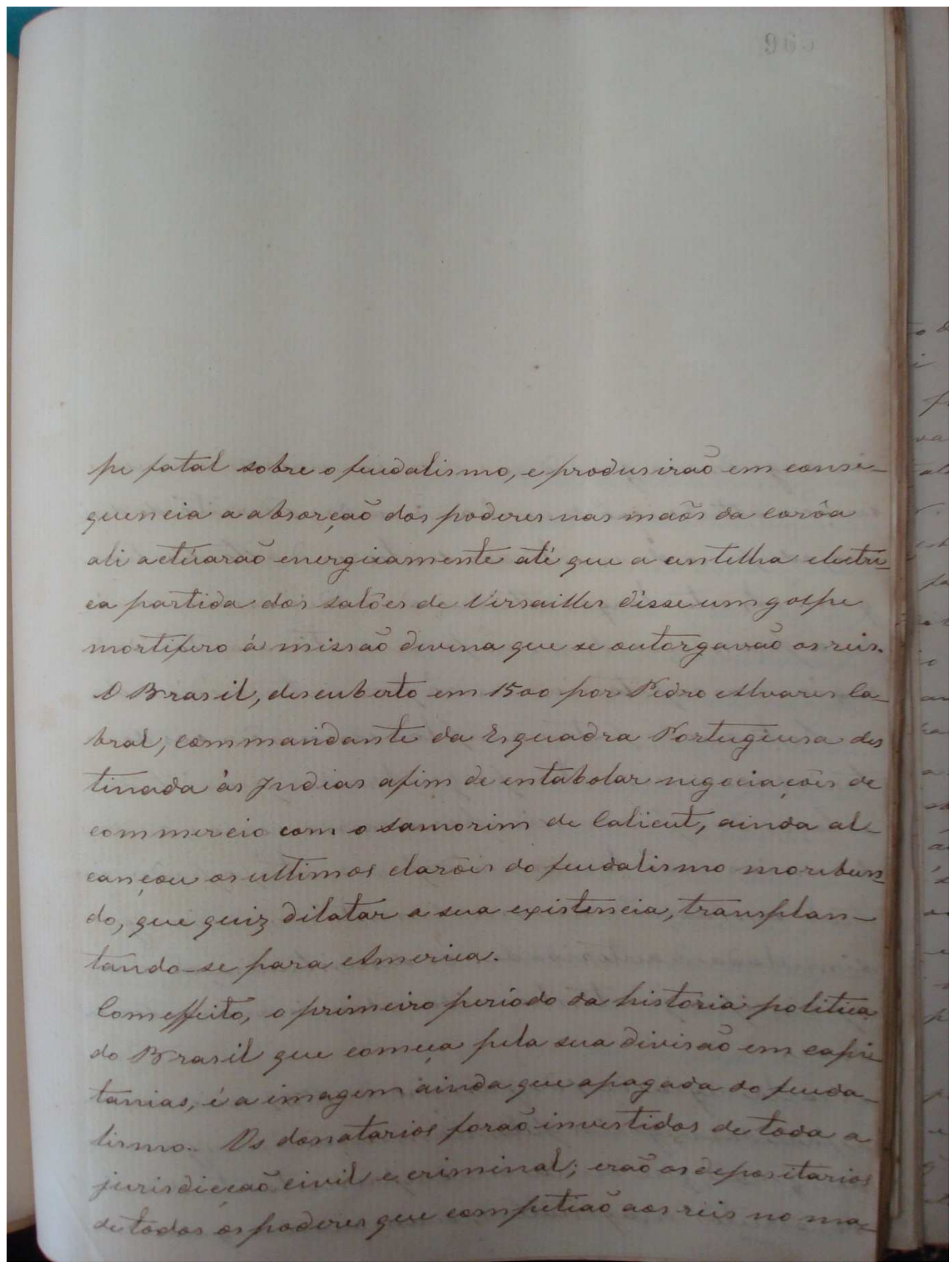




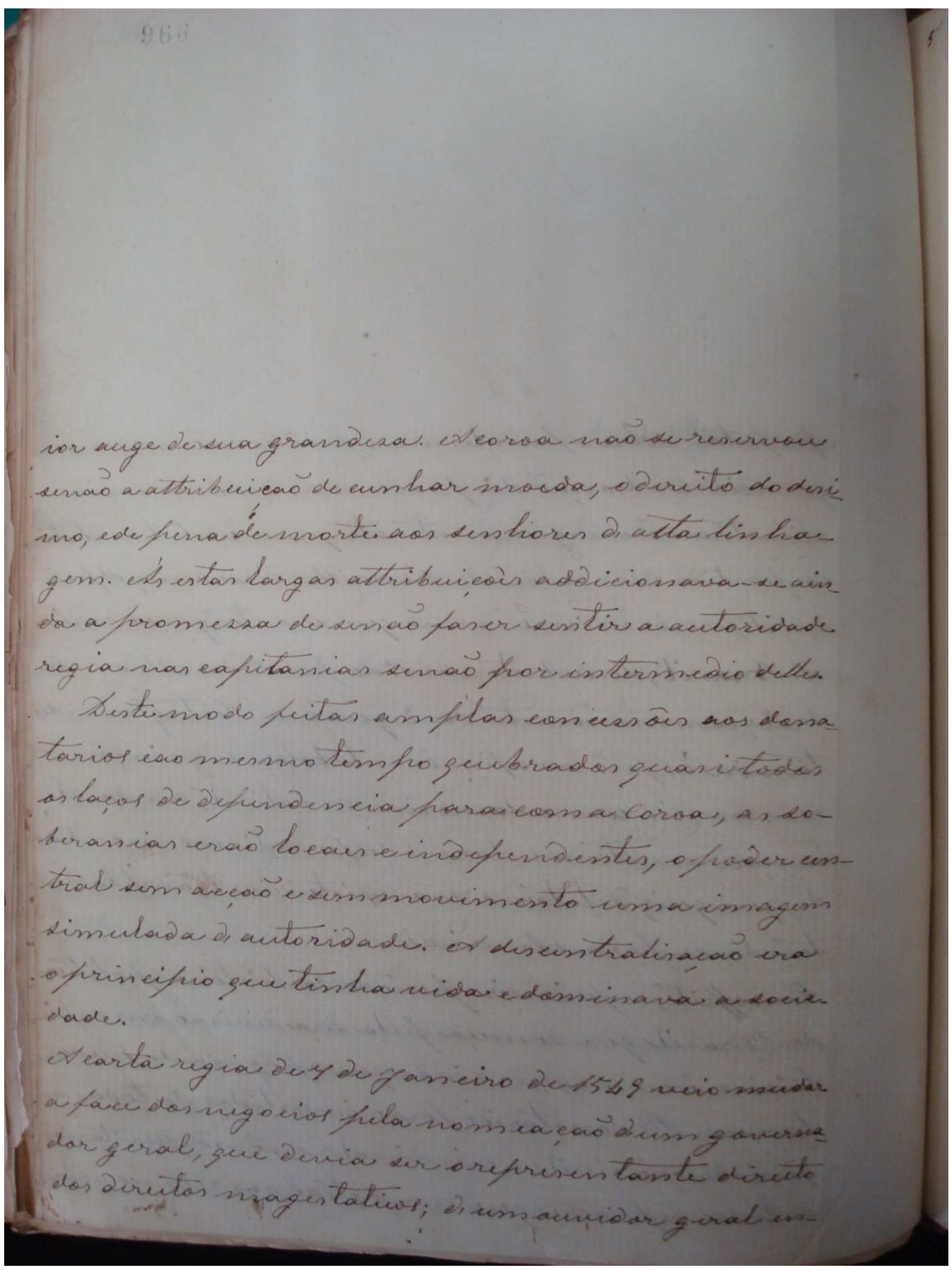


242

carregado de destribuir a jistica einit eeriminal: diem frovedor mór en earregado de exlar vas in tores ses da fasenda fublica. Leria secasiao as ada frara faserm as minveioso exame das attribuicois das dif ferentis acetoridades ati as recebdares e almon arifi,;

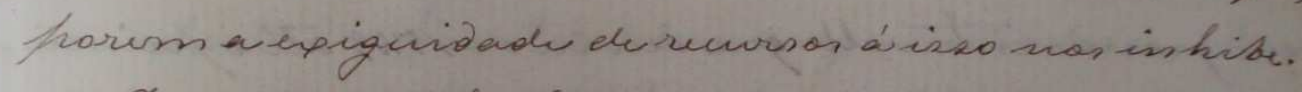
Dodas essas autoridades descumsissadas fula Colonia doman avao diruetamente da earva, unia fos te de

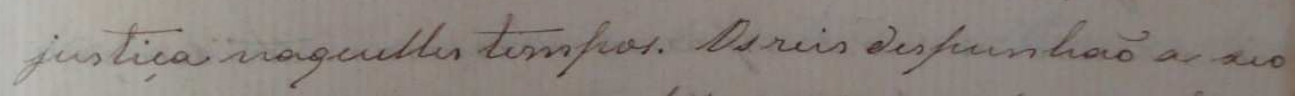
Aelfinaner, da vida, ta liberdade, im lim detadas

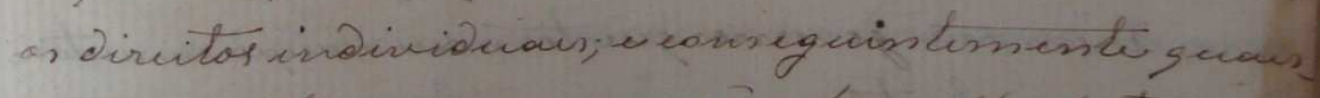

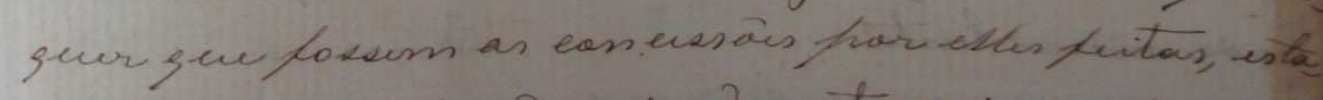

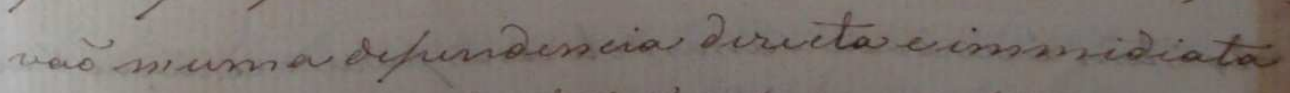
da fonte deque fartirao. Prida folitica dap lorivades constituidas dearipo do-regimess absaluto

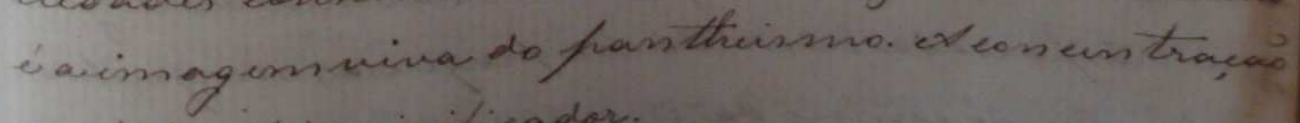
seo frincifio minifieador.

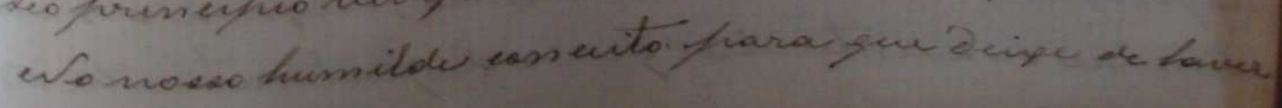




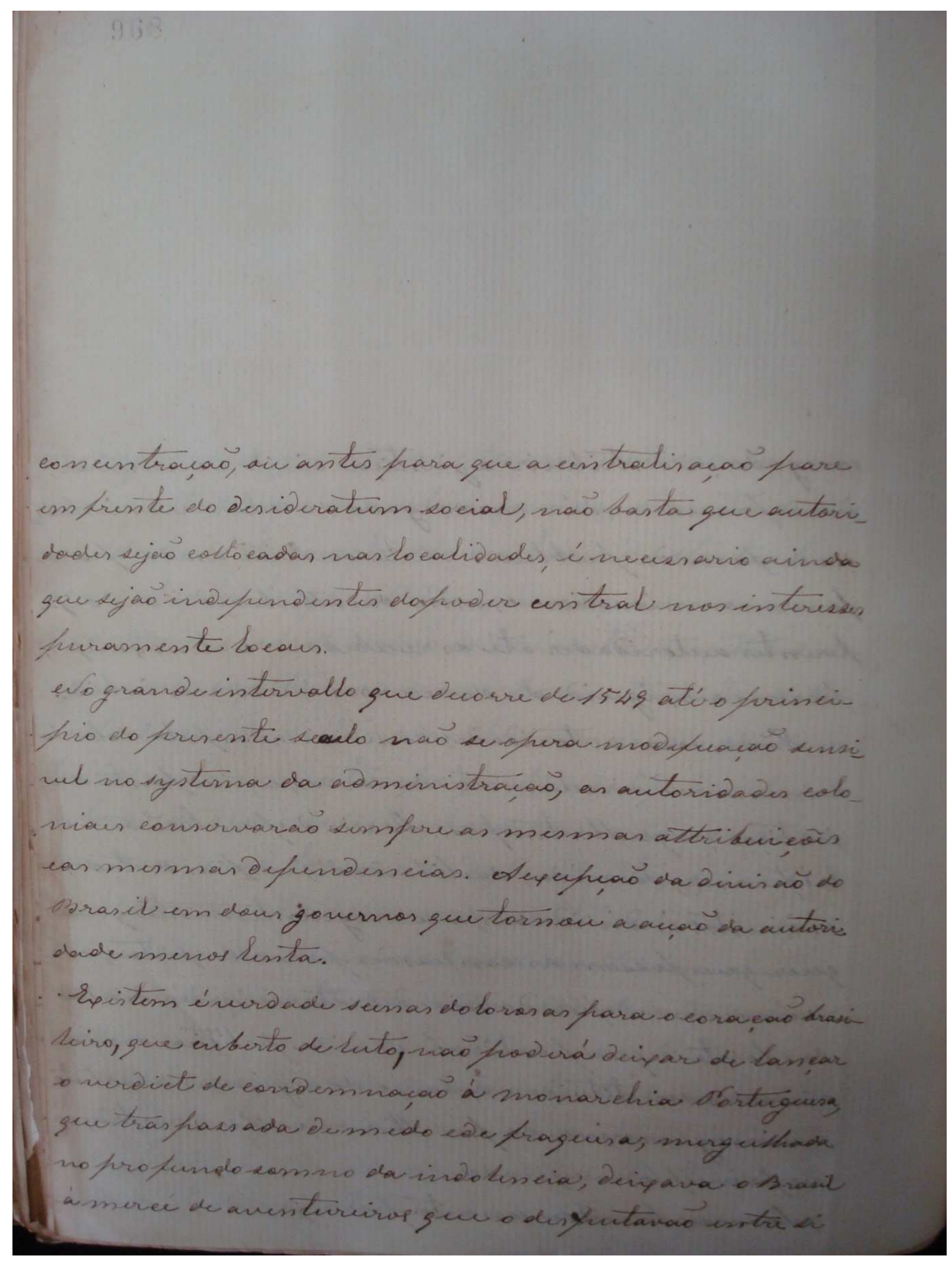




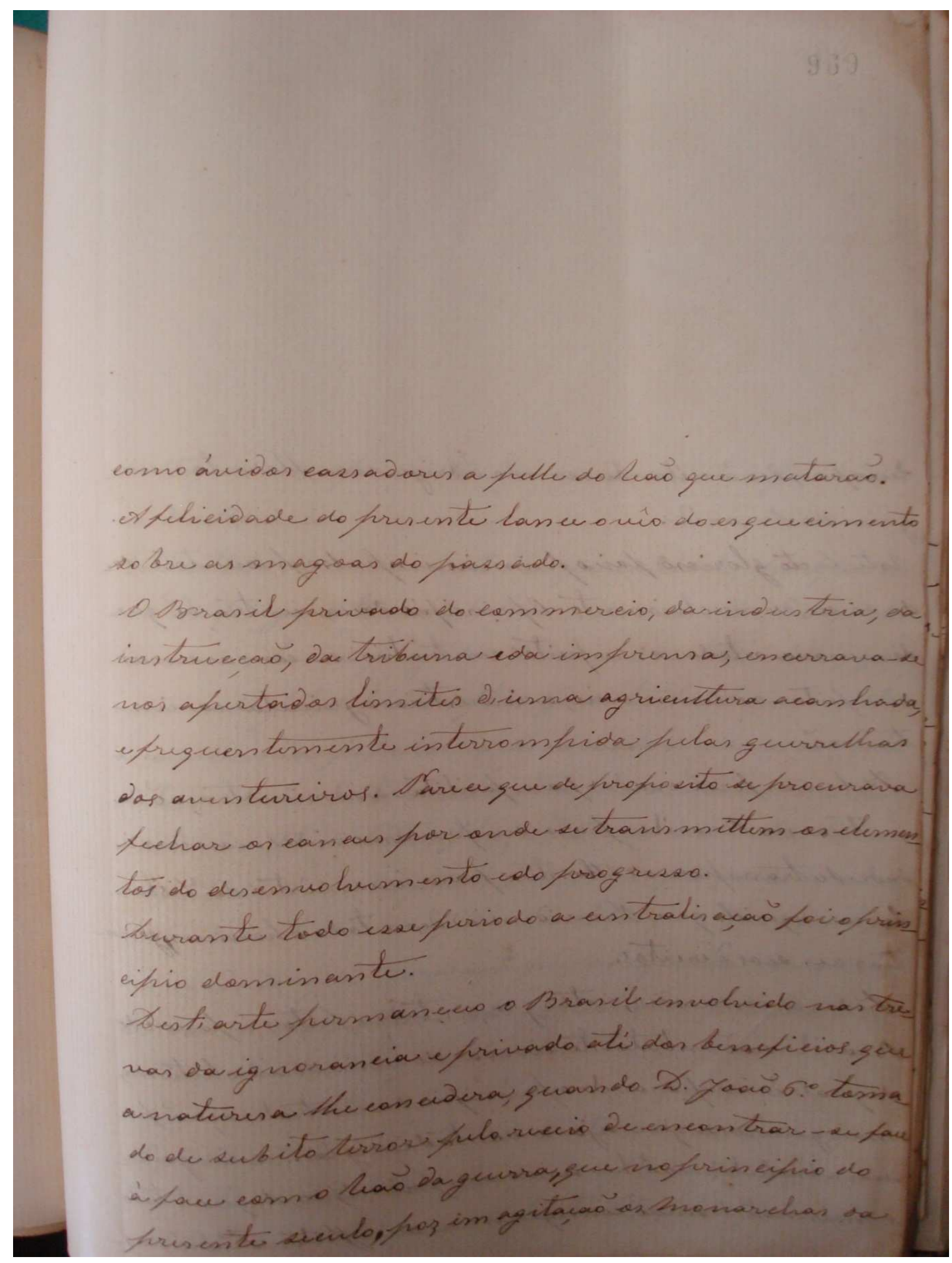




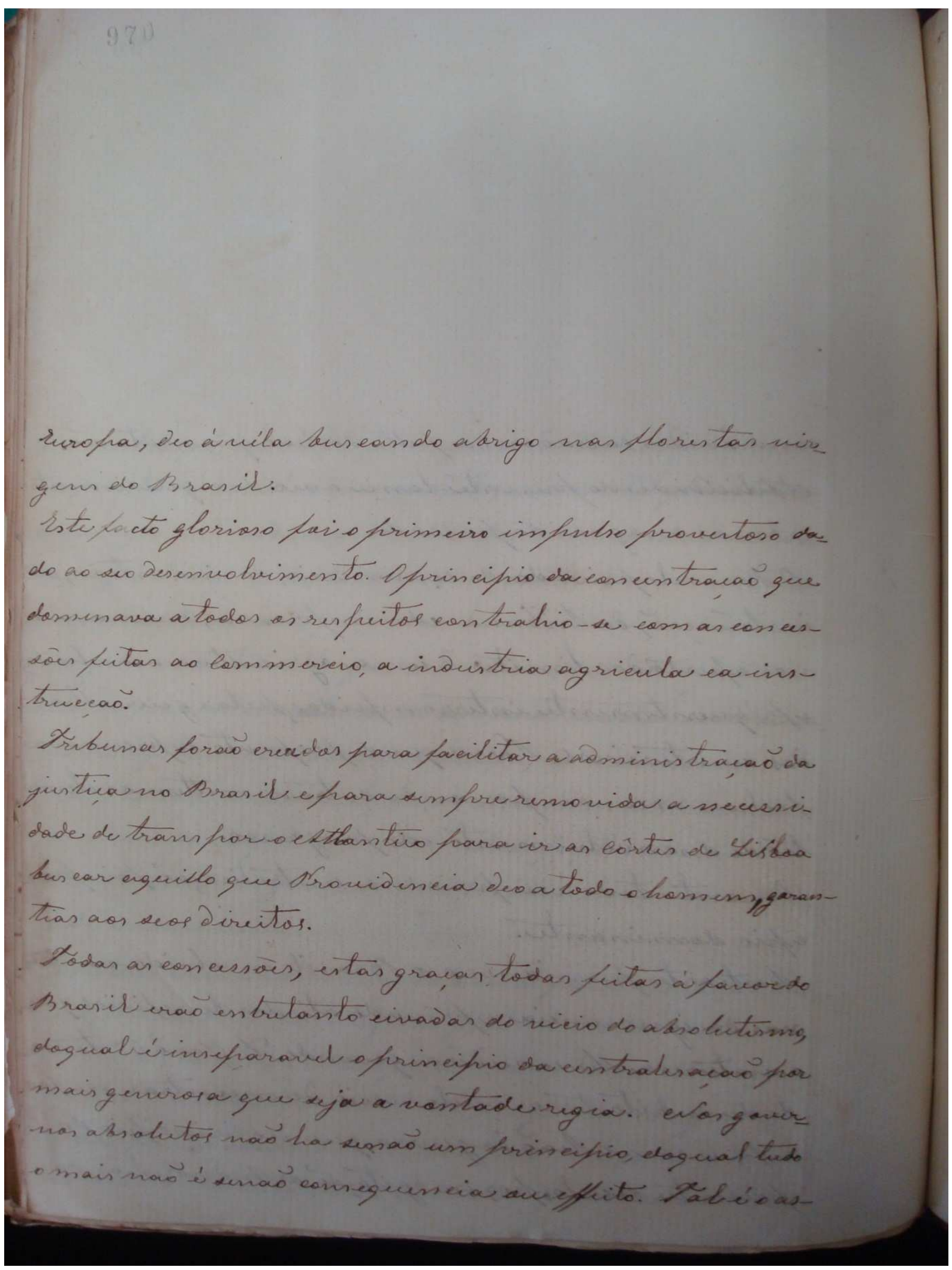




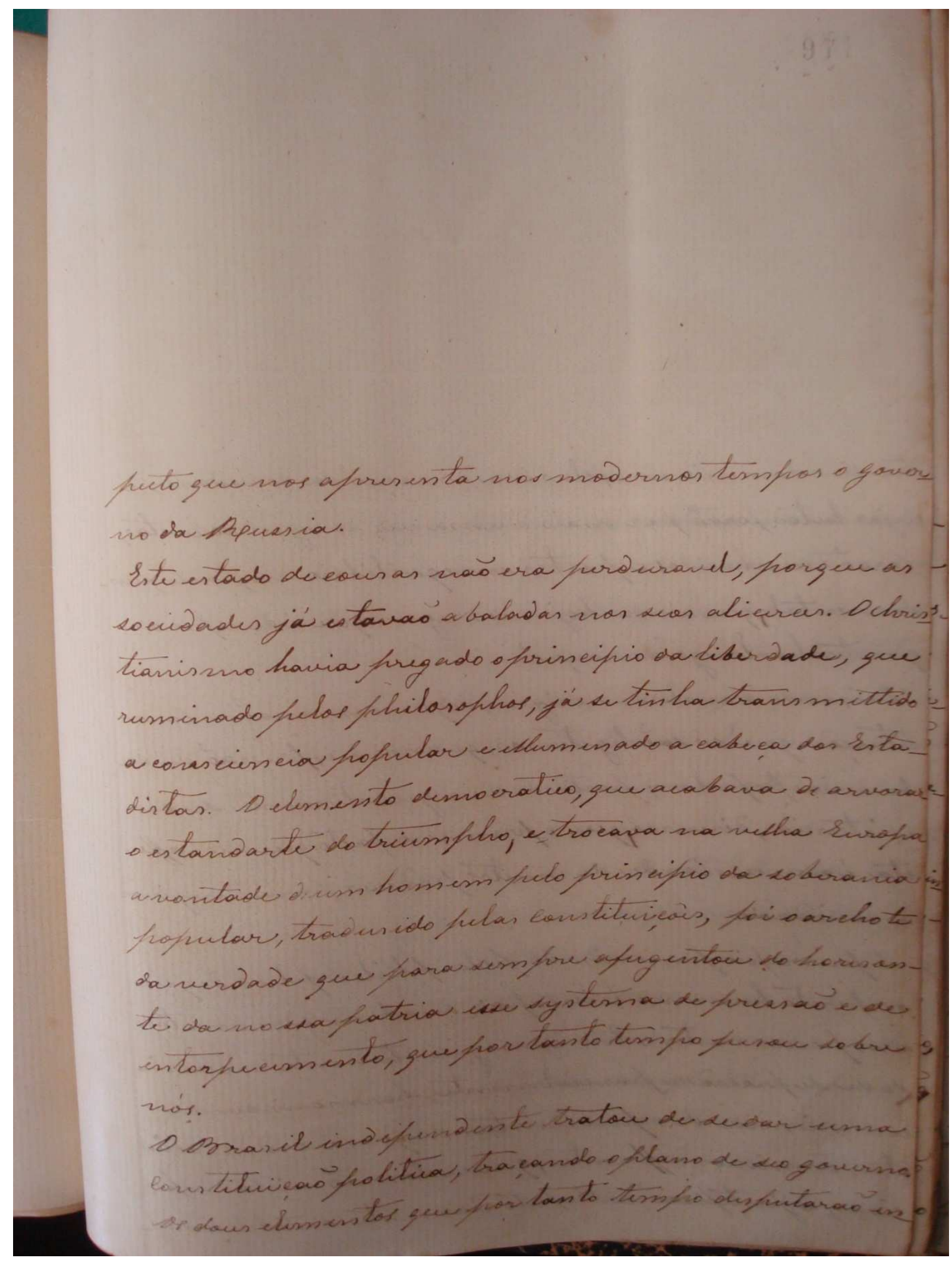




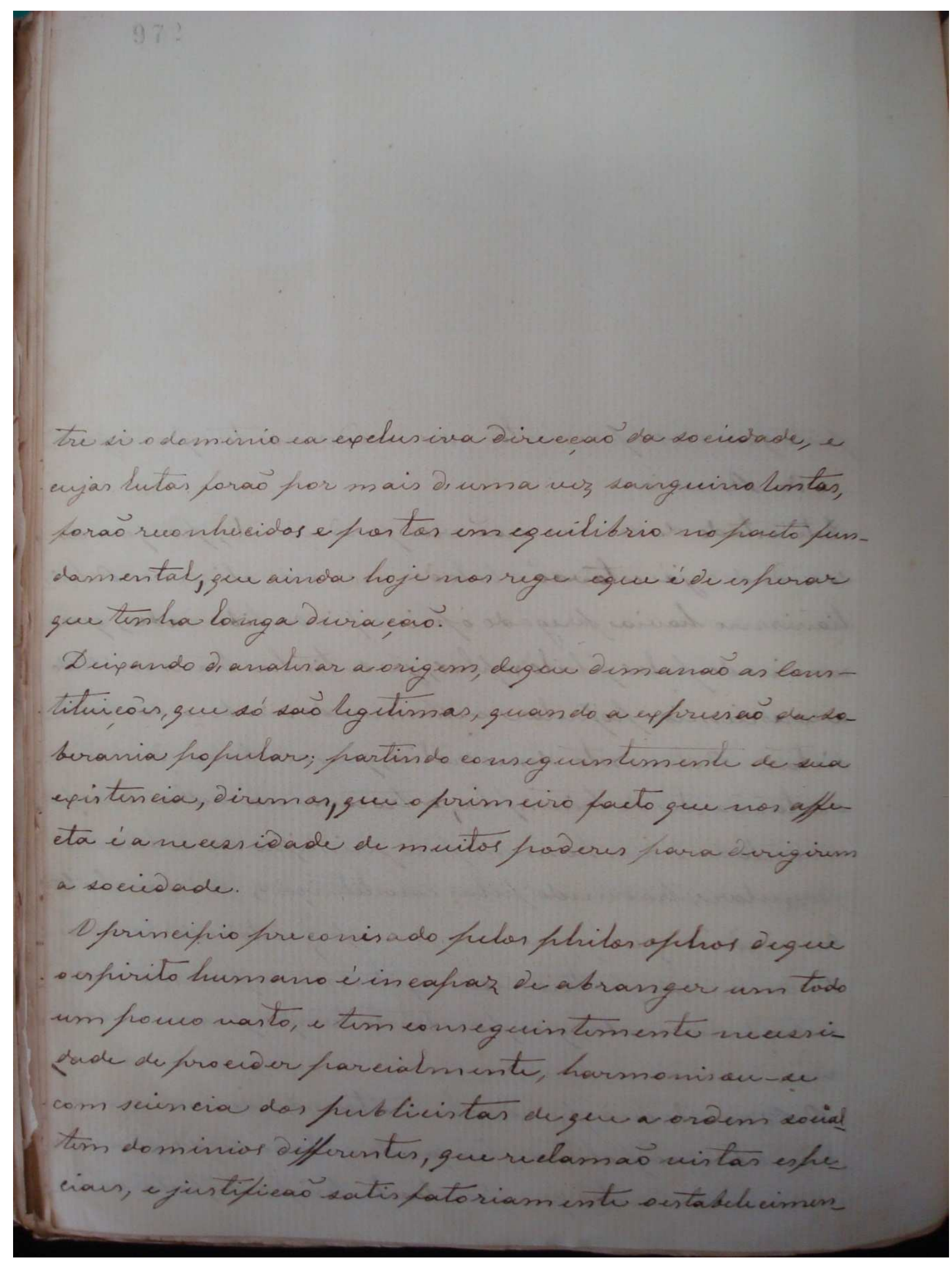




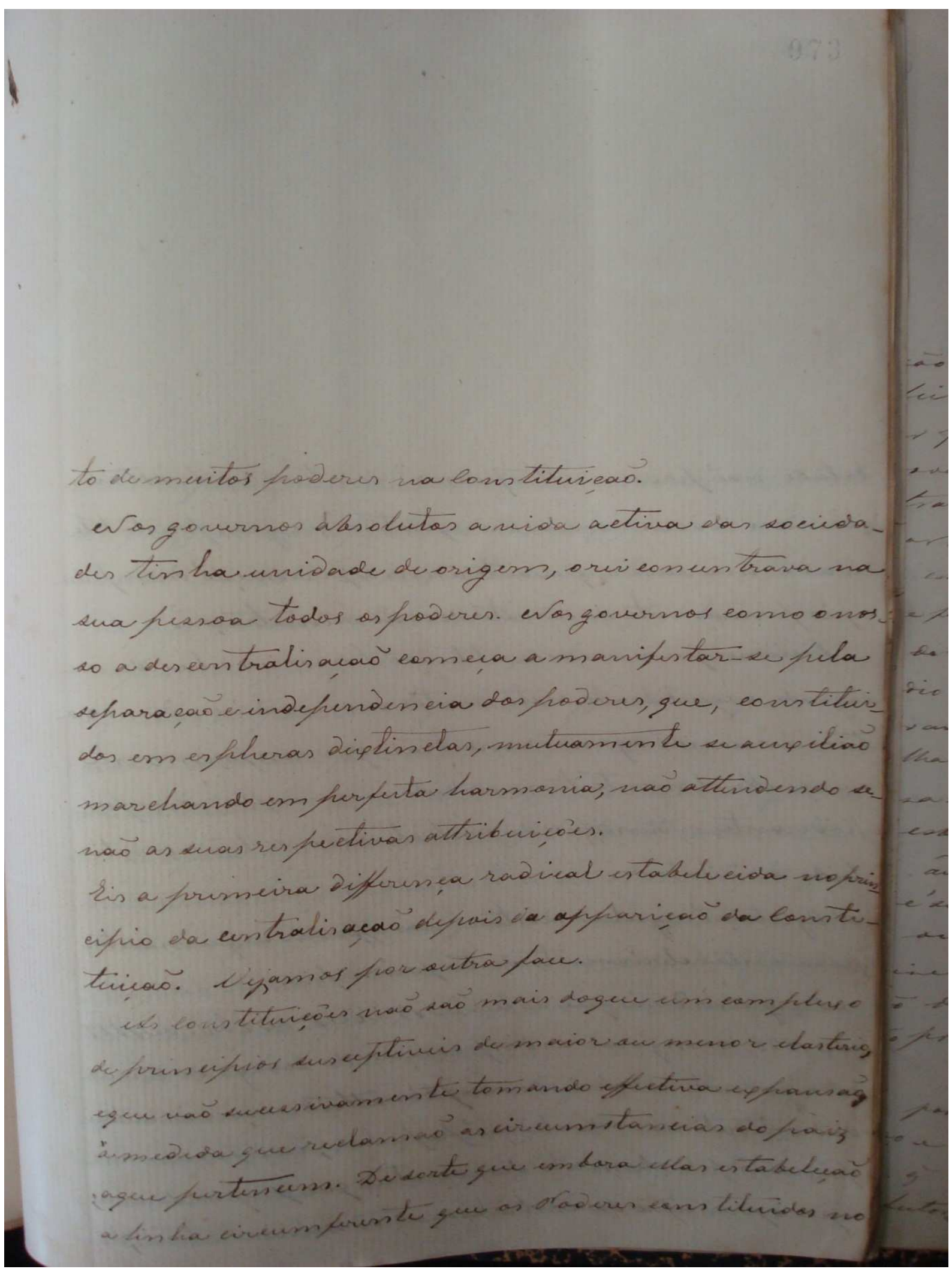




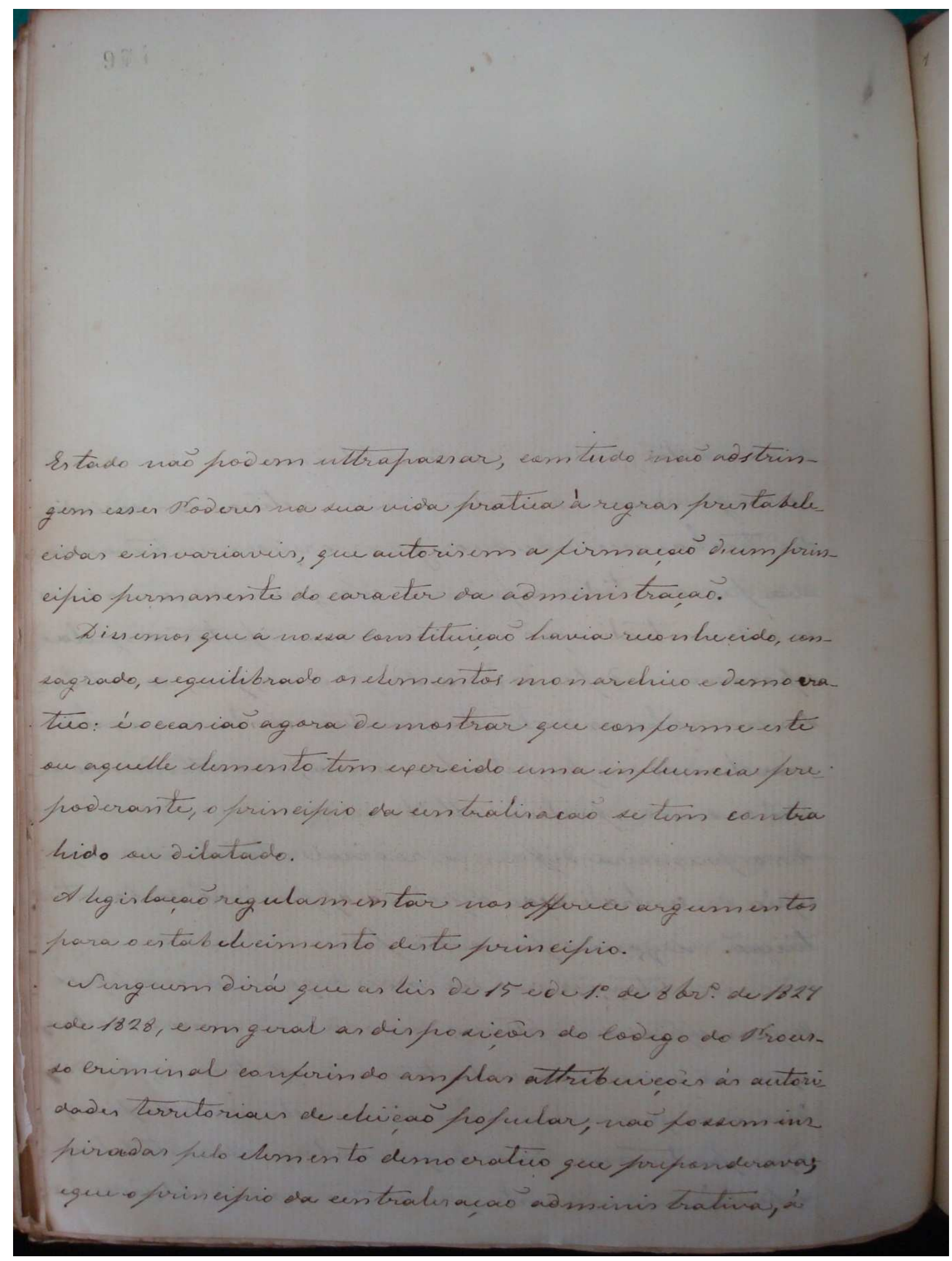




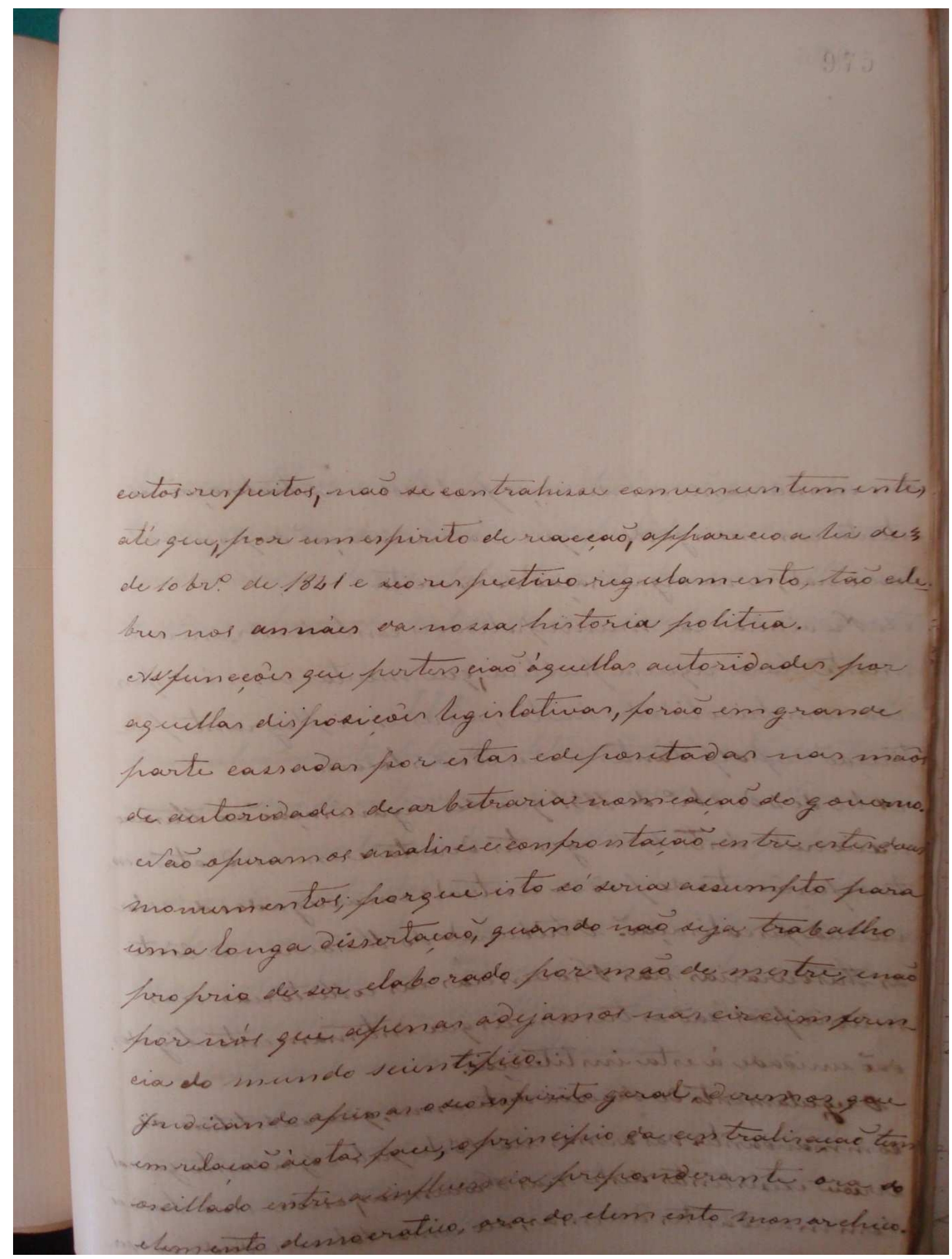




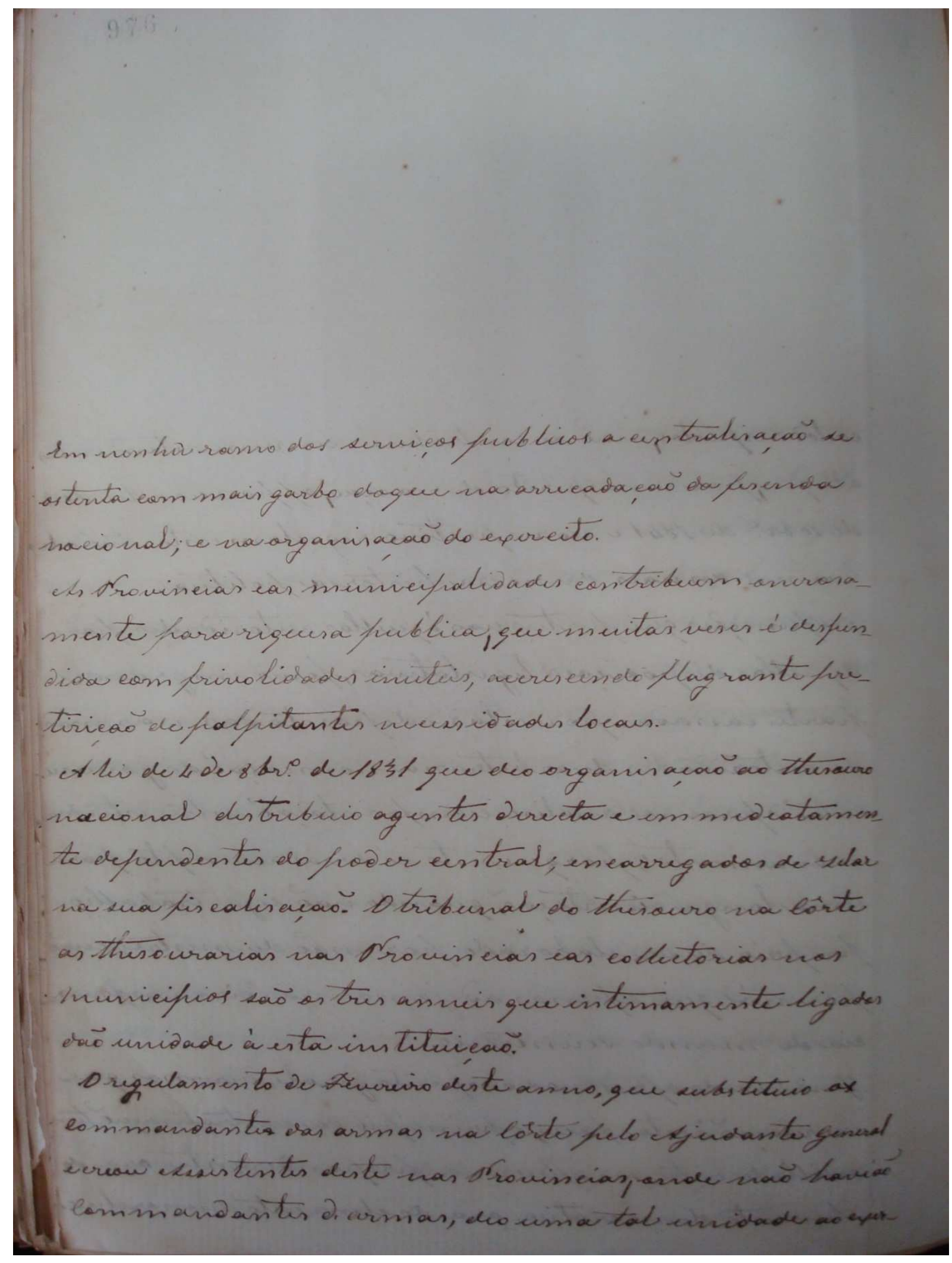


252

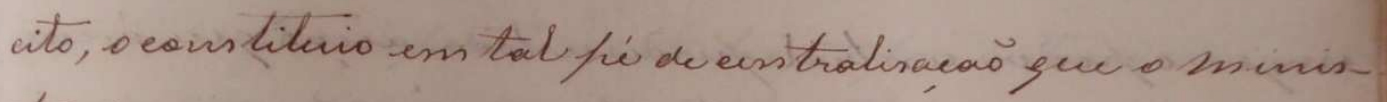
tro era geurra, canso disec un defuntoido na camara, fodia mave to à so talasite nester wageulle sente

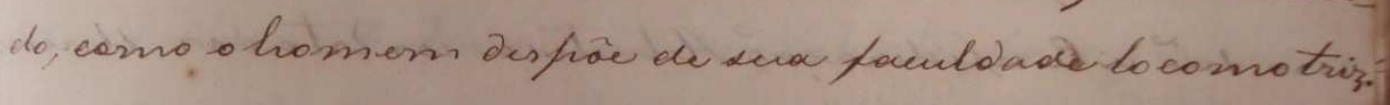

III

Precontweimessto fula Cans tituriea do Diruito geu tesn cadou tidadaö de in tervir nonngocios de tua fravincia

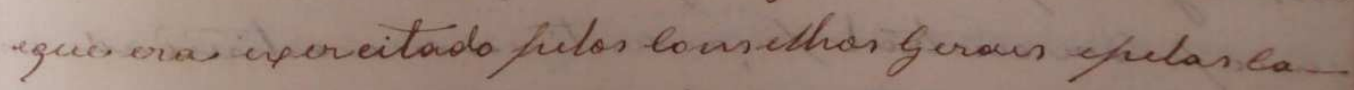

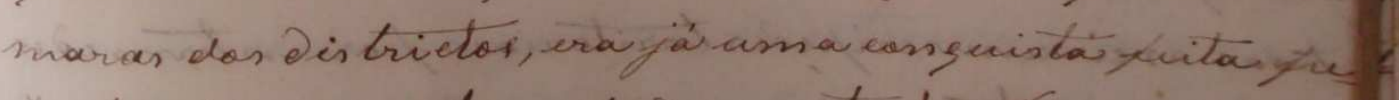

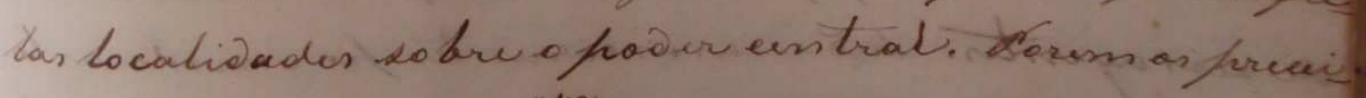

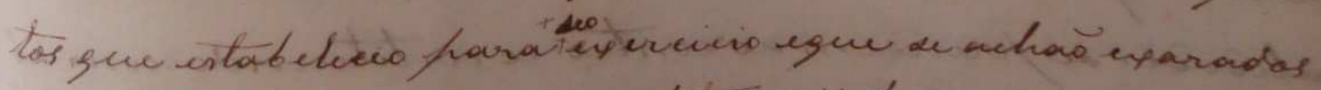

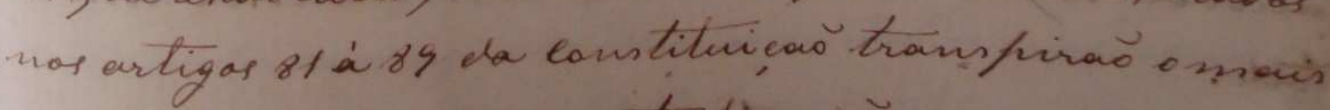

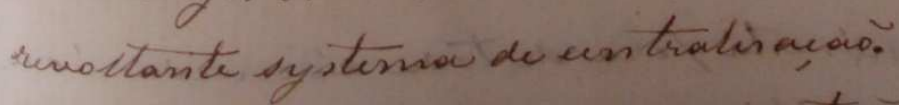

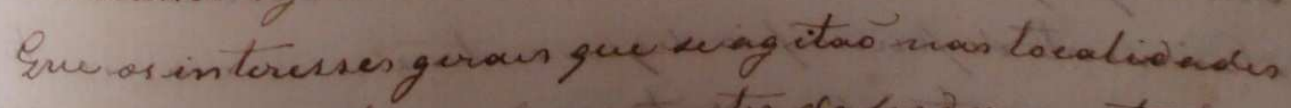

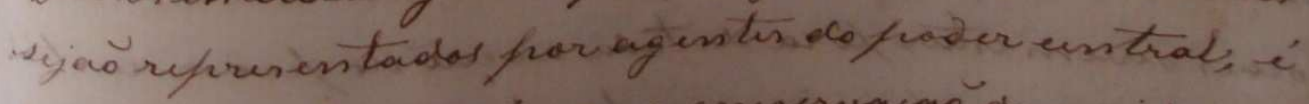
Una neves idade fiara a canservacero ob unidade do

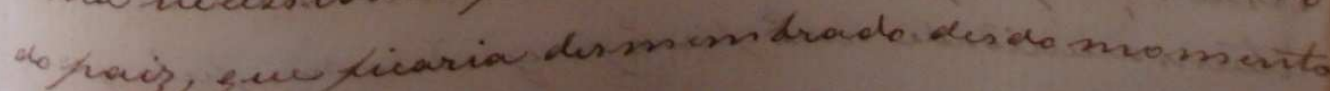


253

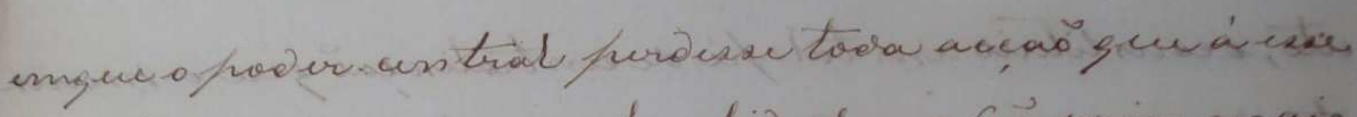

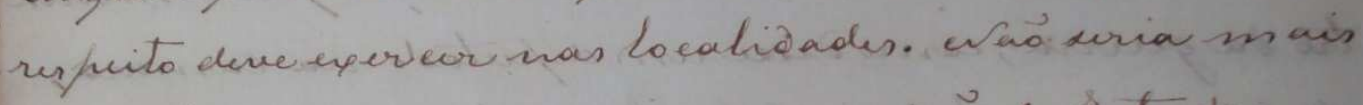
um is tado; form sims una rumiajo do istadas, e0-

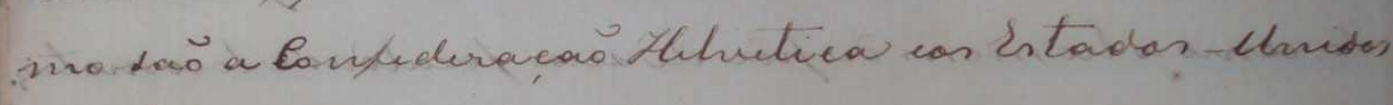
da Arnerica.

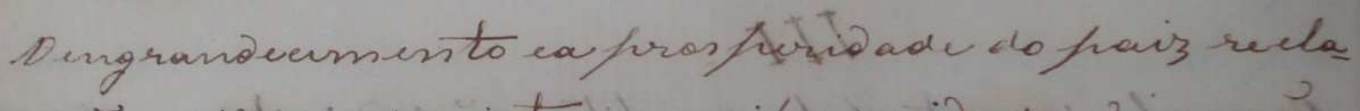

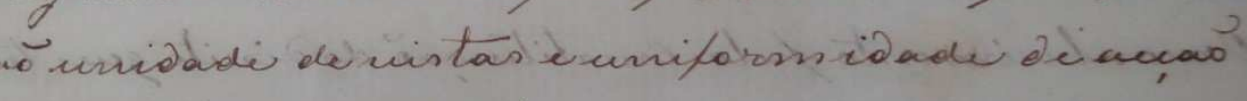

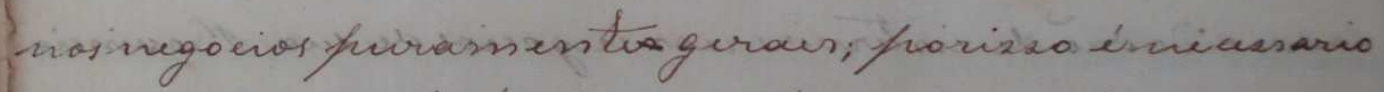
- un of poder en tral facea des tir a sia activid ade em tidas as cirsumserifuois territoriaus foris in term ed io

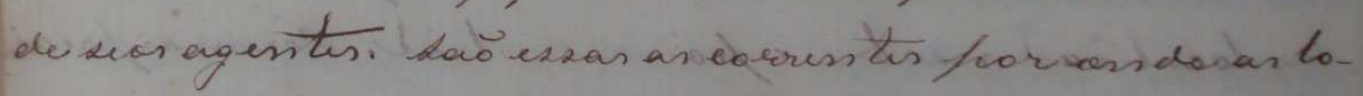

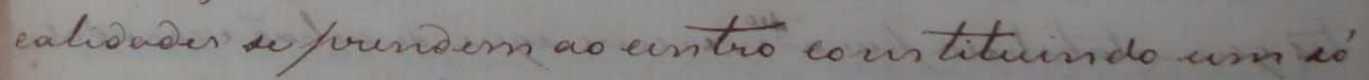
tordo.

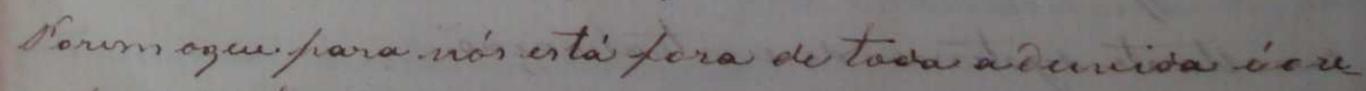

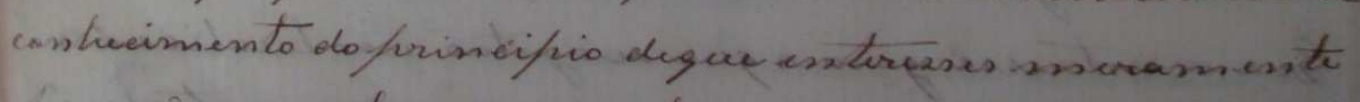

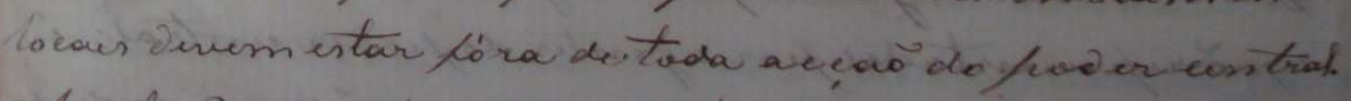

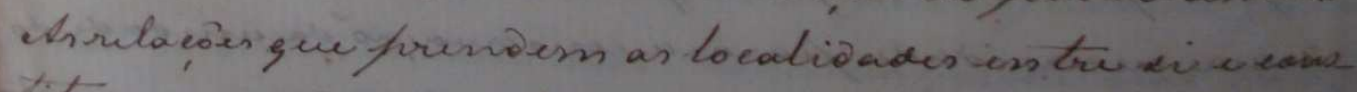

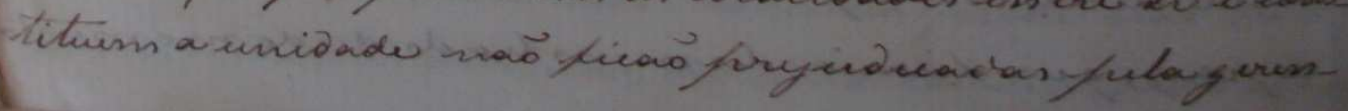




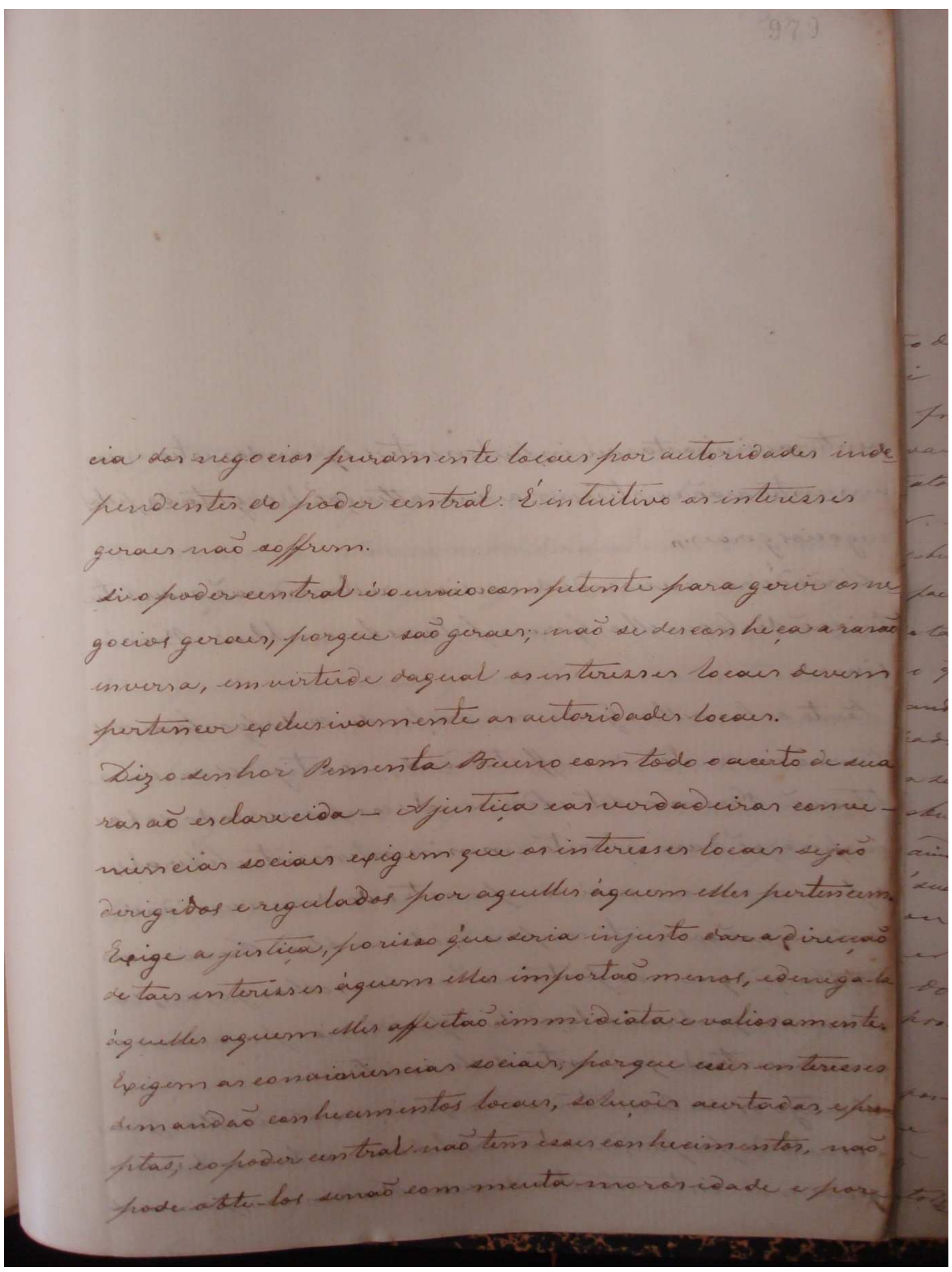




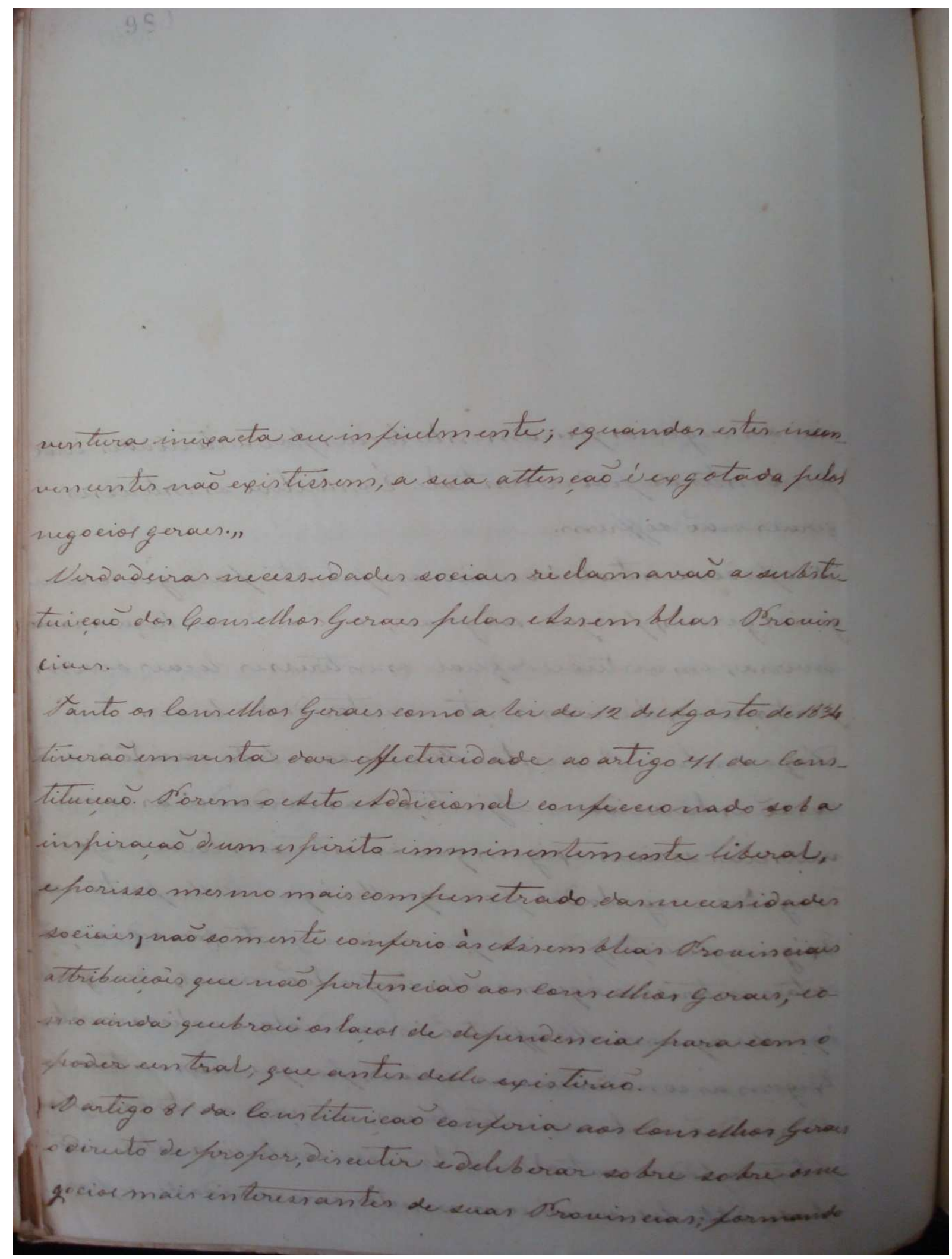




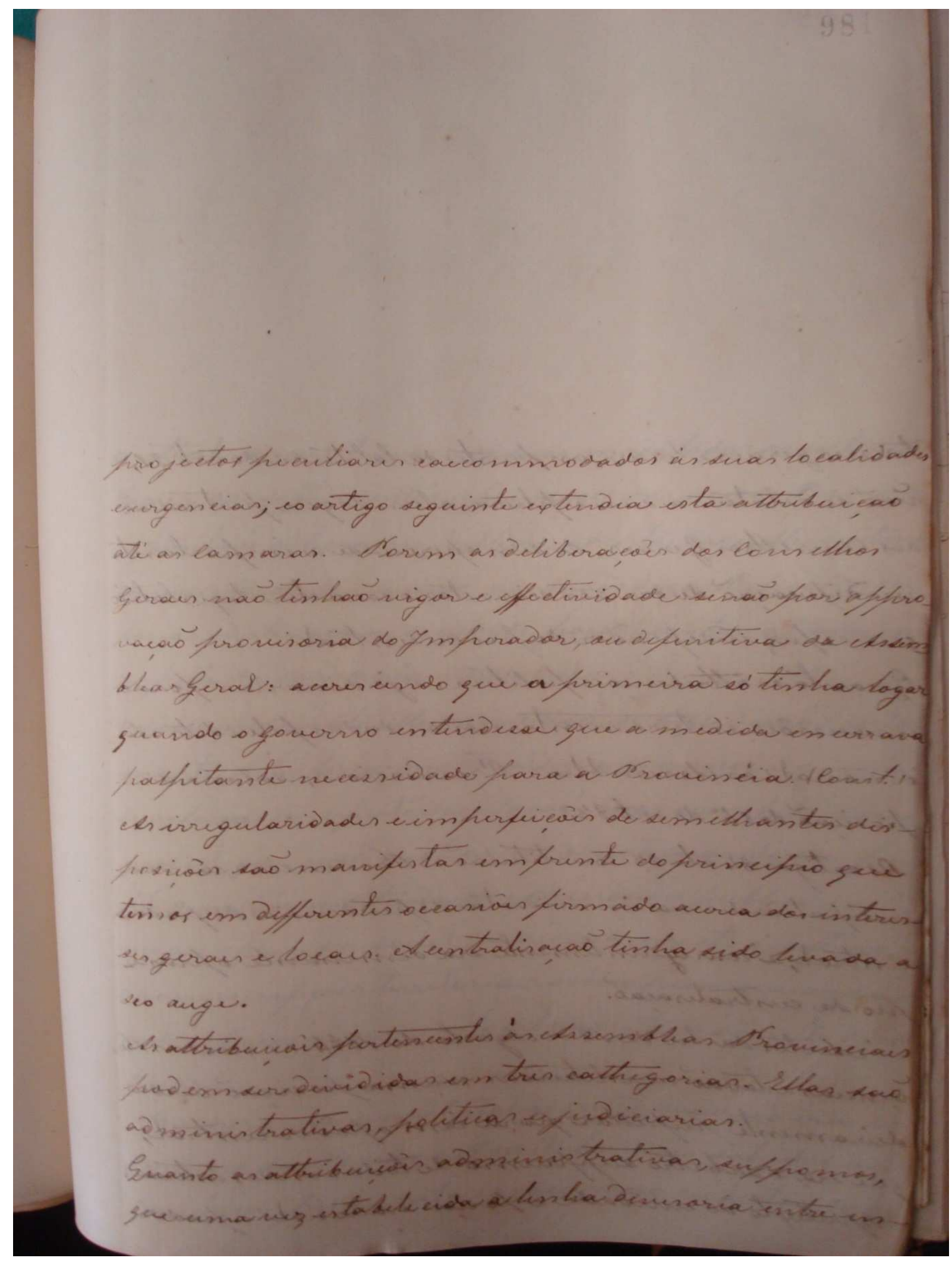




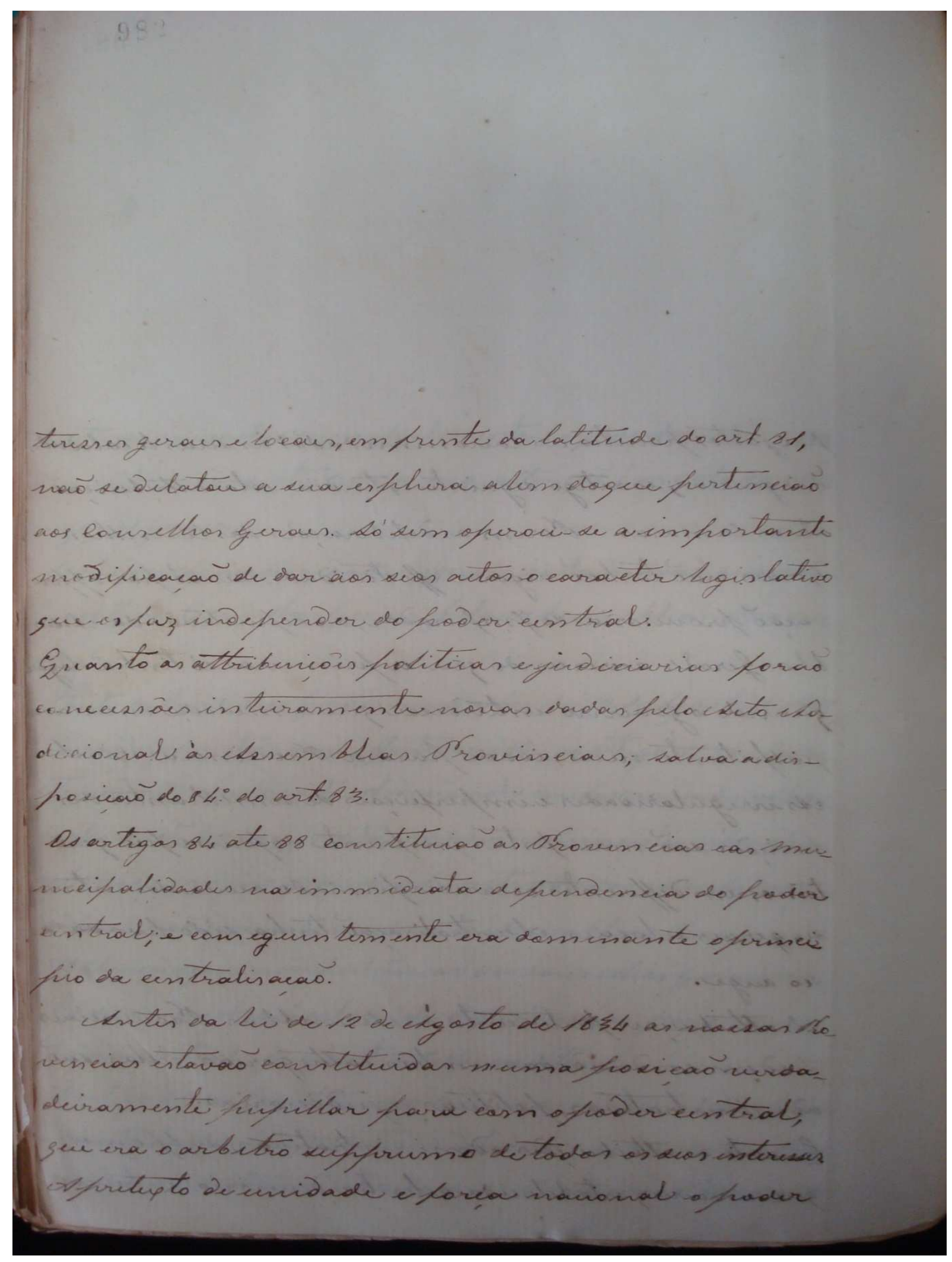




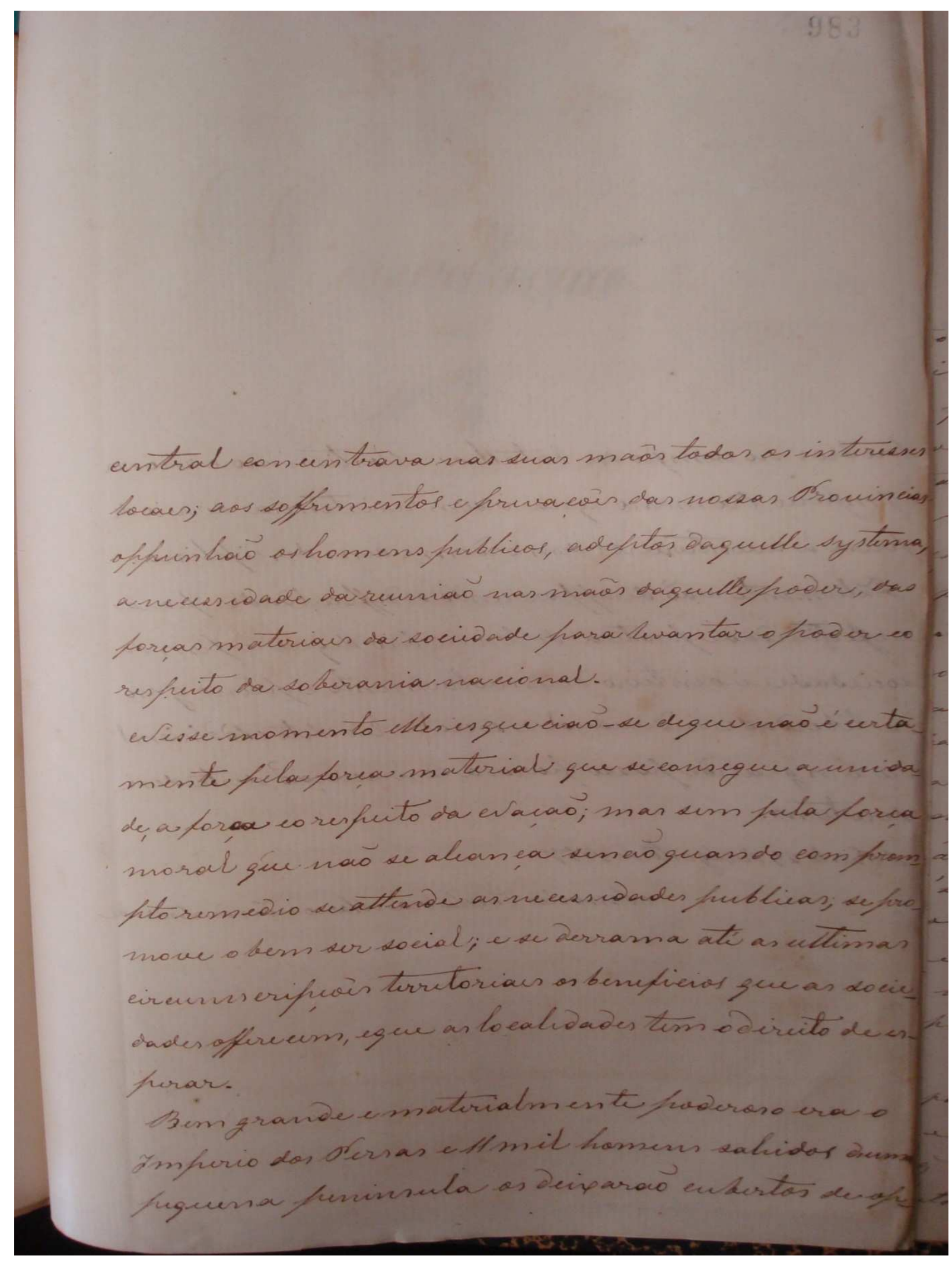




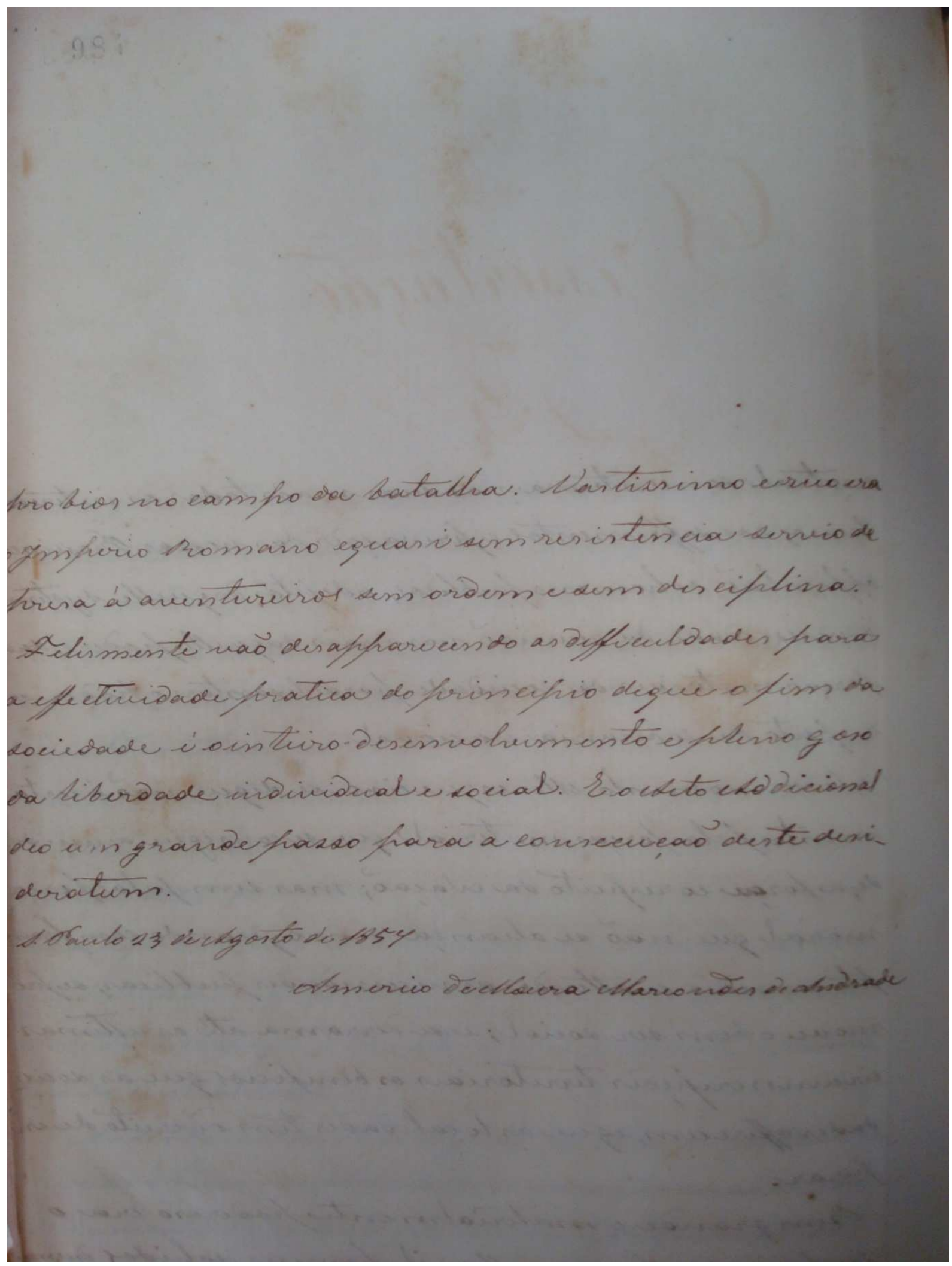


Anexo 3 - Dissertação de Direito Administrativo de João da Rocha Miranda

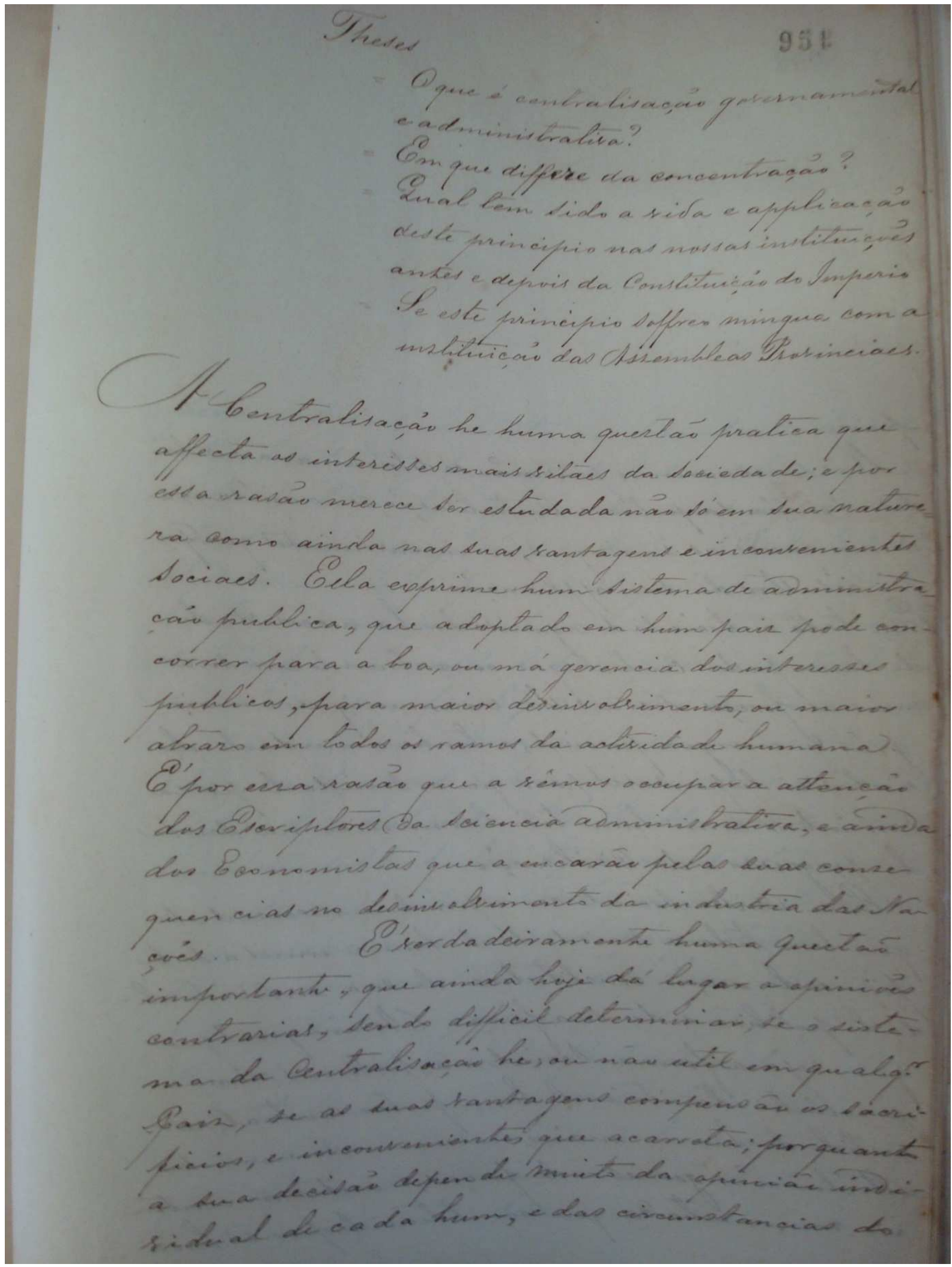




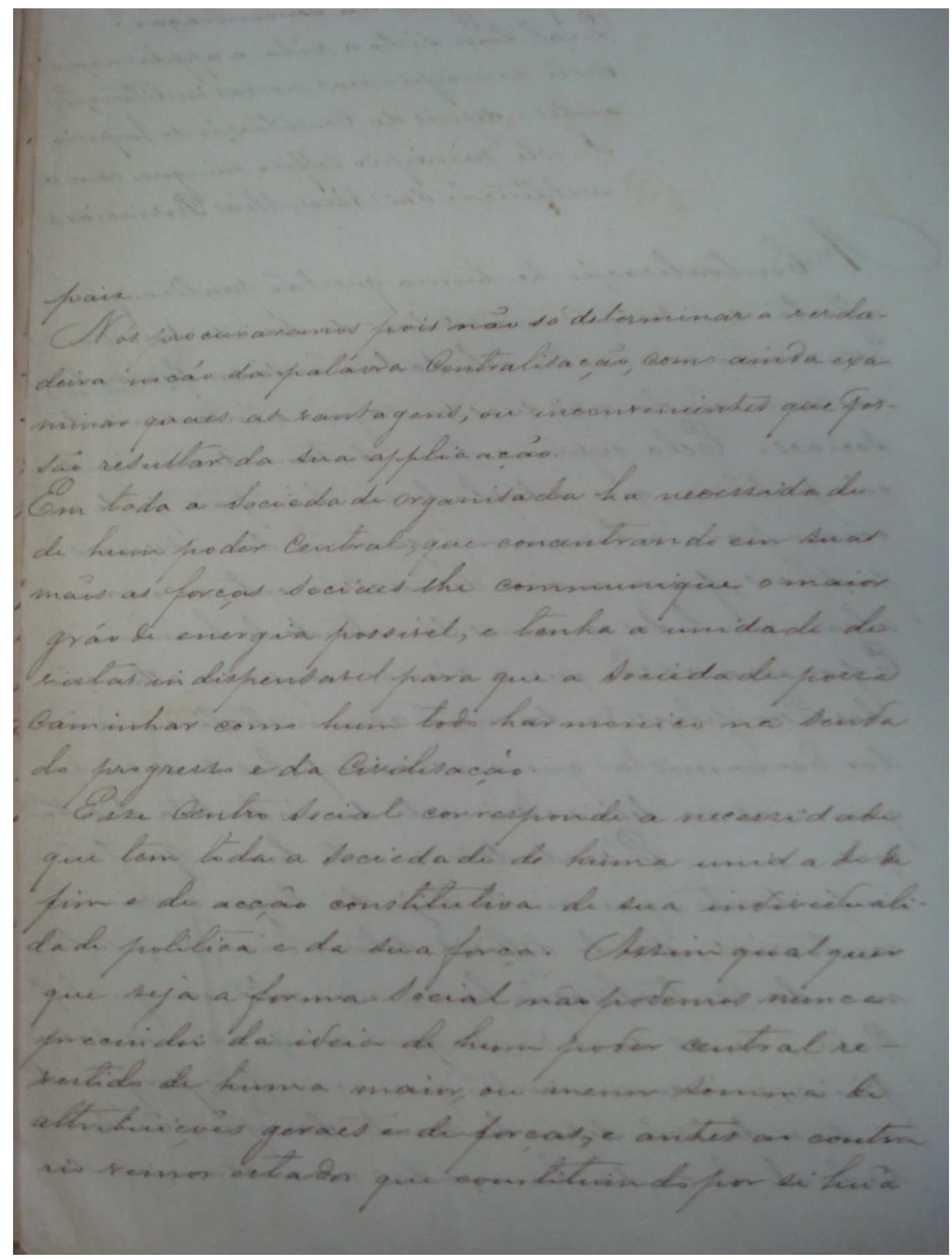




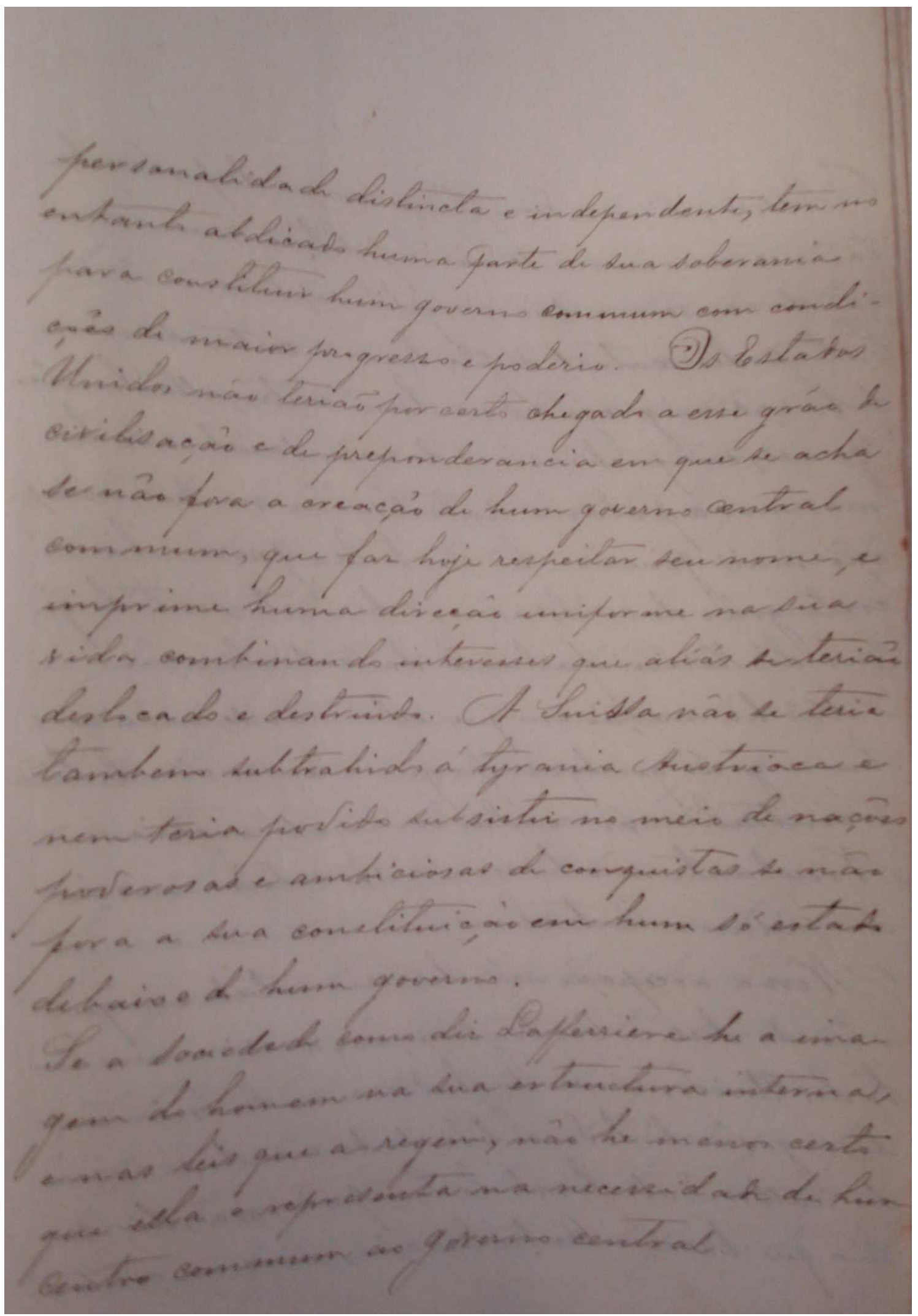




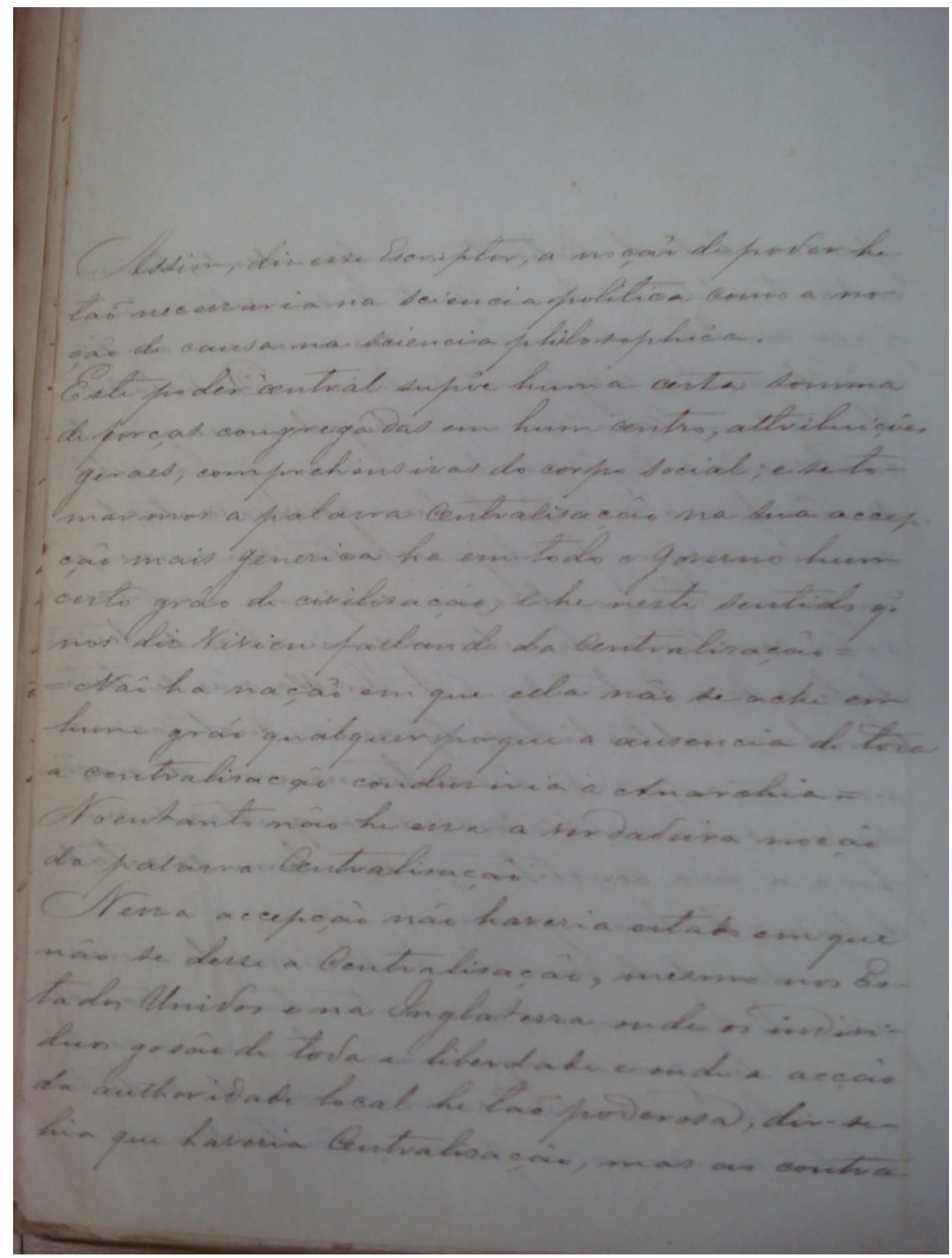




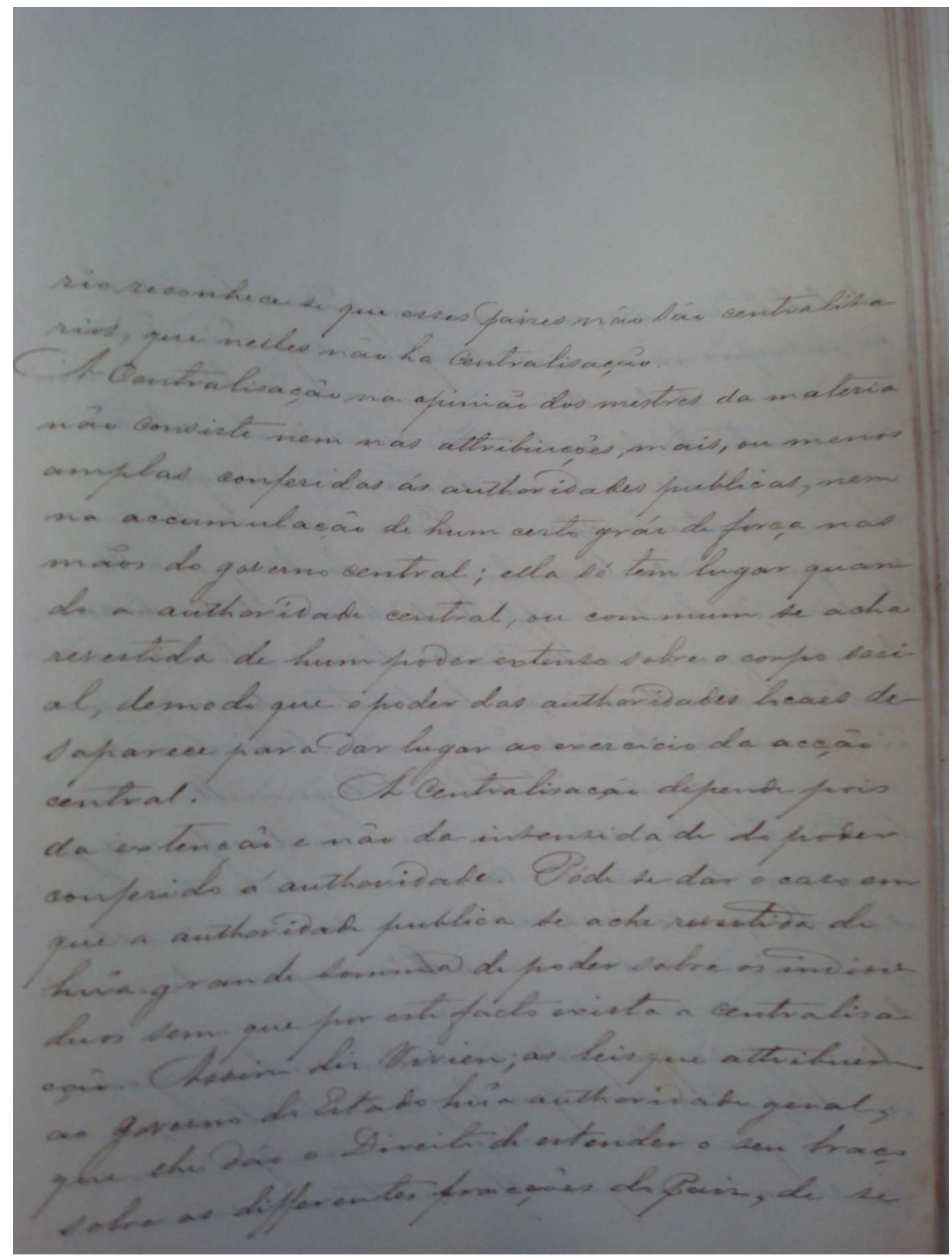




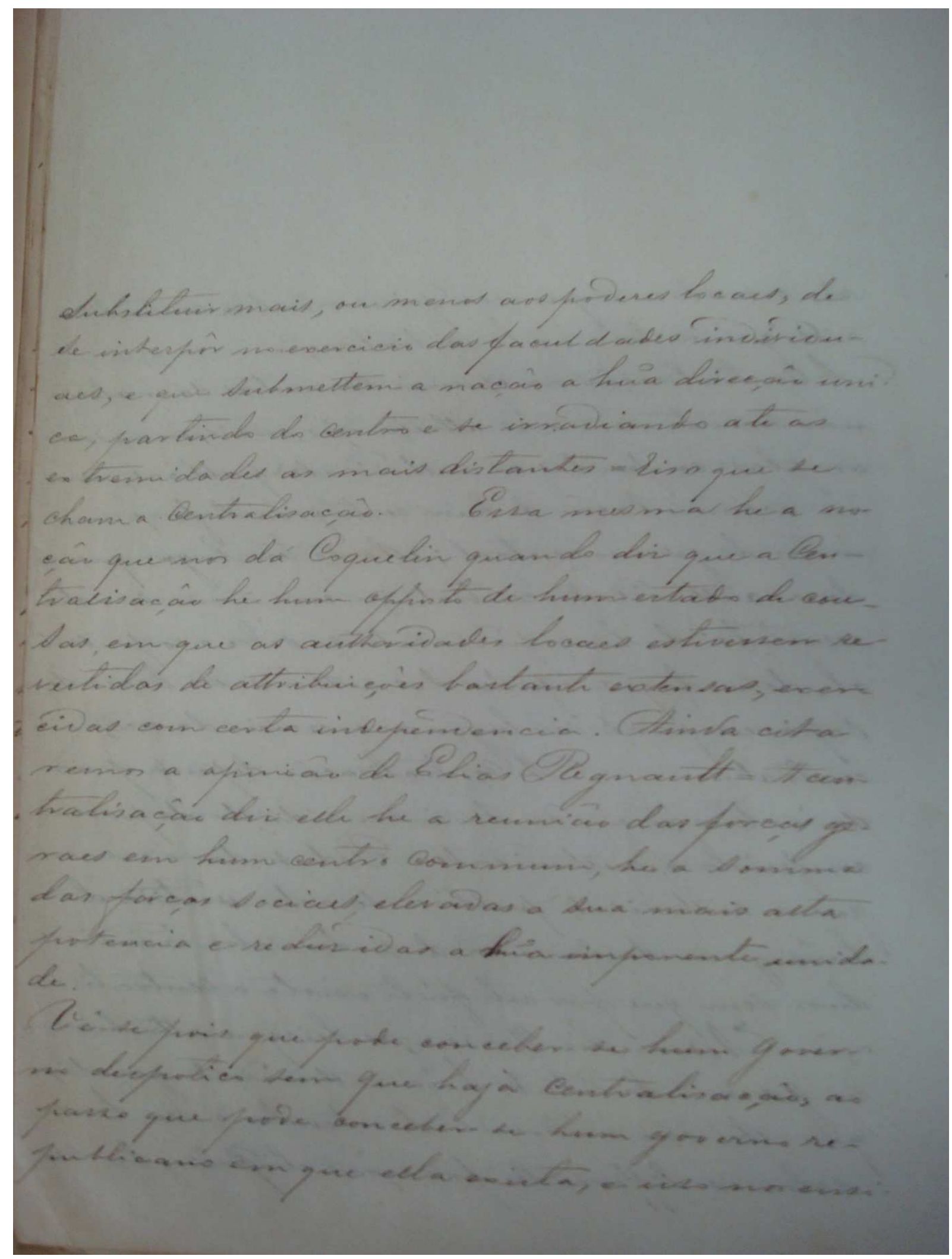




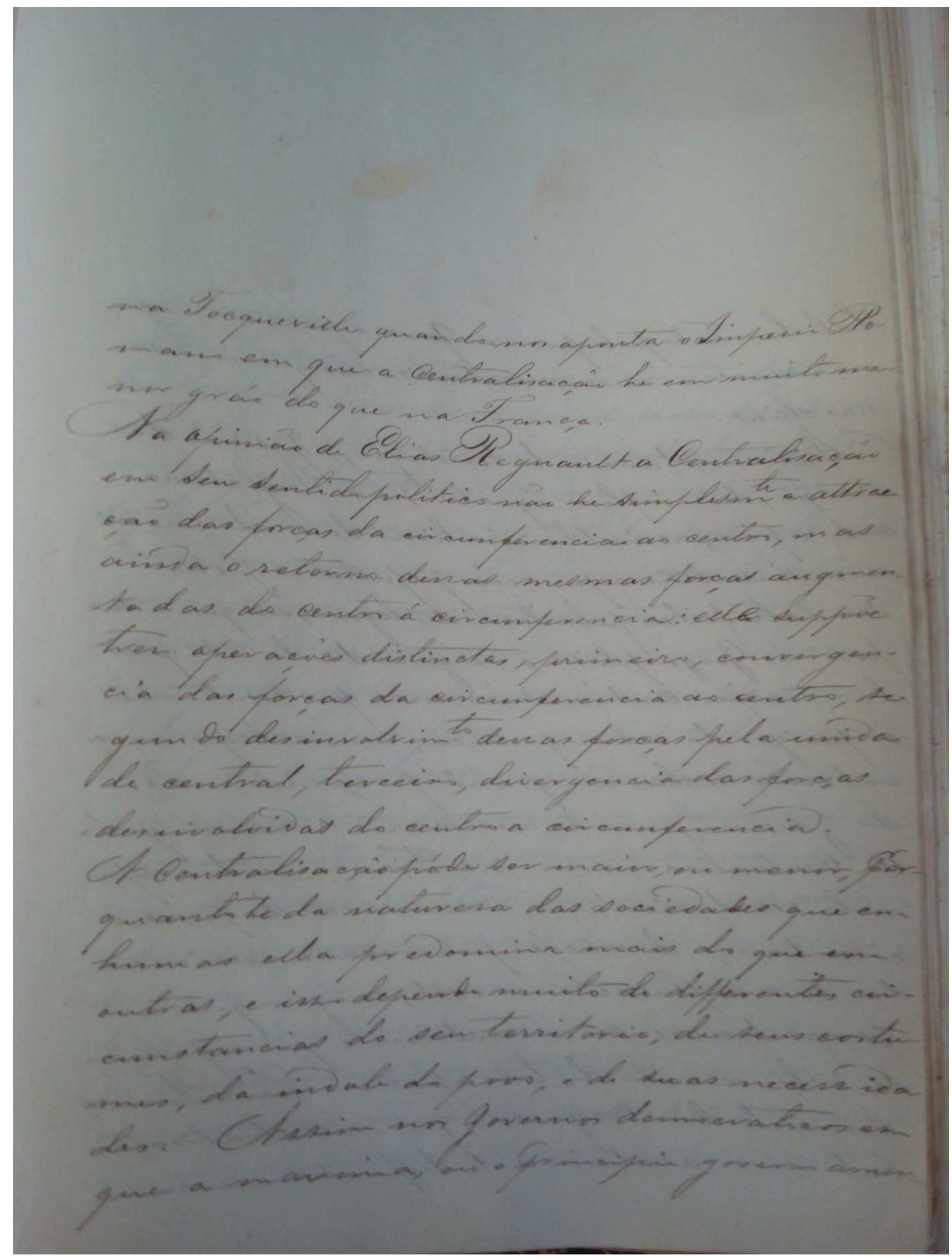




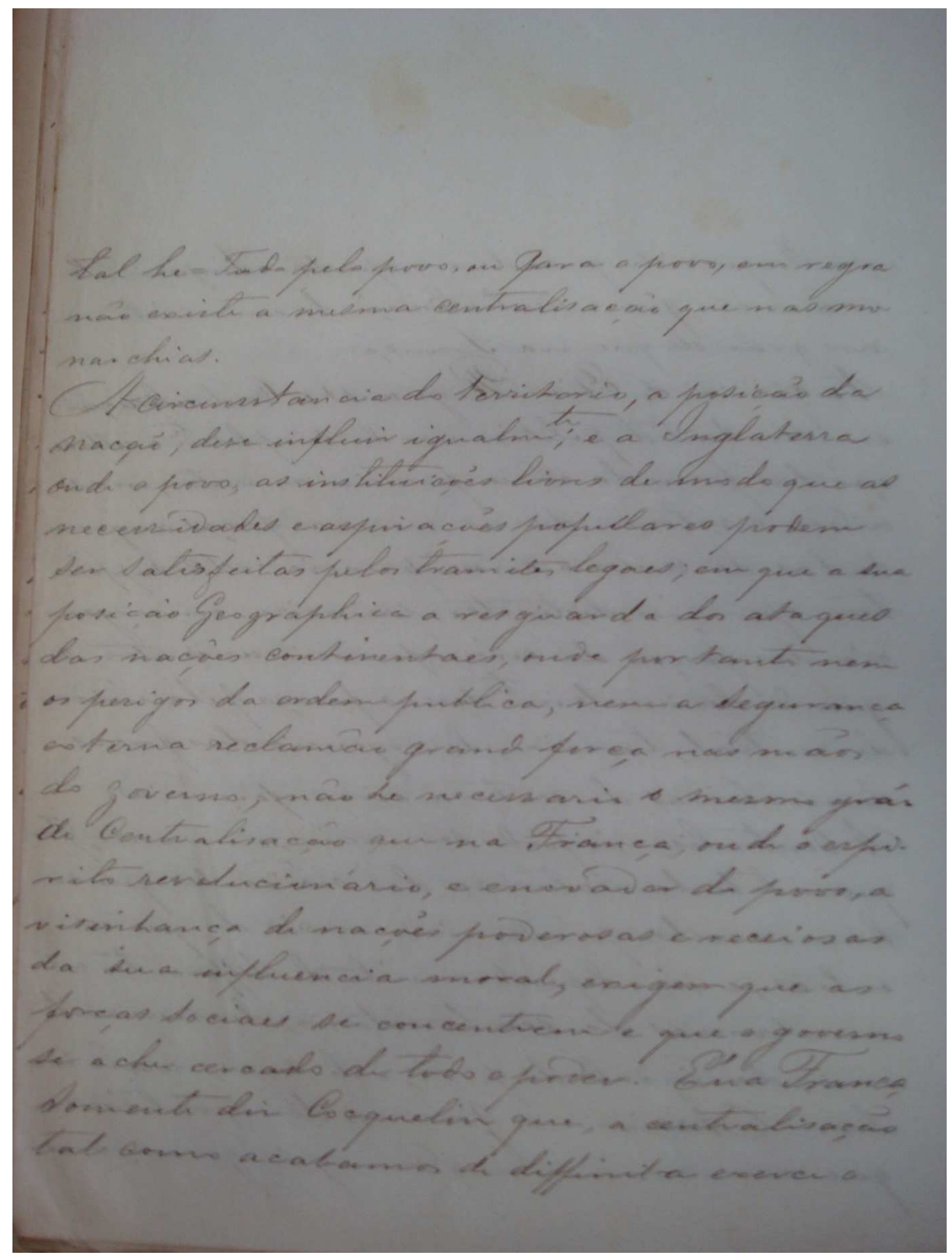




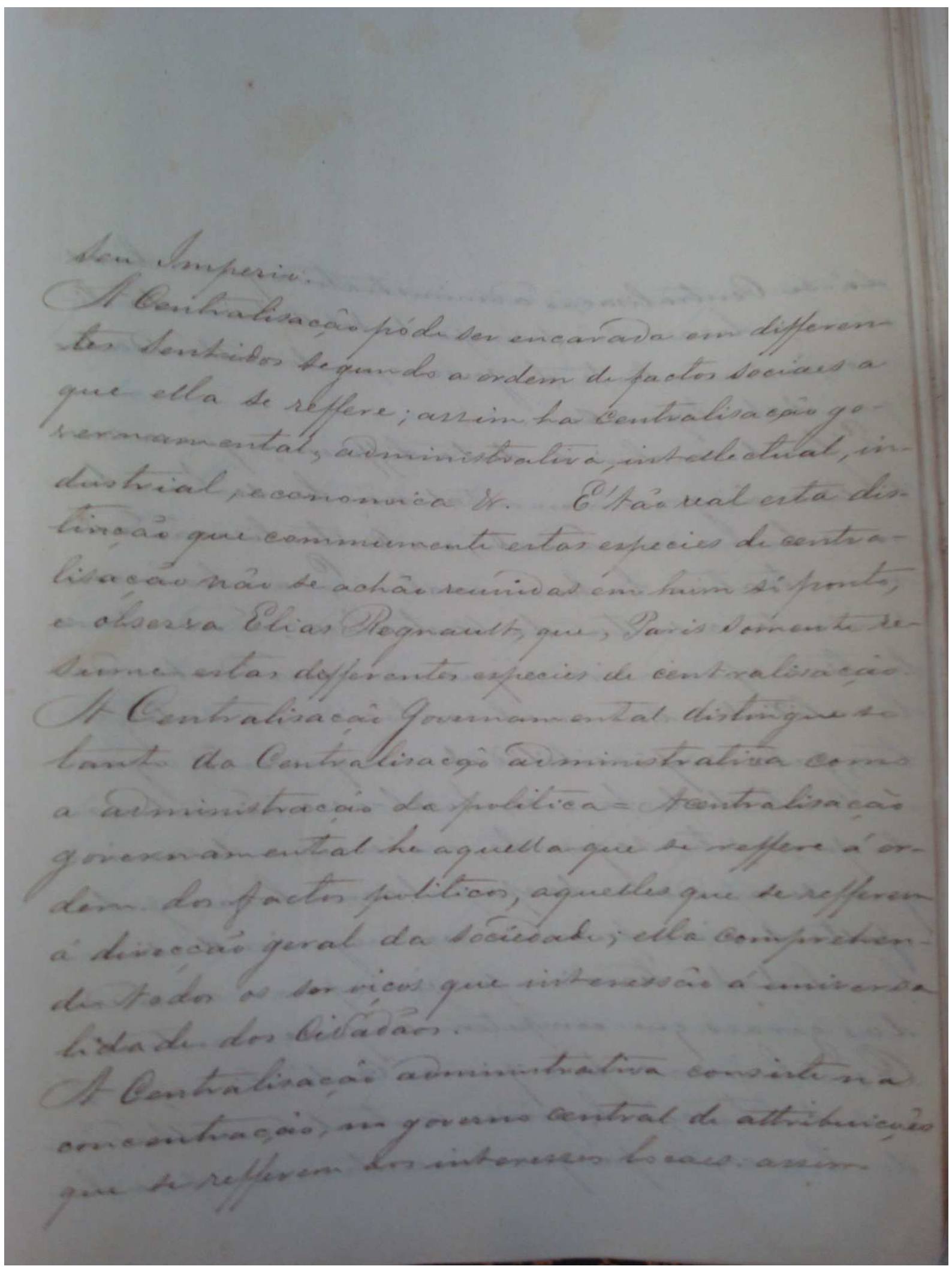




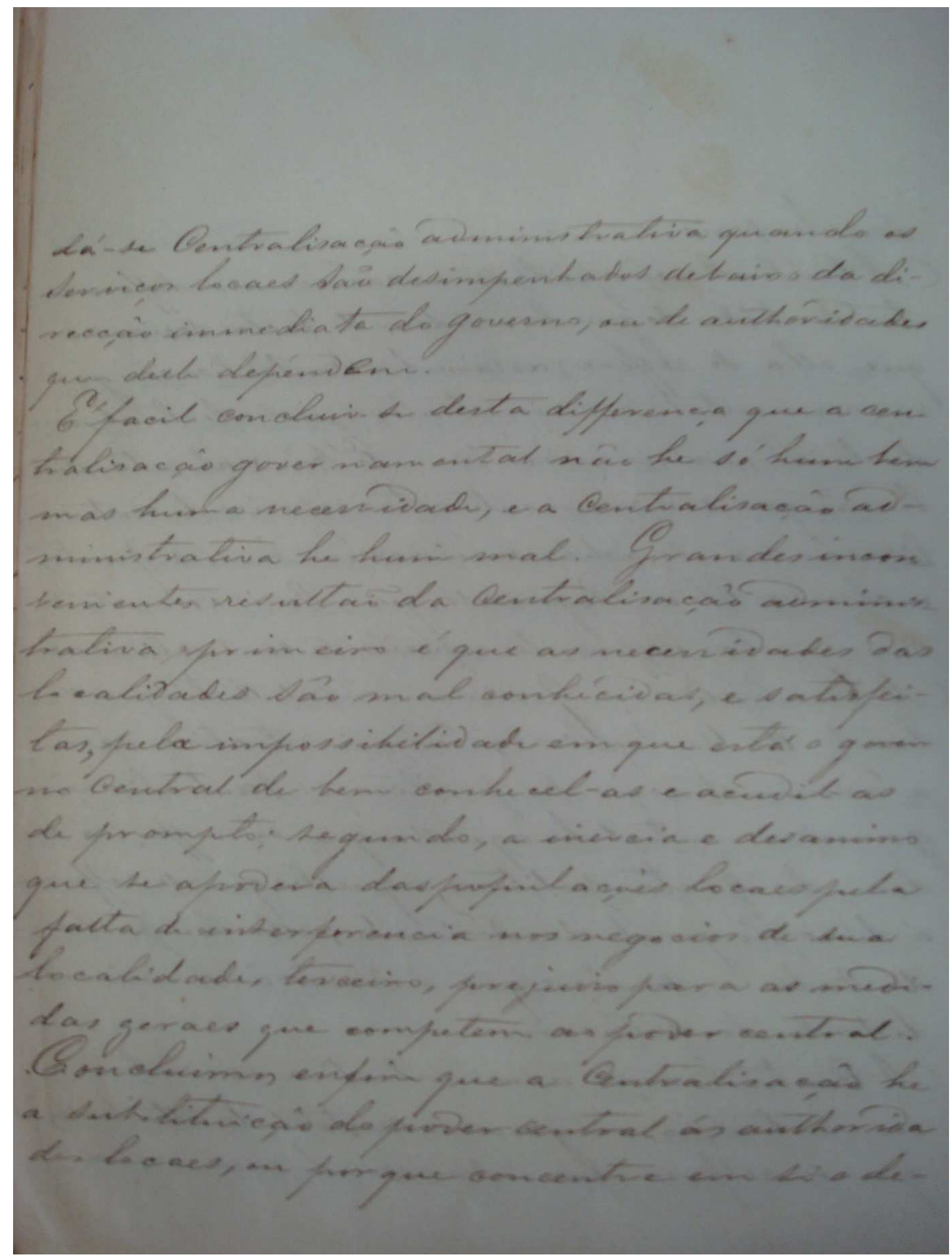




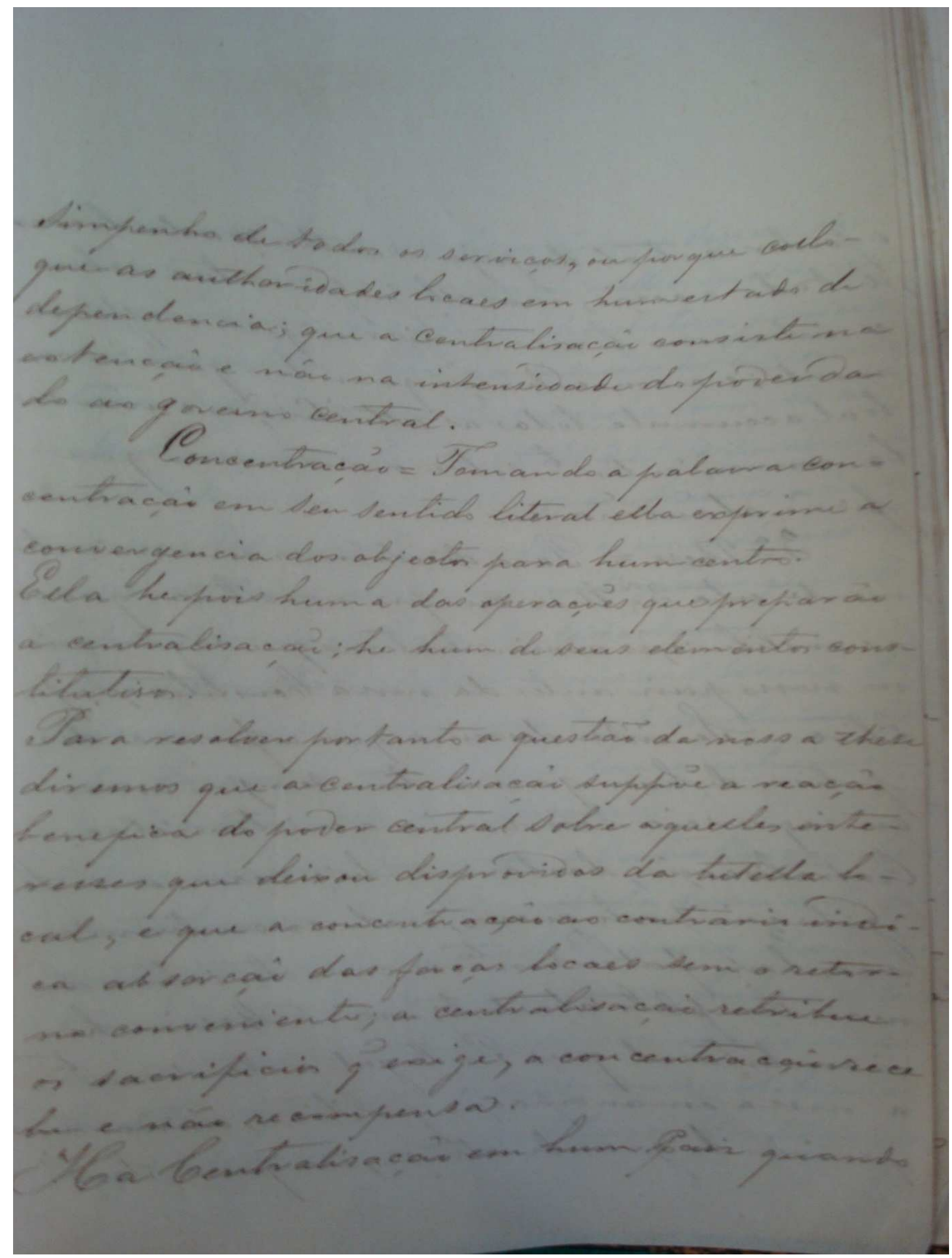




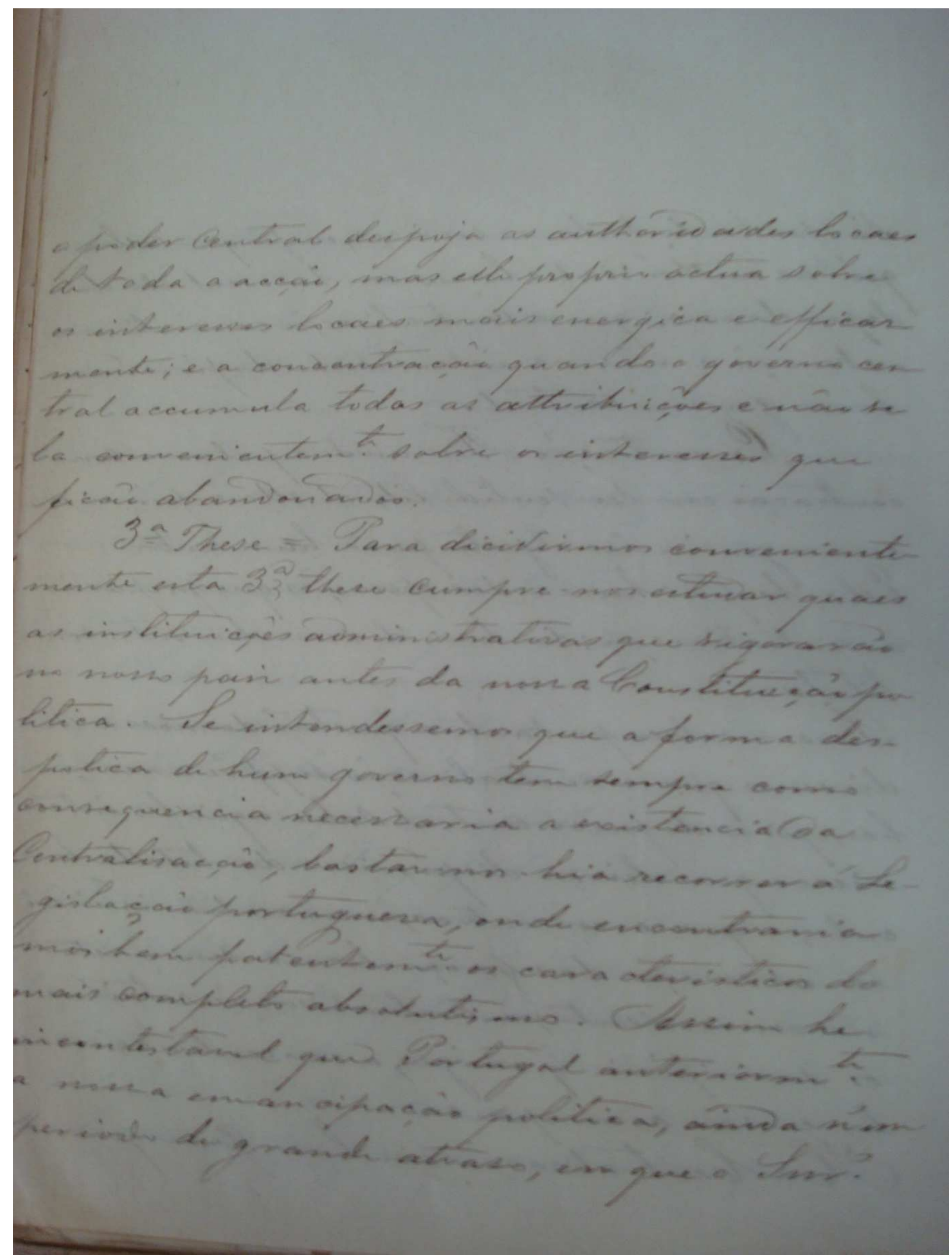




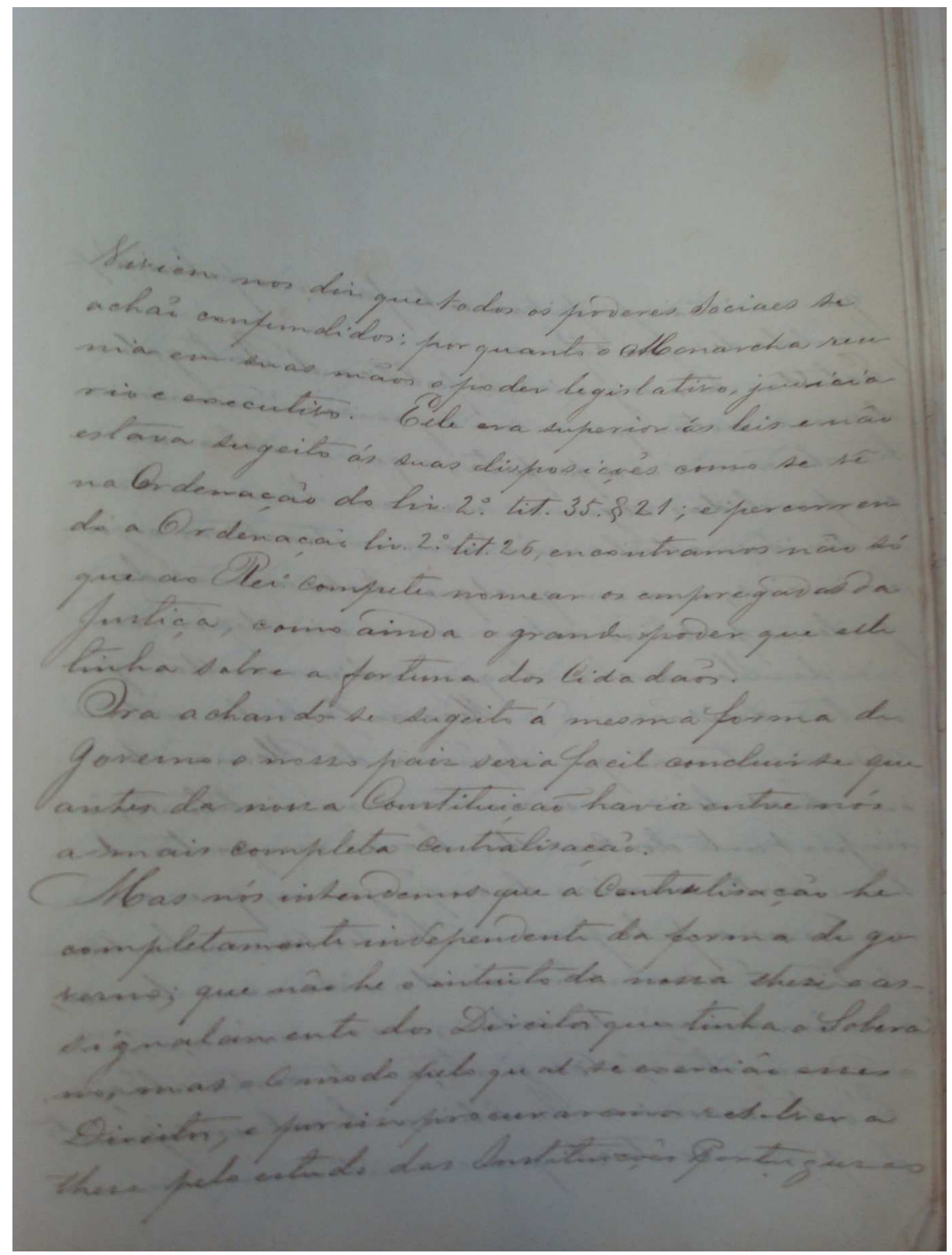




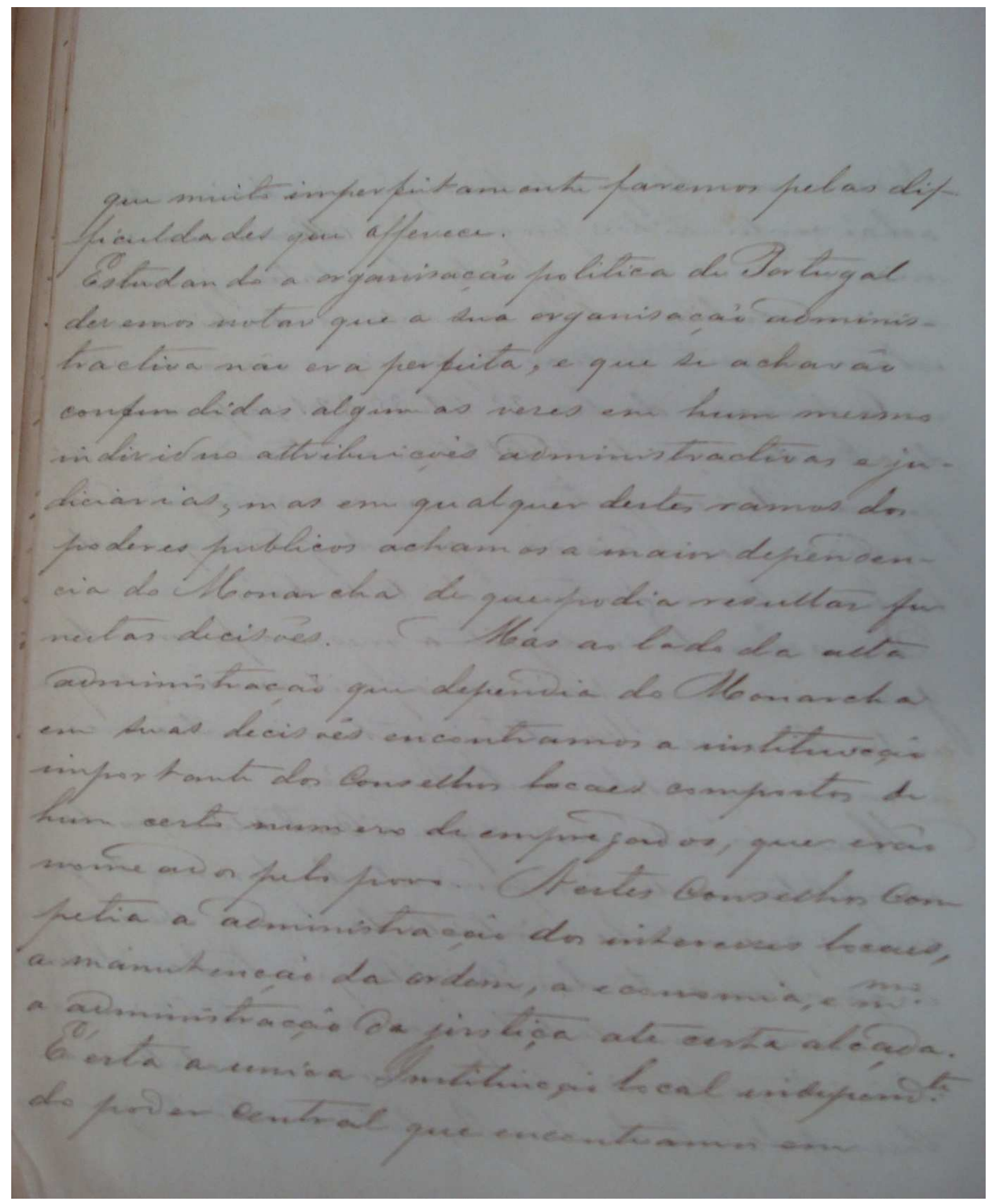




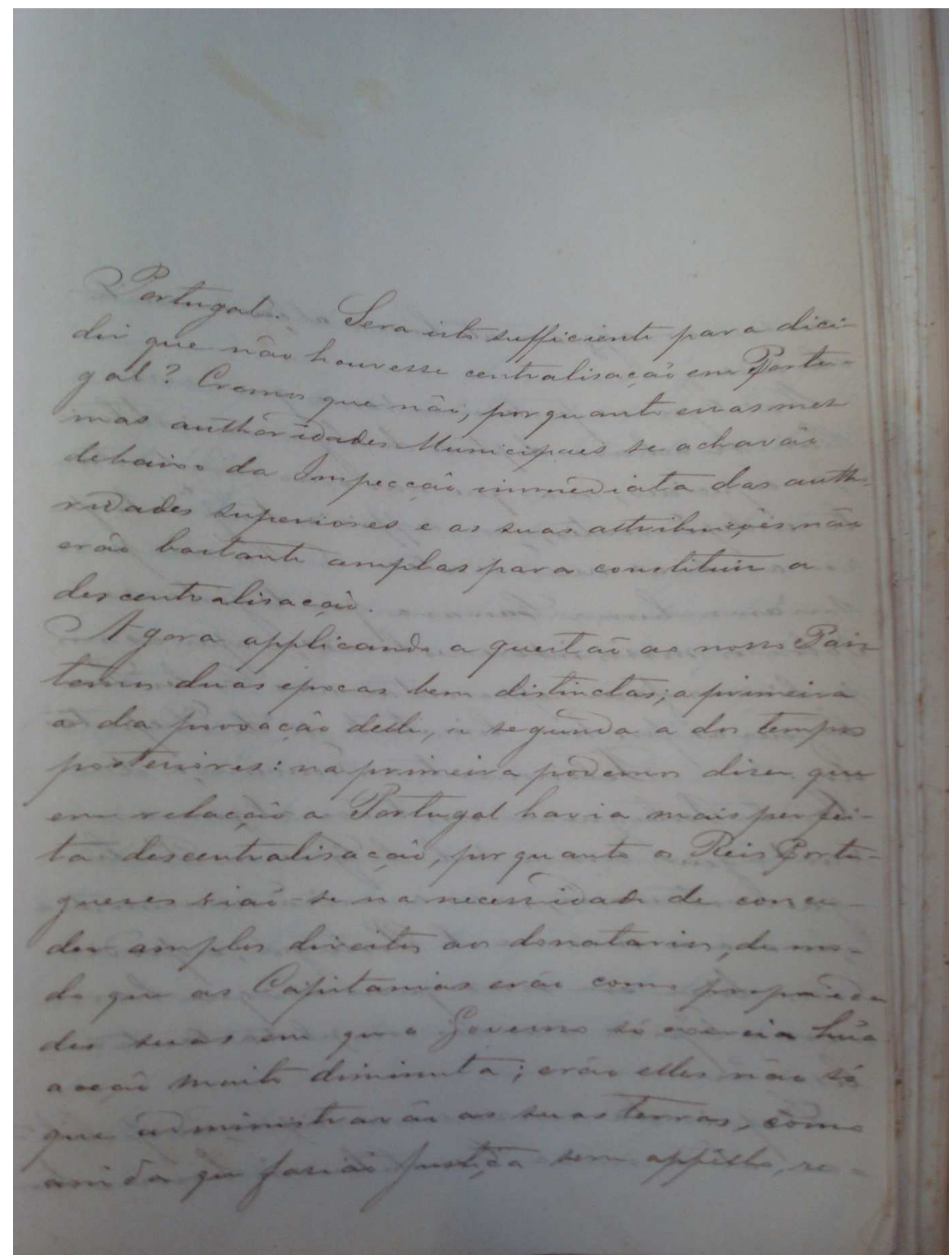




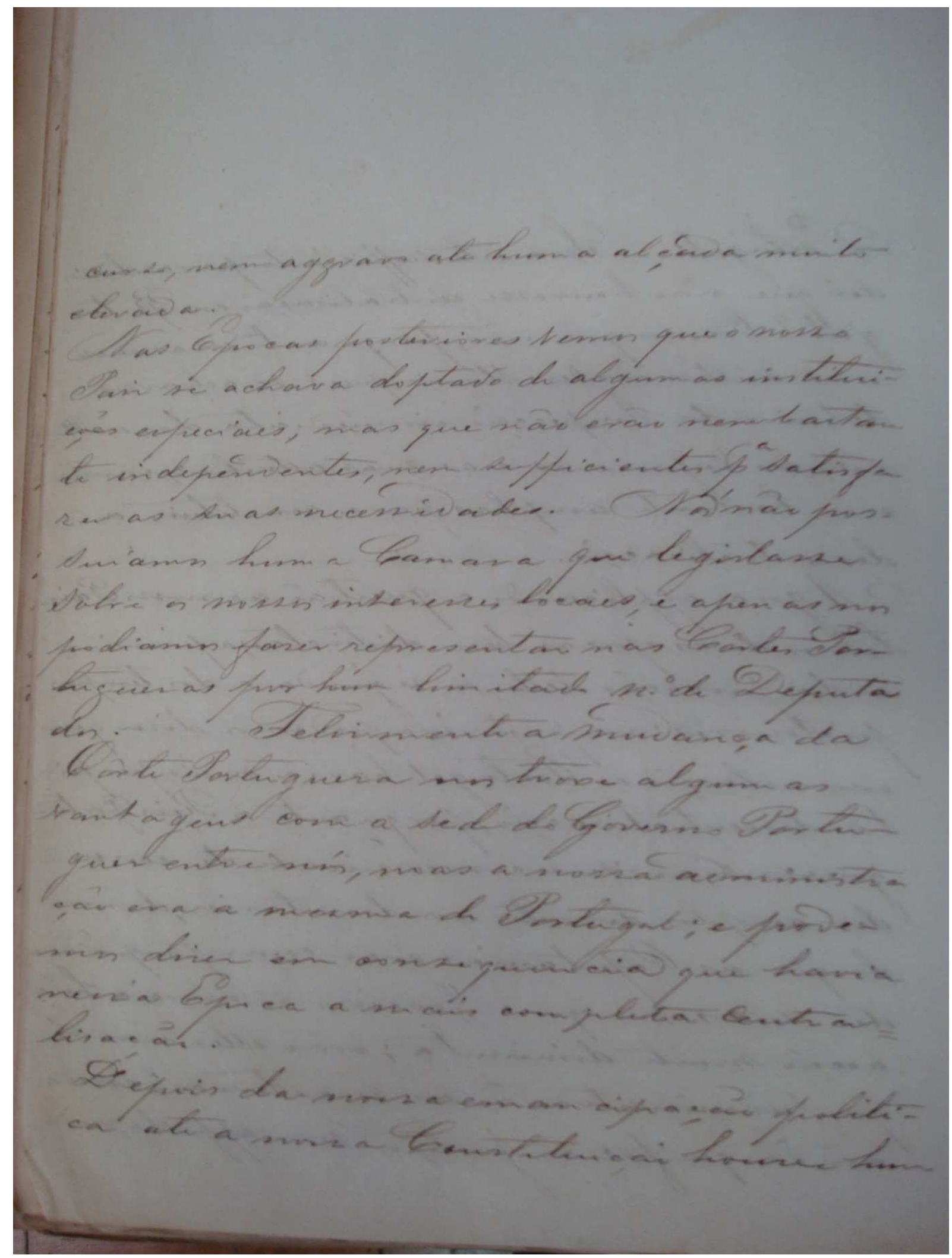




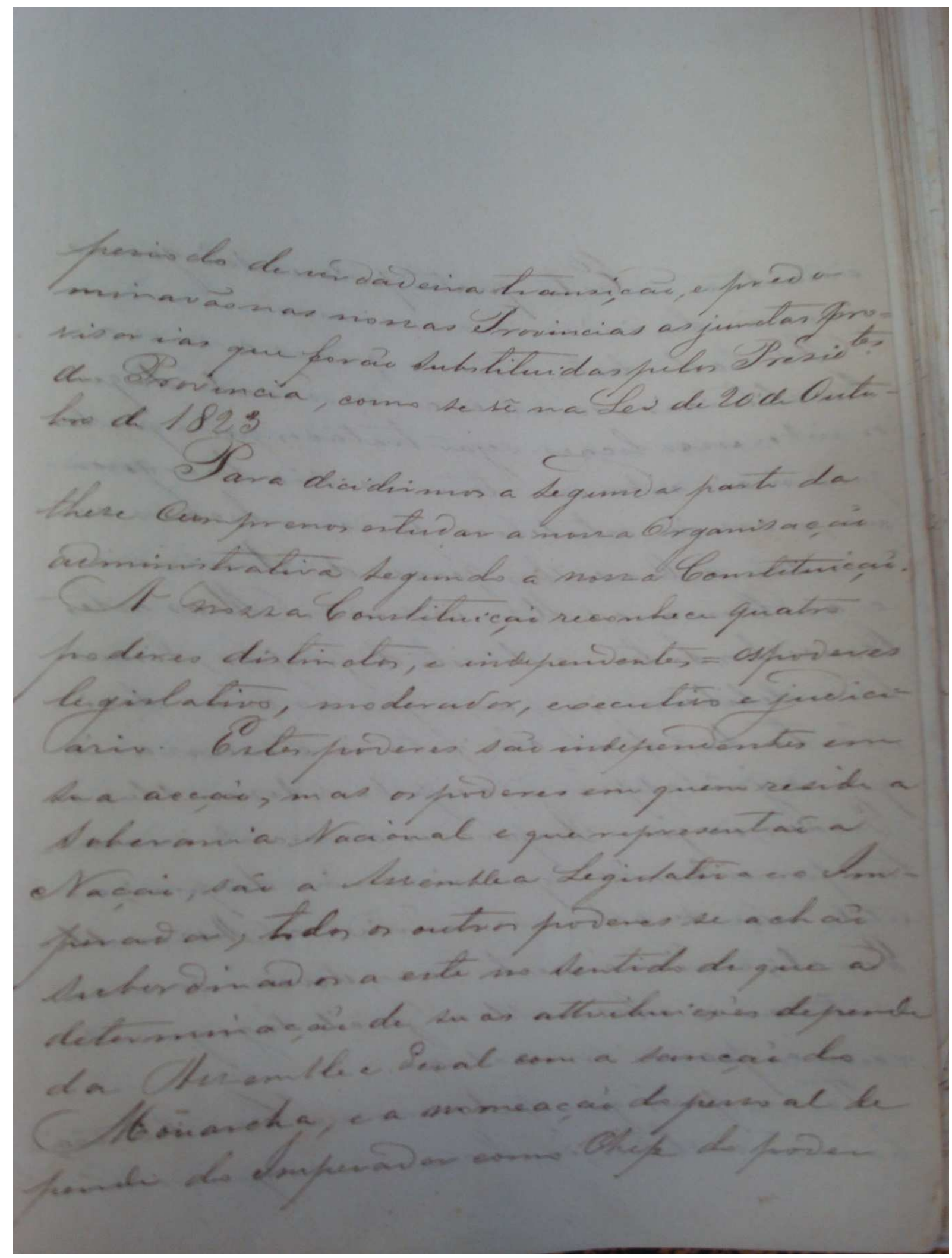




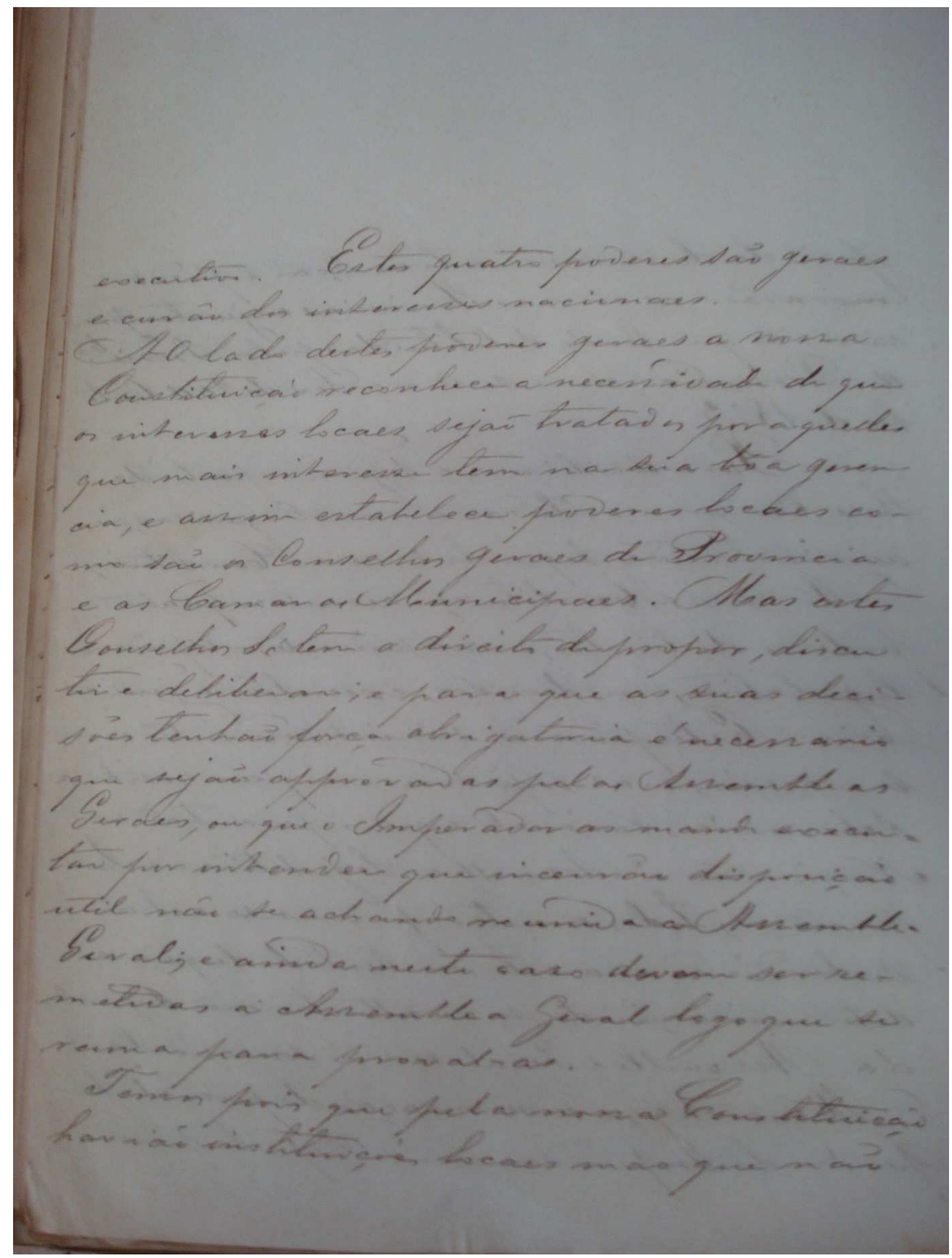




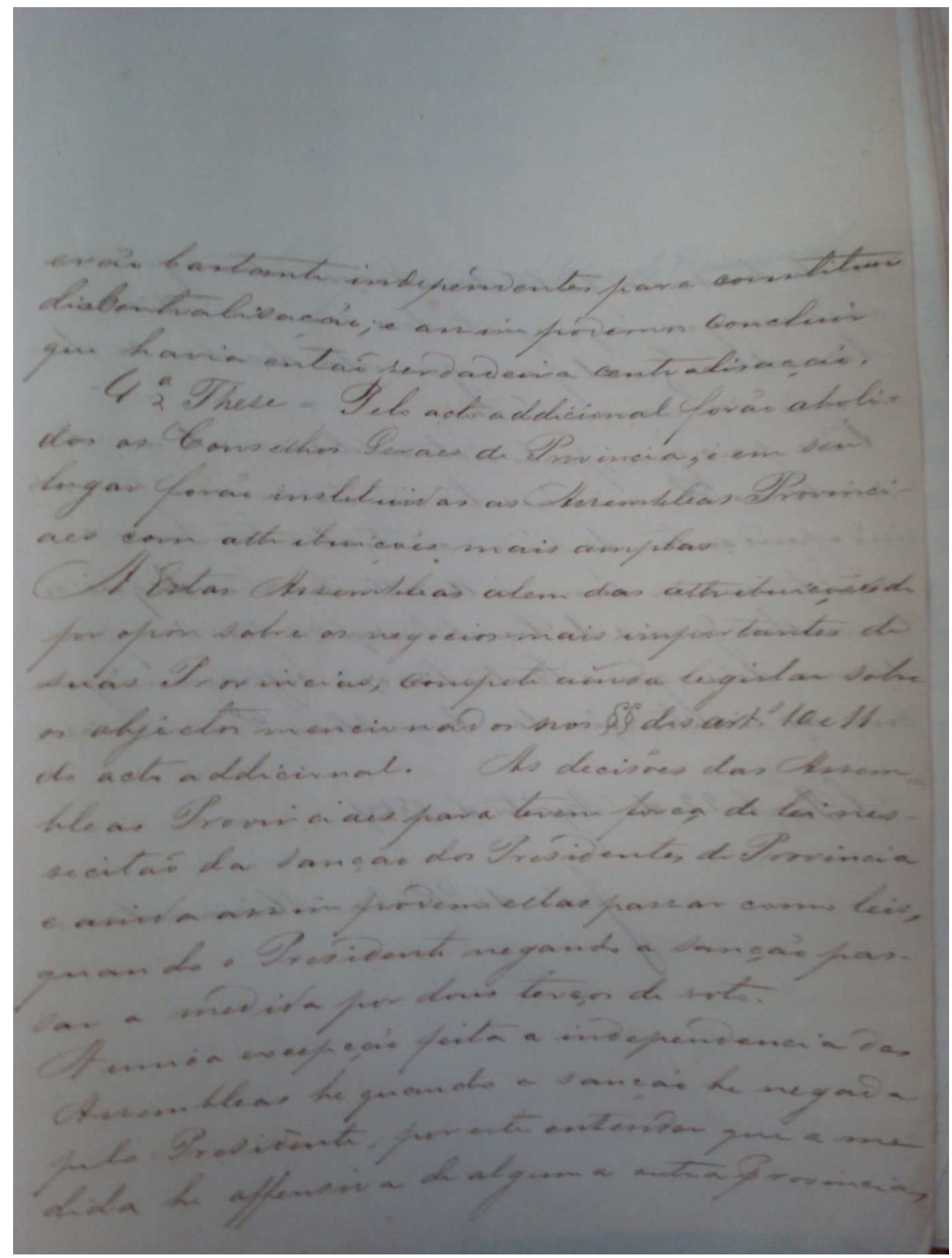


279

970

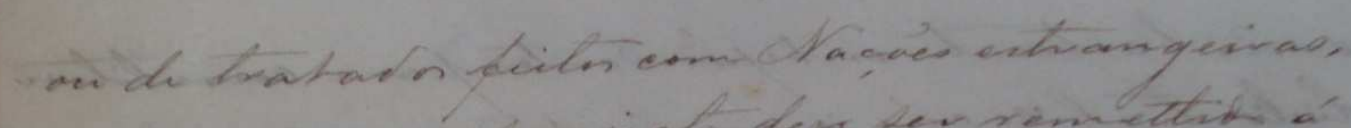

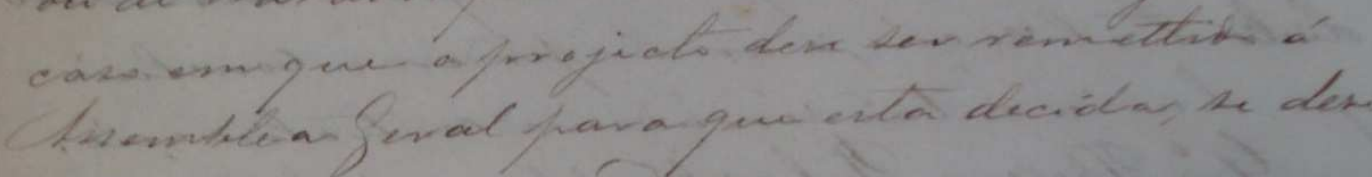

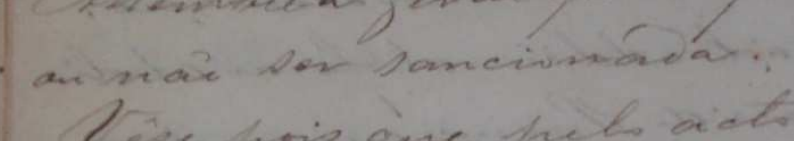

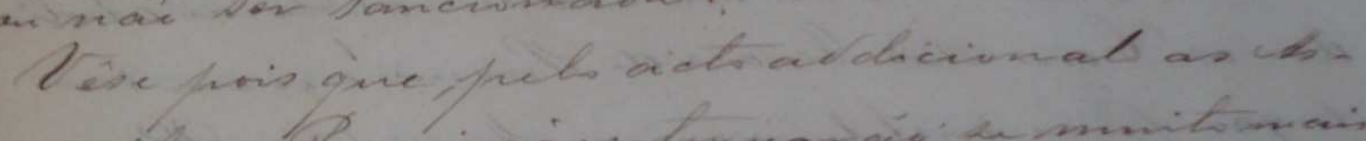

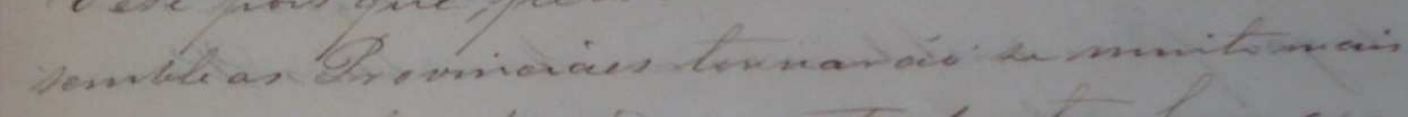

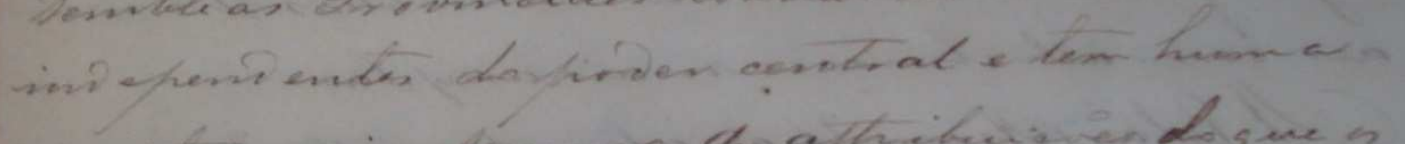

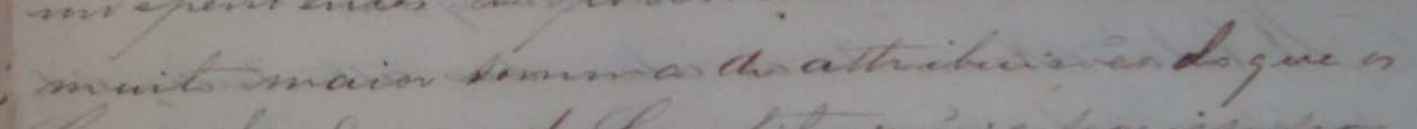

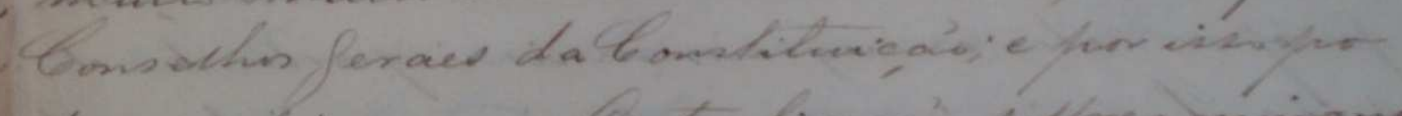

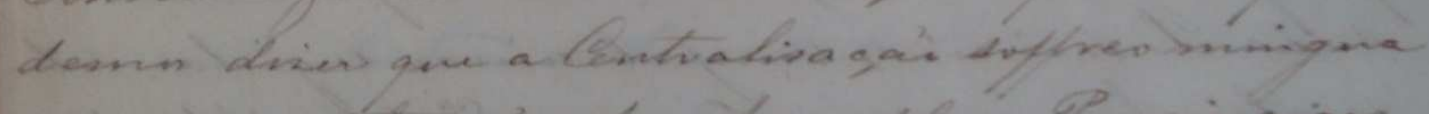

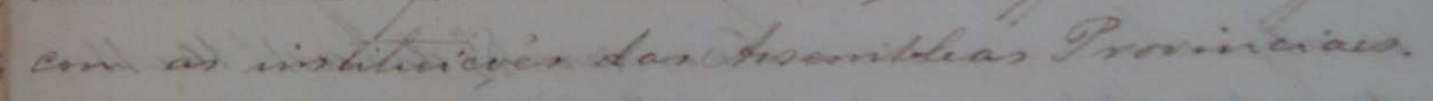

Soub 22 d Cantoid 1854

fous da Proda thimada. 
Anexo 4 - Dissertação de Direito Administrativo de Joaquim Antonio Fernandes de Silveira

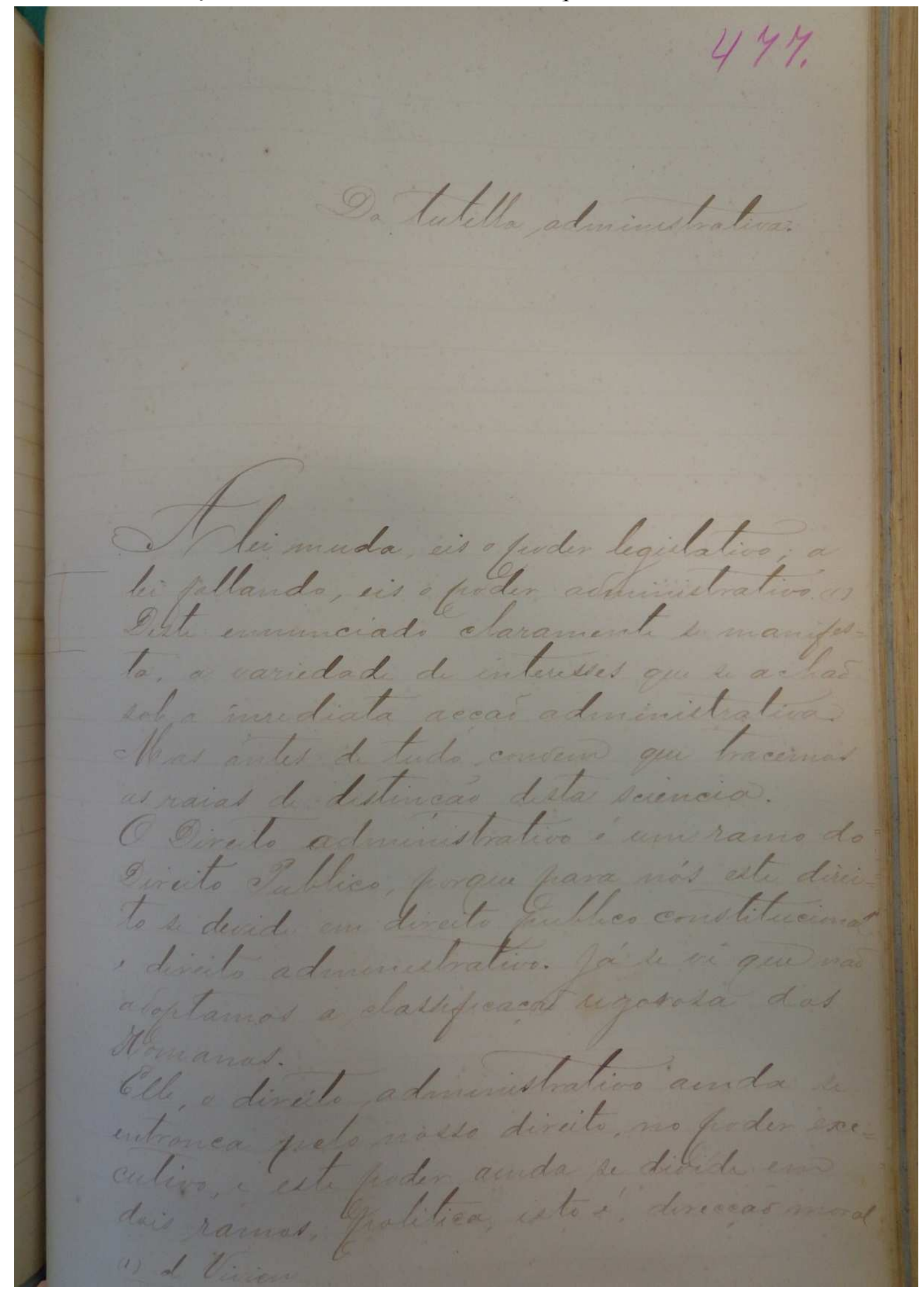




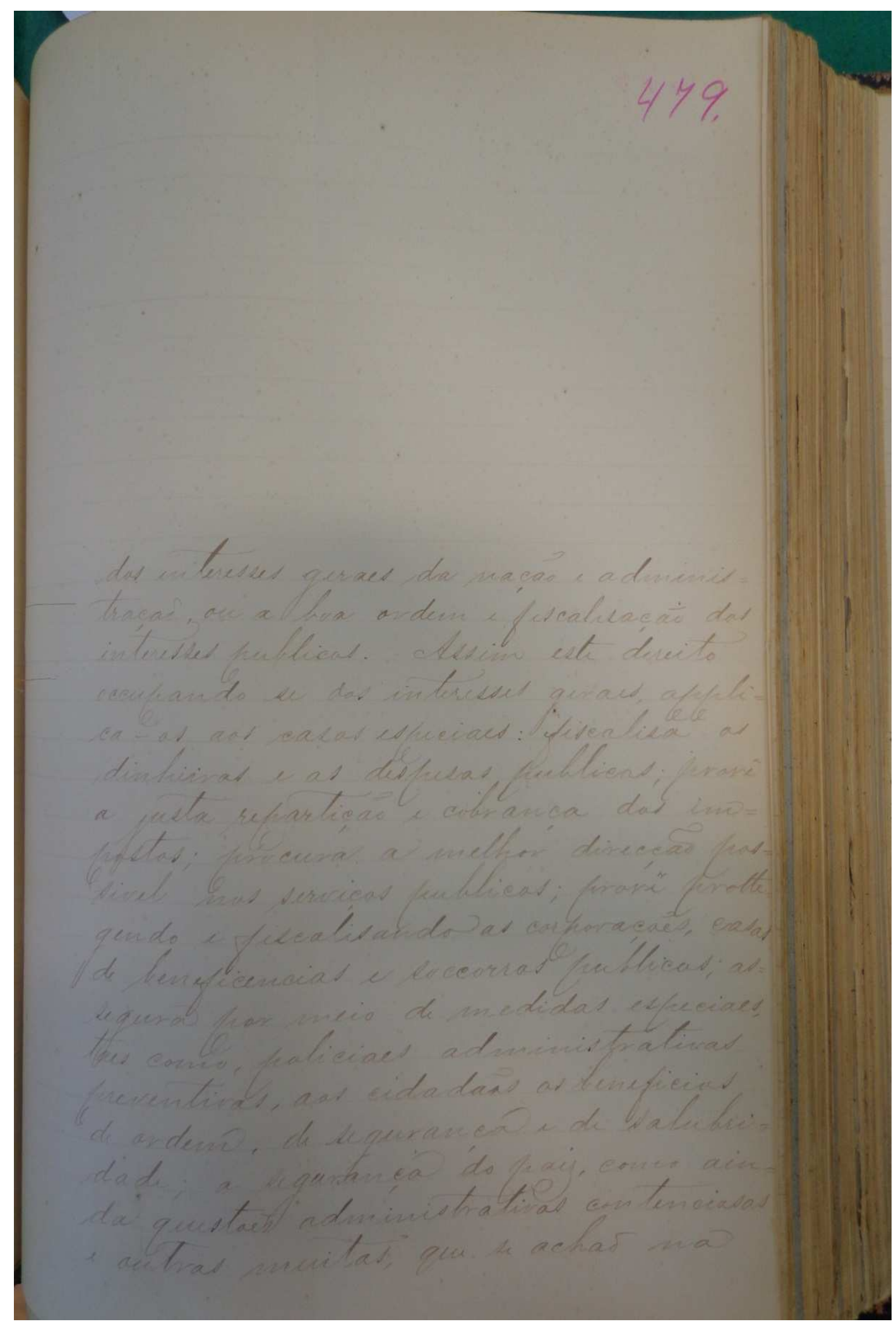







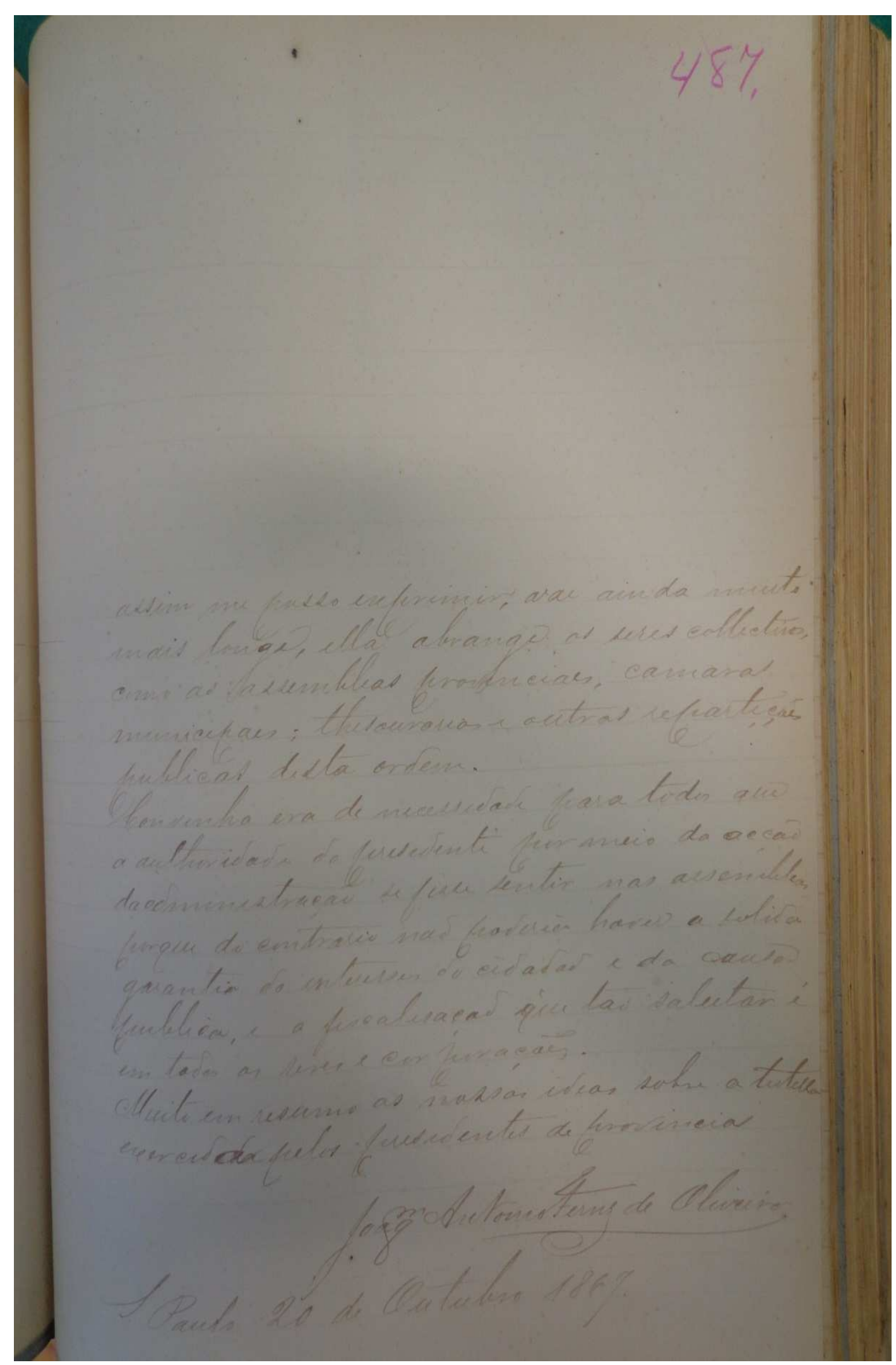


Anexo 5 - Dissertação de Direito Administrativo de Antonio Quirino

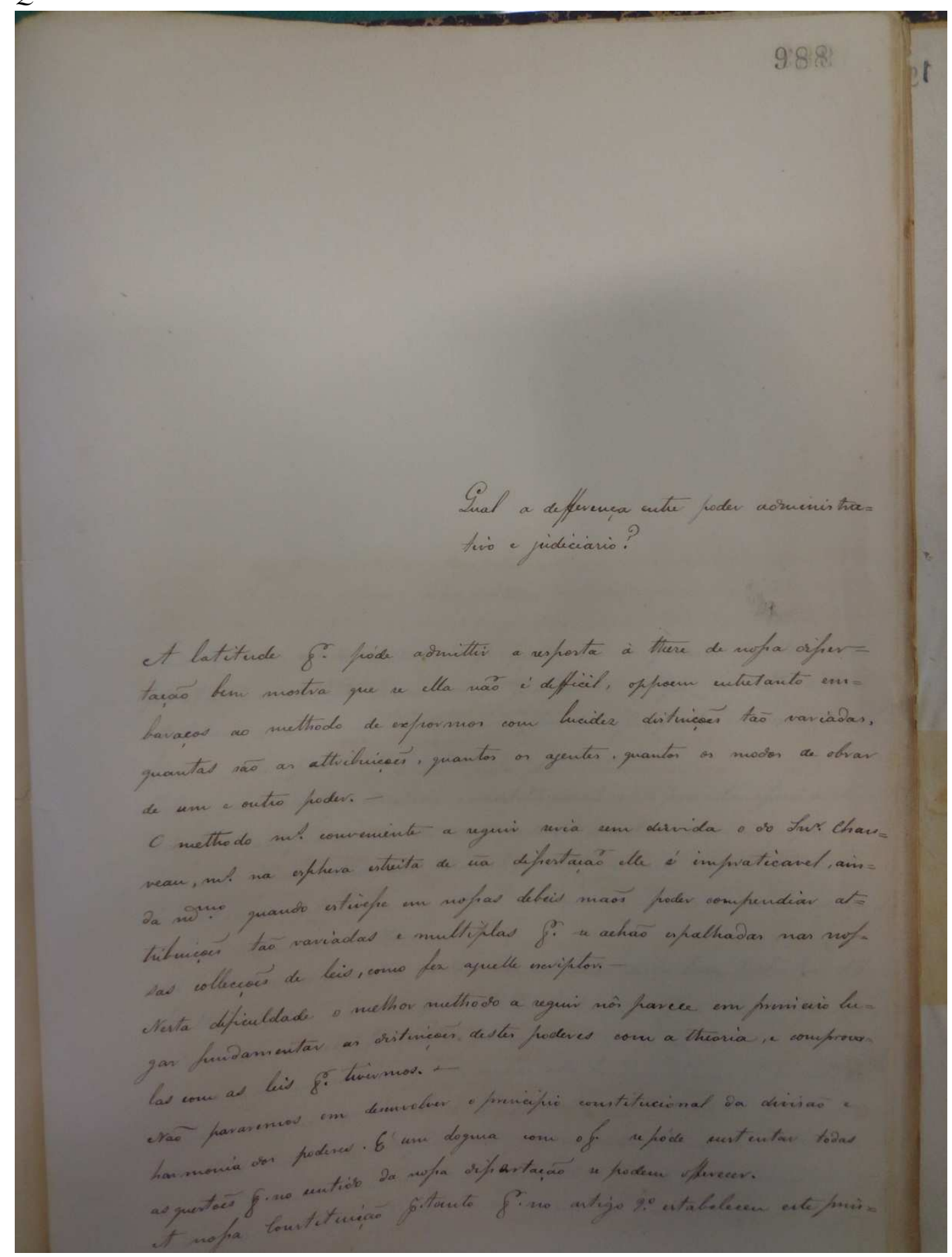




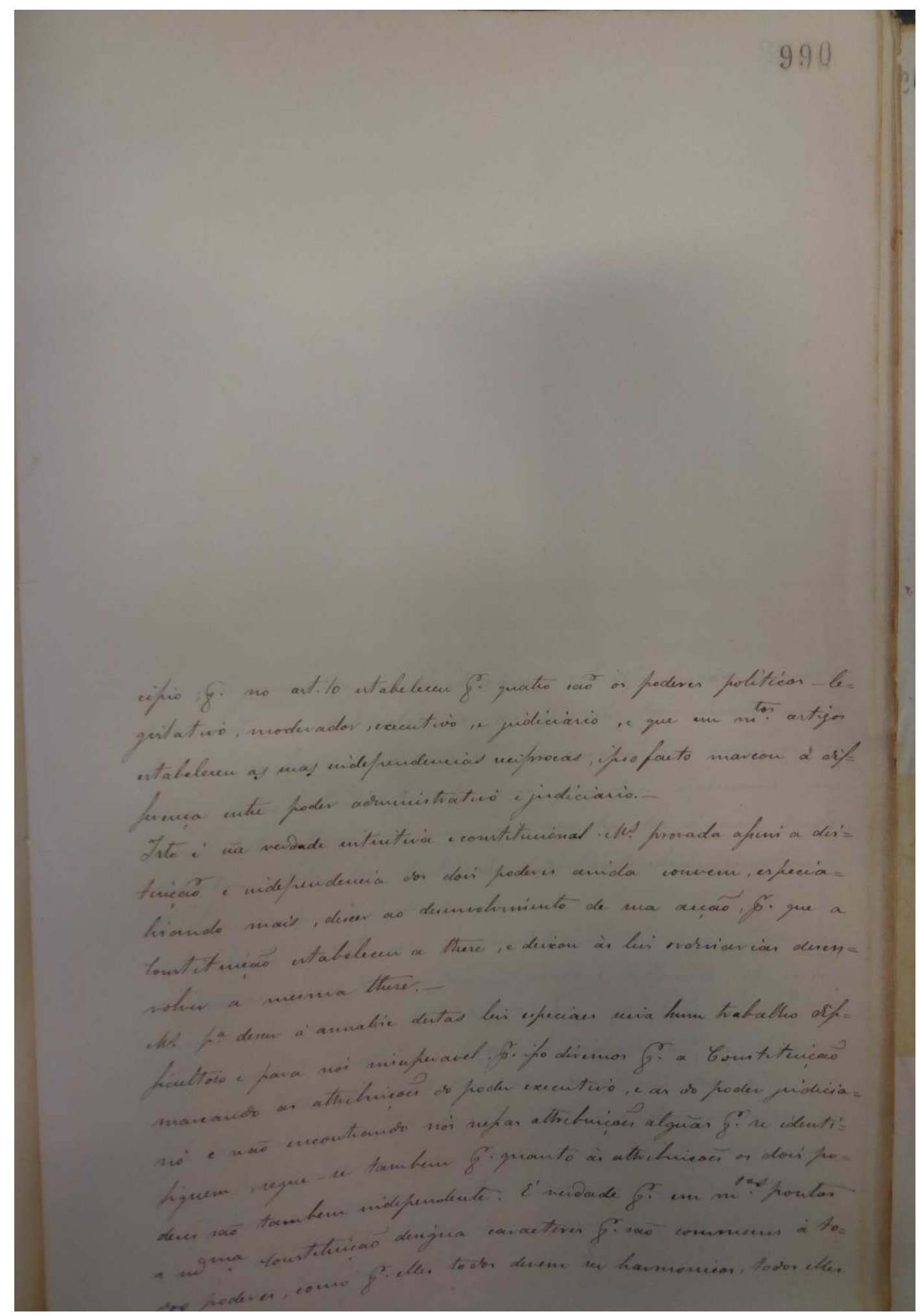




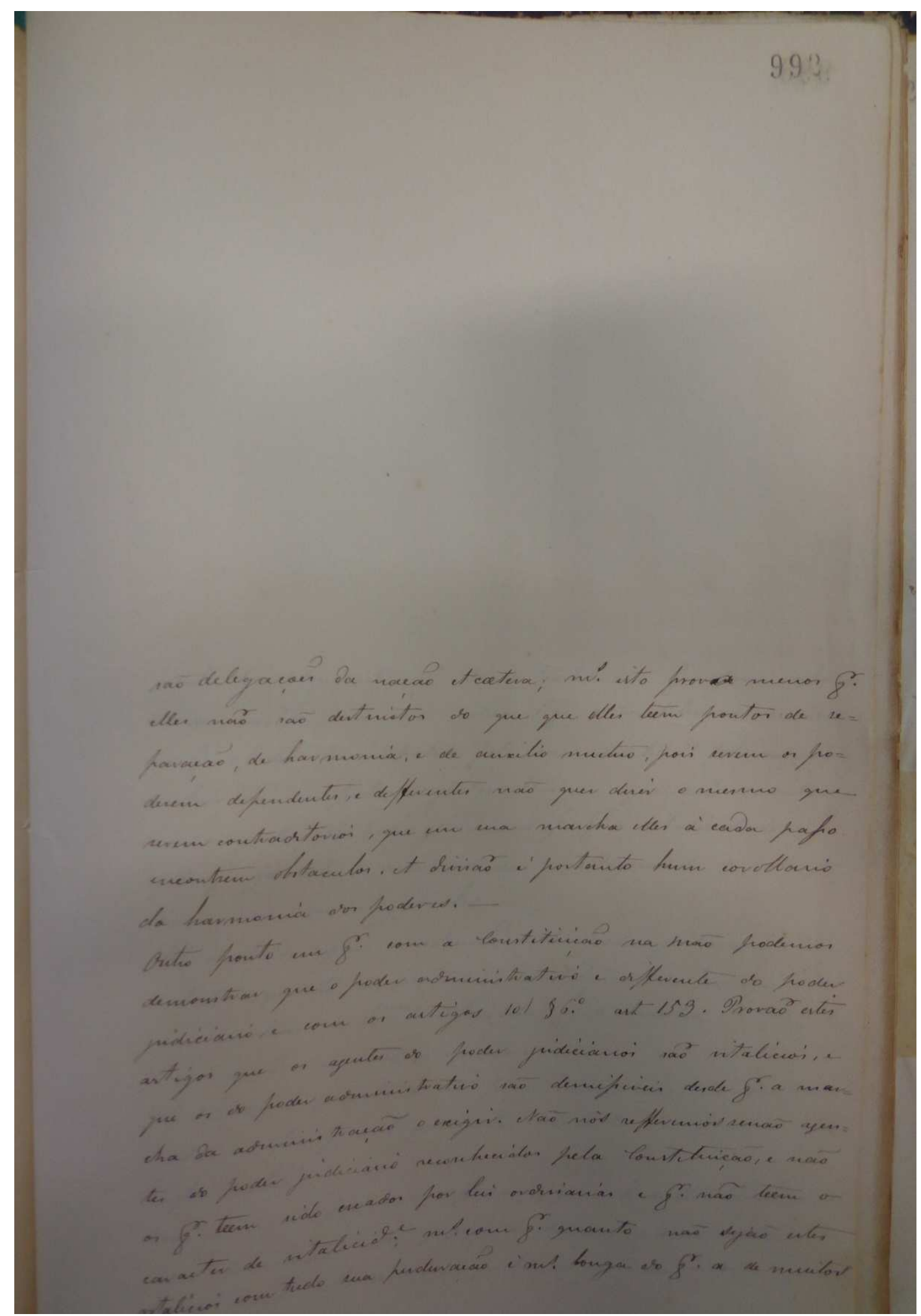




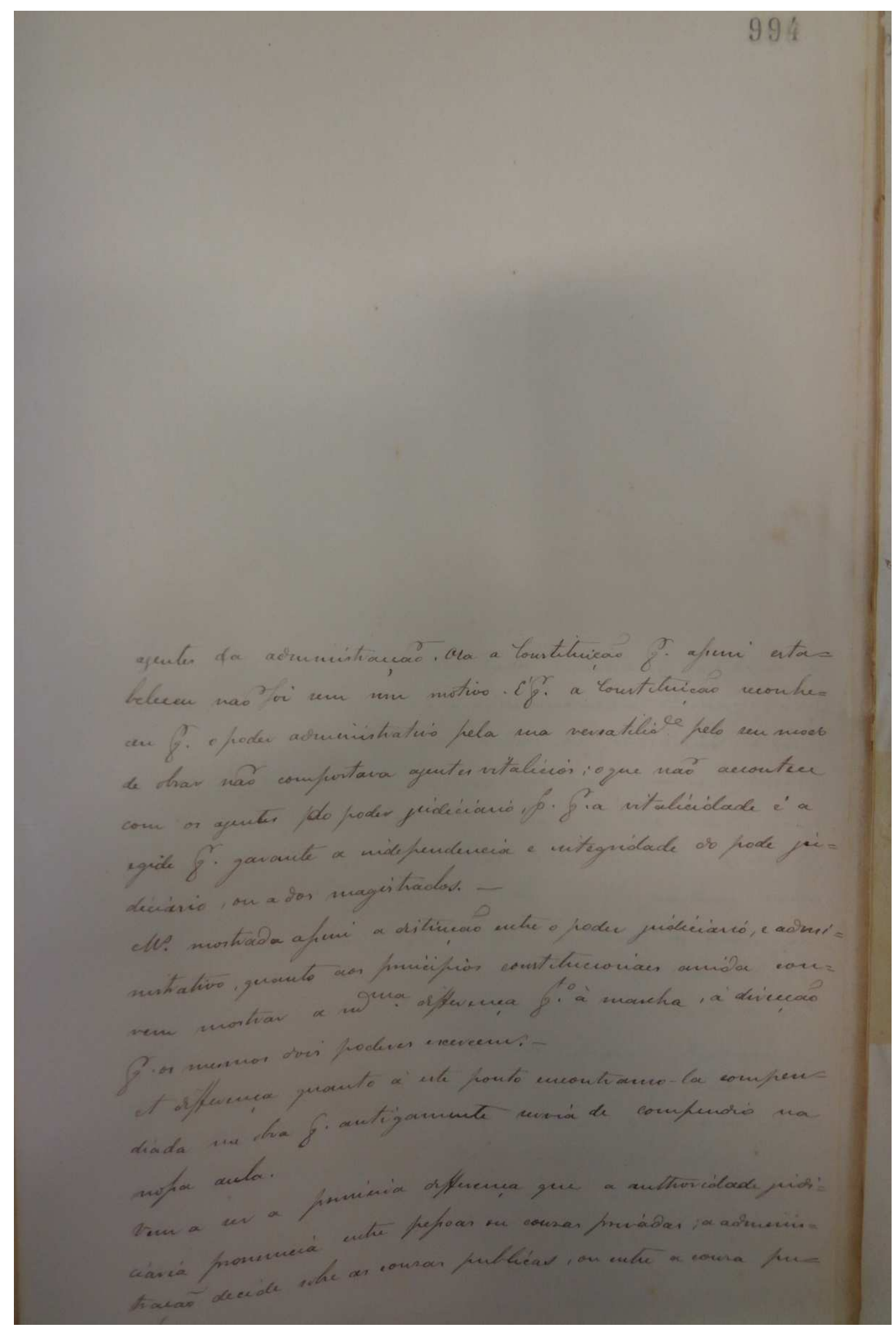




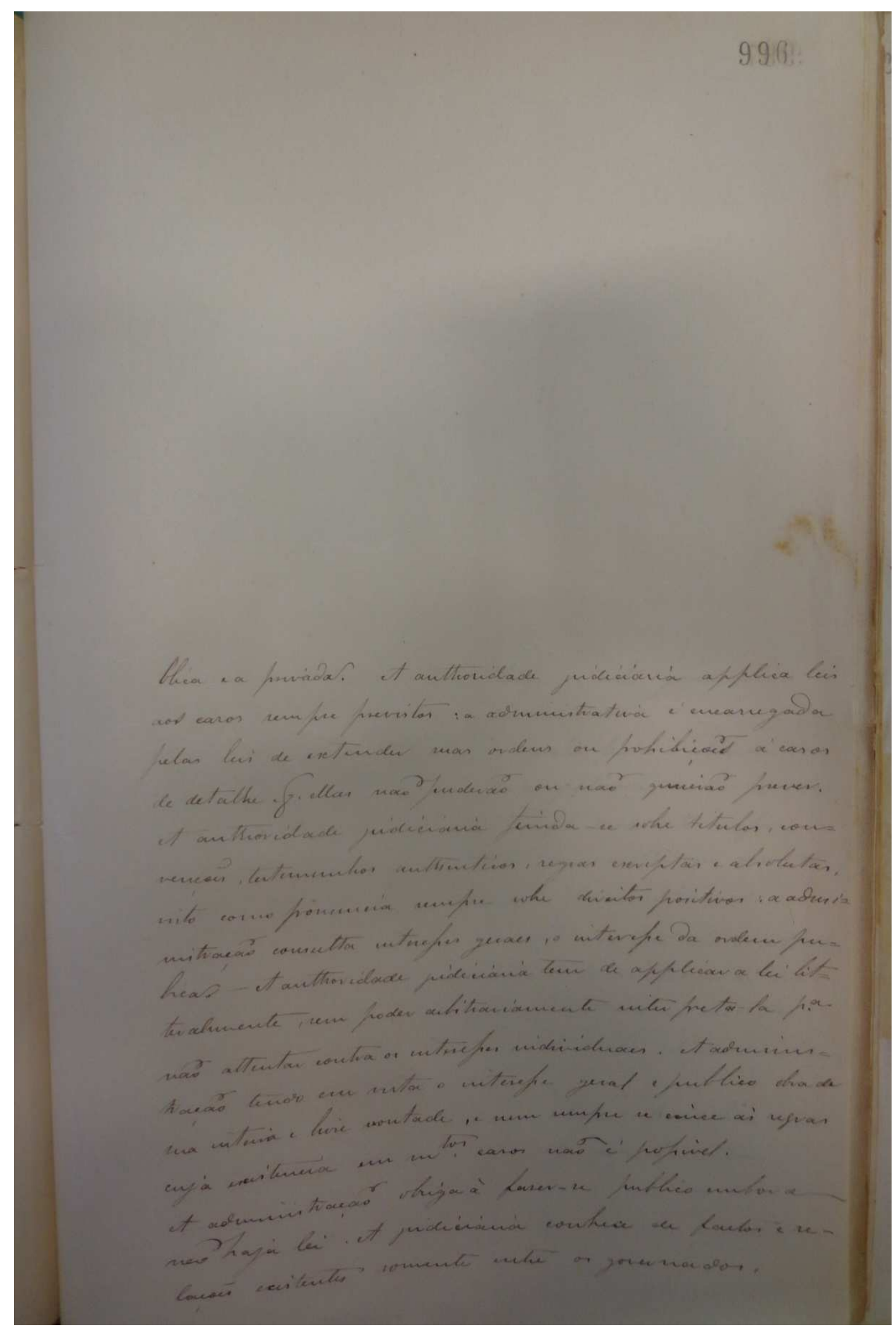




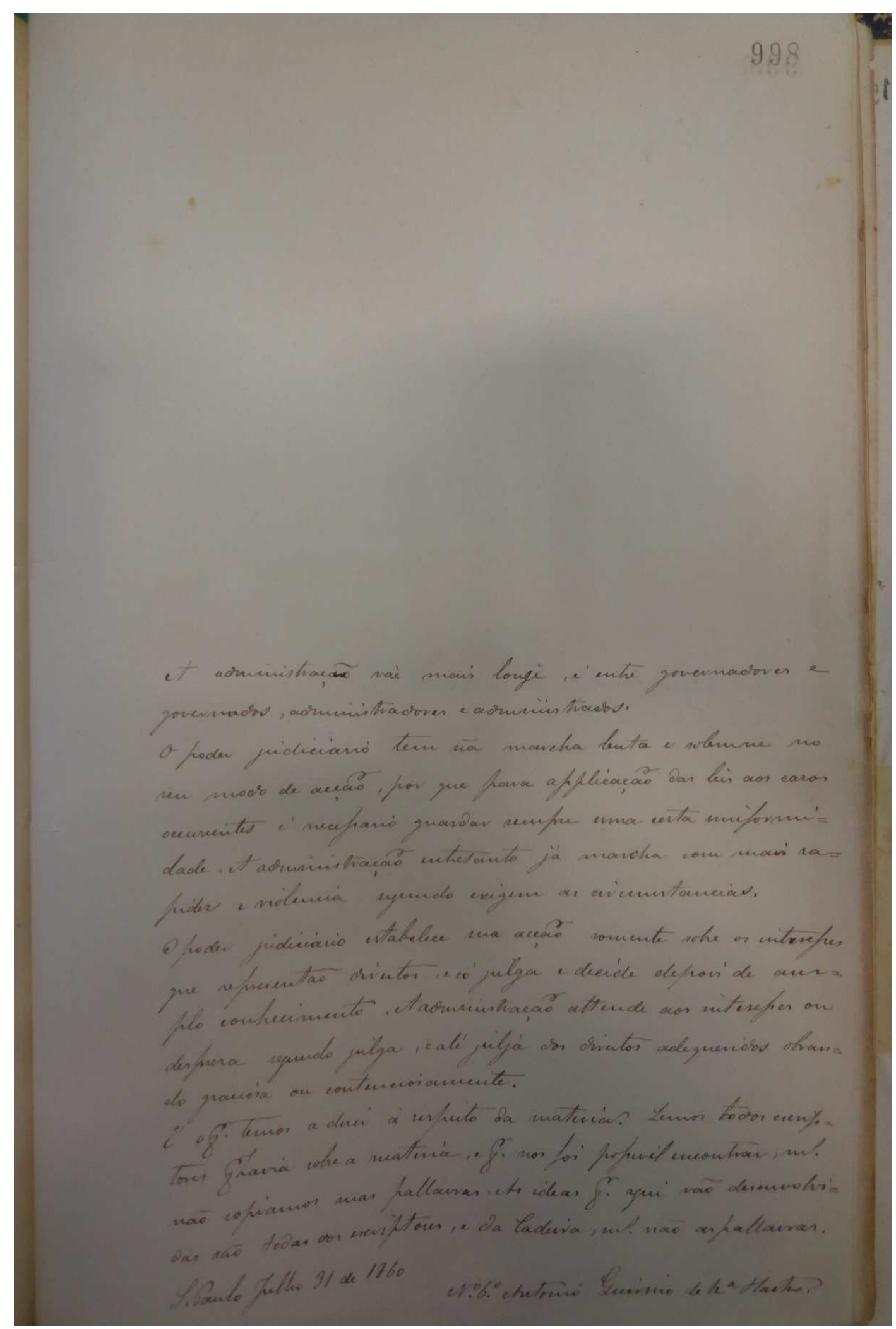


Anexo 6 - Dissertação de Direito Administrativo de Augusto F. daSilva

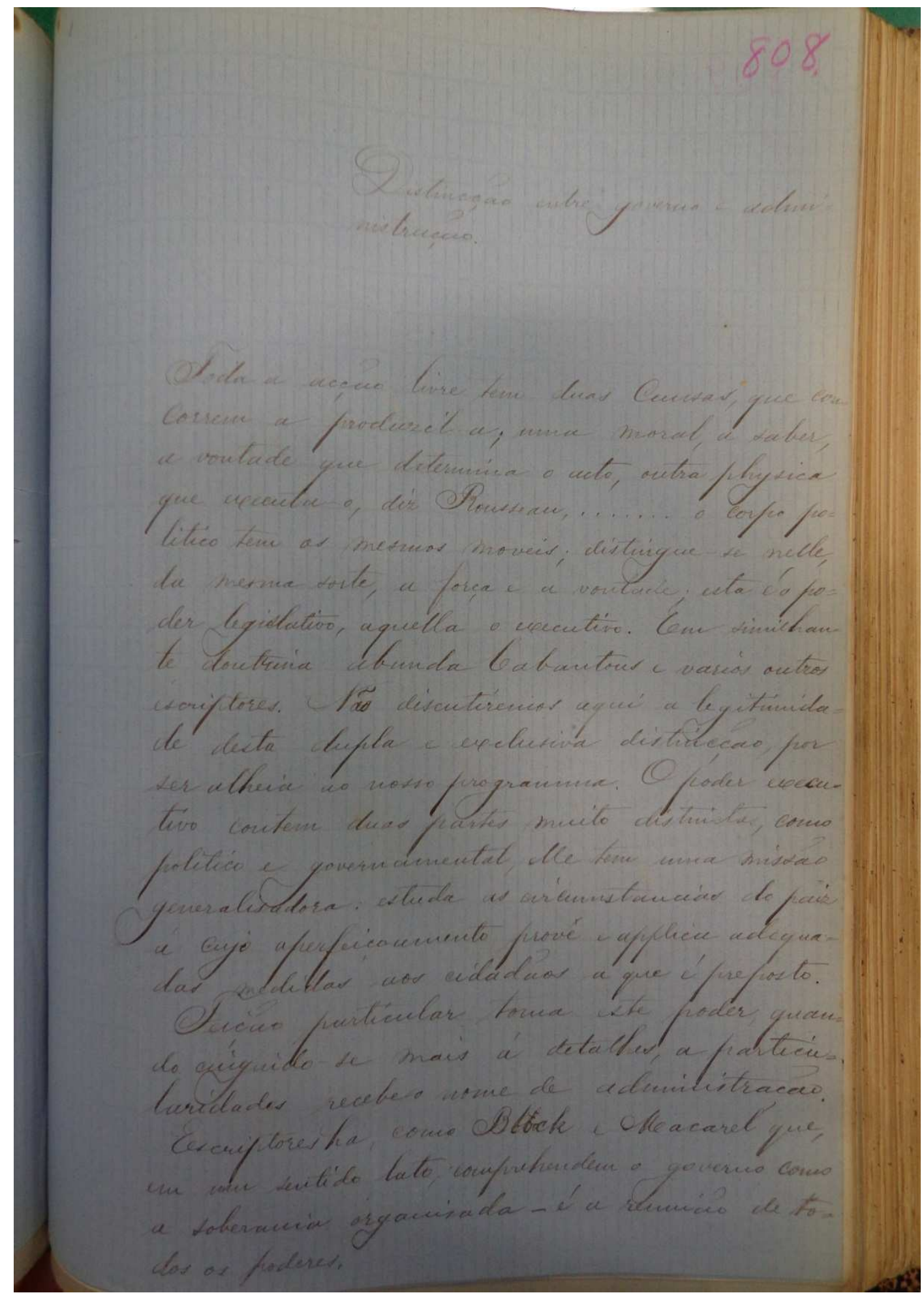




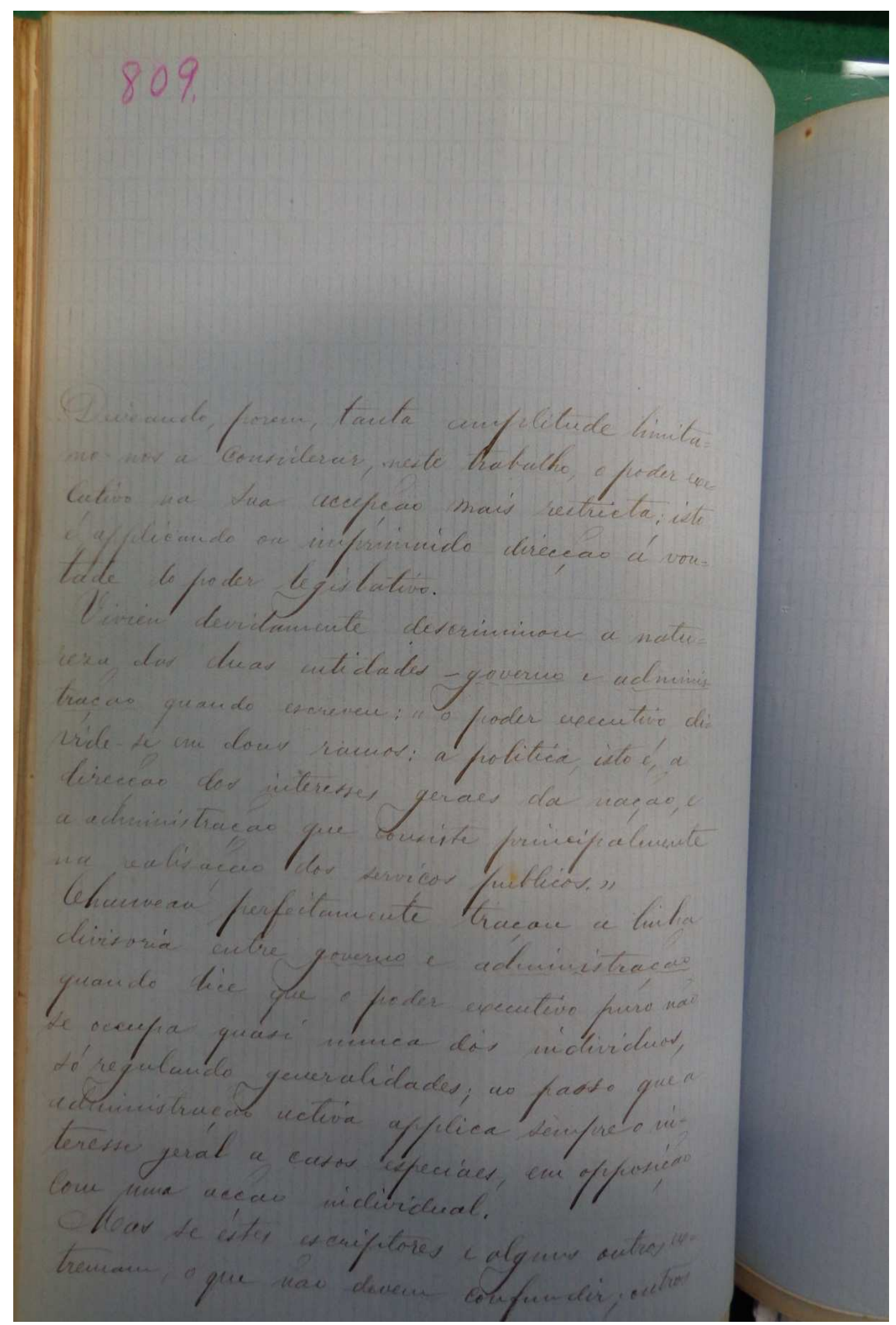




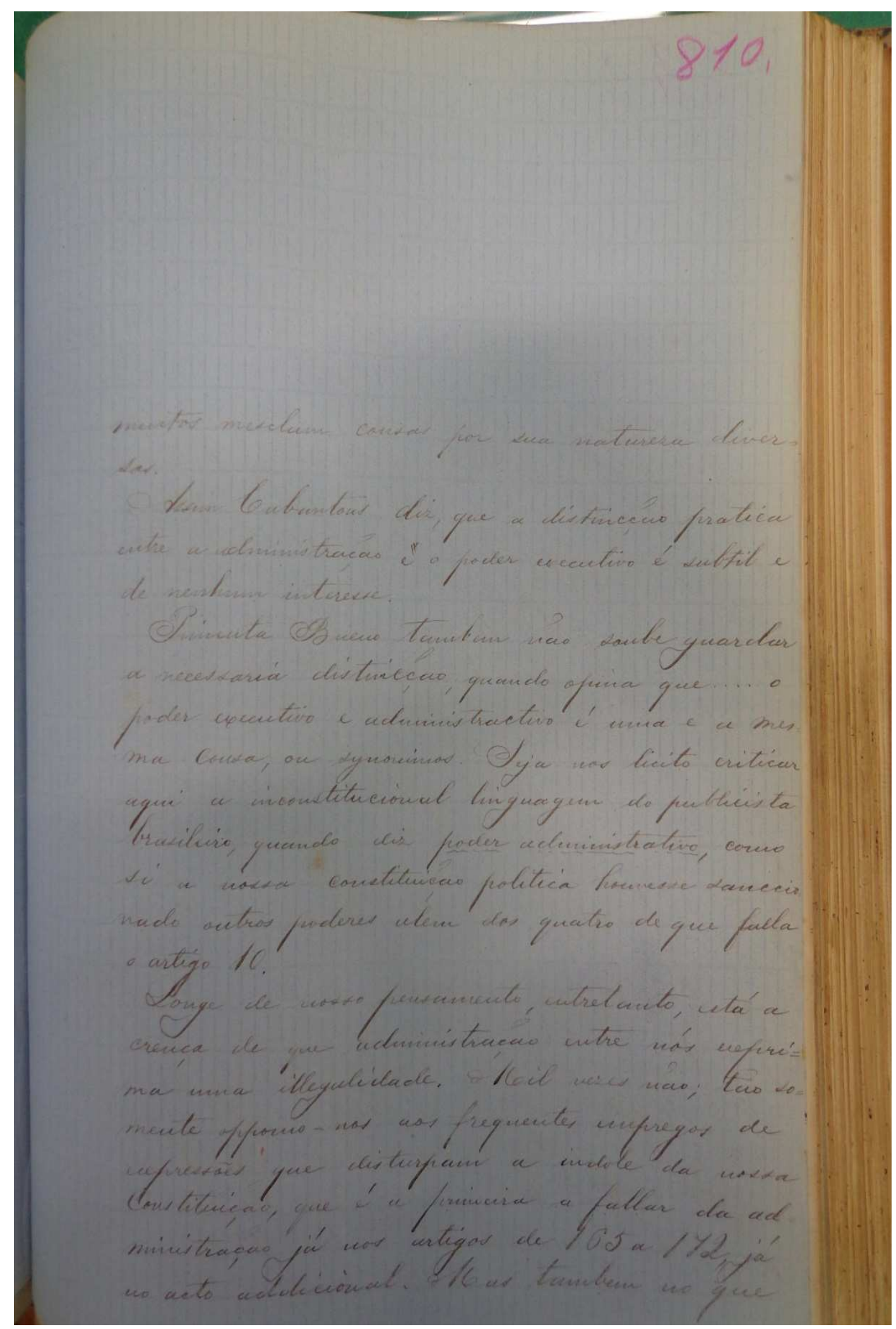




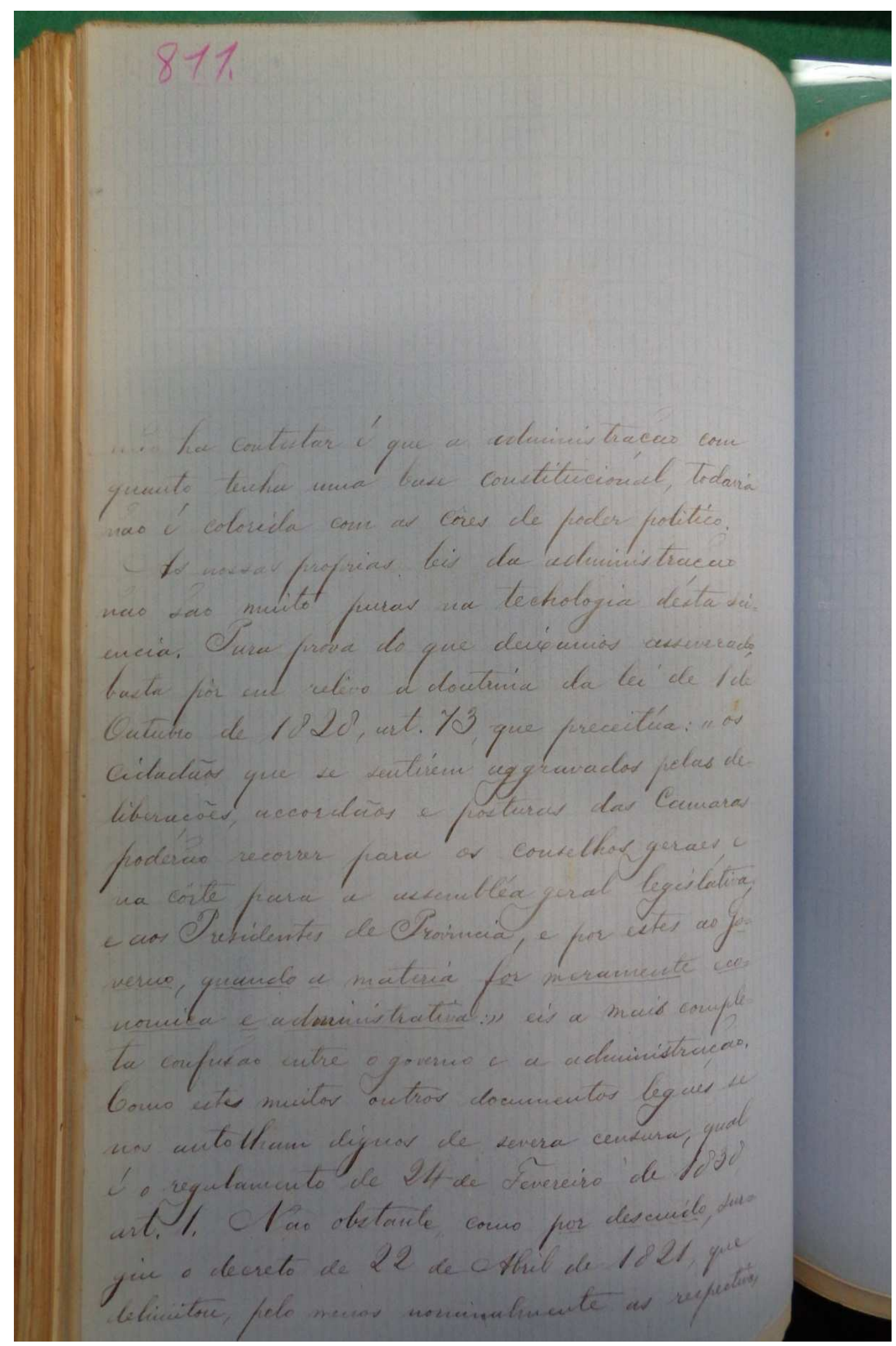




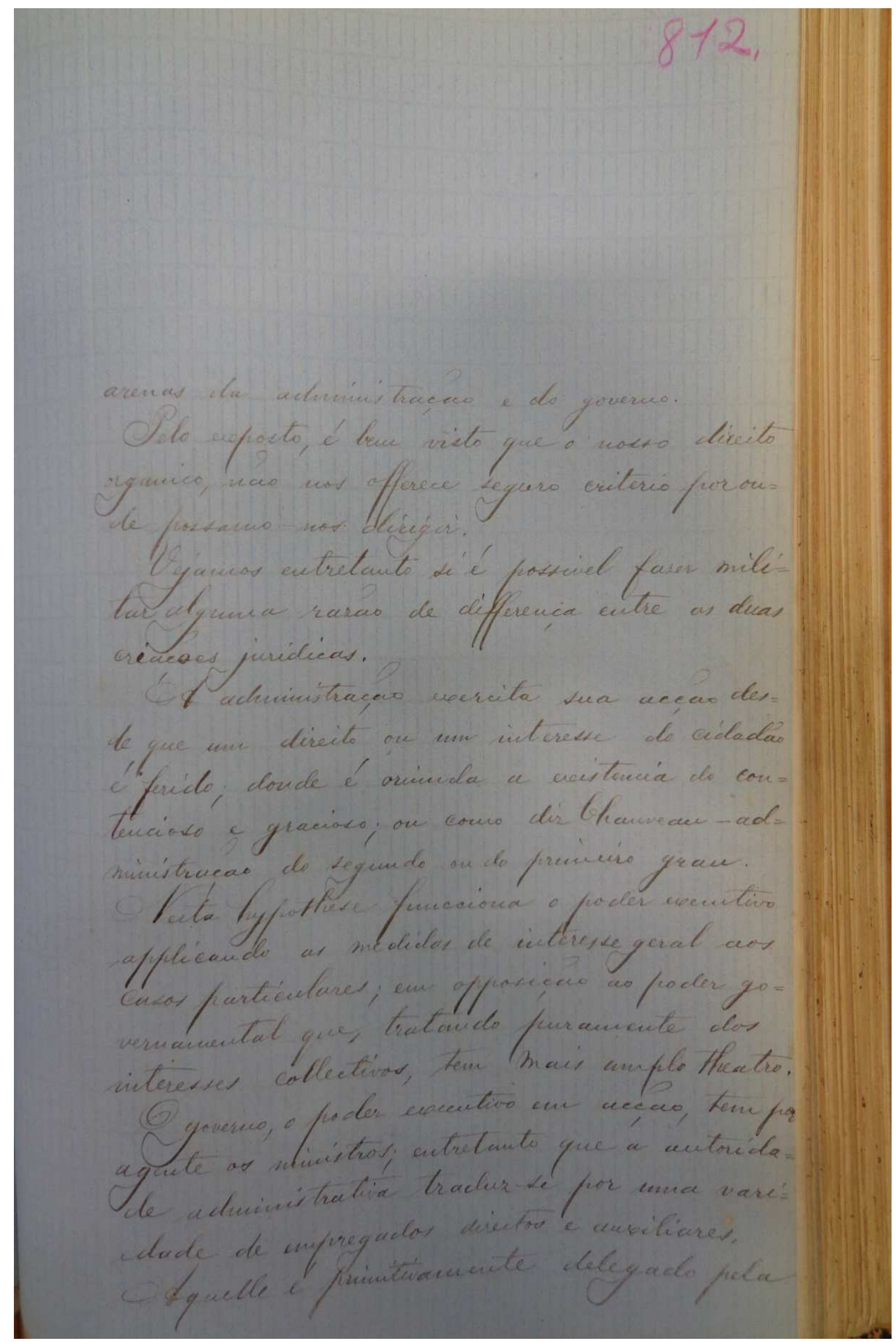




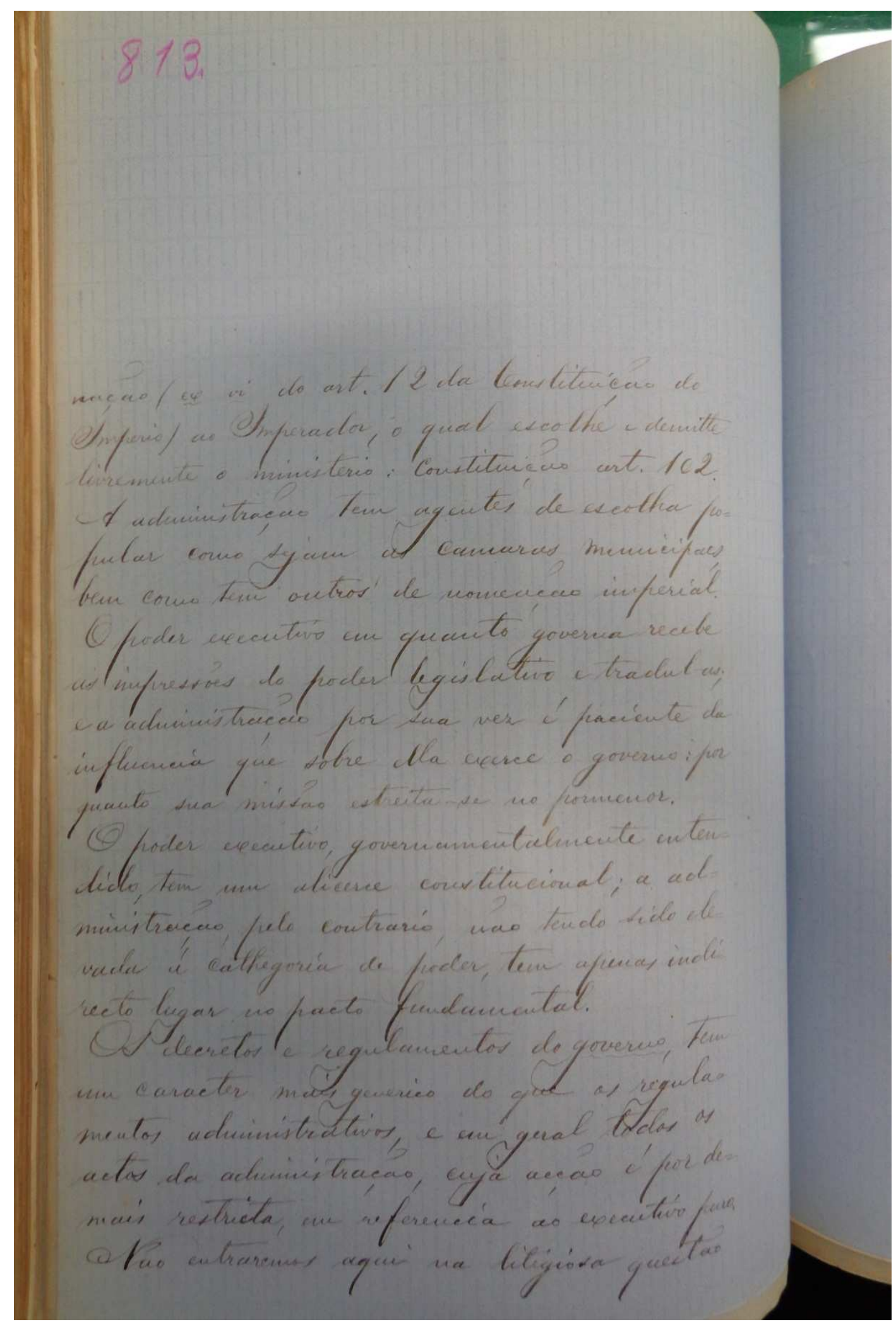




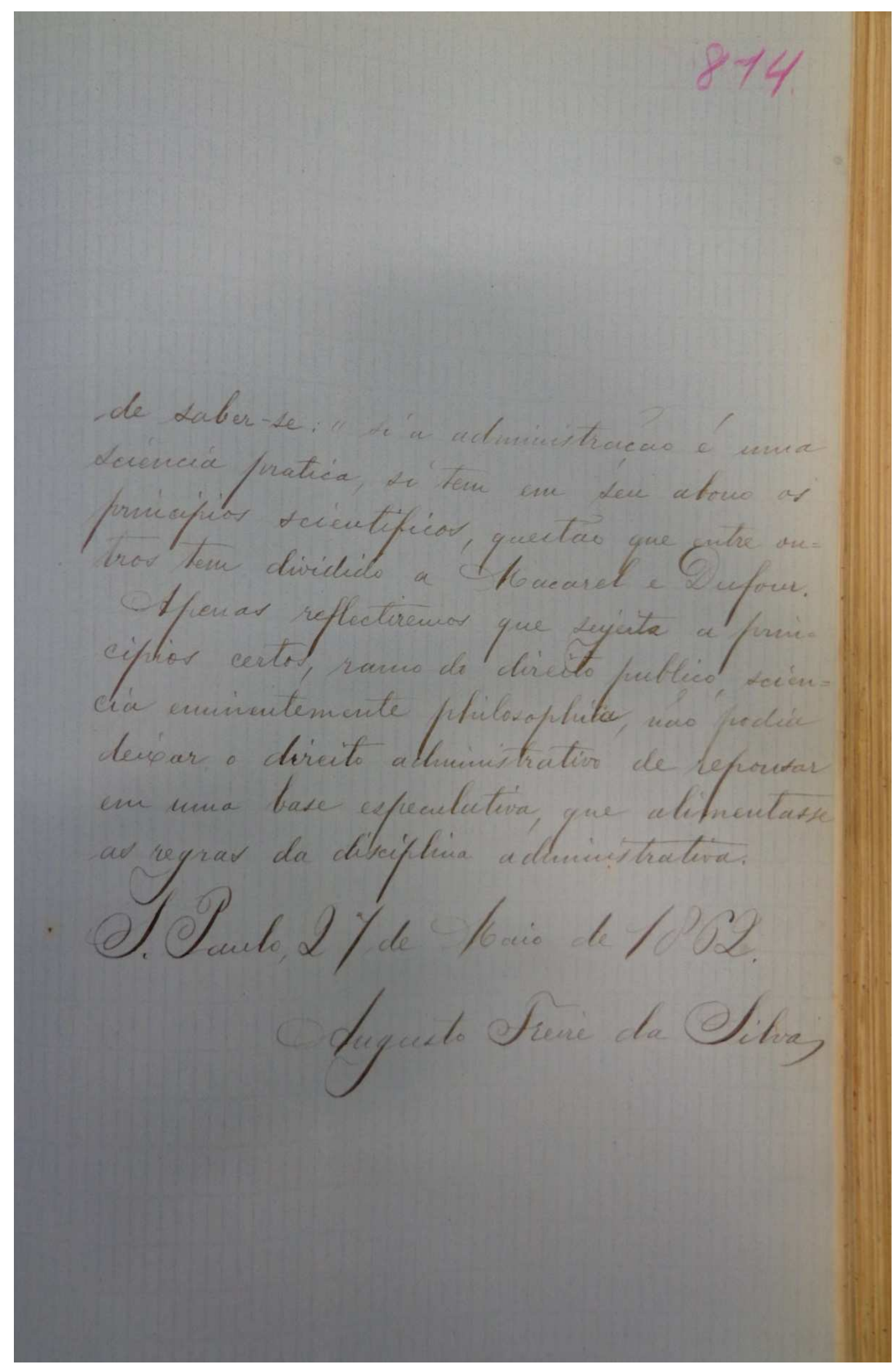


Anexo 7 - Dissertação de Direito Administrativo de Marcellino de Assis Tostes.

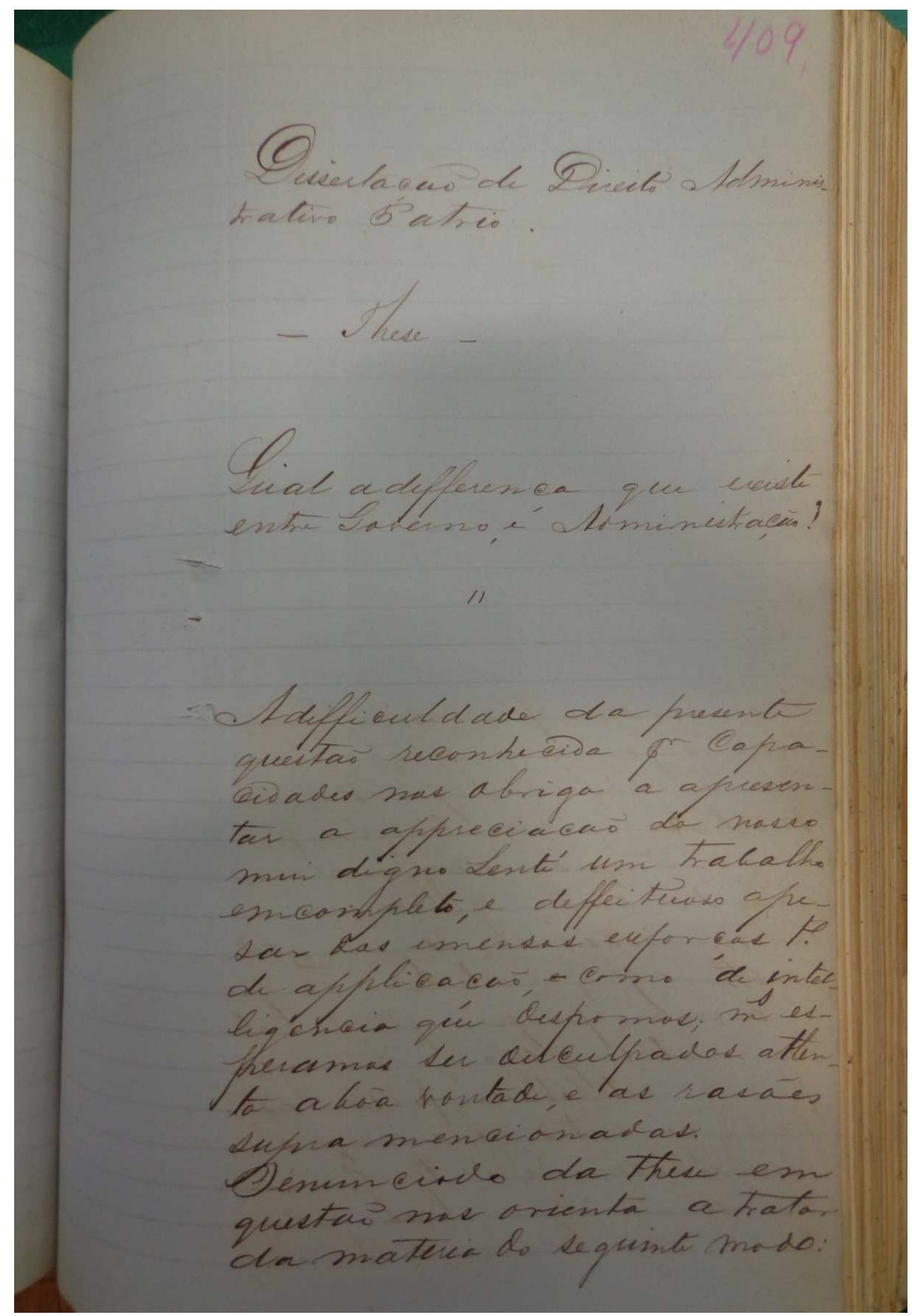




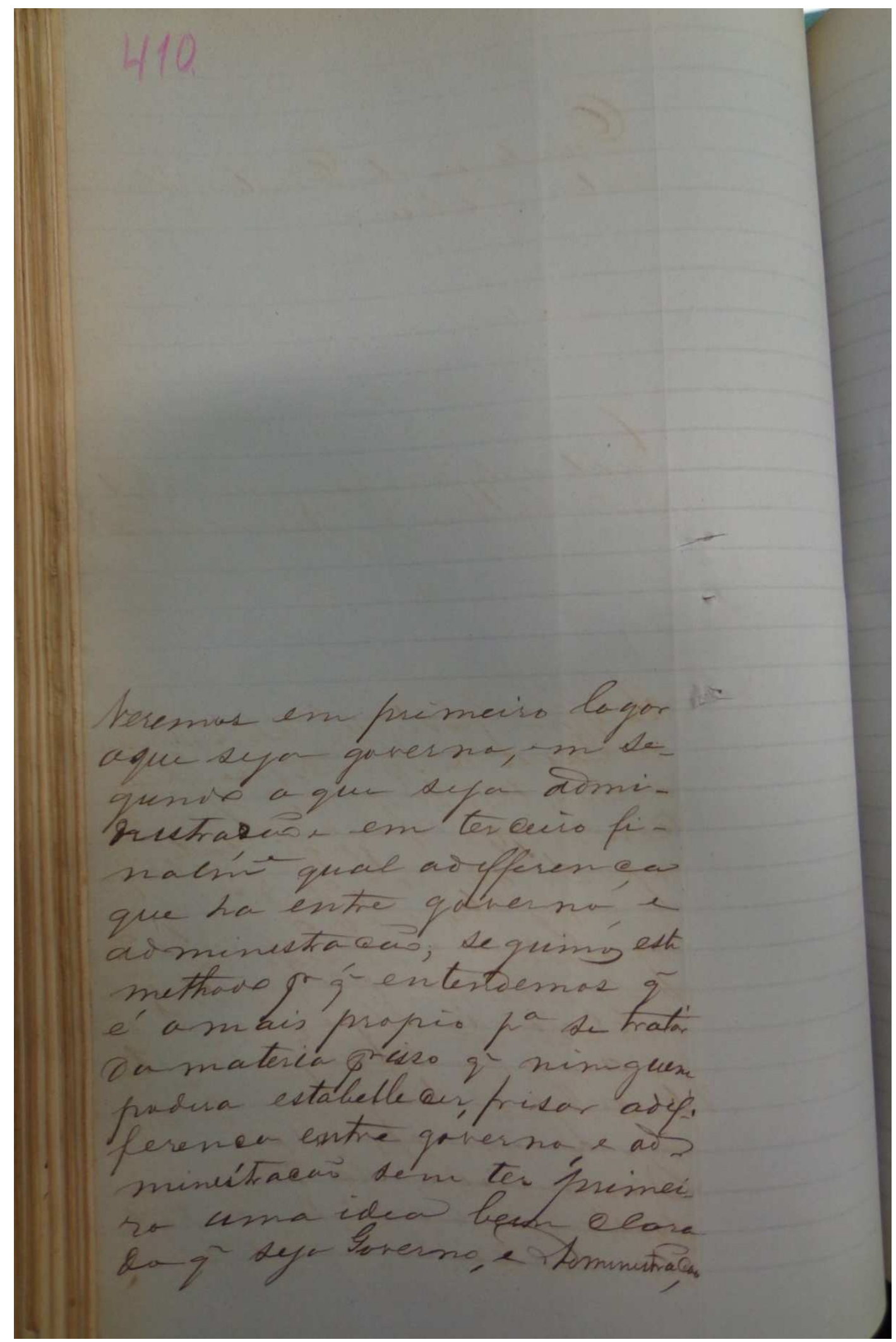


301

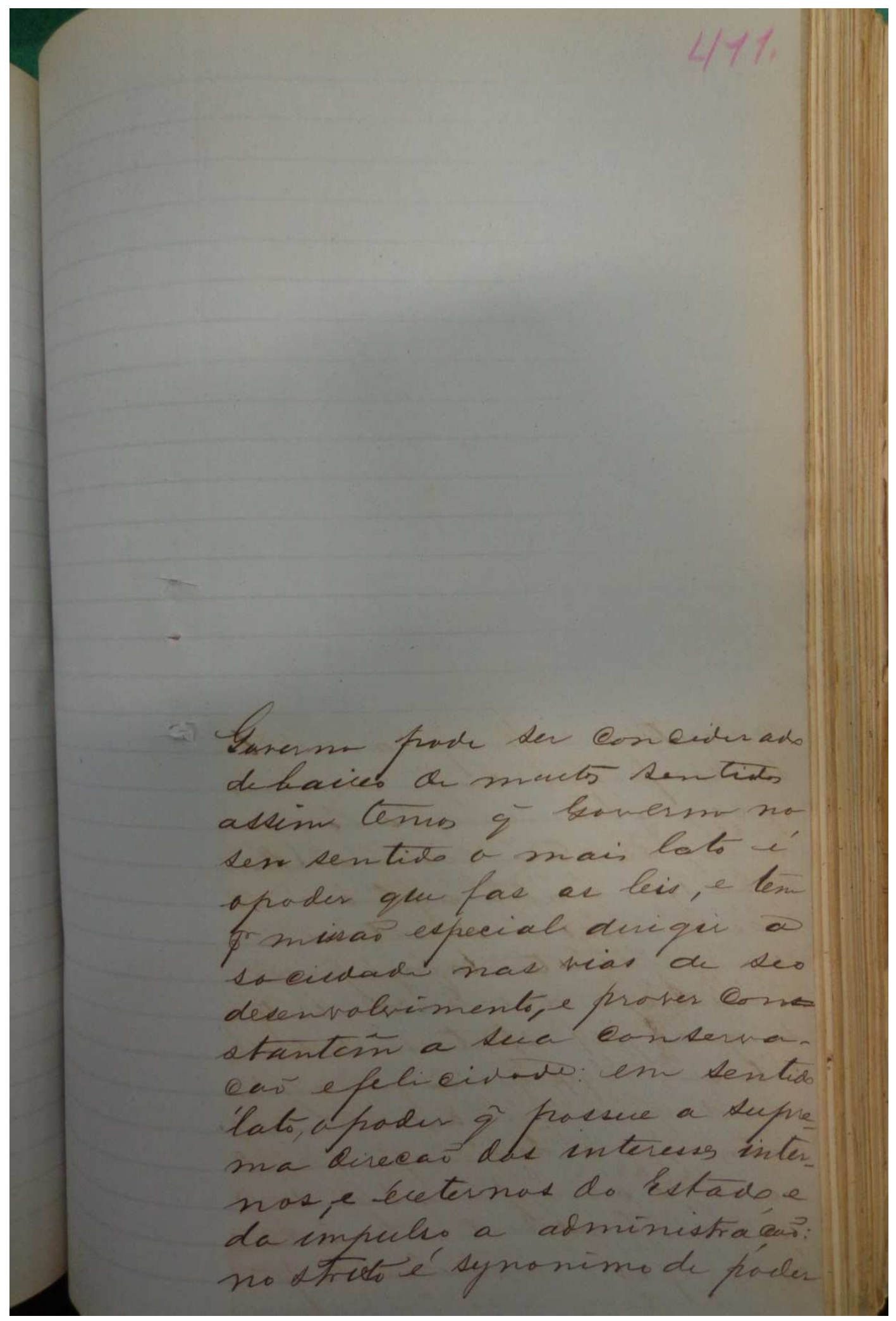




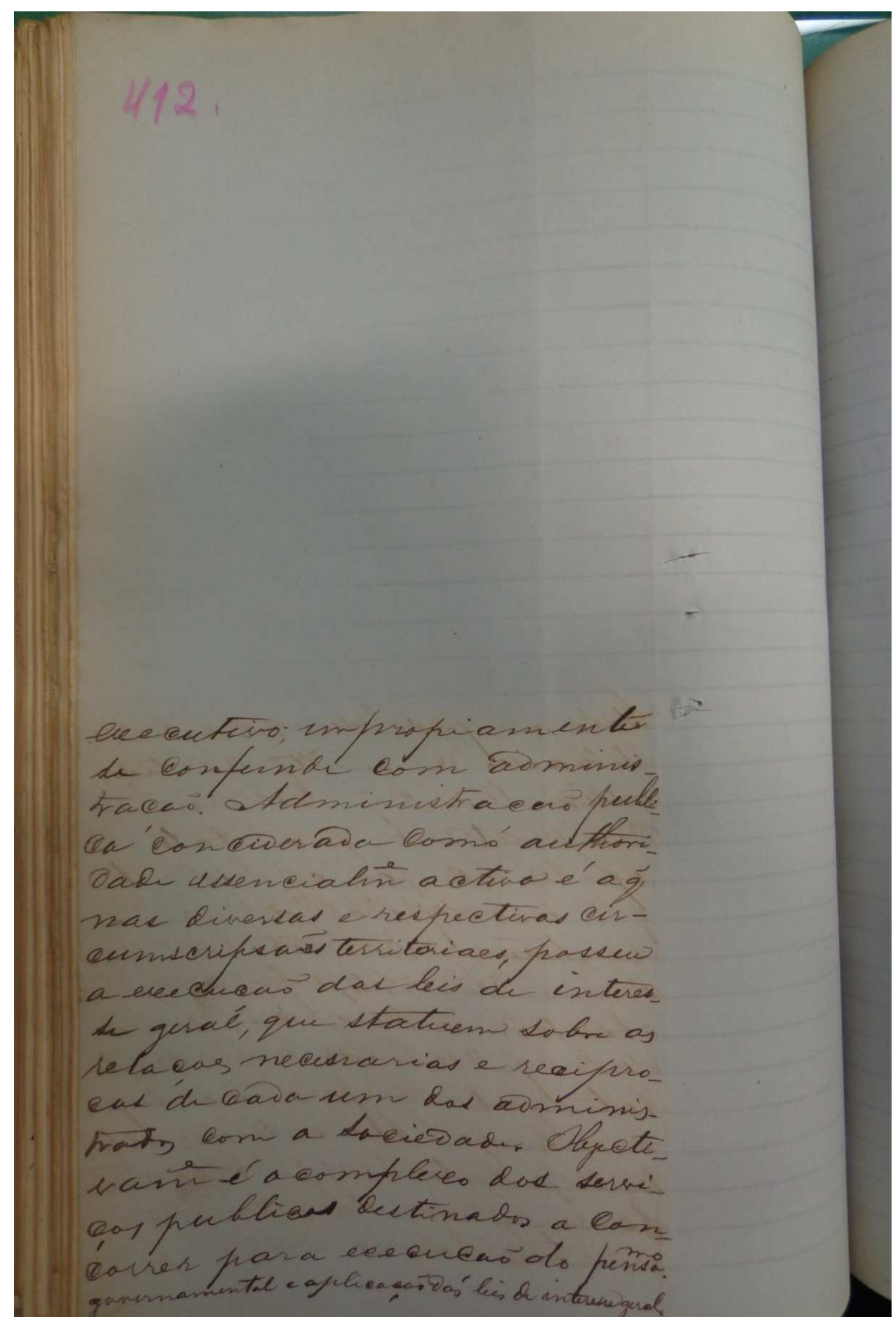




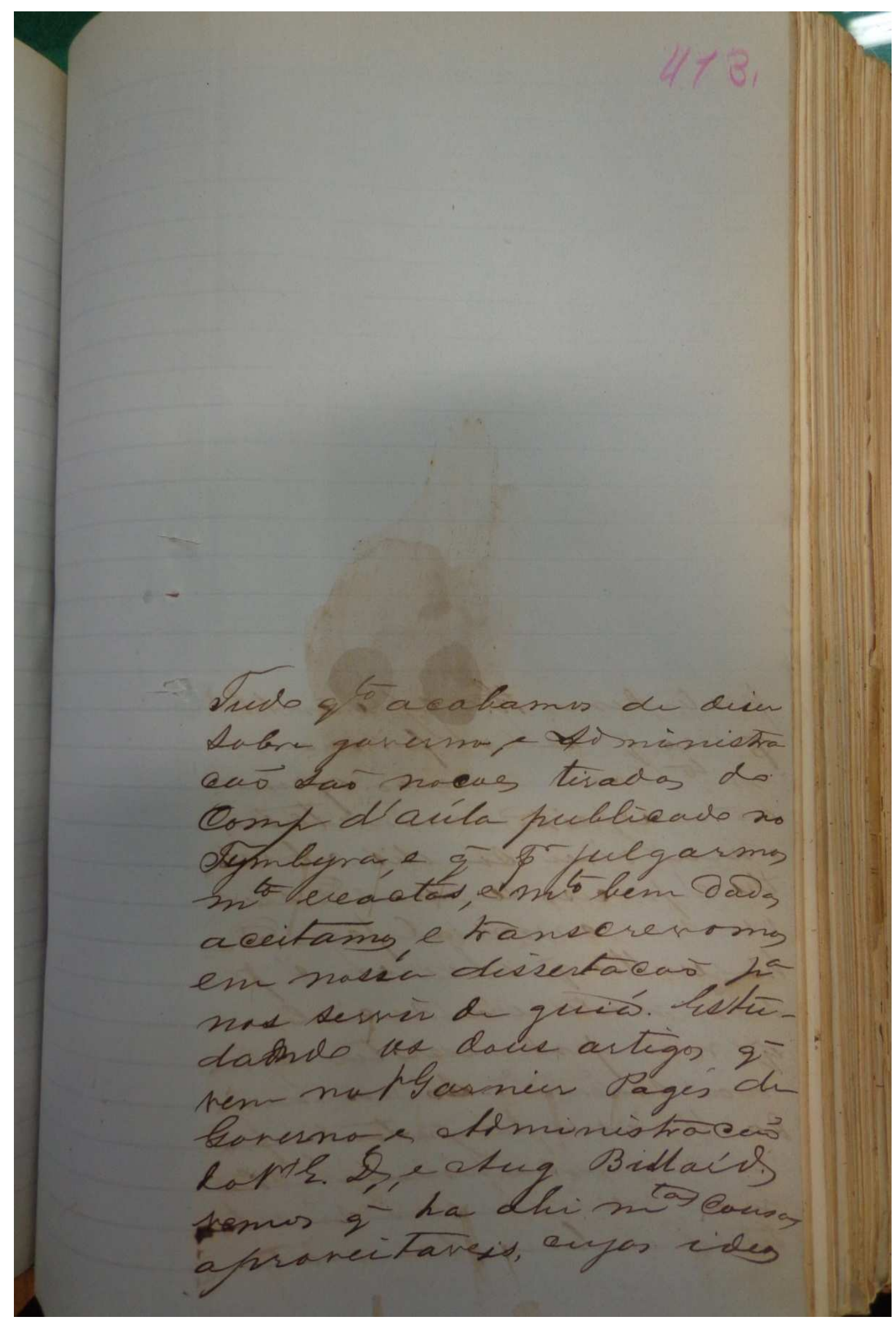


304

414

pretendemm the apresentar no arespeito da materias. Para vires só dis a tristo. the el puciso ser um Deces un um anomal feros Da. hi recutta oi ahomen is pr sua naturesa sweiale q nao pab evitir senas na traid. dón neio Do livinese, infrotint, fra Co, munctio inagín

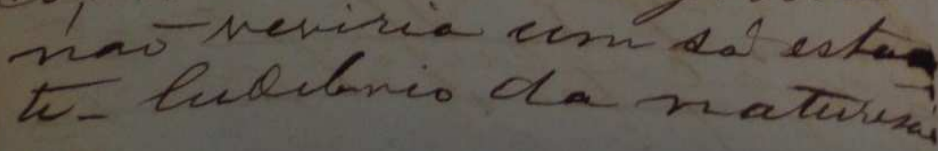




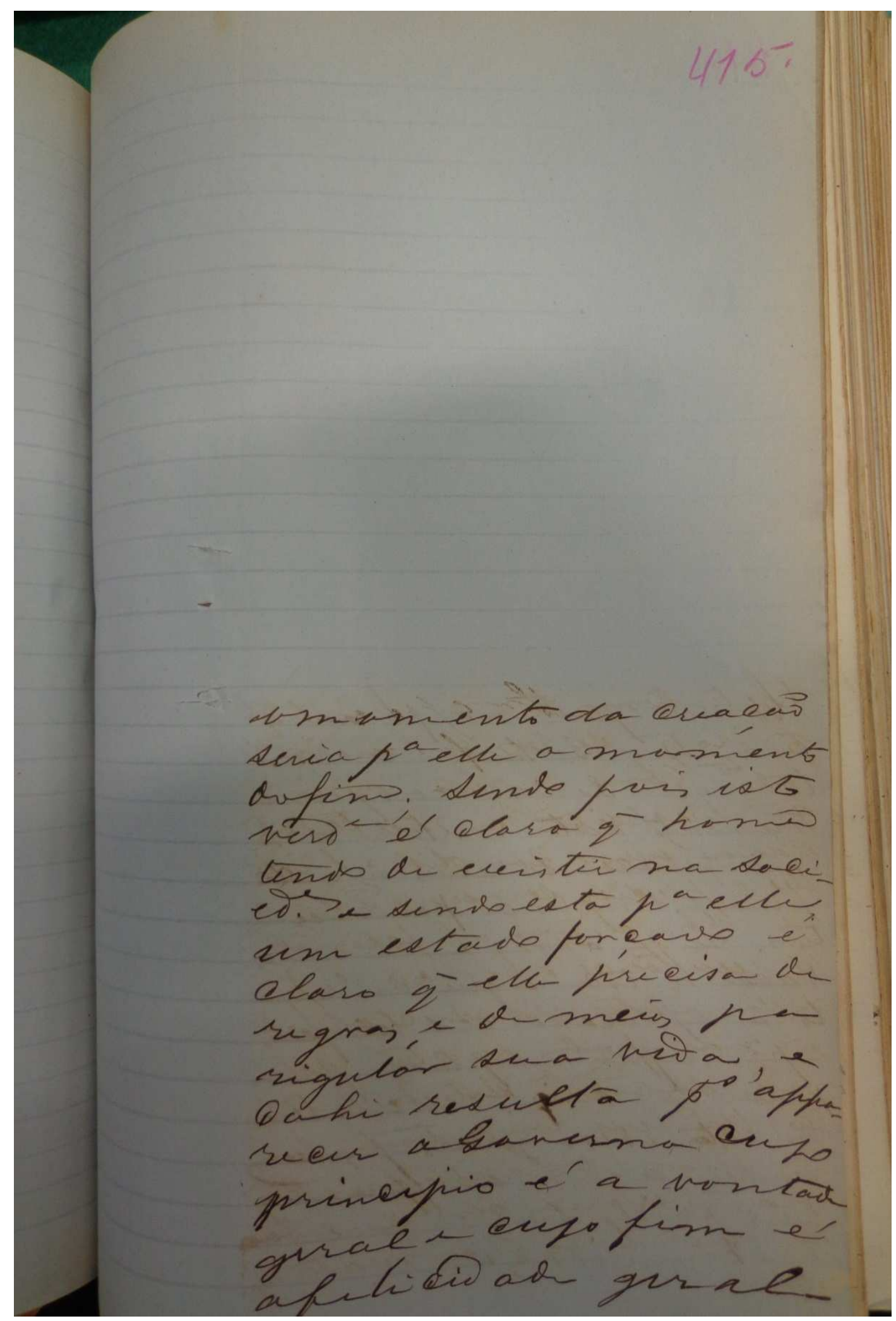




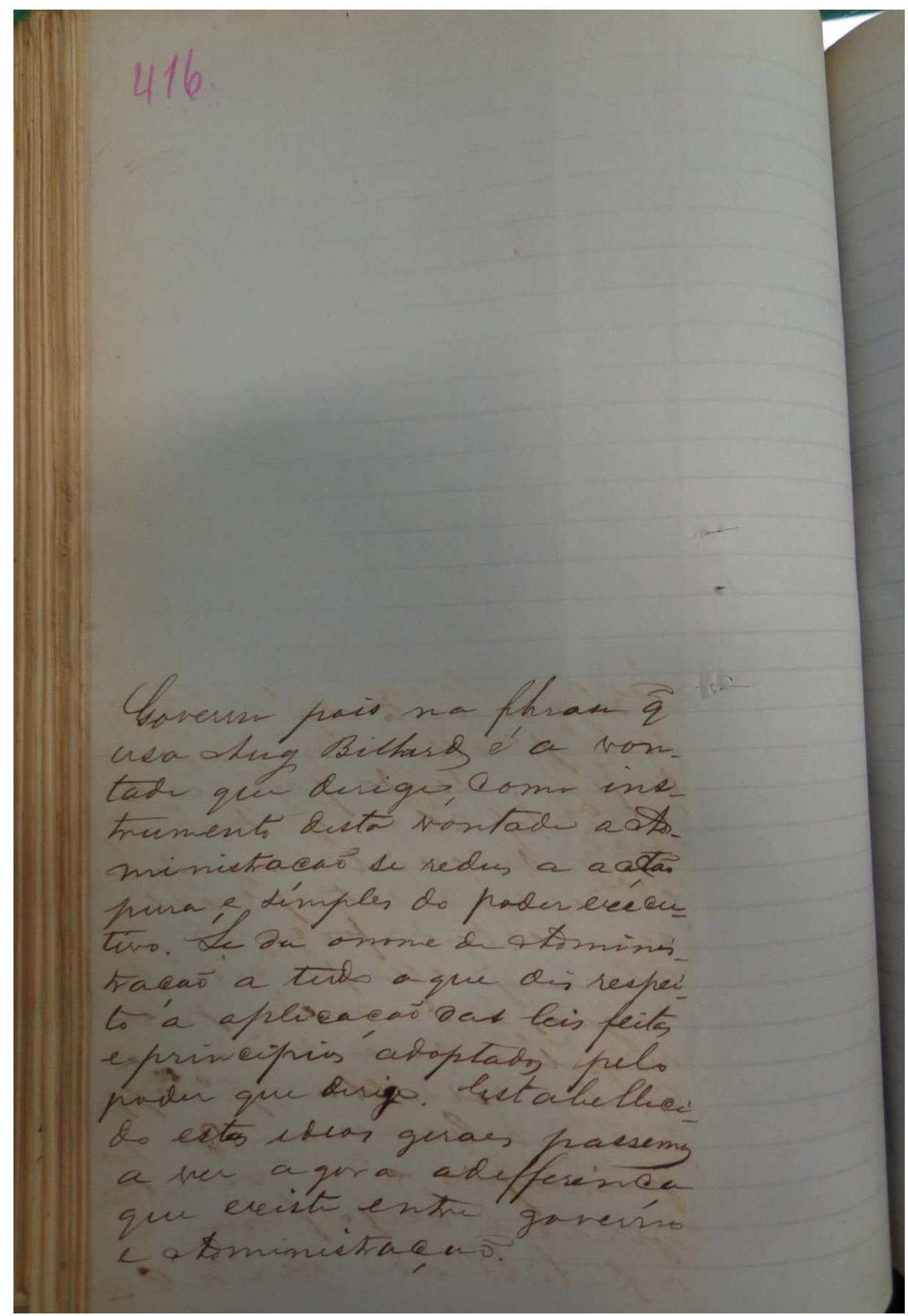




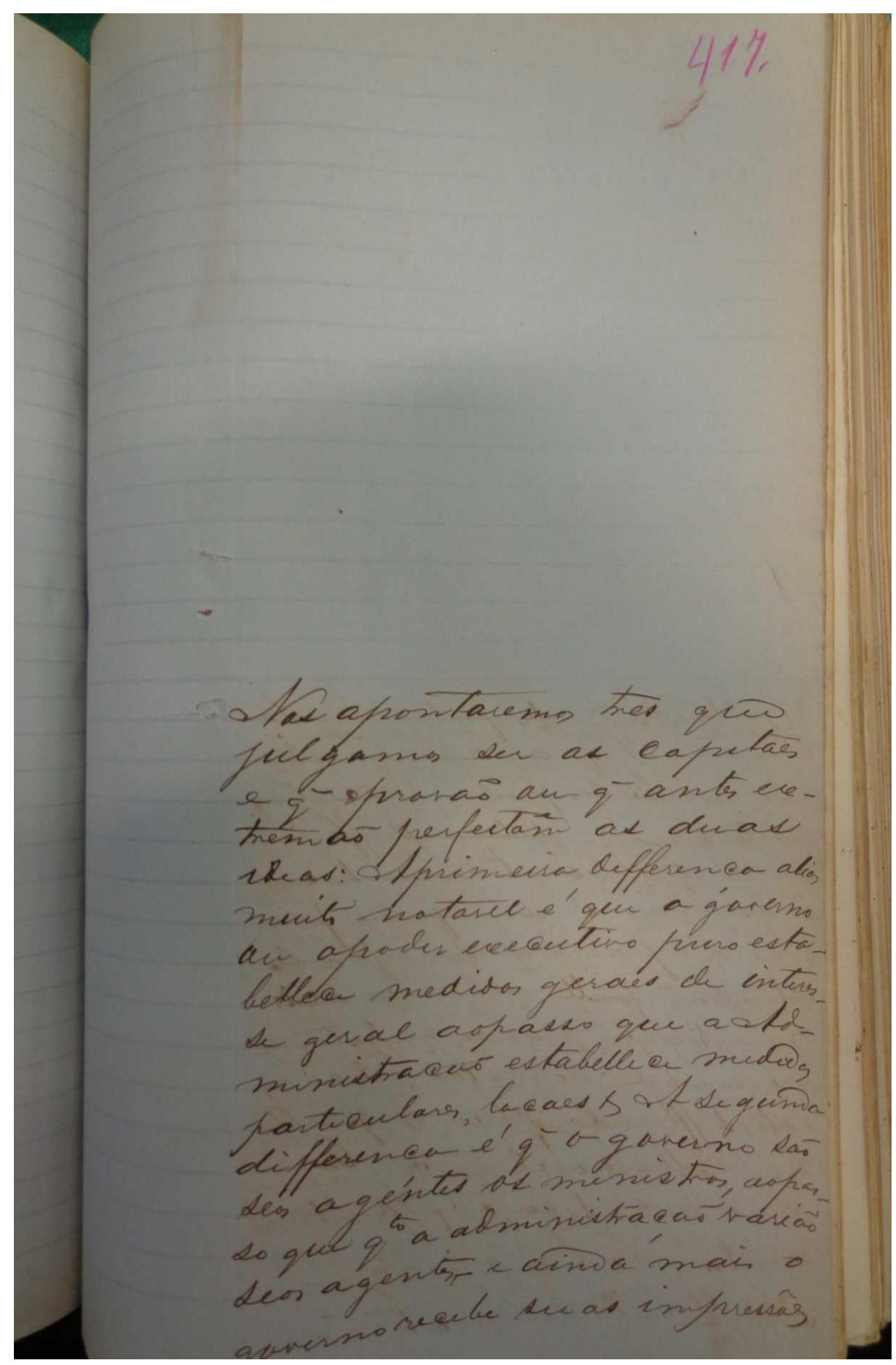


308

418.

imideatañ do pader Lequla.

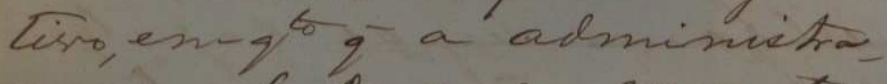

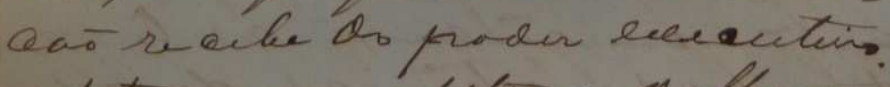
attereura \& Ulna afferen ac e' I atbonet recowhece o á gavesso e' con pacer poli tieo a prano 8 dom $\Sigma^{5} a$ bas titura. fall olg̀ veres dach mistragew, numba enthetant areantha domotat. Dars ettasdferencas duing grulles Com sllaciarel z a Hover no $e^{\prime}$ a Cakceare I a etomi mintaracuó é atraboatofficult. da mater ía 


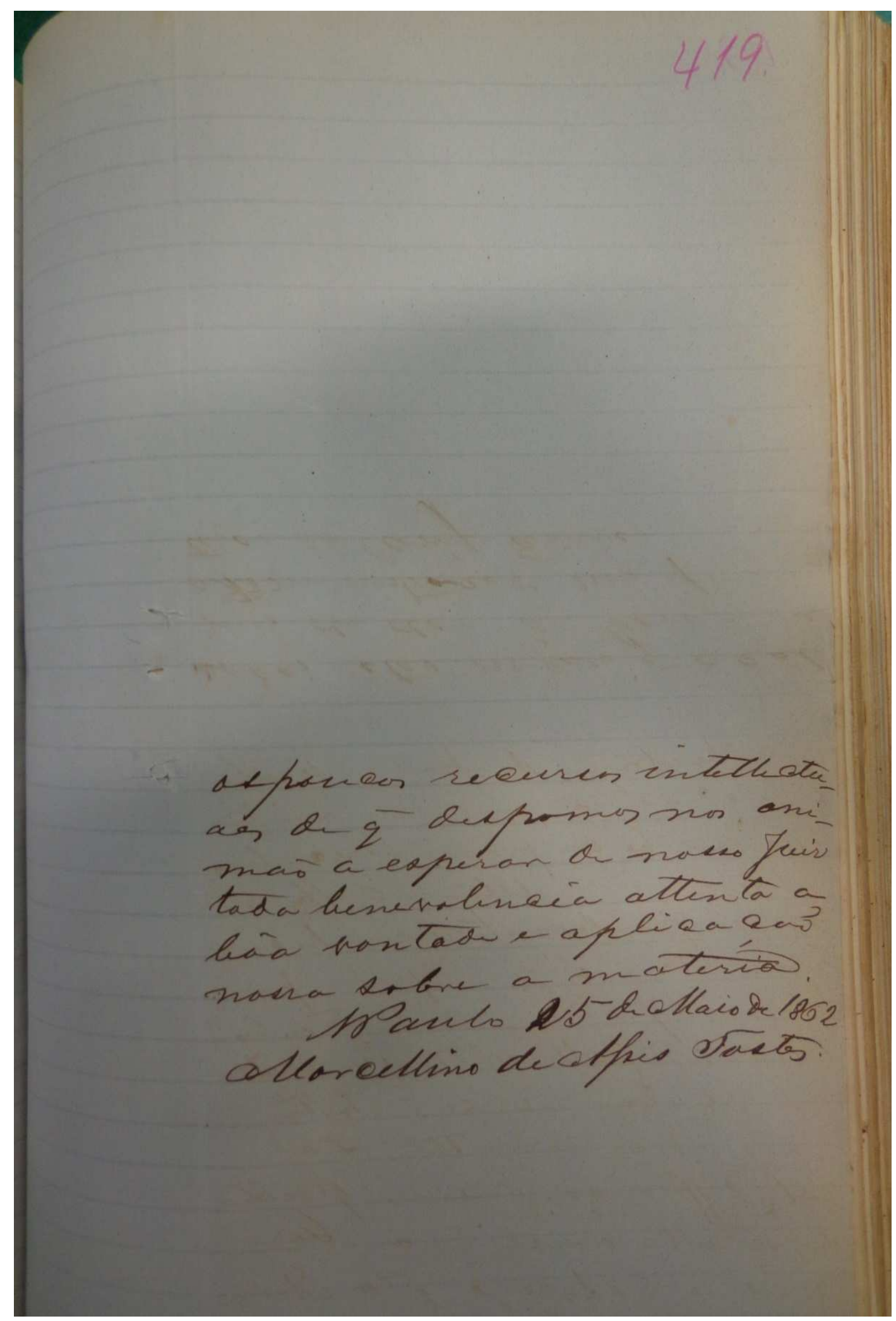


Anexo 8 - Dissertação de Direito Administrativo de Estevam Ribeiro de Souza Rezende.

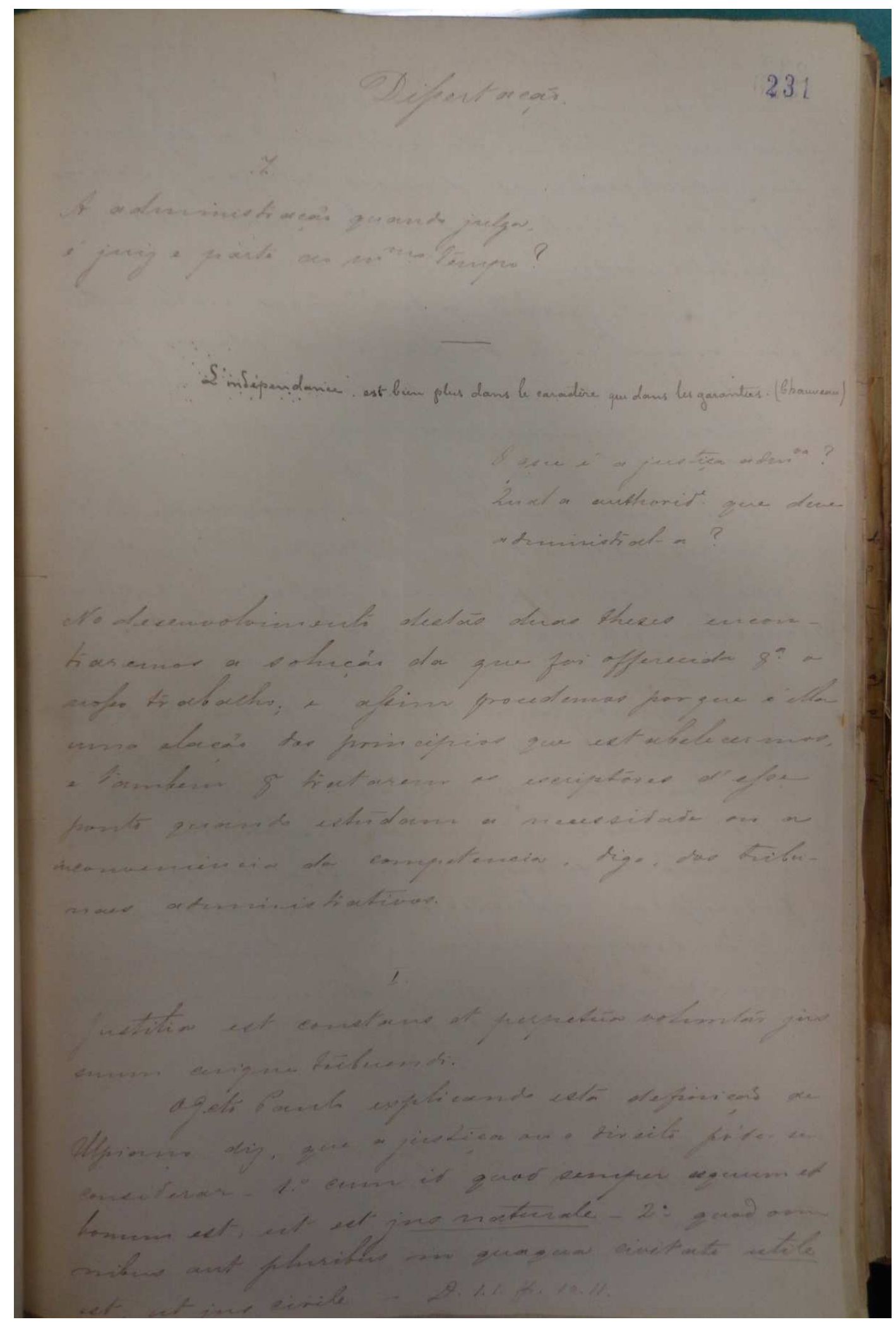




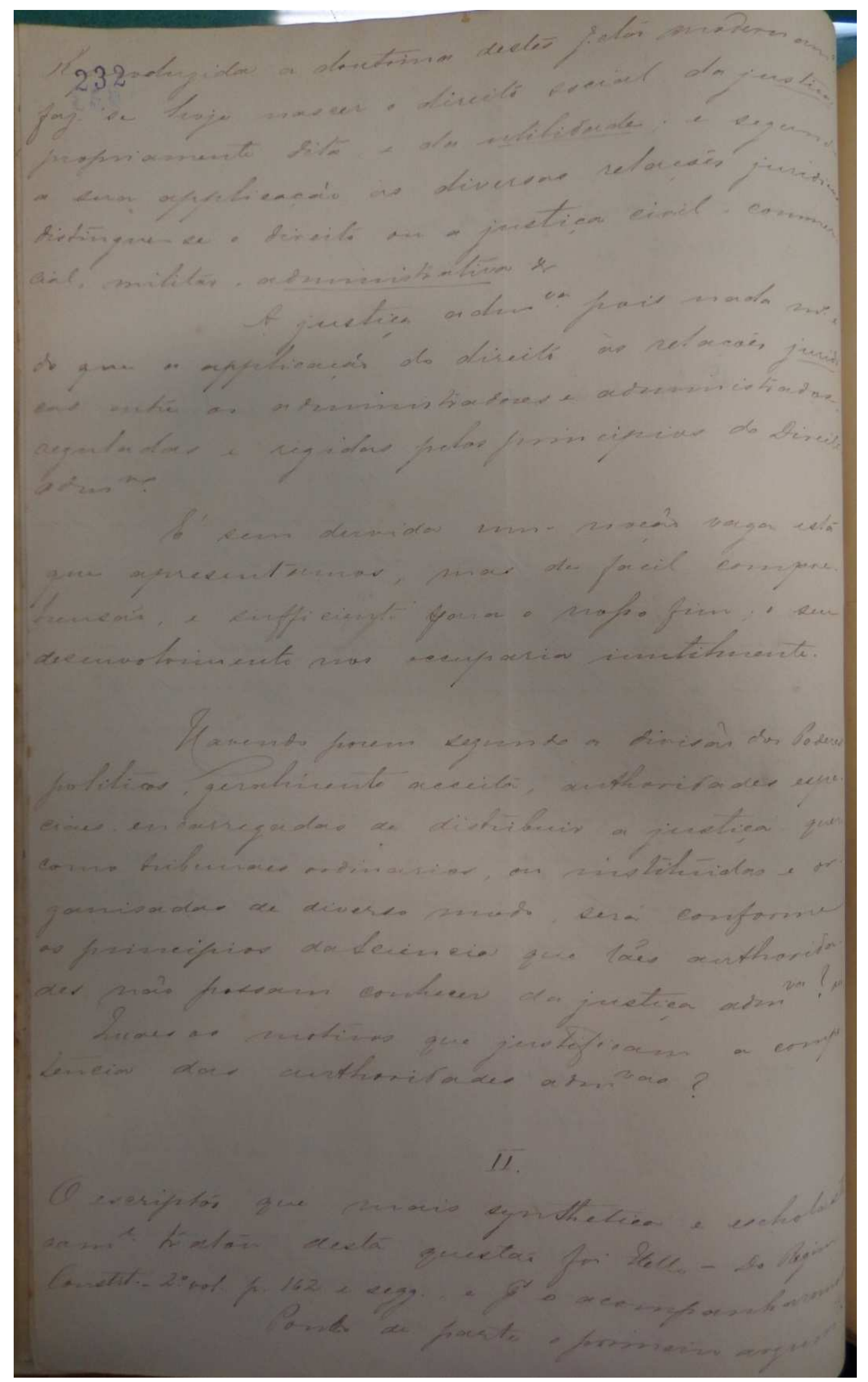


<smiles>C1CCCC1</smiles> 


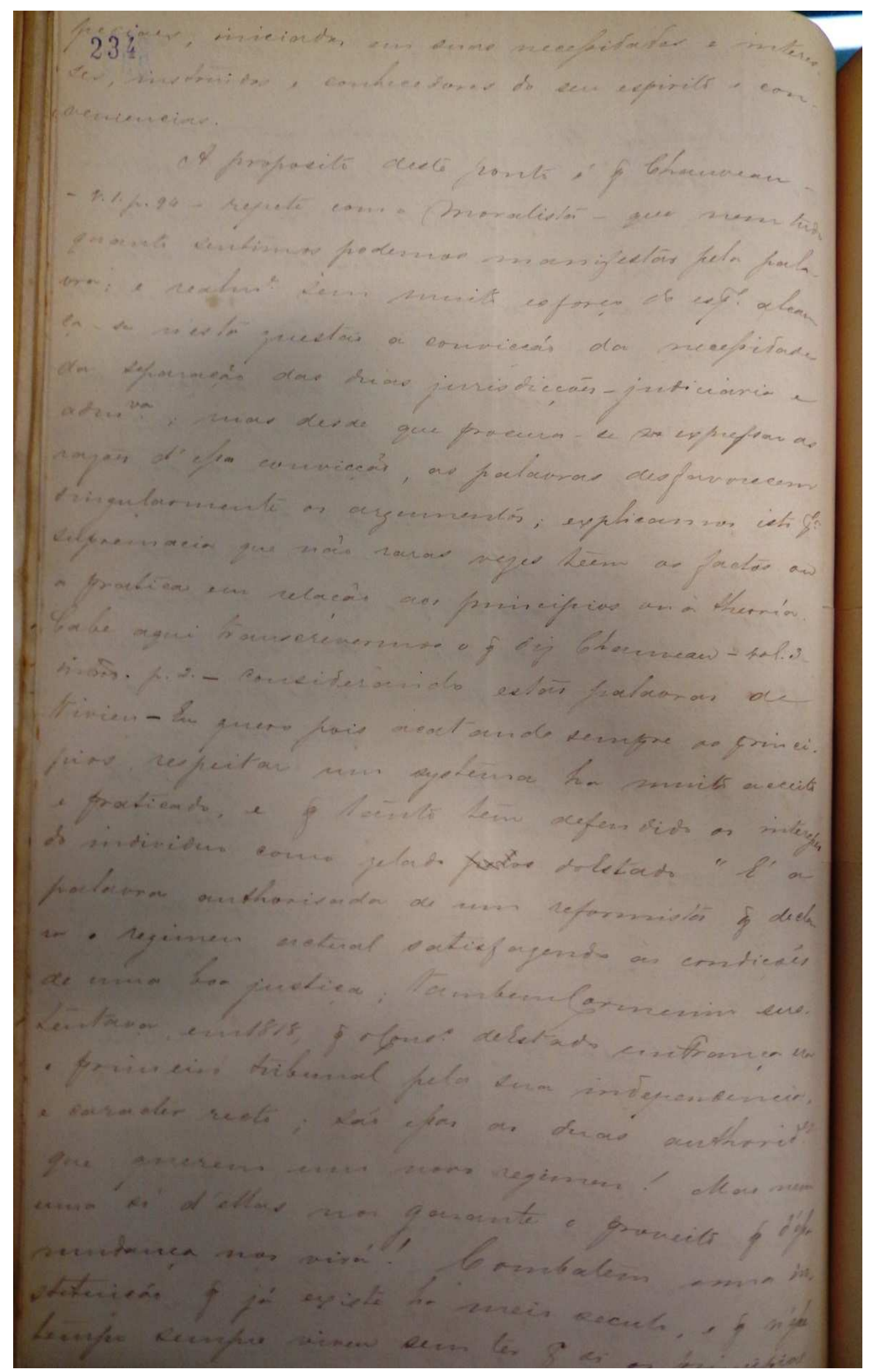





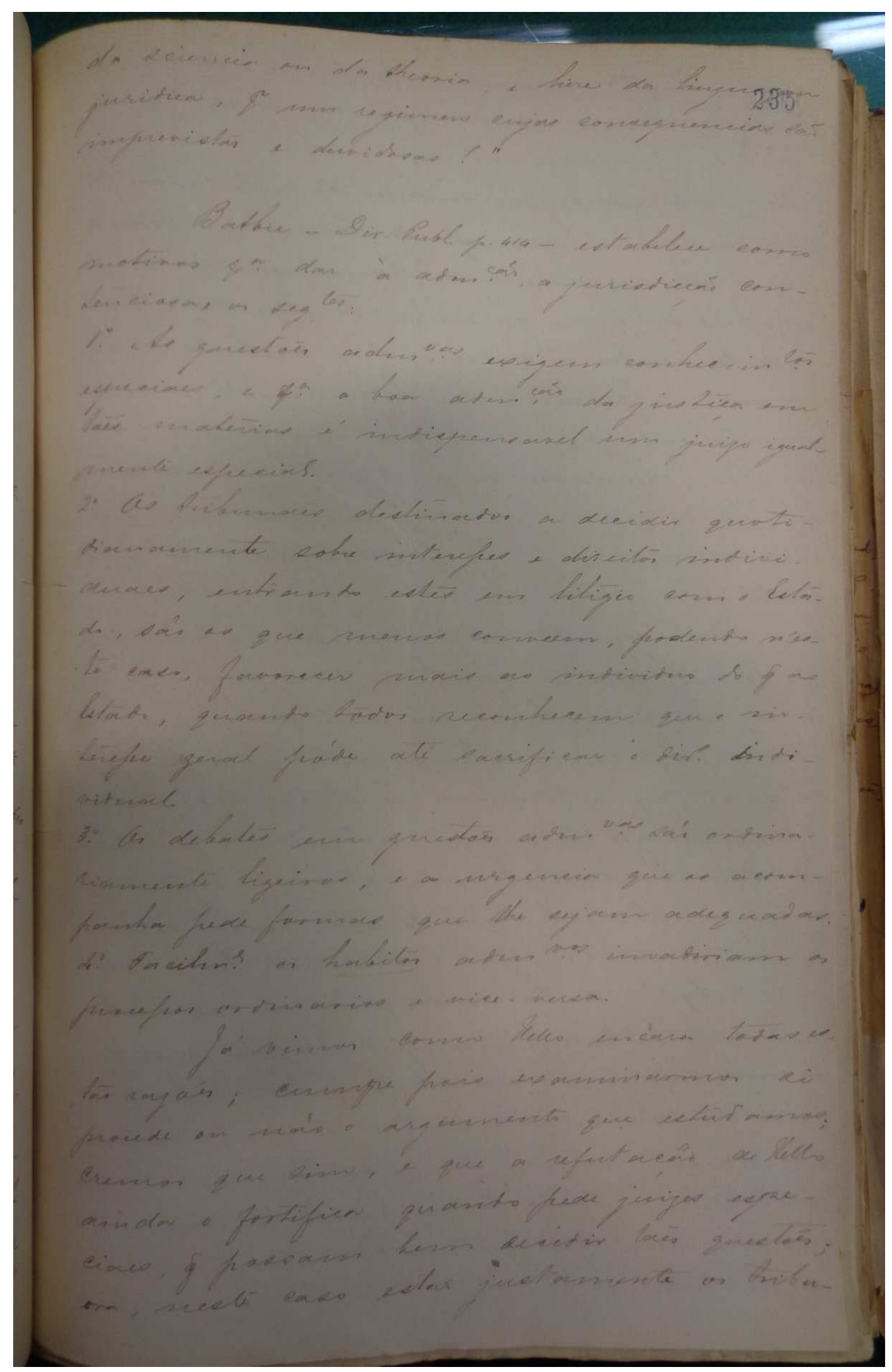



317 


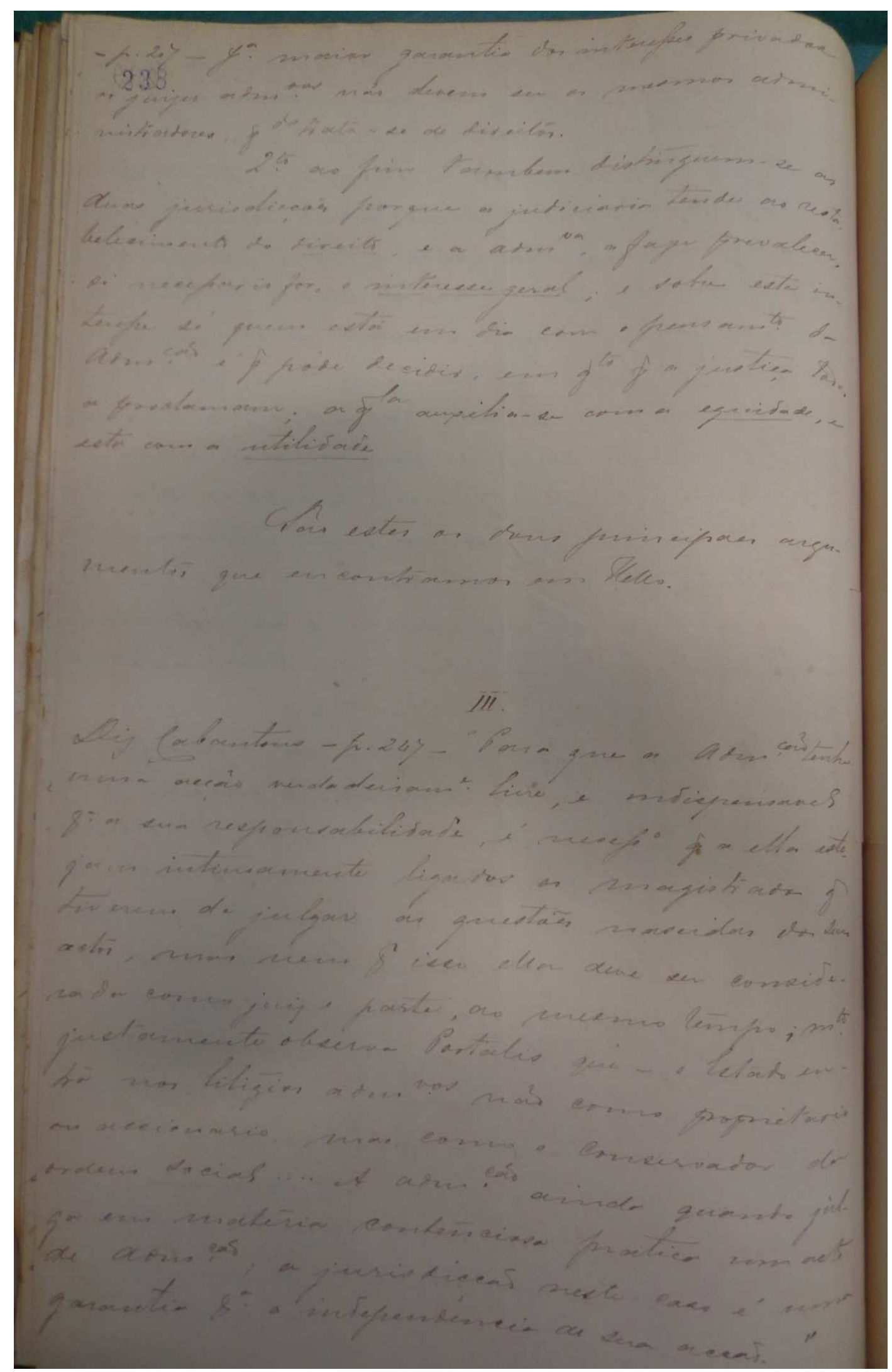





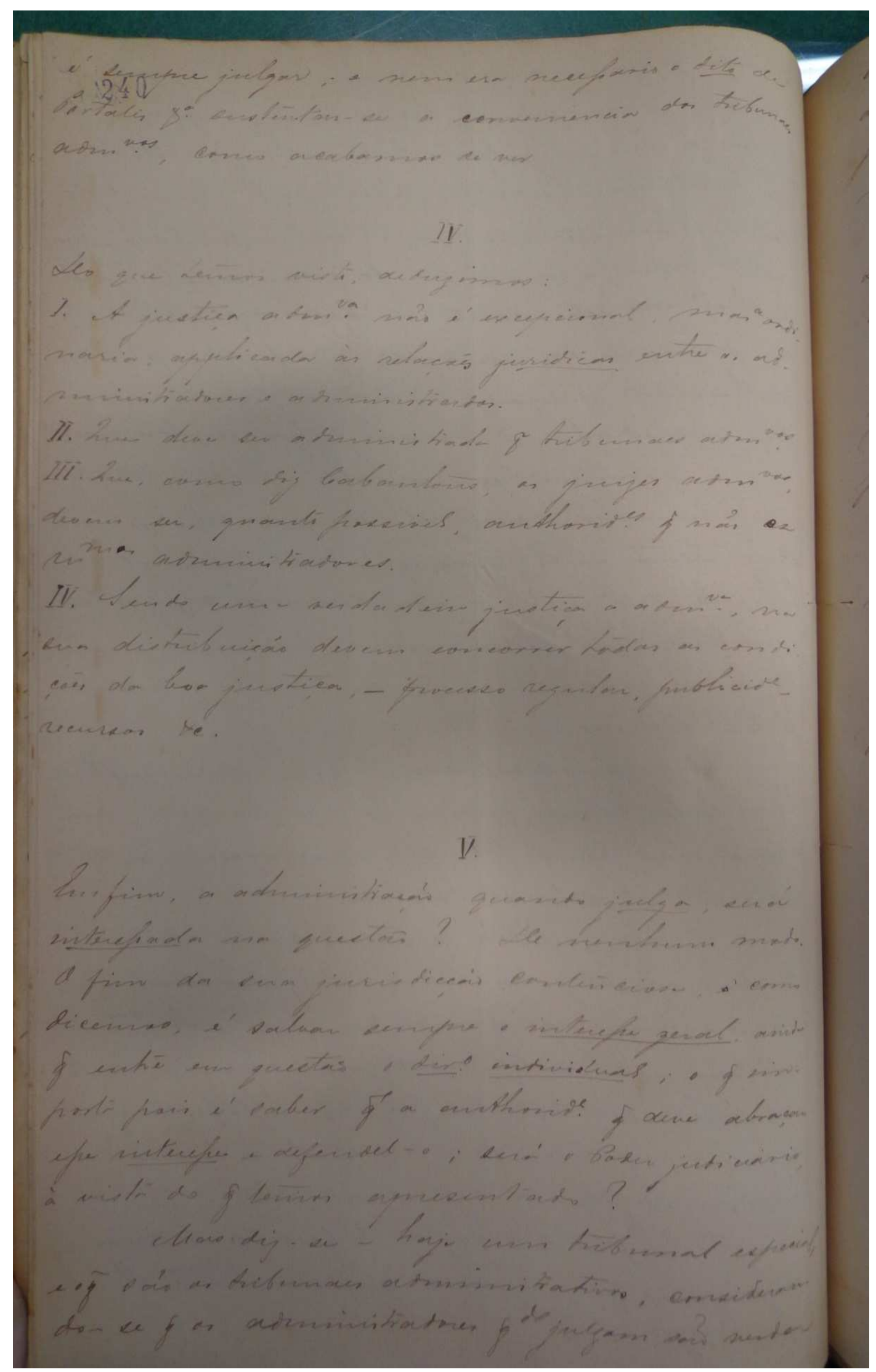


321 


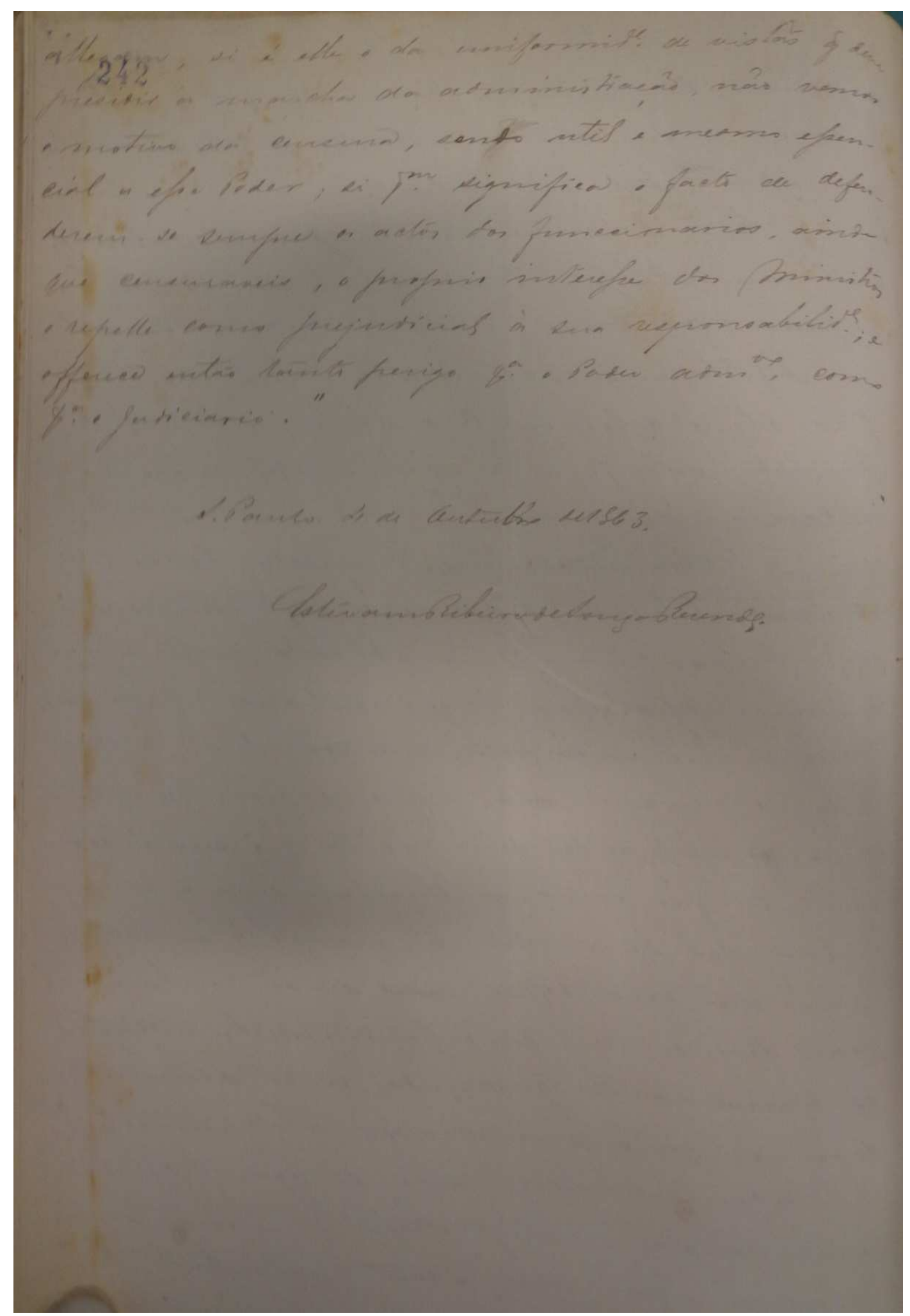


Anexo 9 - Dissertação de Direito Administrativo de Feliciano de Souza Ribeiro Camargo

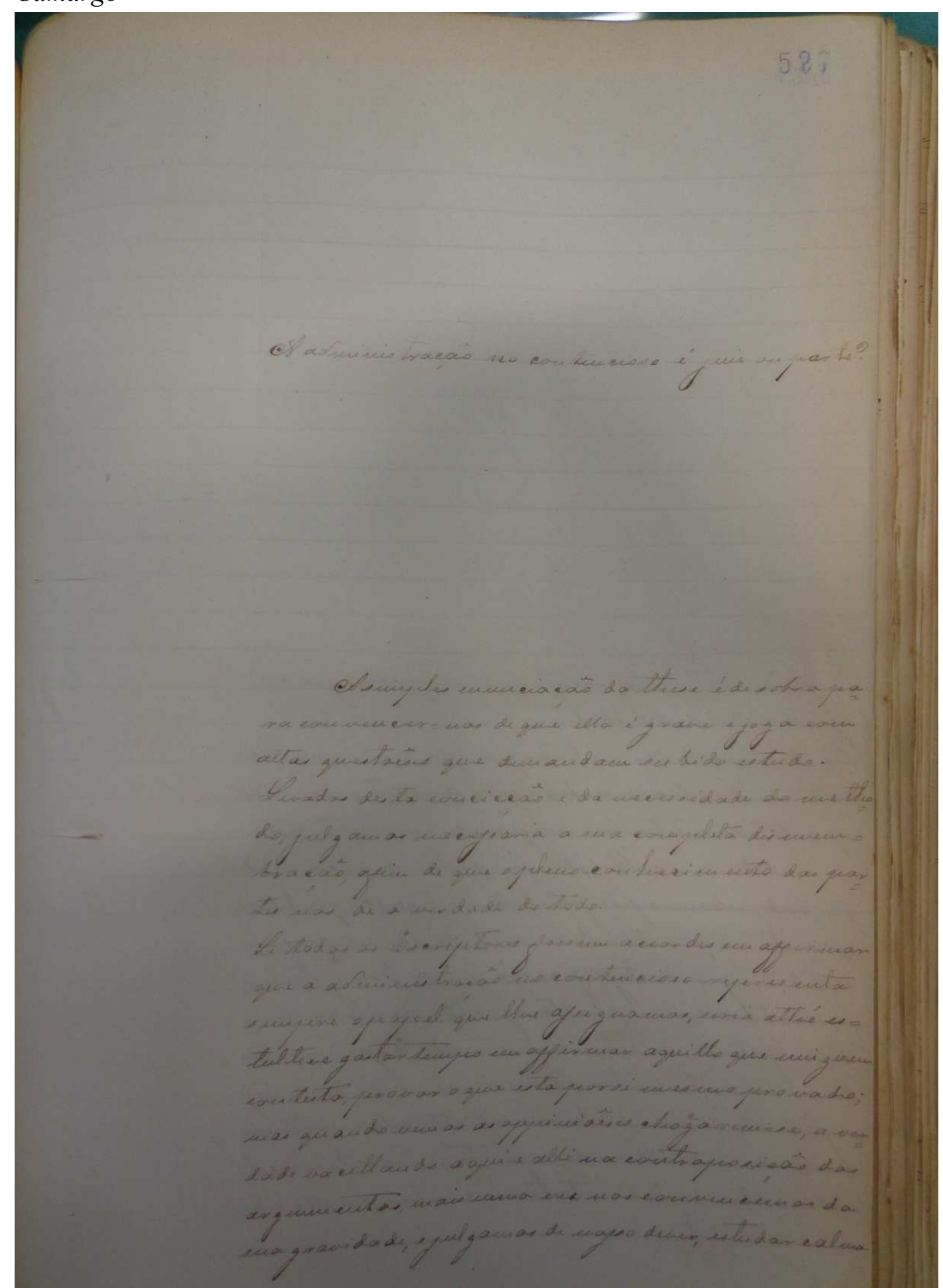




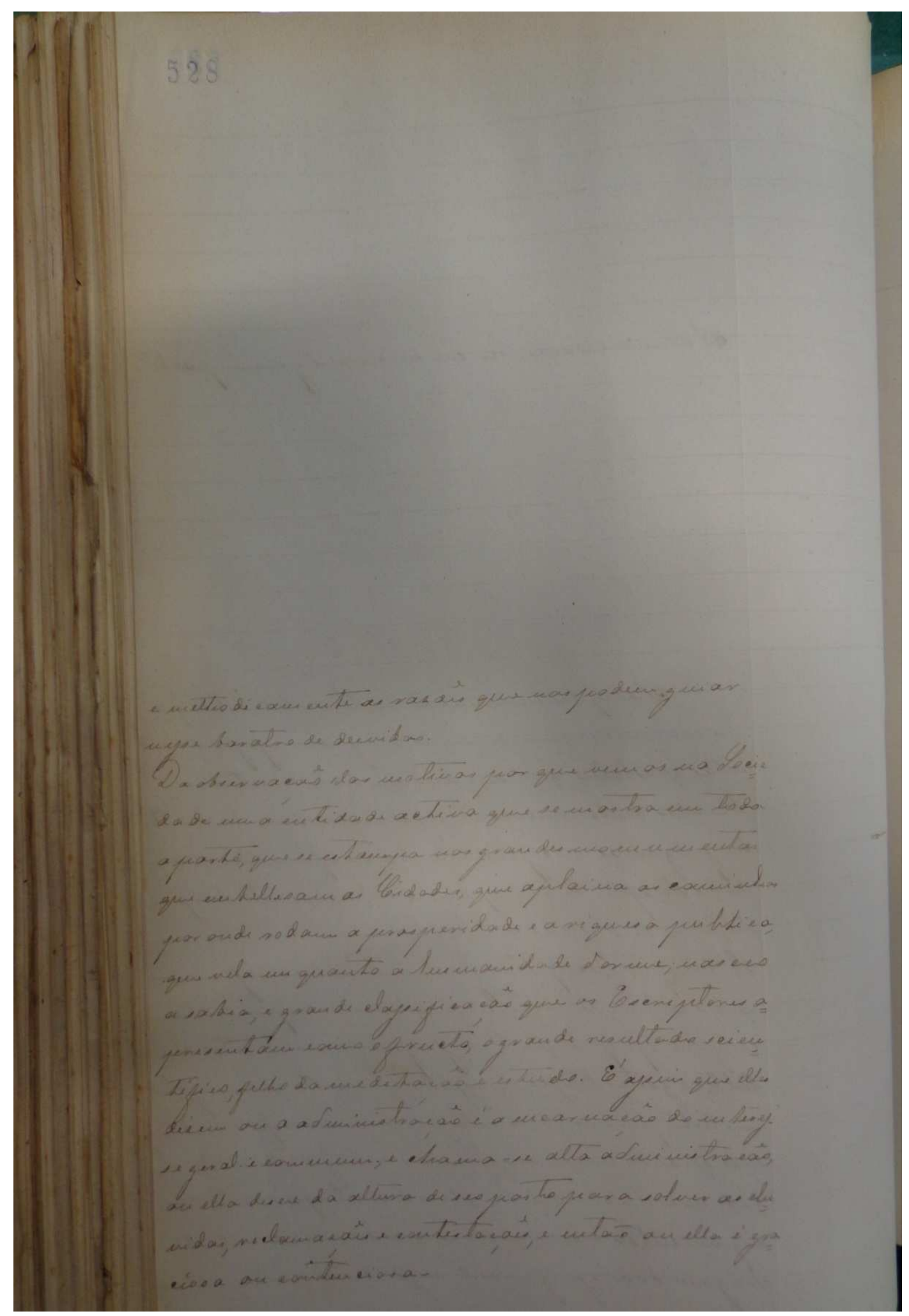




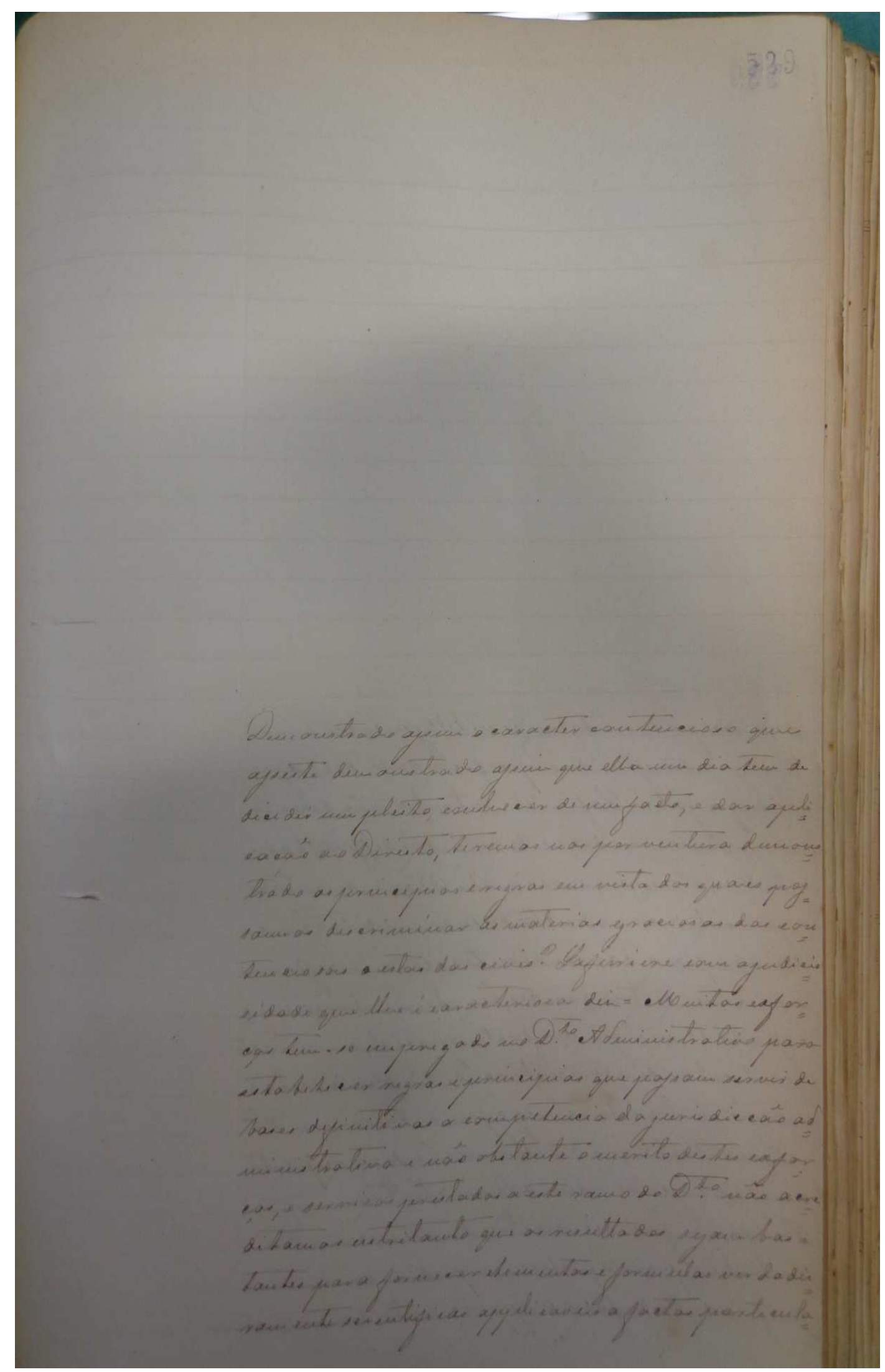



327

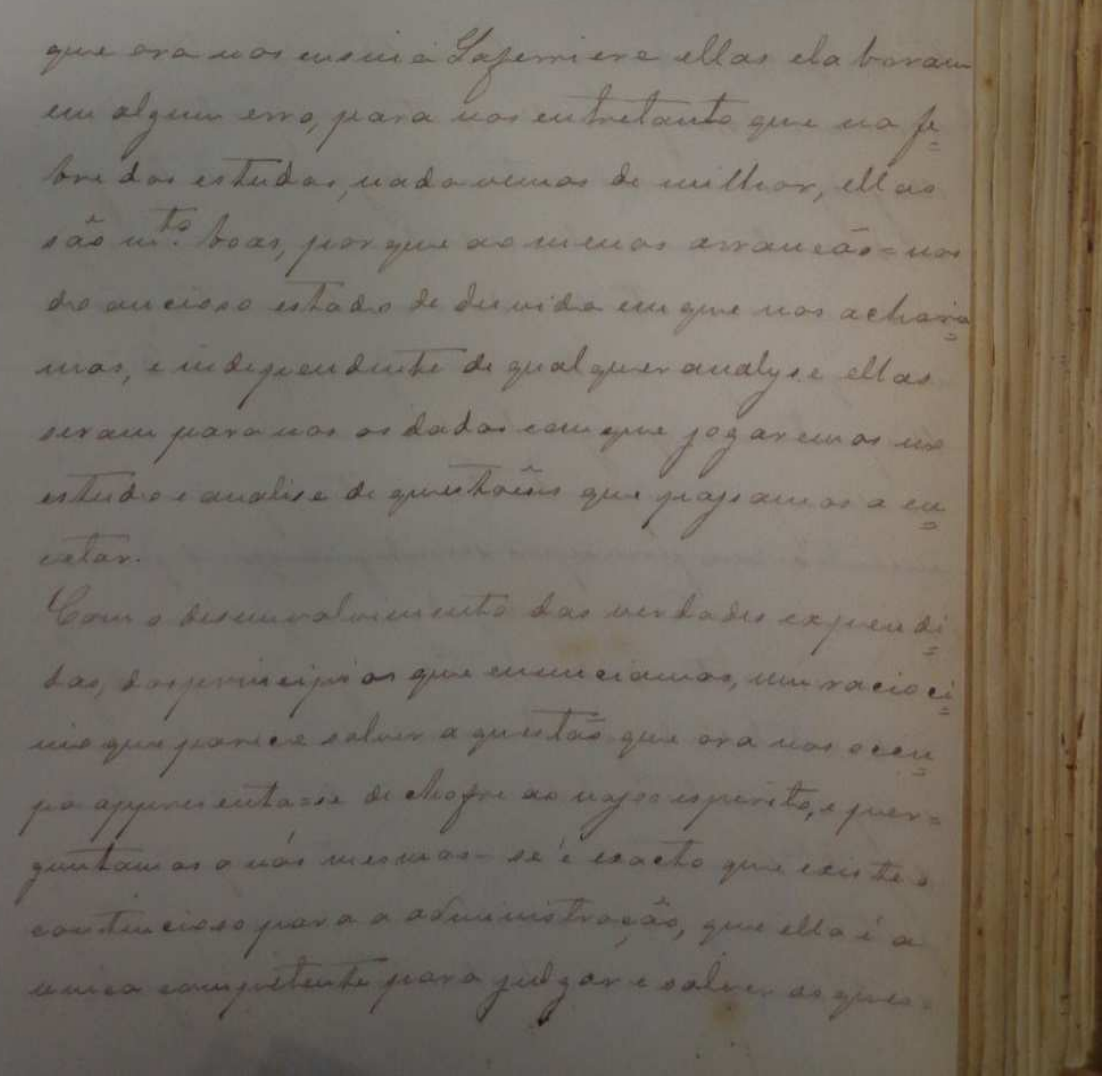




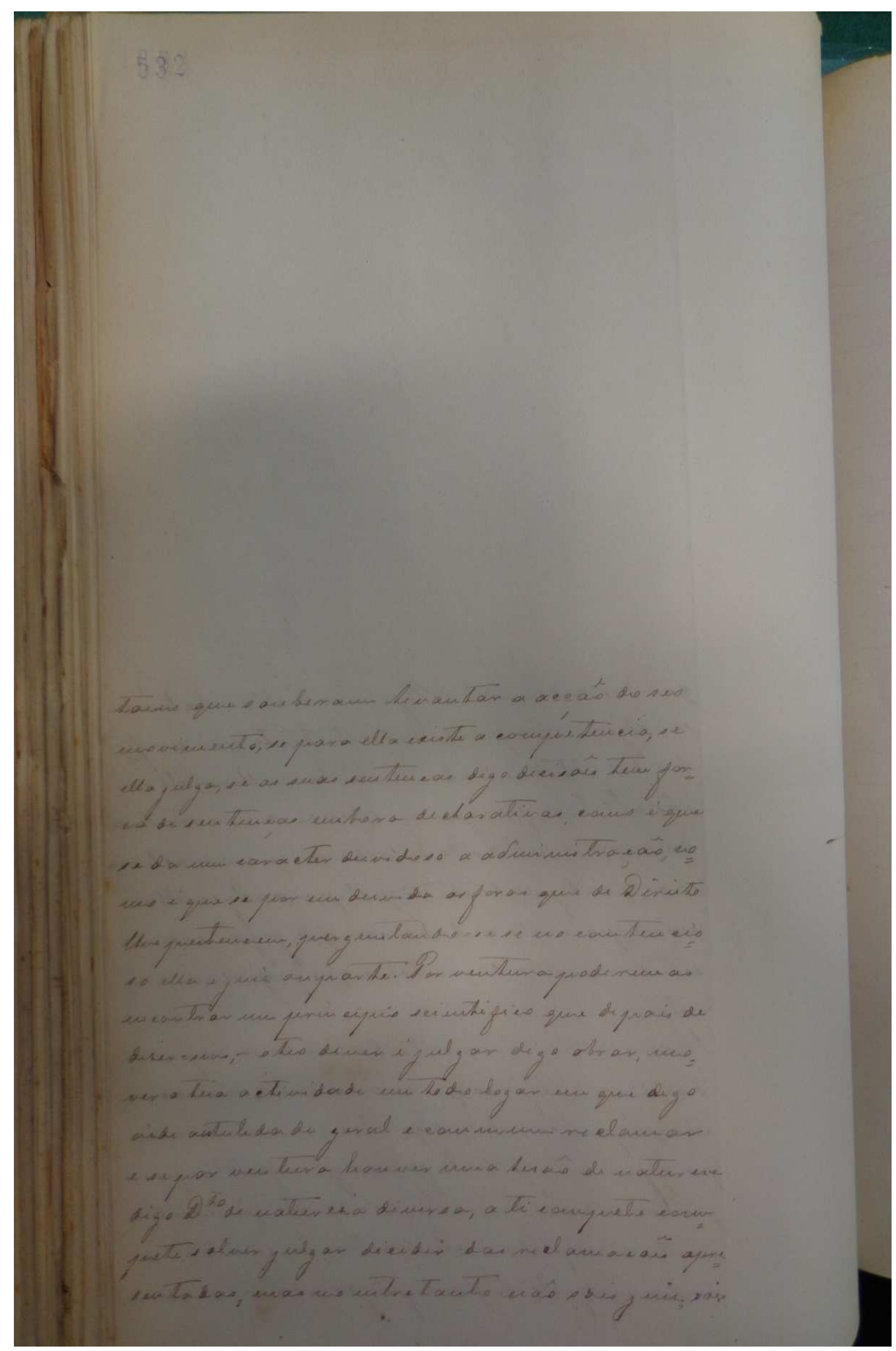




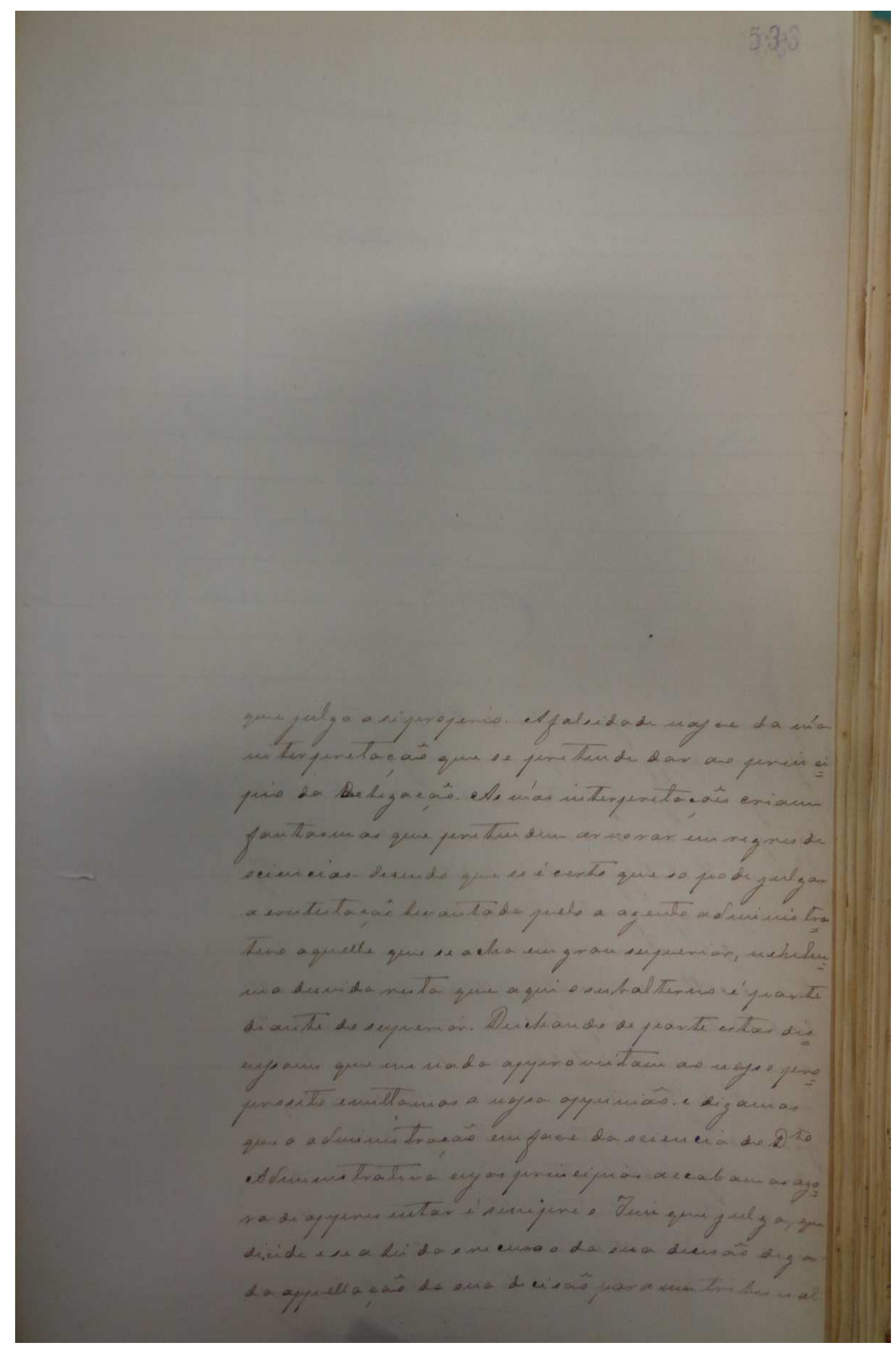




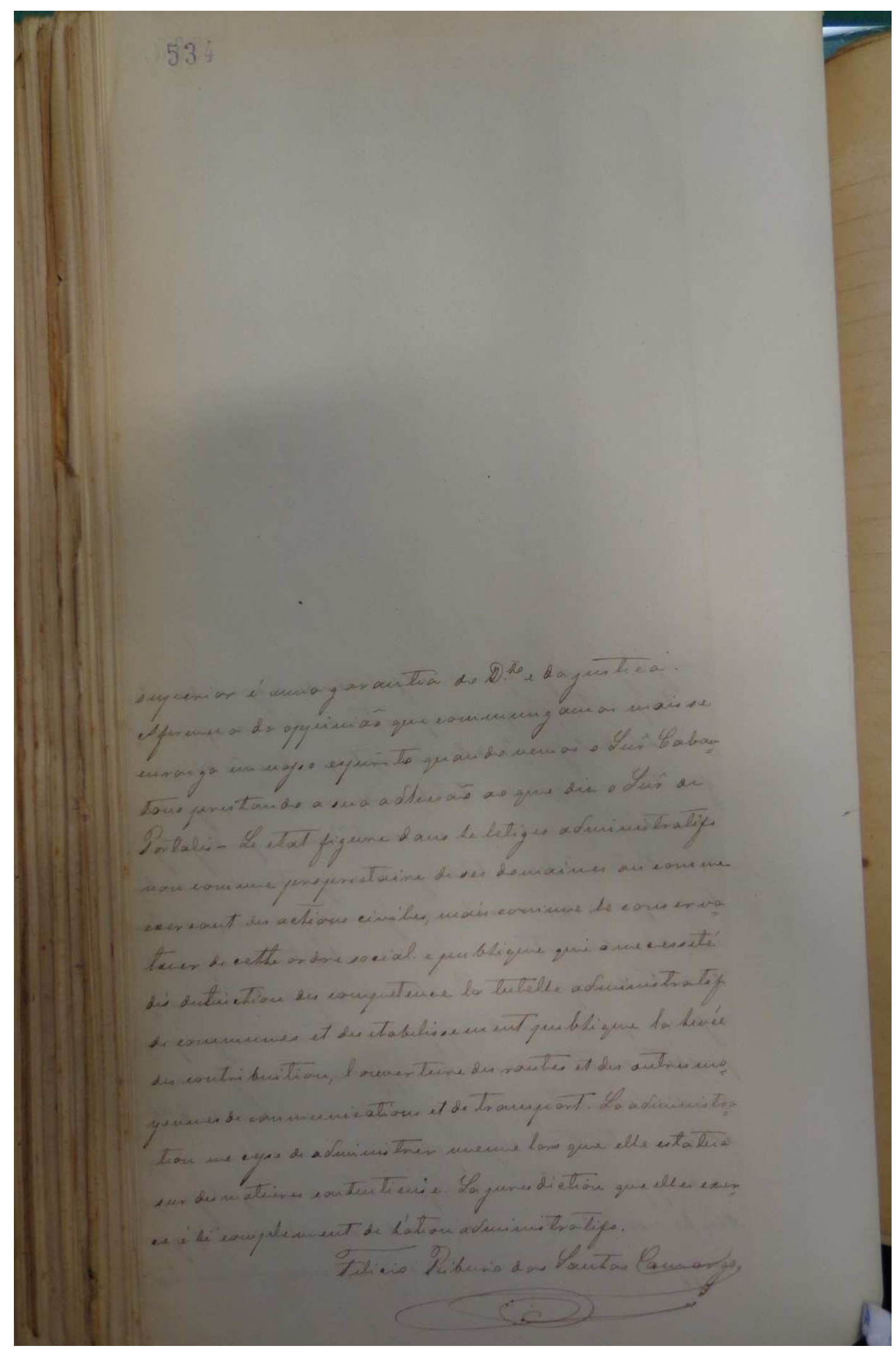


Anexo 10 - Dissertação de Direito Administrativo de Luis Eugenio Horta Barbosa

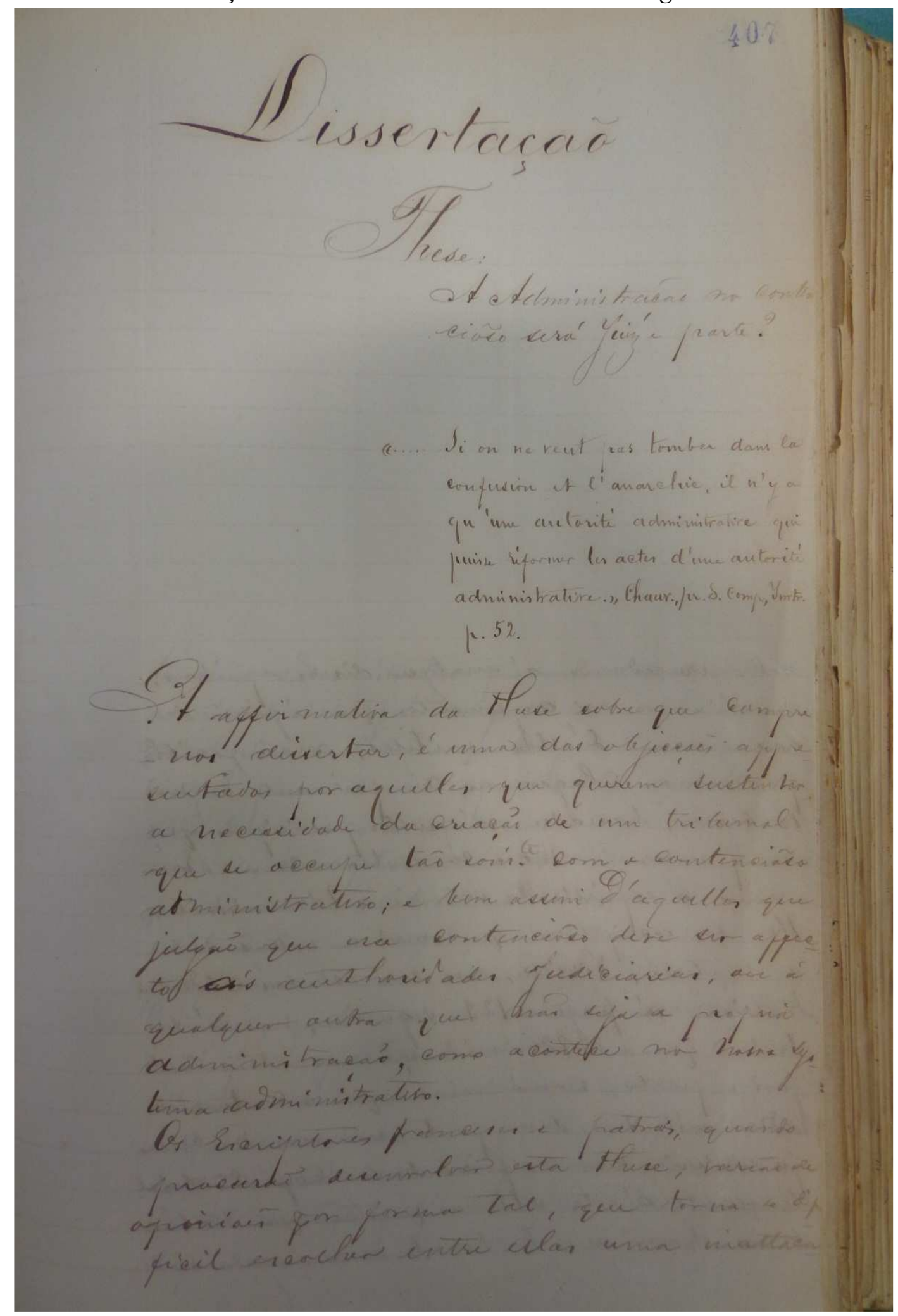




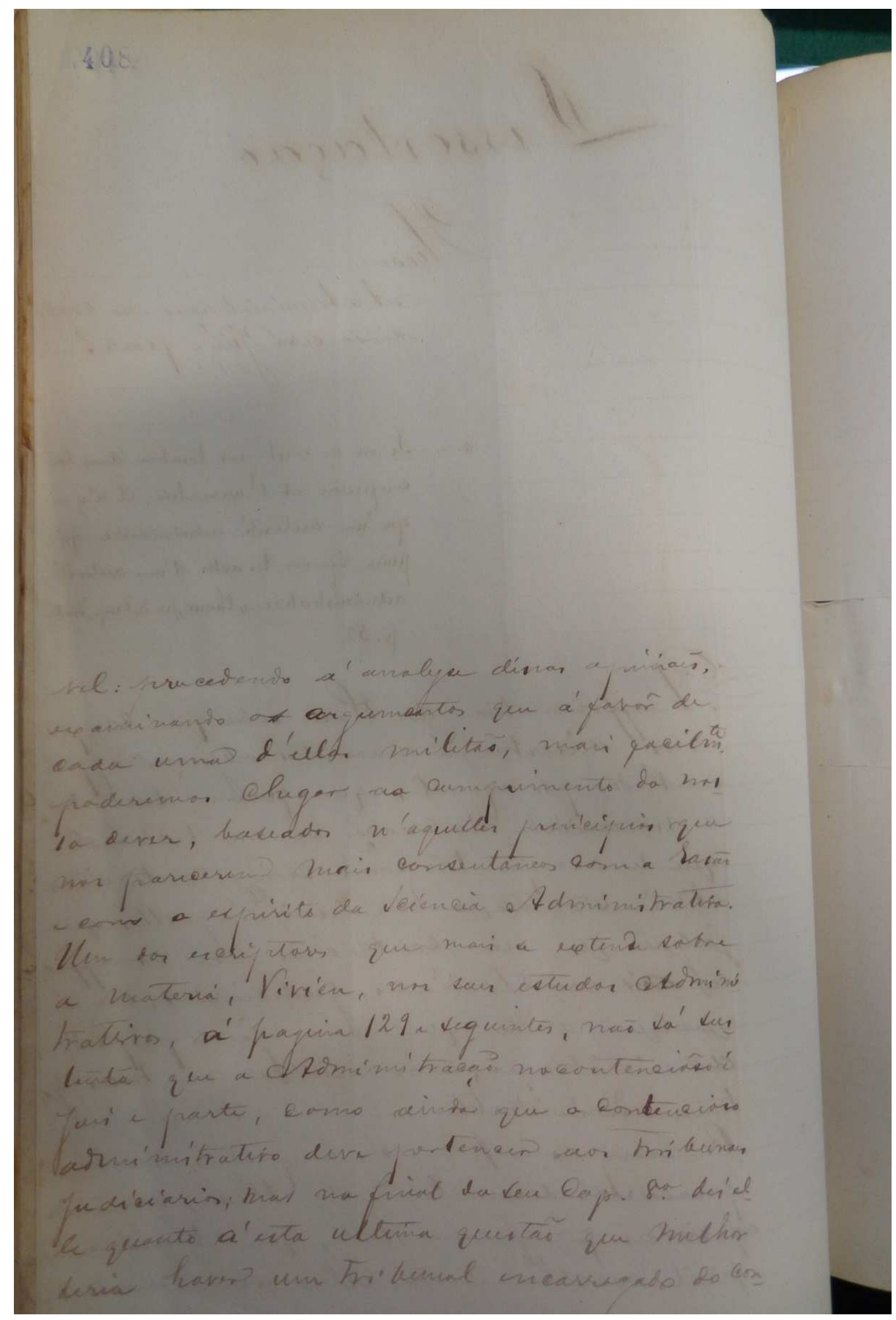





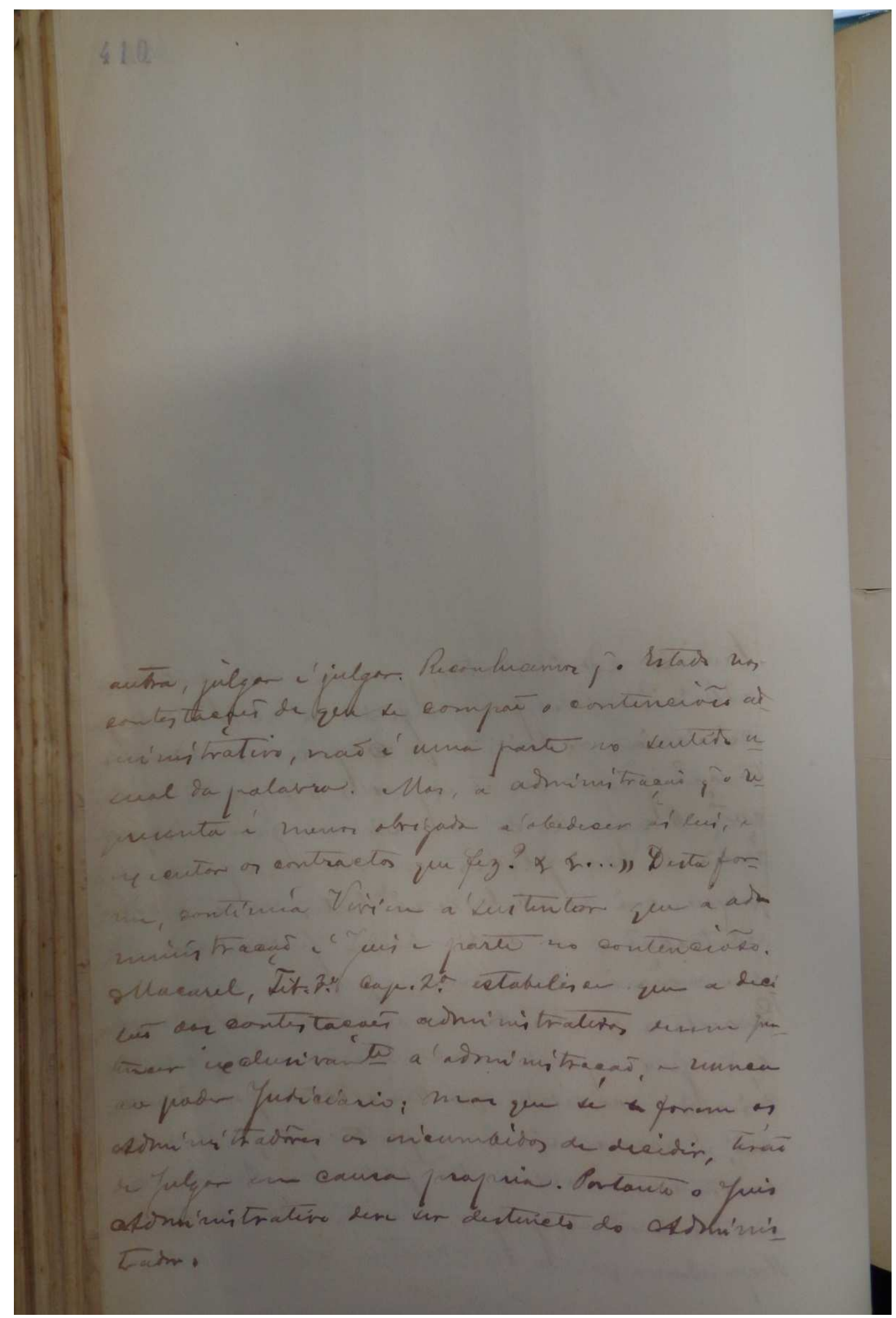




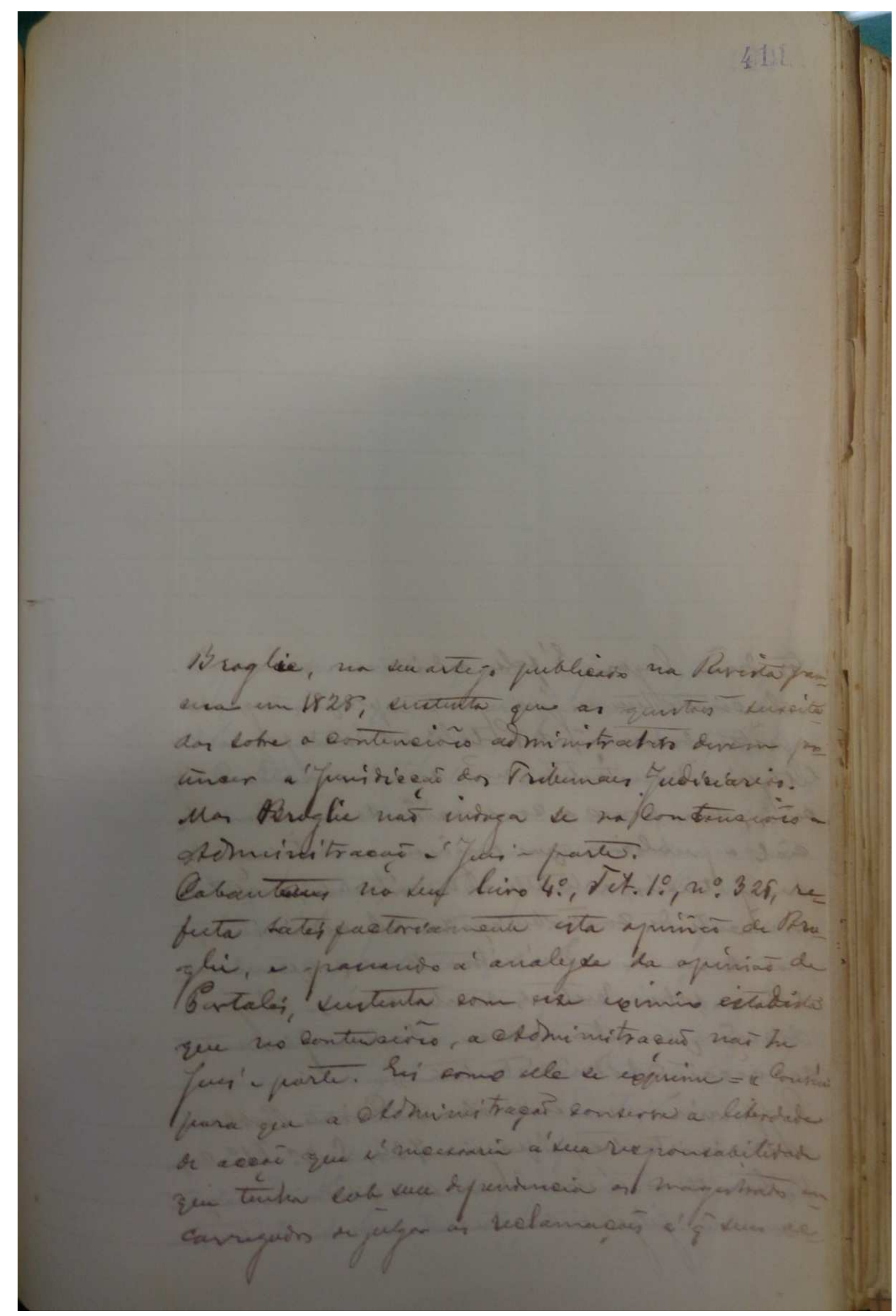




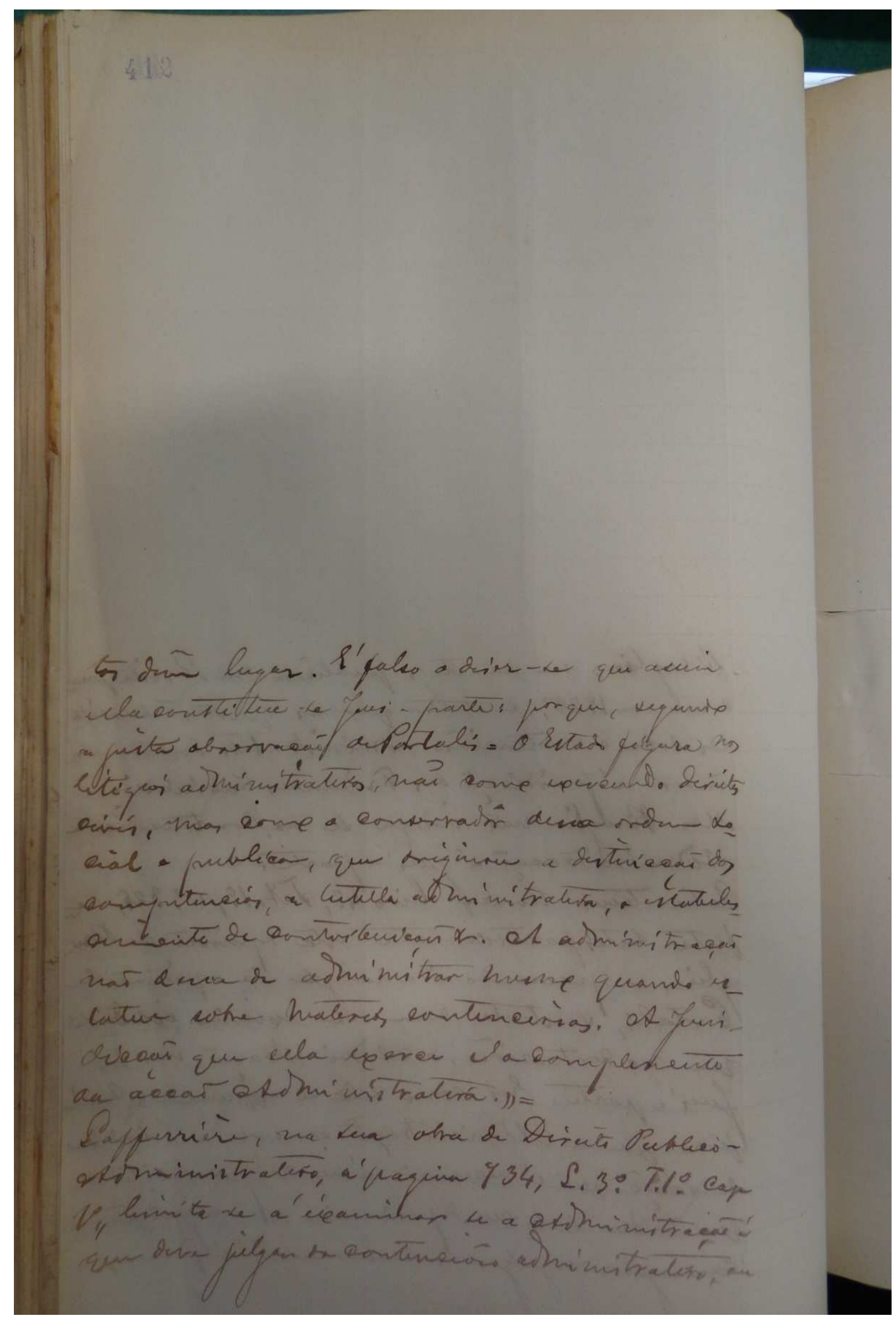


337

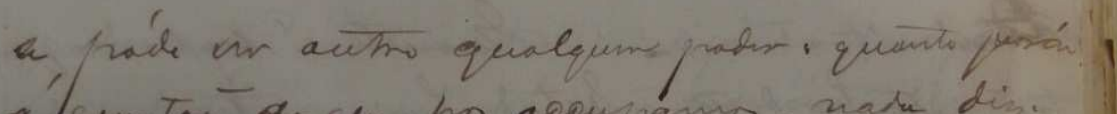

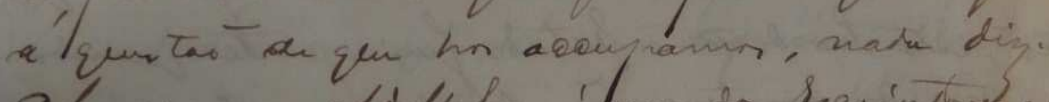

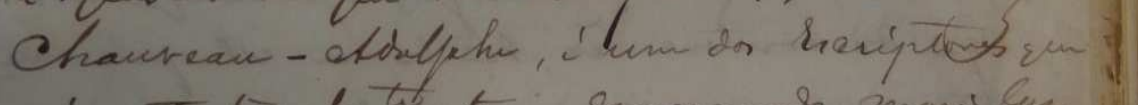

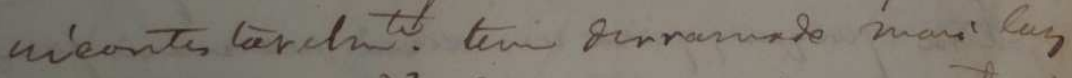

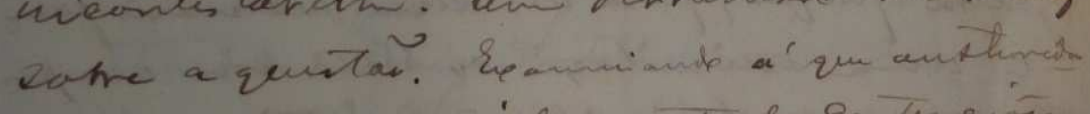

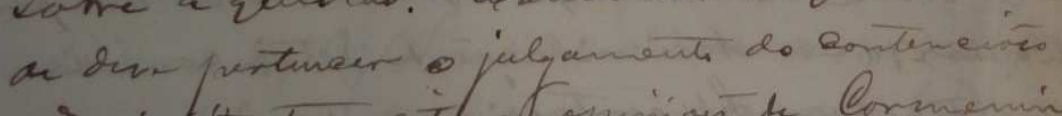
arminitratero, ait at oprinion de Commenin

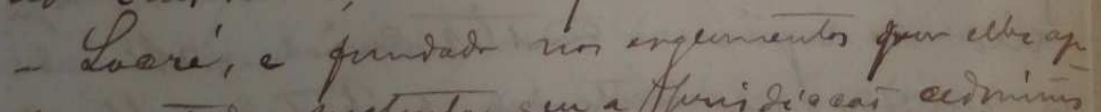

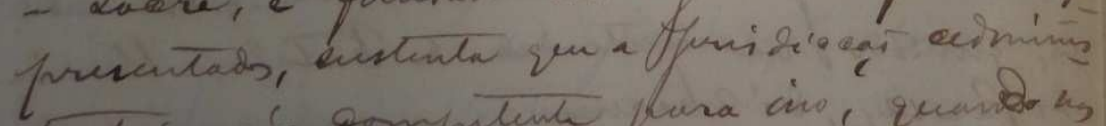

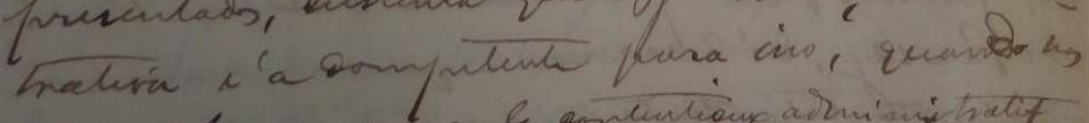

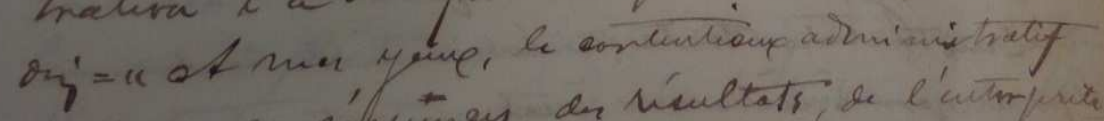

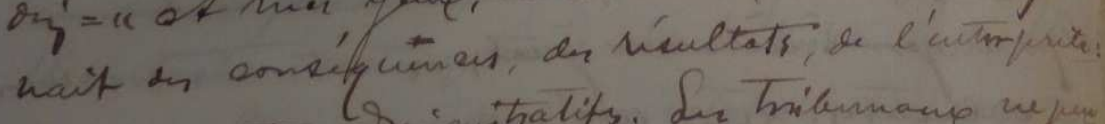
tori on oter Sominitiatifs. Ser Tribunaup nepue

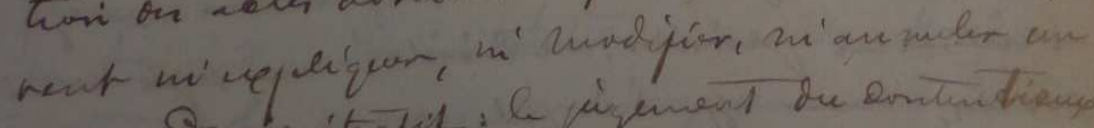

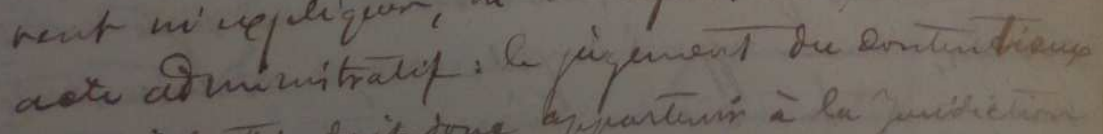

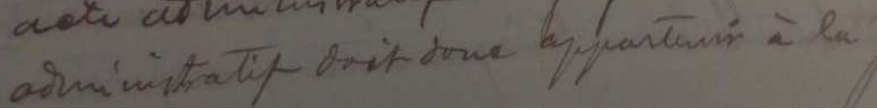




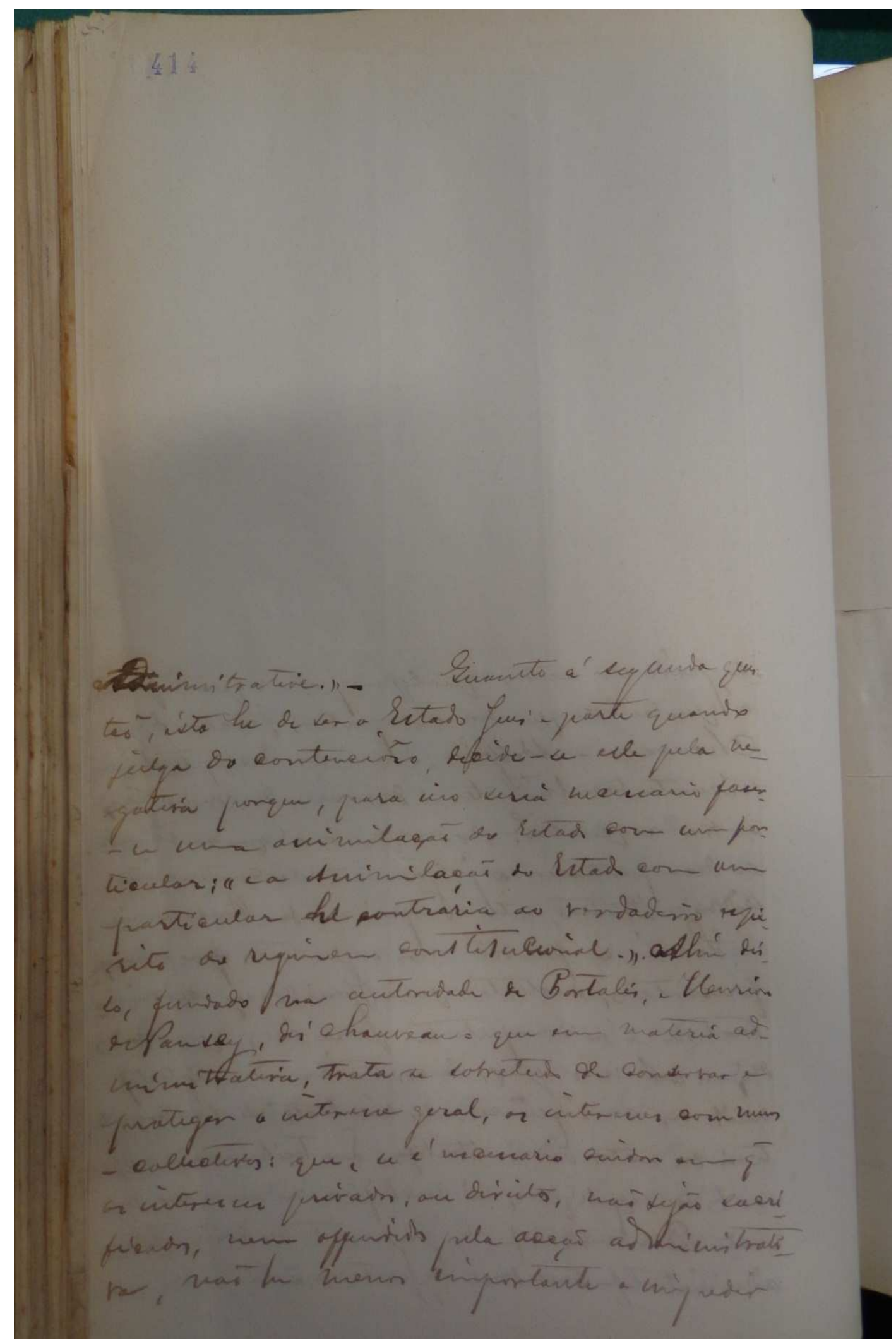




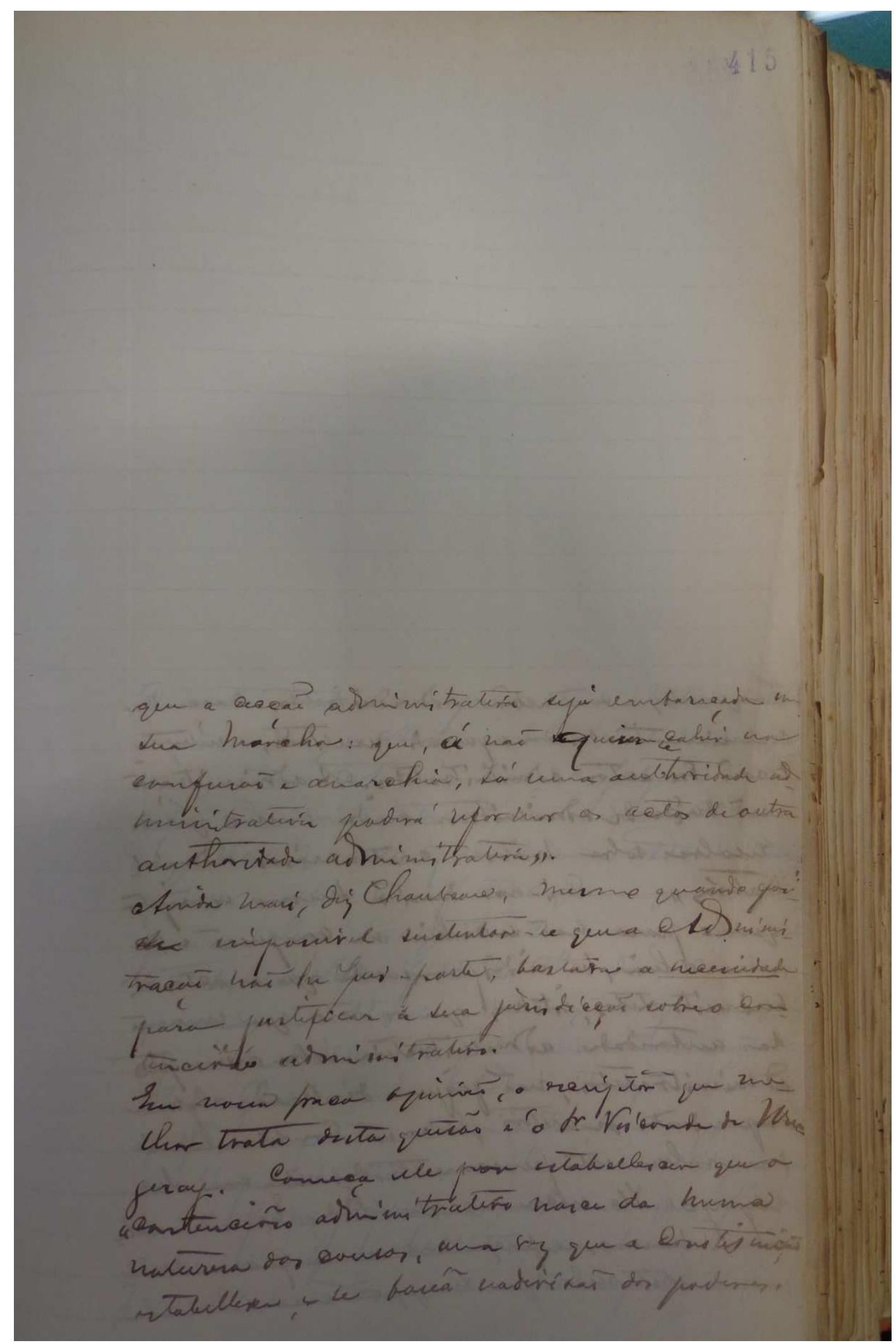




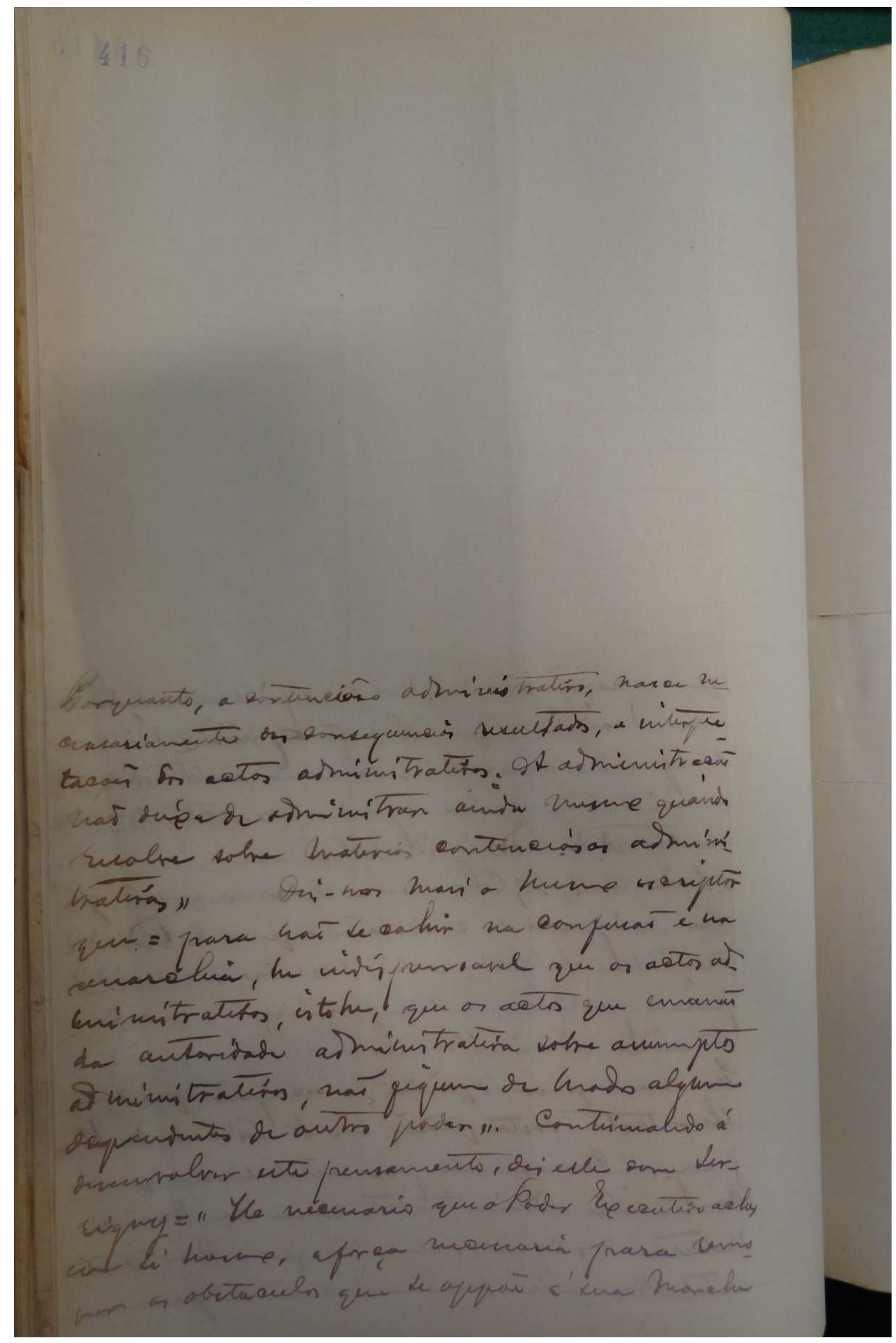


341

De outho undo Errai aprenn cuna hutach debars errai nas. osenci a bau niablave dopo

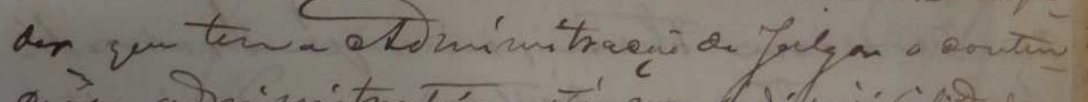

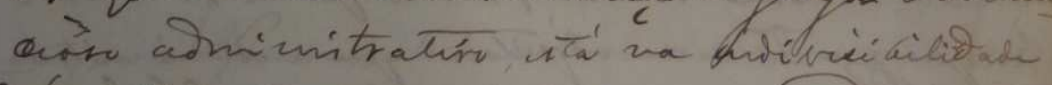
Saqueller inume pour som a Stominimes

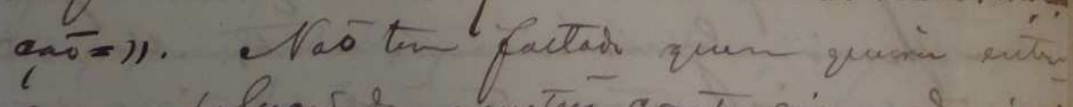
que a volueas on quirtas conterainos abmini

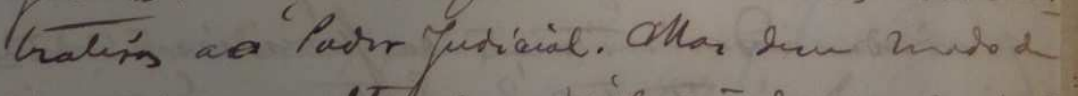

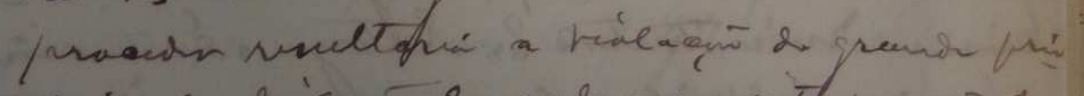

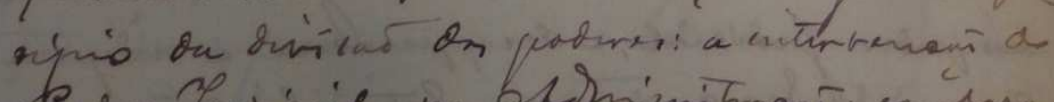

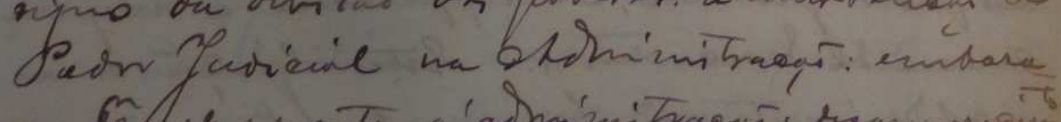

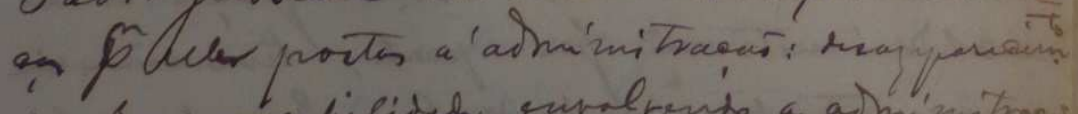

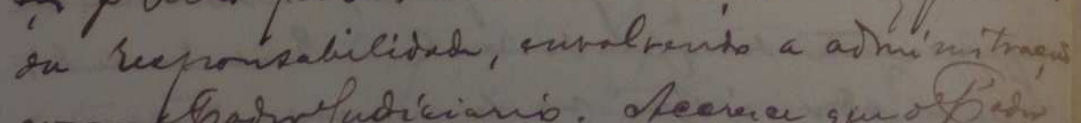

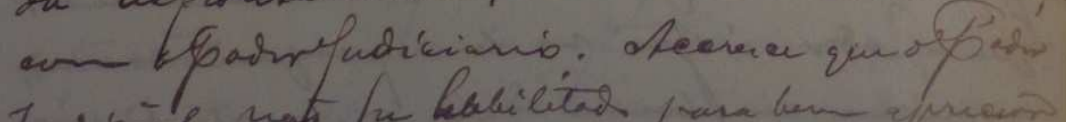

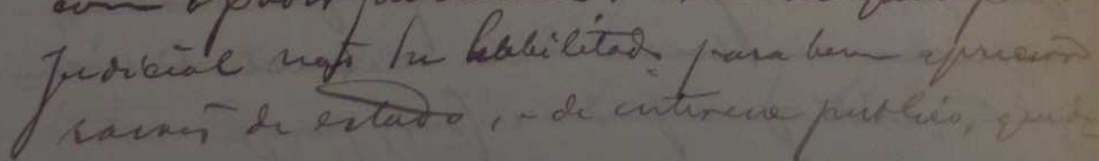




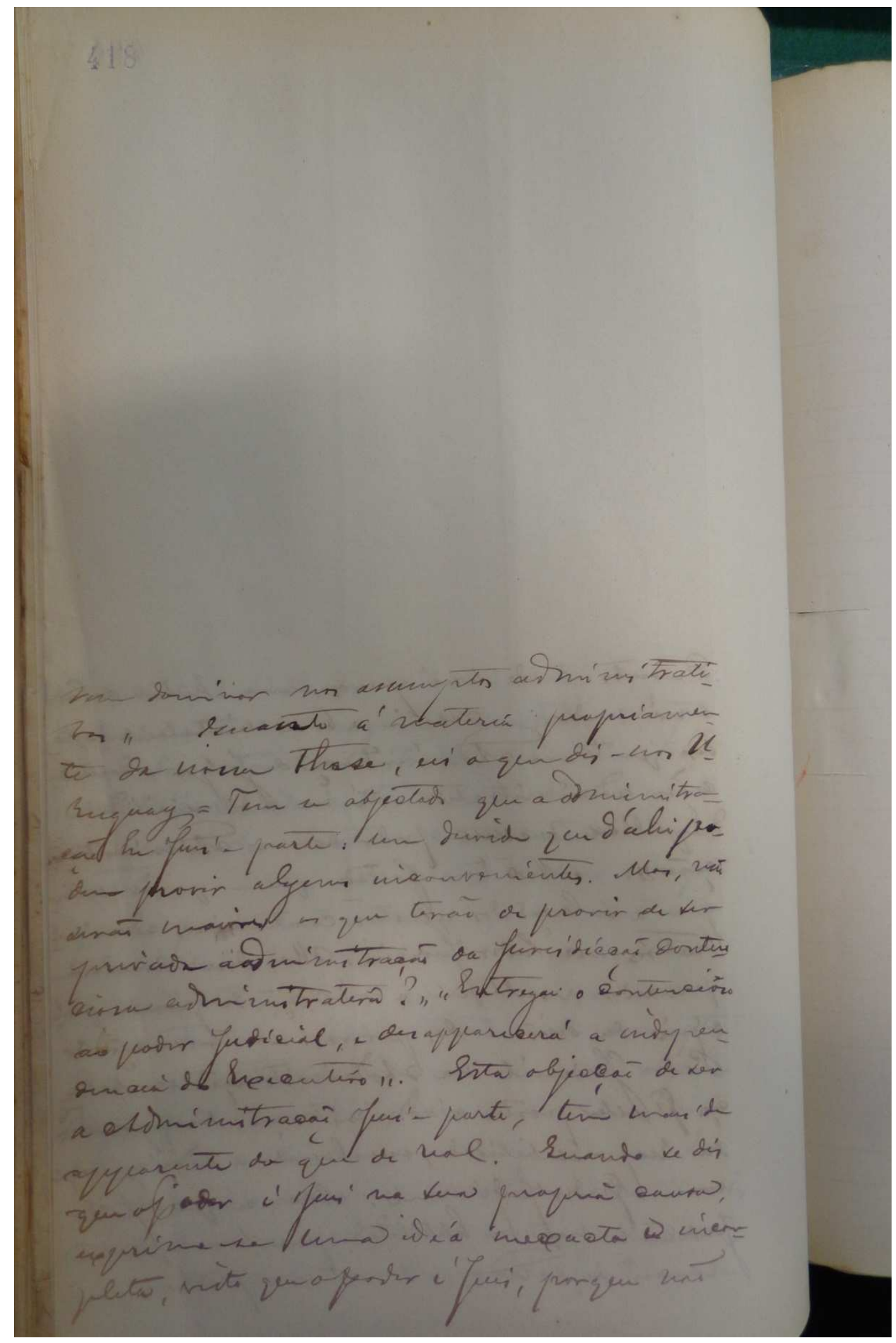


343

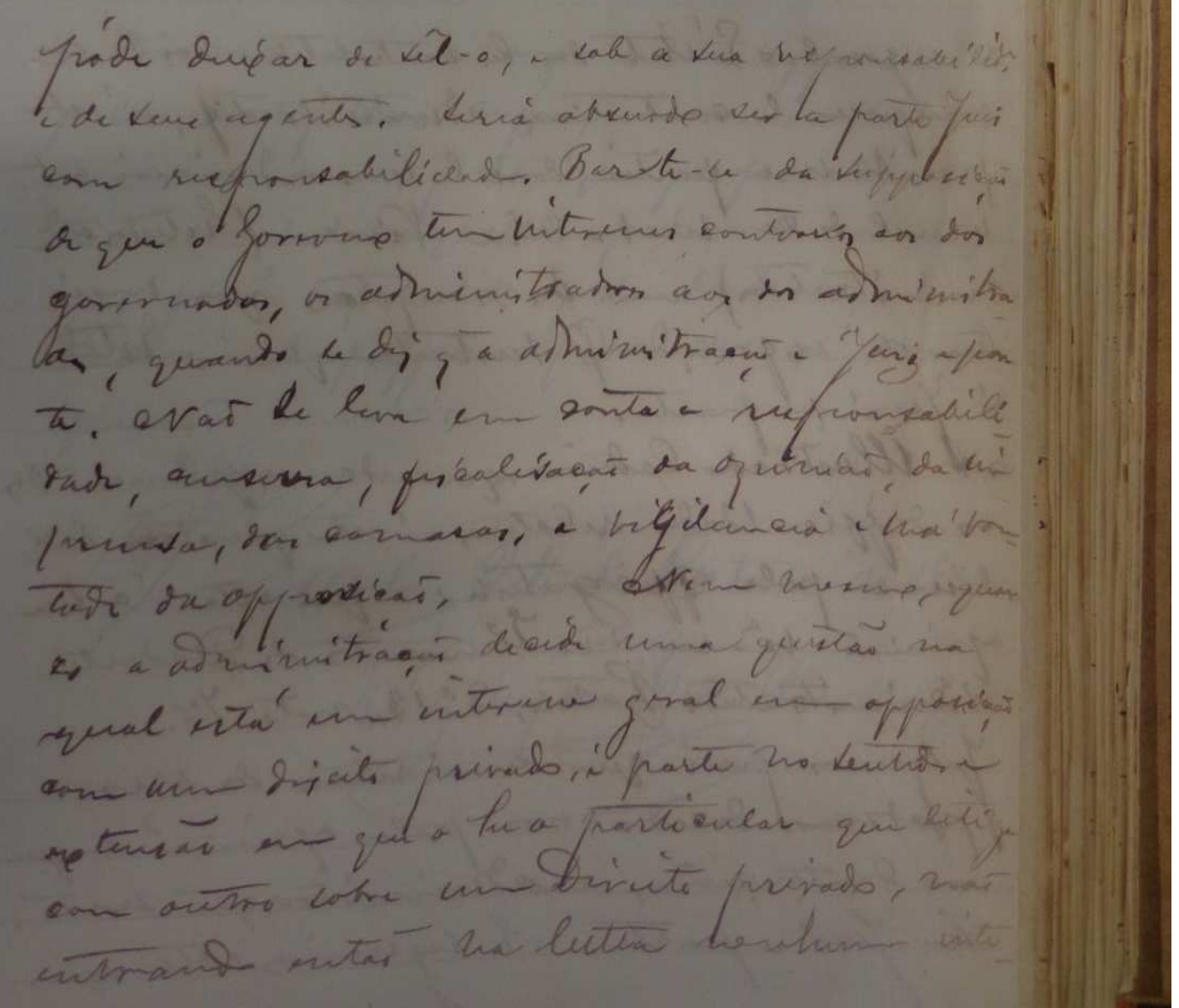




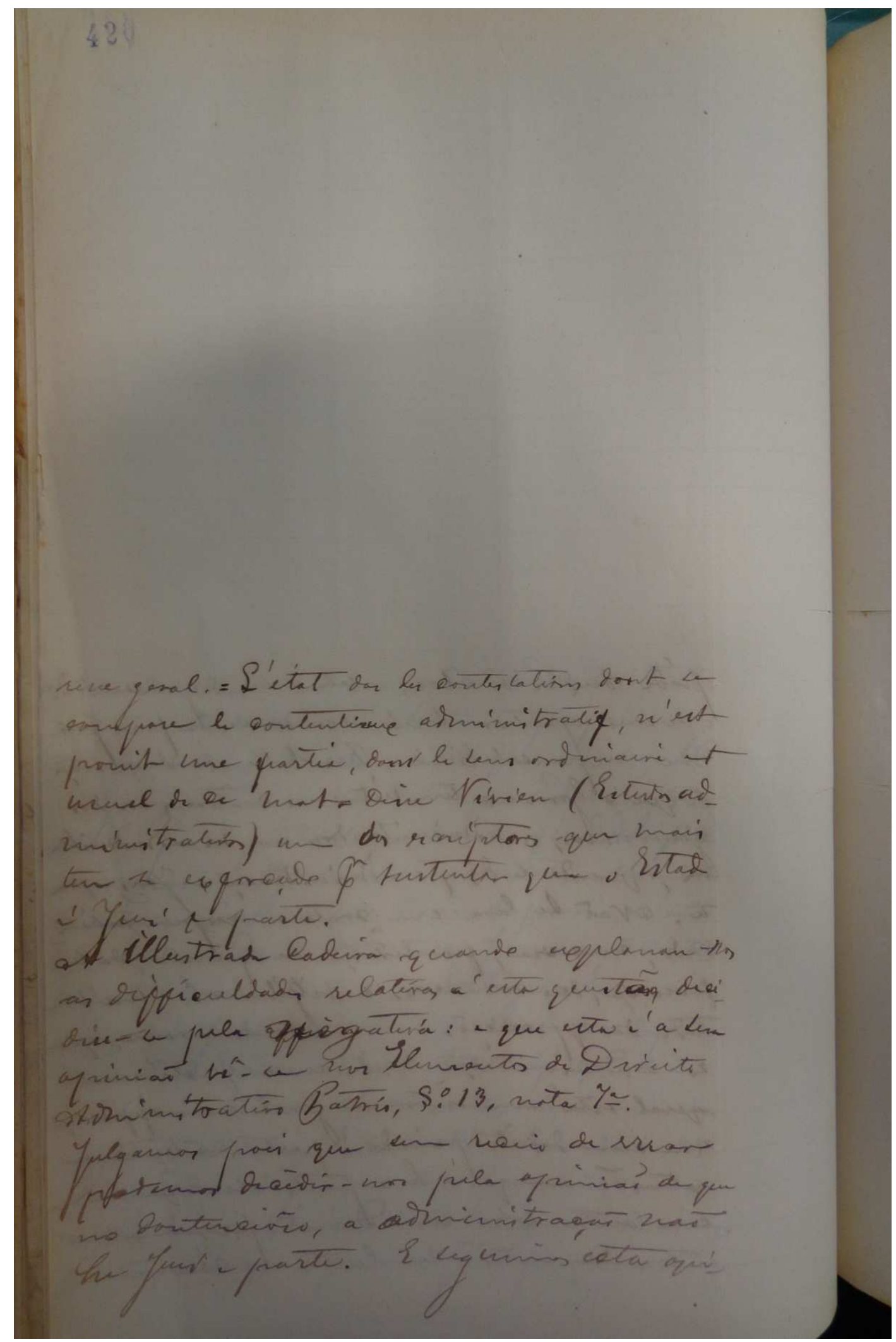


345

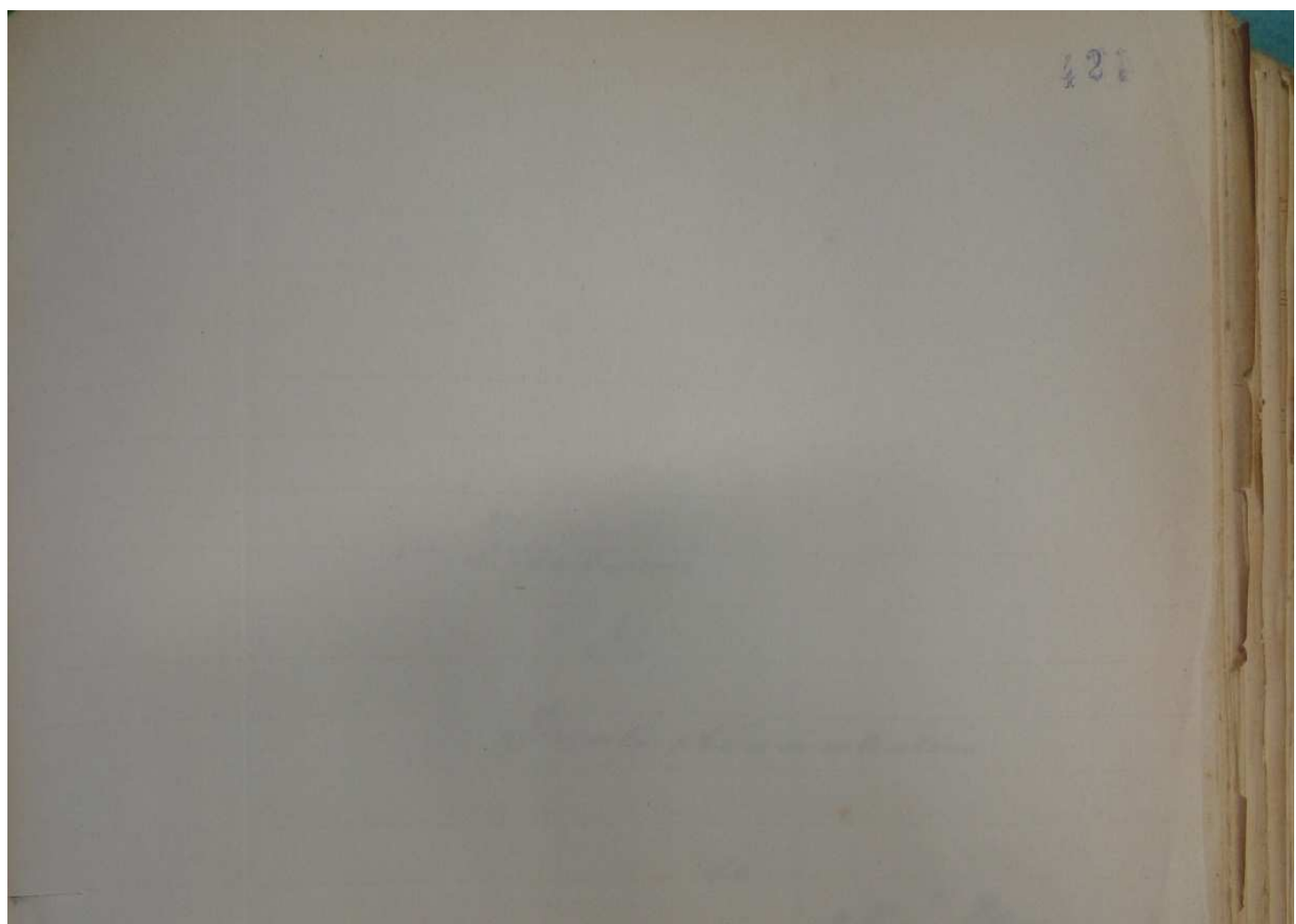

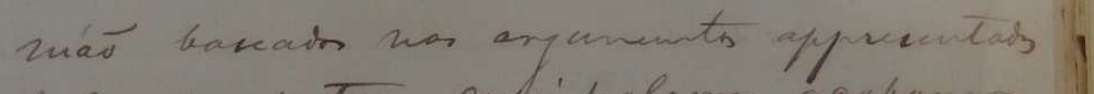

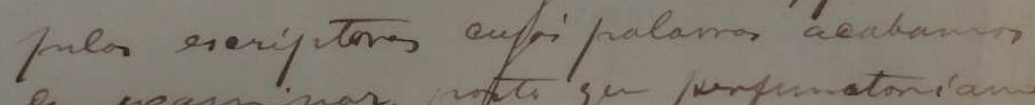

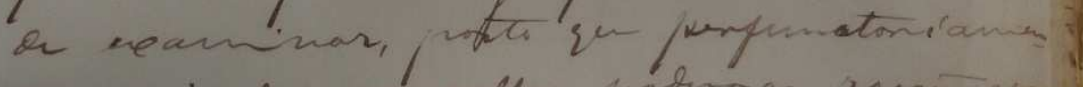

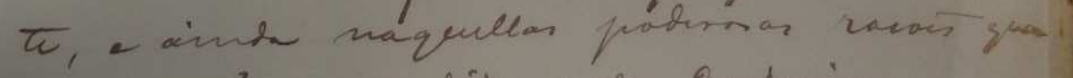
wor frat expentis pila Raviria.

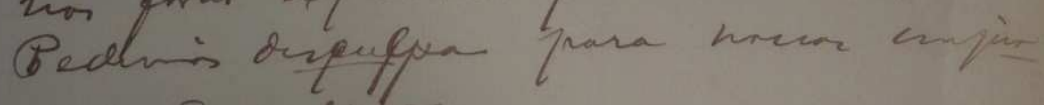
pukar tert.

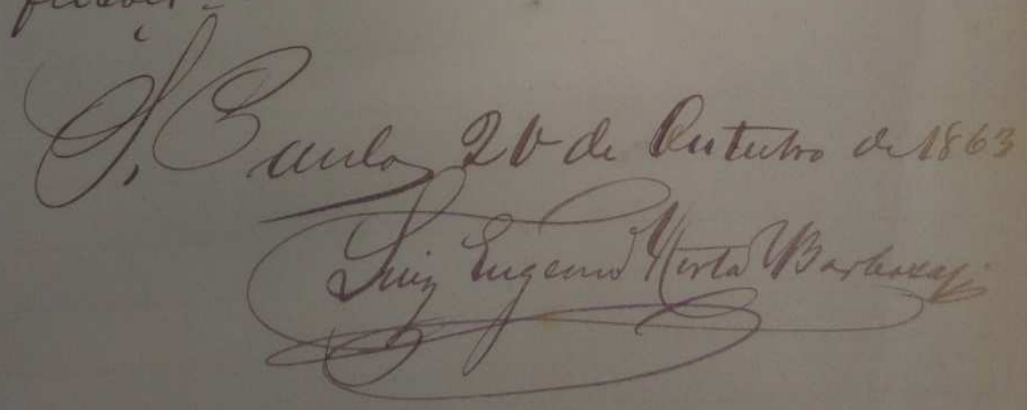


